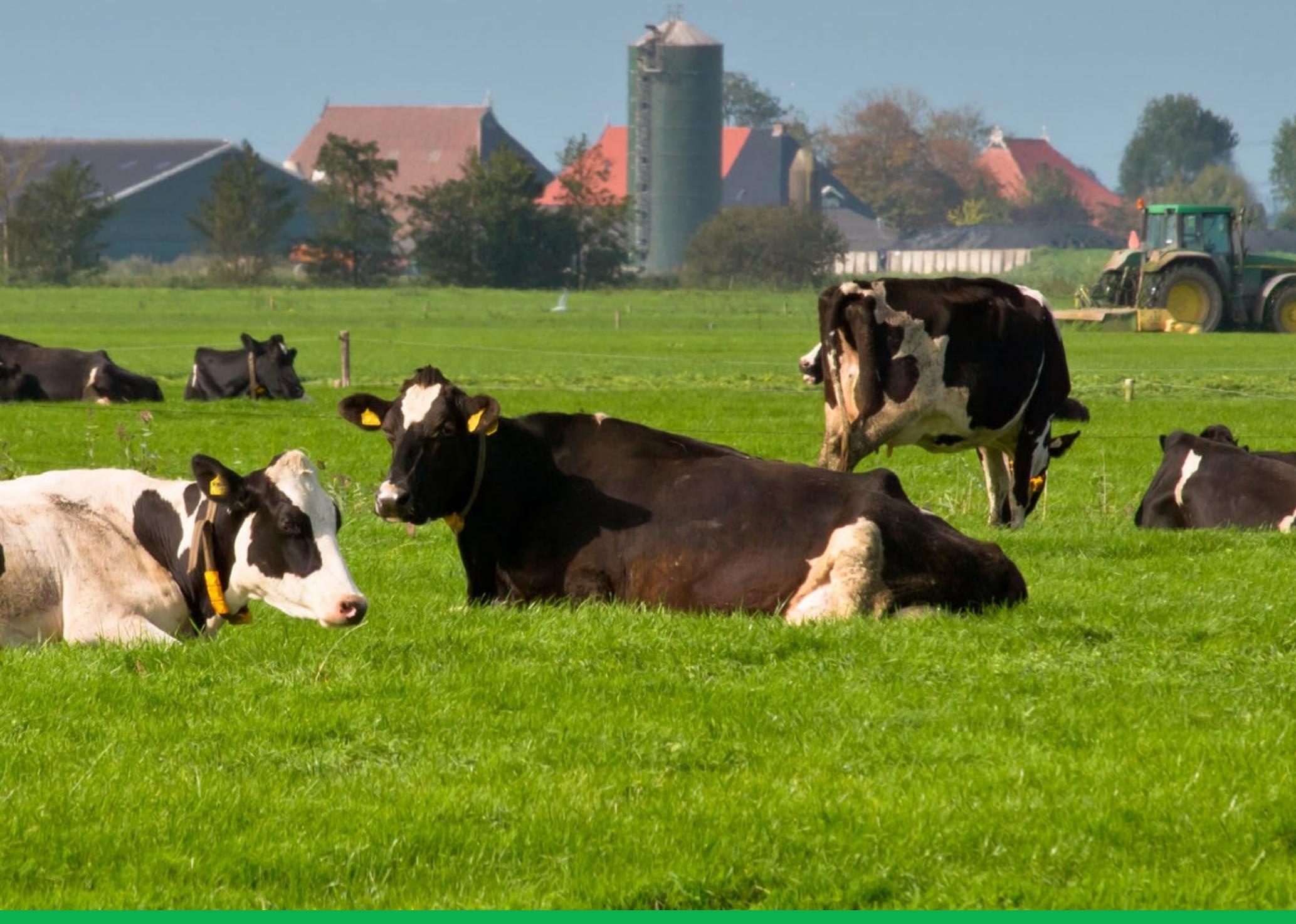

\title{
Emissies naar lucht uit de landbouw berekend met NEMA voor 1990-2019
}

C. van Bruggen, A. Bannink, C.M. Groenestein, J.F.M. Huijsmans, L.A. Lagerwerf, ～｜ WOt-technical report 203 H.H. Luesink, M.B.H. Ros, G.L. Velthof, J. Vonk \& T. van der Zee 

Emissies naar lucht uit de landbouw berekend met NEMA voor 1990-2019 
Dit Technical report is gemaakt conform het Kwaliteitsmanagementsysteem (KMS) van de unit Wettelijke Onderzoekstaken Natuur \& Milieu, onderdeel van Wageningen University \& Research.

De WOT Natuur \& Milieu voert wettelijke onderzoekstaken uit op het beleidsterrein natuur en milieu. Deze taken worden uitgevoerd om een wettelijke verantwoordelijkheid van de Minister van Landbouw, Natuur en Voedselkwaliteit (LNV) te ondersteunen. We zorgen voor rapportages en data voor (inter)nationale verplichtingen op het gebied van agromilieu, biodiversiteit en bodeminformatie, en werken mee aan producten van het Planbureau voor de Leefomgeving zoals de Balans van de Leefomgeving.

\section{Disclaimer WOt-publicaties}

De reeks 'WOt-technical reports' bevat onderzoeksresultaten van projecten die kennisorganisaties voor de unit Wettelijke Onderzoekstaken Natuur \& Milieu hebben uitgevoerd.

WOt-technical report 203 is het resultaat van onderzoek gefinancierd door het ministerie van Landbouw, Natuur en Voedselkwaliteit (LNV). 


\section{Emissies naar lucht uit de landbouw berekend met NEMA voor 1990-2019}

C. van Bruggen ${ }^{1}$, A. Bannink ${ }^{2}$, C.M. Groenestein ${ }^{2}$, J.F.M. Huijsmans ${ }^{3}$, L.A. Lagerwerf ${ }^{2}$, H.H. Luesink ${ }^{5}$, M.B.H. Ros ${ }^{6}$, G.L. Velthof ${ }^{6}$, J. Vonk ${ }^{2} \&$ T. van der Zee ${ }^{4}$

1 Centraal Bureau voor de Statistiek

2 Wageningen Livestock Research

3 Wageningen Plant Research

4 Rijksinstituut voor Volksgezondheid en Milieu

5 Wageningen Economic Research

6 Wageningen Environmental Research

Projectnummer WOT-04-008-031.01 en WOT-04-008-025.02

Wettelijke Onderzoekstaken Natuur \& Milieu

Wageningen, april 2021

wOt-technical report 203

ISSN 2352-2739

DOI $10.18174 / 544296$ 


\section{Referaat}

Bruggen, C. van, A. Bannink, C.M. Groenestein, J.F.M. Huijsmans, L.A. Lagerwerf, H.H. Luesink, M.B.H. Ros, G.L. Velthof, J. Vonk en T. van der Zee (2021). Emissies naar lucht uit de landbouw berekend met NEMA voor 1990-2019. Wageningen, WOT Natuur \& Milieu, WOt-technical report 203. 238 p.; 26 tab.; 8 figs.; 72 ref.; 32 bijl.

Landbouwkundige activiteiten vormen in Nederland een belangrijke bron van gasvormige emissies van ammoniak $\left(\mathrm{NH}_{3}\right)$, stikstofoxide $(\mathrm{NO})$, lachgas $\left(\mathrm{N}_{2} \mathrm{O}\right)$, methaan $\left(\mathrm{CH}_{4}\right)$, niet-methaan vluchtige organische stoffen (NMVOS), $\mathrm{CO}_{2}$ uit kalkmeststoffen en ureum, en fijnstof $\left(\mathrm{PM}_{10}\right.$ en $\left.\mathrm{PM}_{2,5}\right)$. De emissies zijn berekend met het National Emission Model for Agriculture (NEMA). In 2019 bedroeg de $\mathrm{NH}_{3}$-emissie uit dierlijke mest, uit kunstmest en overige bronnen in de landbouw, bij hobbybedrijven, bij particulieren, en bij mestafzet op natuurterreinen in totaal 112,0 miljoen $\mathrm{kg} \mathrm{NH}_{3}, 6,2$ miljoen $\mathrm{kg}$ minder dan in 2018. De stikstofexcretie van de veestapel daalde in 2019 ten opzichte van 2018 door krimp van de melkveestapel. De $\mathrm{N}_{2} \mathrm{O}$-emissie lag in 2019 met 18,8 miljoen $\mathrm{kg} \mathrm{0,6}$ miljoen $\mathrm{kg}$ onder het niveau van 2018. De NO-emissie daalde in 2019 met 0,7 miljoen $\mathrm{kg}$ tot 21,7 miljoen $\mathrm{kg}$. De $\mathrm{CH}_{4}$-emissie daalde door de krimp van de melkveestapel van 484 naar 480 miljoen $\mathrm{kg}$. De emissie van NMVOS daalde van 89,6 naar 87,8 miljoen $\mathrm{kg}$. De emissie van fijnstof $\mathrm{PM}_{10}$ daalde van 5,9 miljoen $\mathrm{kg}$ in 2018 tot 5,4 miljoen $\mathrm{kg}$ in 2019 en de emissie van $\mathrm{PM}_{2,5}$ daalde van 0,6 naar 0,5 miljoen $\mathrm{kg}$. De $\mathrm{CO}_{2}$-emissie uit kalkmeststoffen en ureum daalde van 83,1 tot 80,1 miljoen $\mathrm{kg}$. Op basis van in het rapport beschreven nieuwe gegevens zijn voor enkele jaren in de tijdreeks nieuwe cijfers berekend. Sinds 1990 is de $\mathrm{NH}_{3}$-emissie uit dierlijke mest met tweederde gedaald, vooral door een lagere stikstofexcretie en door emissiearme mesttoediening. Emissies van $\mathrm{N}_{2} \mathrm{O}$ en $\mathrm{NO}$ daalden in dezelfde periode eveneens, maar minder sterk met respectievelijk 42\% en 35\%. Door het in de bodem brengen van mest zijn deze emissies toegenomen ten opzichte van bovengrondse mesttoediening en daarnaast door een verschuiving in excretie van weide naar stallen. Tussen 1990 en 2019 daalde de emissie van $\mathrm{CH}_{4}$ met $18 \%$ door een afname van de dieraantallen en hogere voederefficiënties van melkvee. De $\mathrm{PM}_{10}$ emissies stegen in dezelfde periode met $9 \%$, door de omschakeling bij legpluimvee van stalsystemen met natte naar vaste mest.

Trefwoorden: ammoniak, beweiding, emissie, export, fijnstof, huisvesting, kunstmest, lachgas, Landbouwtelling, mest, mest-opslagen, mesttoediening, mestbewerking, mestverwerking, methaan, Nederland, pluimvee, rundvee, stallen, stalsystemen, stikstof, varkens, NEMA

\section{Abstract}

Bruggen, C. van, A. Bannink, C.M. Groenestein, J.F.M. Huijsmans, L.A. Lagerwerf, H.H. Luesink, M.B.H. Ros, G.L. Velthof, J. Vonk and T. van der Zee (2021). Atmospheric emissions from agricultural activities calculated with NEMA for 1990-2019. Wageningen, Statutory Research Tasks Unit for Nature and the Environment (WOT Natuur \& Milieu). WOt-technical report 203. 238 p; 26 Tab.; 8 Fig.; 72 Ref.; 32 Annexes.

In the Netherlands, agricultural activities are a major source of gaseous emissions of ammonia $\left(\mathrm{NH}_{3}\right)$, nitrogen oxide $(\mathrm{NO})$, nitrous oxide $\left(\mathrm{N}_{2} \mathrm{O}\right)$, methane $\left(\mathrm{CH}_{4}\right)$, non-methane volatile organic compounds (NMVOC), carbon dioxide $\left(\mathrm{CO}_{2}\right)$ from lime fertilisers and urea fertiliser, and particulate matter $\left(\mathrm{PM}_{10}\right.$ and $\mathrm{PM}_{2.5}$ ). The emissions were calculated using the National Emission Model for Agriculture (NEMA). In 2019, $\mathrm{NH}_{3}$ emissions from livestock manure, fertiliser and other sources on farms and hobby farms, from private use and from manure application in terrestrial ecosystems amounted to 112.0 million $\mathrm{kg} \mathrm{NH}, 6.2$ million $\mathrm{kg}$ less than in 2018. This decrease was due mainly to the reduction in the size of the dairy herd. Emissions of $\mathrm{N}_{2} \mathrm{O}$ in 2019 were 18.8 million $\mathrm{kg}, 0.6$ million $\mathrm{kg}$ less than in 2018 . Emissions of $\mathrm{NO}$ in 2019 amounted to 21.7 million kg, 0.7 million $\mathrm{kg}$ less than in 2018. Emissions of $\mathrm{CH}_{4}$ decreased from 484 to 480 million $\mathrm{kg}$ due to the smaller dairy herd. Emissions of NMVOC amounted to 87.8 million $\mathrm{kg}$ in 2019 , down from 89.6 million $\mathrm{kg}$ in 2018. Emissions of particulate matter $\mathrm{PM}_{10}$ decreased from 5.9 in 2018 to 5.4 million $\mathrm{kg}$ in 2019 and $\mathrm{PM}_{2.5}$ emissions decreased from 0.6 to 0.5 million $\mathrm{kg}$. Emissions of $\mathrm{CO}_{2}$ from lime fertilisers and urea decreased from 83.1 to 80.1 million $\mathrm{kg}$. Based on new data for several factors which are described in this report, emission figures have been updated for a number of years in the time series since 1990. Emissions of $\mathrm{NH}_{3}$ from livestock manure have fallen by two-thirds since 1990, mainly as a result of lower nitrogen excretion rates of livestock and the introduction of low-emission manure application. Emissions of $\mathrm{N}_{2} \mathrm{O}$ and NO decreased over this period by $42 \%$ and $35 \%$ respectively, less markedly than the $\mathrm{NH}_{3}$ reduction because of higher emissions from manure injection (compared with surface spreading manure) and a shift from excretion on pasture to excretion in animal houses. Emissions of $\mathrm{CH}_{4}$ decreased by $18 \%$ between 1990 and 2019 due to a decrease in livestock numbers and increased feed use efficiency of dairy cattle. Emissions of $\mathrm{PM}_{10}$ increased by $9 \%$ in the same period due to laying poultry farms switching from housing systems with liquid manure to systems with solid manure.

Keywords: ammonia, grazing, emissions, export, particulate matter, animal housing, fertiliser, nitrous oxide, agricultural census, manure, manure storage, manure application, manure processing, methane, Netherlands, poultry, cattle, housing systems, nitrogen, pigs, NEMA 


\begin{tabular}{|c|c|c|}
\hline \multicolumn{3}{|c|}{$\begin{array}{l}\text { Auteurs: C. van Bruggen (CBS), A. Bannink \& C.M. Groenestein (WLR), J.F.M. Huijsmans (WPR), L.A. Lagerwerf } \\
\text { (WLR), H.H. Luesink (WECR), M.B.H. Ros (WENR), G.L. Velthof (WENR), J. Vonk (WLR), T. Van der Zee (RIVM) }\end{array}$} \\
\hline (C) 2021 & $\begin{array}{l}\text { Centraal Bureau voor de Statistiek (CBS) } \\
\text { Postbus } 24500,2490 \mathrm{HA} \text { Den Haag } \\
\mathrm{T:}(070) 3373800\end{array}$ & $\begin{array}{l}\text { Wageningen Plant Research (WPR) } \\
\text { Postbus 16, } 6700 \mathrm{AA} \text { Wageningen } \\
\text { T: (0317) } 486001\end{array}$ \\
\hline & $\begin{array}{l}\text { Wageningen Livestock Research (WLR) } \\
\text { Postbus } 65,8200 \mathrm{AB} \text { Lelystad } \\
\text { T: (0320) } 238238\end{array}$ & $\begin{array}{l}\text { Wageningen Environmental Research (WENR) } \\
\text { Postbus 47, } 6700 \mathrm{AA} \text { Wageningen } \\
\text { T: (0317) } 480700\end{array}$ \\
\hline & $\begin{array}{l}\text { Wageningen Economic Research (WECR) } \\
\text { Postbus 29703, } 2502 \text { LS Den Haag } \\
\text { T: (070) } 3358330\end{array}$ & $\begin{array}{l}\text { Rijksinstituut voor Volksgezondheid en Milieu } \\
\text { (RIVM) } \\
\text { Postbus } 1,3720 \text { BA Bilthoven } \\
\text { T: (030) } 2749111\end{array}$ \\
\hline
\end{tabular}

Foto omslag: Shutterstock

Wettelijke Onderzoekstaken Natuur \& Milieu (unit binnen de rechtspersoon Stichting Wageningen Research), Postbus 47, 6700 AA Wageningen, T 03174854 71, info.wnm@wur.nl, www.wur.nl/wotnatuurenmilieu.

WOT Natuur \& Milieu is onderdeel van Wageningen University \& Research.

Dit rapport is gratis te downloaden van https://doi.org/10.18174/544296 of op www.wur.nl/wotnatuurenmilieu. De WOT Natuur \& Milieu verstrekt geen gedrukte exemplaren van rapporten.

- Overname, verveelvoudiging of openbaarmaking van deze uitgave is toegestaan mits met duidelijke bronvermelding.

- Overname, verveelvoudiging of openbaarmaking is niet toegestaan voor commerciële doeleinden en/of geldelijk gewin.

- Overname, verveelvoudiging of openbaarmaking is niet toegestaan voor die gedeelten van deze uitgave waarvan duidelijk is dat de auteursrechten liggen bij derden en/of zijn voorbehouden.

Wettelijke Onderzoekstaken Natuur \& Milieu aanvaardt geen aansprakelijkheid voor eventuele schade voortvloeiend uit het gebruik van de resultaten van dit onderzoek of de toepassing van de adviezen. 


\section{Woord vooraf}

Jaarlijks moeten emissiecijfers voor ammoniak, stikstofoxiden, lachgas, methaan, niet-methaan vluchtige organische stoffen, fijnstof en koolstofdioxide worden gerapporteerd aan de Europese Commissie en de Verenigde Naties. Dit zijn verplichte rapportages om na te gaan of Nederland voldoet aan de NEC (National Emission Ceilings)-richtlijn, het Gothenborg-protocol en de Parijse Klimaatconventie. In het kader van de Emissieregistratie worden deze emissies voor de landbouwsector (exclusief energiegerelateerde en landgebruiks-gerelateerde emissies) berekend met het rekenmodel NEMA (National Emission Model for Agriculture).

In dit rapport worden de uitgangspunten en de resultaten gepresenteerd van de berekeningen van de emissies uit de landbouw van ammoniak, stikstofoxiden, lachgas, methaan, niet-methaan vluchtige organische stoffen, fijnstof en koolstofdioxide uit kalkmeststoffen en ureum voor de periode 19902019. Dit werk wordt uitgevoerd door de Taakgroep Landbouwemissies NEMA (tot 1 januari 2021 werkgroep NEMA van de Commissie Deskundigen Meststoffenwet). In deze taakgroep zijn verschillende experts op het gebied van emissies vanuit de landbouw naar de lucht vertegenwoordigd, te weten Centraal Bureau voor de Statistiek, Wageningen Environmental Research, Rijksinstituut voor Volksgezondheid en Milieu, Wageningen Livestock Research, Wageningen Plant Research, Wageningen Economic Research en Planbureau voor de Leefomgeving.

Namens de unit WOT Natuur \& Milieu, thema Agromilieu wil ik deze werkgroep bedanken voor hun bijdragen aan het leveren van de emissiecijfers en onderhavig rapport.

Erwin van Boekel

Themaleider Agromilieu 


\section{Inhoud}

Woord vooraf

$2.1 \quad$ Inleiding

2.2 Dieraantallen

2.3 Excretie van $\mathrm{N}$, TAN en $\mathrm{P}_{2} \mathrm{O}_{5}$

2.4 Mineralisatie en immobilisatie

$\begin{array}{lll}2.5 & \text { Huisvesting van landbouwhuisdieren } & 24\end{array}$

2.6 Emissiefactoren voor $\mathrm{NH}_{3}$ uit huisvesting 26

2.7 Emissiefactoren voor $\mathrm{N}_{2} \mathrm{O}, \mathrm{NO}$ en $\mathrm{N}_{2}$ uit stallen 29

$\begin{array}{lll}2.8 & \text { Mestopslag buiten de stal } & 30\end{array}$

2.9 Mestbewerking en -verwerking $\quad 30$

2.10 Mestafzet buiten de Nederlandse landbouw $\quad 32$

2.11 Mesttoediening $\quad 33$

$\begin{array}{lll}2.12 & \text { Beweiding } & 35\end{array}$

2.13 Overige $\mathrm{N}$-verliezen tijdens toediening van dierlijke mest en bij beweiden $\quad 35$

$3 \quad$ Stikstofverliezen uit andere landbouwbronnen dan dierlijke mest 37

$\begin{array}{lll}3.1 & \text { Kunstmest en spuiwater van luchtwassers } & 37\end{array}$

3.2 Compost en zuiveringsslib 38

3.3 Afrijpende gewassen, gewasresten en graslandvernieuwing 39

$\begin{array}{lll}3.4 & \text { Organische bodems } & 40\end{array}$

4 Indirecte lachgas-emissies $\quad 41$

$\begin{array}{lll}4.1 & \text { Atmosferische depositie } & 41\end{array}$

4.2 Uit- en afspoeling $\quad 41$

5 Methaanemissie door pens- en darmfermentatie, uit opslag van geproduceerde mest en bij mestbewerking

$\begin{array}{lll}5.1 & \text { Pens- en darmfermentatie } & 43\end{array}$

5.2 Opslag van geproduceerde mest $\quad 43$

5.3 Mestbewerking en -verwerking $\quad 45$

$6 \quad$ Emissies van niet-methaan vluchtige organische stoffen (NMVOS) 49

$\begin{array}{llr}7 & \text { Fijnstofemissies } & 51\end{array}$

$8 \quad$ Emissie van $\mathrm{CO}_{2}$ uit kalkmeststoffen en ureum $\quad 53$

$9 \quad$ Resultaten van de emissieberekeningen met NEMA 55

$9.1 \mathrm{NH}_{3}$-emissies $\quad 55$

$9.2 \mathrm{~N}_{2} \mathrm{O}$ - en NO-emissies $\quad 58$

$\begin{array}{lll}9.3 \mathrm{CH}_{4} \text {-emissies } & 60\end{array}$ 
9.4 NMVOS-emissies $\quad 62$

9.5 Fijnstofemissies 63

$\begin{array}{lll}\text { 9.6 } \mathrm{CO}_{2} \text {-emissie uit kalkmeststoffen en ureum } & 65\end{array}$

Literatuur

$\begin{array}{lll}\text { Bijlage } 1 \quad \text { Overzicht van wijzigingen in uitgangspunten } & 77\end{array}$

$\begin{array}{lll}\text { Bijlage } 2 & \text { Aantal dieren } & 81\end{array}$

Bijlage $3 \quad$ Mineralenexcretie in stal en weide $\quad 87$

Bijlage $4 \quad$ Weidegang van melkkoeien en aandeel $\mathrm{N}$-excretie in de stal $\quad 101$

Bijlage $5 \quad$ Stalsystemen met drijfmest 103

Bijlage $6 \quad$ Stalsystemen voor rundvee $\quad 105$

$\begin{array}{lll}\text { Bijlage } 7 & \text { Stalsystemen voor varkens } & 107\end{array}$

Bijlage $8 \quad$ Stalsystemen voor pluimvee 113

Bijlage $9 \quad$ Huisvesting van rundvee, varkens en pluimvee in $2019 \quad 121$

$\begin{array}{lll}\text { Bijlage } 10 & \mathrm{NH}_{3} \text {-emissiefactoren rundveestallen } & 137\end{array}$

Bijlage $11 \quad \mathrm{NH}_{3}$-emissiefactoren voor varkensstallen $\quad 139$

Bijlage $12 \quad \mathrm{NH}_{3}$-emissiefactoren voor pluimveestallen 141

Bijlage 13 Mestopslag buiten de stal 143

Bijlage 14 Mestbewerking 145

Bijlage $15 \quad$ Mestafzet buiten de landbouw 147

Bijlage 16 Berekening mestverdeling met INITIATOR ten behoeve van NEMA voor $\begin{array}{ll}\text { ammoniakemissie en lachgasemissie } & 152\end{array}$

Bijlage 17 Mesttoediening aan grasland en bouwland 157

Bijlage 18 Ammonia emission factors for manure applied to grassland in The

Bijlage 19 Kunstmestverbruik 2015 tot en met $2019 \quad 167$

Bijlage $20 \quad$ Verbruik van kunstmest en spuiwater $\quad 173$

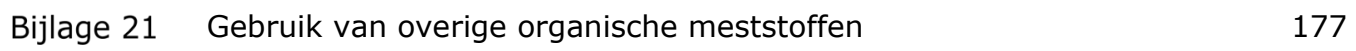

Bijlage 22 Gewasarealen, $\mathrm{N}$ in gewasresten en emissiefactor voor $\mathrm{NH}_{3} \quad 179$

Bijlage 23 Uitgangspunten voor N-verliezen van grasland 187

Bijlage 24 Organische bodems 191

Bijlage 25 Verteerbaarheid van ruw eiwit en organische stof (OS) voor berekening van de TAN-excretie en OS-excretie in $2019 \quad 193$

Bijlage 26 Methaanemissie door melkvee en verteerbaarheid ruw eiwit in $2019 \quad 197$

Bijlage 27 Bruto energie-opname door rundvee 203

Bijlage 28 Emissiefactoren voor $\mathrm{CH}_{4}$ uit pens- en darmfermentatie 205

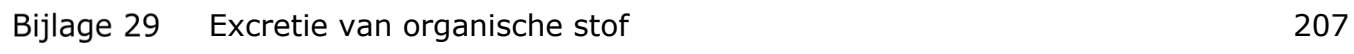

Bijlage $30 \quad$ Emissiefactoren voor $\mathrm{CH}_{4}$ uit dierlijke mest $\quad 211$

Bijlage 31 Organische stof in aanvoer naar mestbewerking 219

Bijlage 32 Verhouding tussen $\mathrm{NH}_{3}$ bij mesttoediening en bij huisvesting 221

Bijlage 33 Aandeel kuilvoer in het rantsoen 223

Bijlage 34 Stalsystemen in de berekening van fijnstofemissies 225

Bijlage 35 Verbruik van kalkmeststoffen $\quad 235$ 


\section{Samenvatting}

\section{Achtergrond}

De landbouw in Nederland is een belangrijke bron van niet aan energie gerelateerde emissies van ammoniak $\left(\mathrm{NH}_{3}\right)$, stikstofoxide (NO), lachgas $\left(\mathrm{N}_{2} \mathrm{O}\right)$, methaan $\left(\mathrm{CH}_{4}\right)$, niet-methaan vluchtige organische stoffen (NMVOS), fijnstof $\left(\mathrm{PM}_{10}\right.$ en $\left.\mathrm{PM}_{2,5}\right)$ en koolstofdioxide $\left(\mathrm{CO}_{2}\right)$ uit kalkmeststoffen en ureum. Emissies van $\mathrm{NH}_{3}$ en $\mathrm{NO}$ dragen bij aan vermesting van natuurgebieden en verzuring van de bodem. $\mathrm{N}_{2} \mathrm{O}$ en $\mathrm{CH}_{4}$ zijn broeikasgassen en $\mathrm{N}_{2} \mathrm{O}$ tast bovendien de ozonlaag aan. Fijnstof heeft een nadelig effect op de gezondheid van mens en dier. Emissies van stikstof $(\mathrm{N})$ in de vorm van $\mathrm{NH}_{3}, \mathrm{~N}_{2} \mathrm{O}$ en NO uit de landbouw verlagen de N-benutting in de landbouw.

De emissies van genoemde stoffen worden jaarlijks berekend met het National Emission Model for Agriculture (NEMA) en gerapporteerd aan de Europese Commissie en aan de Verenigde Naties.

De werkgroep National Emission Model for Agriculture (NEMA) van de Commissie van Deskundigen Meststoffenwet (CDM) heeft in opdracht van het ministerie van Landbouw, Natuur en Voedselkwaliteit (LNV) en het toenmalige ministerie van Volkshuisvesting, Ruimtelijke Ordening en Milieubeheer (VROM) in 2009 een geharmoniseerde rekenmethodiek ontwikkeld waarmee de $\mathrm{NH}_{3}$-emissie kan worden berekend uit stallen en mestopslagen voor de diercategorieën in de Landbouwtelling, en bij beweiding en toediening van meststoffen aan de bodem. Op verzoek van de Emissieregistratie (ER) is bij de berekening van emissiecijfers over onderstaande jaren het rekenmodel uitgebreid:

- 2012: uitbreiding met modules voor de berekening van $\mathrm{NO}, \mathrm{N}_{2} \mathrm{O}, \mathrm{CH}_{4}$ en fijnstof $\left(\mathrm{PM}_{10}\right.$ en $\left.\mathrm{PM}_{2,5}\right)$. De naam van het rekenmodel is daarop gewijzigd van Nationaal Emissie Model voor Ammoniak in National Emission Model for Agriculture;

- 2013: met de implementatie van de IPCC Guidelines 2006 is het model uitgebreid met de berekening van $\mathrm{CO}_{2}$-emissies uit kalkmeststoffen;

- 2017: uitbreiding met de berekening van emissies door mestbewerking. Tevens is in verband met internationale rapportageverplichtigingen een berekening van niet-methaan vluchtige organische stoffen (NMVOS) opgenomen;

- 2019: toevoeging van de berekening van $\mathrm{CO}_{2}$-emissies door het gebruik van ureum als meststof.

In dit rapport worden de uitgangspunten voor de berekeningen en de berekende niet-

energiegerelateerde emissies uit de landbouw van $\mathrm{NH}_{3}, \mathrm{NO}, \mathrm{N}_{2} \mathrm{O}, \mathrm{CH}_{4}, \mathrm{NMVOS}$, fijnstof $\left(\mathrm{PM}_{10}\right.$ en $\left.\mathrm{PM}_{2,5}\right)$ en $\mathrm{CO}_{2}$ uit kalkmeststoffen en ureum voor de periode 1990-2019 weergegeven. Dit rapport is de basis voor de formele rapportage over voornoemde emissies aan de Europese Unie (EU) om te toetsen of Nederland voldoet aan de NEC-richtlijn (National Emission Ceilings Directive; nationale emissieplafonds) en aan de UNECE (toetsing aan de emissieplafonds uit het Gothenburg Protocol). De resultaten worden eveneens gerapporteerd aan de UNFCCC in het kader van de Parijse Conventie (Klimaatverdrag). De toegepaste rekenmethodiek is uitgebreider beschreven in Van der Zee et al. (2021).

Vanaf 2021 zijn de werkzaamheden van de werkgroep NEMA overgenomen door een nieuwe Taakgroep van ER: de Taakgroep Landbouwemissies.

\section{Aanpassingen van de reeks 1990-2018}

Door de toepassing van nieuwe inzichten of door de vervanging van voorlopige cijfers door definitieve cijfers zijn de volgende onderwerpen gewijzigd ten opzichte van berekeningen over 1990-2018 in Van Bruggen et al. (2020):

- Aantal dieren in 2018 (Paragraaf 2.2);

- $\mathrm{NH}_{3}$-emissie uit stallen (Paragraaf 2.6);

- Mestscheiding bij intermediaire bedrijven en mestverwerkers (Paragraaf 2.9);

- Mesttoediening aan grasland en bouwland (Paragraaf 2.11);

- $\mathrm{NH}_{3}$-emissie bij bovengrondse toediening, bij toepassing sleepvoet en bij zodenbemesting op grasland (Paragraaf 2.11); 
- $\quad \mathrm{N}_{2} \mathrm{O}$-emissie bij toediening van dierlijke mest en kunstmest (Paragraaf 2.13 en 3.1);

- Kunstmestgebruik in 2018 (Paragraaf 3.1);

- Graslandvernieuwing in 2018 (Paragraaf 3.3);

- Emissies van niet-methaan vluchtige organische stoffen (NMVOS) (Hoofdstuk 6);

- $\mathrm{CO}_{2}$-emissie uit kalkmeststoffen en ureum (Hoofdstuk 8).

De tijdreeks 1990-2018 is opnieuw doorgerekend met de hiervoor genoemde aanpassingen en een berekening van het jaar 2019 is toegevoegd. De presentatie en discussie van de resultaten in dit rapport hebben steeds betrekking op de nieuwe reeks 1990-2019.

In Bijlage 1 is een overzicht weergegeven van alle wijzigingen in uitgangspunten die in de berekeningen zijn verwerkt sinds de start van de berekeningen met het model NEMA.

\section{$\mathbf{N}$-excretie van de veestapel}

In 2019 daalde het gemiddeld aantal melkkoeien en jongvee met respectievelijk 0,8 en 8,4 procent ten opzichte van 2018. De $\mathrm{N}$-excretie van de melkveestapel daalde met 10 miljoen $\mathrm{kg}$. De $\mathrm{N}$-excretie van de totale veestapel (excl. hobbydieren) daalde van 503,4 miljoen kg N in 2018 naar 489,7 miljoen $\mathrm{kg} \mathrm{N}$ in 2019. De daling van de $\mathrm{N}$-excretie in 2019 werkt door in de emissies uit stallen, uit mestopslagen, bij beweiding en bij mesttoediening.

\section{Ammoniak $\left(\mathrm{NH}_{3}\right)$}

\section{Totale $\mathrm{NH}_{3}$-emissie}

De totale $\mathrm{NH}_{3}$-emissie omvat emissies uit dierlijke mest, kunstmest, en overige bronnen in de landbouw, alsook emissies uit dierlijke mest en kunstmest bij particulieren en hobbybedrijven, en emissies bij het gebruik van dierlijke mest in natuurterreinen.

Sinds 1990 is de totale $\mathrm{NH}_{3}$-emissie met twee derde gedaald door een lagere $\mathrm{N}$-excretie van landbouwhuisdieren, het gebruik van emissiearme huisvesting, het afdekken van mestopslagen, het gebruik van emissiearme toedieningstechnieken en een daling van het kunstmestgebruik. De emissie daalde tot 2013, daarna nam in de periode 2014-2017 de emissie weer toe door de groei van de melkveestapel. In 2019 daalde de $\mathrm{NH}_{3}$-emissie ten opzichte van 2018 met 6,2 miljoen kg tot 112,0 miljoen $\mathrm{kg}$, voornamelijk door de krimp van de melkveestapel. Ook het kunstmestgebruik daalde in 2019 ten opzichte van 2018.

\section{Landbouwbedrijven}

De bijdrage van de landbouw aan de $\mathrm{NH}_{3}$-emissie in 2019 was 105,6 miljoen kg tegen 111,7 miljoen $\mathrm{kg}$ in 2018. De $\mathrm{NH}_{3}$-emissie uit stallen en mestopslagen van landbouwbedrijven daalde van 61,9 miljoen $\mathrm{kg}$ in 2018 tot 58,2 miljoen $\mathrm{kg}$ in 2019. Mestbewerking en beweiding zijn relatief kleine bronnen van $\mathrm{NH}_{3}$-emissie met respectievelijk 1,3 en 1,4 miljoen kg NH 3 in zowel 2018 als 2019. De $\mathrm{NH}_{3}$-emissie bij mesttoediening daalde van 33,4 tot 31,2 miljoen $\mathrm{kg} \mathrm{NH}$. De hoeveelheid $\mathrm{N}$ die via dierlijke mest door landbouwbedrijven aan de bodem wordt toegediend hangt niet alleen af van de omvang van de $\mathrm{N}$-excretie en van de $\mathrm{N}$ die verloren gaat in de stal of tijdens opslag, maar ook van de mestafzet buiten de landbouw en de $\mathrm{N}$-verliezen die optreden bij mestbewerking. De totale afzet buiten de landbouw door mestbe- en verwerking (o.a. export en verbranding) en afzet naar hobbybedrijven, particulieren en natuurterreinen inclusief ingeschaard vee van landbouwbedrijven nam toe van 74,5 miljoen $\mathrm{kg} \mathrm{N}\left(41,0\right.$ miljoen $\left.\mathrm{kg} \mathrm{P}_{2} \mathrm{O}_{5}\right)$ in 2018 tot 76,3 miljoen $\mathrm{kg} \mathrm{N}(42,1 \mathrm{miljoen} \mathrm{kg}$ $\mathrm{P}_{2} \mathrm{O}_{5}$ ) in 2019. De totale $\mathrm{NH}_{3}$-emissie uit dierlijke mest (stallen, mestopslagen, mestbewerking, mesttoediening en beweiding) daalde van 98,0 miljoen $\mathrm{kg}$ in 2018 tot 92,2 miljoen kg in 2019.

In 2019 bedroeg de $\mathrm{NH}_{3}$-emissie uit kunstmest en spuiwater in de landbouw 8,8 miljoen kg, 0,5 miljoen $\mathrm{kg}$ minder dan in 2018. De $\mathrm{NH}_{3}$-emissie uit het totale gebruik van kunstmest en spuiwater in de landbouw is sinds 1990 met 34\% gedaald. Het laagste niveau werd bereikt in 2010 met 8,1 miljoen $\mathrm{kg} \mathrm{NH}$. Daarna nam tot 2015 de emissie toe door een toename van het kunstmestgebruik en een hoger aandeel ureumhoudende meststoffen.

De $\mathrm{NH}_{3}$-emissie uit overige bronnen in de landbouw zoals het gebruik van zuiveringsslib en compost, afrijping van gewassen en gewasresten bedroeg in 2019 4,6 miljoen $\mathrm{kg} \mathrm{NH}_{3}$ tegen 4,5 miljoen $\mathrm{kg}$ in 2018. 
Dierlijke mest en overige bronnen bij hobbybedrijven, particulieren en natuurterreinen

De $\mathrm{NH}_{3}$-emissie uit dierlijke mest, kunstmest en overige bronnen bij hobbybedrijven en particulieren en bij de mestafzet op natuurterreinen daalde van 6,5 miljoen kg in 2018 tot 6,4 miljoen kg in 2019.

\section{Lachgas $\left(\mathrm{N}_{\mathbf{2}} \mathrm{O}\right)$ en stikstofoxide (NO)}

De $\mathrm{N}_{2} \mathrm{O}$-emissie bedroeg in 201918,8 miljoen $\mathrm{kg}$, een daling van 0,6 miljoen $\mathrm{kg}$ ten opzichte van 2018. De NO-emissie daalde in 2019 ten opzichte van 2018 met 0,7 miljoen $\mathrm{kg}$ tot 21,7 miljoen kg. De oorzaken voor de emissiedaling zijn grotendeels dezelfde als die voor de emissiedaling van $\mathrm{NH}_{3}$, namelijk een lagere $\mathrm{N}$-excretie door afname van het aantal runderen, varkens en kippen en een daling van het kunstmestgebruik.

Sinds 1990 daalden de emissies van $\mathrm{N}_{2} \mathrm{O}$ en NO met respectievelijk $42 \%$ en $35 \%$. De daling van de emissies trad op in de periode vóór 2010. De afname van de $\mathrm{N}_{2} \mathrm{O}$ - en NO-emissies zijn minder sterk dan de afname van de $\mathrm{NH}_{3}$-emissie. De verklaring hiervoor is dat de $\mathrm{N}_{2} \mathrm{O}$-emissie toeneemt bij emissiearme mesttoediening (geïmplementeerd in de periode 1990-1995). Daarnaast verlaagt emissiearme huisvesting alleen de stalemissie van $\mathrm{NH}_{3}$ en niet die van $\mathrm{N}_{2} \mathrm{O}$ en $\mathrm{NO}$. Emissiearme mesttoediening is gepaard gegaan met een daling van het kunstmestgebruik waardoor de $\mathrm{N}_{2} \mathrm{O}$-emissie en NO-emissie uit kunstmest zijn gedaald. Daarnaast is de NO-emissie toegenomen door een verschuiving van het aandeel excretie tijdens beweiden, naar excretie in de stal.

\section{Methaan $\left(\mathrm{CH}_{4}\right)$}

De totale emissie van $\mathrm{CH}_{4}$ daalde van 484 miljoen $\mathrm{kg}$ in 2018 tot 480 miljoen $\mathrm{kg}$ in 2019. De belangrijkste oorzaak van deze daling is de krimp van de melkveestapel.

Tussen 1990 en 2019 daalde de emissie van $\mathrm{CH}_{4}$ met 18\% door een afname van de dieraantallen en hogere voerefficiënties van melkvee ten opzichte van 1990. Daarnaast nam bij varkens en pluimvee de excretie van organische stof per dier af en daarmee de $\mathrm{CH}_{4}$-emissie uit de mestopslag. Het laagste niveau werd bereikt in 2005, daarna nam de emissie tot 2016 geleidelijk toe. In 2017 zette een daling in door de krimp van de melkveestapel.

\section{Niet-methaan vluchtige organische stoffen (NMVOS)}

De emissie van NMVOS daalde van 89,6 miljoen $\mathrm{kg}$ in 2018 naar 87,8 miljoen $\mathrm{kg}$ in 2019, voornamelijk door de verminderde voedering van kuilvoer die samenhangt met de krimp van de melkveestapel. Vanaf 1990 zijn de NMVOS-emissies aanvankelijk gedaald, in lijn met lagere rundveeaantallen. In de periode 2014-2017 was sprake van een stijging door een toename van het aantal runderen.

\section{Fijnstof ( $\mathrm{PM}_{10}$ en $\mathrm{PM}_{2,5}$ )}

De emissie van $\mathrm{PM}_{10}$ daalde van 5,9 miljoen $\mathrm{kg}$ in 2018 naar 5,4 miljoen $\mathrm{kg}$ in 2019. De emissie van $\mathrm{PM}_{2,5}$ bedroeg in 2018 0,6 miljoen $\mathrm{kg}$ en in 2019 0,5 miljoen $\mathrm{kg}$. De daling van de fijnstofuitstoot hangt samen met het toegenomen gebruik van additionele technieken voor verwijdering van fijnstof bij pluimveestallen.

Sinds 1990 is de emissie van $\mathrm{PM}_{10}$ uit huisvesting van landbouwhuisdieren per saldo toegenomen van 4,9 naar 5,4 miljoen $\mathrm{kg}$, een toename van $9 \%$. Dit komt met name door de verandering in de huisvesting van pluimvee. Batterijsystemen met natte mest zijn volledig vervangen door huisvesting met vaste mest met als gevolg een hogere emissie van fijnstof. Batterijsystemen komen na 2012 niet meer voor. De emissie van $\mathrm{PM}_{2,5}$ is nagenoeg gelijk gebleven.

\section{Koolstofdioxide $\left(\mathrm{CO}_{2}\right)$ uit kalkmeststoffen en ureum}

De $\mathrm{CO}_{2}$-emissie door het gebruik van kalkmeststoffen en ureumhoudende meststoffen daalde van 83,1 miljoen $\mathrm{kg}$ in 2018 tot 80,1 miljoen kg in 2019. Sinds 1990 daalde de $\mathrm{CO}_{2}$-emissie uit kalkmeststoffen en nam de $\mathrm{CO}_{2}$-emissie uit ureum toe. Per saldo daalde de $\mathrm{CO}_{2}$-emissie uit kalkmeststoffen en ureum met 57\% van 184,7 miljoen kg in 1990 naar 80,1 miljoen kg in 2019. 



\title{
Summary
}

\author{
Background \\ Dutch agriculture is a major source of non-energy-related emissions of ammonia $\left(\mathrm{NH}_{3}\right)$, nitrogen oxide \\ (NO), nitrous oxide $\left(\mathrm{N}_{2} \mathrm{O}\right)$, methane $\left(\mathrm{CH}_{4}\right)$, non-methane volatile organic compounds (NMVOC) and \\ particulate matter $\left(\mathrm{PM}_{10}\right.$ and $\left.\mathrm{PM} \mathrm{M}_{2.5}\right)$ and carbon dioxide $\left(\mathrm{CO}_{2}\right)$ from lime fertilisers and urea. Ammonia \\ and nitrogen oxide contribute to eutrophication and acidification of soils, surface waters and terrestrial \\ ecosystems. Nitrous oxide and methane are greenhouse gases and nitrous oxide also plays a part in \\ damaging the stratospheric ozone layer. Particulate matter affects human and animal health. In \\ addition, agricultural nitrogen $(\mathrm{N})$ emissions reduce $\mathrm{N}$ use efficiency in agriculture. The emissions of \\ these substances are calculated annually using the National Emission Model for Agriculture (NEMA) \\ and are reported to the European Commission and the United Nations.
}

The NEMA working group of the Dutch Scientific Committee on Nutrient Management Policy (CDM) was commissioned by the Ministry of Agriculture, Nature and Food Quality (LNV) and the former Ministry of Housing, Spatial Planning and the Environment (VROM) to develop a method to calculate $\mathrm{NH}_{3}$ emissions. The method, developed in 2009, includes the emissions from animal housing and manure storage for livestock categories in the Dutch agricultural census, as well as from livestock grazing in pastures and applications of livestock manure and fertilisers to the soil.

At the request of the Pollutant Release and Transfer Register (PRTR; in Dutch: Emissieregistratie (ER)), from 2012 the National Emission Model for Ammonia was expanded with the inclusion of modules for the calculation of other nitrogen losses during grazing and manure application (NO and $\mathrm{N}_{2} \mathrm{O}$ ) and for agricultural emissions of $\mathrm{CH}_{4}$ and particulate matter. The name of the model was then changed to the National Emission Model for Agriculture. Under the implementation of the 2006 IPCC Guidelines in 2013, a module for the calculation of $\mathrm{CO}_{2}$ from lime fertilisers was also added. From 2017, the model was extended to include the calculation of emissions from manure processing and, to meet international obligations, emissions of NMVOC. In 2019 the $\mathrm{CO}_{2}$ emissions from the application of urea fertiliser were added for the entire time series.

The model results are used in reports to the European Union (EU) for assessing whether the Netherlands is in compliance with the National Emissions Ceilings Directive and with the UNECE (Gothenburg Protocol). The results are also reported to the UNFCCC in the context of the Paris Agreement on climate change.

This report presents the calculation methodology, activity data and calculated emissions of ammonia, nitrous oxide, nitrogen oxide, methane, particulate matter and carbon dioxide from agriculture used in national and international emission inventory reports. Extended information on the methodology is available in Van der Zee et al. (2021).

\section{Changes in the time series 1990-2018}

The calculations for the period 1990-2018 in Van Bruggen et al. (2020) have been revised by the application of new insights and the replacement of provisional figures by definitive figures for the following items:

- livestock numbers in 2018 (section 2.2);

- $\mathrm{NH}_{3}$ emissions from housing (section 2.6);

- manure separation by intermediate companies and manure processors (section 2.9);

- manure application on grassland and arable land (section. 2.11);

- $\mathrm{NH}_{3}$-emissions from shallow injection on grassland (section 2.11);

- $\mathrm{N}_{2} \mathrm{O}$-emissions from application of livestock manure and artificial fertilisers (section 2.13 and 3.1 );

- fertiliser use in 2018 (section 3.1);

- grassland renewal in 2018 (section 3.3);

- emissions of non-methane organic volatile compounds (NMVOC) (Chapter 6); 
- $\mathrm{CO}_{2}$ emissions from lime fertilisers and urea (Chapter 8).

The time series 1990-2018 has been recalculated with the above amendments and the results of the 2019 calculation have been added. The discussion of the results presented in this report refers to the new time series 1990-2019.

An overview of all changes in the time series that have been made since the first calculations with the NEMA model is given in Appendix 1.

\section{Livestock $\mathbf{N}$ excretion}

In 2019 the average number of dairy cows and young stock fell by 0.8 and 8.4 per cent respectively from the numbers in 2018 . The $\mathrm{N}$ excretion of the dairy herd decreased by 10 million $\mathrm{kg}$. The $\mathrm{N}$ excretion of the total livestock (excluding hobby animals) decreased from 503.4 million $\mathrm{kg}$ in 2018 to 489.7 million $\mathrm{kg}$ in 2019. The decrease in $\mathrm{N}$ excretion in 2019 is reflected in the emissions from animal houses, from manure storage, during grazing and from manure application.

\section{Ammonia $\left(\mathrm{NH}_{3}\right)$}

Total $\mathrm{NH}_{3}$ emission

Total $\mathrm{NH}_{3}$ emissions consist of emissions from manure, fertilisers and other sources in agriculture, emissions from the use of manure and fertilisers on hobby farms and by private persons, and emissions from the use of manure in terrestrial ecosystems. Since $1990, \mathrm{NH}_{3}$ emissions from livestock manure, fertiliser and other sources have fallen by two-thirds due to lower livestock $\mathrm{N}$ excretion, the use of low-emission application techniques, use of low-emission housing, covering outside manure stores and reduced use of fertiliser. Emissions decreased until 2013, after which emissions increased again due to the growth of the dairy herd until 2017. In 2019, $\mathrm{NH}_{3}$ emissions were 112.0 million $\mathrm{kg}$, a reduction of 6.2 million $\mathrm{kg}$ from 2018, mainly as a result of the reduction in the size of the dairy herd.

\section{Agriculture}

The contribution by agriculture to $\mathrm{NH}_{3}$ emissions in 2019 was 105.6 million $\mathrm{kg}$, compared with 111.7 million $\mathrm{kg}$ in 2018. The $\mathrm{NH}_{3}$ emissions from animal housing and manure storage facilities decreased from 61.9 million $\mathrm{kg}$ in 2018 to 58.2 million $\mathrm{kg}$ in 2019. Manure treatment and grazing are relatively small sources of $\mathrm{NH}_{3}$ emissions at 1.3 and 1.4 million $\mathrm{kg} \mathrm{NH}$ respectively in both 2018 and 2019. The $\mathrm{NH}_{3}$ emissions from manure application decreased from 33.4 to 31.2 million $\mathrm{kg} \mathrm{NH}_{3}$. The amount of $\mathrm{N}$ applied to the soil by agricultural holdings in the form of livestock manure depends on the livestock $\mathrm{N}$ excretion rate and the $\mathrm{N}$ losses from animal houses and manure storage, on the manure disposal outside agriculture and on $\mathrm{N}$ losses from manure treatment. Manure is not defined as agricultural if it is processed (export and incineration) and/or delivered to hobby farms or private persons, applied in terrestrial ecosystems or produced by cattle grazing in nature conservation areas. The amount of this 'non-agricultural' manure and losses from manure treatment increased from 74.5 million kg N (41.0 million $\mathrm{kg} \mathrm{P}_{2} \mathrm{O}_{5}$ ) in 2018 to 76.3 million $\mathrm{kg} \mathrm{N}$ (42.1 million $\mathrm{kg} \mathrm{P}_{2} \mathrm{O}_{5}$ ) in 2019. Total $\mathrm{NH}_{3}$ emissions from livestock manure decreased from 98.0 million $\mathrm{kg}$ in 2018 to 92.2 million $\mathrm{kg}$ in 2019.

In 2019, $\mathrm{NH}_{3}$ emissions from fertiliser and effluent from air scrubbers in agriculture amounted to 8.8 million kg, 0.5 million $\mathrm{kg}$ less than in 2018. Ammonia emissions from the use of fertilisers and effluent from air scrubbers in agriculture, on hobby farms and from private use have fallen by $32 \%$ since 1990. The lowest level was 8.1 million $\mathrm{kg} \mathrm{NH}_{3}$ in 2010. Emissions then increased until 2015 due to an increase in fertiliser use and a higher proportion of urea.

Emissions of $\mathrm{NH}_{3}$ from other agricultural sources, such as the use of sewage sludge and compost, ripening of crops and crop residues amounted to 4.6 million $\mathrm{kg} \mathrm{NH}_{3}$ in 2019 , against 4.5 million $\mathrm{kg}$ in 2018.

Livestock manure and other sources on hobby farms, from private use and in terrestrial ecosystems The $\mathrm{NH}_{3}$ emissions from the production and use of manure, fertiliser and other sources on hobby farms and by private persons and from manure application in terrestrial ecosystems decreased from 6.5 million $\mathrm{kg}$ in 2018 to 6.4 million $\mathrm{kg}$ in 2019. 


\section{Nitrous oxide $\left(\mathrm{N}_{2} \mathrm{O}\right)$ and nitrogen oxide (NO)}

Nitrogen oxide emissions in 2019 amounted 18.8 million kg, a decrease of 0.6 million $\mathrm{kg}$ from 2018. Nitrous oxide emissions decreased in 2019 by 0.7 million $\mathrm{kg}$ to 21.7 million $\mathrm{kg}$. The causes for the decrease in emissions are largely the same as for the decrease in $\mathrm{NH}_{3}$ emissions, namely a lower $\mathrm{N}$ excretion due to a decrease in the number of cattle, pigs and poultry and a decrease in fertiliser use.

Since 1990, $\mathrm{N}_{2} \mathrm{O}$ and $\mathrm{NO}$ emissions have decreased by $42 \%$ and $35 \%$ respectively. This decrease occurred in the period before 2010. The reductions in $\mathrm{N}_{2} \mathrm{O}$ and $\mathrm{NO}$ emissions are smaller than the reduction in $\mathrm{NH}_{3}$ emissions because $\mathrm{N}_{2} \mathrm{O}$ emissions increase with low-emission manure application (implemented in the period 1990-1995). In addition, low-emission housing only reduces the housing emission of $\mathrm{NH}_{3}$ but not that of $\mathrm{N}_{2} \mathrm{O}$ and $\mathrm{NO}$, because these emissions are related to total $\mathrm{N}$ excretion in the calculation model. The introduction of low-emission manure application has reduced fertiliser use, which has led to a reduction in $\mathrm{N}_{2} \mathrm{O}$ and $\mathrm{NO}$ emissions from fertilisers. Conversely, NO emissions have increased due to a shift from excretion during grazing to excretion in the animal house.

\section{Methane $\left(\mathrm{CH}_{4}\right)$}

Total $\mathrm{CH}_{4}$ emissions decreased from 484 million $\mathrm{kg}$ in 2018 to 480 million $\mathrm{kg}$ in 2019. The main cause of this decrease is the reduction in the number of dairy cattle.

Between 1990 and 2018, emissions of $\mathrm{CH}_{4}$ decreased by $18 \%$, which can be explained by a reduction in animal numbers and higher feed efficiencies of dairy cattle compared with 1990. In addition, the excretion of organic matter by pig and poultry categories decreased, resulting in lower $\mathrm{CH}_{4}$ emissions from manure storage. The lowest level was reached in 2005, after which emissions increased gradually until 2016, but started to decline again in 2017 due to a reduction in the size of the dairy herd.

\section{Non-methane volatile organic compounds (NMVOC)}

Emissions of NMVOC decreased from 89.6 million $\mathrm{kg}$ in 2018 to 87.8 million $\mathrm{kg}$ in 2019, mainly as a result of lower silage use associated with the reduction in the number of dairy cattle. From 1990, NMVOC emissions at first decreased in line with lower cattle numbers, but more recently emissions increased again until 2017 due to an increase in the number of cattle.

\section{Particulate matter ( $\mathbf{P M}_{10}$ and $\left.\mathbf{P M}_{\mathbf{2 . 5}}\right)$}

Emissions of $\mathrm{PM}_{10}$ decreased from 5.9 million $\mathrm{kg}$ in 2018 to 5.4 million $\mathrm{kg}$ in 2019. Emissions of $\mathrm{PM}_{2.5}$ amounted to 0.6 million $\mathrm{kg}$ in 2018 and 0.5 million $\mathrm{kg}$ in 2019. The decrease in PM emissions is related to the increased use of additional techniques for the removal of particulate matter from poultry housing.

Since 1990, $\mathrm{PM}_{10}$ emissions from animal housing have increased on balance from 4.9 to 5.4 million $\mathrm{kg}$, a $9 \%$ increase. This is mainly due to changes in poultry housing systems. Battery systems with slurry manure have been completely replaced by systems with solid manure, resulting in higher emissions of particulate matter. Battery systems were completely phased out in 2012. Emissions of $\mathrm{PM}_{2.5}$ have remained virtually unchanged.

\section{Carbon dioxide $\left(\mathrm{CO}_{2}\right)$ from lime fertilisers and urea fertiliser}

Emissions of $\mathrm{CO}_{2}$ from the use of lime fertilisers and urea decreased from 83.1 million $\mathrm{kg}$ in 2018 to 80.1 million $\mathrm{kg}$ in 2019. Since 1990, $\mathrm{CO}_{2}$ emissions from lime fertilisers have decreased and $\mathrm{CO}_{2}$ emissions from urea have increased. On average, $\mathrm{CO}_{2}$ emissions from lime fertilisers and urea have decreased by 57\% from 184.7 million $\mathrm{kg}$ in 1990 to 80.1 million $\mathrm{kg}$ in 2019. 



\section{$1 \quad$ Inleiding}

\section{Achtergrond}

De landbouw in Nederland is een belangrijke bron van niet aan energie gerelateerde emissies van ammoniak $\left(\mathrm{NH}_{3}\right)$, stikstofoxide (NO), lachgas $\left(\mathrm{N}_{2} \mathrm{O}\right)$, methaan $\left(\mathrm{CH}_{4}\right)$, niet-methaan vluchtige organische stoffen (NMVOS), fijnstof $\left(\mathrm{PM}_{10}\right.$ en $\left.\mathrm{PM}_{2,5}\right)$ en koolstofdioxide $\left(\mathrm{CO}_{2}\right)$ uit kalkmeststoffen en ureum. Emissies van $\mathrm{NH}_{3}$ en $\mathrm{NO}$ dragen bij aan vermesting van natuurgebieden en verzuring van de bodem. $\mathrm{N}_{2} \mathrm{O}$ en $\mathrm{CH}_{4}$ zijn broeikasgassen en $\mathrm{N}_{2} \mathrm{O}$ tast bovendien de ozonlaag aan. Fijnstof heeft een nadelig effect op de gezondheid van mens en dier. Emissies van stikstof $(\mathrm{N})$ in de vorm van $\mathrm{NH}_{3}, \mathrm{~N}_{2} \mathrm{O}$ en NO uit de landbouw verlagen de N-benutting in de landbouw.

De emissies van genoemde stoffen worden jaarlijks berekend met het National Emission Model for Agriculture (NEMA) en gerapporteerd aan de Europese Commissie en aan de Verenigde Naties.

De werkgroep National Emission Model for Agriculture (NEMA) van de Commissie van Deskundigen Meststoffenwet (CDM) heeft in opdracht van het ministerie van Landbouw, Natuur en Voedselkwaliteit (LNV) en het toenmalige ministerie van Volkshuisvesting, Ruimtelijke Ordening en Milieubeheer (VROM) in 2009 een geharmoniseerde rekenmethodiek ontwikkeld waarmee de $\mathrm{NH}_{3}$-emissie kan worden berekend uit stallen en mestopslagen voor de diercategorieën in de Landbouwtelling, bij beweiding en bij toediening van dierlijke mest en kunstmest aan de bodem (Velthof et al., 2009; Velthof et al., 2012; Vonk et al., 2016; Vonk et al., 2018; Lagerwerf et al., 2019; Van der Zee et al., 2021).

Op verzoek van de Emissieregistratie (ER) is bij de berekening van emissiecijfers over 2012 het rekenmodel uitgebreid met modules voor de berekening van $\mathrm{CH}_{4}$ uit pens- en darmfermentatie en uit stallen en mestopslagen, $\mathrm{NO}$ - en $\mathrm{N}_{2} \mathrm{O}$-verliezen bij beweiding en bij toediening van dierlijke mest en kunstmest aan de bodem en met een module voor de berekening van fijnstof. De naam van het rekenmodel is daarop gewijzigd van Nationaal Emissie Model voor Ammoniak in National Emission Model for Agriculture. Met de implementatie van de 2006 IPCC Guidelines (IPCC, 2006) bij de berekening van emissiecijfers over 2013 is het model verder uitgebreid met de berekening van $\mathrm{CO}_{2}-$ emissies uit kalkmeststoffen. Bij de berekening van emissiecijfers over 2017 is het model uitgebreid met de berekening van emissies van mestbewerking en met de berekening van NMVOS. Emissies van NMVOS moeten ook internationaal worden gerapporteerd. Bij de berekening van emissiecijfers over 2019 is de $\mathrm{CO}_{2}$-emissie uit het gebruik van ureum als meststof toegevoegd.

\section{Doelstelling}

Dit rapport heeft als doel om de uitgangspunten en de uitkomsten van de emissieberekeningen voor $\mathrm{NH}_{3}, \mathrm{NO}, \mathrm{N}_{2} \mathrm{O}, \mathrm{CH}_{4}$, fijnstof $\left(\mathrm{PM}_{10}\right.$ en $\left.\mathrm{PM}_{2,5}\right)$, NMVOS en $\mathrm{CO}_{2}$ uit kalkmeststoffen en ureum uit de landbouw in 1990-2019 te beschrijven. Op basis hiervan kan de Emissieregistratie (ER) de landelijke emissies van $\mathrm{NH}_{3}$, NO, NMVOS en fijnstof rapporteren aan de Europese Commissie en aan de UNECE (Convention on Long-Range Transboundary Air Pollution; CLRTAP) middels het Informative Inventory Report (IIR). Met dit rapport wordt getoetst of Nederland voldoet aan de NEC-richtlijn van de Europese Commissie (National Emission Ceilings Directive; nationale emissieplafonds) en het Gothenburg Protocol van de UNECE. Daarnaast gebruikt de ER de resultaten van de emissieberekeningen van $\mathrm{N}_{2} \mathrm{O}, \mathrm{CH}_{4}$ en $\mathrm{CO}_{2}$ voor rapportage hierover aan de UNFCCC door middel van de NIR (United Nations Framework Convention on Climate Change - National Inventory Report) en voor rapportage in het kader van de Parijse Conventie.

De resultaten en de berekeningen met het NEMA-model worden ook gebruikt voor andere studies, zoals beleidsevaluaties, emissieramingen van het Planbureau voor de Leefomgeving (PBL), het neerschalen van emissies naar lokaal niveau voor depositieberekeningen en verkenningen van de effectiviteit van maatregelen om ammoniakemissies te beperken. 
De emissies van $\mathrm{NH}_{3}, \mathrm{NO}, \mathrm{N}_{2} \mathrm{O}, \mathrm{CH}_{4}$, fijnstof $\left(\mathrm{PM}_{10}\right.$ en $\left.\mathrm{PM}_{2,5}\right)$, NMVOS en $\mathrm{CO}_{2}$ in 1990-2019 zijn berekend met NEMA op basis van de nieuwste wetenschappelijke inzichten, informatie uit de Landbouwtelling (CBS) en met toepassing van het EMEP Guidebook 2019 en de IPCC Guidelines 2006. De methodiek is beschreven in Van der Zee et al. $\left(2021^{1}\right)$.

\section{Methode}

De emissies naar lucht worden berekend door de omvang van een bron (activiteit) te vermenigvuldigen met een emissiefactor. Deze berekening kan op verschillende niveaus worden uitgevoerd. Voor de bronnen die uit oogpunt van het aandeel in de emissies het belangrijkst zijn, wordt zo mogelijk een landspecifieke (IPCC ${ }^{2}$ Tier 3) methode toegepast. Voor minder belangrijke bronnen kan een IPCC Tier 2-benadering worden gevolgd, waarbij bijvoorbeeld de activiteitendata landspecifiek zijn maar de emissiefactoren niet. Voor de minst belangrijke bronnen worden IPCC 2006 standaard emissiefactoren toegepast (Tier 1), bijvoorbeeld een emissiefactor per dier. Voor een uitgebreide beschrijving van de methodiek en de keuze voor een bepaalde Tier-benadering wordt verwezen naar Van der Zee et al. (2021).

Bij aanpassingen in de rekenmethode of bepaalde uitgangspunten wordt de gehele beschikbare tijdreeks vanaf 1990 opnieuw doorgerekend. Dit betekent dat de historische reeks vanaf 1990 is veranderd in de loop van de tijd. In Van Bruggen et al. (2011a, 2011b, 2012 en 2013) zijn de uitgangspunten gedocumenteerd die zijn toegepast in eerdere berekeningen van de $\mathrm{NH}_{3}$-emissie in respectievelijk de periode 1990-2008, 1990-2009, 1990-2010 en 1990-2011. In Van Bruggen et al. (2014, 2015, 2017a, 2017b, 2018, 2019 en 2020) zijn de uitgangpunten opgenomen van de berekening van emissies van $\mathrm{NH}_{3}, \mathrm{~N}_{2} \mathrm{O}, \mathrm{NO}, \mathrm{CH}_{4}$ en fijnstof in respectievelijk de periode 1990-2012, 1990-2013, 1990-2014, 1990-2015, 1990-2016, 1990-2017 en 1990-2018.

In dit WOt-technical report worden de uitgangspunten beschreven die zijn toegepast bij de berekening van de emissies van $\mathrm{NH}_{3}, \mathrm{NO}, \mathrm{N}_{2} \mathrm{O}, \mathrm{CH}_{4}$, fijnstof $\left(\mathrm{PM}_{10}\right.$ en $\mathrm{PM}_{2,5}$ ), $\mathrm{NMVOS}$ en $\mathrm{CO}_{2}$ (uit kalkmeststoffen en ureum) in de periode 1990-2019.

\section{Leeswijzer}

In hoofdstuk 2 zijn de uitgangspunten van 2019 voor de emissies van $\mathrm{NH}_{3}$ en overige $\mathrm{N}$-verbindingen uit dierlijke mest weergegeven en vergeleken met de uitgangspunten voor 2018.

In hoofdstuk 3 staan de uitgangspunten voor overige bronnen zoals kunstmest, compost, zuiveringsslib, gewasresten, afrijpende gewassen en organische bodems.

Hoofdstuk 4 behandelt de indirecte $\mathrm{N}_{2} \mathrm{O}$-emissie door atmosferische depositie van $\mathrm{NH}_{3}$ en $\mathrm{NO}$, en door uit- en afspoeling van $\mathrm{N}$.

Hoofdstuk 5 geeft de uitgangspunten weer voor de berekening van $\mathrm{CH}_{4}$-emissies door pens- en darmfermentatie, uit opgeslagen mest en door mestbewerkingstechnieken.

In hoofdstuk 6 staan de uitgangspunten voor de berekening van emissies van NMVOS.

In hoofdstuk 7 zijn de uitgangspunten voor de berekening van fijnstofemissies en in hoofdstuk 8 voor emissies van $\mathrm{CO}_{2}$ uit kalkmeststoffen en ureum weergegeven.

De resultaten in de vorm van nationale emissies zijn opgenomen in hoofdstuk 9. De emissies uit stal en opslag, tijdens beweiding en bij mesttoediening zijn per diercategorie in een tijdreeks weergegeven.

Ten slotte wordt in hoofdstuk 10 ingegaan op onzekerheden bij de berekeningen en op de vergelijkbaarheid van de uitkomsten in de tijd.

\footnotetext{
${ }^{1}$ Het rapport van Van der Zee et al. (2021) is een update van het rapport van Lagerwerf et al. (2019).

${ }^{2}$ Intergovernmental Panel on Climate Change.
} 
In de Bijlagen worden de belangrijkste uitgangspunten in de tijdreeks 1990-2019 weergegeven. Andere uitgangspunten uit NEMA kunnen bij de eerste auteur worden opgevraagd. Een overzicht van de datastromen die gebruikt worden voor de berekening van ammoniakemissies met NEMA staan samengevat in een infographic:

(http://www.emissieregistratie.nl/erpubliek/documenten/Lucht\%20(Air)/Landbouw\%20en\%20Natuur \%20(Agriculture\%20and\%20Nature)/201119 LNV-databronnen-ammoniak VD-v04.pdf). 



\section{Ammoniakemissie en andere directe stikstofverliezen uit dierlijke mest}

\section{$2.1 \quad$ Inleiding}

De emissie van $\mathrm{NH}_{3}$ uit dierlijke mest wordt in het rekenmodel NEMA berekend door de hoeveelheid Totaal Ammoniakaal N (TAN) in de mest te vermenigvuldigen met emissiefactoren op basis van TAN. De uitgescheiden hoeveelheid TAN wordt berekend uit de totale $\mathrm{N}$-excretie per diercategorie en het percentage TAN hierin, waarbij TAN is gedefinieerd als urine- $N$. Voor de dunne mest van rundvee en varkens wordt rekening gehouden met $10 \%$ netto mineralisatie van de organische $\mathrm{N}$-excretie tijdens de mestopslag. Bij vaste mest, uitgezonderd de mest van pluimvee, wordt uitgegaan van $25 \%$ immobilisatie van TAN direct tijdens de mestopslag.

De $\mathrm{NH}_{3}$-emissies worden berekend per diercategorie en gesplitst naar bron: stal, opslag buiten de stal, mestbe- en verwerking, beweiding en mesttoediening. De berekening van de $\mathrm{NH}_{3}$-emissies uit mestopslag buiten de stal en bij mesttoediening zijn gebaseerd op de hoeveelheid TAN in de mest die overblijft na aftrek van de emissies die in een eerdere fase zijn opgetreden.

De hoeveelheid uitgescheiden $\mathrm{N}$ in de stal en in de weide wordt berekend door het aantal dieren per diercategorie in de Landbouwtelling (Paragraaf 2.2) te vermenigvuldigen met $\mathrm{N}$-excretiefactoren voor excretie in de stal en excretie in de weide per dier per jaar (Paragraaf 2.3). Het aandeel TAN in de uitgescheiden $\mathrm{N}$ is afhankelijk van de stikstofverteerbaarheid van het rantsoen (Paragraaf 2.3) en de netto mineralisatie van de organische $\mathrm{N}$ in de feces (Paragraaf 2.4).

De emissie van $\mathrm{NH}_{3}$ uit stallen is gebaseerd op de implementatiegraden van stalsystemen en de emissiefactoren van die stalsystemen (Paragrafen 2.5 en 2.6). Een deel van de mest wordt buiten de stal opgeslagen. Tijdens deze mestopslag treedt ook $\mathrm{NH}_{3}$-emissie op. Om hiervan de emissie te berekenen, moet eerst worden vastgesteld wat de omvang is van het $\mathrm{N}$-verlies in de stal door $\mathrm{NH}_{3}$ emissie en door verliezen in de vorm van $\mathrm{N}_{2} \mathrm{O}$, NO en $\mathrm{N}_{2}$ (Paragraaf 2.7). Vervolgens wordt per mestsoort vastgesteld hoeveel mest buiten de stal wordt opgeslagen (Paragraaf 2.8).

Vervolgens worden de emissies berekend die optreden tijdens mestbewerking en -verwerking (Paragraaf 2.9). Voordat de emissies tijdens het uitrijden op grasland en bouwland kunnen worden berekend, wordt de mestafzet buiten de landbouw in mindering gebracht (Paragraaf 2.10). De emissies die optreden tijdens het uitrijden op grasland en bouwland zijn afhankelijk van de verdeling van de mest over grasland, onbeteeld en beteeld bouwland en van de implementatiegraden en de emissiefactoren van de toegepaste toedieningstechnieken (Paragraaf 2.11).

De berekening van de $\mathrm{NH}_{3}$-emissie tijdens beweiding is naast het aantal weide-uren per diersoort voor alle graasdieren gebaseerd op de emissiefactor die is afgeleid voor de TAN-excretie van melkkoeien in het weideseizoen (Paragraaf 2.12).

$\mathrm{Na}$ het uitrijden van dierlijke mest en tijdens beweiding vindt ook emissie plaats van overige $\mathrm{N}$ verbindingen door nitrificatie en denitrificatie $\left(\mathrm{N}_{2} \mathrm{O} \text { en NO, Paragraaf } 2.13\right)^{3}$.

\subsection{Dieraantallen}

\section{Dieren op landbouwbedrijven}

De Landbouwtelling is als onderdeel van de Gecombineerde Opgave (GO) de bron van het aantal dieren per diercategorie. In de Landbouwtelling (peildatum 1 april) worden alleen dieren geteld die voorkomen op landbouwbedrijven. Met ingang van 2016 wordt voor de afbakening van de

\footnotetext{
${ }^{3}$ Er treden ook $\mathrm{N}_{2}$-verliezen door denitrificatie op uit de bodem, maar deze hoeven niet te worden gerapporteerd en zijn niet van invloed op de berekeningen van emissies van $\mathrm{NH}_{3}$, NO en $\mathrm{NOx}$ uit de bodem. Er worden geen berekeningen van $\mathrm{N}_{2}-$ emissies uit de bodem uitgevoerd met NEMA.
} 
Landbouwtelling gebruik gemaakt van informatie uit het Handelsregister. Inschrijving in het Handelsregister met een agrarische SBI (Standaard BedrijfsIndeling) is leidend bij de bepaling of er sprake is van een landbouwbedrijf. Met deze afbakening wordt zo nauw mogelijk aangesloten bij de statistische verordeningen van Eurostat en de (Nederlandse) implementatie van het begrip 'actieve landbouwer' uit het Gemeenschappelijk Landbouwbeleid (GLB). De afbakening van de Landbouwtelling op basis van informatie uit het Handelsregister heeft vooral invloed gehad op het aantal bedrijven, hier trad een duidelijke trendbreuk op. De invloed op arealen (behalve bij niet-cultuurgrond en natuurlijk grasland) en op dieraantallen waren beperkt, behalve bij schapen, paarden en pony's. Dit heeft met name te maken met het soort bedrijven dat bij de afbakening op basis van het Handelsregister wordt uitgesloten, zoals maneges, kinderboerderijen en natuurbeherende organisaties.

\section{Hobbymatig gehouden dieren}

Vóór de gewijzigde afbakening van de Landbouwtelling vond al een bijtelling plaats van het geschatte aantal paarden en pony's dat niet op landbouwbedrijven voorkomt. De emissies van deze categorieën werden afzonderlijk berekend en weergegeven. Met ingang van 2016 is deze bijtelling verhoogd met het aantal paarden en pony's dat door de gewijzigde afbakening van landbouwbedrijven buiten de Landbouwtelling valt. Daarnaast wordt nu ook voor schapen en ezels een bijtelling toegepast. De emissies van de dieren buiten de Landbouwtelling worden afzonderlijk weergegeven.

In 2016 heeft Wageningen Economic Research onderzocht of er een betere schatting van het aantal paarden en pony's mogelijk is. Uit dat onderzoek bleek dat de onderzochte dataset uit de centrale databank I\&R-Paard van de Rijksdienst voor Ondernemend Nederland (RVO) nog niet bruikbaar was voor het vaststellen van het aantal paarden en pony's in Nederland (Van Bruggen et al., 2017b).

\section{Identificatie en Registratie van dieren}

Met ingang van 2017 worden de dieraantallen voor de Landbouwtelling in toenemende mate afgeleid uit I\&R-registers (Identificatie en Registratie van dieren), in plaats van door middel van directe uitvraag in de Gecombineerde Opgave. De I\&R-registers vallen onder verantwoordelijkheid van RVO (Rijksdienst voor Ondernemend Nederland). Sinds 2017 worden de rundvee-aantallen afgeleid uit I\&Rrund (Van Os et al., 2017), en vanaf 2018 worden ook de aantallen schapen, geiten en pluimvee afgeleid uit de betreffende I\&R-registers (Van Os et al., 2019 en 2020). De registratie van rundvee, schapen en geiten vindt rechtstreeks bij RVO plaats. Pluimveegegevens worden ingewonnen via de aangewezen databank Koppel Informatiesysteem Pluimvee (KIP) van Avined. Avined is een brancheorganisatie voor de eier- en pluimveevleessector. Avined geeft de gegevens door aan de centrale database van RVO.nl. Het aantal vleeskuikens in de opgave van Avined is in 2018 circa $10 \%$ lager dan het aantal in 2017 volgens de opgave door de veehouders. Blijkbaar werd in het verleden in de Landbouwtelling vaak de stalcapaciteit ingevuld of het aantal dieren aan het begin van een productieronde zonder rekening te houden met leegstand of uitval.

De peildatum van het aantal dieren blijft 1 april van het betreffende jaar. Ook bij het gebruik van I\&Rdata worden alleen dieren meegeteld van bedrijven die ingeschreven staan in het Handelsregister met een agrarische SBI (Standaard BedrijfsIndeling).

Voor bedrijven met tijdelijke leegstand op de peildatum worden met ingang van 2018 door het CBS de dieraantallen voor pluimvee, vleeskalveren en vleesvarkens in de Landbouwtelling bijgeteld. Deze bijtelling is van belang voor een juiste bepaling van het bedrijfstype en de economische omvang van de bedrijven. Het gemiddelde aantal dieren in een jaar wordt hierdoor echter overschat. Daarom wordt voor de emissieberekeningen geen gebruik gemaakt van de bijtellingen voor leegstand op de peildatum. De dieraantallen in de Landbouwtelling die op de CBS-website worden gepubliceerd zijn inclusief de bijtellingen voor leegstand en kunnen dus afwijken van de aantallen die in de emissieberekeningen worden toegepast.

Normaliter wordt er voor alle diercategorieën van uitgegaan dat het aantal dieren op de peildatum van de Landbouwtelling representatief is voor het gemiddelde aantal aanwezige dieren in het betreffende jaar en dat dus de leegstand van de hokken tijdens de telling gelijk is aan de gemiddelde leegstand in een jaar (Van Bruggen et al., 2010). In 2001 (mond-en-klauwzeer), 2003 (vogelpest), 2017 (fosfaatrechten, fipronilcrisis) en 2018 (invoering fosfaatrechten) is afgeweken van het aantal dieren op de peildatum van de Landbouwtelling (zie voor toelichting: Van Bruggen et al., 2010, 2019 en 
2020).

\section{Wijziging van het aantal dieren in 2018}

Het CBS heeft met terugwerkende kracht de aantallen dieren in 2018 van enkele diercategorieën herzien. Het gaat om een aanpassing van het aantal fokvarkens door additionele analyse en om het aantal kippen door een verbeterde afleiding van het aantal dieren uit de I\&R-registratie. In Tabel 2.1 zijn de dieraantallen in de vorige en in de huidige tijdreeks weergegeven.

Tabel 2.1 Dieraantallen in 2018 in de vorige tijdreeks in Van Bruggen et al. (2020) en in dit rapport (x 1.000) / Number of animals in 2018 in the time series in Van Bruggen et al. (2020) and in this report $(x$ 1,000).

\begin{tabular}{|c|c|c|}
\hline Diercategorie / Livestock category & $\begin{array}{r}\text { Vorige reeks } \\
/ \text { Previous } \\
\text { time series }{ }^{1}\end{array}$ & $\begin{array}{r}\text { Huidige } \\
\text { reeks / } \\
\text { Current } \\
\text { time } \\
\text { series }\end{array}$ \\
\hline Opfokzeugen / Gilts & 233 & 217 \\
\hline Ouderdieren van vleeskuikens $<18$ weken / Broiler parents $<18$ weeks & 3.279 & 2.775 \\
\hline Ouderdieren van vleeskuikens $\geq 18$ weken / Broiler parents $\geq 18$ weeks & 4.985 & 4.677 \\
\hline Laying hens $<18$ weeks / Laying hens $<18$ weeks & 11.710 & 11.539 \\
\hline Laying hens $\geq 18$ weeks / Laying hens $\geq 18$ weeks & 35.223 & 35.614 \\
\hline Vleeskuikens / Broilers & 41.789 & 43.188 \\
\hline Eenden / Ducks & 924 & 872 \\
\hline Kalkoenen / Turkeys & 657 & 556 \\
\hline
\end{tabular}

In Bijlage 2 is het aantal dieren in de berekening van de mestproductie en mineralenexcretie weergegeven voor de gehele tijdreeks.

\subsection{Excretie van $\mathrm{N}$, TAN en $\mathrm{P}_{2} \mathrm{O}_{5}$}

De Werkgroep Uniformering berekening Mest- en mineralencijfers (WUM) berekent jaarlijks de $\mathrm{N}$ - en $\mathrm{P}_{2} \mathrm{O}_{5}$-excretie per dier op basis van gegevens over voergebruik en dierlijke productie, inclusief de verdeling van de mest over stal- en weideperiode (CBS, 2020). Bij de berekening van excretiefactoren per dier zijn sommige diercategorieën in de Landbouwtelling samengevoegd tot één categorie om zo beter aan te sluiten bij de beschikbare kengetallen over voerverbruik en dierlijke productie (Van Bruggen et al., 2010).

Bij de vaststelling van de excretiefactoren voor 2019 zijn de uitgangspunten voor de excretieberekening van witvleeskalveren herzien. Na overleg met de sector en aanvullende analyses wordt in de herziene berekening uitgegaan van een hoger fosforgehalte van het dier en een hoger aflevergewicht. Hierdoor wordt een groter deel van de fosfor in het voer in het dier vastgelegd. Daarnaast is het aantal dagen van een productieronde verhoogd evenals de voeropname per ronde (CBS, 2020).

Behalve de $\mathrm{N}$-excretie moet ook het aandeel TAN in de mest worden vastgesteld. TAN is hier gedefinieerd als de som van de totale excretie als urine- $\mathrm{N}$ en de hoeveelheid organisch gebonden $\mathrm{N}$ die tijdens opslag van mest mineraliseert tot ammonium-N. De berekening van de TAN-excretie is gebaseerd op de verteerbaarheid van ruw eiwit van het rantsoen, zie Bijlage 25 . Voor de dunne mest van rundvee en varkens wordt rekening gehouden met $10 \%$ netto mineralisatie van organische $\mathrm{N}$ excretie tijdens opslag van de mest. Bij vaste mest, uitgezonderd de mest van pluimvee, wordt uitgegaan van $25 \%$ immobilisatie van TAN tijdens mestopslag. Mineralisatie en immobilisatie worden verder toegelicht in Paragraaf 2.4.

De excretie van $\mathrm{P}_{2} \mathrm{O}_{5}$ in de stal is van belang voor de berekening van de mestafzet buiten de Nederlandse landbouw en bij de verdeling van mest over bouwland en grasland. De excretiefactoren van $\mathrm{N}$, TAN en $\mathrm{P}_{2} \mathrm{O}_{5}$ zijn opgenomen in Bijlage 3. 
De TAN-excretie van rundvee wordt bepaald met een landspecifieke (Tier 3) berekening van de fecale vertering van ruw eiwit (VCRE), zie bijlage 26. Een toelichting is opgenomen in Van Bruggen et al. (2018).

\section{Verdeling van de excretie over stal en weide}

De lengte van de weideperiode, de toegepaste beweidingssystemen en de duur van de beweiding bepalen de verdeling van de $\mathrm{N}$ - en $\mathrm{P}_{2} \mathrm{O}_{5}$-excretie van melkkoeien en jongvee over stal en weide. In de Gecombineerde Opgave (Landbouwtelling) wordt jaarlijks gevraagd naar de beweiding van melkkoeien en jongvee. Voor melkkoeien wordt gevraagd naar het aantal weken en het gemiddelde aantal uren per etmaal dat een bepaalde vorm van beweiding is toegepast. De volgende vormen van beweiding worden hierbij onderscheiden: onbeperkt weiden, beperkt weiden en permanent opstallen. Voor jongvee wordt alleen gevraagd naar het aantal weken met weidegang. Verondersteld wordt dat jongvee 24 uur per etmaal wordt geweid. Op basis van deze informatie verdeelt de WUM de N-excretie over stal en weide. In NEMA worden de resultaten van beweiding voor de onderscheiden beweidingssystemen (onbeperkt weiden, beperkt weiden en permanent opstallen) gesplitst naar groepen van stalsystemen.

Vanaf 2015 wordt bij beweiding in NEMA onderscheid gemaakt tussen emissiearme loop- en ligboxenstallen en overige (reguliere) stallen. Uit de koppeling van beweidingsgegevens aan huisvesting is namelijk gebleken dat bij emissiearme stallen gemiddeld minder weidegang plaatsvindt. Vervolgens worden de implementatiegraden van de drie beweidingssystemen vermenigvuldigd met het deel van de excretie dat tijdens opstallen in de stal terechtkomt. Bij dag en nacht weiden werd in 2019 per etmaal ongeveer 18 uur geweid en bij overdag weiden gemiddeld 7 uur per etmaal. In NEMA wordt verondersteld dat de excretie die in de stal plaatsvindt evenredig is met het aantal uren opstallen (Van Bruggen et al., 2010). Dit betekent dat op dagen met dag en nacht weiden 25\% (6 uur op stal) en op dagen met overdag weiden $71 \%$ (17 uur op stal) van de excretie plaatsvindt in de stal. Bij permanent opstallen vindt uiteraard alle excretie in de stal plaats. Ten slotte is voor de onderscheiden staltypes de bijdrage berekend van ieder van de beweidingssystemen aan de excretie in de stal. De uitgangspunten over weidegang van melkkoeien en het aandeel van $\mathrm{N}$-excretie in de stal zijn weergegeven in Bijlage 4.

\subsection{Mineralisatie en immobilisatie}

Bij de berekening van de TAN-excretie wordt rekening gehouden met $10 \%$ netto mineralisatie van de organische $\mathrm{N}$-excretie in opslag van drijfmest van rundvee en varkens (Velthof et al., 2009). Er wordt verondersteld dat deze mineralisatie meteen na uitscheiding in de stal plaatsvindt. In werkelijkheid zal de mineralisatie plaatsvinden over de gehele periode waarin de mest is opgeslagen. Methodisch gezien betekent dit dat de hoeveelheid TAN iets wordt overschat. Dit geldt in meerdere mate voor stalsystemen waarbij de mest frequent wordt verwijderd. Bij vaste mest, uitgezonderd de mest van pluimvee, wordt uitgegaan van netto $25 \%$ immobilisatie van de TAN in de opslag direct na uitscheiding. Dat betekent dat de hoeveelheid TAN van deze mestsoort iets wordt onderschat, omdat immobilisatie, net als mineralisatie een voortschrijdend proces is (Velthof et al., 2009). Rekening houden met mineralisatie en immobilisatie heeft geen effect op de emissie in de stal omdat de stalemissie is gedefinieerd in de Regeling ammoniak en veehouderij (Rav; paragraaf 2.6) in $\mathrm{kg} \mathrm{NH}_{3}$ per dierplaats per jaar. Wel valt de emissiefactor waarin de emissie per dierplaats wordt uitgedrukt ten opzichte van de TAN-excretie anders uit. Het effect van mineralisatie en immobilisatie op de TANexcretie komt wel tot uitdrukking in de emissie na mesttoediening, omdat deze gedefinieerd is als een percentage van de toegediende TAN.

\subsection{Huisvesting van landbouwhuisdieren}

\section{Mesttype}

Om emissies uit stallen te kunnen berekenen is, behalve de $\mathrm{N}$ - en TAN-excretie, informatie nodig over de toegepaste stalsystemen en het mesttype (drijfmest of vaste mest). Het mesttype is van belang 
vanwege het verschil in mineralisatie en immobilisatie bij drijfmest en vaste mest. Daarnaast zijn de overige $\mathrm{N}$-verliezen bij vaste mest groter dan bij drijfmest. Ook voor de emissies uit mestopslagen buiten de stal is het mesttype van belang aangezien bij vaste mest wordt aangenomen dat alle mest buiten de stal wordt opgeslagen. In de Landbouwtelling van 2020 is gevraagd naar het mesttype bij huisvesting van rundvee in 2019. In de Landbouwtelling van 2018 is voor het laatst gevraagd naar het mesttype bij varkens. Deze vraag had betrekking op de situatie in 2017. Dit betekent dat voor 2019 voor varkensmest de cijfers van 2017 zijn aangehouden. Een overzicht van het percentage dieren in stallen met drijfmest is weergegeven in Bijlage 5.

\section{Staltype}

Vanaf 2015 wordt in de Gecombineerde Opgave jaarlijks gevraagd naar de huisvesting van landbouwhuisdieren in het voorgaande jaar. Daarbij wordt gevraagd naar de gemiddelde stalbezetting per stal waarbij aan iedere stal een code moet worden toegekend volgens de codering van de Regeling ammoniak en veehouderij (Rav). Voor een toelichting op de gebruikte bronnen van huisvestingsgegevens wordt verwezen naar Van Bruggen et al. (2015). Vanaf 2015 worden in de Gecombineerde Opgave jaarlijks de gebruikte stalsystemen volgens de gedetailleerde codering van de Rav ingevuld. In NEMA vindt aggregatie plaats tot de groepen die voorheen in de Landbouwtelling werden onderscheiden. Voor melkvee zijn dit emissiearme grupstallen, emissiearme loop- en ligboxenstallen en overige stallen en voor varkens zijn dit emissiearme huisvesting met luchtwassers, huisvesting met emissiarme vloeren of mestkelders en reguliere huisvesting. De emissiefactoren voor deze groepen van stalsystemen worden steeds berekend op basis van de implementatiegraden van de afonderlijke staltypen en de bijbehorende Rav-emissiefactoren. Een overzicht van de implementatiegraden van stallen zoals deze in de berekeningen voor de gehele tijdreeks zijn toegepast voor rundvee, varkens en pluimvee is weergegeven in Bijlage 6 tot en met Bijlage 8 . Een gedetailleerd overzicht van de implementatiegraden van stallen in 2019 volgens de indeling van de Rav en de daaruit afgeleide geaggregeerde emissiefactoren in $\mathrm{kg} \mathrm{NH}_{3}$ per dierplaats is weergegeven in Bijlage 9.

\section{Huisvesting van vleesvarkens met het Beter Leven Keurmerk}

In Bijlage 7 is ook de verdeling van het aantal vleesvarkens naar huisvesting volgens het Beter Leven Keurmerk weergegeven. Het Beter Leven Keurmerk is een dierenwelzijnskeurmerk van de Dierenbescherming waarbij onder andere een groter leefoppervlak voor de dieren gehanteerd wordt. Een groter leefoppervlak leidt tot een hogere ammoniakemissie (Groenestein et al., 2015). De gegevens van het Beter Leven Keurmerk hebben betrekking op het totaal aantal afgeleverde varkens met één of meer sterren Beter Leven. Praktisch blijkt dat dit vooral vleesvarkens betreft. Aangezien er per jaar circa drie mestrondes zijn, is voor de periode waarin rekening is gehouden met huisvesting volgens het Beter Leven Keurmerk (vanaf 2010) het aantal afgeleverde varkens met een Beter Leven Keurmerk gedeeld door drie om zo het gemiddeld aantal bezette dierplaatsen per jaar te berekenen met een groter leefoppervlak.

NEMA gaat bij de huisvesting van vleesvarkens uit van verschillen in emissie tussen dierplaatsen met $0,8 \mathrm{~m}^{2}$ en plaatsen met $1,0 \mathrm{~m}^{2}$ oppervlak, zoals modelmatig berekend door Groenestein et al. (2014). Het aantal vleesvarkens op minimaal $1,0 \mathrm{~m}^{2}$ is ontleend aan de registratie van het aantal varkens met 1 of meer sterren Beter Leven (Bijlage 7) plus de biologisch gehouden vleesvarkens in de Landbouwtelling die niet in de Beter Leven-registratie zitten maar automatisch 3 sterren krijgen. Opgemerkt wordt dat grote groepen vleesvarkens met een Beter Leven Keurmerk ook op 0,9 $\mathrm{m}^{2}$ gehuisvest mogen zijn, maar aangenomen wordt dat dit uit managementoverwegingen niet of nauwelijks voorkomt. Het aantal vleesvarkens dat vóór 2010 op 1,0 $\mathrm{m}^{2}$ gehouden werd is op basis van de gegevens van het Beter Leven Keurmerk verwaarloosbaar.

Een beperking van de informatie over vleesvarkens met een Beter Leven Keurmerk, is dat het type huisvesting niet bekend is. De dierplaatsen met $0,8 \mathrm{~m}^{2}$ en $1,0 \mathrm{~m}^{2}$ zijn daarom naar rato over emissiearme en niet-emissiearme huisvesting verdeeld. 


\section{Luchtwassers}

Tot en met 2015 is op de implementatiegraden van luchtwassers een correctie toegepast voor nalevingstekorten. Door de verscherpte controle op de werking van vergunde luchtwassers wordt sinds 2016 geen correctie meer toegepast en wordt er dus van uitgegaan dat alle wassers functioneren zoals beschreven in de Rav. Wel is het rendement van combiwassers aangepast van $85 \%$ naar 59\% conform Melse et al. (2018a). Het is opgevallen dat na de verlaging van het rendement van combiwassers het aandeel van deze systemen bij vleesvarkens volgens de opgaven van veehouders in 2018 is gedaald van $27 \%$ in 2017 naar $15 \%$ in 2018 ten gunste van het aandeel biologische wassers waarvoor wel een rendement geldt van $85 \%$. De oorzaak van deze daling kon niet worden achterhaald, maar het is onwaarschijnlijk dat binnen een jaar de luchtwassers in stalsystemen op grote schaal zijn aangepast.

\subsection{Emissiefactoren voor $\mathrm{NH}_{3}$ uit huisvesting}

\section{Emissiefactoren in $\mathbf{k g ~} \mathrm{NH}_{3}$ per dierplaats}

De Landbouwtelling leverde tot en met 2014 informatie over de implementatiegraden van groepen van stalsystemen voor rundvee, varkens en pluimvee. Deze indeling van stalsystemen bestond uit aggregaties van verschillende staltypen met emissiearme vloeren, stallen met een luchtwasser en overige, reguliere, stallen (reguliere stallen zonder emissiearm systeem). Daarom werd gebruik gemaakt van de implementatiegraden van de onderliggende staltypen in milieuvergunningen van een vijftal provincies (Van Bruggen et al., 2015). Deze werden geëxtrapoleerd naar het hele land. Vanaf 2015 wordt geen gebruik meer gemaakt van deze gegevens in milieuvergunningen omdat in de Gecombineerde Opgave gevraagd wordt naar alle afzonderlijke stalsystemen voor rundvee, varkens en pluimvee zoals deze voorkomen in de Regeling ammoniak en veehouderij (Rav), zie ook Paragraaf 2.5. Om de historische reeks consistent te houden wordt ook na 2014 de geaggregeerde indeling toegepast. Voor het resultaat maakt dit geen verschil. Voor schapen, geiten, paarden, pony's, konijnen en pelsdieren wordt niet gevraagd naar stalsystemen in de Gecombineerde Opgave. De gehanteerde emissiefactoren voor deze diercategorieën in $\mathrm{kg} \mathrm{NH}$ per dierplaats staan beschreven in Van Bruggen et al. (2011a).

De emissies van stalsystemen in $\mathrm{kg} \mathrm{NH}$ per dierplaats zijn gebaseerd op metingen van ammoniakemissie uit stallen of afgeleid van metingen van dezelfde stalsystemen bij vergelijkbare diercategorieën. De metingen zijn volgens een meetprotocol uitgevoerd (Ogink et al., 2017) en vormen de basis voor de emissiefactoren van stalsystemen in de Rav. In principe wordt in NEMA voor de emissie per dierplaats uitgegaan van de emissiefactoren in de Rav tenzij de emissiefactoren in de Rav niet meer aansluiten bij de meest recente wetenschappelijke inzichten. Daarnaast is bij herziening van de emissiefactoren in de Rav voor de tussenliggende jaren soms een interpolatie toegepast.

Staltypen waarvan de emissiefactoren in de Rav niet zonder meer zijn toegepast, komen voor bij rundvee, gespeende biggen en vleesvarkens (Van Bruggen et al., 2015). Voor combiwassers wordt vanaf de reeks 1990-2017 afgeweken van de Rav (paragraaf 2.5). Ook de advieswaarden voor pluimvee in Ellen et al. (2017), waar NEMA vanaf de reeks 1990-2016 mee rekent (Van Bruggen et al., 2018) zijn niet in alle gevallen overgenomen in de Rav. Per staltype is bepaald of de emissiefactor die afwijkt van de Rav met terugwerkende kracht moet worden toegepast of vanaf een bepaald jaar. Voor uitgebreide informatie wordt verwezen naar de afzonderlijke NEMA-rapporten (Van Bruggen et al., 2015, 2018 en 2019).

\section{Correctiefactor voor de emissiefactoren in $\mathbf{k g ~} \mathbf{N H}_{3}$ per dierplaats}

In opdracht van de Commissie Deskundigen Meststoffenwet (CDM) heeft het CBS een studie uitgevoerd naar het stikstofverlies uit stallen en mestopslagen op basis van veranderingen in de N/Pverhoudingen in de mest bij excretie en bij mestafvoer (Vervoersbewijzen Dierlijke mest) voor de periode 2015-2017 (Van Bruggen en Geertjes, 2019). De resultaten van de CBS-studie laten zien dat de totale gasvormige stikstofverliezen $\left(\mathrm{NH}_{3}-\mathrm{N}+\mathrm{NO}-\mathrm{N}+\mathrm{N}_{2} \mathrm{O}-\mathrm{N}+\mathrm{N}_{2}-\mathrm{N}\right)$ uit mest in stallen en mestopslagen groter zijn dan nu berekend met NEMA. Er zijn meerdere oorzaken mogelijk voor dit verschil. Een deel wordt waarschijnlijk veroorzaakt door een onderschatting van de ammoniakemissies uit emissiearme stallen en enkele andere stalsystemen. Een ander deel is waarschijnlijk het resultaat 
van een onderschatting van overige stikstofverliezen, vooral bij stalsystemen met vaste mest. Daarop heeft de CDM besloten om in het advies over actualisering van de forfaitaire excretienormen in de Uitvoeringsregeling Meststoffenwet de gasvormige stikstofverliezen (stikstofcorrecties) te baseren op de resultaten van de CBS-studie (Bikker et al., 2019).

De werkgroep NEMA heeft geconcludeerd dat emissiearme stallen wel werken maar dat het rendement in praktijkomstandigheden bij sommige staltypen lager uitvalt. De huidige emissiefactoren in $\mathrm{kg} \mathrm{NH}_{3}$ per dierplaats blijven gehandhaafd (emissiearme stallen werken), maar er wordt een correctiefactor voor de emissie bij toepassing in de praktijk geïntroduceerd. De correctiefactoren worden toegepast op de geaggregeerde cijfers en zijn weergegeven in Tabel 2.1. De aanpassingen zijn hieronder toegelicht.

\section{Melkvee}

De ammoniakemissie van emissiearme melkveestallen worden met een correctiefactor voor werking in de praktijk gelijkgesteld aan de factor van de reguliere melkveestal, behalve voor de grupstal met drijfmest (A1.1), zie Tabel 2.1. Het aantal grupstallen met drijfmest is de laatste jaren namelijk zeer gering en de berekende $\mathrm{N}$-verliezen op basis van N/P-verhoudingen zijn mogelijk niet representatief voor de gehele tijdreeks. Emissiearme loop- en ligboxenstallen (A1.2 t/m A1.35) kwamen juist in het begin van de tijdreeks niet voor en zijn pas na 2010 significant toegenomen.

\section{Varkens}

Voor emissiearme stalsystemen in varkensstallen (dus exclusief emissiearme stallen door luchtwassers) wordt op basis van de resultaten in Van Bruggen en Geertjes (2019) aangenomen dat ze niet werken zoals verwacht, maar wel minder uitstoten dan reguliere stallen. Voor verschillende staltypen bij vleesvarkens zijn daarom correctiefactoren berekend. Deze factoren zijn ook toegepast op emissiearme stallen van fokvarkens (gespeende biggen, kraamzeugen, dragende zeugen en overige zeugen). Voor fokvarkens kunnen namelijk geen correctiefactoren berekend worden uit de verschillen in N/P-verhoudingen bij excretie en bij mestafvoer, omdat er voor deze diercategorieën geen afzonderlijke excretiefactoren en mestcodes zijn. Er is daarom aangenomen dat de emissiearme vloeren en -kelders zowel bij vleesvarkens als bij fokvarkens in praktijkomstandigheden hetzelfde presteren.

Bij stallen met luchtwassers verdwijnt in principe evenveel stikstof uit de mest als bij reguliere stallen. De ammoniak zal in een stal met een luchtwasser namelijk voor een deel emitteren uit de stal en voor het overige deel in het spuiwater van de luchtwasser terechtkomen. Dit spuiwater mag niet teruggevoerd worden naar de mestkelder maar moet apart worden verwerkt. Aangezien er geen gegevens zijn over afgevoerd spuiwater is het niet mogelijk om iets te zeggen over de werking van de luchtwasser. De ammoniak in de stal kan in de vorm van spuiwater zijn afgevoerd maar het kan ook zijn geëmitteerd als het veronderstelde rendement van de luchtwasser niet wordt gehaald.

\section{Pluimvee}

Opfokleghennen en leghennen: de ammoniakemissie voor volièrestallen zonder mestbeluchting van opfokhennen en leghennen blijft gelijk aan de Rav-factor, ook al is de kans groot dat dit een onderschatting is (Ellen et al., 2017). Het is echter niet reëel om het stikstofverlies van volièrestallen zonder mestbeluchting gelijk te stellen aan het verlies bij grondhuisvesting ('overige stalsystemen') vanwege het verschil in staltypen. Volièrestallen met mestbeluchting werken onvoldoende zoals blijkt uit Ellen et al. (2017) en de CBS studie en dus zijn de emissiefactoren van volièrestallen met mestbeluchting gelijkgesteld aan de factor van stallen zonder mestbeluchting. Voor emissiearme grondhuisvesting bij opfokhennen (E1.11 en E1.14) is een correctiefactor berekend uitgaande van het verschil in $\mathrm{N}$-verlies met de reguliere grondhuisvesting. Voor leghennen zijn eveneens correctiefactoren toegevoegd voor grondhuisvesting met mestbeluchting (E2.9.x) en voor scharrelhuisvesting met mestbanden (E2.12.x).

Uit de CBS-studie blijkt dat het $\mathrm{N}$-verlies van reguliere huisvesting van opfokhennen en leghennen op basis van veranderingen in de N/P-verhoudingen in de mest bij excretie en bij mestafvoer kleiner is dan het berekende $\mathrm{N}$-verlies op basis van de Rav-factor voor $\mathrm{NH}_{3}$ en de $14 \%$ voor overige $\mathrm{N}$-verliezen (Oenema et al., 2000). Dit kan betekenen dat de Rav-factor voor $\mathrm{NH}_{3}$ en/of de overige $\mathrm{N}$-verliezen van $14 \%$ te hoog zijn. Als de $\mathrm{NH}_{3}$-emissie van emissiearme grondhuisvesting bij opfokhennen en leghennen gecorrigeerd zou worden op basis van het berekende $\mathrm{N}$-verlies bij reguliere grondhuisvesting (Rav-factor plus 14\% overig N-verliezen), bestaat de kans dat de emissie van 
emissiearme grondhuisvesting wordt overschat. Bij het vaststellen van de correctiefactor voor de ammoniakemissie van emissiearme grondhuisvesting in relatie tot de emissie van reguliere grondhuisvesting is er daarom van uitgegaan dat het $\mathrm{N}$-verlies van reguliere grondhuisvesting gelijk is aan het $\mathrm{N}$-verlies op basis van veranderingen in de N/P-verhoudingen in de mest bij excretie en bij mestafvoer. De $\mathrm{NH}_{3}$-emissie per dierplaats voor reguliere huisvesting van opfokhennen en leghennen op basis van de Rav-emissiefactor is vooralsnog niet verlaagd.

Vleeskuikenouderdieren: er is een correctiefactor toegevoegd voor emissiearme grondhuisvesting, maar voor groepskooi en volière is geen correctiefactor berekend omdat het aantal waarnemingen te gering was.

Vleeskuikens: er zijn correctiefactoren afgeleid voor twee systemen (vloerverwarming en -verkoeling en ventilatiesystemen); andere systemen (vloer met strooiseldroging en etagesystemen) lijken wel effect te hebben.

In Tabel 2.1 staan de correctiefactoren voor de $\mathrm{NH}_{3}$-emissie per dierplaats van emissiearme stallen voor 2019. In Bijlage 9 zijn per diercategorie de oorspronkelijke en de gecorrigeerde emissiefactor weergegeven.

Tabel 2.1 Correctiefactoren voor de $\mathrm{NH}_{3}$-emissie per dierplaats / Correction factors for the $\mathrm{NH}_{3}$ emission per animal place.

\begin{tabular}{|c|c|}
\hline Diercategorie / Livestock category & 2019 \\
\hline \multicolumn{2}{|l|}{ Melkkoeien } \\
\hline emissiearme loop- en ligboxenstallen & 1,55 \\
\hline \multicolumn{2}{|l|}{ Varkens } \\
\hline emissiearme vloeren en mestkelders & 1,83 \\
\hline \multicolumn{2}{|l|}{ Pluimvee } \\
\hline emissiearme volièrestallen bij opfokhennen & 1,85 \\
\hline emissiearme grondhuisvesting bij opfokhennen & 1,11 \\
\hline emissiearme volièrestallen bij leghennen & 2,02 \\
\hline grondhuisvesting met mestbeluchting bij leghennen & 1,78 \\
\hline scharrelhuisvesting met mestbanden bij leghennen & 2,10 \\
\hline emissiearme huisvesting opfokouderdieren vleeskuikens & 2,71 \\
\hline emissiearme grondhuisvesting bij ouderdieren van vleeskuikens & 1,58 \\
\hline stallen met vloerverwarming/verkoeling bij vleeskuikens & 1,79 \\
\hline stallen met mixlucht, heaters e.d. bij vleeskuikens & 3,78 \\
\hline
\end{tabular}

\section{Emissiefactoren als percentage van de TAN-excretie}

Voor rundvee, varkens en pluimvee zijn op basis van de emissiefactoren in $\mathrm{kg} \mathrm{NH}_{3}$ per dierplaats en de implementatiegraden van stalsystemen (Paragraaf 2.5) gemiddelde emissiefactoren in NEMA berekend als percentage van de TAN-excretie voor dunne en vaste mest. Het resultaat hiervan is weergegeven in Bijlage 10 tot en met Bijlage 12. Wijzigingen in emissiefactoren ten opzichte van de TAN-excretie tussen verschillende jaren hangen samen met veranderingen in de implementatiegraden van de onderliggende staltypen.

Idealiter wordt bij de berekening van emissiefactoren in procent van de TAN-excretie gebruik gemaakt van gemeten TAN-excreties. Aangezien gegevens over de TAN-excretie in de stallen waar ammoniakmetingen zijn uitgevoerd niet beschikbaar zijn, wordt uitgegaan van de berekende gemiddelde TAN-excretie in Nederland voor het jaar waarin de ammoniakmetingen zijn uitgevoerd: het zogenaamde referentiejaar (Velthof et al., 2009). De achterliggende gedachte hierbij is dat de gemeten emissie in een bepaalde periode verband houdt met de TAN-excretie in die periode. Wanneer de periode van de metingen niet bekend is, is het referentiejaar gelijk aan het jaar waarin de emissiefactor in de Rav is opgenomen.

In Van Bruggen et al. (2015) (zie ook Velthof et al., 2009) zijn referentiejaar, stalbezetting en de periode waarvoor deze gelden (verslagperiode) weergegeven. Voor de emissiefactoren van staltypen 
die zijn afgeleid van andere staltypen, geldt als referentiejaar het referentiejaar van het staltype waarvan de emissiefactor is afgeleid.

De Rav-emissiefactor is uitgedrukt in $\mathrm{kg} \mathrm{NH}_{3}$ per dierplaats per jaar, waarbij rekening gehouden wordt met leegstand. Voorbeeld: een Rav-emissie van $10,0 \mathrm{~kg} \mathrm{NH}_{3}$ per dierplaats bij een stalbezetting van 0,9 komt overeen met een emissie van $10,0 / 0,9=11,1 \mathrm{~kg} \mathrm{NH}$ per aanwezig dier.

De TAN-excretie wordt, zoals in Paragraaf 2.4 is aangegeven, gecorrigeerd voor netto mineralisatie in drijfmest of immobilisatie van organisch gebonden $\mathrm{N}$ in vaste mest.

In Tabel 2.2 zijn de emissiefactoren ten opzichte van de TAN-excretie weergegeven voor schapen, geiten, paarden, pony's, konijnen en pelsdieren. Deze factoren gelden voor de gehele tijdreeks. De uitgangspunten zijn vastgesteld in Velthof et al. (2009), maar een aantal uitgangspunten zijn naderhand gewijzigd (Van Bruggen et al., 2011a; 2012; 2019).

Tabel $2.2 \quad \mathrm{NH}_{3}$-emissiefactoren voor overige diercategorieën (\% van TAN-excretie) ${ }^{1)} / \mathrm{NH}_{3}$ emission factors for other livestock categories ( $\%$ of TAN excretion) ${ }^{1}$.

\begin{tabular}{lr} 
Diercategorie / Livestock category & $1990-2019$ \\
Schapen / Sheep & 27,8 \\
\hline Geiten / Goats & 16,9 \\
\hline Paarden / Horses & 19,5 \\
\hline Pony's / Ponies & 29,0 \\
\hline Konijnen / Rabbits & 54,3 \\
\hline Nertsen / Minks & 8,0 \\
\hline Vossen (1990-2007, daarna verboden) / Foxes (1990-2007, since banned) & 23,5 \\
\hline
\end{tabular}

1) Bronnen / Sources: Velthof et al. (2009); Van Bruggen et al. (2011a; 2012; 2019).

\subsection{Emissiefactoren voor $\mathrm{N}_{2} \mathrm{O}, \mathrm{NO}$ en $\mathrm{N}_{2}$ uit stallen}

Om de hoeveelheid $\mathrm{N}$ en TAN die aan de bodem wordt toegediend te kunnen berekenen, moeten ook de emissies van overige gasvormige $\mathrm{N}$-verbindingen $\left(\mathrm{N}_{2} \mathrm{O}\right.$, $\mathrm{NO}$ en $\mathrm{N}_{2}$ ) uit stallen en opslagen worden vastgesteld. De berekening van de $\mathrm{N}_{2} \mathrm{O}$-emissie is gebaseerd op de IPCC Guidelines van 2006 (IPCC, 2006). De emissie wordt berekend over de in de stal uitgescheiden N. De emissiefactoren volgens de Guidelines van 2006 gelden voor de gehele tijdreeks vanaf 1990.

De emissiefactoren voor NO-N zijn gelijkgesteld aan de factoren voor $\mathrm{N}_{2} \mathrm{O}-\mathrm{N}$ (Oenema et al., 2000). De factoren voor $\mathrm{N}_{2}-\mathrm{N}$ zijn voor drijfmest gesteld op tienmaal de factor voor $\mathrm{N}_{2} \mathrm{O}-\mathrm{N}$ en voor vaste mest op vijfmaal de factor voor $\mathrm{N}_{2} \mathrm{O}-\mathrm{N}$ (Oenema et al., 2000).

Er worden geen $\mathrm{N}_{2} \mathrm{O}$-, NO- en $\mathrm{N}_{2}$-emissies berekend voor de mest in de stal voorafgaand aan mestscheiding en vergisting. Het uitgangspunt hierbij is dat de opslagduur vóór scheiden en vergisten korter is en dat de $\mathrm{N}_{2} \mathrm{O}$ - emissie vooral erna plaatsvindt. In de praktijk kan het zeker voorkomen dat de mest nog enige tijd in de stal is opgeslagen voordat gescheiden of vergist wordt. Deze aanname zal de stalemissie van drijfmest enigszins onderschatten en die van de gescheiden producten wellicht overschatten. Zonder deze aanname zijn ingewikkelde berekeningen nodig voor de $\mathrm{NH}_{3}, \mathrm{~N}_{2} \mathrm{O}$, $\mathrm{NO}$ en $\mathrm{N}_{2}$ in de stal met risico op dubbeltellingen. Gezien de variatie in de praktijk is pragmatisch gekozen voor een geïntegreerde emissiefactor voor de $\mathrm{N}$ in de mest die wordt gescheiden (Paragraaf 2.9).

In Tabel 2.3 zijn de emissiefactoren voor overige $\mathrm{N}$-verliezen weergegeven. Voor een toelichting wordt verwezen naar Van Bruggen et al. (2015). 
Tabel 2.3 Emissiefactoren voor overige gasvormige $\mathrm{N}$-verliezen (\% van $\mathrm{N}$-excretie) / Emission factors for other gaseous $N$-losses (\% of $N$ excretion).

\begin{tabular}{|c|c|c|}
\hline Diercategorie / Livestock category & $\left.\mathrm{N}_{2} \mathrm{O}-\mathrm{N}^{1}\right)$ en $\mathbf{N O}-\mathrm{N}^{2)}$ & $\left.\mathbf{N}_{2}-\mathbf{N}^{2}\right)$ \\
\hline \multicolumn{3}{|l|}{ Rundvee / Cattle } \\
\hline - drijfmest / slurry & 0,2 & 2,0 \\
\hline - vaste mest / solid manure & 0,5 & 2,5 \\
\hline \multicolumn{3}{|l|}{ Varkens / Pigs } \\
\hline - drijfmest / slurry & 0,2 & 2,0 \\
\hline - vaste mest / solid manure & 0,5 & 2,5 \\
\hline \multicolumn{3}{|l|}{ Pluimvee / Poultry } \\
\hline - drijfmest / slurry & 0,1 & 1,0 \\
\hline - vaste mest / solid manure & 0,1 & 0,5 \\
\hline Schapen (vaste mest) / Sheep (solid manure) & 0,5 & 2,5 \\
\hline Geiten (vaste mest) / Goats (solid manure) & 1,0 & 5,0 \\
\hline $\begin{array}{l}\text { Paarden en pony's, ezels (vaste mest) / Horses and ponies, mules and } \\
\text { asses (solid manure) }\end{array}$ & 0,5 & 2,5 \\
\hline Pelsdieren (drijfmest) / Fur-bearing animals (slurry) & 0,2 & 2,0 \\
\hline Konijnen (vaste mest) / Rabbits (solid manure) & 0,5 & 2,5 \\
\hline
\end{tabular}

\subsection{Mestopslag buiten de stal}

Een deel van de in de stal geproduceerde mest wordt buiten de stal opgeslagen. Dit gedeelte is afhankelijk van mesttype, staltype en aanwezige opslagcapaciteit. Om de hoeveelheid $\mathrm{N}$ en TAN te kunnen berekenen die aan de bodem wordt toegediend moet de emissie uit mestopslagen buiten de stal worden vastgesteld. Voor de uitgangspunten wordt verwezen naar Velthof et al. (2009) en Van der Zee et al. (2021).

In Bijlage 13 zijn voor de gehele tijdreeks de uitgangspunten voor de berekening van $\mathrm{NH}_{3}$-emissie uit mestopslag buiten de stal weergegeven.

\subsection{Mestbewerking en -verwerking}

De volgende vormen van mestbewerking en -verwerking worden onderscheiden:

- Mestscheiding;

- Kalvergierzuivering;

- Productie van mineralenconcentraat;

- Mestvergisting;

- Mest drogen en korrelen;

- Mestverbranding (vooropslag).

Emissies van ammoniak door andere vormen van mestbewerking, zoals hygiënisering en compostering, zijn verwaarloosbaar omdat deze processen in dichte ruimtes plaatsvinden die veelal zijn uitgerust met een luchtwasser.

Bij de verschillende vormen van mestbewerking en -verwerking kunnen emissies ontstaan van $\mathrm{N}$ verbindingen en $\mathrm{CH}_{4}$. De emissies van $\mathrm{N}$-verbindingen worden berekend door de $\mathrm{N}$ in de dierlijke mest die een vorm van mestbewerking of -verwerking ondergaat te vermenigvuldigen met een emissiefactor per aangevoerde $\mathrm{kg} \mathrm{N}$. De gebruikte activiteitendata en emissiefactoren voor $\mathrm{CH}_{4}$ zijn beschreven in paragraaf 5.3. De uitgangspunten voor het berekenen van de emissiefactoren van zowel $\mathrm{N}$ als $\mathrm{CH}_{4}$ staan beschreven in Melse en Groenestein (2016).

Niet elke vorm van mestbewerking en -verwerking vindt vanaf 1990 plaats, de meeste vormen zijn pas na 2006 opgekomen. Mestscheiding komt voor het eerst in enige mate voor in 2009. De ingaande 
stroom $\mathrm{N}$ is berekend op basis van de $\mathrm{N}$-inhoud van de dikke fractie van gescheiden rundermest en varkensmest die door landbouwbedrijven is afgevoerd plus het saldo van de dikke fractie die door intermediairs en mestverwerkers is aan- en afgevoerd. In deze rapportage is voor het eerst de ingaande stroom $\mathrm{N}$ berekend van de mestscheiding die niet op het primaire landbouwbedrijf plaatsvindt maar bij intermediairs en mestverwerkers. De omvang hiervan is berekend als saldo van de door intermediairs en mestverwerkers af- en aangevoerde $\mathrm{N}$ in dikke fractie.

Het $\mathrm{N}$-gehalte van de dikke fractie waarmee in NEMA wordt gerekend is niet gebaseerd op de gegevens van de vervoersbewijzen, vanwege het veelvuldig voorkomen van onrealistisch hoge waarden, maar op Melse et al. (2018b). Daarbij is het scheidingsrendement gedefinieerd als dat deel van de $\mathrm{N}$ in de drijfmest die in de dikke fractie terechtkomt. Het $\mathrm{N}$-scheidingsrendement voor dikke fractie van rundermest is $23,5 \%$ en voor varkensmest 34,0\% (Melse, 2017; Melse et al., 2018b). Er is hierbij van uitgegaan dat scheiding van rundermest globaal voor de helft gebeurt met een vijzelpers en voor de helft met een centrifuge omdat mobiele mestscheiders over het algemeen werken met een centrifuge (Groenestein, 2017). Bij varkensmest wordt aangenomen dat mestscheiding altijd plaatsvindt met een centrifuge.

Kalvergierzuivering bestaat al decennialang. De omvang wordt afgeleid uit de mestaanvoer naar zuiveringsinstallaties.

Zoals eerder benoemd in Paragraaf 2.7 worden geen $\mathrm{N}_{2} \mathrm{O}$-, NO- en $\mathrm{N}_{2}$-emissies berekend voor de mest in de stal voorafgaand aan mestscheiding en vergisting. Het uitgangspunt hierbij is dat de opslagduur vóór scheiden en vergisten korter is en dat de $\mathrm{N}_{2} \mathrm{O}$ - emissie vooral erna plaatsvindt.

In Bijlage 14 is een overzicht gegeven van de $\mathrm{N}$-aanvoer per mestbewerkingstechniek. Tabel $2.4 \mathrm{geeft}$ de emissiefactoren voor mestbewerkingsprocessen.

Tabel 2.4 Emissiefactoren voor mestbewerking en -verwerking ( $\mathrm{kg} \mathrm{N} / \mathrm{kg} \mathrm{N}$ aangevoerde mest) / Emission factors for manure treatment ( $\mathrm{kg} \mathrm{N} / \mathrm{kg} \mathrm{N}$ supply).

\begin{tabular}{|c|c|c|c|c|}
\hline Mestsoort / Manure type & $\mathrm{NH}_{3}-\mathbf{N}$ & $\mathrm{N}_{2} \mathrm{O}-\mathrm{N}$ & NO-N & $\mathbf{N}_{2}-\mathbf{N}$ \\
\hline \multicolumn{5}{|l|}{$\begin{array}{l}\text { Mestscheiding en kalvergierzuivering / Separation of slurry } \\
\text { and treatment of veal calves slurry }\end{array}$} \\
\hline \multicolumn{5}{|l|}{ Rundermest / Cattle manure: } \\
\hline Proces / Process & 0,0025 & & & \\
\hline Opslag dikke fractie 6 maanden / Storage solid fraction 6 months & 0,0125 & 0,0050 & 0,0050 & 0,0250 \\
\hline Opslag dunne fractie 6 maanden / Storage liquid fraction 6 months & 0,0080 & & & \\
\hline Totaal / Total & 0,0230 & 0,0050 & 0,0050 & 0,0250 \\
\hline \multicolumn{5}{|l|}{ Vleeskalvermest / Veal calves manure: } \\
\hline Proces / Process & 0,0031 & 0,0496 & 0,0496 & 0,4960 \\
\hline Opslag dikke fractie 6 maanden / Storage solid fraction 6 months & 0,0125 & 0,0050 & 0,0050 & 0,0250 \\
\hline Totaal / Total & 0,0156 & 0,0546 & 0,0546 & 0,5210 \\
\hline \multicolumn{5}{|l|}{ Varkensmest / Pig manure: } \\
\hline Proces / Process & 0,0033 & & & \\
\hline Opslag dikke fractie 6 maanden / Storage solid fraction 6 months & 0,0125 & 0,0050 & 0,0050 & 0,0250 \\
\hline Opslag dunne fractie 6 maanden / Storage liquid fraction 6 months & 0,0160 & & & \\
\hline Totaal / Total & 0,0318 & 0,0050 & 0,0050 & 0,0250 \\
\hline \multicolumn{5}{|l|}{$\begin{array}{l}\text { Productie van mineralenconcentraat / Production of mineral } \\
\text { concentrate }\end{array}$} \\
\hline \multicolumn{5}{|l|}{ Varkensmest / Pig manure: } \\
\hline Proces / Process & 0,0033 & & & \\
\hline Opslag dikke fractie 6 maanden / Storage solid fraction 6 months & 0,0125 & 0,0050 & 0,0050 & 0,0250 \\
\hline Opslag dunne fractie 6 maanden / Storage liquid fraction 6 months & 0,0160 & & & \\
\hline Totaal / Total & 0,0318 & 0,0050 & 0,0050 & 0,0250 \\
\hline \multicolumn{5}{|l|}{ Mestvergisting / Manure digestion } \\
\hline Rundermest - opslag digestaat / Cattle manure - digestate storage & 0,0100 & & & \\
\hline Varkensmest - opslag digestaat / Pig manure - digestate storage & 0,0200 & & & \\
\hline
\end{tabular}

Mest drogen en korrelen / Manure drying and pelleting 


\begin{tabular}{|c|c|c|c|c|}
\hline Mestsoort / Manure type & $\mathrm{NH}_{3}-\mathrm{N}$ & $\mathbf{N}_{2} \mathbf{O}-\mathbf{N}$ & NO-N & $\mathrm{N}_{2}-\mathrm{N}$ \\
\hline \multicolumn{5}{|l|}{ Pluimveemest / Poultry manure: } \\
\hline Proces / Process & 0,0135 & & & \\
\hline Korte vooropslag / Short pre-storage & 0,0008 & & & \\
\hline Totaal / Total & 0,0143 & & & \\
\hline \multicolumn{5}{|l|}{$\begin{array}{l}\text { Mestverbranding (vooropslag) / Manure incineration (pre- } \\
\text { storage) }\end{array}$} \\
\hline $\begin{array}{l}\text { Pluimveemest - korte vooropslag / Poultry manure - short pre- } \\
\text { storage }\end{array}$ & 0,0008 & & & \\
\hline
\end{tabular}

Bron / Source: Melse en/and Groenestein (2016).

\subsection{Mestafzet buiten de Nederlandse landbouw}

Om de emissies van het gebruik van dierlijke mest in de Nederlandse landbouw te kunnen berekenen, wordt de omvang berekend van de mestafvoer naar het buitenland, naar hobbybedrijven en particulieren en van het gebruik van mest uit de landbouw op natuurterreinen. De uitgangspunten voor de berekening van de mestafzet buiten de landbouw zijn weergegeven in Bijlage 15.

De berekening van de afzet van mest is gebaseerd op $\mathrm{P}_{2} \mathrm{O}_{5}$ en de verhouding tussen $\mathrm{N}$ en $\mathrm{P}_{2} \mathrm{O}_{5}$ na aftrek van de gasvormige verliezen uit stallen en mestopslagen die met NEMA zijn berekend. Er is dus geen gebruik gemaakt van de $\mathrm{N}$-afzet volgens Vervoersbewijzen Dierlijke Mest (VDM).

Bij de export van onbewerkte vaste mest, nertsenmest en de afzet van vaste mest naar hobbybedrijven en particulieren wordt vanaf 2006 uitgegaan van mesthoeveelheden op basis van vervoersbewijzen en het berekende $\mathrm{P}_{2} \mathrm{O}_{5}$-gehalte van vaste mest volgens de WUM (mestvolume en $\mathrm{P}_{2} \mathrm{O}_{5}$-excretie). Deze werkwijze volgt op de constatering dat mestmonsters van vaste mest niet representatief zijn voor de gehele partij (Hoogeveen et al., 2010; zie ook Van Bruggen et al., 2015 ).

De cijfers over export worden mogelijk beïnvloed door mestfraude (De Koeijer et al., 2018). Uit een vergelijking van de samenstelling van dikke en dunne fracties op basis van vervoersbewijzen van 2016 met de samenstelling van dikke en dunne fracties van rundvee- en varkensmest in praktijkproeven kwamen grote verschillen naar voren (Tabel 2.5). De stikstof- en fosfaatgehalten van dikke fracties op basis van vervoersbewijzen waren onrealistisch hoog. De geëxporteerde hoeveelheden stikstof en fosfaat zijn daarom in NEMA opnieuw berekend door de geëxporteerde mestvracht op basis van vervoersbewijzen te vermenigvuldigen met de samenstelling op basis van praktijkproeven. Daarbij is aangenomen dat scheiding van rundveemest in de helft van de gevallen wordt uitgevoerd met een centrifuge en voor de andere helft met een vijzelpers en dat varkensmest wordt gescheiden met een centrifuge (Buisonjé, 2017). Deze herberekening is uitgevoerd vanaf 2009. Vóór 2009 vond mestscheiding vrijwel niet plaats. Zie ook Van Bruggen et al., 2015 en 2018. Daarnaast zijn signalen ontvangen over onregelmatigheden met de hoeveelheden geëxporteerde dikke fractie. Om ook hiervoor een correctie toe te passen onbreken echter voldoende betrouwbare gegevens.

Tabel 2.5 Samenstelling van gescheiden mest op basis van vervoersbewijzen en op basis van praktijkproeven ( $\mathrm{kg} / \mathrm{ton}$ ) / Composition of separated manure based on registered transports and based on experimental data ( $\mathrm{kg} / \mathrm{ton})$.

\begin{tabular}{|c|c|c|c|c|}
\hline \multirow[t]{3}{*}{ Mestsoort / Manure type } & \multirow{2}{*}{\multicolumn{2}{|c|}{$\begin{array}{r}\text { Vervoersbewijzen } 2016 / \\
\text { Registered transports } \\
2016\end{array}$}} & \multicolumn{2}{|c|}{$\begin{array}{l}\text { Praktijkproeven / } \\
\text { Experimental data }\end{array}$} \\
\hline & & & & \\
\hline & $\mathbf{N}$ & $\mathrm{P}_{2} \mathrm{O}_{5}$ & $\mathbf{N}$ & $\mathrm{P}_{2} \mathrm{O}_{5}$ \\
\hline Rundermest - dikke fractie / Cattle manure - solid fraction & 16,4 & 12,4 & 5,3 & 4,1 \\
\hline Rundermest - dunne fractie / Cattle manure - liquid fraction & 5,6 & 2,3 & 4,1 & 0,9 \\
\hline Varkensmest - dikke fractie / Pig manure - solid fraction & 16,3 & 23,7 & 11,0 & 15,0 \\
\hline Varkensmest - dunne fractie / Pig manure - liquid fraction & 4,6 & 1,7 & 6,9 & 1,3 \\
\hline
\end{tabular}

1) Bewerkte gegevens van Melse (2017) / Edited data from Melse (2017). 
De afzet naar hobbybedrijven is tot en met 2016 gebaseerd op een schatting van areaal en mestgift van hobbybedrijven en vanaf 2017 op de geregistreerde afvoer op vervoersbewijzen naar kleine bedrijven plus de afvoer naar bedrijven die niet herkend zijn als landbouwbedrijf, intermediair of mestverwerker.

Door onzekerheden in de data kan het voorkomen dat de afzet buiten de landbouw van sommige soorten pluimveemest groter is dan de hoeveelheid geproduceerde pluimveemest. In voorkomende gevallen is de export van pluimveemest verlaagd tot het niveau van de productie.

\subsection{Mesttoediening}

Bij huisvestingssystemen voor pluimvee met uitloop wordt ervan uitgegaan dat $15 \%$ van de excretie in de uitloop terechtkomt (Oenema et al., 2000). De excretie in de uitloop wordt niet beschouwd als toegediende mest; de emissie die plaatsvindt in de uitloop is relatief gering vergeleken met de emissie in de stal (Aarnink et al., 2005; 2006).

\section{Mestverdeling over grasland en bouwland}

De hoeveelheden (ammoniakale) $\mathrm{N}$ en $\mathrm{P}_{2} \mathrm{O}_{5}$ die aan grasland en bouwland worden toegediend zijn het resultaat van de berekende excretie in de stal en in de wei, minus de gasvormige verliezen in de stal en bij opslag buiten de stal, minus de gasvormige verliezen bij mestbewerking en verwerkingsprocessen en minus de mestafzet buiten de Nederlandse landbouw. In dit rapport is de verdeling van de mest over grasland en bouwland in de periode 2016-2018 gebaseerd op de resultaten van het model INITIATOR van Wageningen Environmental Research (Bijlage 16, zie ook Kros et al., 2019). Deze gegevens vervangen de resultaten van het model MAMBO van Wageningen Economic Research die eeder voor de periode 2016-2018 zijn toegepast en gebaseerd waren op gegevens van het Bedrijveninformatienet (BIN) van 2014. De resultaten van het model INITIATOR laten zien dat er in de periode 2014-2018 een flinke verschuiving heeft plaatsgevonden van mesttoediening op grasland naar toediening op bouwland. Hiervoor is een aantal oorzaken aan te wijzen (Luesink, 2020):

- In 2018 zijn vergeleken met 2014 de fosfaatgebruiksnormen op grasland met $5 \mathrm{~kg}$ per ha verlaagd, behalve voor arealen met een lage fosfaattoestand, maar daarvan is de omvang beperkt. Daardoor ging op basis van fosfaat ruim 6\% minder (rundvee-)mest naar grasland.

- Verder is tussen 2014 en 2017 de melkveestapel flink uitgebreid waarbij de extra mest, die niet meer op grasland kon worden afgezet, naar bouwland is gegaan.

- $\quad B i j$ een deel van de melkveebedrijven is de stikstofgebruiksnorm voor dierlijke mest beperkend en is er daardoor nog wel ruimte voor fosfaat uit dierlijke mest. Een deel van die bedrijven is gaan mestscheiden zodat met de resterende drijfmest en de dikke fractie de fosfaatgebruiksnorm werd opgevuld. De dunne fractie met veel stikstof is op bouwland afgezet. De extra afzet van rundveemest op bouwland heeft de afzet van varkensmest op bouwland voor een deel verdrongen waardoor meer varkensmest is geëxporteerd.

- Ook bij de varkensmest is in de genoemde periode veel meer mest gescheiden. De dikke fractie wordt geëxporteerd en de dunne fractie blijft in Nederland en wordt in de akkerbouw afgezet.

Samengevat: rundveemest met hogere N/P verhoudingen dan varkensmest heeft voor een deel de varkensmest die naar bouwland gaat verdrongen. $\mathrm{Er}$ is daarnaast meer dunne fractie van mestscheiding op de markt gekomen met een hoge N/P verhouding. Ook die dunne fractie wordt veelal op bouwland afgezet.

Een overzicht vanaf 1990 van de verdeling van mest, exclusief weidemest, over grasland en bouwland is opgenomen in Bijlage 17.

\section{Praktijkresultaat van mesttoediening}

In de Landbouwtelling van 2020 is gevraagd naar het praktijkresultaat van de mesttoediening in 2019 . Het onderscheid in de praktijkresultaten van mesttoediening in de Landbouwtelling van 2020 wijkt enigszins af van het onderscheid in de Landbouwtelling van 2016. De wijzigingen vloeien voort uit veranderingen in wettelijke bepalingen rond mesttoediening. 
Voor toediening van vaste mest op onbeteeld bouwland en voor drijfmest op beteeld bouwland worden de resultaten van de Landbouwtelling niet gebruikt. In de Landbouwtelling van 2020 is namelijk niet gevraagd naar bovengronds verspreiden van vaste mest op onbeteeld bouwland en naar drijfmesttoediening in strookjes op de grond bij beteeld bouwland. Hoewel deze werkresultaten wettelijk niet zijn toegestaan, blijkt uit praktijkinformatie dat beide wel voorkomen.

In Tabel 2.6 zijn de implementatiegraden van de mesttoediening weergegeven volgens de Landbouwtelling. Opvallend is het grote aandeel zodenbemester (mest in sleufjes) bij grasland en mestinjectie bij bouwland. Er bestaat dan ook discussie over de werkelijke uitvoering van de mesttoediening (in relatie tot grondsoort) in de praktijk. In 2019 en 2020 is een verkenning gestart om hier meer zicht op te krijgen. Een overzicht van de implementatiegraden voor de gehele tijdreeks is weergegeven in Bijlage 17. De toediening van vaste mest op grasland staat niet in de bijlage, dit is altijd bovengrondse toediening.

Tabel 2.6 Implementatiegraden van mesttoediening in de praktijk (\%) / Implementation of manure application methods in practice (\%).

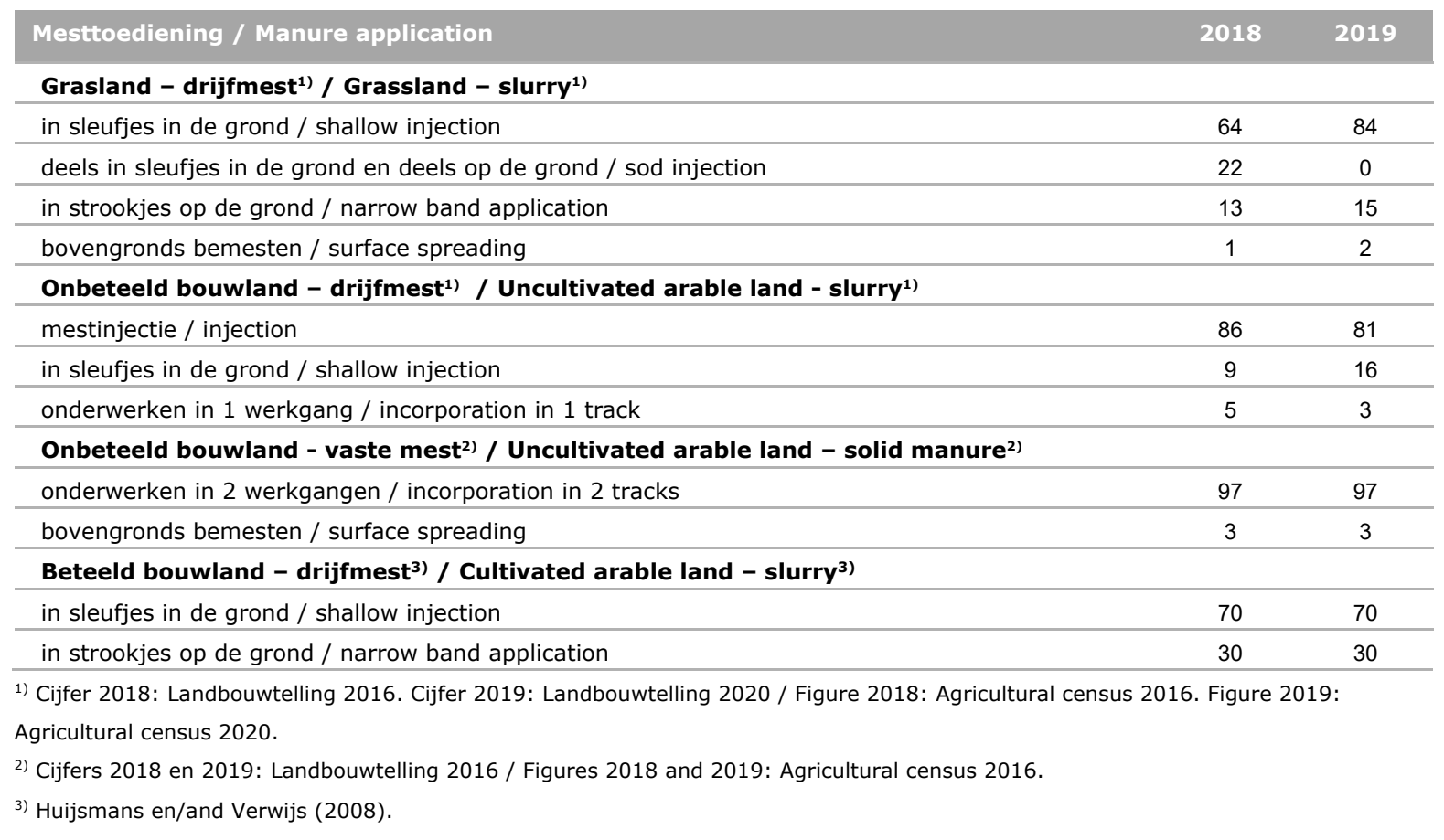

\section{Emissiefactoren mesttoediening}

De emissiefactoren zijn voor de gehele tijdreeks weergegeven in Bijlage 17. De emissiefactoren voor mesttoediening op grasland zijn aangepast naar Goedhart et al. (2020). Een toelichting hierop is opgenomen in Bijlage 18. De aanpassingen gelden voor de hele tijdreeks met uitzondering van de zodenbemesting op grasland in de periode 1990-1998 en voor bovengrondse toediening op grasland in 1990. Voor zodenbemesting op grasland in 1990-1993 blijft de emissiefactor 10\%, omdat in die periode dieper werd geïnjecteerd, en voor de jaren 1994-1998 is een interpolatie toegepast. Voor bovengrondse mesttoediening op grasland in 1990 is de herziene emissiefactor evenredig verlaagd. In Tabel 2.7 zijn de wijzigingen samengevat.

Tabel 2.7 Emissiefactoren voor mesttoediening op grasland (\% van TAN) / Emission factors for manure application on grassland (\% of TAN).

\begin{tabular}{|c|c|c|}
\hline Mesttoediening / Manure application & $\begin{array}{l}\text { Vorige } \\
\text { waarde }\end{array}$ & $\begin{array}{c}\text { Nieuwe } \\
\left.\text { waarde }^{3}\right)\end{array}$ \\
\hline \multicolumn{3}{|l|}{ Grasland - drijfmest / Grassland - slurry } \\
\hline in sleufjes in de grond / shallow injection & 19,0 & 17,0 \\
\hline deels in sleufjes in de grond en deels op de grond ${ }^{1)}{ }^{2)} /$ sod injection ${ }^{1)}{ }^{2}$ ) & 24,8 & $21,7(17,0)$ \\
\hline in strookjes op de grond²) / narrow band application²) & 30,5 & $26,4(17,0)$ \\
\hline bovengronds bemesten / surface spreading & 71,0 & 68,0 \\
\hline
\end{tabular}


2) Met ingang van 2019 moet de mest worden verdund bij gehele of gedeeltelijke toediening op de grond. Bij verdunning geldt dezelfde emissiefactor als voor zodenbemesting (17\%) / As of 2019, manure must be diluted in case of full or partial application on the soil. The same emission factor applies to diluted manure as for shallow injection (17\%).

Zie ook Bijlage 18 / See also Annex 18.

3) Naar Goedhart, PW, Mosquera, J, Huijsmans, JFM (2020). Estimating ammonia emission after field application of manure by the integrated horizontal flux method: a comparison of concentration and wind speed profiles.

\subsection{Beweiding}

De $\mathrm{NH}_{3}$-emissie door beweiding is gebaseerd op de uitscheiding van $\mathrm{N}$ tijdens weidegang van graasdieren, het TAN-percentage van de uitgescheiden $\mathrm{N}$ en de emissiefactor ten opzichte van de TAN-excretie tijdens beweiding (Van der Zee et al., 2021).

In Tabel 2.8 is de emissiefactor voor $\mathrm{NH}_{3}$ tijdens beweiding van melkkoeien weergegeven. De emissiefactor is toegepast op de TAN-excretie tijdens beweiding van alle graasdiercategorieën. De gehanteerde emissiefactor voor de periode 2003-2019 is slechts afgeleid van een enkele meting eind jaren 80 /begin jaren 90 . Recent buitenlands onderzoek gaat uit van een hogere emissiefactor bij beweiding.

Tabel 2.8 Emissiefactoren voor $\mathrm{NH}_{3}$ uit weidemest van melkkoeien (\% van TAN-excretie in de wei) / $\mathrm{NH}_{3}$ emission factors for grazing dairy cattle (\% of TAN excretion).

\begin{tabular}{|c|c|}
\hline & $\%$ \\
\hline 1990 & 9,4 \\
\hline 1991 & 10,6 \\
\hline 1992 & 10,9 \\
\hline 1993 & 9,8 \\
\hline 1994 & 7,6 \\
\hline 1995 & 9,4 \\
\hline 1996 & 11,0 \\
\hline 1997 & 8,3 \\
\hline 1998 & 5,0 \\
\hline 1999 & 5,7 \\
\hline 2000 & 4,4 \\
\hline 2001 & 6,1 \\
\hline 2002 & 4,9 \\
\hline 2003-2019 & 4,0 \\
\hline
\end{tabular}

\subsection{Overige $\mathrm{N}$-verliezen tijdens toediening van dierlijke mest en bij beweiden}

Om de emissie van $\mathrm{N}_{2} \mathrm{O}$ door mesttoediening te berekenen, wordt de berekende $\mathrm{N}$-aanvoer via dierlijke mest naar de bodem verdeeld over bovengronds uitrijden en onderwerken. Bij onderwerken is de emissie van $\mathrm{N}_{2} \mathrm{O}$ hoger, omdat door een lagere $\mathrm{NH}_{3}$-emissie meer $\mathrm{N}$ in de bodem blijft. Hierdoor kan er bij nitrificatie- en denitrificatieprocessen meer $\mathrm{N}_{2} \mathrm{O}$ ontstaan. Emissiearme mesttoediening (onderwerken) leidt daarnaast echter tot een reductie van kunstmestgebruik (als rekening gehouden wordt met de hogere stikstofwerking van emissiearm toegediende mest) en daarmee indirect tot een reductie van de aan kunstmest gerelateerde $\mathrm{N}_{2} \mathrm{O}$-emissie (Huijsmans en Schils, 2009).

De emissiefactoren voor $\mathrm{N}_{2} \mathrm{O}$-emissie uit mesttoediening en weidemest zijn gebaseerd op onderzoek van Velthof en Mosquera (2011), waarbij de emissiefactoren werden onderscheiden naar bodemtype en landgebruik. Voor het gebruik in de nationale registratie van de broeikasgasemissies werden deze emissiefactoren echter geaggregeerd naar één gemiddelde emissiefactor voor Nederland op basis van de verdeling van uitgereden mest op grasland en bouwland en minerale gronden en veengronden in 
de periode 1990-2005 (zie ook Lagerwerf et al., 2019). Om beter aan te sluiten bij veranderingen in landgebruik en de verdeling van uitgereden mest over de verschillende grondsoorten is besloten om niet langer uit te gaan van geaggregeerde emissiefactoren maar gebruik te maken van de oorspronkelijke emissiefactoren in Velthof en Mosquera (2011). Voor de verdeling van de uitgereden mest en de weidemest over grondsoorten in de periode 2000-2019 is gebruik gemaakt van het rekenmodel INITIATOR (Kros et al., 2019). Voor de periode 1990-1999 waren geen gegevens van het INITIATOR-model beschikbaar en daarom is voor die jaren nog gebruik gemaakt van geaggregeerde emissiefactoren.

Voor NO-emissie wordt de standaard (default) emissiefactor uit de EMEP/EEA air pollutant emission inventory guidebook gehanteerd (EEA, 2019).

Een overzicht van de gebruikte emissiefactoren is gegeven in Tabel 2.9.

Tabel 2.9 Emissiefactoren voor $\mathrm{N}_{2} \mathrm{O}$ en $\mathrm{NO}$ bij mesttoediening en beweiding ( $\mathrm{kg} \mathrm{N}_{2} \mathrm{O}-\mathrm{N} / \mathrm{NO}-\mathrm{N}$ per $\mathrm{kg} \mathrm{N}$-aanvoer) / Emission factors for $\mathrm{N}_{2} \mathrm{O}$ and $\mathrm{NO}$ for manure application and grazing ( $\mathrm{kg} \mathrm{N}_{2} \mathrm{O}-\mathrm{N} / \mathrm{NO}-\mathrm{N}$ per kg $N$ supply).

\begin{tabular}{|c|c|c|c|c|c|}
\hline \multirow[t]{2}{*}{ Emissiebron / Emission source } & \multirow{2}{*}{$\begin{array}{l}\text { Grasland } \\
\text { veengrond } \\
\text { / peat soil }\end{array}$} & \multirow{2}{*}{$\begin{array}{l}\text { Grassland } \\
\text { minerale } \\
\text { grond / } \\
\text { mineral soil }\end{array}$} & \multicolumn{2}{|c|}{ Bouwland / Arable land } & \multirow{2}{*}{$\begin{array}{l}\text { Gemiddelc } \\
\text { / Average }\end{array}$} \\
\hline & & & $\begin{array}{l}\text { veengrond } \\
\text { / peat soil }\end{array}$ & $\begin{array}{c}\text { minerale } \\
\text { grond / } \\
\text { mineral soil }\end{array}$ & \\
\hline $\begin{array}{l}\left.\mathrm{N}_{2} \mathrm{O} \text { - bovengrondse toediening }{ }^{2}\right) / \mathrm{N}_{2} \mathrm{O} \text { - surface } \\
\text { spreading }\end{array}$ & 0,005 & 0,001 & 0,005 & 0,006 & $0,004^{1)}$ \\
\hline $\mathrm{N}_{2} \mathrm{O}$ - onderwerken ${ }^{2)} / \mathrm{N}_{2} \mathrm{O}$ - incorporation ${ }^{2)}$ & 0,010 & 0,003 & 0,010 & 0,013 & $0,009^{1)}$ \\
\hline $\mathrm{N}_{2} \mathrm{O}-$ weidemest $\left.^{2}\right) / \mathrm{N}_{2} \mathrm{O}-$ grazing $^{2)}$ & 0,060 & 0,025 & & & $0,033^{1)}$ \\
\hline NO - mesttoediening ${ }^{3)}$ / NO - manure application ${ }^{3)}$ & 0,012 & 0,012 & 0,012 & 0,012 & 0,012 \\
\hline NO - weidemest ${ }^{3)}$ / NO - grazing ${ }^{3)}$ & 0,012 & 0,012 & 0,012 & 0,012 & 0,012 \\
\hline
\end{tabular}

Bronnen / Sources:

1) Van der Zee et al. (2021).

2) Velthof en/and Mosquera (2011).

3) EEA (2019). 


\section{Stikstofverliezen uit andere landbouwbronnen dan dierlijke mest}

\subsection{Kunstmest en spuiwater van luchtwassers}

De gegevens over het kunstmestverbruik zijn tot en met 2015 afkomstig uit een inventarisatie bij kunstmestfabrikanten en handelaren (Wageningen Economic Research) en met ingang van 2016 uit het Bedrijveninformatienet (BIN) van Wageningen Economic Research.

De cijfers in het BIN hebben betrekking op landbouwbedrijven met een minimale omvang van 25.000 euro Standaardopbrengst (SO). Het gebruik door landbouwbedrijven onder deze grens is geschat door het verbruik in het BIN te verhogen met 3\%, een schatting op basis van het aandeel landbouwgrond op landbouwbedrijven met minder dan 25.000 euro SO.

In de emissieberekeningen van de reeks 1990-2018 (Van Bruggen et al., 2020) werd uitgegaan van een voorlopig cijfer van het kunstmestgebruik in 2018. Dit cijfer is in de nieuwe tijdreeks vervangen door een definitief cijfer. Het kunstmestgebruik in 2018 valt hierdoor 6,5 miljoen kg N hoger uit (3\%). Het kunstmestgebruik in 2019 is nog een voorlopig cijfer. Het kunstmestverbruik in de glastuinbouw, 8,1 miljoen $\mathrm{kg} \mathrm{N}$ in 2019, leidt vanwege de wijze van toedienen niet tot $\mathrm{NH}_{3}$-emissie.

In Bijlage 19 is een toelichting opgenomen op het kunstmestverbruik in 2015-2019 en in Bijlage 20 is een overzicht opgenomen van het gebruik van kunstmest en spuiwater voor de gehele tijdreeks.

Voor meer informatie over de uitgangspunten om $\mathrm{NH}_{3}$-emissie en overige $\mathrm{N}$-verliezen uit kunstmest en spuiwater te berekenen, wordt verwezen naar Van Bruggen et al. (2017b).

In Tabel 3.1 zijn de emissiefactoren voor $\mathrm{NH}_{3}-\mathrm{N}$ voor kunstmest en spuiwater van luchtwassers weergegeven bij toediening aan landbouwgronden. Niet alle kunstmestsoorten worden nog gebruikt in Nederland.

Tabel 3.1 Emissiefactor voor $\mathrm{NH}_{3}-\mathrm{N}$ voor kunstmest (\% van toegediende $\mathrm{N}$ ) / $\mathrm{NH}_{3}-\mathrm{N}$ emission factor for inorganic fertiliser (\% of $N$ applied).

\begin{tabular}{|c|c|}
\hline Kunstmestsoort / Fertiliser type & $\mathrm{EF} \mathrm{NH}_{3}-\mathrm{N}^{1)}(\%)$ \\
\hline Ammoniumnitraat / Ammonium nitrate & 5,2 \\
\hline Ammoniumsulfaat / Ammonium sulphate & 11,3 \\
\hline Ammoniumsulfaatsalpeter / Mix ammonium nitrate/ammonium sulphate & 8,2 \\
\hline Chilisalpeter / Sodium nitrate & 0 \\
\hline Diammoniumfosfaat / Diammonium phosphate & 7,4 \\
\hline Gemengde stikstofmeststof / Mixed nitrogen fertiliser & 2,5 \\
\hline Kalisalpeter / Potassium nitrate & 0 \\
\hline Kalkammonsalpeter / Calcium ammonium nitrate & 2,5 \\
\hline Kalksalpeter / Calcium nitrate & 0 \\
\hline Monoammoniumfosfaat / Mono ammonium phosphate & 7,4 \\
\hline Overige NPK-, NP- en NK-meststoffen volle grond / Other NPK, NP and NK fertilisers open field & 4,5 \\
\hline $\begin{array}{l}\text { Overige NPK-, NP- en NK-meststoffen in de glastuinbouw / Other NPK, NP and NK fertilisers in } \\
\text { greenhouse cultivation }\end{array}$ & 0 \\
\hline Stikstoffosfaatkalimagnesiummeststoffen / N, P, K, Mg fertilisers & 2,5 \\
\hline Stikstofmagnesia / Nitrogen magnesia & 2,5 \\
\hline Ureum: / Urea: & \\
\hline korrelvormig incl. ureum met nitrificatieremmer / granular incl. urea with nitrification inhibitor & 14,3 \\
\hline korrelvormig met ureaseremmer / granular with urease inhibitor & 5,9 \\
\hline vloeibaar, oppervlakkig toegediend / liquid, surface spreading & 7,5 \\
\hline vloeibaar, geïnjecteerd / liquid, injected & 1,5 \\
\hline vloeibaar, met ureaseremmer / liquid, with uease inhibitor & 3,1 \\
\hline
\end{tabular}


2017 zijn de gegevens over het gebruik van zuiveringsslib in de landbouw gebaseerd op de Vervoersbewijzen Zuiveringsslib en Compost (VZC) zoals geregisteerd bij RVO.

In Bijlage 21 is een overzicht weergegeven van de uitgangspunten voor de berekening van $\mathrm{NH}_{3}$ emissies uit overige organische meststoffen zoals compost en zuiveringsslib.

De emissiefactoren voor $\mathrm{N}_{2} \mathrm{O}-\mathrm{N}$ en NO-N zijn weergegeven in Tabel 3.3.

Tabel 3.3 Emissiefactoren voor het gebruik van overige organische meststoffen / Emission factors for the application of other organic fertilisers.

\begin{tabular}{|c|c|c|}
\hline Overige organische meststoffen / Other organic fertilisers & 1990-1991 & 1992-2018 \\
\hline \multicolumn{3}{|l|}{ Zuiveringsslib / Sewage sludge } \\
\hline $\mathrm{N}_{2} \mathrm{O}-\mathrm{N}$ emissiefactor (\% van toegediende $\mathrm{N}$ ) / $\mathrm{N}_{2} \mathrm{O}-\mathrm{N}$ emission factor (\% of applied $\mathrm{N}$ ) & 0,4 & 0,9 \\
\hline NO-N emissiefactor ( $\%$ van toegediende $\mathrm{N}$ ) / NO-N emission factor ( $\%$ of applied $\mathrm{N}$ ) & 1,2 & 1,2 \\
\hline \multicolumn{3}{|l|}{$\begin{array}{l}\text { Compost en overige organische meststoffen / Compost and other organic } \\
\text { fertilisers }\end{array}$} \\
\hline $\mathrm{N}_{2} \mathrm{O}-\mathrm{N}$ emissiefactor ( $\%$ van toegediende $\mathrm{N}$ ) / $\mathrm{N}_{2} \mathrm{O}-\mathrm{N}$ emission factor (\% of applied $\mathrm{N}$ ) & 0,4 & 0,4 \\
\hline NO-N emissiefactor ( $\%$ van toegediende $\mathrm{N}$ ) / NO-N emission factor (\% of applied N) & 1,2 & 1,2 \\
\hline
\end{tabular}

Bronnen / Sources: Van der Zee et al. (2021), EEA (2019), Velthof en/and Mosquera (2011).

\subsection{Afrijpende gewassen, gewasresten en graslandvernieuwing}

\section{Afrijpende gewassen}

De ammoniakemissie van (afrijpende) gewassen is gedefinieerd als de totale netto emissie vanaf zaaien of planten tot het moment van oogsten. Deze emissie is ingeschat op 1,5 miljoen $\mathrm{kg} \mathrm{NH}-\mathrm{N}$ gebaseerd op data van 2003 en 2008 (De Ruijter et al., 2013). Dit cijfer is voor alle jaren in de tijdreeks aangehouden.

\section{Gewasresten}

Voor de berekening van de $\mathrm{NH}_{3}-{ }^{-}, \mathrm{N}_{2} \mathrm{O}$ - en $\mathrm{NO}$-emissies is de totale hoeveelheid $\mathrm{N}$ in gewasresten van belang. Deze wordt berekend als de som van het product van de $\mathrm{N}$-gehalten in bovengrondse en ondergrondse gewasresten vermenigvuldigd met het areaal. De berekening van de ammoniakemissie uit gewasresten is gebaseerd op de methode zoals beschreven door De Ruijter en Huijsmans (2019). De emissiefactor voor $\mathrm{N}_{2} \mathrm{O}-\mathrm{N}$ uit gewasresten is gelijk aan de IPCC-default (IPCC, 2006) en bedraagt $1 \%$ van de totale hoeveelheid $\mathrm{N}$ in gewasresten $(0,01 \mathrm{~kg} \mathrm{~N} 2 \mathrm{O}-\mathrm{N} / \mathrm{kg} \mathrm{N})$. De emissiefactor voor NO-N uit gewasresten is $1,2 \%$, gelijk aan de standaard (default) emissiefactor uit de EMEP/EEA air pollutant emission inventory guidebook (EEA, 2019).

In Bijlage 22 is voor de gehele tijdreeks een overzicht opgenomen van de gewasarealen, de hoeveelheid $\mathrm{N}$ in gewasresten van akkerbouwgewassen en de emissiefactoren voor $\mathrm{NH}_{3}$.

\section{Graslandvernieuwing}

Het voorlopige cijfer voor het percentage grasland dat in 2018 is vernieuwd (omploegfactor) is bijgesteld van 2,3\% naar 2,1\% op basis van definitieve cijfers uit het Bedrijveninformatienet (BIN) van Wageningen Economic Research. Voor 2019 is de omploegfactor 1,6\%. De omploegfactor wordt gebruikt voor de berekening van gewasrestemissies van grasland. De berekening van ammoniakemissies vanuit doodspuiten voor graslandvernieuwing en maaiverliezen is gebaseerd op De Ruijter en Huijsmans (2019).

In Bijlage 23 zijn de uitgangspunten voor de berekening van $\mathrm{N}$-verliezen uit grasland voor de gehele tijdreeks weergegeven.

De $\mathrm{N}_{2} \mathrm{O}$-emissie bij verandering van landgebruik (bijvoorbeeld wisselbouw; rotatie van gras en mais) wordt apart gerapporteerd door de werkgroep LULUCF.

Voor een toelichting wordt verwezen naar Van der Zee et al. (2021). 


\subsection{Organische bodems}

De uitgangspunten voor de berekening van $\mathrm{N}_{2} \mathrm{O}$-emissies uit organische bodems zijn beschreven in Van der Zee et al. (2021), zie ook Van Bruggen et al. (2015).

Bij veengrond wordt uitgegaan van een mineralisatie van $233,5 \mathrm{~kg} \mathrm{~N}$ per ha per jaar en een emissiefactor van 0,02 kg N $2 \mathrm{O}-\mathrm{N}$ per $\mathrm{kg}$ gemineraliseerde $\mathrm{N}$. Dit levert een emissiefactor op van 4,67 kg $\mathrm{N}_{2} \mathrm{O}-$ $\mathrm{N} /$ ha (Kuikman et al., 2005). Bij moerige grond wordt uitgegaan van een mineralisatie van $204,5 \mathrm{~kg}$ $\mathrm{N} /$ ha en een emissiefactor van $0,02 \mathrm{~kg} \mathrm{~N} 2 \mathrm{O}-\mathrm{N}$ per $\mathrm{kg}$ gemineraliseerde $\mathrm{N}$ (resulterend in 4,09 kg $\mathrm{N}_{2} \mathrm{O}-$ $\mathrm{N} / \mathrm{ha}$ ).

De $\mathrm{N}_{2} \mathrm{O}$-emissie bij verandering van landgebruik wordt gerapporteerd door de werkgroep LULUCF en apart gerapporteerd.

Een overzicht van de arealen is opgenomen in Bijlage 24. 


\section{$4 \quad$ Indirecte lachgas-emissies}

\subsection{Atmosferische depositie}

Ongeacht de geografische locatie van depositie (dus ook buiten de landsgrenzen), is een lidstaat verantwoordelijk voor de indirecte $\mathrm{N}_{2} \mathrm{O}$-emissies die ontstaan na depositie van in eigen land uitgestoten $\mathrm{NH}_{3}$ en $\mathrm{NO}$. Deze indirecte $\mathrm{N}_{2} \mathrm{O}$-emissie maakt onderdeel uit van het National Inventory Report (NIR) van broeikasgasemissies. De hoeveelheid N-depositie, staat daarom gelijk aan de totale $\mathrm{N}$-emissie in de vorm van $\mathrm{NH}_{3}$ en $\mathrm{NO}$ uit stallen en mestopslagen, en uit landbouwbodems. Tot de emissies uit landbouwbodems worden de emissies gerekend die optreden tijdens beweiding van graasdieren, bij toediening van mest, kunstmest, compost en zuiveringsslib. De emissies van $\mathrm{NH}_{3}$ en NO van afrijpende gewassen en gewasresten inclusief verliezen door graslandvernieuwing en maaiverliezen blijven in de 2006 IPCC Guidelines buiten beschouwing maar zijn in NEMA wel meegeteld als bron van indirecte $\mathrm{N}_{2} \mathrm{O}$-emissie uit de landbouw.

In Tabel 4.1 is de emissiefactor voor depositie weergegeven.

\section{$4.2 \quad$ Uit- en afspoeling}

Ook de uit- en afspoeling van (naar de bodem aangevoerde) $\mathrm{N}$ naar het oppervlaktewater is een bron van indirecte $\mathrm{N}_{2} \mathrm{O}$-emissie. In de emissieberekeningen wordt aangenomen dat de uitgespoelde stikstof ergens wordt gedenitrificeerd en dat hierdoor $\mathrm{N}_{2} \mathrm{O}$ naar de atmosfeer emitteert.

In de berekening van indirecte $\mathrm{N}_{2} \mathrm{O}$-verliezen door uit- en afspoeling wordt uitgegaan van de $\mathrm{N}$ aanvoer naar de bodem. Hierbij worden de volgende $\mathrm{N}$-bronnen onderscheiden: kunstmest, dierlijke mest inclusief beweiding, compost, zuiveringsslib, gewasresten inclusief graslandvernieuwing en mineralisatie van organische bodems. In de uitwerking van Paragraaf 11.2.2.1 van de IPPC Guidelines 2006 ontbreekt de N-mineralisatie van organische bodems (IPPC-term: FOS), terwijl deze wel wordt genoemd als bron in de inleidende tekst van Hoofdstuk 11.2.2 van de Guidelines. Er is in onderhavig rapport van uitgegaan dat $\mathrm{N}$-mineralisatie van organische bodems wèl een bron is van $\mathrm{N}$-aanvoer naar landbouwgronden.

De bronnen van $\mathrm{N}$-aanvoer naar de bodem worden vermenigvuldigd met een voor Nederland jaar- en landspecifieke factor voor uit- en afspoeling (IPPC-term: FRACleach) (Van der Zee et al., 2021, zie ook Velthof \& Mosquera, 2011). Deze uit- en afgespoelde $\mathrm{N}$ wordt daarop vermenigvuldigd met de IPCCdefault emissiefactor van 0,0075 kg N2O-N per kg uit- en afgespoelde $\mathrm{N}$ (Van der Zee et al., 2021).

In Tabel 4.1 zijn de factor voor uit- en afspoeling (FRACleach) en de emissiefactoren voor $\mathrm{N}_{2} \mathrm{O}$ weergegeven.

Tabel 4.1 Factor voor uit- en afspoeling (FRACleach) en emissiefactoren voor $\mathrm{N}_{2} \mathrm{O}$ van atmosferische depositie en uit- en afspoeling / Factor for leaching and runoff (FRACleach) and $\mathrm{N}_{2} \mathrm{O}$ emission factors for atmospheric deposition and for leaching and runoff.

\begin{tabular}{|c|c|c|c|}
\hline Indirecte $\mathrm{N}_{2} \mathrm{O}$-emissies / Indirect $\mathrm{N}_{2} \mathrm{O}$-emissions & 1990-1991 & 1992-1997 & $1998-2019$ \\
\hline FRACleach & 0,15 & 0,14 & 0,13 \\
\hline \multicolumn{4}{|l|}{ Emissiefactor $\left.\mathrm{N}_{2} \mathrm{O}^{1}\right)$ : / Emission factor $\mathrm{N}_{2} \mathrm{O}^{1}$ : } \\
\hline atmosferische depositie ( $\mathrm{kg} \mathrm{N}_{2} \mathrm{O}-\mathrm{N} / \mathrm{kg} \mathrm{N}$-emissie) / & & & \\
\hline atmospheric deposition ( $\mathrm{kg} \mathrm{N} \mathrm{N}_{2} \mathrm{O}-\mathrm{N} / \mathrm{kg} \mathrm{N}$-emission) & 0,01 & 0,01 & 0,01 \\
\hline $\begin{array}{l}\text { uit- en afspoeling ( } \mathrm{kg} \mathrm{N} \mathrm{N}_{2} \mathrm{O} / \mathrm{kg} \mathrm{N} \text { leaching) / leaching } \\
\text { (kg } \mathrm{N}_{2} \mathrm{O} / \mathrm{kg} \mathrm{N} \text { leaching) }\end{array}$ & 0,0075 & 0,0075 & 0,0075 \\
\hline
\end{tabular}

1) IPCC (2006). 



\section{$5 \quad$ Methaanemissie door pens- en darmfermentatie, uit opslag van geproduceerde mest en bij mestbewerking}

Emissies van methaan in de landbouw ontstaan door pens- en darmfermentatie (enterische methaanproductie), door fermentatieprocessen in opgeslagen dierlijke mest en door mestbewerking.

\subsection{Pens- en darmfermentatie}

Fermentatieprocessen vinden bij herkauwers (rundvee, schapen en geiten) plaats in de pens en de dikke darm, waarbij vooral pensfermentatie een grote bijdrage levert aan de $\mathrm{CH}_{4}$-productie. $\mathrm{Bij}$ éénmagigen (varkens en paarden) vindt dit proces alleen in de dikke darm plaats. Bij pluimvee heeft het voer een hoge doorloopsnelheid in het dier waardoor de methanogene activiteit in de darmen niet echt op gang komt. De enterische $\mathrm{CH}_{4}$-productie is bij deze diercategorie verwaarloosbaar.

Conform de 2006 IPCC Guidelines worden voor de bijdrage van de onderscheiden diercategorieën verschillende methodieken toegepast. Pens- en darmfermentatie van melkkoeien levert een significante bijdrage aan de nationale emissies (key source) en wordt daarom op landspecifieke wijze (Tier 3) gemodelleerd. Bannink (2011) geeft een beschrijving van de methodiek, waarmee jaarlijks een emissiefactor wordt berekend. De Tier 3-methode wordt ook toegepast voor de berekening van de fecale N-verteerbaarheid (VCRE) (Bannink et al., 2018).

In Bijlage 26 wordt de berekening van de emissiefactor voor $\mathrm{CH}_{4}$ uit pensfermentatie en de berekening van de fecale $\mathrm{N}$-verteerbaarheid voor 2019 toegelicht.

De emissie door ander rundvee dan melkkoeien wordt berekend met jaar- en landspecifieke emissiefactoren per dier (Tier 2). De jaar- en landspecifieke emissiefactor is berekend door de bruto energieopname in MJ op basis van WUM-rantsoenen te vermenigvuldigen met de fractie hiervan die in $\mathrm{CH}_{4}$ wordt omgezet (de methaanconversiefactor $\mathrm{Y}_{\mathrm{m}}$ volgens IPCC defaults). Ten slotte wordt de energieopname die in $\mathrm{CH}_{4}$ wordt omgezet omgerekend in $\mathrm{CH}_{4}$ door te delen door $55,65 \mathrm{MJ} / \mathrm{kg} \mathrm{CH}_{4}$, de standaard energie-inhoud van $1 \mathrm{~kg} \mathrm{CH}_{4}$ (IPCC, 2006). De methaanconversiefactor voor overig rundvee uitgezonderd witvleeskalveren is $6,5 \%$ (IPCC, 2006). De methaanconversiefactor voor witvleeskalveren wordt vanwege het afwijkende rantsoen van deze dieren berekend op basis van Gerrits et al. (2014), zoals beschreven in Van Bruggen et al. (2015).

Voor schapen, geiten, paarden, pony's, ezels en varkens wordt de Tier 1-benadering van de IPCC gebruikt. In tegenstelling tot een Tier 2-benadering waarbij gebruik gemaakt wordt van een berekening op basis van rantsoen, voeropname en methaanconversiefactor $Y_{m}$, wordt in een Tier 1benadering gebruik gemaakt van standaard emissiefactoren per dier in kg/jaar (IPCC defaults).

In Bijlage 27 is de bruto energie-opname door rundvee weergegeven. In Bijlage 28 zijn de emissiefactoren weergegeven voor $\mathrm{CH}_{4}$ uit pens- en darmfermentatie.

\subsection{Opslag van geproduceerde mest}

$\mathrm{CH}_{4}$-productie vindt met name plaats in opgeslagen drijfmest en in mindere mate in vaste mest en in weidemest. $\mathrm{CH}_{4}$ wordt door methanogene bacteriën geproduceerd en deze zijn onder anaërobe omstandigheden actief. Daarom is de $\mathrm{CH}_{4}$-emissie uit drijfmest groter dan uit vaste mest. $\mathrm{Na}$ 
mesttoediening aan de bodem is de $\mathrm{CH}_{4}$-productie verwaarloosbaar, omdat de mest is uitgespreid over een groot oppervlak en er zuurstof in landbouwgronden aanwezig is (aeroob). $\mathrm{De} \mathrm{CH}_{4}$ die in dat stadium vrijkomt, is al ontstaan in de opslag en ook toegerekend aan de opslag.

De berekeningswijze van de $\mathrm{CH}_{4}$-emissie uit dierlijke mest is beschreven in Van der Zee et al. (2021). $\mathrm{CH}_{4}$-emissie is het product van de excretie van organische stof (OS), de potentiële fractie daarvan die omgezet wordt in $\mathrm{CH}_{4}$ (Biochemisch Methaan Potentieel, BMP) en de fractie van de BMP die daadwerkelijk wordt omgezet in $\mathrm{CH}_{4}$ (Methaan Conversie Factor, MCF). De berekening van de OSexcretie voor rundvee, varkens en pluimvee is beschreven in Zom en Groenestein (2015). De actualisatie van deze berekening is opgenomen in Van Bruggen et al. (2020, Bijlage 24).

In Bijlage 29 is de OS-excretie per dier weergegeven voor diercategorieën waarvoor een Tier 2berekening wordt toegepast.

\section{$\mathrm{CH}_{4}$-emissie uit opslag bij scheiden en vergisten}

$\mathrm{Er}$ is van uitgegaan dat bij mestscheiden en mestvergisten de opslagduur van mest voorafgaand aan het bewerkingsproces korter is waardoor de $\mathrm{CH}_{4}$-emissies uit opgeslagen mest vóór mestbewerking halveren. De $\mathrm{CH}_{4}$-emissiefactoren voor opslag van gescheiden mest zijn dan eveneens de helft van de factoren in Melse en Groenestein (2016). De totale emissie van mestopslag vóór en na mestscheiden en mestvergisten wordt dus voor de helft toegekend aan de mestopslag voorafgaand aan het bewerkingsproces en voor de helft aan de opslag erna.

Voor de kleinere diercategorieën (schapen, geiten, paarden, pony's, ezels, konijnen en nertsen) is de IPCC Tier 1-methode aangehouden met vaste emissiefactoren per dier, met waar van toepassing een opsplitsing naar stal en weide aan de hand van het aantal stal- en weidedagen. Aangezien de MCF van weidemest $(0,01)$ lager is dan de MCF van vaste mest $(0,02)$ is de MCF als wegingsfactor toegepast bij de verdeling over stal en weide bij schapen, paarden, pony's en ezels.

In Tabel 5.1 zijn de factoren voor BMP en MCF weergegeven met uitzondering van die diercategorieën waarvoor een (Tier 1)-methode is toegepast met vaste emissiefactoren per dier.

Tabel 5.1 Biochemisch methaan potentieel (BMP in $\mathrm{m}^{3} \mathrm{CH}_{4} / \mathrm{kg}$ OS) en methaanconversiefactoren (MCF) / Biochemical methane potential (BMP in $\mathrm{m}^{3} \mathrm{CH}_{4} / \mathrm{kg}$ VS) and methane conversion factors (MCF).

\begin{tabular}{|c|c|c|c|c|}
\hline \multirow[t]{2}{*}{ Diercategorie / Livestock category } & \multirow[t]{2}{*}{ BMP } & \multicolumn{3}{|c|}{ MCF } \\
\hline & & $\begin{array}{l}\text { Drijf- } \\
\text { mest / } \\
\text { Slurry }\end{array}$ & $\begin{array}{l}\text { Vaste mest / } \\
\text { Solid manure }\end{array}$ & $\begin{array}{c}\text { Weidemest/ } \\
\text { Pasture } \\
\text { manure }\end{array}$ \\
\hline \multicolumn{5}{|l|}{ Melk- en fokvee / Dairy cattle } \\
\hline vrouwelijk jongvee $<1 \mathrm{jr} /$ female young stock $<1 \mathrm{yr}$ & 0,22 & 0,17 & 0,02 & 0,01 \\
\hline mannelijk jongvee $<1 \mathrm{jr} /$ male young stock $<1 \mathrm{yr}$ & 0,22 & 0,17 & 0,02 & \\
\hline vrouwelijk jongvee 1-2 jr / female young stock 1-2 yr & 0,22 & 0,17 & 0,02 & 0,01 \\
\hline mannelijk jongvee $1-2 \mathrm{jr} /$ male young stock $1-2 \mathrm{yr}$ & 0,22 & 0,17 & 0,02 & \\
\hline vrouwelijk jongvee $\geq 2 \mathrm{jr} /$ female young stock $\geq 2 \mathrm{yr}$ & 0,22 & 0,17 & 0,02 & 0,01 \\
\hline melk- en kalfkoeien / dairy cows & 0,22 & 0,17 & 0,02 & 0,01 \\
\hline fokstieren $\geq 2 \mathrm{jr} /$ breeding bulls $\geq 2 \mathrm{yr}$ & 0,22 & 0,17 & 0,02 & \\
\hline \multicolumn{5}{|l|}{ Vlees- en weidevee / Beef cattle } \\
\hline witvleeskalveren / calves for white veal production & 0,22 & 0,17 & & \\
\hline rosévleeskalveren / calves for rosé veal production & 0,22 & 0,17 & & \\
\hline vrouwelijk jongvee $<1 \mathrm{jr} /$ female young stock $<1 \mathrm{yr}$ & 0,22 & 0,17 & 0,02 & 0,01 \\
\hline $\begin{array}{l}\text { mannelijk jongvee (incl. ossen) }<1 \mathrm{jr} / \text { male young stock } \\
\text { (incl. bullocks) }<1 \mathrm{yr}\end{array}$ & 0,22 & 0,17 & 0,02 & \\
\hline vrouwelijk jongvee $1-2 \mathrm{jr} /$ female young stock 1-2 yr & 0,22 & 0,17 & 0,02 & 0,01 \\
\hline $\begin{array}{l}\text { mannelijk jongvee (incl. ossen) } 1-2 \mathrm{jr} / \text { male young stock } \\
\text { (incl. bullocks) } 1-2 \mathrm{yr}\end{array}$ & 0,22 & 0,17 & 0,02 & \\
\hline vrouwelijk jongvee $\geq 2 \mathrm{jr} /$ female young stock $\geq 2 \mathrm{yr}$ & 0,22 & 0,17 & 0,02 & 0,01 \\
\hline $\begin{array}{l}\text { mannelijk jongvee (incl. ossen) } \geq 2 \mathrm{jr} / \text { male young stock } \\
\text { (incl. bullocks) } \geq 2 \mathrm{yr}\end{array}$ & 0,22 & 0,17 & 0,02 & \\
\hline
\end{tabular}




\begin{tabular}{|c|c|c|c|c|}
\hline \multirow{2}{*}{ Diercategorie / Livestock category } & \multirow[t]{2}{*}{ BMP } & \multicolumn{3}{|c|}{ MCF } \\
\hline & & $\begin{array}{l}\text { Drijf- } \\
\text { mest / } \\
\text { Slurry }\end{array}$ & $\begin{array}{l}\text { Vaste mest / } \\
\text { Solid manure }\end{array}$ & $\begin{array}{c}\text { Weidemest/ } \\
\text { Pasture } \\
\text { manure }\end{array}$ \\
\hline $\begin{array}{l}\text { zoog-, mest- en weidekoeien } \geq 2 \mathrm{jr} / \text { suckling cows and } \\
\text { female fatteners } \geq 2 \mathrm{yr}\end{array}$ & 0,22 & 0,17 & 0,02 & 0,01 \\
\hline Varkens / Pigs & 0,31 & 0,36 & 0,02 & \\
\hline \multicolumn{5}{|l|}{ Pluimvee / Poultry } \\
\hline leghennen / laying hens & 0,34 & 0,36 & 0,015 & \\
\hline vleeskuikens / broilers & 0,34 & & 0,015 & \\
\hline vleeskuikenouderdieren / broiler breeders & 0,34 & & 0,015 & \\
\hline eenden / ducks & 0,34 & & 0,015 & \\
\hline kalkoenen / turkeys & 0,34 & & 0,015 & \\
\hline
\end{tabular}

In Bijlage 30 zijn de emissiefactoren weergegeven in $\mathrm{kg} \mathrm{CH}_{4}$ per dier per jaar voor drijfmest, vaste mest en weidemest.

\subsection{Mestbewerking en -verwerking}

Deze paragraaf handelt over de $\mathrm{CH}_{4}$-emissie bij mestbewerking en -verwerking. Voor een beschrijving van de verschillende vormen van mestbewerking en -verwerking en de emissies van stikstofverbindingen wordt verwezen naar Paragraaf 2.9. Niet elke vorm van mestbewerking en verwerking vindt over de hele tijdreeks plaats, de meeste vormen zijn na 2006 opgekomen.

De $\mathrm{CH}_{4}$-emissie is per vorm van mestbewerking gebaseerd op de hoeveelheid organische stof (OS) in de aangevoerde mest. Hierbij is gebruik gemaakt van de hoeveelheid $\mathrm{P}_{2} \mathrm{O}_{5}$ in de aangevoerde mest op basis van vervoersbewijzen, zoals geregistreerd bij RVO, en de verhouding tussen $O S$ en $\mathrm{P}_{2} \mathrm{O}_{5}$ in geproduceerde mest.

\section{Mestscheiding en kalvergierzuivering}

Mestscheiding komt voor vanaf 2009 en kalvergierzuivering al vóór 1990. De hoeveelheid ingaande OS voor de berekening van de $\mathrm{CH}_{4}$-emissie is als volgt berekend:

Ingaande OS naar mestscheiding $=$ OS excretie in de stal $\times\left(\mathrm{P}_{2} \mathrm{O}_{5}\right.$ naar mestscheiding $/ \mathrm{P}_{2} \mathrm{O}_{5}$

excretie in de stal).

De aanvoer naar mestscheiding is berekend op basis van de hoeveelheid van de dikke fractie die door landbouwbedrijven van het bedrijf is afgevoerd, plus het saldo van de aan- en afvoer van dikke fractie door mestverwerkingsbedrijven, het gehalte uit praktijkproeven volgens Tabel 2.4 en het scheidingsrendement voor $\mathrm{P}_{2} \mathrm{O}_{5}$.

\section{Mineralenconcentraat}

Vanaf 2011 is voor varkensmest in NEMA rekening gehouden met verwerking van mest tot mineralenconcentraat. De hoeveelheid ingaande OS is berekend met:

Ingaande OS naar mestscheiding t.b.v. mineralenconcentraat $=$ OS excretie in de stal $\times\left(\mathrm{P}_{2} \mathrm{O}_{5}\right.$ van bedrijven die mineralenconcentraat produceren / $\mathrm{P}_{2} \mathrm{O}_{5}$ excretie in de stal).

De aanvoer naar mestscheiding t.b.v. de productie van mineralenconcentraat is gebaseerd op vervoersbewijzen.

\section{Mestvergisting}

Voor rundvee- en varkensmest is mest vergisten in NEMA als mestbewerking meegenomen vanaf 2006. Een belangrijk punt hierbij is dat onbekend is hoe lang de mest in de mestkelder of buitenopslag ligt voordat deze vergist wordt, vooral bij afvoer naar centrale vergisters. Daarom is verondersteld dat de opslagemissie voorafgaand aan vergisting (decentraal en centraal) slechts voor de helft gereduceerd wordt en niet voor meer dan $95 \%$ in geval van vergisting van verse mest. De 
eventuele overschatting van de methaanemissies is bij de huidige omvang van de mestvergisting verwaarloosbaar.

De hoeveelheid ingaande OS is berekend op basis van de hoeveelheid $\mathrm{P}_{2} \mathrm{O}_{5}$ in de mestproductie van bedrijven met een vergistingsinstallatie en de mestaanvoer naar bedrijven met een vergister. De $\mathrm{P}_{2} \mathrm{O}_{5}$ in rundermest en varkensmest is verdeeld over melkkoeien/jongvee en fokvarkens/vleesvarkens op basis van de hoeveelheid $\mathrm{P}_{2} \mathrm{O}_{5}$ in geproduceerde stalmest. De hoeveelheid ingaande OS is berekend met:

Ingaande OS naar vergisting $=$ OS excretie in de stal $x\left(\mathrm{P}_{2} \mathrm{O}_{5}\right.$ naar co-vergisting $/ \mathrm{P}_{2} \mathrm{O}_{5}$ excretie in de stal).

\section{Mest drogen en korrelen}

Vanaf 1998 is rekening gehouden met het drogen en korrelen van pluimveemest. Voor de hoeveelheid ingaande $\mathrm{OS}$ is gebruik gemaakt van de hoeveelheid $\mathrm{P}_{2} \mathrm{O}_{5}$ in transporten van legpluimveemest en vleeskuikenmest met bestemming drogen/korrelen. De hoeveelheid ingaande OS is berekend met:

Ingaande OS naar drogen en korrelen = OS excretie in de stal $\times\left(\mathrm{P}_{2} \mathrm{O}_{5}\right.$ naar drogen en korrelen / $\mathrm{P}_{2} \mathrm{O}_{5}$ excretie in de stal).

De hoeveelheid $\mathrm{P}_{2} \mathrm{O}_{5}$ in de aangevoerde mest is berekend door het mestvolume op vervoersbewijzen te vermenigvuldigen met het berekende $\mathrm{P}_{2} \mathrm{O}_{5}$-gehalte op basis van de WUM-excretie en het WUMmestvolume.

Voor de periode 1990-1997 konden geen gegevens over de omvang van het drogen en korrelen van pluimveemest worden achterhaald.

\section{Mestverbranding}

Vanaf 2001 vindt verbranding van pluimveemest plaats. $\mathrm{CH}_{4}$-emissie vindt plaats tijdens de kortdurende opslag voorafgaand aan het verbrandingsproces. Voor de berekening van de hoeveelheid ingaande OS is gebruik gemaakt van de hoeveelheid $\mathrm{P}_{2} \mathrm{O}_{5}$ in transporten van legpluimveemest, vleeskuikenmest en kalkoenenmest met bestemming verbranden. De hoeveelheid ingaande OS is berekend met:

Ingaande OS naar verbranding $=$ OS excretie in de stal $\times\left(\mathrm{P}_{2} \mathrm{O}_{5}\right.$ naar verbranding $/ \mathrm{P}_{2} \mathrm{O}_{5}$ excretie in de stal).

In tegenstelling tot drogen en korrelen is er bij verbranden geen correctie toegepast op het $\mathrm{P}_{2} \mathrm{O}_{5}{ }^{-}$ gehalte van de mest op vervoersbewijzen omdat ervan uitgegaan wordt dat bij verbranding de aangevoerde mest wordt gecontroleerd op drogestofgehalte.

In Tabel 5.2 zijn de emissiefactoren per aangevoerde $\mathrm{kg}$ OS per proces weergegeven. In Bijlage 31 is een overzicht gegeven van de OS-aanvoer per mestbewerkingstechniek.

Tabel 5.2 Methaanemissiefactoren voor mestbewerking ( $\mathrm{kg} \mathrm{CH}_{4} / \mathrm{kg}$ OS-aanvoer) / Methane emission factors for manure treatment ( $\mathrm{kg} \mathrm{CH} / \mathrm{kg}$ VS supply).

\begin{tabular}{|c|c|}
\hline Mestbewerkingsproces / Manure treatment process & $\mathrm{CH}_{4}$ \\
\hline \multicolumn{2}{|l|}{ Rundermest / Cattle manure: } \\
\hline opslag dunne fractie 6 maanden / storage liquid fraction 6 months & 0,0086 \\
\hline totaal / total & 0,0125 \\
\hline opslag dikke fractie 6 maanden / storage solid fraction 6 months & 0,0039 \\
\hline \multicolumn{2}{|l|}{ Varkensmest / Pig manure: } \\
\hline opslag dikke fractie 6 maanden / storage solid fraction 6 months & 0,0116 \\
\hline opslag dunne fractie 6 maanden / storage liquid fraction 6 months & 0,0258 \\
\hline opslag dikke fractie 6 maanden / storage solid fraction 6 months & 0,0116 \\
\hline opslag dunne fractie 6 maanden / storage liquid fraction 6 months & 0,0258 \\
\hline
\end{tabular}


Mestvergisting / Manure digesting

Rundermest - process / Cattle manure - process

Varkensmest - process / Pig manure - process

Mest drogen en korrelen / Manure drying and pelleting

Pluimveemest - korte vooropslag / Poultry manure - short pre-storage

Mestverbranding / Manure incineration

Pluimveemest - korte vooropslag / Poultry manure - short pre-storage

Bron / Source: Melse en/and Groenestein (2016).

N.B. Er is van uitgegaan dat bij mestscheiden en mestvergisten de opslagduur van mest korter is waardoor de $\mathrm{CH}_{4}$-emissie uit opgeslagen mest voorafgaand aan mestscheiden en vergisten halveren. De emissiefactoren voor de opslag van dikke en dunne fracties van gescheiden mest in Melse en Groenestein (2016) zijn eveneens gehalveerd / Note: It is assumed that slurry separation into liquid and solid fractions and manure digesting shorten the storage time of manure before treatment, reducing the $\mathrm{CH}_{4}$ emissions from storage by half. The emission factors for storage of the solid and liquid fractions of separated manure in Melse and Groenestein (2016) have also been halved. 



\section{Emissies van niet-methaan vluchtige organische stoffen (NMVOS)}

NMVOS zijn vluchtige organische verbindingen, behalve methaan. De emissies van NMVOS worden conform het EMEP/EEA air pollutant emission inventory guidebook (EEA, 2019) berekend voor de volgende bronnen:

- Huisvesting (stallen);

- Voedering van kuilvoer;

- Mestopslag buiten de stal;

- Mesttoediening;

- Weidemest;

- Opslag van kuilvoer;

- Gewasarealen.

\section{Stallen en voedering van kuilvoer}

Voor rundvee wordt de NMVOS-emissie berekend door vermenigvuldiging per diercategorie van de bruto energieopname tijdens het opstallen met emissiefactoren voor huisvesting respectievelijk voedering van kuilvoer. Voor andere diercategorieën wordt de NMVOS-emissie berekend door vermenigvuldiging van de OS-excretie met emissiefactoren voor huisvesting en voedering van kuilvoer.

\section{Mestopslag buiten de stal}

De NMVOS-emissie voor mestopslagen buiten de stal wordt berekend door vermenigvuldiging van de NMVOS-emissie uit huisvesting met de verhouding tussen de $\mathrm{NH}_{3}$-emissie uit mestopslagen buiten de stal en de $\mathrm{NH}_{3}$-emissie uit huisvesting.

\section{Mesttoediening}

De NMVOS-emissie bij het toedienen van mest aan de bodem wordt berekend door vermenigvuldiging van de NMVOS-emissie uit huisvesting met de verhouding tussen de $\mathrm{NH}_{3}$-emissie bij mesttoediening en de $\mathrm{NH}_{3}$-emissie uit huisvesting. Door de aanpassingen van de $\mathrm{NH}_{3}$-emissies uit huisvesting (Paragraaf 2.6) en bij mesttoediening (Paragraaf 2.11), verandert ook de emissie van NMVOS bij mesttoediening. Deze verhouding is voor de hele tijdreeks opgenomen in Bijlage 32.

\section{Weidemest}

Voor rundvee wordt de NMVOS-emissie tijdens beweiding berekend door vermenigvuldiging per diercategorie van de bruto energieopname tijdens beweiding met de emissiefactor voor NMVOS. Voor andere diercategorieën wordt de NMVOS-emissie berekend door vermenigvuldiging van de OS-excretie tijdens beweiding met de emissiefactor voor NMVOS.

\section{Opslag van kuilvoer}

Voor rundvee wordt de NMVOS-emissie berekend door vermenigvuldiging per diercategorie van de bruto energieopname tijdens het opstallen met het aandeel van het kuilvoer in het rantsoen en de emissiefactor voor opslag van kuilvoer. Deze uitkomst wordt vermenigvuldigd met 0,25 waarbij dit cijfer de verhouding aangeeft tussen de NMVOS-emissie uit opslag van kuilvoer in verhouding tot de NMVOS-emissie bij voedering van kuilvoer.

In Bijlage 33 is het aandeel kuilvoer in het rantsoen voor de gehele tijdreeks weergegeven. Als het aandeel kuilvoer in het rantsoen groter is dan 0,5 wordt het aandeel op 1 gesteld.

Voor andere diercategorieën wordt dezelfde berekening toegepast met dit verschil dat niet de bruto energieopname wordt gebruikt maar de OS-excretie.

\section{Gewasarealen}

Het totale areaal aan akkerbouwgewassen wordt vermenigvuldigd met de standaard emissiefactor (EEA, 2019) van 0,86 kg NMVOS per hectare. 
Een uitgebreide beschrijving van de methodiek is opgenomen in Van der Zee et al. (2021).

In Tabel 6.1 zijn de emissiefactoren weergegeven voor de NMVOS-emissies uit huisvesting, bij de voedering van kuilvoer en bij beweiding.

Tabel 6.1 Emissiefactoren voor NMVOS-emissies / Emission factors for NMVOC emissions.

\begin{tabular}{|c|c|c|c|}
\hline Diercategorie / Livestock category & $\begin{array}{r}\text { Huisvesting / } \\
\text { Housing }\end{array}$ & $\begin{array}{r}\text { Voedering van } \\
\text { kuilvoer / Silage } \\
\text { feeding }\end{array}$ & $\begin{array}{r}\text { Beweiding / } \\
\text { Grazing }\end{array}$ \\
\hline & $\begin{array}{l}\text { kg/MJ voeropname } \\
\text { / kg/MJ feed intake }\end{array}$ & $\begin{array}{l}\mathrm{kg} / \mathrm{MJ} \text { voeropname } \\
/ \mathrm{kg} / \mathrm{MJ} \text { feed intake }\end{array}$ & $\begin{array}{l}\mathrm{kg} / \mathrm{MJ} \text { voeropname } \\
/ \mathrm{kg} / \mathrm{MJ} \text { feed intake }\end{array}$ \\
\hline \multirow[t]{2}{*}{ Alle categorieën rundvee / All categories of cattle } & 0,0002002 & 0,0000353 & 0,0000069 \\
\hline & $\begin{array}{l}\mathrm{kg} / \mathrm{kg} \text { OS-excretie / } \\
\mathrm{kg} / \mathrm{kg} \text { OM excretion }\end{array}$ & $\begin{array}{r}\mathrm{kg} / \mathrm{kg} \text { OS-excretie } \\
/ \mathrm{kg} / \mathrm{kg} \text { OM } \\
\text { excretion }\end{array}$ & $\begin{array}{r}\mathrm{kg} / \mathrm{kg} \text { OS-excretie } \\
/ \mathrm{kg} / \mathrm{kg} \text { OM } \\
\text { excretion }\end{array}$ \\
\hline $\begin{array}{l}\text { Alle categorieën varkens behalve zeugen / All } \\
\text { categories of pigs except sows }\end{array}$ & & 0,001703 & \\
\hline Zeugen / Sows & & 0,007042 & \\
\hline \multicolumn{4}{|l|}{ Pluimvee / Poultry } \\
\hline $\begin{array}{l}\text { ouderdieren van vleeskuikens }<18 \text { weken / broiler } \\
\text { breeders }<18 \text { weeks }\end{array}$ & & 0,009147 & \\
\hline $\begin{array}{l}\text { ouderdieren van vleeskuikens } \geq 18 \text { weken / broiler } \\
\text { breeders } \geq 18 \text { weeks }\end{array}$ & & 0,009147 & \\
\hline laying hens $<18$ weeks / laying hens $<18$ weeks & & 0,005684 & \\
\hline laying hens $\geq 18$ weeks / laying hens $\geq 18$ weeks & & 0,005684 & \\
\hline vleeskuikens / broilers & & 0,009147 & \\
\hline eenden / ducks & & 0,005684 & \\
\hline kalkoenen / turkeys & & 0,005684 & \\
\hline \multicolumn{4}{|l|}{ Schapen, geiten, paarden, pony's en ezels / } \\
\hline Sheep, goats, horses, ponies, mules and asses & 0,01076 & 0,001614 & 0,00002349 \\
\hline Pelsdieren / Fur-bearing animals & & 0,005684 & \\
\hline Konijnen / Rabbits & & 0,001614 & \\
\hline
\end{tabular}

Bron / Source: Van der Zee et al. (2021).

In Tabel 6.2 zijn de IPCC-standaardwaarden weergegeven voor de excretie van organische stof voor die diercategorieën waarvoor geen excretie van organische stof wordt berekend.

Tabel 6.2 Excretie van organische stof $(\mathrm{kg} / \mathrm{dag}) /$ Excretion of volatile solids ( $\mathrm{kg} / \mathrm{day})$.

\begin{tabular}{lr} 
Diercategorie / Livestock category & OS-excretie \\
Schapen / Sheep & 0,40 \\
\hline Geiten / Goats & 0,30 \\
\hline Paarden / Horses & 2,13 \\
\hline Pony's / Ponies & 0,94 \\
\hline Ezels / Mules and asses & 0,94 \\
\hline Pelsdieren / Fur-bearing animals & 0,14 \\
\hline Konijnen / Rabbits & 0,10 \\
\hline
\end{tabular}

Bron / Source: IPCC (2006). 


\section{$7 \quad$ Fijnstofemissies}

Fijnstofemissies uit de landbouw komen vooral uit stallen en bestaan uit huid-, mest-, voer- en strooiseldeeltjes. De emissies worden berekend door het aantal dieren per stalsysteem te vermenigvuldigen met emissiefactoren $\mathrm{PM}_{10}$ en $\mathrm{PM}_{2,5}$ in gram per dier per jaar. Daarnaast is $\mathrm{NH}_{3}$ een "precursor" van secundair fijnstof (Brunekreef et al., 2015). $\mathrm{NH}_{3}$ wordt hier niet nader besproken, hiervoor wordt verwezen naar Hoofdstuk 2.

De aandelen van gebruikte stalsystemen komen uit de Landbouwtelling en vóór 2015 ook uit gegevens van milieuvergunningen.

De emissiefactoren zijn gebaseerd op een meetprogramma (publicatiereeks 'Fijnstofemissie uit stallen'; Mosquera et al., 2009a, 2009b, 2009c, 2010a, 2010b, 2010c en Winkel et al., 2009a, 2009b, 2010).

Voor stallen met een luchtwasser wordt gerekend met de volgende reducties voor emissie van fijnstof ten opzichte van reguliere huisvesting:

- Chemische luchtwasser: 35\%;

- Biologische luchtwasser met korte verblijftijd: 60\%;

- Biologische luchtwasser met lange verblijftijd: 75\%;

- Combi-luchtwasser: $80 \%$.

In Bijlage 34 is een overzicht opgenomen van de aandelen van de stalsystemen (B34.1) en een overzicht van de emissiefactoren voor $\mathrm{PM}_{10}$ en $\mathrm{PM}_{2,5}$ (B34.2). In Van Bruggen et al. (2017b) is de herkomst van de emissiefactoren toegelicht.

Voor emissies die ontstaan tijdens de teelt van gewassen worden default emissiefactoren gebruikt uit het EMEP/EEA air pollutant emission inventory guidebook (EEA, 2019). De fijnstofemissies uit andere bronnen (hooien en het gebruik van krachtvoer, kunstmest en gewasbeschermingsmiddelen) zijn geschat op basis van de studie van Chardon en Van der Hoek (2002). Tabel 7.1 geeft hiervan een overzicht.

Tabel 7.1 Emissiefactoren voor fijnstof van gewassen en geschatte totale emissie voor andere bronnen / Emission factors for particulate matter from crops and added estimates for other sources.

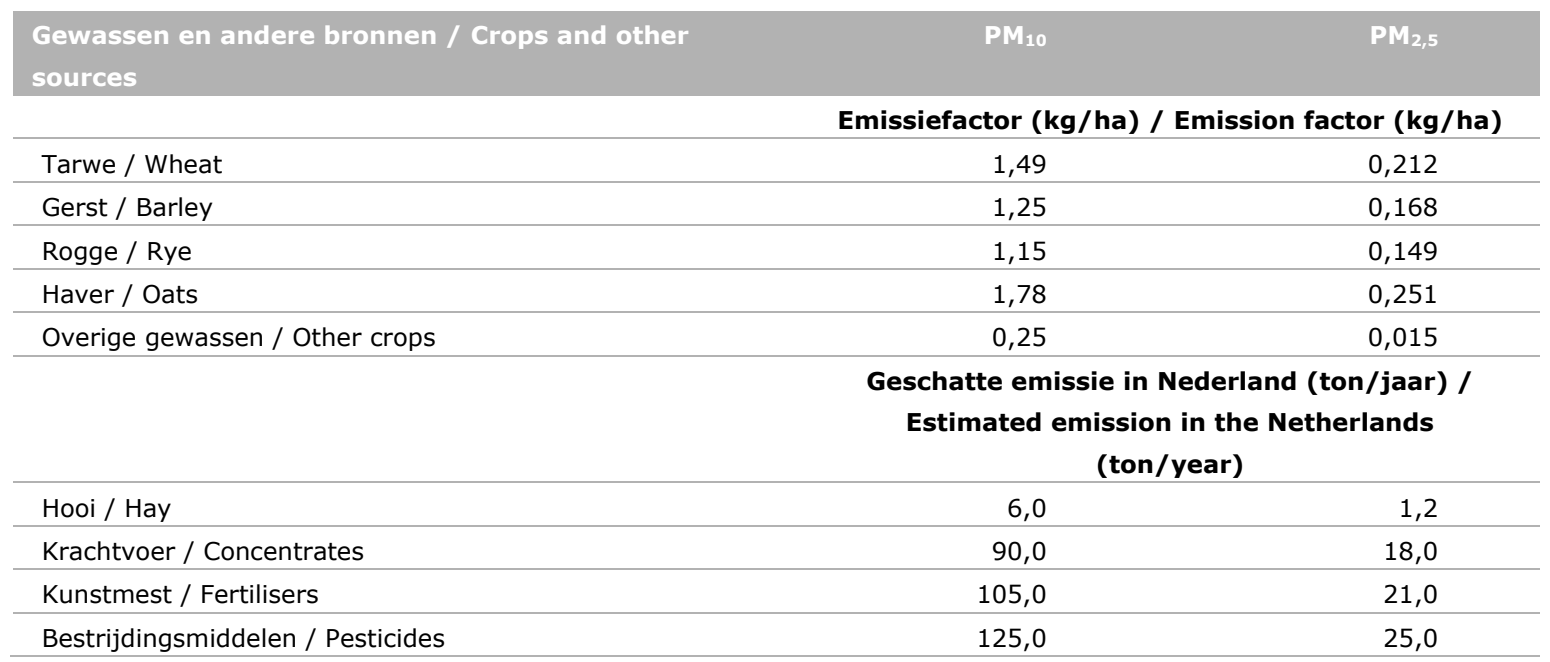

Bronnen / Sources: EEA (2019), Chardon en/and Van der Hoek (2002). 



\section{Emissie van $\mathrm{CO}_{2}$ uit kalkmeststoffen en ureum}

Kalksteen $\left(\mathrm{CaCO}_{3}\right)$ en dolomiet $\left(\mathrm{CaMg}\left(\mathrm{CO}_{3}\right)_{2}\right)$ worden als kalkmeststoffen gebruikt om verzuring van de bodem tegen te gaan. Na toediening aan de bodem wordt de kalk in de loop van de tijd omgezet in $\mathrm{CO}_{2}$. Dit jaar is voor het eerst voor de gehele tijdreeks het gebruik van ureum toegevoegd als bron van $\mathrm{CO}_{2}$-emissie. Bij het gebruik van ureum $\left(\mathrm{CH}_{4} \mathrm{~N}_{2} \mathrm{O}\right)$ als stikstofmeststof komt de $\mathrm{CO}_{2}$ die werd vastgelegd tijdens de productie van ureum weer vrij. Alle NPK, NP en NK stikstofmeststoffen, waarvan de stikstofvorm voor $50 \%$ of meer uit ureum bestaat zijn ingedeeld als ureummeststof. Dit betekent wel dat de $\mathrm{CO}_{2}$-emissie uit ureum enigszins wordt overschat. De methode voor de berekening van $\mathrm{CO}_{2}$-emissie als gevolg van het gebruik van kalkmeststoffen en ureum is beschreven in Van der Zee et al. (2021).

Het verbruik van kalkmeststoffen en ureum is gebaseerd op databronnen van Wageningen Economic Research. Tot en met 2015 zijn de cijfers afkomstig van een inventarisatie bij fabrikanten en de groothandel in kunstmest en kalkmeststoffen en vanaf 2016 van het Bedrijveninformatienet (BIN), zie ook Bijlage 4 in Van Bruggen et al. (2019).

Voorlopige cijfers over het gebruik van kalkmeststoffen en ureum in 2018 zijn vervangen door definitieve cijfers. De cijfers van 2019 zijn voorlopige cijfers.

Voor de berekening van de $\mathrm{CO}_{2}$-emissie uit kalkmeststoffen en ureum worden standaardfactoren gebruikt van 0,440 $\mathrm{kg} \mathrm{CO}_{2}$-emissie per $\mathrm{kg}$ kalksteen, $0,477 \mathrm{~kg} \mathrm{CO}_{2}$-emissie per $\mathrm{kg}$ dolomiet en 0,733 $\mathrm{kg} \mathrm{CO}_{2}$ per $\mathrm{kg}$ ureum (IPCC, 2006).

Het verbruik van kalkmeststoffen en ureum is opgenomen in Bijlage 35. 



\section{Resultaten van de emissieberekeningen met NEMA}

In dit hoofdstuk worden de resultaten van de NEMA-berekeningen getoond voor achtereenvolgens $\mathrm{NH}_{3}, \mathrm{~N}_{2} \mathrm{O}, \mathrm{NO}, \mathrm{CH}_{4}$, NMVOS, fijnstof en $\mathrm{CO}_{2}$ uit kalkmeststoffen en ureum. De belangrijkste verschillen tussen 2018 en 2019 worden besproken. Daarnaast worden de belangrijkste verschillen tussen de nieuwe tijdreeks en de vorige reeks benoemd.

Voor gedetailleerde resultaten van de gehele tijdreeks wordt verwezen naar Emissieregistratie.nl.

\section{$9.1 \quad \mathrm{NH}_{3}$-emissies}

Figuur 9.1 toont vanaf 1990 de emissie van $\mathrm{NH}_{3}$ in de landbouw, bij hobbybedrijven en particulieren en door het gebruik van mest op natuurterreinen. De emissie is uitgesplitst naar emissiebron: dierlijke mest, kunstmest (inclusief spuiwater) en andere meststoffen (zuiveringsslib en compost) en gewassen (afrijpende gewassen en gewasresten).

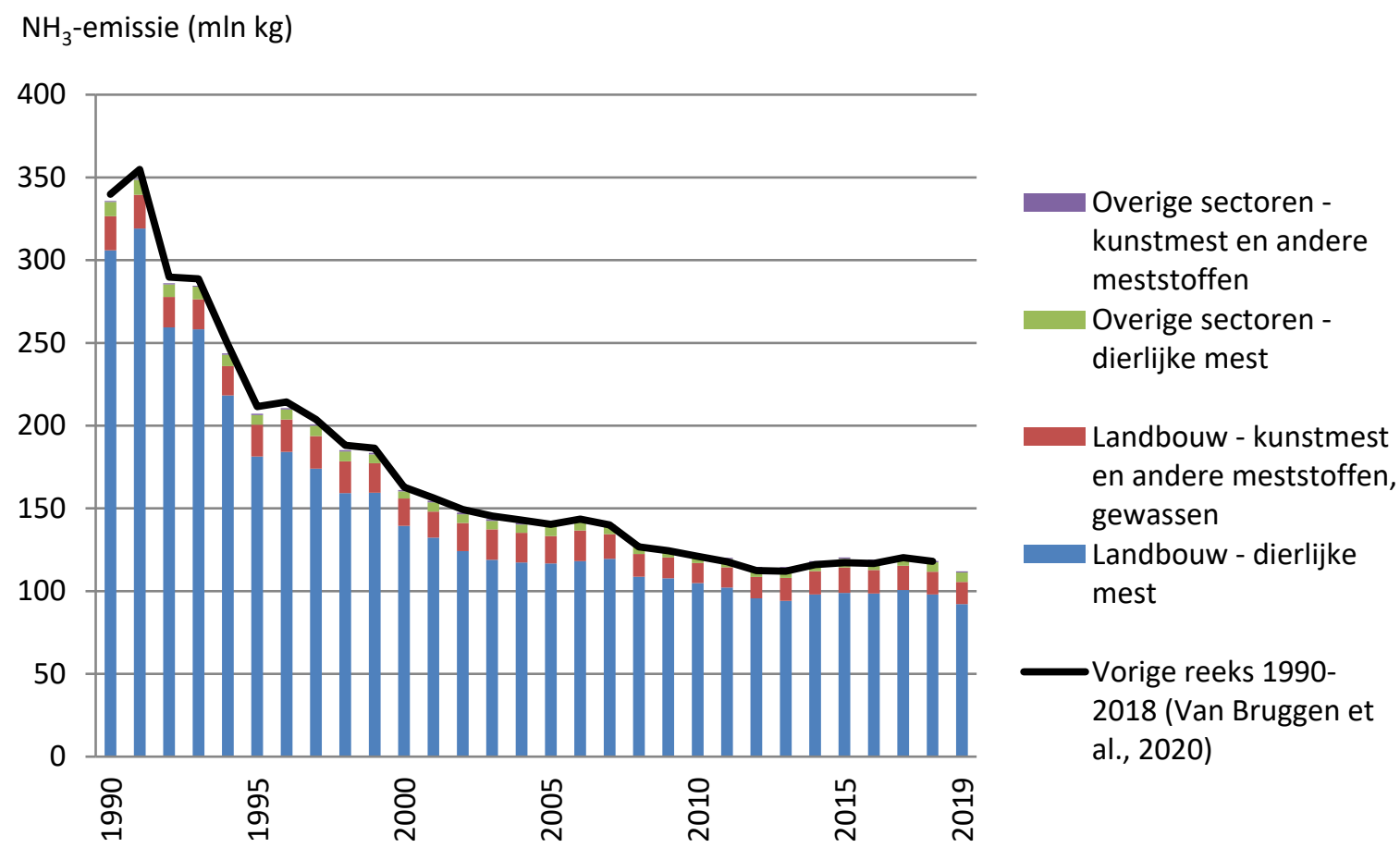

Figuur 9.1 Ammoniakemissie uit dierlijke mest, kunstmest en andere meststoffen, gewasresten en afrijping van gewassen in de landbouw en uit het gebruik van meststoffen door hobbybedrijven en particulieren en door het gebruik van dierlijke mest op natuurterreinen ( $\mathrm{mln} . \mathrm{kg} \mathrm{NH_{3 } ) / A m m o n i a}$ emissions from livestock manure, artificial fertiliser and other fertilisers, crop residues and ripening crops in agriculture and from the use of fertilisers by hobby farms and private parties and from the use of manure in nature areas ( $\mathrm{mln} . \mathrm{kg} \mathrm{NH}$ ).

In Tabel 9.1 is voor enkele jaren de $\mathrm{NH}_{3}$-emissie uit dierlijke mest, kunstmest en overige bronnen in de landbouw gesplitst naar diercategorie en naar de plaats waar de emissie optreedt, zoals stal en opslag, beweiding en mesttoediening. Verder staan in de tabel de emissies die plaatsvinden buiten de landbouw door productie en gebruik van dierlijke mest, kunstmest en compost en de emissie in natuurterreinen door begrazing met vee van landbouwbedrijven en door enige afzet van mest van landbouwbedrijven. 
Tabel 9.1 Ammoniakemissie uit dierlijke mest, kunstmest en overige bronnen binnen en buiten de landbouw (m/n. $\mathrm{kg} \mathrm{NH} /$ jaar) berekend voor 1990, 2010 en 2018 [1] uit Van Bruggen et al. (2020) en berekend voor 1990, 2010, 2018 en 2019 [2] (dit rapport)1) / Ammonia emissions from livestock manure and fertiliser inside and outside agriculture ( $\mathrm{m} / \mathrm{n} . \mathrm{kg} \mathrm{NH} / \mathrm{year}$ ) calculated for 1990, 2010 and 2018 [1] derived from Van Bruggen et al. (2020) and calculated for 1990, 2010, 2018 and 2019 [2] (this report $)^{1)}$.

\begin{tabular}{|c|c|c|c|c|c|c|c|}
\hline \multirow[t]{2}{*}{ Emissiebron / Emission source } & \multicolumn{2}{|c|}{1990} & \multicolumn{2}{|c|}{2010} & \multicolumn{2}{|c|}{2018} & \multirow{2}{*}{$\begin{array}{r}2019 \\
{[2}\end{array}$} \\
\hline & [1] & [2] & [1] & [2] & [1] & [2] & \\
\hline \multicolumn{8}{|l|}{ LANDBOUW / AGRICULTURE } \\
\hline Rundvee / Cattle & 169,0 & 166,1 & 55,0 & 52,7 & 64,4 & 61,0 & 57,2 \\
\hline Stal en opslag / Housing and storage & 33,4 & 33,4 & 27,1 & 27,1 & 32,3 & 33,5 & 31,8 \\
\hline Weiden / Grazing & 13,2 & 13,2 & 1,7 & 1,7 & 1,1 & 1,1 & 1,1 \\
\hline Mesttoediening / Manure application & 122,4 & 119,5 & 26,1 & 23,7 & 30,8 & 26,2 & 24,2 \\
\hline Mestbewerking / Manure treatment & 0,0 & 0,0 & 0,1 & 0,1 & 0,1 & 0,2 & 0,1 \\
\hline \multicolumn{8}{|l|}{ Schapen, geiten, paarden en ezels / Sheep, } \\
\hline Stal en opslag / Housing and storage & 1,0 & 1,0 & 1,1 & 1,1 & 1,4 & 1,4 & 1,5 \\
\hline Weiden / Grazing & 1,8 & 1,8 & 0,4 & 0,4 & 0,3 & 0,3 & 0,3 \\
\hline Mesttoediening / Manure application & 1,5 & 1,5 & 1,5 & 1,5 & 2,3 & 2,1 & 2,4 \\
\hline Varkens / Pigs & 100,6 & 100,1 & 30,6 & 33,3 & 18,8 & 19,3 & 18,4 \\
\hline Stal en opslag / Housing and storage & 49,2 & 49,2 & 23,5 & 26,8 & 12,0 & 14,5 & 13,1 \\
\hline Mesttoediening / Manure application & 51,4 & 50,9 & 6,9 & 6,3 & 6,2 & 3,8 & 4,3 \\
\hline Mestbewerking / Manure treatment & 0,0 & 0,0 & 0,2 & 0,2 & 0,6 & 1,0 & 1,1 \\
\hline \multicolumn{8}{|l|}{ Pluimvee, konijnen en pelsdieren / Poultry, } \\
\hline Stal en opslag / Housing and storage & 14,7 & 14,7 & 13,1 & 14,3 & 9,2 & 12,5 & 11,8 \\
\hline Mesttoediening / Manure application & 21,2 & 20,8 & 1,5 & 1,5 & 1,1 & 1,2 & 0,3 \\
\hline Mestbewerking / Manure treatment & 0,0 & 0,0 & 0,1 & 0,1 & 0,1 & 0,1 & 0,1 \\
\hline \multicolumn{8}{|l|}{ Totaal dierlijke mest landbouw / Total } \\
\hline livestock manure agriculture & 309,9 & 306,0 & 103,3 & 104,8 & 97,6 & 98,0 & 92,2 \\
\hline Stal en opslag / Housing and storage & 98,3 & 98,3 & 64,8 & 69,3 & 54,9 & 61,9 & 58,2 \\
\hline Weiden / Grazing & 15,0 & 15,0 & 2,1 & 2,1 & 1,4 & 1,4 & 1,4 \\
\hline Mesttoediening / Manure application & 196,6 & 192,7 & 36,0 & 33,0 & 40,4 & 33,4 & 31,2 \\
\hline Mestbewerking / Manure treatment & 0,0 & 0,0 & 0,3 & 0,4 & 0,9 & 1,3 & 1,3 \\
\hline \multicolumn{8}{|l|}{ Kunstmest inclusief spuiwater luchtwassers / } \\
\hline Fertiliser including effluent from air scrubbers & 13,2 & 13,2 & 7,6 & 7,6 & 9,0 & 9,2 & 8,8 \\
\hline $\begin{array}{l}\text { Zuiveringsslib en compost / Sewage sludge and } \\
\text { compost }\end{array}$ & 1,6 & 1,6 & 0,5 & 0,5 & 0,5 & 0,5 & 0,4 \\
\hline $\begin{array}{l}\text { Afrijping gewassen en gewasresten / Ripening } \\
\text { crops and crop residues }\end{array}$ & 5,8 & 5,8 & 4,1 & 4,1 & 4,1 & 4,1 & 4,2 \\
\hline Totaal landbouw / Total agriculture & 330,5 & 326,6 & 115,5 & 117,0 & 111,2 & 111,7 & 105,6 \\
\hline
\end{tabular}

\section{(KUNST)MEST IN ANDERE SECTOREN / \\ ARTIFICIAL FERTILISERS AND MANURE IN OTHER SECTORS}

Hobbybedrijven en particulieren / Hobby farms and private parties

Stal en opslag / Housing and storage

Weiden / Grazing

\begin{tabular}{|c|c|c|c|c|c|c|}
\hline 8,8 & 8,6 & 4,6 & 4,4 & 5,5 & 5,2 & 5,2 \\
\hline 1,3 & 1,3 & 1,2 & 1,2 & 1,6 & 1,6 & 1,6 \\
\hline 0,7 & 0,7 & 0,3 & 0,3 & 0,4 & 0,4 & 0,4 \\
\hline 6,8 & 6,6 & 3,1 & 2,9 & 3,6 & 3,3 & 3,2 \\
\hline 0,0 & 0,0 & 0,4 & 0,4 & 0,6 & 0,6 & 0,6 \\
\hline 8,8 & 8,6 & 5,0 & 4,7 & 6,1 & 5,8 & 5,7 \\
\hline
\end{tabular}

Natuurterreinen / Nature areas

\begin{tabular}{|c|c|c|c|c|c|c|}
\hline 8,8 & 8,6 & 4,6 & 4,4 & 5,5 & 5,2 & 5,2 \\
\hline 1,3 & 1,3 & 1,2 & 1,2 & 1,6 & 1,6 & 1,6 \\
\hline 0,7 & 0,7 & 0,3 & 0,3 & 0,4 & 0,4 & 0,4 \\
\hline 6,8 & 6,6 & 3,1 & 2,9 & 3,6 & 3,3 & 3,2 \\
\hline 0,0 & 0,0 & 0,4 & 0,4 & 0,6 & 0,6 & 0,6 \\
\hline 8,8 & 8,6 & 5,0 & 4,7 & 6,1 & 5,8 & 5,7 \\
\hline
\end{tabular}

Totaal dierlijke mest andere sectoren /

Total livestock manure other sectors 


\begin{tabular}{|c|c|c|c|c|c|c|c|}
\hline \multirow[t]{2}{*}{ Emissiebron / Emission source } & \multicolumn{2}{|c|}{1990} & \multicolumn{2}{|c|}{2010} & \multicolumn{2}{|c|}{2018} & \multirow{2}{*}{$\begin{array}{r}2019 \\
\text { [2 }\end{array}$} \\
\hline & [1] & [2] & [1] & [2] & [1] & [2] & \\
\hline Kunstmest / Fertiliser & 0,6 & 0,6 & 0,5 & 0,5 & 0,6 & 0,6 & 0,6 \\
\hline Compost / Compost & 0,0 & 0,0 & 0,2 & 0,2 & 0,1 & 0,1 & 0,1 \\
\hline \multicolumn{8}{|c|}{ Totaal andere sectoren / Total other } \\
\hline sectors & 9,4 & 9,2 & 5,6 & 5,4 & 6,8 & 6,5 & 6,4 \\
\hline \multicolumn{8}{|c|}{ Totaal landbouw en andere sectoren / Total } \\
\hline agriculture and other sectors & 339,9 & 335,8 & 121,1 & 122,5 & 118,0 & 118,2 & 112,0 \\
\hline
\end{tabular}

\section{Verschillen tussen de nieuwe en de vorige reeks}

Veranderingen in het niveau van de $\mathrm{NH}_{3}$-emissie in de nieuwe reeks ten opzichte van de vorige reeks vloeien voort uit de bijstelling van de $\mathrm{NH}_{3}$-emissie uit emissiearme stallen (Paragraaf 2.6), een aangepaste verdeling van toegediende mest aan grasland en bouwland en het gebruik van lagere emissiefactoren voor bemesting op grasland (Paragraaf 2.11).

De totale $\mathrm{NH}_{3}$-emissie uit dierlijke mest, kunstmest en overige bronnen bij landbouwbedrijven, hobbybedrijven, particulieren en natuurterreinen in 2019 bedroeg 112,0 miljoen $\mathrm{kg} \mathrm{NH}_{3}$, een daling van 6,2 miljoen $\mathrm{kg}$ ten opzichte van 2018.

Sinds 1990 is de $\mathrm{NH}_{3}$-emissie uit dierlijke mest, kunstmest en overige bronnen met twee derde gedaald door een lagere stikstofexcretie van landbouwhuisdieren, het gebruik van emissiearme toedieningstechnieken, emissiearme huisvesting, het afdekken van mestopslagen en een verminderd kunstmestgebruik.

\section{Landbouw}

De totale $\mathrm{NH}_{3}$-emissie uit dierlijke mest van landbouwbedrijven daalde van 98,0 miljoen $\mathrm{kg}$ in 2018 tot 92,2 miljoen $\mathrm{kg}$ in 2019. Eén van de oorzaken voor de afname van de $\mathrm{NH}_{3}$-emissie is de daling van de $\mathrm{N}$-excretie van de veestapel. De $\mathrm{N}$-excretie daalde van 503,4 miljoen $\mathrm{kg} \mathrm{N}$ in 2018 tot 489,7 miljoen $\mathrm{kg} \mathrm{N}$ in 2019. Er zijn meerdere oorzaken voor deze daling, zoals de afname van het aantal runderen, varkens en kippen en lagere gehalten aan stikstof en fosfor van ruwvoer en krachtvoer (CBS, 2020). De daling van de stikstof- en fosfaatexcretie in 2019 ten opzichte van 2018 komt, net als in voorgaande jaren, grotendeels voor rekening van de melkveehouderij.

De $\mathrm{N}$-excretie van varkens daalde door een lichte krimp van de varkensstapel. Bij pluimvee was sprake van een daling van het aantal leghennen en ouderdieren van vleeskuikens.

De $\mathrm{NH}_{3}$-emissie uit stallen en mestopslagen van landbouwbedrijven daalde van 61,9 miljoen $\mathrm{kg}$ in 2018 tot 58,2 miljoen $\mathrm{kg}$ in 2019. Dit heeft deels te maken met de afname van de $\mathrm{N}$-excretie en deels met de toename van emissiearme huisvesting bij varkens en pluimvee.

De $\mathrm{NH}_{3}$-emissie bij mesttoediening daalde van 33,4 tot 31,2 miljoen $\mathrm{kg} \mathrm{NH}_{3}$. Deze daling wordt vooral veroorzaakt door de verplichte verdunning van drijfmest bij mesttoediening op grasland in strookjes op de grond (sleepvoetbemesting). De totale afzet van stikstof buiten de landbouw en de stikstof die verloren is gegaan bij mestbewerkingsprocessen nam toe van 74,5 miljoen $\mathrm{kg} \mathrm{N}$ in 2018 tot 76,3 miljoen $\mathrm{kg} \mathrm{N}$ in 2019.

In 2019 bedroeg de $\mathrm{NH}_{3}$-emissie uit kunstmest en spuiwater in de landbouw 8,8 miljoen $\mathrm{kg}$, een daling van afgerond 0,5 miljoen $\mathrm{kg}$ ten opzichte van 2018. De daling werd veroorzaakt door een lager gebruik van kunstmest. De $\mathrm{NH}_{3}$-emissie tijdens beweiding bedroeg in 2019 en in 20181 1,4 miljoen $\mathrm{kg}$ $\mathrm{NH}_{3}$. De $\mathrm{NH}_{3}$-emissie uit overige bronnen zoals het gebruik van zuiveringsslib en compost, afrijping van gewassen en gewasresten bedroeg in 2019 4,6 miljoen $\mathrm{kg} \mathrm{NH}_{3}$ en bleef daarmee vrijwel gelijk aan 2018.

\section{Hobbybedrijven, particulieren en natuurterreinen}

De (kunst)mestgerelateerde $\mathrm{NH}_{3}$-emissie die niet op landbouwbedrijven plaatsvindt bestaat uit een aantal bronnen. In de eerste plaats gebruiken hobbybedrijven en particulieren dierlijke mest en kunstmest. Daarnaast komt een deel van de paarden, pony's, ezels en schapen voor op 
hobbybedrijven en bij particulieren. Ten slotte vindt ook emissie plaats in natuurterreinen door begrazing met vee van landbouwbedrijven en door een geringe toepassing van mest van landbouwbedrijven op natuurterrein.

De $\mathrm{NH}_{3}$-emissie van hobbybedrijven en van mestafzet bij particulieren en op natuurterreinen daalde licht van 6,5 miljoen $\mathrm{kg}$ in 2018 tot 6,4 miljoen $\mathrm{kg}$ in 2019.

\section{$9.2 \quad \mathrm{~N}_{2} \mathrm{O}$ - en NO-emissies}

Figuur 9.2 toont de totale emissie van $\mathrm{N}_{2} \mathrm{O}$ door directe en indirecte landbouwgerelateerde stikstofverliezen. Voor broeikasgassen wordt geen expliciet onderscheid gemaakt tussen (kunst)mest in de landbouw en buiten de landbouw. De overige bronnen bestaan uit organische bodems, gewasresten, mestbewerking en het gebruik van zuiveringsslib en compost.

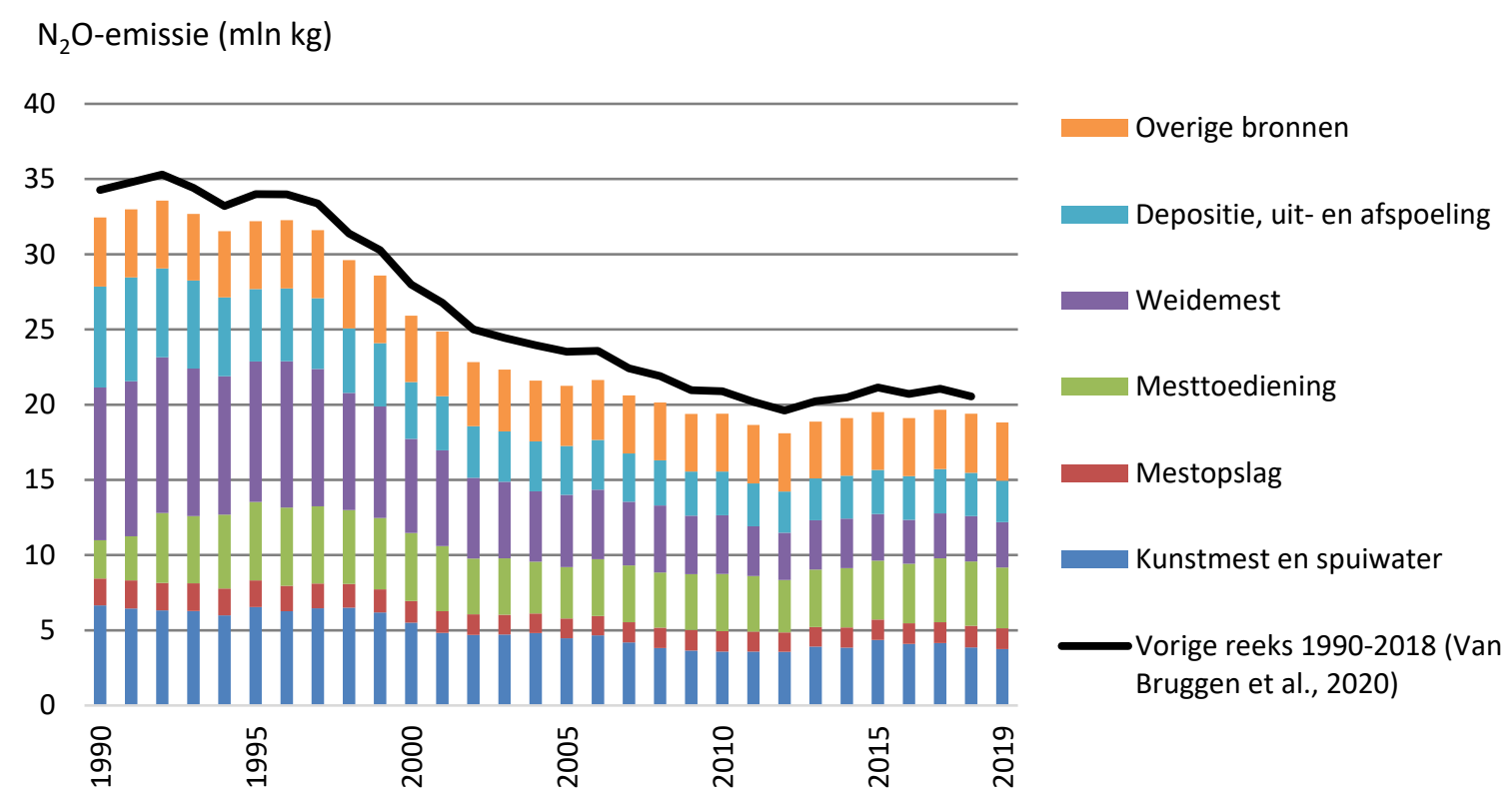

Figuur 9.2 Directe en indirecte lachgasemissie door landbouwkundige activiteiten bij landbouwbedrijven, hobbybedrijven, particulieren en in natuurterreinen ( $\mathrm{mln} . \mathrm{kg} \mathrm{N} 2 \mathrm{O}$ ) / Direct and indirect $\mathrm{N}_{2} \mathrm{O}$ emissions from agricultural activities at agricultural businesses, hobby farms, private parties and in nature areas ( $\mathrm{m} / \mathrm{n} . \mathrm{kg} \mathrm{N} \mathrm{N}_{2} \mathrm{O}$ ).

In Tabel 9.2 is voor enkele jaren een overzicht van de $\mathrm{N}_{2} \mathrm{O}$-emissie gegeven van de vorige en de huidige reeks.

Tabel 9.2 Lachgasemissies uit landbouwkundige activiteiten bij landbouwbedrijven, hobbybedrijven, particulieren en in natuurterreinen ( $\mathrm{mln} . \mathrm{kg} \mathrm{N} \mathrm{N}_{2} \mathrm{O} / \mathrm{jaar}$ ) berekend voor 1990, 2010 en 2018 [1] uit Van Bruggen et al. (2020) en berekend voor 1990, 2010, 2018 en 2019 [2] (dit rapport)1) / Nitrous oxide emissions from agricultural activities at agricultural businesses, hobby farms, private parties and in nature areas (m/n. $\mathrm{kg} \mathrm{N}$ O/year) calculated for 1990, 2010 and 2018 [1] derived from Van Bruggen et al. (2020) and calculated for 1990, 2010, 2018 and 2019 [2] (this report) ${ }^{1}$.

\begin{tabular}{|c|c|c|c|c|c|c|c|}
\hline \multirow[t]{2}{*}{ Emissiebron / Emission source } & \multicolumn{2}{|c|}{1990} & \multicolumn{2}{|c|}{2010} & \multicolumn{2}{|c|}{2018} & \multirow{2}{*}{$\begin{array}{r}2019 \\
\text { [2] }\end{array}$} \\
\hline & {$[1]$} & [2] & [1] & [2] & [1] & [2] & \\
\hline Mestopslag / Manure storage & 1,8 & 1,8 & 1,4 & 1,4 & 1,5 & 1,4 & 1,4 \\
\hline $\begin{array}{l}\text { Toediening van dierlijke mest / Application of } \\
\text { livestock manure }\end{array}$ & 2,6 & 2,6 & 4,1 & 3,8 & 4,5 & 4,3 & 4,0 \\
\hline $\begin{array}{l}\text { Weidemest van graasdieren / Manure from grazing } \\
\text { livestock }\end{array}$ & 10,2 & 10,2 & 4,2 & 3,9 & 3,2 & 3,0 & 3,0 \\
\hline Toediening van kunstmest / Application of fertiliser & 8,4 & 6,6 & 4,5 & 3,6 & 4,7 & 3,9 & 3,7 \\
\hline
\end{tabular}




\begin{tabular}{|c|c|c|c|c|c|c|c|}
\hline \multirow[t]{2}{*}{ Emissiebron / Emission source } & \multicolumn{2}{|c|}{1990} & \multicolumn{2}{|c|}{2010} & \multicolumn{2}{|c|}{2018} & \multirow{2}{*}{$\begin{array}{r}2019 \\
\text { [2 }\end{array}$} \\
\hline & [1] & [2] & [1] & [2] & [1] & [2] & \\
\hline \multicolumn{8}{|l|}{ Gebruik zuiveringsslib / Application of sewage } \\
\hline sludge & 0,0 & 0,0 & 0,0 & 0,0 & 0,0 & 0,0 & 0,0 \\
\hline Gebruik van compost / Application of compost & 0,0 & 0,0 & 0,0 & 0,0 & 0,1 & 0,1 & 0,0 \\
\hline Gewasresten / Crop residues & 1,0 & 1,0 & 1,0 & 1,0 & 1,0 & 1,0 & 1,0 \\
\hline Graslandvernieuwing / Pasture renewal & 0,5 & 0,5 & 0,2 & 0,2 & 0,1 & 0,1 & 0,1 \\
\hline Organische bodems / Organic soils & 2,9 & 2,9 & 2,4 & 2,4 & 2,3 & 2,3 & 2,3 \\
\hline \multicolumn{7}{|l|}{ Indirect door atmosferische depositie / Indirect } & 1,6 \\
\hline \multicolumn{8}{|l|}{ Indirect door N-uit- en afspoeling / Indirect from } \\
\hline leaching and run-off & 2,1 & 2,1 & 1,2 & 1,2 & 1,2 & 1,2 & 1,1 \\
\hline Mestbewerking / Manure treatment & 0,1 & 0,1 & 0,2 & 0,2 & 0,4 & 0,4 & 0,4 \\
\hline Totaal / Total & 34,3 & 32,4 & 20,9 & 19,4 & 20,5 & 19,4 & 18,8 \\
\hline
\end{tabular}

1) Verschillen tussen de tijdreeksen zijn het gevolg van herberekeningen / Differences between the time series are the result of recalculations.

\section{Verschillen tussen de nieuwe en de vorige reeks}

Het niveau van de $\mathrm{N}_{2} \mathrm{O}$-emissie in de nieuwe reeks ligt lager dan het niveau in de vorige reeks. Dit is het effect van de vervanging van geaggregeerde (gemiddelde) emissiefactoren voor het gebruik van dierlijke mest en kunstmest door uitgesplitste emissiefactoren voor het gebruik op grasland en bouwland en voor minerale grond en veengrond, zie ook Paragraaf 2.13 en Paragraaf 3.1.

De $\mathrm{N}_{2} \mathrm{O}$-emissie bedroeg in 201918,8 miljoen $\mathrm{kg}$, een daling van 0,6 miljoen $\mathrm{kg}$ ten opzichte van 2018. De oorzaken voor de emissiedaling in 2019 ten opzichte van 2018 zijn grotendeels dezelfde als die voor de emissiedaling van $\mathrm{NH}_{3}$, namelijk een lagere $\mathrm{N}$-excretie door afname van het aantal runderen, varkens en kippen en een daling van het kunstmestgebruik.

Sinds 1990 daalden de emissies van $\mathrm{N}_{2} \mathrm{O}$ en $\mathrm{NO}$ met 42\% respectievelijk 35\%. Deze dalingen zijn minder sterk dan de daling van de $\mathrm{NH}_{3}$-emissie. De verklaring hiervoor is dat de $\mathrm{N}_{2} \mathrm{O}$-emissie bij $\mathrm{NH}_{3}$ emissiearme mesttoediening toeneemt. Daarnaast verlaagt $\mathrm{NH}_{3}$-emissiearme huisvesting alleen de stalemissie van $\mathrm{NH}_{3}$ maar niet die van $\mathrm{N}_{2} \mathrm{O}$ en $\mathrm{NO}$. $\mathrm{NH}_{3}$-emissiearme mesttoediening is gepaard gegaan met een daling van het kunstmestgebruik waardoor de $\mathrm{N}_{2} \mathrm{O}$-emissie en de $\mathrm{NO}$-emissie uit kunstmest zijn gedaald.

In Figuur 9.3 en in Tabel 9.3 is de NO-emissie door landbouwkundige activiteiten weergegeven. De NO-emissie daalde in 2019 met 0,7 miljoen $\mathrm{kg}$ tot 21,7 miljoen $\mathrm{kg}$. De oorzaken voor de emissiedaling in 2019 ten opzichte van 2018 zijn grotendeels dezelfde als die voor de emissiedaling van $\mathrm{NH}_{3}$ en $\mathrm{N}_{2} \mathrm{O}$, namelijk een lagere $\mathrm{N}$-excretie door afname van het aantal runderen, varkens en kippen en een daling van het kunstmestgebruik.

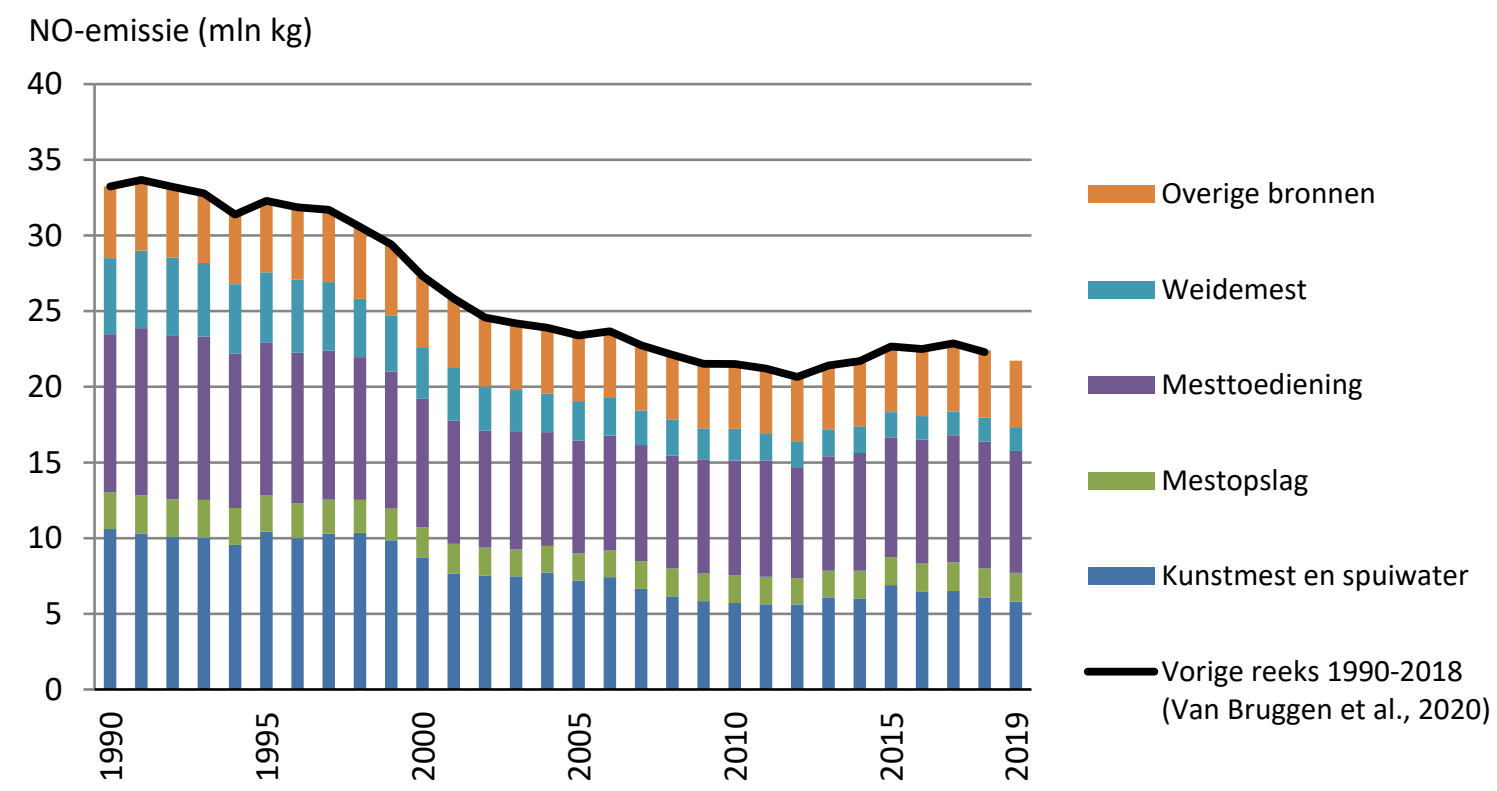


Figuur 9.3 Emissie van stikstofoxide door landbouwkundige activiteiten bij landbouwbedrijven, hobbybedrijven, particulieren en in natuurterreinen ( $\mathrm{mln} . \mathrm{kg} \mathrm{NO}$ ) / Nitric oxide emissions from agricultural activities at agricultural businesses, hobby farms, private parties and in nature areas ( $\mathrm{m} / \mathrm{n} . \mathrm{kg} N O)$.

Tabel 9.3 Stikstofoxide-emissies uit landbouwkundige activiteiten bij landbouwbedrijven, hobbybedrijven, particulieren en in natuurterreinen ( $\mathrm{m} / \mathrm{n} . \mathrm{kg}$ NO/jaar) berekend voor 1990, 2010 en 2018 [1] uit Van Bruggen et al. (2020) en berekend voor 1990, 2010, 2018 en 2019 [2] (dit rapport) ${ }^{1)}$ / Nitrogen monoxide emissions from agricultural activities at agricultural businesses, hobby farms, private parties and in nature areas (m/n. $\mathrm{kg}$ NO/year) calculated for 1990, 2010 and 2018 [1] derived from Van Bruggen et al. (2020) and calculated for 1990, 2010, 2018 and 2019 [2] (this report) ${ }^{1)}$.

\begin{tabular}{|c|c|c|c|c|c|c|c|}
\hline \multirow[t]{2}{*}{ Emissiebron / Emission source } & \multicolumn{2}{|c|}{1990} & \multicolumn{2}{|c|}{2010} & \multicolumn{2}{|c|}{2018} & \multirow{2}{*}{$\begin{array}{r}2019 \\
{[2]}\end{array}$} \\
\hline & [1] & [2] & [1] & [2] & [1] & [2] & \\
\hline Mestopslag / Manure storage & 2,4 & 2,4 & 1,9 & 1,9 & 2,0 & 2,0 & 1,9 \\
\hline Toedienen van kunstmest / Application of fertiliser & 10,6 & 10,6 & 5,7 & 5,7 & 5,9 & 6,1 & 5,8 \\
\hline $\begin{array}{l}\text { Toedienen van dierlijke mest / Application of } \\
\text { livestock manure }\end{array}$ & 10,4 & 10,4 & 7,6 & 7,6 & 8,4 & 8,4 & 8,1 \\
\hline $\begin{array}{l}\text { Weidemest van graasdieren / Manure from grazing } \\
\text { livestock }\end{array}$ & 5,0 & 5,0 & 2,1 & 2,1 & 1,6 & 1,6 & 1,6 \\
\hline $\begin{array}{l}\text { Toedienen van zuiveringsslib en compost / } \\
\text { Application of sewage sludge and compost }\end{array}$ & 0,2 & 0,2 & 0,2 & 0,2 & 0,2 & 0,2 & 0,2 \\
\hline $\begin{array}{l}\text { Gewasresten en graslandvernieuwing / Crop } \\
\text { residues and pasture renewal }\end{array}$ & 2,1 & 2,1 & 1,7 & 1,7 & 1,7 & 1,7 & 1,7 \\
\hline Organische bodems / Organic soils & 2,4 & 2,4 & 2,0 & 2,0 & 1,9 & 1,9 & 1,9 \\
\hline Mestbewerking / Manure treatment & 0,1 & 0,1 & 0,3 & 0,3 & 0,5 & 0,6 & 0,6 \\
\hline Totaal / Total & 33,2 & 33,2 & 21,5 & 21,4 & 22,3 & 22,4 & 21,7 \\
\hline
\end{tabular}

1) Verschillen tussen de tijdreeksen zijn het gevolg van herberekeningen / Differences between the time series are the result of recalculations.

\section{3 $\quad \mathrm{CH}_{4}$-emissies}

In Figuur 9.4 is de totale $\mathrm{CH}_{4}$-emissie door mestmanagement en pens- en darmfermentatie weergegeven. Voor broeikasgassen wordt geen expliciet onderscheid gemaakt tussen dierlijke mest in de landbouw en buiten de landbouw.

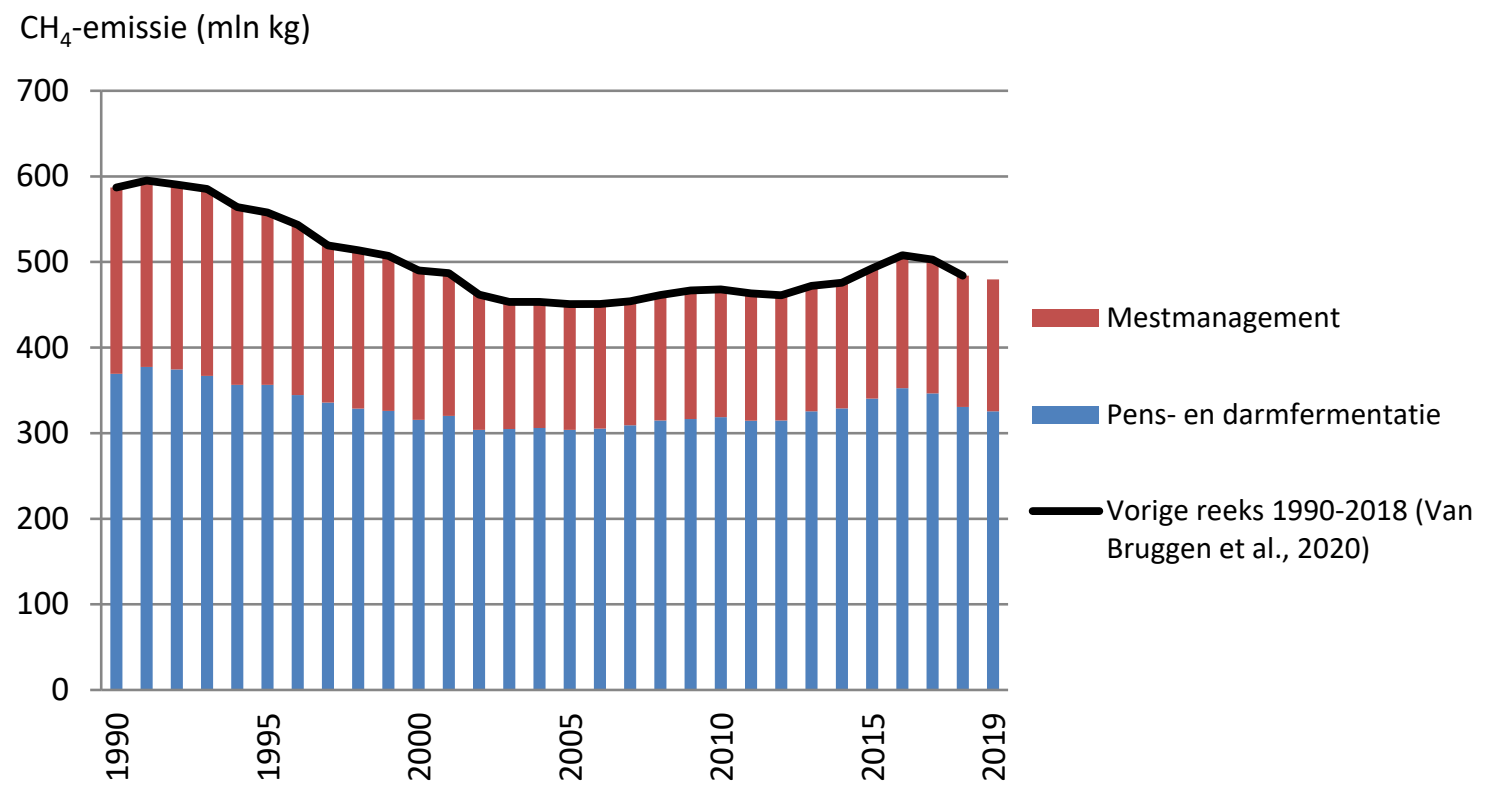

Figuur 9.4: $\mathrm{CH}_{4}$-emissie door landbouwkundige activiteiten ( $\mathrm{mln} . \mathrm{kg} \mathrm{CH}$ ) / $\mathrm{CH}_{4}$-emissions from agricultural activities ( $\mathrm{mln} . \mathrm{kg} \mathrm{CH}$ ). 
In Tabel 9.4 is voor enkele jaren een overzicht gegeven van $\mathrm{CH}_{4}$-emissies door pens- en darmfermentatie en mestmanagement.

Tabel 9.4 Methaanemissies uit landbouwkundige activiteiten ( $\mathrm{m} / \mathrm{n} . \mathrm{kg} \mathrm{CH} / \mathrm{jaar}$ ) berekend voor 1990, 2010 en 2018 1] uit Van Bruggen et al. (2020) en berekend voor 1990, 2010, 2018 en 2019 [2] (dit rapport) ${ }^{1)} /$ Methane emissions from agricultural activities ( $\mathrm{m} / \mathrm{n} . \mathrm{kg} \mathrm{CH} / \mathrm{year}$ ) calculated for 1990, 2010 and 2018 [1] derived from Van Bruggen et al. (2020) and calculated for 1990, 2010, 2018 and 2019 [2] (this report) ${ }^{1}$.

\begin{tabular}{|c|c|c|c|c|c|c|c|}
\hline & \multicolumn{2}{|c|}{1990} & \multicolumn{2}{|c|}{2010} & \multicolumn{2}{|c|}{2018} & \multirow{2}{*}{$\begin{array}{r}2019 \\
{[2]}\end{array}$} \\
\hline & [1] & [2] & [1] & [2] & [1] & [2] & \\
\hline \multicolumn{8}{|l|}{$\begin{array}{l}\text { Pens- en darmfermentatie / Enteric } \\
\text { fermentation }\end{array}$} \\
\hline \multicolumn{8}{|l|}{ Melkkoeien NoordWest / Dairy cows } \\
\hline NorthWest & 94,3 & 94,3 & 79,5 & 79,5 & 90,8 & 90,8 & 91,6 \\
\hline Melkkoeien ZuidOost / Dairy cows SouthEast & 113,0 & 113,0 & 109,8 & 109,8 & 123,4 & 123,4 & 121,9 \\
\hline \multicolumn{8}{|l|}{ Rundvee jongvee, vleeskalveren en stieren / } \\
\hline \multicolumn{8}{|l|}{ Zoog-, mest- en weidekoeien / Suckling cows } \\
\hline and female fatteners & 8,4 & 8,4 & 9,0 & 9,0 & 5,4 & 5,4 & 4,8 \\
\hline Schapen / Sheep & 13,6 & 13,6 & 9,0 & 9,0 & 7,6 & 7,6 & 7,9 \\
\hline Geiten / Goats & 0,3 & 0,3 & 1,8 & 1,8 & 2,9 & 2,9 & 3,1 \\
\hline Paarden / Horses & 6,7 & 6,7 & 7,9 & 7,9 & 7,4 & 7,4 & 7,3 \\
\hline Varkens / Pigs & 20,9 & 20,9 & 18,4 & 18,4 & 18,6 & 18,6 & 18,3 \\
\hline Ezels / Mules and asses & 0,0 & 0,0 & 0,0 & 0,0 & 0,0 & 0,0 & 0,0 \\
\hline \multicolumn{8}{|l|}{ Totaal pens- en darmfermentatie / Total } \\
\hline \multicolumn{8}{|l|}{ Mestmanagement / Manure management } \\
\hline Rundvee, mestopslag / Cattle, manure storage & 62,4 & 62,4 & 68,1 & 68,1 & 78,2 & 78,0 & 77,4 \\
\hline \multicolumn{8}{|l|}{ Schapen, mestopslag / Sheep, manure } \\
\hline Geiten, mestopslag / Goats, manure storage & 0,0 & 0,0 & 0,0 & 0,0 & 0,1 & 0,1 & 0,1 \\
\hline \multicolumn{8}{|l|}{ Paarden, mestopslag / Horses, manure } \\
\hline \multicolumn{8}{|l|}{ Ezels, mestopslag / Mules and asses, manure } \\
\hline Varkens, mestopslag / Pigs, manure storage & 134,7 & 134,7 & 73,4 & 73,3 & 61,4 & 56,0 & 56,1 \\
\hline \multicolumn{8}{|l|}{ Pluimvee, mestopslag / Poultry, manure } \\
\hline $\begin{array}{l}\text { Konijnen en pelsdieren, mestopslag / Rabbits } \\
\text { and fur-bearing animals, manure storage }\end{array}$ & 0,4 & 0,4 & 0,7 & 0,7 & 0,6 & 0,6 & 0,6 \\
\hline $\begin{array}{l}\text { Weidemest van graasdieren / Manure from } \\
\text { grazing livestock }\end{array}$ & Weidemest van graasdieren / Manure from & 2,3 & 1,4 & 1,4 & 1,1 & 1,1 & 1,1 \\
\hline Mestbewerking $^{2)} /$ Manure treatment $^{2)}$ & 0,0 & 0,0 & 2,0 & 2,2 & 8,8 & 14,3 & 15,8 \\
\hline \multicolumn{8}{|l|}{ Totaal mestmanagement / Total manure } \\
\hline management & 217,7 & 217,7 & 149,3 & 149,3 & 153,4 & 153,2 & 154,2 \\
\hline Totaal / Total & 586,9 & 586,9 & 468,0 & 468,0 & 484,1 & 483,9 & 479,7 \\
\hline
\end{tabular}

1) Verschillen tussen de tijdreeksen zijn het gevolg van herberekeningen / Differences between the time series are the result of recalculations.

2) Inclusief mestvergisting. De Emissieregistratie rapporteert de emissie door mestvergisting niet onder landbouw maar onder afvalverwerking / Including manure digesting. The Pollutant Release and Transfer Register does not report emissions from manure digesting under agriculture, but under waste processing.

De totale $\mathrm{CH}_{4}$-emissie daalde, met name door de krimp van de melkveestapel, van 483,9 miljoen $\mathrm{kg}$ in 2018 tot 479,7 miljoen $\mathrm{kg}$ in 2019 . Tegenover de daling van de melkveestapel stond een hogere melkproductie en voeropname per koe, wat een hogere $\mathrm{CH}_{4}$-emissie per koe tot gevolg heeft, maar netto nog steeds een daling opleverde. 
Tussen 1990 en 2019 daalde de $\mathrm{CH}_{4}$-emissie met 18\%, wat verklaard kan worden door een afname van het aantal runderen en varkens en hogere voerefficiënties van melkvee ten opzichte van 1990. Daarnaast nam bij varkens de excretie van organische stof per dier sterk af en daarmee de $\mathrm{CH}_{4}{ }^{-}$ emissie uit de mestopslag.

Voor mestmanagement geldt dat er bij rundvee een verschuiving heeft plaatsgevonden van weidemest naar de productie van drijfmest in de stal. Omdat drijfmest een veel hogere $\mathrm{CH}_{4}$-emissie heeft dan weidemest, neemt bij afnemende beweiding de emissie per saldo toe. Bij leghennen heeft een daling van de $\mathrm{CH}_{4}$-emissie plaatsgevonden doordat gedurende de tijdreeks batterijsystemen met natte mest volledig zijn vervangen door huisvesting met vaste mest.

\subsection{NMVOS-emissies}

In Figuur 9.5 zijn de emissies van NMVOS weergegeven. In de eerste helft van de jaren negentig daalt de emissie door de overgang naar emissiearme mesttoediening en lagere rundvee-aantallen. Vanaf ongeveer 2005 neemt de emissie weer toe door een groter aandeel kuilvoer in het rantsoen van melkvee. In de periode 2014-2016 neemt de emissie toe door een toename van het aantal runderen en hogere producties. Vanaf 2017 daalt de emissie vooral door de krimp van de melkveestapel.

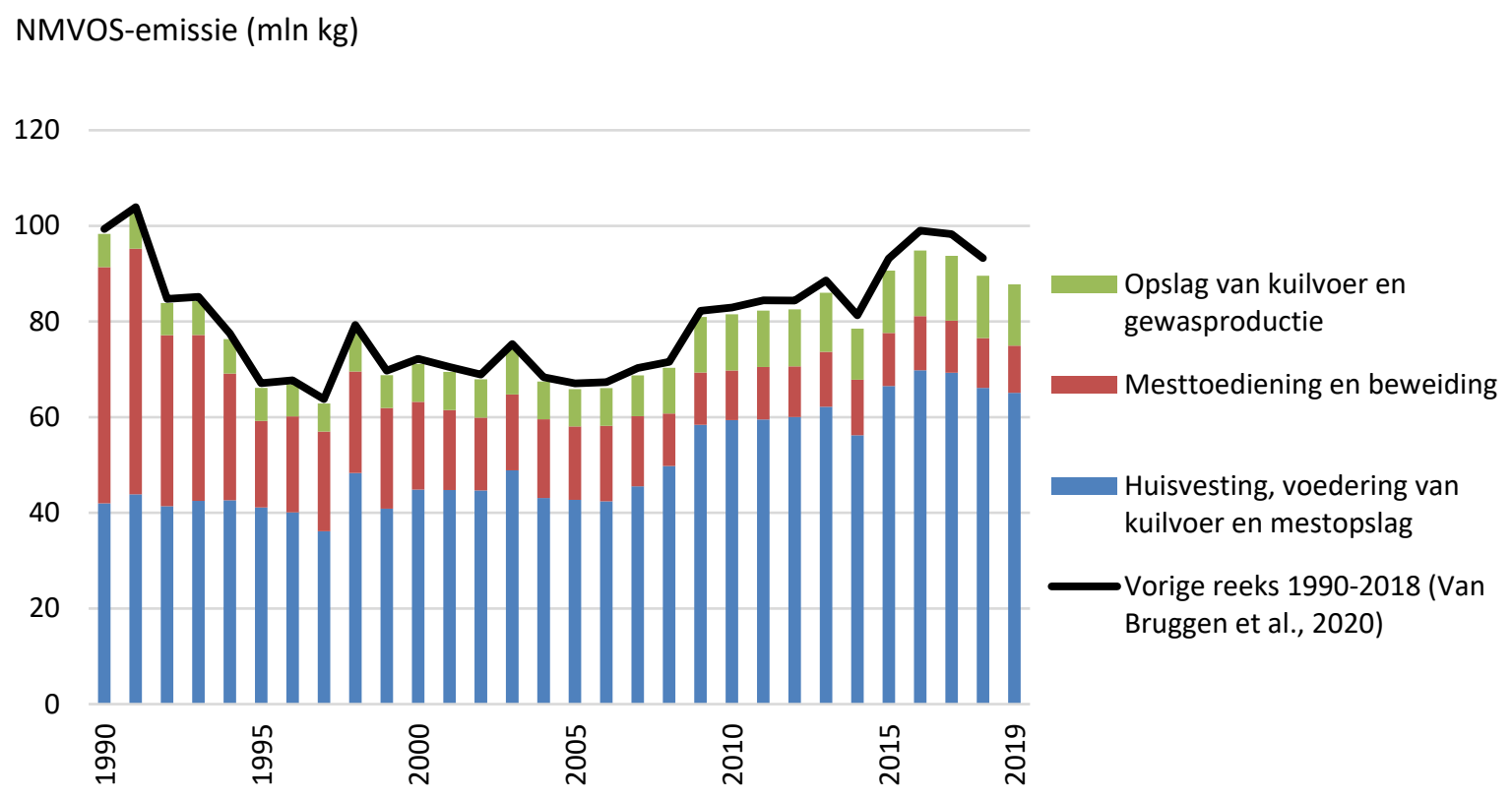

Figuur 9.5 NMVOS emissies door landbouwkundige activiteiten ( $\mathrm{mln} . \mathrm{kg}$ ) / NMVOC emissions from agricultural activities ( $\mathrm{m} / \mathrm{n} . \mathrm{kg})$.

Tabel 9.5 geeft voor enkele jaren een overzicht van de NMVOS-emissies.

Tabel 9.5 NMVOS emissies door landbouwkundige activiteiten ( $\mathrm{m} / \mathrm{n} . \mathrm{kg})$ berekend voor 1990, 2010 en 2018 [1] uit Van Bruggen et al. (2020) en berekend voor 1990, 2010, 2018 en 2019 [2] (dit rapport $)^{1)}$ / NMVOC emissions from agricultural activities ( $\mathrm{mln} . \mathrm{kg}$ ) calculated for 1990, 2010 and 2018 [1] derived from Van Bruggen et al. (2020) and calculated for 1990, 2010, 2018 and 2019 [2] (this report) ${ }^{1}$.

\begin{tabular}{|c|c|c|c|c|c|c|c|}
\hline \multirow[t]{2}{*}{ Emissiebron / Emission source } & \multicolumn{2}{|c|}{1990} & \multicolumn{2}{|c|}{2010} & \multicolumn{2}{|c|}{2018} & \multirow{2}{*}{$\begin{array}{r}2019 \\
\text { [2] }\end{array}$} \\
\hline & [1] & [2] & [1] & [2] & [1] & [2] & \\
\hline \multicolumn{8}{|l|}{$\begin{array}{l}\text { Huisvesting, voedering van kuilvoer en mestopslag } \\
\text { / Housing, silage feeding and manure storage }\end{array}$} \\
\hline Rundvee / Cattle & 29,4 & 29,4 & 48,3 & 48,3 & 54,9 & 54,9 & 54,0 \\
\hline $\begin{array}{l}\text { Schapen, geiten, paarden en pony's, ezels / Sheep, } \\
\text { goats, horses and ponies, mules and asses }\end{array}$ & 0,4 & 0,4 & 0,6 & 0,6 & 0,8 & 0,8 & 0,8 \\
\hline
\end{tabular}




\begin{tabular}{lrrrrrrr} 
Varkens / Pigs & 5,9 & 5,9 & 3,6 & 3,6 & 3,5 & 3,5 & 3,5 \\
\hline $\begin{array}{l}\text { Pluimvee, konijnen en pelsdieren / Poultry, rabbits and } \\
\text { fur-bearing animals }\end{array}$ & 6,3 & 6,3 & 7,1 & 7 & 7,3 & 6,9 & 6,8 \\
\hline Totaal / Total & 42 & 42 & 59,5 & 59,4 & 66,5 & 66,1 & 65,1
\end{tabular}

\begin{tabular}{|c|c|c|c|c|c|c|c|}
\hline $\begin{array}{l}\text { Mesttoediening en beweiding / Manure application } \\
\text { and grazing }\end{array}$ & & & & & & & \\
\hline Rundvee / Cattle & 32,4 & 31,7 & 8,4 & 7,7 & 9,5 & 7,8 & 7,4 \\
\hline $\begin{array}{l}\text { Schapen, geiten, paarden en pony's, ezels / Sheep, } \\
\text { goats, horses and ponies, mules and asses }\end{array}$ & 0,4 & 0,4 & 0,4 & 0,4 & 0,5 & 0,5 & 0,5 \\
\hline Varkens / Pigs & 7,7 & 7,7 & 1,5 & 1,2 & 2,5 & 1,2 & 1,4 \\
\hline $\begin{array}{l}\text { Pluimvee, konijnen en pelsdieren / Poultry, rabbits and } \\
\text { fur-bearing animals }\end{array}$ & 9,8 & 9,7 & 1,4 & 1,1 & 1,2 & 1,0 & 0,5 \\
\hline Totaal / Total & 50,4 & 49,4 & 11,7 & 10,4 & 13,7 & 10,4 & 9,9 \\
\hline $\begin{array}{l}\text { Opslag van kuilvoer en gewasproductie / Silage storage } \\
\text { and crop production }\end{array}$ & 7 & 7 & 11,7 & 11,7 & 13 & 13,0 & 12,9 \\
\hline Totaal / Total & 99,3 & 98,3 & 82,9 & 81,5 & 93,3 & 89,6 & 87,8 \\
\hline
\end{tabular}

1) Verschillen tussen de tijdreeksen zijn het gevolg van herberekeningen / Differences between the time series are the result of recalculations.

\section{Verschillen tussen de nieuwe en de vorige reeks}

Het verschil tussen de nieuwe reeks en de vorige reeks wordt veroorzaakt door herberekeningen van de $\mathrm{NH}_{3}-$ emissie uit stallen en bij mesttoediening. De NMVOS-emissie bij mesttoediening is namelijk evenredig met de verhouding tussen de $\mathrm{NH}_{3}$-emissie bij mesttoedienen en de $\mathrm{NH}_{3}$-emissie uit stallen. Deze verhouding is door meerdere oorzaken in de nieuwe reeks kleiner geworden. In de eerste plaats valt de $\mathrm{NH}_{3}$-emissie uit stallen hoger uit door een bijstelling van de emissie uit emissiearme huisvesting (Paragraaf 2.6). In de tweede plaats valt de $\mathrm{NH}_{3}$-emissie bij mesttoediening lager uit door het gebruik van nieuwe gegevens over de mestverdeling op grasland en bouwland vanaf 2016 (Paragraaf 2.11). Verhoudingsgewijs gaat meer mest naar bouwland waardoor de $\mathrm{NH}_{3}$-emissie, door het grote aandeel mestinjectie, lager uitvalt dan bij toediening op grasland. Ten slotte zijn de emissiefactoren voor zodenbemesting en sleufkouterbemesting op grasland verlaagd (Paragraaf 2.11).

\subsection{Fijnstofemissies}

In de figuren 9.6 en 9.7 zijn de emissies van fijnstof $\mathrm{PM}_{10}$ en $\mathrm{PM}_{2,5}$ weergegeven.

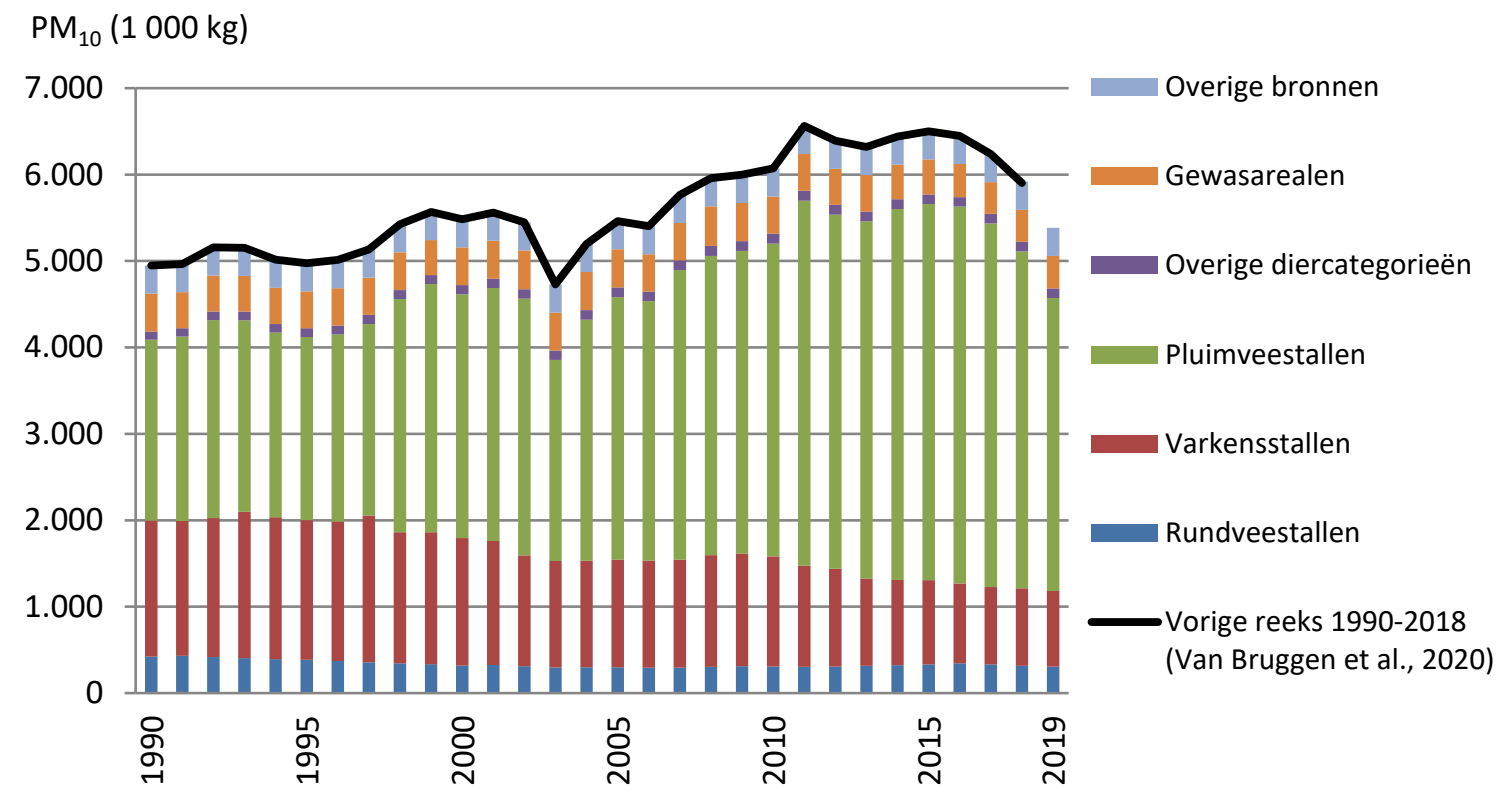


Figuur 9.6 Fijnstofemissie $P M_{10}$ door landbouwkundige activiteiten (1.000 kg $P M_{10}$ ) / Particulate matter emissions $P M_{10}$ from agricultural activities $\left(1,000 \mathrm{~kg} P M_{10}\right)$.

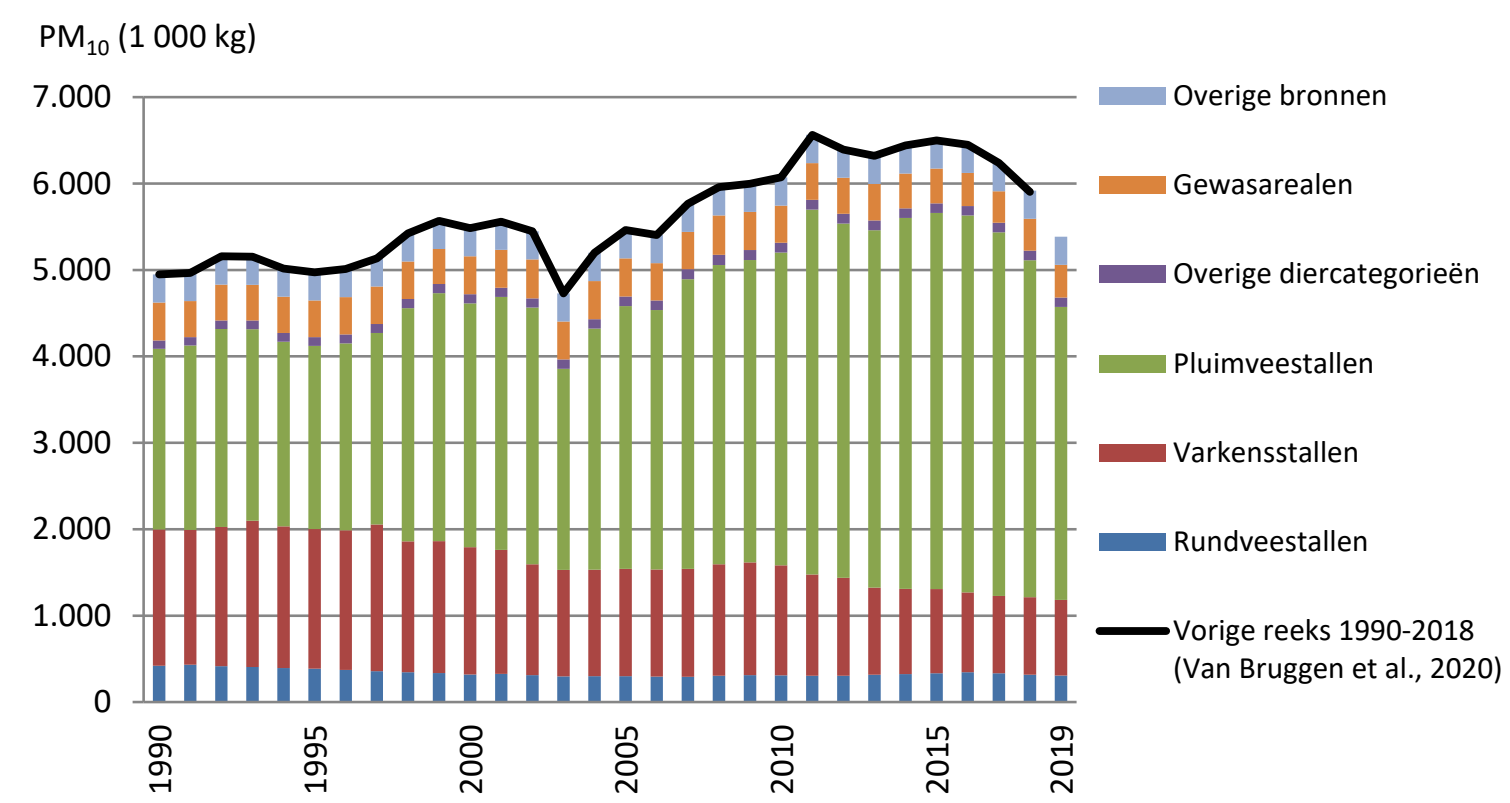

Figuur 9.7 Fijnstofemissie $P M_{2,5}$ door landbouwkundige activiteiten (1.000 kg $\left.P M_{2,5}\right)$ / Particulate matter $P M_{2.5}$ emissions from agricultural activities $\left(1,000 \mathrm{~kg} P M_{2.5}\right)$.

Tabel 9.6 geeft voor een aantal jaren een overzicht van de fijnstofemissies ( $\mathrm{PM}_{10}$ en $\left.\mathrm{PM}_{2,5}\right)$. De emissie van $\mathrm{PM}_{10}$ daalde van 5,9 miljoen $\mathrm{kg}$ in 2018 naar 5,4 miljoen $\mathrm{kg}$ in 2019. De daling van de fijnstofuitstoot hangt samen met het toegenomen gebruik van additionele technieken voor verwijdering van fijnstof bij pluimveestallen. De emissie van $\mathrm{PM}_{2,5}$ daalde van 0,6 miljoen $\mathrm{kg}$ in 2018 naar 0,5 miljoen $\mathrm{kg}$ in 2019.

Sinds 1990 zijn de emissies van $\mathrm{PM}_{10}$ toegenomen en die van $\mathrm{PM}_{2.5}$ nagenoeg gelijk gebleven. De emissie uit huisvesting van pluimvee is toegenomen door de vervanging van batterijhuisvesting met natte mest door huisvesting met vaste mest.

De emissies uit huisvesting van rundvee en andere graasdieren zijn sinds 1990 over het algemeen gedaald, in overeenstemming met de lagere aantallen dieren. Uitzonderingen zijn vleeskalveren, geiten en paarden. De emissies uit varkensstallen daalden eveneens. Hier speelt de toenemende implementatie van luchtwassers een rol.

Tabel 9.6 Fijnstofemissies door landbouwkundige activiteiten (x $1.000 \mathrm{~kg} P M_{10} / \mathrm{jaar}, \mathrm{PM}_{2,5} / \mathrm{jaar}$ ) berekend voor 1990, 2010 en 2018 [1] uit Van Bruggen et al. (2020) en berekend voor 1990, 2010, 2018 en 2019 [2] (dit rapport) ${ }^{1)}$ / Particulate matter emissions from agricultural activities ( $x$ 1,000 kg $P M_{10} /$ year, $P M_{2.5}$ /year) calculated for 1990, 2010 and 2018 [1] derived from Van Bruggen et al. (2020) and calculated for 1990, 2010, 2018 and 2019 [2] (this report) ${ }^{1)}$.

\begin{tabular}{|c|c|c|c|c|c|c|c|}
\hline \multirow[t]{2}{*}{ Emissiebron / Emission source } & \multicolumn{2}{|c|}{1990} & \multicolumn{2}{|c|}{2010} & \multicolumn{2}{|c|}{2018} & \multirow{2}{*}{$\begin{array}{r}2019 \\
\text { [2] }\end{array}$} \\
\hline & [1] & [2] & [1] & [2] & [1] & [2] & \\
\hline \multicolumn{8}{|l|}{$\mathbf{P M}_{10}$} \\
\hline \multicolumn{8}{|c|}{ Huisvestingssystemen / Housing systems: } \\
\hline varkens / pigs & 1.577 & 1.577 & 1.273 & 1.273 & 898 & 896 & 875 \\
\hline \multicolumn{8}{|c|}{ pluimvee, konijnen en pelsdieren / poultry, } \\
\hline rabbits and fur-bearing animals & 2.097 & 2.097 & 3.628 & 3.628 & 3.891 & 3.908 & 3.397 \\
\hline
\end{tabular}




\begin{tabular}{|c|c|c|c|c|c|c|c|}
\hline \multirow[t]{2}{*}{ Emissiebron / Emission source } & \multicolumn{2}{|c|}{1990} & \multicolumn{2}{|c|}{2010} & \multicolumn{2}{|c|}{2018} & \multirow{2}{*}{2019} \\
\hline & [1] & [2] & [1] & [2] & [1] & [2] & \\
\hline $\begin{array}{l}\text { Krachtvoeraanvoer op het bedrijf / Concentrat } \\
\text { supply to farms }\end{array}$ & 90 & 90 & 90 & 90 & 90 & 90 & 90 \\
\hline $\begin{array}{l}\text { Kunstmestaanvoer en verwerking op het } \\
\text { bedrijf / Fertiliser supply to and use on farms }\end{array}$ & 105 & 105 & 105 & 105 & 105 & 105 & 105 \\
\hline $\begin{array}{l}\text { Toepassing van gewasbeschermingsmiddelen } \\
\text { Application of plant protection products }\end{array}$ & 125 & 125 & 125 & 125 & 125 & 125 & 125 \\
\hline $\begin{array}{l}\text { Oogstwerkzaamheden van hooi en } \\
\text { akkerbouwgewassen / Harvesting of hay and } \\
\text { arable crops }\end{array}$ & 444 & 444 & 436 & 436 & 375 & 375 & 383 \\
\hline Totaal / Total & 4.948 & 4.948 & 6.071 & 6.071 & 5.903 & 5.918 & 5.385 \\
\hline $\mathbf{P M}_{2,5}$ & & & & & & & \\
\hline Huisvestingssystemen: / Housing systems: & & & & & & & \\
\hline $\begin{array}{l}\text { rundvee en andere graasdieren / cattle and } \\
\text { other grazing livestock }\end{array}$ & 170 & 170 & 150 & 150 & 148 & 148 & 146 \\
\hline varkens / pigs & 81 & 81 & 62 & 62 & 42 & 42 & 41 \\
\hline $\begin{array}{l}\text { pluimvee, konijnen en pelsdieren / poultry, } \\
\text { rabbits and fur-bearing animals }\end{array}$ & 213 & 213 & 284 & 284 & 279 & 276 & 245 \\
\hline $\begin{array}{l}\text { Krachtvoeraanvoer op het bedrijf / Concentrat } \\
\text { supply to farms }\end{array}$ & 18 & 18 & 18 & 18 & 18 & 18 & 18 \\
\hline $\begin{array}{l}\text { Kunstmestaanvoer en verwerking op het } \\
\text { bedrijf / Fertiliser supply to and use on farms }\end{array}$ & 21 & 21 & 21 & 21 & 21 & 21 & 21 \\
\hline $\begin{array}{l}\text { Toepassing van gewasbeschermingsmiddelen } \\
\text { Application of plant protection products }\end{array}$ & 25 & 25 & 25 & 25 & 25 & 25 & 25 \\
\hline $\begin{array}{l}\text { Oogstwerkzaamheden van hooi en } \\
\text { akkerbouwgewassen / Harvesting of hay and } \\
\text { arable crops }\end{array}$ & 50 & 50 & 49 & 49 & 41 & 41 & 42 \\
\hline Totaal / Total & 577 & 577 & 609 & 609 & 574 & 571 & 538 \\
\hline
\end{tabular}

${ }^{1)}$ Verschillen tussen de tijdreeksen zijn het gevolg van herberekeningen / Differences between the time series are the result of recalculations.

\section{6 $\mathrm{CO}_{2}$-emissie uit kalkmeststoffen en ureum}

In dit rapport is voor het eerst de $\mathrm{CO}_{2}$-emissie door het gebruik van ureum als meststof opgenomen. Cijfers over het gebruik van kalkmeststoffen en ureum laten een daling zien van de $\mathrm{CO}_{2}$-emissie van 83,1 miljoen $\mathrm{kg}$ in 2018 tot 80,1 miljoen $\mathrm{kg}$ in 2019. Het cijfer van 2018 is gewijzigd door het gebruik van definitieve cijfers over de afzet van kalkmeststoffen. Het cijfer van 2019 is nog een voorlopig cijfer. Sinds 1990 daalde de $\mathrm{CO}_{2}$-emissie uit kalkmeststoffen en nam de $\mathrm{CO}_{2}$-emissie uit ureum toe. Per saldo daalde de $\mathrm{CO}_{2}$-emissie uit kalkmeststoffen en ureum met 57\% van 184,7 miljoen kg in 1990 naar 80,1 miljoen kg in 2019 (Figuur 9.8 en Tabel 9.7). 


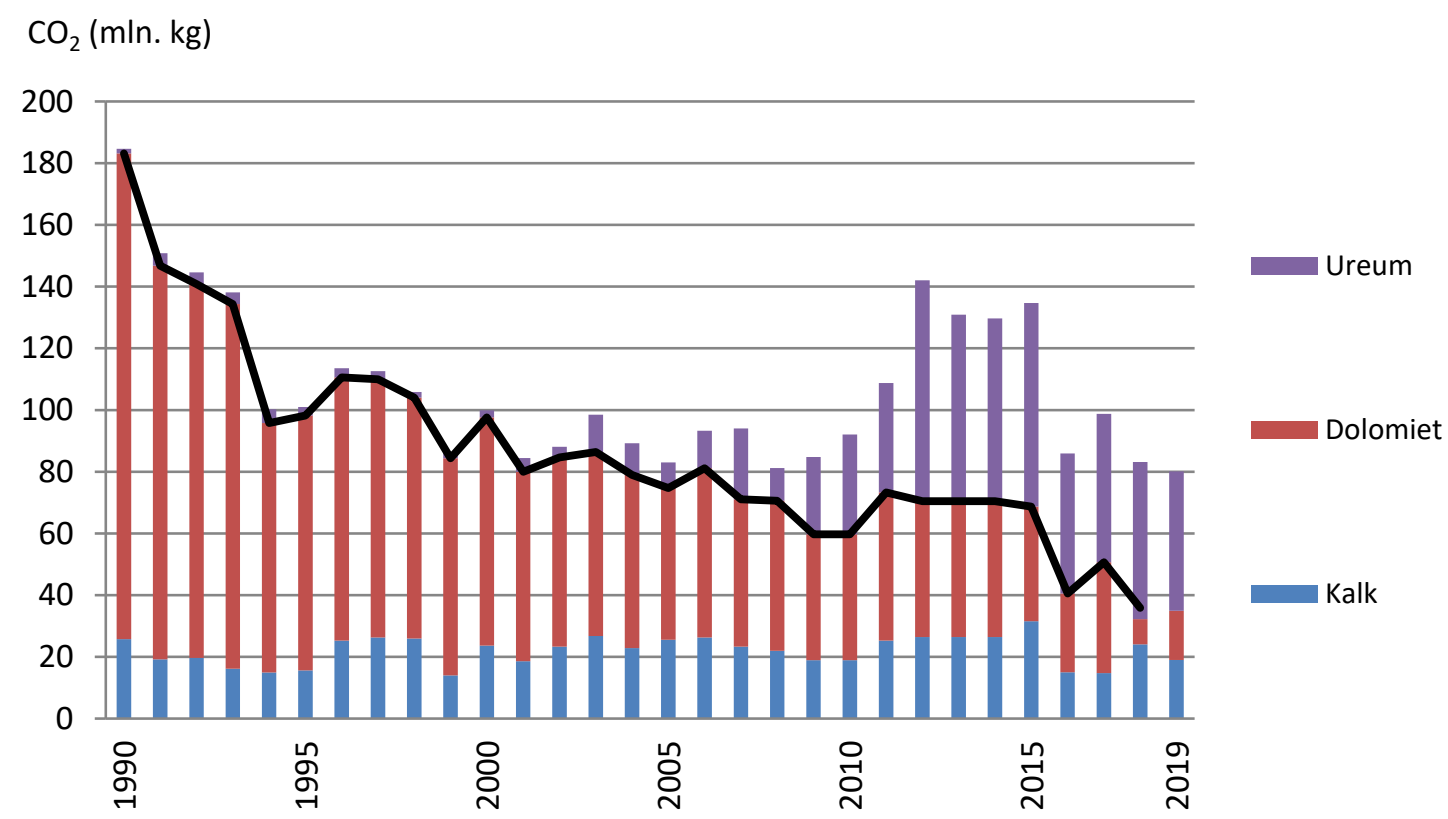

Figuur $9.8 \mathrm{CO}_{2}$-emissie door het gebruik van kalkmeststoffen ( $\left.\mathrm{mln} . \mathrm{kg} \mathrm{CO} 2\right) / \mathrm{CO}_{2}$-emissions from the use of calcareous fertilisers ( $\mathrm{mln} . \mathrm{kg} \mathrm{CO} 2)$.

Tabel 9.7 $\mathrm{CO}_{2}$-emissie binnen en buiten de landbouw door het gebruik van kalkmeststoffen ( $\mathrm{m} / \mathrm{n}$. kg CO $2 / j a a r)$ berekend voor 1990, 2010 en 2018 [1] uit Van Bruggen et al. (2020) en de $\mathrm{CO}_{2}$-emissie door het gebruik van kalkmeststoffen en ureum berekend voor 1990, 2010, 2018 en 2019 [2] (dit rapport $)^{1)} / \mathrm{CO}_{2}$-emissions inside and outside agriculture from the use of calcareous fertilisers $(\mathrm{m} / \mathrm{n} . \mathrm{kg}$ $\mathrm{CO}_{2}$ /year) calculated for 1990, 2010 and 2018 [1] derived from Van Bruggen et al. (2020) and $\mathrm{CO}_{2}$ emissions from the use of calcareous fertilisers and urea calculated for 1990, 2010, 2018 and 2019 [2] (this report) ${ }^{1}$.

\begin{tabular}{|c|c|c|c|c|c|c|c|}
\hline & \multicolumn{2}{|c|}{1990} & \multicolumn{2}{|c|}{2010} & \multicolumn{2}{|c|}{2018} & \multirow{2}{*}{$\begin{array}{r}2019 \\
{[2]}\end{array}$} \\
\hline & {$[1]$} & {$[2]$} & {$[1]$} & {$[2]$} & {$[1]$} & {$[2]$} & \\
\hline $\mathrm{CO}_{2}$-emissie $/ \mathrm{CO}_{2}$ emission & 183 & 185 & 60 & 92 & 36 & 83 & 80 \\
\hline
\end{tabular}

1) Verschillen tussen de tijdreeksen zijn het gevolg van herberekeningen / Differences between the time series are the result of recalculations.

\section{Verschillen tussen de nieuwe en de vorige reeks}

Het verschil tussen de nieuwe reeks en de vorige reeks wordt veroorzaakt door de toevoeging van de $\mathrm{CO}_{2}$-emissie door het gebruik van ureum als meststof. 


\title{
10 Onzekerheidsanalyse en vergelijkbaarheid in de tijd
}

\begin{abstract}
Onzekerheidsanalyse
Met behulp van onzekerheidsanalyses wordt een bandbreedte aangegeven waarbinnen de berekende emissies met een 95\%-betrouwbaarheid (waarschijnlijkheid) zullen liggen. In deze onzekerheidsanalyses is de onzekerheid in naleving en handhaving niet of slechts deels meegenomen.
\end{abstract}

Voor de methode van onzekerheidsberekening en de schattingen van de onzekerheden in activiteitendata en emissiefactoren van $\mathrm{CH}_{4}, \mathrm{~N}_{2} \mathrm{O}, \mathrm{NO}, \mathrm{NH}_{3}$, NMVOS, fijnstof en koolstofdioxide uit kalkmeststoffen wordt verwezen naar Van der Zee et al. (2021).

In Van der Zee et al. (2021) is het resultaat opgenomen van een onzekerheidsanalyse voor 2015 op de totale berekende $\mathrm{NH}_{3}$-emissie (inclusief niet-landbouw) met de methode van propagation of error. Hiervoor is gebruik gemaakt van geactualiseerde onzekerheidsschattingen van de basisgegevens (CBS, 2012) en expert judgement (deels gebaseerd op variatie in emissiefactoren die zijn afgeleid uit metingen), zoals beschreven in Van der Zee et al. (2021).

De onzekerheidsschatting voor 2015 is ook van toepassing op andere recente jaren, voor eerdere jaren zal de onzekerheid hoger liggen, omdat er grotere onzekerheden zijn in activiteiten-data en emissiefactoren.

In Tabel 10.1 zijn onzekerheidspercentages voor $\mathrm{NH}_{3}$ uit Van der Zee et al. (2021) weergegeven per onderdeel en voor het totaal.

Tabel 10.1 Onzekerheidsschatting van $\mathrm{NH}_{3}$-emissies berekend met NEMA (\%) / Uncertainty estimates of $\mathrm{NH}_{3}$ emissions calculated with NEMA (\%).

\begin{tabular}{ll}
\hline Emissiebron / Emission source & $\begin{array}{c}\text { Geschatte onzekerheid } \mathrm{NH}_{3} \text {-emissie / } \\
\text { Uncertainty estimates } \mathrm{NH}_{3} \text { emission }\end{array}$ \\
\hline Stallen en mestopslagen / Housing and manure storages & 20 \\
\hline Landbouwbodems (totaal) / Agricultural soils (total) & 29 \\
\hline waarvan / of which: & 38 \\
\hline toediening van dierlijke mest / application of livestock manure & 37 \\
\hline gebruik van kunstmest / fertiliser use & 56 \\
\hline beweiding / grazing & 25 \\
\hline Totale onzekerheid landbouw / Total uncertainty agriculture & 61 \\
\hline Afzet buiten de landbouw en hobbydieren / Marketing outside & \\
agriculture and hobby animals & \\
\hline Bron / Source: Van der Zee et al. (2021).
\end{tabular}

De onzekerheden in totale $\mathrm{N}_{2} \mathrm{O}$ - en NO-emissies berekend met NEMA, is met de methode van propagation of error berekend op respectievelijk $36 \%$ en $74 \%$. Voor $\mathrm{CH}_{4}$ bedraagt de onzekerheid $9 \%$ en voor $\mathrm{CO}_{2} 25 \%$. Onzekerheid in fijnstofemissies is $24 \%$ voor $\mathrm{PM}_{10}$ en $31 \%$ voor $\mathrm{PM}_{2,5}$. De onzekerheid in de NMVOS-emissie bedraagt 106\%.

\section{Vergelijkbaarheid in de tijd}

De inwinning van basisgegevens verloopt voor een groot aantal jaren, soms tientallen jaren, op dezelfde manier en berekeningen worden voor de gehele tijdreeks op dezelfde wijze uitgevoerd waardoor de vergelijkbaarheid in de tijd groot is. Wanneer wijzigingen in de rekenmethodiek toegepast worden, gebeurt dat waar mogelijk voor de gehele emissiereeks vanaf 1990 en volgt een herberekening. Indien nodig wordt hierbij tevens de onzekerheidsanalyse aangepast. 



\section{Literatuur}

Aarnink, A.J.A., J.M.G. Hol, A.G.C. Beurskens \& M.J.M. Wagemans (2005). Ammoniakemissie en mineralenbelasting op de uitloop van leghennen. Rapport 337. Agrotechnology \& Food Innovations B.V., Wageningen.

Aarnink, A.J.A., J.M.G. Hol \& A.G.C. Beurskens (2006). Ammonia emission and nutrient load in outdoor runs of laying hens. NJAS 54(2) 223-224. Wageningen UR, Wageningen.

Bannink, A. (2011). Methane emissions from enteric fermentation by dairy cows, 1990-2008. Background document on the calculation method and uncertainty analysis for the Dutch National Inventory Report on Greenhouse Gas emissions. WOt-werkdocument 265. WOT Natuur \& Milieu, Wageningen UR, Wageningen.

Bannink, A., W. Spek, J. Dijkstra \& L.B.J. Šebek (2018). A Tier 3 Method for enteric methane in dairy cows applied for fecal $\mathrm{N}$ digestibility in the ammonia inventory. Frontiers in Sustainable Food Systems (Waste Management in Agroecosystems) 2:66. doi: 10.3389/fsufs.2018.00066

Bikker, P., L.B. Šebek, C. van Bruggen \& O. Oenema (2019). Stikstof- en fosfaatexcretie van gangbaar en biologisch gehouden landbouwhuisdieren. Herziening excretieforfaits Meststoffenwet 2019. Wettelijke Onderzoekstaken Natuur \& Milieu, WUR, Wageningen. WOt-technical report 152.

Bouwman A.F., L.J.M. Bouman \& N.H. Batjes (2002). Estimation of global $\mathrm{NH}_{3}$ volatilizationloss from synthetic fertilisers and animal manure applied to arable lands and grasslands. Glob. Biogeochem. Cycl., vol.16, No.2, 1024.

Brunekreef, B., R.M. Harrison, N. Künzli, X. Querol, M.A Sutton, D.J.J. Heederik \& T. Sigsgaard (2015). Reducing the health effect of particles from agriculture. The Lancet, respiratory medicine 3: 831832.

CBS (2012). Uncertainty analysis of mineral excretion and manure production. Statistics Netherlands, The Hague/Heerlen.

CBS (2020). Dierlijke mest en mineralen 2019 (C. van Bruggen).

Chardon, W.J. \& K.W. van der Hoek (2002). Berekeningsmethode voor de emissie van fijn stof vanuit de landbouw. Alterra-rapport 682/RIVM-rapport 773004014. Alterra/RIVM, Wageningen/Bilthoven.

De Koeijer, T.J., C.C. de Lauwere, H.H. Luesink \& H. Prins (2018). Handelsverkeer in de mestmarkt: opties voor interventies. Rapport 2018-057. Wageningen Economic Research, Wageningen.

De Ruijter, F.J., J.F.M. Huijsmans, M.C. van Zanten, W.A.H. Asman \& W.A.J. van Pul (2013). Ammonia emissions from standing crops and crop residues. Contribution to total ammonia emissions in the Netherlands. Report 535. Plant Research International - Wageningen UR, Wageningen.

De Ruijter \& Huijsmans (2019). A methodology for estimating the ammonia emission from crop residues at a national scale. Atmospheric Environment: Volume 2, April 2019, 100028 https://doi.org/10.1016/j.aeaoa.2019.100028

EEA (2019). EMEP/EEA air pollutant emission inventory guidebook 2019. Technical guidance to prepare national emission inventories. EEA Report doi:10.2800/293657. European Environment Agency, Kopenhagen, Denemarken.

Ellen, H.H., C.M. Groenestein \& N.W.M. Ogink (2017). Actualisering ammoniak emissiefactoren pluimvee; Advies voor aanpassing van ammoniak emissiefactoren van pluimvee in de Regeling ammoniak en veehouderij (Rav). Rapport 1015. Wageningen Livestock Research, Wageningen.

Gerrits, W.J.J., J. Dijkstra \& A. Bannink (2014). Methaanproductie bij witvleeskalveren. Livestock Research Report 813. Wageningen UR Livestock Research, Wageningen.

Goedhart, PW, Mosquera, J, Huijsmans, JFM (2020). Estimating ammonia emission after field application of manure by the integrated horizontal flux method: a comparison of concentration and wind speed profiles. Soil Use and Management, 36, 338- 350. https://doi.org/10.1111/sum.12564

Groenestein, C.M., A.J.A. Aarnink \& N.W.M. Ogink (2014). Actualisering ammoniakemissiefactoren vleesvarkens en biggen: advies herberekening op basis van welzijnseisen. Livestock Research rapport 786. Wageningen UR Livestock Research, Wageningen.

Groenestein, C.M., J.M.G. Hol \& H.H. Ellen (2015). Beter leven en ammoniak. Livestock Research Report 799. Wageningen UR Livestock Research, Wageningen. 
Groenestein, C.M., J. Mosquera \& R.W. Melse (2016). Methaanemissie uit mest; Schatters voor biochemisch methaan potentieel (BMP) en methaanconversiefactor (MCF). Wageningen Livestock Research, Rapport 961.

Hoogeveen, M.W., P.W. Blokland, H. van Kernebeek, H.H. Luesink \& J.H. Wisman (2010). Ammoniakemissie uit de landbouw in 1990 en 2005-2008; Achtergrondrapportage. WOtwerkdocument 191. WOT Natuur \& Milieu, Wageningen UR, Wageningen.

Huijsmans, J. \& B. Verwijs (2008). Beoordeling van mesttoediening in de praktijk. Rapport 219. Plant Research International B.V., Wageningen UR, Wageningen.

Huijsmans, J.F.M. \& R.L.M. Schils (2009). Ammonia and nitrous oxide emissions following field application of manure: state of the art measurements in the Netherlands. International Fertiliser Society (IFS), Proceedings No. 655.

Huijsmans, J.F.M. \& J.M.G. Hol (2012). Ammoniakemissie bij mesttoediening in wintertarwe op kleibouwland. Rapport 446. Plant Research International, Wageningen UR, Wageningen.

Huijsmans, J.F.M., G.D. Vermeulen, J.M.G. Hol \& P.W. Goedhart (2018). A model for estimating seasonal trends of ammonia emission from cattle manure applied to grassland in the Netherlands. Atmospheric Environment 173: 231-238.

IPCC (2006). 2006 IPCC Guidelines for National Greenhouse Gas Inventories. Prepared by the National Greenhouse Gas Inventories Programme. Eggleson H.S., L. Buendia, K. Miwa, T. Ngara and K. Tanabe (eds.). Published: IGES, Japan.

Kros, H., J. van Os, J.C. Voogd, P. Groenendijk, C. van Bruggen, R. te Molder \& G. Ros (2019). Ruimtelijke allocatie van mesttoediening en ammoniakemissie: beschrijving mestverdelingsmodule INITIATOR versie 5. Wageningen Environmental Research, rapport no. 2939).

Kuikman, P.J., J.J.H. van den Akker \& F. de Vries (2005). Lachgasemissie uit organische landbouwbodems. Alterra rapport 1035-2. Alterra Wageningen UR, Wageningen.

Lagerwerf, L.A., A. Bannink, C. van Bruggen, C.M. Groenestein, J.F.M. Huijsmans, J.W.H. van der Kolk, H.H. Luesink, S.M. van der Sluis, G.L. Velthof \& J. Vonk (2019). Methodology for estimating emissions from agriculture in the Netherlands. Calculations of $\mathrm{CH}_{4}, \mathrm{NH}_{3}, \mathrm{~N} 2 \mathrm{O}, \mathrm{NO}_{x}, \mathrm{NMVOC}_{1} \mathrm{PM}_{10}$, $\mathrm{PM}_{2.5}$ and $\mathrm{CO}_{2}$ with the National Emission Model for Agriculture (NEMA) - update 2019. WOttechnical report 148. The Statutory Research Tasks Unit for Nature and the Environment, Wageningen UR, Wageningen.

Luesink, H.H., P.W. Blokland \& J.N. Bosma (2011). Monitoring mestmarkt 2010. Achtergronddocumentatie. LEI-rapport 2011-048. LEI-Wageningen UR, Den Haag.

Melse, R.W. \& C.M. Groenestein (2016). Emissiefactoren mestbewerking. Inschatting van emissiefactoren van ammoniak, methaan en lachgas uit mestbewerking. Livestock Research Rapport 962. Wageningen Livestock Research, Wageningen.

Melse, R.W., G.M. Nijeboer \& N.W.M. Ogink (2018a). Evaluatie geurverwijdering door luchtwassystemen bij stallen; Deel 2: Steekproef rendement luchtwassers in de praktijk. Rapport 1082. Wageningen Livestock Research, Wageningen.

Melse, R.W., P. Hoeksma \& N.W.M. Ogink (2018b). Technische bovengrenzen van $\mathrm{P}_{2} \mathrm{O}_{5}$ gehalte dikke fractie na scheiding drijfmest met decanteercentrifuge: Verkennende studie - versie januari 2017. Rapport 1100. Wageningen Livestock Research, Wageningen.

Mosquera, J., R.A. van Emous, A. Winkel, F. Dousma, E. Lovink, N.W.M. Ogink \& A.J.A. Aarnink (2009a). Fijnstofemissie uit stallen: (groot)ouderdieren van vleeskuikens. Rapport 276. Wageningen UR Livestock Research, Lelystad.

Mosquera, J., A. Winkel, R.K. Kwikkel, F.A. Gerrits, N.W.M. Ogink \& A.J.A. Aarnink (2009b). Fijnstofemissie uit stallen: vleeskalkoenen. Rapport 277. Wageningen UR Livestock Research, Lelystad.

Mosquera, J., A. Winkel, F. Dousma, E. Lovink, N.W.M. Ogink \& A.J.A. Aarnink (2009c). Fijnstofemissie uit stallen: leghennen in scharrelhuisvesting. Rapport 279. Wageningen UR Livestock Research, Lelystad.

Mosquera, J., J.M.G. Hol, A. Winkel, E. Lovink, N.W.M. Ogink \& A.J.A. Aarnink (2010a). Fijnstofemissie uit stallen: vleesvarkens. Rapport 292. Wageningen UR Livestock Research, Lelystad.

Mosquera, J., J.M.G. Hol, A. Winkel, G.M. Nijeboer, N.W.M. Ogink \& A.J.A. Aarnink (2010b). Fijnstofemissie uit stallen: dragende zeugen. Rapport 294. Wageningen UR Livestock Research, Lelystad. 
Mosquera, J., J.M.G. Hol, A. Winkel, J.W.H. Huis in 't Veld, F.A. Gerrits, N.W.M. Ogink \& A.J.A. Aarnink (2010c). Fijnstofemissie uit stallen: melkvee. Rapport 296. Wageningen UR Livestock Research, Lelystad.

Oenema, O., G.L. Velthof, N. Verdoes, P.W.G. Groot-Koerkamp, G.J. Monteny, A. Bannink, H.G. van der Meer \& K.W. van der Hoek (2000). Forfaitaire waarden voor gasvormige stikstofverliezen uit stallen en mestopslagen. Alterra-rapport 107, gewijzigde druk. Alterra Wageningen UR, Wageningen.

Ogink, N.W.M., C.M. Groenestein \& J. Mosquera (2014). Actualisering ammoniakemissiefactoren rundvee: advies voor aanpassing in de Regeling ammoniak en veehouderij. Rapport 744. Wageningen UR Livestock Research, Lelystad.

Ogink, N.W.M., Mosquera, J., Hol, J.M.G. (2017). Protocol voor meting van ammoniakemissie uit huisvestingssystemen in de veehouderij 2013a. Wageningen Livestock Research, Rapport 1032.

Van Bruggen, C., M.J.C. de Bode, A.G. Evers, K.W. van der Hoek, H.H. Luesink \& M.W. van Schijndel (2010). Gestandaardiseerde berekeningsmethode voor dierlijke mest en mineralen.

Standaardcijfers 1990-2008. Werkgroep Uniformering berekening Mest- en mineralencijfers. CBS, Den Haag.

Van Bruggen, C., C.M. Groenestein, B.J. de Haan, M.W. Hoogeveen, J.F.M. Huijsmans, S.M. van der Sluis \& G.L. Velthof (2011a). Ammoniakemissie uit dierlijke mest en kunstmest, 1990-2008. Berekeningen met het Nationaal Emissiemodel voor Ammoniak (NEMA). WOt-werkdocument 250. WOT Natuur \& Milieu, Wageningen UR, Wageningen.

Van Bruggen, C., C.M. Groenestein, B.J. de Haan, M.W. Hoogeveen, J.F.M. Huijsmans, S.M. van der Sluis \& G.L. Velthof (2011b). Ammoniakemissie uit dierlijke mest en kunstmest in 2009. Berekeningen met het Nationaal Emissiemodel voor Ammoniak (NEMA). WOt-werkdocument 251. WOT Natuur \& Milieu, Wageningen UR, Wageningen.

Van Bruggen, C., C.M. Groenestein, B.J. de Haan, M.W. Hoogeveen, J.F.M. Huijsmans, S.M. van der Sluis \& G.L. Velthof (2012). Ammoniakemissie uit dierlijke mest en kunstmest in 2010. Berekeningen met het Nationaal Emissiemodel voor Ammoniak (NEMA). WOt-werkdocument 294. WOT Natuur \& Milieu, Wageningen UR, Wageningen.

Van Bruggen, C., C.M. Groenestein, B.J. de Haan, M.W. Hoogeveen, J.F.M. Huijsmans, S.M. van der Sluis \& G.L. Velthof (2013). Ammoniakemissie uit dierlijke mest en kunstmest in 2011.

Berekeningen met het Nationaal Emissiemodel voor Ammoniak (NEMA). WOt-werkdocument 330. WOT Natuur \& Milieu, Wageningen UR, Wageningen.

Van Bruggen, C., A. Bannink, C.M. Groenestein, B.J. de Haan, J.F.M. Huijsmans, H.H. Luesink, S.M. van der Sluis, G.L. Velthof \& J. Vonk (2014). Emissies naar lucht uit de landbouw in 2012. Berekeningen met het Nationaal Emissiemodel voor Ammoniak (NEMA). WOt-technical report 3. WOT Natuur \& Milieu, Wageningen UR, Wageningen.

Van Bruggen, C., A. Bannink, C.M. Groenestein, J.F.M. Huijsmans, H.H. Luesink, S.M. van der Sluis, G.L. Velthof \& J. Vonk (2015). Emissies naar lucht uit de landbouw 1990-2013. Berekeningen van ammoniak, stikstofoxide, lachgas, methaan en fijnstof met het model NEMA. WOt-technical report 46. WOT Natuur \& Milieu, Wageningen UR, Wageningen.

Van Bruggen, C., A. Bannink, C.M. Groenestein, J.F.M. Huijsmans, H.H. Luesink, S.V. Oude Voshaar, S.M. van der Sluis, G.L. Velthof \& J. Vonk (2017a). Emissies naar lucht uit de landbouw in 2014. Berekeningen met het model NEMA. WOt-technical report 90. WOT Natuur \& Milieu, Wageningen UR, Wageningen.

Van Bruggen, C., A. Bannink, C.M. Groenestein, J.F.M. Huijsmans, H.H. Luesink, S.V. Oude Voshaar, S.M. van der Sluis, G.L. Velthof \& J. Vonk (2017b). Emissies naar lucht uit de landbouw in 2015. Berekeningen met het model NEMA. WOt-technical report 98. WOT Natuur \& Milieu, Wageningen UR, Wageningen.

Van Bruggen, C., A. Bannink, C.M. Groenestein, J.F.M. Huijsmans, L.A. Lagerwerf, H.H. Luesink, S.M. van der Sluis, G.L. Velthof \& J. Vonk (2018). Emissies naar lucht uit de landbouw in 2016. Berekeningen met het model NEMA. WOt-technical report 119. WOT Natuur \& Milieu, Wageningen UR, Wageningen.

Van Bruggen, C., A. Bannink, C.M. Groenestein, J.F.M. Huijsmans, L.A. Lagerwerf, H.H. Luesink, G.L. Velthof \& J. Vonk (2019). Emissies naar lucht uit de landbouw in 2017. Berekeningen met het model NEMA. WOt-technical report 147. WOT Natuur \& Milieu, Wageningen UR, Wageningen. 
Van Bruggen, C., A. Bannink, C.M. Groenestein, J.F.M. Huijsmans, L.A. Lagerwerf, H.H. Luesink, G.L. Velthof \& J. Vonk (2020). Emissies naar lucht uit de landbouw, 1990-2018. Berekeningen met het model NEMA. Wageningen, WOT Natuur \& Milieu, WOt-technical report 178.

Van Bruggen, C. \& K. Geertjes (2019). Stikstofverlies uit opgeslagen mest - Stikstofverlies berekend uit het verschil in verhouding tussen stikstof en fosfaat bij excretie en bij mestafvoer. Centraal Bureau voor de Statistiek, Den Haag/Heerlen/Bonaire, 2019.

Van der Hoek, K.W. (2002). Uitgangspunten voor de mest- en ammoniakberekeningen 1999 tot en met 2001 zoals gebruikt in de Milieubalans 2001 en 2002, inclusief datasets landbouwemissies 1980-2001. RIVM rapport 773004013/2002. RIVM, Bilthoven.

Van der Hoek, K.W., M.W. van Schijndel \& P.J. Kuikman (2007). Direct and indirect nitrous oxide emissions from agricultural soils, 1990-2003. Background document on the calculation method for the Dutch National Inventory Report. RIVM report 68012003/2007; MNP report 500080003/2007. RIVM/MNP, Bilthoven.

Van der Zee, T., A. Bannink, C. van Bruggen, C.M. Groenestein, J.F.M. Huijsmans, J.W.H. van der Kolk, Lagerwerf, L.A., H.H. Luesink, G.L. Velthof \& J. Vonk (2021). Methodology for estimating emissions from agriculture in the Netherlands. Calculations of $\mathrm{CH}_{4}, \mathrm{NH}_{3}, \mathrm{~N}_{2} \mathrm{O}, \mathrm{NO}_{x}, \mathrm{NMVOC} \mathrm{PM}_{10}$, $\mathrm{PM}_{2.5}$ and $\mathrm{CO}_{2}$ using the National Emission Model for Agriculture (NEMA) - update 2021. RIVM Report 2021-0008. RIVM, Bilthoven.

Van Os, J., M.G.T.M. Bartholomeus, L.J.J. Jeurissen \& C.G. van Reenen (2017). Rekenregels rundvee voor de Landbouwtelling; Verantwoording van het gebruik van het Identificatie \& Registratiesysteem. WOt-technical report 91. WOT Natuur \& Milieu, Wageningen UR, Wageningen.

Van Os, J., L.J.J. Jeurissen \& H.H. Ellen (2019). Rekenregels pluimvee voor de Landbouwtelling; Verantwoording van het gebruik van het Identificatie \& Registratiesysteem. Wettelijke Onderzoekstaken Natuur \& Milieu, WOt-technical report 154.

Van Os, J. (2020). Rekenregels schapen en geiten voor de Landbouwtelling; Verantwoording van het gebruik van het Identificatie \& Registratiesysteem. Wettelijke Onderzoekstaken Natuur \& Milieu, WOt-technical report 185.

Velthof G.J. \& P.J. Kuikman (2000). Beperking van lachgasemissie uit gewasresten; een systeemanalyse. Alterra rapport 114-3. Alterra, Wageningen UR, Wageningen.

Velthof, G.L., C. van Bruggen, C.M. Groenestein, B.J. de Haan, M.W. Hoogeveen \& J.F.M. Huijsmans (2009). Methodiek voor berekening van ammoniakemissie uit de landbouw in Nederland. WOtrapport 70. WOT Natuur \& Milieu, Wageningen UR, Wageningen.

Velthof, G.L. \& J. Mosquera (2011). Calculation of nitrous oxide emission from agriculture in the Netherlands. Update of emission factors and leaching fraction. Alterra report 2151. Alterra Wageningen UR, Wageningen.

Velthof, G.L., C. van Bruggen, C.M. Groenestein, B.J. de Haan, M.W. Hoogeveen \& J.F.M. Huijsmans (2012). A model for inventory of ammonia emissions from agriculture in the Netherlands. Atmospheric Environment 46 (2012), p. 248-255.

Vonk, J., A. Bannink, C. van Bruggen, C.M. Groenestein, J.F.M. Huijsmans, J.W.H. van der Kolk, H.H. Luesink, S.V. Oude Voshaar, S.M. van der Sluis \& G.L. Velthof (2016). Methodology for estimating emissions from agriculture in the Netherlands. Calculations of $\mathrm{CH}_{4}, \mathrm{NH}_{3}, \mathrm{~N}_{2} \mathrm{O}, \mathrm{NO}_{x}$, $\mathrm{PM}_{10}, \mathrm{PM}_{2.5}$ and $\mathrm{CO}_{2}$ with the National Emission Model for Agriculture (NEMA). WOt-technical report 53. WOT Natuur \& Milieu, Wageningen UR, Wageningen.

Vonk, J., S.M. van der Sluis, A. Bannink, C. van Bruggen, C.M. Groenestein, J.F.M. Huijsmans, J.W.H. van der Kolk, L.A. Lagerwerf, H.H. Luesink, S.V. Oude Voshaar \& G.L. Velthof (2018). Methodology for estimating emissions from agriculture in the Netherlands - update 2018. Calculations of $\mathrm{CH}_{4}$, $\mathrm{NH}_{3}, \mathrm{~N}_{2} \mathrm{O}, \mathrm{NO}_{\mathrm{x}}, \mathrm{PM}_{10}, \mathrm{PM}_{2.5}$ and $\mathrm{CO}_{2}$ with the National Emission Model for Agriculture (NEMA). WOttechnical report 115. WOT Natuur \& Milieu, Wageningen UR, Wageningen.

Wever, D., P.W.H.G. Coenen, R. Dröge, G.P. Geilenkirchen, M. 't Hoen, E. Honig, W.W.R. Koch, A.J. Leekstra, L.A. Lagerwerf, R.A.B. te Molder, W.L.M. Smeets, J. Vonk \& T. van der Zee. Informative Inventory Report 2020. Informative Inventory Report 2020. Emissions of transboundary air pollutants in the Netherlands 1990-2018. RIVM Report 2020-0032. Rijksinstituut voor Volksgezondheid en Milieu, Bilthoven.

Winkel, A., J. Mosquera, R.K. Kwikkel, F.A. Gerrits, N.W.M. Ogink \& A.J.A. Aarnink (2009a). Fijnstofemissie uit stallen: vleeskuikens. Rapport 275. Wageningen UR Livestock Research, Lelystad. 
Winkel, A., J. Mosquera, J.M.G. Hol, G.M. Nijeboer, N.W.M. Ogink \& A.J.A. Aarnink (2009b). Fijnstofemissie uit stallen: leghennen in volièrehuisvesting. Rapport 278. Wageningen UR Livestock Research, Lelystad.

Winkel, A., J. Mosquera, J.M.G. Hol, T.G. van Hattum, E. Lovink, N.W.M. Ogink \& A.J.A. Aarnink (2010). Fijnstofemissie uit stallen: biggen. Rapport 293. Wageningen UR Livestock Research, Lelystad.

Zom, R.L.G. \& C.M. Groenestein (2015). Excretion of volatile solids by livestock to calculate methane production from manure. Paper TC-O_20 of the Proceedings of RAMIRAN 2015 - 16th International Conference on Rural-Urban Symbiosis, 8th - 10th September 2015, Hamburg, Germany.

\section{Niet gepubliceerde bronnen}

Buisonjé, F.E. (2017). Persoonlijke mededeling. Wageningen Livestock Research.

De Ruijter, F.J.\& J.F.M. Huijsmans (2016). Ondergrondse delen van groenbemesters en afvoer van gewasresten. Interne notitie 13 juni 2016. Wageningen Plant Research, Wageningen.

Groenestein, C.M. (2017). Persoonlijke mededeling. Wageningen Livestock Research, Wageningen.

Luesink, H.H. (2020). Persoonlijke mededeling. Wageningen Economic Research, Den Haag.

Melse, R.W. (2017). Persoonlijke mededeling. Wageningen Livestock Research, Wageningen.

Scholtens (2015; 2017). Persoonlijke mededeling. Stichting Beter Leven keurmerk, Den Haag.

Vaandrager, E. (2018; 2019; 2020). Persoonlijke mededeling. Stichting Beter Leven keurmerk, Den Haag. 



\section{Verantwoording}

WOt-technical report: 203

Projectnummer: WOT-04-008-031.01 en WOT-04-008-025.02

De Emissieregistratie heeft tot doel om jaarlijks de emissies van ongeveer 170 stoffen naar lucht, water en bodem in kaart te brengen. Deze worden door ministeries en instituten gebruikt voor diverse doeleinden, zoals beleidsanalyses, de balans van de leefomgeving en internationale rapportages. Binnen de Emissieregistratie is de Taakgroep Landbouwemissies verantwoordelijk voor de emissies vanuit de landbouw. Belangrijke emissies zijn koolstofdioxide, ammoniak, fijnstof, lachgas en methaan. Het vastleggen van deze emissies is vooral belangrijk voor Nederland in het kader van de broeikasgasrapportages en de NEC (National Emission Ceiling).

Dit rapport is een verantwoording van de berekening van de emissies van ammoniak, stikstofoxide, lachgas, methaan, fijnstof, NMVOS en koolstofdioxide uit de landbouw in 1990-2019 met het rekenmodel NEMA. De emissiecijfers zijn gepubliceerd via de website: www.emissieregistratie.nl. De berekeningen zijn uitgevoerd onder verantwoordelijkheid van de Taakgroep Landbouwemissies. Het conceptrapport is beoordeeld en goedgekeurd door de externe contactpersoon bij het ministerie van LNV (Alice van Rixel) en door de themaleider binnen de unit WOT Natuur \& Milieu, thema Agromilieu (Erwin van Boekel).

Akkoord Referent/ Extern contactpersoon

functie: Beleidsmedewerker klimaat

naam: $\quad$ Alice van Rixel

datum: $\quad 21$ april 2021

Akkoord Intern contactpersoon

naam: $\quad$ Erwin van Boekel

datum: $\quad 6$ april 2021 



\section{Bijlage 1 Overzicht van wijzigingen in uitgangspunten}

In deze bijlage is een overzicht opgenomen van de wijzigingen in uitgangspunten die jaarlijks in de tijdreeks zijn verwerkt. Voor meer informatie over de achtergrond en het effect van de wijzigingen wordt verwezen naar de afzonderlijke rapporten in de reeks 'Emissies naar lucht uit de landbouw'.

Emissies naar lucht uit de landbouw in 2012 (Van Bruggen et al., 2014):

- Er wordt van uitgegaan dat er geen voorraadvorming- of onttrekking van mest plaatsvindt. De vorming van mestvoorraden sinds 2010 op basis van bevindingen in het project Monitoring mestmarkt zijn teruggedraaid, omdat gegevens over 2012 ontbreken en er grote onzekerheden zitten in de berekening van mestvoorraden in eerdere jaren;

- Op basis van nieuw onderzoek zijn de emissiefactoren voor huisvesting van melkvee aangepast. Op basis van dit onderzoek heeft de werkgroep NEMA door middel van interpolatie de emissiefactoren voor huisvesting van melkkoeien in de periode 2001-2007 verhoogd van 11,0 tot $13,0 \mathrm{~kg} \mathrm{NH}$ per dierplaats;

- Op basis van onderzoek naar het gebruik van luchtwassers, zijn de implementatiegraden van luchtwassers gecorrigeerd voor geconstateerde tekortkomingen. Een deel van de luchtwassers bleek niet in werking te zijn of was niet aanwezig. Tot en met 2009 is de implementatiegraad van luchtwassers met 40\% verlaagd en in 2010, 2011 en 2012 met respectievelijk 32\%, 24\% en $16 \%$;

- Het spuiwater van luchtwassers wordt niet langer gezien als dierlijke mest maar als een kunstmest. Bij toediening wordt de gemiddelde emissiefactor voor ammoniak uit kunstmest toegepast;

- Berekening van ammoniakemissie uit mest van ouderdieren van vleeskalkoenen in 1999 is toegevoegd.

Emissies naar lucht uit de landbouw 1990-2013 (Van Bruggen et al., 2015):

In dit rapport zijn de eerder gepubliceerde cijfers gewijzigd als gevolg van de implementatie van nieuwe IPCC Guidelines (IPCC, 2006) en nieuwe wetenschappelijke inzichten. De volgende wijzigingen zijn doorgevoerd:

- Nieuwe, hogere ammoniakemissiefactoren voor huisvesting van vleesvarkens;

- Nieuwe, hogere ammoniakemissiefactoren voor huisvesting van vleeskalveren;

- Splitsing van bouwland in onbeteeld en beteeld bouwland;

- Herziene, hogere emissiefactoren voor zodenbemesting en sleepvoetbemesting bij onbeteeld en beteeld bouwland;

- Hogere emissiefactoren voor overige stikstofverbindingen uit in de stal geproduceerde dunne mest van rundvee en varkens en lagere emissiefactoren voor overige stikstofverbindingen uit vaste mest. Per saldo vallen de verliezen van overige stikstofverbindingen uit in de stal geproduceerde mest door het gebruik van nieuwe IPCC-factoren lager uit;

- Nieuwe bronnen van ammoniak- en lachgasemissie zijn toegevoegd zoals afrijping van gewassen, gewasresten inclusief graslandvernieuwing, het gebruik van compost en zuiveringsslib, moerige gronden;

- Nieuwe methaanconversiefactoren $\left(Y_{m}\right)$ voor rundvee uitgezonderd melkkoeien. Voor witvleeskalveren wordt een landspecifieke factor gebruikt en voor de overige runderen de nieuwe IPCC default waarde;

- Nieuwe berekening voor methaan uit mest op basis van berekende organische stofexcreties in plaats van mestvolumes en gemeten organische stofgehalte van mest. 
Emissies naar lucht uit de landbouw 2014 (Van Bruggen et al., 2017a):

- Correctie van de berekening van de excretie van melkkoeien tijdens opstallen in het weideseizoen waarbij rekening wordt gehouden met de relatie tussen beweiding en staltype (dunne of vaste mest;

- Herziening van de jaarrond emissie voor ammoniak uit melkveestallen bij beweiding overdag;

- $\quad$ Correctie van de afzet (export) van pluimveemest buiten de landbouw wanneer de totale afzet buiten de landbouw groter is dan de mest in opslag;

- De implementatiegraden van mesttoediening in de Landbouwtelling van 2015 zijn toegepast vanaf 2008;

- Verhoging van de minimale emissiefactor voor ammoniak tijdens beweiding naar 4,0\%;

- Correctie van de bodembelasting met bovengronds toegediende vaste mest voor de berekening van de $\mathrm{N}_{2} \mathrm{O}$-emissie;

- Van enkele gewassen is de hoeveelheid $\mathrm{N}$ in gewasresten en de emissiefactor voor ammoniak uit gewasresten aangepast;

- $\quad$ Uitgangspunten in de berekeningen van de fijnstofemissies zijn aangepast.

Emissies naar lucht uit de landbouw 2015 (Van Bruggen et al., 2017b):

- In de berekening van mestafzet buiten de landbouw en bij de weergave van de resultaten is de categorie vleespluimvee nu gesplitst in vleeskuikens, eenden en kalkoenen. In enkele gevallen leidde dit tot kleine correcties in de afzet buiten de landbouw;

- Verwerking van nieuwe gegevens over de kunstmestafzet in 2013 en 2014;

- Splitsing van de ureumafzet over verschillende typen en toedieningswijzen, en differentiatie van emissiefactoren voor ureum-kunstmeststoffen;

- Nieuwe emissiefactor voor ammoniak bij gebruik van spuiwater van luchtwassers;

- Berekening van $\mathrm{N}_{2} \mathrm{O}$-emissie van ondergrondse gewasresten toegevoegd;

- $\quad$ Aanpassing van uitgangspunten in de berekeningen van de fijnstofemissies.

Emissies naar lucht uit de landbouw 2016 (Van Bruggen et al., 2018):

- Aandelen Totaal Ammoniakaal Stikstof (TAN) in de stikstofexcretie van rundvee;

- Emissiefactoren voor ammoniak per dierplaats uit pluimveestallen;

- Export van stikstof via producten van mestscheiding;

- Emissiefactoren voor mesttoediening op grasland;

- Afvoer van gewasresten van granen;

- Ammoniakemissie van gewasresten van groenbemesters;

- Graslandvernieuwing in 2015;

- Nieuwe bronnen van directe stikstofverliezen in de vorm van stikstofoxiden;

- Het areaal organische bodems;

- Methaanemissie uit pensfermentatie;

- Methaanemissie uit opgeslagen mest.

Emissies naar lucht uit de landbouw 2017 (Van Bruggen et al., 2019):

- Aantal dieren in de periode 2000-2004;

- $\quad$ Aandeel TAN in de $\mathrm{N}$-excretie van rundvee en geiten;

- Huisvesting van vleesvarkens met het 'Beter Leven'-keurmerk;

- Emissiearme huisvesting eenden;

- Rendement van combiwassers;

- Emissies door mestbe- en verwerking;

- Graslandvernieuwing in 2016;

- Nieuwe bronnen (maaiverliezen) van directe stikstofverliezen in de vorm van stikstofoxiden;

- Oppervlakte organische bodems;

- Aanpassing organische stofexcretie varkens in 1997;

- Methaanemissie uit opgeslagen mest;

- Berekening van NMVOS;

- Fijnstofemissies schapen en pluimvee;

- $\quad \mathrm{CO}_{2}$-emissie uit kalkmeststoffen in 2016. 
Emissies naar lucht uit de landbouw, 1990-2018 (Van Bruggen et al. 2020):

- Kunstmestcijfers (Paragraaf 3.1);

- Graslandvernieuwing in 2017 (Paragraaf 3.3);

- Gewasresten (Paragraaf 3.3)

- Oppervlakte organische bodems (Paragraaf 3.4);

- $\quad \mathrm{CO}_{2}$-emissie uit kalkmeststoffen in 2017 (Hoofdstuk 8)

Emissies naar lucht uit de landbouw, 1990-2019 (Van Bruggen et al. 2021 (dit rapport)):

- Aantal dieren in 2018 (Paragraaf 2.2);

- $\mathrm{NH}_{3}$-emissie uit stallen (Paragraaf 2.6);

- $\quad$ Mestscheiding bij intermediaire bedrijven en mestverwerkers (Paragraaf 2.9);

- $\quad$ Mesttoediening aan grasland en bouwland (Paragraaf 2.11)

- $\quad \mathrm{NH}_{3}$-emissie bij zodenbemesting op grasland (Paragraaf 2.11);

- $\quad \mathrm{N}_{2} \mathrm{O}$-emissie bij toediening van dierlijke mest en kunstmest (Paragraaf 2.13 en 3.1);

- Kunstmestgebruik in 2018 (Paragraaf 3.1);

- Graslandvernieuwing in 2018 (Paragraaf 3.3);

- Emissies van niet-methaan vluchtige organische stoffen (NMVOS) (Hoofdstuk 6);

- $\quad \mathrm{CO}_{2}$-emissie uit kalkmeststoffen en ureum (Hoofdstuk 8) 


\section{Bijlage 2 Aantal dieren}

\begin{tabular}{|c|c|c|c|c|c|c|c|c|c|c|}
\hline & 1990 & 1991 & 1992 & 1993 & 1994 & 1995 & 1996 & 1997 & 1998 & 1999 \\
\hline \multicolumn{11}{|l|}{ Melk- en fokvee / Dairy cattle } \\
\hline vrouwelijk jongvee $<1 \mathrm{jr}$ / female young stock $<1 \mathrm{yr}$ & 752,7 & 760,6 & 720,3 & 687,3 & 687,4 & 696,1 & 703,2 & 651,0 & 615,8 & 596,6 \\
\hline mannelijk jongvee $<1 \mathrm{jr} /$ male young stock $<1 \mathrm{yr}$ & 53,2 & 59,0 & 53,9 & 49,8 & 47,8 & 44,2 & 57,2 & 46,8 & 41,8 & 37,7 \\
\hline vrouwelijk jongvee $1-2 \mathrm{jr} /$ female young stock $1-2 \mathrm{yrs}$ & 734,1 & 754,9 & 748,3 & 696,2 & 679,0 & 682,9 & 679,8 & 684,0 & 639,9 & 607,7 \\
\hline mannelijk jongvee $1-2 \mathrm{jr} /$ male young stock $1-2 \mathrm{yrs}$ & 34,6 & 37,6 & 39,3 & 32,0 & 33,0 & 33,1 & 37,2 & 31,6 & 27,6 & 25,3 \\
\hline vrouwelijk jongvee $\geq 2 \mathrm{jr}$ / female young stock $\geq 2 \mathrm{yrs}$ & 145,6 & 153,0 & 144,5 & 139,9 & 123,9 & 125,0 & 125,2 & 137,9 & 117,1 & 106,3 \\
\hline melk- en kalfkoeien & $1.877,7$ & $1.852,2$ & $1.775,3$ & $1.746,7$ & $1.697,9$ & $1.707,9$ & $1.664,6$ & $1.590,6$ & $1.610,6$ & $1.588,5$ \\
\hline fokstieren $\geq 2 \mathrm{jr} /$ bulls for service $\geq 2 \mathrm{yrs}$ & 8,8 & 9,9 & 8,5 & 8,6 & 8,0 & 8,7 & 9,2 & 8,2 & 8,1 & 10,3 \\
\hline \multicolumn{11}{|l|}{ Vlees- en weidevee / Beef cattle } \\
\hline witvleeskalveren / calves for white veal production & 572,7 & 581,8 & 586,7 & 593,2 & 612,3 & 583,5 & 577,2 & 603,2 & 609,7 & 634,3 \\
\hline rosévleeskalveren / calves for rosé veal production & 28,9 & 39,8 & 51,0 & 63,0 & 77,2 & 85,8 & 100,4 & 100,9 & 101,3 & 118,4 \\
\hline vrouwelijk jongvee $<1 \mathrm{jr}$ / female young stock $<1 \mathrm{yr}$ & 53,0 & 65,6 & 61,4 & 63,0 & 63,1 & 57,2 & 55,6 & 47,7 & 42,4 & 46,0 \\
\hline $\begin{array}{l}\text { mannelijk jongvee (incl. ossen) }<1 \mathrm{jr} / \text { male young stock } \\
\text { (incl. bullocks) }<1 \mathrm{yr}\end{array}$ & 255,4 & 275,4 & 244,2 & 233,5 & 226,5 & 188,2 & 147,6 & 137,1 & 115,1 & 97,5 \\
\hline vrouwelijk jongvee $1-2 \mathrm{jr} /$ female young stock $1-2 \mathrm{yrs}$ & 56,9 & 70,4 & 77,0 & 78,9 & 70,3 & 66,7 & 60,1 & 54,1 & 50,2 & 46,5 \\
\hline $\begin{array}{l}\text { mannelijk jongvee (incl. ossen) } 1-2 \mathrm{jr} / \text { male young stock } \\
\text { (incl. bullocks) } 1-2 \mathrm{yrs}\end{array}$ & 178,3 & 198,5 & 199,3 & 186,8 & 179,7 & 169,5 & 139,5 & 142,1 & 130,1 & 112,2 \\
\hline vrouwelijk jongvee $\geq 2 \mathrm{jr} /$ female young stock $\geq 2 \mathrm{yrs}$ & 42,6 & 51,5 & 50,8 & 49,9 & 50,8 & 48,4 & 37,1 & 22,3 & 20,2 & 17,5 \\
\hline $\begin{array}{l}\text { mannelijk jongvee (incl. ossen) } \geq 2 \mathrm{jr} / \text { male young stock } \\
\text { (incl. bullocks) } \geq 2 \mathrm{yrs}\end{array}$ & 12,1 & 12,5 & 13,3 & 11,6 & 12,2 & 11,0 & 11,2 & 8,7 & 7,8 & 8,4 \\
\hline $\begin{array}{l}\text { zoog-, mest- en weidekoeien } \geq 2 \mathrm{jr} / \text { suckling cows incl. } \\
\text { fattening/grazing } \geq 2 \mathrm{yrs}\end{array}$ & 119,5 & 139,4 & 145,7 & 156,5 & 146,5 & 146,2 & 146,4 & 144,5 & 145,4 & 152,6 \\
\hline \multicolumn{11}{|l|}{ Other grazing livestock } \\
\hline schapen - ooien / sheep - ewes & 789,7 & 858,8 & 876,3 & 874,7 & 794,3 & 770,7 & 785,0 & 719,2 & 693,9 & 715,8 \\
\hline overige schapen / other sheep & 912,7 & $1.023,4$ & $1.075,6$ & $1.041,6$ & 971,7 & 903,4 & 842,3 & 746,2 & 700,0 & 684,9 \\
\hline melkgeiten / dairy goats & 37,5 & 43,7 & 38,1 & 34,6 & 37,6 & 43,2 & 55,3 & 61,4 & 71,2 & 85,8 \\
\hline overige geiten / other goats & 23,3 & 26,5 & 25,0 & 22,2 & 26,4 & 32,8 & 46,3 & 57,1 & 61,0 & 67,0 \\
\hline horses - landbouw / horses - agriculture & 49,9 & 55,4 & 62,2 & 65,1 & 68,3 & 70,1 & 73,4 & 75,5 & 76,6 & 76,6 \\
\hline pony's - landbouw / ponies - agriculture & 19,7 & 21,3 & 24,0 & 26,6 & 29,0 & 29,9 & 33,3 & 36,9 & 37,0 & 38,5 \\
\hline
\end{tabular}




\begin{tabular}{|c|c|c|c|c|c|c|c|c|c|c|}
\hline & 1990 & 1991 & 1992 & 1993 & 1994 & 1995 & 1996 & 1997 & 1998 & 1999 \\
\hline paarden - particulieren / horses - private parties & 195,0 & 195,0 & 195,0 & 195,0 & 195,0 & 195,0 & 195,0 & 195,0 & 195,0 & 195,0 \\
\hline pony's - particulieren / ponies - private parties & 105,0 & 105,0 & 105,0 & 105,0 & 105,0 & 105,0 & 105,0 & 105,0 & 105,0 & 105,0 \\
\hline \multicolumn{11}{|l|}{ ezels - particulieren / mules - private parties } \\
\hline \multicolumn{11}{|l|}{ schapen - ooien - particulieren / sheep - ewes - private parties } \\
\hline \multicolumn{11}{|l|}{ overige schapen - particulieren / other sheep - private parties } \\
\hline \multicolumn{11}{|l|}{ Varkens / Pigs } \\
\hline biggen / piglets & $5.190,7$ & $4.465,9$ & $5.270,4$ & $5.672,9$ & $5.599,8$ & $5.596,1$ & $5.626,2$ & $5.996,1$ & $5.094,5$ & $5.238,8$ \\
\hline vleesvarkens / fattening pigs & $7.025,1$ & $7.040,9$ & $7.144,7$ & $7.525,9$ & $7.270,9$ & $7.123,9$ & $7.094,5$ & $7.432,6$ & $6.591,2$ & $6.774,1$ \\
\hline opfokzeugen / gilts & 385,5 & 396,1 & 398,9 & 392,4 & 367,7 & 357,5 & 375,3 & 393,7 & 421,1 & 343,6 \\
\hline zeugen / sows & $1.272,2$ & $1.272,6$ & $1.307,7$ & $1.334,9$ & $1.293,9$ & $1.287,2$ & $1.292,4$ & $1.318,0$ & $1.293,6$ & $1.171,0$ \\
\hline opfokberen / young boars & 13,9 & 14,3 & 12,9 & 13,1 & 10,5 & 11,4 & 8,6 & 18,8 & 19,3 & 7,1 \\
\hline dekberen / boars for service & 27,6 & 26,8 & 25,8 & 25,2 & 22,3 & 21,3 & 21,6 & 29,9 & 26,1 & 32,3 \\
\hline \multicolumn{11}{|l|}{ Pluimvee / Poultry } \\
\hline $\begin{array}{l}\text { ouderdieren van vleeskuikens }<18 \text { weken / broiler breed } \\
18 \text { weeks }\end{array}$ & $2.882,3$ & $3.088,2$ & $3.007,1$ & $3.003,7$ & $3.166,1$ & $3.065,2$ & $2.688,2$ & $3.090,4$ & $3.482,9$ & $3.254,7$ \\
\hline laying hens $<18$ weeks / laying hens $<18$ weeks & $11.120,8$ & $10.954,6$ & $11.851,4$ & $10.054,1$ & $10.430,2$ & $8.890,1$ & $9.784,6$ & $10.388,6$ & $10.585,6$ & $11.043,1$ \\
\hline laying hens $\geq 18$ weeks / laying hens $\geq 18$ weeks & $33.199,1$ & $33.553,8$ & $33.138,0$ & $32.179,9$ & $30.437,8$ & $29.271,7$ & $29.793,8$ & $29.688,3$ & $30.848,8$ & $31.417,9$ \\
\hline vleeskuikens / broilers & $41.172,1$ & $41.639,4$ & $46.525,0$ & $45.780,9$ & $43.055,8$ & $43.827,3$ & $44.142,1$ & $44.986,8$ & $48.537,0$ & $53.246,6$ \\
\hline eenden / ducks & $1.085,5$ & $1.151,7$ & $1.036,0$ & 843,9 & 756,1 & 869,0 & 861,1 & 906,2 & 970,3 & $1.076,7$ \\
\hline kalkoenen / turkeys & $1.052,4$ & $1.236,1$ & $1.364,2$ & $1.322,7$ & $1.294,9$ & $1.206,7$ & $1.249,9$ & $1.357,1$ & $1.500,2$ & $1.438,4$ \\
\hline \multicolumn{11}{|l|}{ Konijnen, pelsdieren / Rabbits, fur-bearing animals } \\
\hline konijnen - voedsters / rabbits - does & 105,2 & 105,2 & 105,2 & 89,4 & 73,7 & 64,2 & 61,5 & 64,4 & 61,3 & 54,7 \\
\hline gespeende vleeskonijnen / weaned rabbits for slaughter & 680,5 & 680,5 & 692,5 & 610,3 & 505,9 & 423,9 & 405,6 & 420,7 & 382,2 & 354,9 \\
\hline nertsen - moederdieren / nertsen - mothers & 544,0 & 544,0 & 563,1 & 465,7 & 476,3 & 456,1 & 485,4 & 525,1 & 565,6 & 575,8 \\
\hline vossen - moederdieren / foxes - mothers & 10,0 & 10,0 & 7,9 & 7,3 & 7,1 & 7,1 & 6,7 & 6,7 & 7,6 & 5,3 \\
\hline
\end{tabular}

82 | wot-technical report 203 


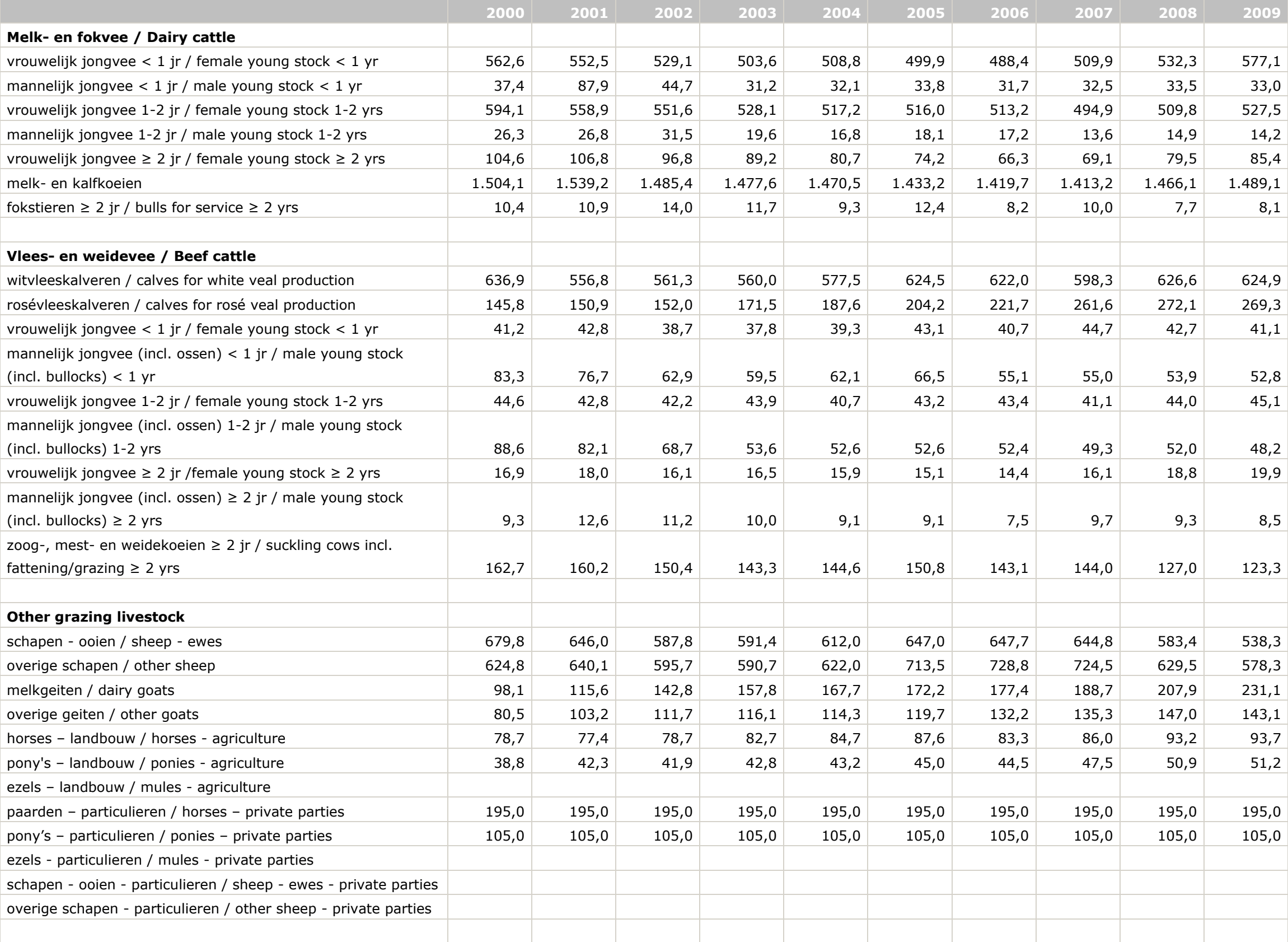




\begin{tabular}{|c|c|c|c|c|c|c|c|c|c|c|}
\hline & 2000 & 2001 & 2002 & 2003 & 2004 & 2005 & 2006 & 2007 & 2008 & 2009 \\
\hline \multicolumn{11}{|l|}{ Varkens / Pigs } \\
\hline biggen / piglets & $5.102,4$ & $5.418,4$ & $4.744,5$ & $4.541,7$ & $4.523,6$ & $4.563,0$ & $4.646,5$ & $4.837,4$ & $4.965,9$ & $5.068,5$ \\
\hline vleesvarkens / fattening pigs & $6.504,5$ & $6.216,3$ & $5.591,0$ & $5.367,5$ & $5.382,5$ & $5.504,3$ & $5.475,7$ & $5.558,8$ & $5.839,0$ & $5.872,4$ \\
\hline opfokzeugen / gilts & 339,6 & 313,0 & 282,5 & 289,4 & 276,0 & 274,1 & 273,1 & 285,4 & 231,5 & 249,1 \\
\hline zeugen / sows & $1.129,2$ & $1.071,5$ & $1.007,2$ & 950,4 & 953,9 & 946,5 & 946,1 & 966,4 & 978,0 & 985,2 \\
\hline opfokberen / young boars & 6,9 & 7,4 & 6,6 & 5,5 & 6,0 & 6,5 & 5,5 & 4,2 & 4,3 & 3,6 \\
\hline dekberen / boars for service & 35,2 & 15,1 & 15,8 & 14,7 & 10,4 & 17,2 & 9,0 & 10,5 & 7,8 & 7,7 \\
\hline
\end{tabular}

Pluimvee / Poultry

ouderdieren van vleeskuikens $<18$ weken / broiler breeders $<$

18 weeks

\begin{tabular}{|l|l|l|}
\hline $3.644,1$ & $2.932,8$ & $2.553,7$ \\
\hline
\end{tabular}

18 weeks

\begin{tabular}{|l|r|r|r|r|r|r|r|r|r|}
\hline $5.397,5$ & $4.548,1$ & $4.949,3$ & $3.723,9$ & $3.650,7$ & $3.596,7$ & $3.992,6$ & $4.260,4$ & $4.862,7$ & $4.288,0$ \\
\hline
\end{tabular}

laying hens $<18$ weeks / laying hens $<18$ weeks

laying hens $\geq 18$ weeks / laying hens $\geq 18$ weeks

\begin{tabular}{|l|l|l|l|l|l|l|l|l|l|}
\hline $11.463,4$ & $10.888,1$ & $10.185,9$ & $6.897,9$ & $8.449,2$ & $10.787,3$ & $10.963,2$ & $10.040,4$ & $11.507,6$ & $11.346,7$ \\
\hline
\end{tabular}

vleeskuikens / broilers

\begin{tabular}{|l|l|l|l|l|l|l|l|l|l|}
\hline $32.573,0$ & $31.837,7$ & $28.702,7$ & $20.557,6$ & $27.219,1$ & $31.842,4$ & $32.059,8$ & $32.299,3$ & $33.586,1$ & $35.293,7$ \\
\hline
\end{tabular}

eenden / ducks

\begin{tabular}{|l|l|l|l|l|l|l|}
\hline $50.936,6$ & $50.127,0$ & $54.660,3$ & $39.319,2$ & $44.262,2$ & $44.496,1$ \\
\hline
\end{tabular}

\begin{tabular}{|r|r|r|r|}
\hline $41.914,0$ & $43.351,9$ & $44.357,8$ & $43.285,1$ \\
\hline
\end{tabular}

kalkoenen / turkeys

$1.543,8$

\begin{tabular}{r|r|r}
866,9 & 852,4
\end{tabular}

655,3

722,7

Konijnen, pelsdieren / Rabbits, fur-bearing animals

konijnen - voedsters / rabbits - does

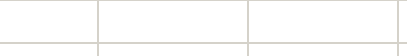

gespeende vleeskonijnen / weaned rabbits for slaughter

nertsen - moederdieren / nertsen - mothers

$49,4 \quad 50,4$

\begin{tabular}{|l|l|l|}
\hline & $1.238,5$ & $1.245,4$ \\
\hline
\end{tabular}

$1.139,8$

$1.232,4-1.044,3$

156,7

vossen - moederdieren / foxes - mothers

339

320,5

44,6

49,4

48,0

40,5

49,4

41,4

40,8

\begin{tabular}{|r|r|r|r|}
\hline 584,8 & 611,4 & 617,5 & 613,3 \\
\hline 3,8 & 4,6 & 4,9 & 4,2 \\
\hline
\end{tabular}

631,8

691,9

694,0

337,7
802,9

281,6

271,3

3,8

$4,6 \quad 4,9$

4,2

$5 \quad 5,2$

4,5

4,9

84 | wot-technical report 203 


\begin{tabular}{|c|c|c|c|c|c|c|c|c|c|c|}
\hline & 2010 & 2011 & 2012 & 2013 & 2014 & 2015 & 2016 & 2017 & 2018 & 2019 \\
\hline \multicolumn{11}{|l|}{ Melk- en fokvee / Dairy cattle } \\
\hline vrouwelijk jongvee $<1 \mathrm{jr}$ / female young stock $<1 \mathrm{yr}$ & 545,4 & 536,9 & 541,8 & 573,1 & 601,9 & 598,8 & 621,4 & 495,8 & 428,9 & 409,5 \\
\hline mannelijk jongvee $<1 \mathrm{jr} /$ male young stock $<1 \mathrm{yr}$ & 28,9 & 30,7 & 33,3 & 40,4 & 46,3 & 41,2 & 43,2 & 47,1 & 50,1 & 43,4 \\
\hline vrouwelijk jongvee $1-2 \mathrm{jr} /$ female young stock $1-2$ yrs & 564,0 & 531,9 & 521,8 & 530,9 & 544,5 & 581,8 & 553,8 & 506,2 & 427,4 & 388,3 \\
\hline mannelijk jongvee $1-2 \mathrm{jr} /$ male young stock $1-2 \mathrm{yrs}$ & 13,8 & 11,6 & 11,1 & 13,1 & 14,4 & 12,7 & 11,9 & 9,5 & 8,4 & 8,2 \\
\hline vrouwelijk jongvee $\geq 2 \mathrm{jr} /$ female young stock $\geq 2 \mathrm{yrs}$ & 86,9 & 89,8 & 79,6 & 85,7 & 98,5 & 102,5 & 86,3 & 106,3 & 93,2 & 74,2 \\
\hline melk- en kalfkoeien & $1.478,6$ & $1.469,7$ & $1.484,0$ & $1.552,9$ & $1.572,3$ & $1.621,8$ & $1.744,8$ & $1.671,7$ & $1.591,3$ & $1.578,0$ \\
\hline fokstieren $\geq 2 \mathrm{jr} /$ bulls for service $\geq 2 \mathrm{yrs}$ & 7,8 & 7,6 & 6,6 & 6,5 & 7,2 & 6,3 & 5,9 & 7,4 & 6,6 & 6,0 \\
\hline \multicolumn{11}{|l|}{ Vlees- en weidevee / Beef cattle } \\
\hline witvleeskalveren / calves for white veal production & 633,8 & 602,6 & 578,8 & 588,4 & 567,0 & 551,3 & 594,7 & 574,5 & 618,4 & 631,7 \\
\hline rosévleeskalveren / calves for rosé veal production & 293,9 & 303,6 & 329,6 & 337,0 & 354,3 & 358,0 & 362,9 & 352,3 & 363,7 & 373,5 \\
\hline vrouwelijk jongvee $<1 \mathrm{jr}$ / female young stock $<1 \mathrm{yr}$ & 39,2 & 38,5 & 38,0 & 34,4 & 32,0 & 32,7 & 31,8 & 32,2 & 33,0 & 31,2 \\
\hline $\begin{array}{l}\text { mannelijk jongvee (incl. ossen) }<1 \mathrm{jr} / \text { male young stock } \\
\text { (incl. bullocks) }<1 \mathrm{yr}\end{array}$ & 48,8 & 46,1 & 47,7 & 43,5 & 41,8 & 42,5 & 40,7 & 60,1 & 53,0 & 47,2 \\
\hline vrouwelijk jongvee $1-2 \mathrm{jr} /$ female young stock $1-2$ yrs & 43,1 & 40,2 & 40,3 & 37,6 & 33,0 & 35,2 & 30,0 & 26,2 & 28,5 & 27,3 \\
\hline $\begin{array}{l}\text { mannelijk jongvee (incl. ossen) } 1-2 \mathrm{jr} / \text { male young stock } \\
\text { (incl. bullocks) } 1-2 \text { yrs }\end{array}$ & 46,4 & 41,7 & 40,7 & 42,3 & 41,9 & 42,1 & 34,8 & 38,4 & 38,2 & 36,0 \\
\hline vrouwelijk jongvee $\geq 2 \mathrm{jr}$ /female young stock $\geq 2 \mathrm{yrs}$ & 19,8 & 20,1 & 18,4 & 22,2 & 22,4 & 19,6 & 15,4 & 22,6 & 25,4 & 24,6 \\
\hline $\begin{array}{l}\text { mannelijk jongvee (incl. ossen) } \geq 2 \mathrm{jr} / \text { male young stock } \\
\text { (incl. bullocks) } \geq 2 \mathrm{yrs}\end{array}$ & 9,5 & 9,5 & 9,1 & 7,7 & 8,5 & 7,2 & 5,6 & 8,0 & 8,1 & 8,2 \\
\hline $\begin{array}{l}\text { zoog-, mest- en weidekoeien } \geq 2 \mathrm{jr} / \text { suckling cows incl. } \\
\text { fattening/grazing } \geq 2 \mathrm{yrs}\end{array}$ & 115,3 & 105,0 & 98,5 & 83,6 & 82,2 & 80,4 & 68,3 & 64,6 & 69,5 & 62,5 \\
\hline \multirow{2}{*}{\multicolumn{11}{|c|}{ Other grazing livestock }} \\
\hline & & & & & & & & & & \\
\hline schapen - ooien / sheep - ewes & 558,2 & 546,3 & 544,4 & 551,4 & 536,8 & 523,1 & 433,7 & 437,7 & 516,6 & 556,4 \\
\hline overige schapen / other sheep & 571,3 & 542,2 & 498,4 & 482,2 & 421,8 & 423,1 & 350,2 & 361,1 & 349,4 & 361,8 \\
\hline melkgeiten / dairy goats & 222,0 & 220,1 & 243,6 & 245,1 & 266,1 & 292,1 & 305,5 & 322,1 & 386,6 & 419,7 \\
\hline overige geiten / other goats & 130,9 & 160,2 & 153,2 & 167,5 & 165,3 & 177,7 & 194,0 & 210,8 & 201,2 & 195,0 \\
\hline horses - landbouw / horses - agriculture & 92,7 & 90,6 & 87,7 & 87,4 & 85,4 & 80,9 & 57,3 & 59,4 & 62,0 & 61,9 \\
\hline pony's - landbouw / ponies - agriculture & 48,8 & 45,5 & 43,6 & 41,9 & 40,1 & 36,4 & 24,2 & 25,4 & 24,7 & 24,9 \\
\hline ezels - landbouw / mules - agriculture & 1,1 & 1,1 & 1,0 & 1,2 & 1,1 & 1,1 & 0,8 & 0,7 & 0,8 & 0,8 \\
\hline paarden - particulieren / horses - private parties & 195,0 & 195,0 & 195,0 & 195,0 & 195,0 & 195,0 & 210,6 & 209,4 & 208,7 & 208,1 \\
\hline pony's - particulieren / ponies - private parties & 105,0 & 105,0 & 105,0 & 105,0 & 105,0 & 105,0 & 114,2 & 113,9 & 113,5 & 112,8 \\
\hline overige schapen - particulieren / other sheep - private parties & & & & & & & 48,5 & 40,9 & 35,5 & 30,6 \\
\hline
\end{tabular}




\begin{tabular}{|c|c|c|c|c|c|c|c|c|c|c|}
\hline & 2010 & 2011 & 2012 & 2013 & 2014 & 2015 & 2016 & 2017 & 2018 & 2019 \\
\hline \multicolumn{11}{|l|}{ Varkens / Pigs } \\
\hline biggen / piglets & $5.123,8$ & $5.297,5$ & $5.179,8$ & $5.273,8$ & $5.381,9$ & $5.597,8$ & $5.595,3$ & $5.611,6$ & $5.653,0$ & $5.548,9$ \\
\hline vleesvarkens / fattening pigs & $5.904,2$ & $5.905,0$ & $5.873,9$ & $5.754,1$ & $5.657,2$ & $5.803,7$ & $5.726,3$ & $5.630,5$ & $5.591,5$ & $5.562,6$ \\
\hline opfokzeugen / gilts & 232,3 & 238,5 & 233,2 & 231,1 & 235,8 & 223,4 & 217,6 & 218,4 & 216,6 & 206,8 \\
\hline zeugen / sows & 983,6 & 978,5 & 937,8 & 945,0 & 955,3 & 970,0 & 931,0 & 933,0 & 922,6 & 889,2 \\
\hline opfokberen / young boars & 3,9 & 2,9 & 2,7 & 2,3 & 1,7 & 2,2 & 1,9 & 1,8 & 1,8 & 1,7 \\
\hline dekberen / boars for service & 7,2 & 6,8 & 6,2 & 6,1 & 6,3 & 5,8 & 6,6 & 5,4 & 5,2 & 5,1 \\
\hline $\begin{array}{l}\text { ouderdieren van vleeskuikens }<18 \text { weken / broiler breeders }< \\
18 \text { weeks }\end{array}$ & $2.896,0$ & $3.200,7$ & $3.052,9$ & $3.325,2$ & $3.489,4$ & $3.393,0$ & $3.357,0$ & $3.630,3$ & $2.774,6$ & $2.543,6$ \\
\hline $\begin{array}{l}\text { ouderdieren van vleeskuikens } \geq 18 \text { weken / broiler breeders } \geq \\
18 \text { weeks }\end{array}$ & $4.447,5$ & $4.137,0$ & $4.322,3$ & $4.179,5$ & $4.405,4$ & $5.125,6$ & $5.384,7$ & $5.359,4$ & $4.676,5$ & $4.619,6$ \\
\hline laying hens $<18$ weeks / laying hens $<18$ weeks & $13.008,4$ & $10.607,3$ & $10.421,8$ & $10.361,0$ & $12.089,6$ & $12.417,2$ & $9.964,7$ & $11.868,8$ & $11.539,1$ & $10.186,2$ \\
\hline laying hens $\geq 18$ weeks / laying hens $\geq 18$ weeks & $36.147,9$ & $35.061,9$ & $33.630,0$ & $35.611,5$ & $36.034,3$ & $36.720,0$ & $37.724,7$ & $34.999,5$ & $35.614,0$ & $33.996,9$ \\
\hline vleeskuikens / broilers & $44.747,9$ & $43.911,6$ & $43.846,3$ & $44.242,0$ & $47.019,8$ & $49.107,2$ & $49.188,4$ & $48.232,7$ & $43.187,7$ & $42.617,0$ \\
\hline eenden / ducks & $1.087,0$ & $1.015,8$ & 915,8 & 810,4 & 852,9 & 932,2 & 930,6 & $1.009,4$ & 871,8 & 919,8 \\
\hline \multicolumn{11}{|l|}{ Konijnen, pelsdieren / Rabbits, fur-bearing animals } \\
\hline konijnen - voedsters / rabbits - does & 38,5 & 39,4 & 43,0 & 41,0 & 42,8 & 48,2 & 44,7 & 43,3 & 40,7 & 47,9 \\
\hline gespeende vleeskonijnen / weaned rabbits for slaughter & 260,3 & 262,5 & 283,9 & 270,0 & 277,9 & 333,0 & 318,5 & 299,6 & 291,0 & 288,5 \\
\hline nertsen - moederdieren / nertsen - mothers & 962,4 & 976,6 & $1.031,2$ & $1.031,1$ & $1.002,9$ & $1.023,0$ & 923,3 & 918,8 & 913,1 & 807,5 \\
\hline vossen - moederdieren / foxes - mothers & & & & & & & & & & \\
\hline
\end{tabular}

Bron: Landbouwtelling / Source: Agricultural census. 


\section{Bijlage 3 Mineralenexcretie in stal en weide}

\begin{tabular}{|c|c|c|c|c|c|c|c|c|c|c|c|c|c|c|c|}
\hline & 1990 & 1991 & 1992 & 1993 & 1994 & 1995 & 1996 & 1997 & 1998 & 1999 & 2000 & 2001 & 2002 & 2003 & 2004 \\
\hline \multicolumn{16}{|l|}{ Melk- en fokvee / Dairy cattle } \\
\hline vrouwelijk jongvee $<1 \mathrm{jr} /$ female young stock $<1 \mathrm{yr}$ & 26,5 & 28,7 & 28,4 & 28,7 & 30,0 & 29,8 & 27,8 & 30,9 & 30,1 & 30,1 & 29,0 & 28,9 & 27,6 & 23,7 & 23,2 \\
\hline mannelijk jongvee $<1 \mathrm{jr} /$ male young stock $<1 \mathrm{yr}$ & 39,6 & 40,4 & 40,0 & 40,2 & 41,7 & 40,8 & 39,6 & 41,6 & 39,5 & 37,9 & 37,0 & 37,1 & 36,4 & 36,9 & 37,2 \\
\hline vrouwelijk jongvee $1-2 \mathrm{jr} /$ female young stock $1-2 \mathrm{yr}$ & 43,1 & 47,0 & 46,3 & 46,7 & 49,5 & 48,4 & 45,0 & 51,3 & 50,1 & 48,4 & 46,4 & 46,3 & 43,7 & 44,2 & 43,3 \\
\hline mannelijk jongvee $1-2 \mathrm{jr} /$ male young stock $1-2 \mathrm{yr}$ & 90,6 & 99,1 & 97,6 & 98,2 & 104,5 & 101,9 & 94,7 & 108,5 & 105,8 & 101,0 & 96,8 & 96,6 & 90,8 & 91,7 & 89,7 \\
\hline vrouwelijk jongvee $\geq 2 \mathrm{jr} /$ female young stock $\geq 2 \mathrm{yr}$ & 43,0 & 46,9 & 46,3 & 46,6 & 49,4 & 48,4 & 45,0 & 51,2 & 50,0 & 48,3 & 46,3 & 46,3 & 43,7 & 44,2 & 43,3 \\
\hline melk- en kalfkoeien-stalperiode / dairy cows-housing season & 60,8 & 66,1 & 59,4 & 65,1 & 68,8 & 69,0 & 63,9 & 64,5 & 70,2 & 66,4 & 71,0 & 70,6 & 66,2 & 72,4 & 68,4 \\
\hline melk- en kalfkoeien-weideperiode / dairy cows-grazing season & 35,1 & 35,7 & 38,4 & 35,8 & 33,9 & 35,0 & 37,3 & 35,6 & 27,5 & 29,6 & 26,2 & 28,0 & 37,1 & 34,6 & 35,1 \\
\hline fokstieren $\geq 2 \mathrm{jr} /$ breeding bulls $\geq 2 \mathrm{yr}$ & 90,6 & 99,1 & 97,6 & 98,2 & 104,5 & 101,9 & 94,7 & 108,5 & 105,8 & 101,0 & 96,8 & 96,6 & 90,8 & 91,7 & 89,7 \\
\hline & & & & & & & & & & & & & & & \\
\hline \multicolumn{16}{|l|}{ Vlees- en weidevee / Beef cattle } \\
\hline witvleeskalveren / calves for white veal production & 10,6 & 10,6 & 10,6 & 10,6 & 10,6 & 11,6 & 11,4 & 10,3 & 11,6 & 10,9 & 11,9 & 11,9 & 12,1 & 12,2 & 10,5 \\
\hline rosévleeskalveren / calves for rosé veal production & 28,9 & 28,9 & 28,9 & 28,9 & 28,9 & 28,9 & 29,3 & 27,9 & 27,8 & 34,3 & 34,1 & 34,9 & 30,5 & 30,8 & 27,1 \\
\hline vrouwelijk jongvee $<1 \mathrm{jr} /$ female young stock $<1 \mathrm{yr}$ & 26,2 & 28,4 & 28,2 & 28,5 & 29,7 & 29,4 & 27,5 & 30,4 & 29,6 & 29,7 & 28,6 & 28,5 & 27,2 & 23,4 & 23,0 \\
\hline $\begin{array}{l}\text { mannelijk jongvee (incl. ossen) }<1 \mathrm{jr} / \text { male young stock } \\
\text { (incl. bullocks) }<1 \mathrm{yr}\end{array}$ & 28,9 & 29,9 & 29,4 & 27,8 & 30,4 & 29,5 & 28,4 & 28,0 & 27,3 & 27,4 & 26,6 & 27,1 & 26,2 & 26,6 & 27,2 \\
\hline vrouwelijk jongvee $1-2 \mathrm{jr} /$ female young stock $1-2 \mathrm{yr}$ & 43,0 & 46,8 & 46,2 & 46,6 & 49,3 & 48,2 & 44,8 & 50,9 & 49,7 & 48,0 & 46,0 & 45,9 & 43,4 & 43,9 & 43,0 \\
\hline $\begin{array}{l}\text { mannelijk jongvee (incl. ossen) } 1-2 \mathrm{jr} / \text { male young stock } \\
\text { (incl. bullocks) } 1-2 \mathrm{yr}\end{array}$ & 72,6 & 79,3 & 81,8 & 84,1 & 71,5 & 64,7 & 63,6 & 59,0 & 58,1 & 58,4 & 56,1 & 59,1 & 57,4 & 57,8 & 57,5 \\
\hline vrouwelijk jongvee $\geq 2 \mathrm{jr} /$ female young stock $\geq 2 \mathrm{yr}$ & 43,1 & 47,0 & 46,4 & 46,7 & 49,4 & 48,4 & 45,0 & 51,1 & 49,7 & 48,1 & 46,1 & 45,9 & 43,3 & 43,9 & 43,0 \\
\hline $\begin{array}{l}\text { mannelijk jongvee (incl. ossen) } \geq 2 \mathrm{jr} / \text { male young stock } \\
\text { (incl. bullocks) } \geq 2 \mathrm{yr}\end{array}$ & 72,6 & 79,3 & 81,8 & 84,1 & 71,5 & 64,7 & 63,6 & 59,0 & 58,1 & 58,4 & 56,1 & 59,1 & 57,4 & 57,8 & 57,5 \\
\hline $\begin{array}{l}\text { zoog-, mest- en weidekoeien } \geq 2 \mathrm{jr} / \text { suckling cows and } \\
\text { female fatteners } \geq 2 \mathrm{yr}\end{array}$ & 42,3 & 46,3 & 45,7 & 46,2 & 48,7 & 48,0 & 44,5 & 50,5 & 48,5 & 43,2 & 42,4 & 42,3 & 41,1 & 40,4 & 40,0 \\
\hline schapen - ooien / sheep - ewes & 3,9 & 4,0 & 3,9 & 4,0 & 4,2 & 4,0 & 3,9 & 4,4 & 4,4 & 3,9 & 3,9 & 3,9 & 3,7 & 3,7 & 2,6 \\
\hline melkgeiten / dairy goats & 19,9 & 20,9 & 20,4 & 21,1 & 21,6 & 21,5 & 20,7 & 22,0 & 22,4 & 19,3 & 19,4 & 20,6 & 20,1 & 20,0 & 17,8 \\
\hline paarden / horses & 33,3 & 33,3 & 33,3 & 33,3 & 33,3 & 33,3 & 33,3 & 33,3 & 33,3 & 33,3 & 33,3 & 33,3 & 33,3 & 33,3 & 33,3 \\
\hline pony's en ezels / ponies and mules and asses & 14,4 & 14,4 & 14,4 & 14,4 & 14,4 & 14,4 & 14,4 & 14,4 & 14,4 & 14,4 & 14,4 & 14,4 & 14,4 & 14,4 & 14,4 \\
\hline vleesvarkens / fattening pigs & 14,3 & 13,7 & 14,4 & 14,5 & 14,9 & 14,5 & 14,3 & 13,0 & 13,8 & 13,3 & 12,3 & 11,8 & 11,6 & 11,9 & 1,7 \\
\hline
\end{tabular}




\begin{tabular}{|c|c|c|c|c|c|c|c|c|c|c|c|c|c|c|c|}
\hline & 1990 & 1991 & 1992 & 1993 & 1994 & 1995 & 1996 & 1997 & 1998 & 1999 & 2000 & 2001 & 2002 & 2003 & 2004 \\
\hline $\begin{array}{l}\text { opfokzeugen en opfokberen }<50 \mathrm{~kg} / \text { gilts and young boars } \\
<50 \mathrm{~kg}\end{array}$ & 14,0 & 14,1 & 14,0 & 13,7 & 13,6 & 14,4 & 13,9 & 13,8 & 13,4 & 13,9 & 14,2 & 12,9 & 13,1 & 14,2 & 13,2 \\
\hline zeugen / sows & 33,8 & 30,9 & 31,8 & 31,9 & 30,1 & 31,4 & 31,3 & 29,9 & 29,9 & 30,6 & 30,9 & 30,3 & 29,9 & 29,9 & 28,0 \\
\hline opfokberen $>50 \mathrm{~kg} /$ young boars $>50 \mathrm{~kg}$ & 14,0 & 14,1 & 14,0 & 13,7 & 13,6 & 14,4 & 13,9 & 13,8 & 13,4 & 13,9 & 14,2 & 12,9 & 13,1 & 14,2 & 13,2 \\
\hline dekberen / breeding boars & 25,0 & 24,5 & 25,4 & 24,6 & 23,0 & 24,6 & 23,7 & 22,8 & 22,4 & 22,4 & 22,9 & 23,2 & 23,1 & 23,8 & 23,7 \\
\hline $\begin{array}{l}\text { ouderdieren van vleeskuikens }<18 \text { weken / broiler breeders }< \\
18 \text { weeks }\end{array}$ & 0,52 & 0,54 & 0,59 & 0,54 & 0,52 & 0,45 & 0,42 & 0,45 & 0,41 & 0,38 & 0,37 & 0,33 & 0,34 & 0,32 & 0,33 \\
\hline $\begin{array}{l}\text { ouderdieren van vleeskuikens } \geq 18 \text { weken / broiler breeders } \geq \\
18 \text { weeks }\end{array}$ & 1,33 & 1,42 & 1,48 & 1,55 & 1,41 & 1,29 & 1,29 & 1,18 & 1,17 & 1,18 & 1,13 & 1,07 & 1,08 & 1,05 & 1,11 \\
\hline leghennen $<18$ weken / laying hens $<18$ weeks & 0,38 & 0,39 & 0,43 & 0,39 & 0,38 & 0,36 & 0,34 & 0,36 & 0,33 & 0,33 & 0,31 & 0,29 & 0,29 & 0,30 & 0,33 \\
\hline leghennen $\geq 18$ weken / laying hens $\geq 18$ weeks & 0,75 & 0,82 & 0,87 & 0,91 & 0,81 & 0,81 & 0,80 & 0,70 & 0,69 & 0,71 & 0,67 & 0,65 & 0,66 & 0,70 & 0,71 \\
\hline vleeskuikens / broilers & 0,61 & 0,64 & 0,64 & 0,62 & 0,57 & 0,63 & 0,61 & 0,59 & 0,52 & 0,54 & 0,51 & 0,49 & 0,53 & 0,53 & 0,52 \\
\hline eenden / ducks & 1,12 & 1,12 & 1,12 & 1,12 & 1,12 & 1,09 & 1,09 & 1,09 & 1,10 & 1,00 & 0,99 & 0,95 & 0,95 & 0,90 & 0,96 \\
\hline kalkoenen / turkeys & 2,01 & 2,01 & 2,01 & 2,11 & 2,10 & 1,99 & 2,00 & 2,04 & 1,91 & 1,87 & 1,85 & 1,70 & 1,68 & 1,76 & 1,74 \\
\hline konijnen - voedsters / rabbits - does & 8,7 & 8,7 & 8,7 & 8,7 & 8,7 & 8,1 & 8,1 & 8,1 & 7,9 & 7,9 & 7,6 & 7,6 & 7,6 & 7,8 & 8,0 \\
\hline nertsen - moederdieren / minks - mothers & 4,1 & 4,1 & 4,1 & 4,1 & 4,1 & 4,1 & 3,5 & 3,5 & 3,7 & 4,2 & 3,5 & 3,3 & 3,0 & 2,9 & 2,8 \\
\hline vossen - moederdieren / foxes - mothers & 13,9 & 13,9 & 13,9 & 13,9 & 13,9 & 13,9 & 9,0 & 9,0 & 9,6 & 9,9 & 8,3 & 7,7 & 7,0 & 6,6 & 7,2 \\
\hline
\end{tabular}

88 | wot-technical report 203 


\begin{tabular}{|c|c|c|c|c|c|c|c|c|c|c|c|c|c|c|c|}
\hline & 2005 & 2006 & 2007 & 2008 & 2009 & 2010 & 2011 & 2012 & 2013 & 2014 & 2015 & 2016 & 2017 & 2018 & 2019 \\
\hline \multicolumn{16}{|l|}{ Melk- en fokvee / Dairy cattle } \\
\hline vrouwelijk jongvee $<1 \mathrm{jr} /$ female young stock $<1 \mathrm{yr}$ & 23,0 & 22,8 & 24,6 & 29,2 & 28,8 & 28,6 & 28,9 & 28,7 & 29,1 & 30,3 & 29,7 & 29,3 & 30,7 & 30,8 & 29,8 \\
\hline mannelijk jongvee $<1 \mathrm{jr} /$ male young stock $<1 \mathrm{yr}$ & 37,0 & 36,7 & 36,6 & 35,9 & 33,2 & 33,2 & 32,4 & 31,2 & 31,8 & 32,4 & 31,1 & 30,8 & 31,7 & 33,2 & 32,7 \\
\hline vrouwelijk jongvee $1-2 \mathrm{jr} /$ female young stock $1-2 \mathrm{yr}$ & 42,7 & 40,1 & 42,5 & 45,8 & 45,0 & 44,4 & 49,2 & 48,6 & 49,0 & 51,7 & 50,0 & 50,8 & 52,5 & 56,1 & 55,1 \\
\hline mannelijk jongvee $1-2 \mathrm{jr} /$ male young stock $1-2 \mathrm{yr}$ & 88,5 & 87,4 & 89,6 & 86,0 & 84,4 & 83,4 & 82,7 & 80,9 & 81,8 & 85,9 & 83,5 & 80,8 & 83,5 & 88,5 & 85,6 \\
\hline vrouwelijk jongvee $\geq 2 \mathrm{jr} /$ female young stock $\geq 2 \mathrm{yr}$ & 42,7 & 40,1 & 42,5 & 45,8 & 45,0 & 44,5 & 49,3 & 48,7 & 49,0 & 51,7 & 50,1 & 50,9 & 52,6 & 56,2 & 55,2 \\
\hline melk- en kalfkoeien-stalperiode / dairy cows-housing season & 66,0 & 67,7 & 70,2 & 68,3 & 66,0 & 68,1 & 68,8 & 66,6 & 65,9 & 67,7 & 70,8 & 71,0 & 78,5 & 79,8 & 79,6 \\
\hline melk- en kalfkoeien-weideperiode / dairy cows-grazing season & 37,2 & 36,2 & 40,6 & 34,9 & 38,2 & 39,8 & 39,3 & 37,6 & 38,9 & 42,0 & 42,5 & 44,1 & 48,6 & 49,8 & 48,4 \\
\hline fokstieren $\geq 2 \mathrm{jr} /$ breeding bulls $\geq 2 \mathrm{yr}$ & 88,5 & 87,4 & 89,6 & 86,0 & 84,4 & 83,4 & 82,7 & 80,9 & 81,8 & 85,9 & 83,5 & 80,8 & 83,5 & 88,5 & 85,6 \\
\hline \multirow{2}{*}{\multicolumn{16}{|c|}{ Vlees- en weidevee / Beef cattle }} \\
\hline & & & & & & & & & & & & & & & \\
\hline witvleeskalveren / calves for white veal production & 10,6 & 11,2 & 11,0 & 10,7 & 10,6 & 12,4 & 14,0 & 14,4 & 14,5 & 17,2 & 16,9 & 18,6 & 19,9 & 20,2 & 19,2 \\
\hline rosévleeskalveren / calves for rosé veal production & 27,2 & 27,0 & 28,1 & 27,4 & 28,0 & 28,2 & 27,3 & 25,2 & 23,2 & 24,9 & 24,6 & 25,1 & 24,1 & 27,9 & 27,2 \\
\hline vrouwelijk jongvee $<1 \mathrm{jr} /$ female young stock $<1 \mathrm{yr}$ & 22,8 & 22,5 & 24,4 & 28,8 & 28,4 & 28,2 & 28,6 & 28,2 & 28,7 & 29,9 & 29,3 & 28,8 & 30,1 & 30,2 & 29,2 \\
\hline $\begin{array}{l}\text { mannelijk jongvee (incl. ossen) }<1 \mathrm{jr} / \text { male young stock } \\
\text { (incl. bullocks) }<1 \mathrm{yr}\end{array}$ & 27,0 & 27,3 & 26,6 & 26,0 & 26,9 & 26,8 & 23,9 & 21,9 & 20,0 & 24,5 & 26,5 & 24,7 & 26,2 & 28,5 & 28,6 \\
\hline vrouwelijk jongvee $1-2 \mathrm{jr} /$ female young stock $1-2 \mathrm{yr}$ & 42,4 & 39,8 & 42,4 & 45,0 & 44,1 & 43,6 & 48,6 & 48,2 & 48,5 & 51,2 & 49,6 & 50,5 & 52,2 & 55,9 & 55,1 \\
\hline $\begin{array}{l}\text { mannelijk jongvee (incl. ossen) } 1-2 \mathrm{jr} / \text { male young stock } \\
\text { (incl. bullocks) } 1-2 \mathrm{yr}\end{array}$ & 56,8 & 57,3 & 54,5 & 53,8 & 54,9 & 53,8 & 51,1 & 47,8 & 44,6 & 50,1 & 51,2 & 49,8 & 50,3 & 52,7 & 52,8 \\
\hline vrouwelijk jongvee $\geq 2 \mathrm{jr} /$ female young stock $\geq 2 \mathrm{yr}$ & 42,5 & 39,9 & 42,4 & 44,9 & 44,1 & 43,6 & 48,6 & 48,2 & 48,6 & 51,2 & 49,5 & 50,5 & 52,3 & 55,9 & 55,1 \\
\hline $\begin{array}{l}\text { mannelijk jongvee (incl. ossen) } \geq 2 \mathrm{jr} / \text { male young stock } \\
\text { (incl. bullocks) } \geq 2 \mathrm{yr}\end{array}$ & 56,8 & 57,3 & 54,5 & 53,8 & 54,9 & 53,8 & 51,1 & 47,8 & 44,6 & 50,1 & 51,2 & 49,8 & 50,3 & 52,7 & 52,8 \\
\hline $\begin{array}{l}\text { zoog-, mest- en weidekoeien } \geq 2 \mathrm{jr} \text { / suckling cows and } \\
\text { female fatteners } \geq 2 \mathrm{yr}\end{array}$ & 39,1 & 38,7 & 39,4 & 38,7 & 37,9 & 37,6 & 37,6 & 35,7 & 35,7 & 38,2 & 37,5 & 36,4 & 37,8 & 40,5 & 38,9 \\
\hline schapen - ooien / sheep - ewes & 2,6 & 2,6 & 2,6 & 2,5 & 1,4 & 1,3 & 1,2 & 1,2 & 1,2 & 1,2 & 1,2 & 1,2 & 1,3 & 1,4 & 1,4 \\
\hline melkgeiten / dairy goats & 17,7 & 17,7 & 15,8 & 16,0 & 16,1 & 17,5 & 17,6 & 17,1 & 16,9 & 17,4 & 18,6 & 18,5 & 18,7 & 19,7 & 20,5 \\
\hline paarden / horses & 33,3 & 33,3 & 32,1 & 30,3 & 30,3 & 30,3 & 30,3 & 30,3 & 30,4 & 30,4 & 30,4 & 30,4 & 30,4 & 40,8 & 40,8 \\
\hline pony's en ezels / ponies and mules and asses & 14,4 & 14,4 & 13,8 & 13,2 & 13,2 & 13,2 & 13,2 & 13,2 & 13,2 & 13,2 & 13,2 & 13,2 & 13,2 & 16,1 & 16,1 \\
\hline vleesvarkens / fattening pigs & 12,3 & 12,6 & 12,6 & 12,9 & 12,7 & 12,2 & 12,5 & 12,5 & 12,0 & 11,9 & 11,6 & 11,5 & 11,7 & 11,7 & 11,5 \\
\hline $\begin{array}{l}\text { opfokzeugen en opfokberen }<50 \mathrm{~kg} / \text { gilts and young boars } \\
<50 \mathrm{~kg}\end{array}$ & 14,3 & 14,6 & 14,2 & 13,5 & 13,6 & 15,4 & 15,9 & 15,3 & 15,5 & 14,4 & 14,1 & 14,6 & 14,5 & 14,5 & 14,5 \\
\hline zeugen / sows & 30,7 & 30,8 & 31,5 & 30,8 & 30,3 & 30,2 & 30,1 & 29,6 & 31,1 & 29,1 & 29,5 & 29,7 & 30,2 & 30,2 & 29,9 \\
\hline opfokberen $>50 \mathrm{~kg} /$ young boars $>50 \mathrm{~kg}$ & 14,3 & 14,6 & 14,2 & 13,5 & 13,6 & 15,4 & 15,9 & 15,3 & 15,5 & 14,4 & 14,1 & 14,6 & 14,5 & 14,5 & 14,5 \\
\hline dekberen / breeding boars & 23,7 & 23,9 & 23,3 & 23,5 & 23,2 & 23,3 & 23,4 & 23,7 & 23,7 & 22,7 & 22,8 & 22,7 & 23,5 & 22,5 & 22,5 \\
\hline
\end{tabular}


ouderdieren van vleeskuikens $<18$ weken / broiler breeders $<$

\begin{tabular}{|c|c|c|c|c|c|c|c|c|c|c|c|c|c|c|c|}
\hline 18 weeks & 0,32 & 0,33 & 0,33 & 0,33 & 0,34 & 0,35 & 0,36 & 0,35 & 0,35 & 0,38 & 0,37 & 0,35 & 0,36 & 0,35 & 0,36 \\
\hline $\begin{array}{l}\text { ouderdieren van vleeskuikens } \geq 18 \text { weken / broiler breeders } \geq \\
18 \text { weeks }\end{array}$ & 1,10 & 1,10 & 1,13 & 1,12 & 1,14 & 1,11 & 1,12 & 1,11 & 1,11 & 1,10 & 1,09 & 1,09 & 1,06 & 0,99 & 0,99 \\
\hline leghennen $<18$ weken / laying hens $<18$ weeks & 0,32 & 0,33 & 0,34 & 0,34 & 0,33 & 0,34 & 0,35 & 0,35 & 0,35 & 0,35 & 0,35 & 0,36 & 0,34 & 0,36 & 0,36 \\
\hline leghennen $\geq 18$ weken / laying hens $\geq 18$ weeks & 0,71 & 0,74 & 0,74 & 0,75 & 0,77 & 0,80 & 0,78 & 0,76 & 0,77 & 0,75 & 0,75 & 0,75 & 0,76 & 0,78 & 0,82 \\
\hline vleeskuikens / broilers & 0,55 & 0,53 & 0,53 & 0,53 & 0,54 & 0,50 & 0,52 & 0,48 & 0,49 & 0,44 & 0,43 & 0,43 & 0,40 & 0,41 & 0,41 \\
\hline eenden / ducks & 0,89 & 0,91 & 0,85 & 0,76 & 0,78 & 0,79 & 0,79 & 0,76 & 0,74 & 0,72 & 0,74 & 0,76 & 0,73 & 0,70 & 0,69 \\
\hline kalkoenen / turkeys & 1,81 & 1,66 & 1,69 & 1,71 & 1,98 & 1,91 & 1,85 & 1,72 & 1,74 & 1,69 & 1,74 & 1,81 & 1,81 & 1,68 & 1,64 \\
\hline konijnen - voedsters / rabbits - does & 8,2 & 8,1 & 8,0 & 7,9 & 7,7 & 7,7 & 7,8 & 8,4 & 8,2 & 9,3 & 8,4 & 8,5 & 8,3 & 8,2 & 8,3 \\
\hline nertsen - moederdieren / minks - mothers & 2,7 & 2,6 & 2,5 & 2,4 & 1,9 & 2,2 & 2,2 & 2,3 & 2,2 & 2,0 & 2,4 & 2,3 & 2,3 & 2,2 & 2,2 \\
\hline vossen - moederdieren / foxes - mothers & 6,9 & 6,5 & 6,4 & & & & & & & & & & & & \\
\hline
\end{tabular}

vossen - moederdieren / foxes - mothers

\begin{tabular}{l|l|l|l}
6,9 & 6,5 & 6,4
\end{tabular}

Bron: Werkgroep Uniformering berekeningswijze Mest en mineralen (WUM) / Source: Working group Standardization calculation method Manure and Nutrients (WUM).

B3.2

TAN excretie in de stal (\% van $N$ excretie in de stal) / TAN excretion during housing (\% of $N$ excretion during housing).

\begin{tabular}{|c|c|c|c|c|c|c|c|c|c|c|c|c|c|c|c|}
\hline & 1990 & 1991 & 1992 & 1993 & 1994 & 1995 & 1996 & 1997 & 1998 & 1999 & 2000 & 2001 & 2002 & 2003 & 2004 \\
\hline \multicolumn{16}{|l|}{ Melk- en fokvee / Dairy cattle } \\
\hline vrouwelijk jongvee $<1 \mathrm{jr} /$ female young stock $<1 \mathrm{yr}$ & 67 & 67 & 66 & 67 & 67 & 67 & 67 & 68 & 67 & 65 & 65 & 65 & 65 & 66 & 65 \\
\hline mannelijk jongvee $<1 \mathrm{jr} /$ male young stock $<1 \mathrm{yr}$ & 62 & 62 & 62 & 62 & 62 & 62 & 61 & 63 & 62 & 60 & 59 & 59 & 59 & 59 & 58 \\
\hline vrouwelijk jongvee $1-2 \mathrm{jr} /$ female young stock $1-2 \mathrm{yr}$ & 71 & 71 & 70 & 71 & 71 & 71 & 71 & 72 & 71 & 69 & 70 & 69 & 69 & 66 & 65 \\
\hline mannelijk jongvee $1-2 \mathrm{jr} /$ male young stock $1-2 \mathrm{yr}$ & 64 & 65 & 64 & 65 & 66 & 65 & 64 & 67 & 67 & 65 & 65 & 65 & 64 & 63 & 62 \\
\hline vrouwelijk jongvee $\geq 2 \mathrm{jr}$ / female young stock $\geq 2 \mathrm{yr}$ & 71 & 71 & 70 & 71 & 71 & 71 & 71 & 71 & 71 & 69 & 70 & 69 & 69 & 66 & 65 \\
\hline melk- en kalfkoeien / dairy cows & 67 & 68 & 68 & 66 & 65 & 66 & 67 & 66 & 62 & 64 & 60 & 61 & 59 & 58 & 56 \\
\hline fokstieren $\geq 2 \mathrm{jr} /$ breeding bulls $\geq 2 \mathrm{yr}$ & 64 & 65 & 64 & 65 & 66 & 65 & 64 & 67 & 67 & 65 & 65 & 65 & 64 & 63 & 62 \\
\hline & & & & & & & & & & & & & & & \\
\hline \multicolumn{16}{|l|}{ Vlees- en weidevee / Beef cattle } \\
\hline witvleeskalveren / calves for white veal production & 68 & 68 & 68 & 68 & 68 & 67 & 67 & 66 & 67 & 66 & 67 & 67 & 67 & 67 & 64 \\
\hline rosévleeskalveren / calves for rosé veal production & 55 & 55 & 55 & 55 & 55 & 56 & 56 & 55 & 57 & 54 & 54 & 54 & 56 & 56 & 52 \\
\hline vrouwelijk jongvee $<1 \mathrm{jr} /$ female young stock $<1 \mathrm{yr}$ & 67 & 67 & 66 & 67 & 67 & 66 & 67 & 68 & 67 & 65 & 65 & 65 & 64 & 66 & 65 \\
\hline $\begin{array}{l}\text { mannelijk jongvee (incl. ossen) }<1 \mathrm{jr} / \text { male young stock } \\
\text { (incl. bullocks) }<1 \mathrm{yr}\end{array}$ & 53 & 53 & 54 & 53 & 53 & 52 & 51 & 51 & 48 & 47 & 47 & 48 & 47 & 47 & 50 \\
\hline vrouwelijk jongvee $1-2 \mathrm{jr} /$ female young stock $1-2 \mathrm{yr}$ & 71 & 71 & 70 & 71 & 71 & 71 & 71 & 71 & 71 & 69 & 70 & 69 & 69 & 66 & 65 \\
\hline $\begin{array}{l}\text { mannelijk jongvee (incl. ossen) } 1-2 \mathrm{jr} / \text { male young stock } \\
\text { (incl. bullocks) } 1-2 \mathrm{yr}\end{array}$ & 59 & 60 & 60 & 60 & 60 & 58 & 58 & 57 & 56 & 55 & 55 & 55 & 55 & 55 & 55 \\
\hline vrouwelijk jongvee $\geq 2 \mathrm{jr}$ / female young stock $\geq 2 \mathrm{yr}$ & 71 & 71 & 70 & 71 & 71 & 71 & 71 & 72 & 71 & 69 & 70 & 69 & 69 & 66 & 65 \\
\hline $\begin{array}{l}\text { mannelijk jongvee (incl. ossen) } \geq 2 \mathrm{jr} / \text { male young stock } \\
\text { (incl. bullocks) } \geq 2 \mathrm{yr}\end{array}$ & 59 & 60 & 60 & 60 & 60 & 58 & 58 & 57 & 56 & 55 & 55 & 55 & 55 & 55 & 55 \\
\hline
\end{tabular}

90 | wot-technical report 203 


\begin{tabular}{|c|c|c|c|c|c|c|c|c|c|c|c|c|c|c|c|}
\hline & 1990 & 1991 & 1992 & 1993 & 1994 & 1995 & 1996 & 1997 & 1998 & 1999 & 2000 & 2001 & 2002 & 2003 & 2004 \\
\hline $\begin{array}{l}\text { zoog-, mest- en weidekoeien } \geq 2 \mathrm{jr} / \text { suckling cows and } \\
\text { female fatteners } \geq 2 \mathrm{yr}\end{array}$ & 72 & 72 & 71 & 71 & 71 & 71 & 72 & 72 & 72 & 68 & 68 & 67 & 66 & 66 & 64 \\
\hline schapen - ooien / sheep - ewes & 69 & 69 & 69 & 70 & 71 & 70 & 69 & 72 & 72 & 70 & 70 & 70 & 69 & 68 & 66 \\
\hline melkgeiten / dairy goats & 69 & 69 & 69 & 70 & 70 & 70 & 69 & 71 & 70 & 68 & 68 & 66 & 66 & 65 & 61 \\
\hline paarden / horses & 72 & 72 & 72 & 72 & 72 & 72 & 72 & 72 & 72 & 72 & 72 & 72 & 72 & 72 & 72 \\
\hline pony's en ezels / ponies and mules and asses & 73 & 73 & 73 & 73 & 73 & 73 & 73 & 73 & 73 & 73 & 73 & 73 & 73 & 73 & 73 \\
\hline vleesvarkens / fattening pigs & 72 & 72 & 72 & 71 & 71 & 70 & 70 & 70 & 69 & 69 & 68 & 68 & 68 & 67 & 67 \\
\hline $\begin{array}{l}\text { opfokzeugen en opfokberen }<50 \mathrm{~kg} / \text { gilts and young boars } \\
<50 \mathrm{~kg}\end{array}$ & 71 & 71 & 71 & 71 & 71 & 71 & 71 & 71 & 71 & 71 & 71 & 71 & 71 & 70 & 69 \\
\hline zeugen / sows & 72 & 72 & 72 & 72 & 72 & 71 & 70 & 69 & 69 & 68 & 67 & 66 & 65 & 64 & 64 \\
\hline opfokberen $>50 \mathrm{~kg} /$ young boars $>50 \mathrm{~kg}$ & 69 & 69 & 69 & 68 & 68 & 68 & 68 & 68 & 67 & 67 & 67 & 67 & 67 & 66 & 66 \\
\hline dekberen / breeding boars & 76 & 76 & 76 & 76 & 76 & 76 & 76 & 76 & 76 & 76 & 76 & 75 & 75 & 75 & 75 \\
\hline $\begin{array}{l}\text { ouderdieren van vleeskuikens }<18 \text { weken / broiler breeders }< \\
18 \text { weeks }\end{array}$ & 71 & 71 & 71 & 71 & 71 & 71 & 71 & 71 & 71 & 71 & 71 & 71 & 71 & 71 & 71 \\
\hline $\begin{array}{l}\text { ouderdieren van vleeskuikens } \geq 18 \text { weken / broiler breeders } \geq \\
18 \text { weeks }\end{array}$ & 79 & 79 & 79 & 79 & 79 & 79 & 79 & 79 & 79 & 79 & 79 & 78 & 78 & 78 & 78 \\
\hline leghennen $<18$ weken / laying hens $<18$ weeks & 74 & 74 & 73 & 73 & 73 & 73 & 73 & 73 & 73 & 73 & 72 & 72 & 72 & 72 & 72 \\
\hline leghennen $\geq 18$ weken / laying hens $\geq 18$ weeks & 77 & 77 & 77 & 77 & 77 & 77 & 76 & 76 & 76 & 76 & 76 & 76 & 76 & 75 & 75 \\
\hline vleeskuikens / broilers & 70 & 70 & 70 & 70 & 70 & 70 & 70 & 70 & 70 & 70 & 70 & 70 & 70 & 70 & 70 \\
\hline eenden / ducks & 70 & 70 & 70 & 70 & 70 & 70 & 70 & 70 & 70 & 70 & 70 & 70 & 70 & 70 & 70 \\
\hline kalkoenen / turkeys & 73 & 73 & 73 & 73 & 73 & 73 & 73 & 73 & 73 & 72 & 72 & 72 & 71 & 71 & 71 \\
\hline konijnen - voedsters / rabbits - does & 70 & 70 & 70 & 70 & 70 & 70 & 70 & 70 & 70 & 70 & 70 & 70 & 70 & 70 & 70 \\
\hline nertsen - moederdieren / minks - mothers & 70 & 70 & 70 & 70 & 70 & 70 & 70 & 70 & 70 & 70 & 70 & 70 & 70 & 70 & 70 \\
\hline vossen - moederdieren / foxes - mothers & 70 & 70 & 70 & 70 & 70 & 70 & 70 & 70 & 70 & 70 & 70 & 70 & 70 & 70 & 70 \\
\hline
\end{tabular}




\section{Melk- en fokvee / Dairy cattle}

\begin{tabular}{|c|c|c|c|c|c|c|c|c|c|c|c|c|c|c|c|}
\hline \\
\hline vrouwelijk jongvee $<1 \mathrm{jr} /$ female young stock $<1 \mathrm{yr}$ & 65 & 64 & 64 & 62 & 61 & 62 & 61 & 60 & 60 & 61 & 60 & 60 & 61 & 62 & 61 \\
\hline mannelijk jongvee $<1 \mathrm{jr} /$ male young stock $<1 \mathrm{yr}$ & 58 & 57 & 58 & 58 & 56 & 56 & 55 & 54 & 55 & 56 & 54 & 54 & 56 & 57 & 57 \\
\hline vrouwelijk jongvee $1-2 \mathrm{jr} /$ female young stock $1-2 \mathrm{yr}$ & 66 & 65 & 65 & 65 & 64 & 65 & 63 & 62 & 63 & 63 & 62 & 62 & 63 & 64 & 64 \\
\hline mannelijk jongvee $1-2 \mathrm{jr} /$ male young stock $1-2 \mathrm{yr}$ & 63 & 62 & 64 & 63 & 63 & 63 & 63 & 62 & 62 & 63 & 63 & 62 & 63 & 64 & 63 \\
\hline vrouwelijk jongvee $\geq 2 \mathrm{jr} /$ female young stock $\geq 2 \mathrm{yr}$ & 66 & 65 & 65 & 65 & 64 & 65 & 63 & 62 & 63 & 63 & 62 & 62 & 63 & 64 & 64 \\
\hline melk- en kalfkoeien / dairy cows & 56 & 55 & 55 & 55 & 53 & 53 & 53 & 50 & 51 & 53 & 53 & 53 & 56 & 55 & 54 \\
\hline fokstieren $\geq 2 \mathrm{jr} /$ breeding bulls $\geq 2 \mathrm{yr}$ & 63 & 62 & 64 & 63 & 63 & 63 & 63 & 62 & 62 & 63 & 63 & 62 & 63 & 64 & 63 \\
\hline \multirow{2}{*}{\multicolumn{16}{|c|}{ Vlees- en weidevee / Beef cattle }} \\
\hline & & & & & & & & & & & & & & & \\
\hline witvleeskalveren / calves for white veal production & 64 & 63 & 63 & 62 & 62 & 61 & 63 & 66 & 64 & 66 & 66 & 66 & 63 & 64 & 62 \\
\hline rosévleeskalveren / calves for rosé veal production & 52 & 51 & 54 & 52 & 53 & 55 & 54 & 51 & 49 & 54 & 53 & 53 & 52 & 54 & 53 \\
\hline vrouwelijk jongvee $<1 \mathrm{jr} /$ female young stock $<1 \mathrm{yr}$ & 65 & 64 & 64 & 62 & 61 & 61 & 60 & 59 & 60 & 61 & 60 & 60 & 60 & 61 & 61 \\
\hline $\begin{array}{l}\text { mannelijk jongvee (incl. ossen) }<1 \mathrm{jr} / \text { male young stock } \\
\text { (incl. bullocks) }<1 \mathrm{yr}\end{array}$ & 49 & 49 & 50 & 48 & 49 & 48 & 43 & 40 & 36 & 45 & 48 & 46 & 48 & 51 & 52 \\
\hline vrouwelijk jongvee $1-2 \mathrm{jr} /$ female young stock $1-2 \mathrm{yr}$ & 66 & 65 & 65 & 64 & 64 & 65 & 63 & 62 & 63 & 63 & 62 & 62 & 63 & 64 & 64 \\
\hline $\begin{array}{l}\text { mannelijk jongvee (incl. ossen) } 1-2 \mathrm{jr} / \text { male young stock } \\
\text { (incl. bullocks) } 1-2 \mathrm{yr}\end{array}$ & 55 & 54 & 55 & 54 & 54 & 53 & 51 & 49 & 47 & 52 & 53 & 52 & 52 & 54 & 55 \\
\hline vrouwelijk jongvee $\geq 2 \mathrm{jr} /$ female young stock $\geq 2 \mathrm{yr}$ & 66 & 65 & 65 & 64 & 64 & 65 & 63 & 62 & 63 & 63 & 62 & 62 & 63 & 64 & 64 \\
\hline $\begin{array}{l}\text { mannelijk jongvee (incl. ossen) } \geq 2 \mathrm{jr} / \text { male young stock } \\
\text { (incl. bullocks) } \geq 2 \mathrm{yr}\end{array}$ & 55 & 54 & 55 & 54 & 54 & 53 & 51 & 49 & 47 & 52 & 53 & 52 & 52 & 54 & 55 \\
\hline $\begin{array}{l}\text { zoog-, mest- en weidekoeien } \geq 2 \mathrm{jr} / \text { suckling cows and } \\
\text { female fatteners } \geq 2 \mathrm{yr}\end{array}$ & 64 & 64 & 63 & 63 & 63 & 64 & 62 & 61 & 62 & 62 & 61 & 61 & 63 & 64 & 64 \\
\hline schapen - ooien / sheep - ewes & 66 & 66 & 66 & 64 & 66 & 64 & 68 & 68 & 69 & 69 & 57 & 57 & 60 & 62 & 62 \\
\hline melkgeiten / dairy goats & 61 & 60 & 60 & 58 & 58 & 59 & 59 & 58 & 58 & 60 & 60 & 61 & 62 & 61 & 61 \\
\hline paarden / horses & 72 & 72 & 73 & 73 & 73 & 73 & 73 & 73 & 73 & 73 & 73 & 73 & 73 & 69 & 69 \\
\hline pony's en ezels / ponies and mules and asses & 73 & 73 & 74 & 74 & 74 & 74 & 74 & 74 & 74 & 74 & 74 & 74 & 74 & 69 & 69 \\
\hline vleesvarkens / fattening pigs & 67 & 67 & 67 & 67 & 68 & 68 & 69 & 68 & 68 & 67 & 68 & 67 & 66 & 67 & 65 \\
\hline $\begin{array}{l}\text { opfokzeugen en opfokberen }<50 \mathrm{~kg} / \text { gilts and young boars } \\
<50 \mathrm{~kg}\end{array}$ & 69 & 69 & 69 & 69 & 70 & 72 & 71 & 70 & 70 & 70 & 70 & 70 & 70 & 70 & 69 \\
\hline zeugen / sows & 63 & 63 & 63 & 63 & 65 & 66 & 66 & 64 & 64 & 64 & 64 & 64 & 64 & 64 & 63 \\
\hline opfokberen $>50 \mathrm{~kg} /$ young boars $>50 \mathrm{~kg}$ & 66 & 66 & 66 & 66 & 70 & 72 & 71 & 70 & 70 & 70 & 70 & 70 & 70 & 70 & 69 \\
\hline dekberen / breeding boars & 75 & 75 & 75 & 75 & 72 & 72 & 73 & 71 & 71 & 72 & 71 & 71 & 72 & 72 & 71 \\
\hline $\begin{array}{l}\text { ouderdieren van vleeskuikens }<18 \text { weken / broiler breeders }< \\
18 \text { weeks }\end{array}$ & 71 & 71 & 71 & 71 & 69 & 68 & 71 & 70 & 70 & 75 & 76 & 75 & 74 & 75 & 72 \\
\hline
\end{tabular}

92 | wot-technical report 203 
ouderdieren van vleeskuikens $\geq 18$ weken / broiler breeders $\geq$

\begin{tabular}{|c|c|c|c|c|c|c|c|c|c|c|c|c|c|c|c|}
\hline 18 weeks & 78 & 78 & 78 & 78 & 77 & 76 & 77 & 78 & 78 & 78 & 78 & 78 & 79 & 78 & 78 \\
\hline leghennen $<18$ weken / laying hens $<18$ weeks & 72 & 72 & 72 & 72 & 75 & 74 & 76 & 76 & 75 & 76 & 76 & 76 & 77 & 78 & 77 \\
\hline leghennen $\geq 18$ weken / laying hens $\geq 18$ weeks & 75 & 75 & 75 & 75 & 78 & 74 & 76 & 77 & 77 & 76 & 76 & 75 & 76 & 78 & 76 \\
\hline vleeskuikens / broilers & 70 & 70 & 70 & 70 & 71 & 67 & 67 & 66 & 65 & 62 & 62 & 61 & 62 & 63 & 62 \\
\hline eenden / ducks & 70 & 70 & 70 & 70 & 70 & 69 & 69 & 69 & 67 & 68 & 68 & 69 & 69 & 68 & 68 \\
\hline kalkoenen / turkeys & 71 & 71 & 71 & 71 & 77 & 73 & 73 & 73 & 73 & 72 & 73 & 74 & 76 & 73 & 75 \\
\hline konijnen - voedsters / rabbits - does & 70 & 70 & 70 & 70 & 70 & 70 & 70 & 70 & 70 & 70 & 70 & 70 & 70 & 70 & 70 \\
\hline nertsen - moederdieren / minks - mothers & 70 & 70 & 70 & 70 & 70 & 70 & 70 & 70 & 70 & 70 & 70 & 70 & 70 & 70 & 70 \\
\hline vossen - moederdieren / foxes - mothers & 70 & 70 & 70 & & & & & & & & & & & & \\
\hline
\end{tabular}

B3.3

Stikstofexcretie in de weide ( $\mathrm{kg} /$ dier/jaar) / Nitrogen excretion during grazing ( $\mathrm{kg} / \mathrm{animal} / \mathrm{year}$ ).

\begin{tabular}{|c|c|c|c|c|c|c|c|c|c|c|c|c|c|c|c|}
\hline & 1990 & 1991 & 1992 & 1993 & 1994 & 1995 & 1996 & 1997 & 1998 & 1999 & 2000 & 2001 & 2002 & 2003 & 2004 \\
\hline \multicolumn{16}{|l|}{ Melk- en fokvee / Dairy cattle } \\
\hline vrouwelijk jongvee $<1 \mathrm{jr} /$ female young stock $<1 \mathrm{yr}$ & 15,3 & 14,7 & 14,5 & 14,5 & 14,4 & 14,4 & 15,0 & 14,9 & 14,2 & 12,4 & 13,0 & 12,9 & 12,8 & 18,4 & 16,9 \\
\hline vrouwelijk jongvee $1-2 \mathrm{jr} /$ female young stock $1-2 \mathrm{yr}$ & 51,2 & 49,1 & 48,0 & 48,1 & 47,8 & 47,5 & 50,1 & 49,8 & 47,3 & 41,2 & 42,9 & 42,8 & 42,4 & 36,9 & 33,2 \\
\hline vrouwelijk jongvee $\geq 2 \mathrm{jr} /$ female young stock $\geq 2 \mathrm{yr}$ & 51,2 & 49,1 & 48,0 & 48,1 & 47,8 & 47,5 & 50,1 & 49,8 & 47,3 & 41,2 & 42,9 & 42,8 & 42,4 & 36,9 & 33,2 \\
\hline melk- en kalfkoeien / dairy cows & 52,6 & 53,6 & 57,6 & 53,7 & 50,9 & 52,5 & 56,0 & 53,5 & 41,3 & 44,4 & 39,3 & 42,0 & 30,6 & 28,9 & 29,3 \\
\hline \multicolumn{16}{|l|}{ Vlees- en weidevee / Beef cattle } \\
\hline vrouwelijk jongvee $<1 \mathrm{jr} /$ female young stock $<1 \mathrm{yr}$ & 15,2 & 14,6 & 14,4 & 14,4 & 14,3 & 14,3 & 14,9 & 14,8 & 14,1 & 12,3 & 12,8 & 12,7 & 12,7 & 18,3 & 16,8 \\
\hline vrouwelijk jongvee $1-2 \mathrm{jr} /$ female young stock $1-2 \mathrm{yr}$ & 51,2 & 49,1 & 48,0 & 48,1 & 47,8 & 47,5 & 50,1 & 49,8 & 47,3 & 41,2 & 42,9 & 42,8 & 42,4 & 36,9 & 33,2 \\
\hline vrouwelijk jongvee $\geq 2 \mathrm{jr} /$ female young stock $\geq 2 \mathrm{yr}$ & 51,2 & 49,1 & 48,0 & 48,1 & 47,8 & 47,5 & 50,1 & 49,8 & 47,3 & 41,2 & 42,9 & 42,8 & 42,4 & 36,9 & 33,2 \\
\hline $\begin{array}{l}\text { zoog-, mest- en weidekoeien } \geq 2 \mathrm{jr} / \text { suckling cows and } \\
\text { female fatteners } \geq 2 \mathrm{yr}\end{array}$ & 68,4 & 65,4 & 63,9 & 64,0 & 63,7 & 63,1 & 66,7 & 66,4 & 62,8 & 51,6 & 52,7 & 52,8 & 52,6 & 51,4 & 46,0 \\
\hline schapen - ooien / sheep - ewes & 21,1 & 20,7 & 19,7 & 20,2 & 20,3 & 20,3 & 21,9 & 21,0 & 21,6 & 18,8 & 19,5 & 19,1 & 18,9 & 18,8 & 12,1 \\
\hline paarden / horses & 30,2 & 30,2 & 30,2 & 30,2 & 30,2 & 30,2 & 30,2 & 30,2 & 30,2 & 30,2 & 30,2 & 30,2 & 30,2 & 30,2 & 30,2 \\
\hline pony's en ezels / ponies and mules and asses & 19,9 & 19,9 & 19,9 & 19,9 & 19,9 & 19,9 & 19,9 & 19,9 & 19,9 & 19,9 & 19,9 & 19,9 & 19,9 & 19,9 & 19,9 \\
\hline
\end{tabular}




\section{Melk- en fokvee / Dairy cattle}

\begin{tabular}{|c|c|c|c|c|c|c|c|c|c|c|c|c|c|c|c|}
\hline \\
\hline vrouwelijk jongvee $<1 \mathrm{jr} /$ female young stock $<1 \mathrm{yr}$ & 17,0 & 16,6 & 14,3 & 7,5 & 7,1 & 7,4 & 5,9 & 5,3 & 5,5 & 5,4 & 4,9 & 4,3 & 4,3 & 4,1 & 4,1 \\
\hline vrouwelijk jongvee $1-2 \mathrm{jr} /$ female young stock $1-2 \mathrm{yr}$ & 33,1 & 34,1 & 32,2 & 29,0 & 28,2 & 28,8 & 22,0 & 21,0 & 21,9 & 21,4 & 19,7 & 18,1 & 16,8 & 16,8 & 16,8 \\
\hline vrouwelijk jongvee $\geq 2 \mathrm{jr} /$ female young stock $\geq 2 \mathrm{yr}$ & 33,1 & 34,1 & 32,2 & 29,0 & 28,2 & 28,7 & 22,0 & 21,0 & 21,9 & 21,4 & 19,7 & 18,1 & 16,9 & 16,9 & 17,0 \\
\hline melk- en kalfkoeien / dairy cows & 30,8 & 28,8 & 25,7 & 31,3 & 22,8 & 22,3 & 19,5 & 18,1 & 18,5 & 18,7 & 17,1 & 15,0 & 16,9 & 17,5 & 17,7 \\
\hline \multicolumn{16}{|l|}{ Vlees- en weidevee / Beef cattle } \\
\hline vrouwelijk jongvee $<1 \mathrm{jr} /$ female young stock $<1 \mathrm{yr}$ & 16,9 & 16,5 & 14,0 & 7,4 & 7,0 & 7,2 & 5,7 & 5,0 & 5,3 & 5,2 & 4,7 & 4,2 & 4,0 & 3,8 & 3,8 \\
\hline vrouwelijk jongvee $1-2 \mathrm{jr} /$ female young stock $1-2 \mathrm{yr}$ & 33,1 & 34,1 & 32,0 & 29,4 & 28,6 & 29,2 & 22,1 & 21,0 & 21,9 & 21,4 & 19,7 & 17,9 & 16,6 & 16,6 & 16,5 \\
\hline vrouwelijk jongvee $\geq 2 \mathrm{jr} /$ female young stock $\geq 2 \mathrm{yr}$ & 33,1 & 34,1 & 32,0 & 29,4 & 28,6 & 29,2 & 22,1 & 21,0 & 21,9 & 21,4 & 19,7 & 17,9 & 16,6 & 16,6 & 16,4 \\
\hline $\begin{array}{l}\text { zoog-, mest- en weidekoeien } \geq 2 \mathrm{jr} \text { / suckling cows and } \\
\text { female fatteners } \geq 2 \mathrm{yr}\end{array}$ & 45,8 & 44,5 & 43,4 & 46,2 & 44,9 & 45,7 & 43,0 & 42,2 & 44,0 & 43,0 & 39,3 & 41,1 & 43,7 & 43,6 & 44,9 \\
\hline schapen - ooien / sheep - ewes & 12,2 & 11,7 & 11,1 & 11,9 & 12,5 & 12,8 & 11,8 & 11,5 & 12,2 & 11,7 & 10,8 & 11,4 & 12,4 & 12,4 & 12,8 \\
\hline paarden / horses & 30,2 & 30,2 & 29,4 & 28,2 & 28,2 & 28,2 & 28,2 & 28,2 & 28,2 & 28,2 & 28,2 & 28,2 & 28,2 & 35,7 & 35,7 \\
\hline pony's en ezels / ponies and & 19,9 & 19,9 & 19,4 & 18,9 & 18,9 & 18,9 & 18,9 & 18,9 & 18,9 & 18,9 & 18,9 & 18,9 & 18,9 & 19,5 & 19,5 \\
\hline
\end{tabular}

pony's en ezels / ponies and mules and asses

\begin{tabular}{|l|l|l|l|l|l|l|l|l|l|l|}
\hline 19,9 & 19,9 & 19,4 & 18,9 & 18,9 & 18,9 & 18,9 & 18,9 & 18,9 & 18,9 & 18,9 \\
\hline
\end{tabular}

B3.4 TAN-excretie in de weide (\% van $N$-excretie in de wei) / TAN excretion during grazing (\% of $N$ excretion during grazing).

\begin{tabular}{|c|c|c|c|c|c|c|c|c|c|c|c|c|c|c|c|}
\hline & 1990 & 1991 & 1992 & 1993 & 1994 & 1995 & 1996 & 1997 & 1998 & 1999 & 2000 & 2001 & 2002 & 2003 & 2004 \\
\hline \multicolumn{16}{|l|}{ Melk- en fokvee / Dairy cattle } \\
\hline vrouwelijk jongvee $<1 \mathrm{jr} /$ female young stock $<1 \mathrm{yr}$ & 67 & 67 & 66 & 67 & 67 & 67 & 67 & 68 & 67 & 65 & 65 & 65 & 65 & 66 & 65 \\
\hline vrouwelijk jongvee $1-2 \mathrm{jr} /$ female young stock $1-2 \mathrm{yr}$ & 71 & 71 & 70 & 71 & 71 & 71 & 71 & 72 & 71 & 69 & 70 & 69 & 69 & 66 & 65 \\
\hline vrouwelijk jongvee $\geq 2 \mathrm{jr} /$ female young stock $\geq 2 \mathrm{yr}$ & 71 & 71 & 70 & 71 & 71 & 71 & 71 & 71 & 71 & 69 & 70 & 69 & 69 & 66 & 65 \\
\hline melk- en kalfkoeien / dairy cows & 67 & 68 & 68 & 66 & 65 & 66 & 67 & 66 & 62 & 64 & 60 & 61 & 59 & 58 & 56 \\
\hline \multicolumn{16}{|l|}{ Vlees- en weidevee / Beef cattle } \\
\hline vrouwelijk jongvee $<1 \mathrm{jr} /$ female young stock $<1 \mathrm{yr}$ & 67 & 67 & 66 & 67 & 67 & 66 & 67 & 68 & 67 & 65 & 65 & 65 & 64 & 66 & 65 \\
\hline vrouwelijk jongvee $1-2 \mathrm{jr} /$ female young stock $1-2 \mathrm{yr}$ & 71 & 71 & 70 & 71 & 71 & 71 & 71 & 71 & 71 & 69 & 70 & 69 & 69 & 66 & 65 \\
\hline vrouwelijk jongvee $\geq 2 \mathrm{jr} /$ female young stock $\geq 2 \mathrm{yr}$ & 71 & 71 & 70 & 71 & 71 & 71 & 71 & 72 & 71 & 69 & 70 & 69 & 69 & 66 & 65 \\
\hline $\begin{array}{l}\text { zoog-, mest- en weidekoeien } \geq 2 \mathrm{jr} \text { / suckling cows and } \\
\text { female fatteners } \geq 2 \mathrm{yr}\end{array}$ & 72 & 72 & 71 & 71 & 71 & 71 & 72 & 72 & 72 & 68 & 68 & 67 & 66 & 66 & 64 \\
\hline schapen - ooien / sheep - ewes & 87 & 87 & 85 & 85 & 85 & 85 & 87 & 85 & 85 & 83 & 83 & 82 & 82 & 82 & 76 \\
\hline paarden / horses & 74 & 74 & 74 & 74 & 74 & 74 & 74 & 74 & 74 & 74 & 74 & 74 & 74 & 74 & 74 \\
\hline pony's en ezels / ponies and mules and asses & 77 & 77 & 77 & 77 & 77 & 77 & 77 & 77 & 77 & 77 & 77 & 77 & 77 & 77 & 77 \\
\hline
\end{tabular}

94 | wot-technical report 203 


\section{Melk- en fokvee / Dairy cattle}

vrouwelijk jongvee $<1 \mathrm{jr} /$ female young stock $<1 \mathrm{yr}$ vrouwelijk jongvee $1-2 \mathrm{jr} /$ female young stock $1-2 \mathrm{yr}$ vrouwelijk jongvee $\geq 2 \mathrm{jr} /$ female young stock $\geq 2 \mathrm{yr}$ melk- en kalfkoeien / dairy cows

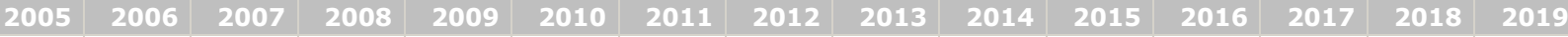

\section{Vlees- en weidevee / Beef cattle}

vrouwelijk jongvee $<1 \mathrm{jr} /$ female young stock $<1$ yr vrouwelijk jongvee $1-2 \mathrm{jr} /$ female young stock $1-2 \mathrm{yr}$ vrouwelijk jongvee $\geq 2 \mathrm{jr} /$ female young stock $\geq 2 \mathrm{yr}$ zoog-, mest- en weidekoeien $\geq 2 \mathrm{jr} /$ suckling cows and

female fatteners $\geq 2 \mathrm{yr}$

\begin{tabular}{|l|l|l|l|l|l|l|l|l|l|l|l|l|l|l|l|}
\hline 65 & 64 & 64 & 62 & 61 & 62 & 61 & 60 & 60 & 61 & 60 & 60 & 61 & 62 & 61 \\
\hline 66 & 65 & 65 & 65 & 64 & 65 & 63 & 62 & 63 & 63 & 62 & 62 & 63 & 64 & 64 \\
\hline 66 & 65 & 65 & 65 & 64 & 65 & 63 & 62 & 63 & 63 & 62 & 62 & 63 & 64 & 64 \\
\hline 5 & 55 & 55 & 53 & 53 & 53 & 50 & 51 & 53 & 53 & 53 & 56 & 55 & 54 \\
\hline
\end{tabular}

\begin{tabular}{|l|r|r|r|r|r|r|r|r|r|r|r|r|r|r|r|r|r|}
\hline 65 & 64 & 64 & 62 & 61 & 61 & 60 & 59 & 60 & 61 & 60 & 60 & 60 & 61 & 61 \\
\hline
\end{tabular}

\begin{tabular}{|l|l|l|l|l|l|l|l|l|l|l|l|l|l|l|l|}
66 & 65 & 65 & 64 & 64 & 65 & 63 & 62 & 63 & 63 & 62 & 62 & 63 & 64 & 64 \\
\hline 66 & 65 & 65 & 64 & 64 & 65 & 63 & 62 & 63 & 63 & 62 & 62 & 63 & 64 & 64 \\
\hline
\end{tabular}

schapen - ooien / sheep - ewes

paarden / horses

pony's en ezels / ponies and mules and asses

\begin{tabular}{l|l|l|l|l|l|l|l}
64 & 64 & 63 & 63 \\
\hline
\end{tabular}

B3.5

Fosfaatexcretie in de stal ( $\mathrm{kg} \mathrm{P}_{2} \mathrm{O}_{5} /$ dier/jaar) / Phosphate excretion during housing ( $\mathrm{kg} \mathrm{P}_{2} \mathrm{O}_{5} /$ animal/year).

\begin{tabular}{|c|c|c|c|c|c|c|c|c|c|c|c|c|c|c|c|}
\hline & 1990 & 1991 & 1992 & 1993 & 1994 & 1995 & 1996 & 1997 & 1998 & 1999 & 2000 & 2001 & 2002 & 2003 & 2004 \\
\hline \multicolumn{16}{|l|}{ Melk- en fokvee / Dairy cattle } \\
\hline vrouwelijk jongvee $<1 \mathrm{jr} /$ female young stock $<1 \mathrm{yr}$ & 6,6 & 7,5 & 7,1 & 7,4 & 7,8 & 7,8 & 6,9 & 6,8 & 7,5 & 8,2 & 7,5 & 8,1 & 7,3 & 6,8 & 6,3 \\
\hline mannelijk jongvee $<1 \mathrm{jr} /$ male young stock $<1 \mathrm{yr}$ & 9,1 & 9,3 & 8,3 & 9,1 & 9,6 & 9,0 & 7,7 & 8,2 & 8,5 & 9,2 & 8,8 & 9,3 & 8,9 & 9,2 & 9,2 \\
\hline vrouwelijk jongvee $1-2 \mathrm{jr} /$ female young stock $1-2 \mathrm{yr}$ & 11,1 & 12,8 & 12,4 & 12,8 & 13,5 & 13,5 & 12,0 & 11,7 & 13,5 & 14,3 & 12,9 & 14,1 & 12,5 & 13,7 & 12,8 \\
\hline mannelijk jongvee $1-2 \mathrm{jr} /$ male young stock $1-2 \mathrm{yr}$ & 23,5 & 27,1 & 26,7 & 27,5 & 28,7 & 28,8 & 25,6 & 25,0 & 29,1 & 30,6 & 27,6 & 30,0 & 26,6 & 29,2 & 27,1 \\
\hline vrouwelijk jongvee $\geq 2 \mathrm{jr} /$ female young stock $\geq 2 \mathrm{yr}$ & 11,1 & 12,8 & 12,4 & 12,8 & 13,4 & 13,5 & 11,9 & 11,7 & 13,5 & 14,3 & 12,9 & 14,0 & 12,5 & 13,7 & 12,8 \\
\hline melk- en kalfkoeien-stalperiode / dairy cows-housing season & 19,7 & 21,5 & 18,9 & 21,5 & 22,5 & 22,5 & 20,3 & 19,8 & 22,1 & 22,0 & 23,6 & 24,5 & 22,4 & 24,5 & 22,2 \\
\hline melk- en kalfkoeien-weideperiode / dairy cows-grazing season & 8,7 & 8,1 & 9,0 & 9,4 & 8,7 & 8,6 & 7,8 & 8,6 & 7,2 & 8,5 & 7,7 & 8,0 & 10,9 & 10,3 & 10,4 \\
\hline fokstieren $\geq 2 \mathrm{jr} /$ breeding bulls $\geq 2 \mathrm{yr}$ & 23,5 & 27,1 & 26,7 & 27,5 & 28,7 & 28,8 & 25,6 & 25,0 & 29,1 & 30,6 & 27,6 & 30,0 & 26,6 & 29,2 & 27,1 \\
\hline \multicolumn{16}{|l|}{ Vlees- en weidevee / Beef cattle } \\
\hline witvleeskalveren / calves for white veal production & 4,3 & 4,3 & 4,3 & 4,3 & 4,3 & 4,6 & 4,0 & 4,1 & 6,1 & 5,7 & 5,0 & 5,0 & 5,1 & 5,2 & 4,6 \\
\hline rosévleeskalveren / calves for rosé veal production & 9,3 & 9,3 & 9,3 & 9,3 & 9,3 & 9,3 & 9,1 & 9,0 & 9,8 & 12,3 & 12,4 & 12,8 & 10,4 & 10,3 & 8,7 \\
\hline vrouwelijk jongvee $<1 \mathrm{jr} /$ female young stock $<1 \mathrm{yr}$ & 6,6 & 7,4 & 7,0 & 7,3 & 7,7 & 7,7 & 6,8 & 6,7 & 7,4 & 8,1 & 7,4 & 8,0 & 7,2 & 6,7 & 6,2 \\
\hline $\begin{array}{l}\text { mannelijk jongvee (incl. ossen) }<1 \mathrm{jr} / \text { male young stock } \\
\text { (incl. bullocks) }<1 \mathrm{yr}\end{array}$ & 8,9 & 9,0 & 8,6 & 8,0 & 10,0 & 9,0 & 8,0 & 8,5 & 7,3 & 7,4 & 7,3 & 7,6 & 7,7 & 7,6 & 7,3 \\
\hline vrouwelijk jongvee $1-2 \mathrm{jr} /$ female young stock $1-2$ & 11,1 & 12,7 & 12,4 & 12,8 & 13,4 & 13,5 & 11,9 & 11,7 & 13,4 & 14,2 & 12,8 & 14,0 & 12,5 & 13,6 & 12,7 \\
\hline
\end{tabular}




\begin{tabular}{|c|c|c|c|c|c|c|c|c|c|c|c|c|c|c|c|}
\hline & 1990 & 1991 & 1992 & 1993 & 1994 & 1995 & 1996 & 1997 & 1998 & 1999 & 2000 & 2001 & 2002 & 2003 & 2004 \\
\hline $\begin{array}{l}\text { mannelijk jongvee (incl. ossen) } 1-2 \mathrm{jr} / \text { male young stock } \\
\text { (incl. bullocks) } 1-2 \mathrm{yr}\end{array}$ & 23,0 & 24,4 & 25,5 & 27,2 & 22,8 & 20,9 & 19,8 & 18,9 & 18,2 & 18,5 & 18,3 & 19,8 & 19,8 & 19,2 & 19,0 \\
\hline vrouwelijk jongvee $\geq 2 \mathrm{jr}$ / female young stock $\geq 2 \mathrm{yr}$ & 11,1 & 12,8 & 12,5 & 12,9 & 13,4 & 13,5 & 11,9 & 11,7 & 13,4 & 14,2 & 12,8 & 14,0 & 12,5 & 13,6 & 12,7 \\
\hline $\begin{array}{l}\text { mannelijk jongvee (incl. ossen) } \geq 2 \mathrm{jr} / \text { male young stock } \\
\text { (incl. bullocks) } \geq 2 \mathrm{yr}\end{array}$ & 23,0 & 24,4 & 25,5 & 27,2 & 22,8 & 20,9 & 19,8 & 18,9 & 18,2 & 18,5 & 18,3 & 19,8 & 19,8 & 19,2 & 19,0 \\
\hline $\begin{array}{l}\text { zoog-, mest- en weidekoeien } \geq 2 \mathrm{jr} \text { / suckling cows and } \\
\text { female fatteners } \geq 2 \mathrm{yr}\end{array}$ & 11,7 & 13,3 & 13,2 & 13,6 & 14,1 & 14,2 & 12,7 & 12,4 & 14,0 & 14,5 & 13,9 & 14,4 & 13,7 & 14,3 & 13,5 \\
\hline schapen - ooien / sheep - ewes & 1,1 & 1,2 & 1,1 & 1,2 & 1,2 & 1,2 & 1,1 & 1,1 & 1,3 & 1,2 & 1,2 & 1,2 & 1,2 & 1,2 & 0,9 \\
\hline melkgeiten / dairy goats & 6,1 & 6,5 & 6,3 & 6,6 & 6,8 & 6,8 & 6,2 & 6,1 & 7,1 & 6,8 & 6,0 & 6,9 & 6,7 & 7,0 & 5,4 \\
\hline paarden / horses & 12,4 & 12,4 & 12,4 & 12,4 & 12,4 & 12,4 & 12,4 & 12,4 & 12,4 & 12,4 & 12,4 & 12,4 & 12,4 & 12,4 & 12,4 \\
\hline pony's en ezels / ponies and mules and asses & 5,2 & 5,2 & 5,2 & 5,2 & 5,2 & 5,2 & 5,2 & 5,2 & 5,2 & 5,2 & 5,2 & 5,2 & 5,2 & 5,2 & 5,2 \\
\hline vleesvarkens / fattening pigs & 5,8 & 6,0 & 5,8 & 5,8 & 5,6 & 5,3 & 5,2 & 4,6 & 4,9 & 4,6 & 4,5 & 4,1 & 4,3 & 4,4 & 4,2 \\
\hline $\begin{array}{l}\text { opfokzeugen en opfokberen }<50 \mathrm{~kg} / \text { gilts and young boars } \\
<50 \mathrm{~kg}\end{array}$ & 7,7 & 7,7 & 7,9 & 7,9 & 7,2 & 6,6 & 6,2 & 6,0 & 6,3 & 6,4 & 6,8 & 6,0 & 5,8 & 6,4 & 6,3 \\
\hline zeugen / sows & 19,5 & 18,3 & 18,4 & 18,7 & 16,6 & 15,2 & 14,3 & 13,6 & 14,4 & 13,7 & 14,3 & 13,7 & 13,7 & 13,6 & 13,2 \\
\hline opfokberen > $50 \mathrm{~kg} /$ young boars $>50 \mathrm{~kg}$ & 7,7 & 7,7 & 7,9 & 7,9 & 7,2 & 6,6 & 6,2 & 6,0 & 6,3 & 6,4 & 6,8 & 6,0 & 5,8 & 6,4 & 6,3 \\
\hline dekberen / breeding boars & 14,8 & 14,8 & 15,5 & 12,9 & 13,8 & 12,6 & 11,4 & 11,6 & 11,4 & 10,3 & 11,3 & 10,8 & 10,3 & 11,7 & 12,7 \\
\hline $\begin{array}{l}\text { ouderdieren van vleeskuikens }<18 \text { weken / broiler breeders }< \\
18 \text { weeks }\end{array}$ & 0,30 & 0,33 & 0,29 & 0,29 & 0,30 & 0,24 & 0,21 & 0,22 & 0,21 & 0,20 & 0,20 & 0,19 & 0,19 & 0,18 & 0,20 \\
\hline $\begin{array}{l}\text { ouderdieren van vleeskuikens } \geq 18 \text { weken / broiler breeders } \geq \\
18 \text { weeks }\end{array}$ & 0,75 & 0,78 & 0,77 & 0,77 & 0,75 & 0,64 & 0,61 & 0,59 & 0,60 & 0,60 & 0,59 & 0,55 & 0,55 & 0,54 & 0,54 \\
\hline leghennen $<18$ weken / laying hens $<18$ weeks & 0,19 & 0,21 & 0,18 & 0,19 & 0,19 & 0,17 & 0,15 & 0,15 & 0,15 & 0,14 & 0,14 & 0,14 & 0,14 & 0,15 & 0,16 \\
\hline leghennen $\geq 18$ weken / laying hens $\geq 18$ weeks & 0,48 & 0,51 & 0,51 & 0,50 & 0,49 & 0,45 & 0,43 & 0,40 & 0,41 & 0,43 & 0,42 & 0,39 & 0,40 & 0,40 & 0,38 \\
\hline vleeskuikens / broilers & 0,22 & 0,22 & 0,23 & 0,23 & 0,22 & 0,21 & 0,21 & 0,22 & 0,19 & 0,22 & 0,22 & 0,18 & 0,18 & 0,20 & 0,19 \\
\hline eenden / ducks & 0,63 & 0,63 & 0,63 & 0,63 & 0,63 & 0,60 & 0,60 & 0,60 & 0,50 & 0,44 & 0,41 & 0,41 & 0,40 & 0,37 & 0,41 \\
\hline kalkoenen / turkeys & 0,96 & 0,96 & 0,96 & 1,01 & 1,00 & 0,86 & 0,87 & 0,91 & 0,88 & 0,82 & 0,82 & 0,75 & 0,75 & 0,96 & 0,90 \\
\hline konijnen - voedsters / rabbits - does & 4,9 & 4,9 & 4,9 & 4,9 & 4,9 & 4,2 & 4,2 & 4,2 & 3,6 & 3,7 & 3,4 & 3,4 & 3,3 & 3,6 & 3,7 \\
\hline nertsen - moederdieren / minks - mothers & 2,8 & 2,8 & 2,8 & 2,8 & 2,8 & 2,8 & 2,6 & 2,6 & 2,2 & 2,4 & 1,9 & 2,0 & 2,0 & 1,8 & 1,9 \\
\hline vossen - moederdieren / foxes - mothers & 9,8 & 9,8 & 9,8 & 9,8 & 9,8 & 9,8 & 6,9 & 6,9 & 5,8 & 5,7 & 4,4 & 4,7 & 4,8 & 4,1 & 4,9 \\
\hline
\end{tabular}

96 | wot-technical report 203 


\section{Melk- en fokvee / Dairy cattle}

\begin{tabular}{|c|c|c|c|c|c|c|c|c|c|c|c|c|c|c|c|}
\hline \\
\hline vrouwelijk jongvee $<1 \mathrm{jr}$ / female young stock $<1 \mathrm{yr}$ & 6,2 & 6,2 & 6,4 & 8,2 & 8,1 & 8,2 & 7,9 & 7,8 & 8,1 & 8,2 & 8,3 & 7,6 & 7,7 & 7,1 & 6,9 \\
\hline mannelijk jongvee $<1 \mathrm{jr} /$ male young stock $<1 \mathrm{yr}$ & 9,3 & 9,3 & 9,2 & 9,4 & 8,3 & 8,6 & 8,2 & 8,0 & 8,0 & 8,5 & 8,6 & 7,6 & 7,5 & 7,2 & 6,8 \\
\hline vrouwelijk jongvee $1-2 \mathrm{jr} /$ female young stock $1-2 \mathrm{yr}$ & 12,5 & 11,8 & 12,0 & 14,1 & 13,8 & 13,2 & 14,5 & 15,0 & 15,2 & 15,6 & 15,9 & 15,4 & 15,1 & 14,8 & 14,4 \\
\hline mannelijk jongvee $1-2 \mathrm{jr} /$ male young stock $1-2 \mathrm{yr}$ & 26,5 & 26,5 & 26,5 & 27,5 & 27,1 & 26,1 & 25,5 & 25,9 & 26,4 & 26,9 & 27,3 & 25,3 & 25,0 & 24,7 & 23,8 \\
\hline vrouwelijk jongvee $\geq 2 \mathrm{jr}$ / female young stock $\geq 2 \mathrm{yr}$ & 12,5 & 11,8 & 12,0 & 14,1 & 13,9 & 13,2 & 14,5 & 15,1 & 15,2 & 15,6 & 15,9 & 15,4 & 15,1 & 14,8 & 14,4 \\
\hline melk- en kalfkoeien-stalperiode / dairy cows-housing season & 21,6 & 22,0 & 21,8 & 22,4 & 21,3 & 22,8 & 21,9 & 21,1 & 21,1 & 21,7 & 22,8 & 22,0 & 22,9 & 22,0 & 22,2 \\
\hline melk- en kalfkoeien-weideperiode / dairy cows-grazing season & 11,2 & 11,0 & 12,3 & 10,9 & 11,9 & 13,0 & 12,5 & 11,7 & 12,3 & 13,1 & 14,4 & 13,4 & 13,7 & 13,6 & 13,0 \\
\hline fokstieren $\geq 2 \mathrm{jr} /$ breeding bulls $\geq 2 \mathrm{yr}$ & 26,5 & 26,5 & 26,5 & 27,5 & 27,1 & 26,1 & 25,5 & 25,9 & 26,4 & 26,9 & 27,3 & 25,3 & 25,0 & 24,7 & 23,8 \\
\hline \multicolumn{16}{|l|}{ Vlees- en weidevee / Beef cattle } \\
\hline witvleeskalveren / calves for white veal production & 4,6 & 5,1 & 4,8 & 4,3 & 4,4 & 4,8 & 5,6 & 5,5 & 5,2 & 6,3 & 5,4 & 6,8 & 6,8 & 7,3 & 5,2 \\
\hline rosévleeskalveren / calves for rosé veal production & 8,6 & 9,0 & 9,0 & 8,6 & 8,9 & 8,8 & 8,3 & 7,5 & 7,0 & 7,9 & 7,9 & 8,1 & 8,0 & 9,3 & 8,6 \\
\hline vrouwelijk jongvee $<1 \mathrm{jr} /$ female young stock $<1 \mathrm{yr}$ & 6,2 & 6,1 & 6,4 & 8,1 & 8,0 & 8,1 & 7,9 & 7,6 & 8,0 & 8,1 & 8,2 & 7,5 & 7,5 & 7,0 & 6,7 \\
\hline $\begin{array}{l}\text { mannelijk jongvee (incl. ossen) }<1 \mathrm{jr} / \text { male young stock } \\
\text { (incl. bullocks) }<1 \mathrm{yr}\end{array}$ & 7,5 & 7,7 & 7,2 & 7,1 & 7,9 & 8,3 & 6,5 & 5,8 & 5,4 & 6,7 & 7,0 & 6,5 & 6,1 & 6,6 & 6,7 \\
\hline vrouwelijk jongvee $1-2 \mathrm{jr} /$ female young stock $1-2 \mathrm{yr}$ & 12,4 & 11,8 & 12,0 & 13,9 & 13,6 & 12,9 & 14,3 & 14,9 & 15,1 & 15,5 & 15,8 & 15,3 & 15,0 & 14,7 & 14,4 \\
\hline $\begin{array}{l}\text { mannelijk jongvee (incl. ossen) } 1-2 \mathrm{jr} / \text { male young stock } \\
\text { (incl. bullocks) } 1-2 \mathrm{yr}\end{array}$ & 19,5 & 19,8 & 18,9 & 18,4 & 19,0 & 19,1 & 16,7 & 15,5 & 14,9 & 16,6 & 16,8 & 16,3 & 15,8 & 16,0 & 15,7 \\
\hline vrouwelijk jongvee $\geq 2 \mathrm{jr}$ / female young stock $\geq 2 \mathrm{yr}$ & 12,4 & 11,8 & 12,0 & 13,9 & 13,6 & 12,9 & 14,3 & 14,9 & 15,1 & 15,4 & 15,7 & 15,3 & 15,0 & 14,7 & 14,4 \\
\hline $\begin{array}{l}\text { mannelijk jongvee (incl. ossen) } \geq 2 \mathrm{jr} / \text { male young stock } \\
\text { (incl. bullocks) } \geq 2 \mathrm{yr}\end{array}$ & 19,5 & 19,8 & 18,9 & 18,4 & 19,0 & 19,1 & 16,7 & 15,5 & 14,9 & 16,6 & 16,8 & 16,3 & 15,8 & 16,0 & 15,7 \\
\hline $\begin{array}{l}\text { zoog-, mest- en weidekoeien } \geq 2 \mathrm{jr} \text { / suckling cows and } \\
\text { female fatteners } \geq 2 \mathrm{yr}\end{array}$ & 13,2 & 13,2 & 13,1 & 13,0 & 13,0 & 12,4 & 12,3 & 12,3 & 12,4 & 12,8 & 13,3 & 12,4 & 12,2 & 12,0 & 11,6 \\
\hline schapen - ooien / sheep - ewes & 0,9 & 0,9 & 0,9 & 0,9 & 0,5 & 0,5 & 0,5 & 0,5 & 0,5 & 0,5 & 0,5 & 0,5 & 0,5 & 0,5 & 0,5 \\
\hline melkgeiten / dairy goats & 5,5 & 5,6 & 6,1 & 6,4 & 6,3 & 6,9 & 6,9 & 6,9 & 6,9 & 7,0 & 6,1 & 6,0 & 6,1 & 5,9 & 6,2 \\
\hline paarden / horses & 12,4 & 12,4 & 14,1 & 12,0 & 12,0 & 12,0 & 12,0 & 12,0 & 11,7 & 11,7 & 11,7 & 11,7 & 11,7 & 15,6 & 15,6 \\
\hline pony's en ezels / ponies and mules and asses & 5,2 & 5,2 & 5,9 & 5,1 & 5,1 & 5,1 & 5,1 & 5,1 & 4,9 & 4,9 & 4,9 & 4,9 & 4,9 & 6,1 & 6,1 \\
\hline vleesvarkens / fattening pigs & 4,6 & 4,9 & 4,8 & 5,0 & 5,1 & 4,9 & 4,7 & 4,3 & 4,2 & 4,2 & 4,3 & 4,3 & 4,2 & 4,2 & 4,2 \\
\hline $\begin{array}{l}\text { opfokzeugen en opfokberen }<50 \mathrm{~kg} / \text { gilts and young boars } \\
<50 \mathrm{~kg}\end{array}$ & 6,7 & 6,6 & 6,2 & 5,9 & 6,4 & 6,7 & 6,4 & 5,9 & 6,5 & 6,7 & 6,7 & 5,9 & 6,4 & 6,0 & 6,1 \\
\hline zeugen / sows & 14,9 & 14,8 & 14,6 & 14,7 & 15,1 & 15,1 & 14,6 & 13,3 & 14,6 & 14,0 & 14,0 & 14,2 & 13,3 & 13,8 & 13,6 \\
\hline opfokberen > $50 \mathrm{~kg} /$ young boars $>50 \mathrm{~kg}$ & 6,7 & 6,6 & 6,2 & 5,9 & 6,4 & 6,7 & 6,4 & 5,9 & 6,5 & 6,7 & 6,7 & 5,9 & 6,4 & 6,0 & 6,1 \\
\hline dekberen / breeding boars & 12,7 & 11,5 & 11,5 & 11,7 & 12,2 & 12,3 & 12,0 & 11,3 & 11,4 & 12,2 & 11,5 & 11,1 & 10,5 & 10,7 & 11,0 \\
\hline
\end{tabular}




\begin{tabular}{|c|c|c|c|c|c|c|c|c|c|c|c|c|c|c|c|}
\hline & 2005 & 2006 & 2007 & 2008 & 2009 & 2010 & 2011 & 2012 & 2013 & 2014 & 2015 & 2016 & 2017 & 2018 & 2019 \\
\hline $\begin{array}{l}\text { ouderdieren van vleeskuikens }<18 \text { weken / broiler breeders }< \\
18 \text { weeks }\end{array}$ & 0,20 & 0,20 & 0,20 & 0,20 & 0,21 & 0,21 & 0,21 & 0,21 & 0,20 & 0,20 & 0,21 & 0,21 & 0,21 & 0,21 & 0,21 \\
\hline $\begin{array}{l}\text { ouderdieren van vleeskuikens } \geq 18 \text { weken / broiler breeders } \geq \\
18 \text { weeks }\end{array}$ & 0,55 & 0,57 & 0,56 & 0,55 & 0,57 & 0,56 & 0,57 & 0,56 & 0,56 & 0,55 & 0,56 & 0,58 & 0,54 & 0,51 & 0,51 \\
\hline leghennen $<18$ weken / laying hens $<18$ weeks & 0,16 & 0,17 & 0,17 & 0,17 & 0,17 & 0,17 & 0,17 & 0,18 & 0,17 & 0,17 & 0,17 & 0,17 & 0,16 & 0,17 & 0,17 \\
\hline leghennen $\geq 18$ weken / laying hens $\geq 18$ weeks & 0,38 & 0,40 & 0,39 & 0,39 & 0,40 & 0,41 & 0,40 & 0,40 & 0,40 & 0,40 & 0,40 & 0,41 & 0,42 & 0,42 & 0,43 \\
\hline vleeskuikens / broilers & 0,20 & 0,19 & 0,19 & 0,19 & 0,19 & 0,17 & 0,18 & 0,15 & 0,16 & 0,15 & 0,14 & 0,14 & 0,13 & 0,12 & 0,12 \\
\hline eenden / ducks & 0,41 & 0,38 & 0,33 & 0,36 & 0,38 & 0,38 & 0,37 & 0,36 & 0,38 & 0,45 & 0,39 & 0,40 & 0,40 & 0,39 & 0,39 \\
\hline kalkoenen / turkeys & 0,99 & 0,89 & 0,92 & 0,87 & 0,99 & 0,94 & 0,93 & 0,91 & 0,98 & 0,90 & 0,84 & 0,89 & 0,81 & 0,72 & 0,70 \\
\hline konijnen - voedsters / rabbits - does & 3,8 & 4,1 & 3,7 & 3,6 & 3,8 & 3,6 & 3,5 & 4,1 & 4,1 & 3,7 & 4,4 & 4,4 & 4,5 & 4,4 & 4,3 \\
\hline nertsen - moederdieren / minks - mothers & 1,7 & 1,5 & 1,2 & 1,2 & 1,0 & 1,2 & 1,2 & 1,2 & 1,3 & 1,2 & 1,2 & 1,2 & 1,0 & 1,0 & 1,0 \\
\hline vossen - moederdieren / foxes - mothers & 4,3 & 3,9 & 3,3 & & & & & & & & & & & & \\
\hline
\end{tabular}

\begin{tabular}{ll|l}
4,3 & 3,9 & 3,3
\end{tabular}

Bron: Werkgroep Uniformering berekeningswijze Mest en mineralen (WUM) / Source: Working group Standardization calculation method Manure and Nutrients (WUM),

B3.6

Fosfaatexcretie in de weide ( $k g \mathrm{P}_{2} \mathrm{O}_{5} /$ dier/jaar) / Phosphate excretion during grazing ( $k g \mathrm{P}_{2} \mathrm{O}_{5} /$ animal/year).

\begin{tabular}{|c|c|c|c|c|c|c|c|c|c|c|c|c|c|c|c|}
\hline & 1990 & 1991 & 1992 & 1993 & 1994 & 1995 & 1996 & 1997 & 1998 & 1999 & 2000 & 2001 & 2002 & 2003 & 2004 \\
\hline \multicolumn{16}{|l|}{ Melk- en fokvee / Dairy cattle } \\
\hline vrouwelijk jongvee $<1 \mathrm{jr} /$ female young stock $<1 \mathrm{yr}$ & 3,0 & 2,6 & 2,7 & 3,1 & 2,8 & 2,6 & 2,2 & 2,8 & 2,7 & 2,8 & 3,0 & 2,9 & 3,0 & 3,9 & 4,0 \\
\hline vrouwelijk jongvee $1-2 \mathrm{jr} /$ female young stock $1-2 \mathrm{yr}$ & 10,6 & 9,2 & 9,8 & 11,0 & 10,0 & 9,4 & 8,0 & 10,0 & 10,0 & 10,1 & 10,8 & 10,4 & 10,7 & 11,0 & 10,9 \\
\hline vrouwelijk jongvee $\geq 2 \mathrm{jr} /$ female young stock $\geq 2 \mathrm{yr}$ & 10,6 & 9,2 & 9,8 & 11,0 & 10,0 & 9,4 & 8,0 & 10,0 & 10,0 & 10,1 & 10,8 & 10,4 & 10,7 & 11,0 & 10,9 \\
\hline melk- en kalfkoeien / dairy cows & 13,1 & 12,2 & 13,4 & 14,1 & 13,1 & 13,0 & 11,7 & 13,0 & 10,8 & 12,7 & 11,5 & 12,1 & 8,9 & 8,5 & 8,6 \\
\hline \multicolumn{16}{|l|}{ Vlees- en weidevee / Beef cattle } \\
\hline vrouwelijk jongvee $<1 \mathrm{jr} /$ female young stock $<1 \mathrm{yr}$ & 3,0 & 2,6 & 2,7 & 3,1 & 2,8 & 2,6 & 2,2 & 2,8 & 2,7 & 2,8 & 3,0 & 2,9 & 3,0 & 3,9 & 4,0 \\
\hline vrouwelijk jongvee $1-2 \mathrm{jr} /$ female young stock $1-2 \mathrm{yr}$ & 10,6 & 9,2 & 9,8 & 11,0 & 10,0 & 9,4 & 8,0 & 10,0 & 10,0 & 10,1 & 10,8 & 10,4 & 10,7 & 11,0 & 10,9 \\
\hline vrouwelijk jongvee $\geq 2 \mathrm{jr}$ / female young stock $\geq 2 \mathrm{yr}$ & 10,6 & 9,2 & 9,8 & 11,0 & 10,0 & 9,4 & 8,0 & 10,0 & 10,0 & 10,1 & 10,8 & 10,4 & 10,7 & 11,0 & 10,9 \\
\hline $\begin{array}{l}\text { zoog-, mest- en weidekoeien } \geq 2 \mathrm{jr} / \text { suckling cows and } \\
\text { female fatteners } \geq 2 \mathrm{yr}\end{array}$ & 14,4 & 12,5 & 13,2 & 14,9 & 13,5 & 12,7 & 10,8 & 13,6 & 13,6 & 14,1 & 14,5 & 14,2 & 14,5 & 16,0 & 15,8 \\
\hline schapen - ooien / sheep - ewes & 4,5 & 4,1 & 4,2 & 4,8 & 4,4 & 4,2 & 3,7 & 4,4 & 4,9 & 4,9 & 5,2 & 4,9 & 5,1 & 4,7 & 4,2 \\
\hline paarden / horses & 10,8 & 10,8 & 10,8 & 10,8 & 10,8 & 10,8 & 10,8 & 10,8 & 10,8 & 10,8 & 10,8 & 10,8 & 10,8 & 10,8 & 10,8 \\
\hline pony's en ezels / ponies and mules and asses & 6,9 & 6,9 & 6,9 & 6,9 & 6,9 & 6,9 & 6,9 & 6,9 & 6,9 & 6,9 & 6,9 & 6,9 & 6,9 & 6,9 & 6,9 \\
\hline
\end{tabular}

98 | wot-technical report 203 


\begin{tabular}{|c|c|c|c|c|c|c|c|c|c|c|c|c|c|c|c|}
\hline & 2005 & 2006 & 2007 & 2008 & 2009 & 2010 & 2011 & 2012 & 2013 & 2014 & 2015 & 2016 & 2017 & 2018 & 2019 \\
\hline \multicolumn{16}{|l|}{ Melk- en fokvee / Dairy cattle } \\
\hline vrouwelijk jongvee $<1 \mathrm{jr}$ / female young stock $<1 \mathrm{yr}$ & 4,1 & 4,0 & 3,6 & 1,9 & 1,7 & 1,9 & 1,5 & 1,4 & 1,4 & 1,5 & 1,5 & 1,1 & 1,1 & 0,9 & 0,8 \\
\hline vrouwelijk jongvee $1-2 \mathrm{jr} /$ female young stock $1-2 \mathrm{yr}$ & 11,1 & 11,6 & 11,5 & 9,1 & 8,4 & 8,9 & 7,0 & 7,2 & 6,7 & 7,5 & 7,6 & 6,0 & 5,0 & 4,8 & 4,3 \\
\hline vrouwelijk jongvee $\geq 2 \mathrm{jr}$ / female young stock $\geq 2 \mathrm{yr}$ & 11,1 & 11,6 & 11,5 & 9,1 & 8,4 & 8,8 & 7,0 & 7,2 & 6,7 & 7,5 & 7,6 & 6,0 & 5,1 & 4,8 & 4,3 \\
\hline melk- en kalfkoeien / dairy cows & 9,3 & 8,7 & 7,7 & 9,7 & 7,0 & 7,2 & 6,2 & 5,6 & 5,8 & 5,8 & 5,9 & 4,5 & 4,8 & 4,8 & 4,7 \\
\hline \multicolumn{16}{|l|}{ Vlees- en weidevee / Beef cattle } \\
\hline vrouwelijk jongvee $<1 \mathrm{jr}$ / female young stock $<1 \mathrm{yr}$ & 4,1 & 4,0 & 3,6 & 1,9 & 1,7 & 1,9 & 1,4 & 1,3 & 1,3 & 1,4 & 1,4 & 1,1 & 1,0 & 0,8 & 0,8 \\
\hline vrouwelijk jongvee $1-2 \mathrm{jr} /$ female young stock $1-2 \mathrm{yr}$ & 11,1 & 11,6 & 11,4 & 9,2 & 8,6 & 9,0 & 7,0 & 7,2 & 6,7 & 7,5 & 7,6 & 6,0 & 4,9 & 4,7 & 4,2 \\
\hline vrouwelijk jongvee $\geq 2 \mathrm{jr}$ / female young stock $\geq 2 \mathrm{yr}$ & 11,1 & 11,6 & 11,4 & 9,3 & 8,5 & 9,0 & 7,0 & 7,2 & 6,7 & 7,5 & 7,6 & 6,0 & 5,0 & 4,7 & 4,2 \\
\hline $\begin{array}{l}\text { zoog-, mest- en weidekoeien } \geq 2 \mathrm{jr} \text { / suckling cows and } \\
\text { female fatteners } \geq 2 \mathrm{yr}\end{array}$ & 16,0 & 15,8 & 16,3 & 15,1 & 14,0 & 14,7 & 14,3 & 15,2 & 14,1 & 15,8 & 16,1 & 14,3 & 13,9 & 13,3 & 12,3 \\
\hline schapen - ooien / sheep - ewes & 4,3 & 4,2 & 4,1 & 3,9 & 3,9 & 4,1 & 3,9 & 4,1 & 3,9 & 4,3 & 4,4 & 3,9 & 3,9 & 3,8 & 3,5 \\
\hline paarden / horses & 10,8 & 10,8 & 12,0 & 10,6 & 10,6 & 10,6 & 10,6 & 10,6 & 10,4 & 10,4 & 10,4 & 10,4 & 10,4 & 13,1 & 13,1 \\
\hline pony's en ezels / ponies and mules and asses & 6,9 & 6,9 & 7,4 & 6,7 & 6,7 & 6,7 & 6,7 & 6,7 & 6,6 & 6,6 & 6,6 & 6,6 & 6,6 & 6,9 & 6,9 \\
\hline
\end{tabular}

Bron: Werkgroep Uniformering berekeningswijze Mest en mineralen (WUM) / Source: Working group Standardization calculation method Manure and Nutrients (WUM). 



\section{Bijlage 4 Weidegang van melkkoeien en aandeel $\mathrm{N}$-excretie in de stal}

\begin{tabular}{|c|c|c|c|c|c|c|c|c|c|c|c|c|c|c|}
\hline & $\begin{array}{r}1990- \\
2001\end{array}$ & 2002 & 2003 & 2004 & 2005 & 2006 & 2007 & 2008 & 2009 & 2010 & 2011 & 2012 & 2013 & 2014 \\
\hline \multicolumn{15}{|c|}{$\begin{array}{l}\text { Stalsysteem (\% melkkoeien) / Housing system (\% dairy } \\
\text { cows) }\end{array}$} \\
\hline $\begin{array}{l}\text { grupstal en potstal (dag en nacht weiden) / tie-stalls } \\
\text { bedding (day and night grazing) }\end{array}$ & 12,8 & 12,8 & 12,8 & 8,7 & 8,7 & 8,7 & 8,7 & 5,8 & 5,8 & 5,8 & 4,1 & 4,1 & 4,1 & 4,1 \\
\hline ligboxenstal en loopstal / cubicle and loose housing & 87,2 & 87,2 & 87,2 & 91,3 & 91,3 & 91,3 & 91,3 & 94,2 & 94,2 & 94,2 & 95,9 & 95,9 & 95,9 & 95,9 \\
\hline \multicolumn{15}{|c|}{$\begin{array}{l}\text { Beweidingssystemen ( } \% \text { melkkoeien) / Grazing systems } \\
\text { (\% dairy cows) }\end{array}$} \\
\hline permanent opstallen / permanent housing & 5 & 17 & 14 & 17 & 17 & 21 & 20 & 21 & 24 & 26 & 29 & 30 & 30 & 32 \\
\hline \multicolumn{15}{|c|}{$\begin{array}{l}\left.\text { Weide-duur }(\% \text { van koeien } \times \text { weken })^{1}\right) / \text { grazing time ( } \% \text { of } \\
\text { cows } x \text { weeks })^{1)}\end{array}$} \\
\hline dag en nacht weiden / day and night grazing & 50 & 30 & 32 & 37 & 37 & 43 & 29 & 49 & 29 & 27 & 25 & 24 & 23 & 22 \\
\hline overdag weiden / daytime grazing & 50 & 70 & 68 & 63 & 63 & 57 & 71 & 51 & 71 & 73 & 75 & 76 & 77 & 78 \\
\hline \multicolumn{15}{|c|}{$\begin{array}{l}\text { Excretie in de stal (\% excretie/etmaal) / Excretion during } \\
\text { housing (\% excretion/ } 24 \text { hours) }\end{array}$} \\
\hline dag en nacht weiden / day and night grazing & 15 & 15 & 15 & 15 & 15 & 15 & 15 & 15 & 15 & 15 & 15 & 15 & 15 & 15 \\
\hline overdag weiden / daytime grazing & 60 & 60 & 60 & 60 & 60 & 67 & 67 & 67 & 67 & 67 & 67 & 67 & 67 & 67 \\
\hline permanent opstallen / permanent housing & 100 & 100 & 100 & 100 & 100 & 100 & 100 & 100 & 100 & 100 & 100 & 100 & 100 & 100 \\
\hline
\end{tabular}




\begin{tabular}{|c|c|c|c|c|c|}
\hline & 2015 & 2016 & 2017 & 2018 & 2019 \\
\hline \multicolumn{6}{|l|}{$\begin{array}{l}\text { Stalsysteem (\% melkkoeien) / Housing system (\% dairy } \\
\text { cows) }\end{array}$} \\
\hline grupstal (dag en nacht weiden) / tie-stalls (day and night grazing) & 2,1 & 1,8 & 1,6 & 1,6 & 1,4 \\
\hline ligboxenstal en loopstal / cubicle and loose housing & 97,9 & 98,2 & 98,4 & 98,4 & 98,6 \\
\hline \multicolumn{6}{|l|}{$\begin{array}{l}\text { Beweidingssystemen niet-emissiearme stal (\% melkkoeien) } \\
\text { / Grazing systems other housing types ( } \% \text { dairy cows) }\end{array}$} \\
\hline permanent opstallen / permanent housing & 30 & 29 & 25 & 24 & 21 \\
\hline \multicolumn{6}{|l|}{$\begin{array}{l}\text { Weide-duur (koeien } x \text { weken) }{ }^{1} \text { / grazing time (cows } x \\
\text { weeks) }^{1)}\end{array}$} \\
\hline dag en nacht weiden / day and night grazing & 20 & 18 & 19 & 16 & 16 \\
\hline overdag weiden / daytime grazing & 80 & 82 & 81 & 84 & 84 \\
\hline \multicolumn{6}{|l|}{$\begin{array}{l}\text { Beweidingssystemen emissiearme ligboxenstal of loopstal } \\
\text { (\% melkkoeien) / Grazing systems low emission cubicle or } \\
\text { loose housing ( } \% \text { dairy cows) }\end{array}$} \\
\hline permanent opstallen / permanent housing & 65 & 61 & 57 & 58 & 56 \\
\hline \multicolumn{6}{|l|}{$\begin{array}{l}\left.\text { Weide-duur }(\% \text { van koeien } x \text { weken })^{1}\right) / \text { grazing time }(\% \text { of } \\
\text { cows } x \text { weeks })^{1)}\end{array}$} \\
\hline dag en nacht weiden / day and night grazing & 20 & 16 & 15 & 13 & 13 \\
\hline overdag weiden / daytime grazing & 80 & 84 & 85 & 87 & 87 \\
\hline \multicolumn{6}{|l|}{ Excretie in de stal / Excretion during housing } \\
\hline dag en nacht weiden / day and night grazing & 15 & 20 & 20 & 20 & 25 \\
\hline overdag weiden / daytime grazing & 67 & 71 & 71 & 71 & 71 \\
\hline permanent opstallen / permanent housing & 100 & 100 & 100 & 100 & 100 \\
\hline
\end{tabular}

epstallen / permanent housing

1) Berekend uit het aandeel melkkoeien per systeem maal het aandeel weken per beweidingsvorm / Share of dairy cows per grazing system multiplied by the the number of weeks per type of grazing Bron: 1990-2008: Wageningen Economic Research en CBS-onderzoek graslandgebruik; 2009-2019: Landbouwtelling / Source: 1990-2008: Wageningen Economic Research and CBS-inquiry grassland use; 20092019: Agricultural census. 


\section{Bijlage 5 Stalsystemen met drijfmest}

\begin{tabular}{|c|c|c|c|c|c|c|c|c|c|c|c|c|c|c|c|}
\hline & 1990 & 1991 & 1992 & 1993 & 1994 & 1995 & 1996 & 1997 & 1998 & 1999 & 2000 & 2001 & 2002 & 2003 & 2004 \\
\hline \multicolumn{16}{|l|}{ Melk- en fokvee / Dairy cattle } \\
\hline vrouwelijk jongvee $<1 \mathrm{jr} /$ female young stock $<1 \mathrm{yr}$ & 56 & 56 & 56 & 56 & 56 & 56 & 56 & 56 & 56 & 56 & 56 & 56 & 56 & 56 & 56 \\
\hline mannelijk jongvee $<1 \mathrm{jr} /$ male young stock $<1 \mathrm{yr}$ & 56 & 56 & 56 & 56 & 56 & 56 & 56 & 56 & 56 & 56 & 56 & 56 & 56 & 56 & 56 \\
\hline vrouwelijk jongvee $\geq 1 \mathrm{jr}$ / female young stock $\geq 1 \mathrm{yr}$ & 85 & 86 & 86 & 87 & 88 & 88 & 89 & 90 & 90 & 91 & 91 & 92 & 93 & 93 & 94 \\
\hline mannelijk jongvee $1-2 \mathrm{jr} /$ male young stock $1-2 \mathrm{yr}$ & 85 & 86 & 86 & 87 & 88 & 88 & 89 & 90 & 90 & 91 & 91 & 92 & 93 & 93 & 94 \\
\hline melk- en kalfkoeien / dairy cows & 89 & 90 & 90 & 91 & 92 & 92 & 93 & 94 & 95 & 95 & 96 & 96 & 97 & 97 & 97 \\
\hline fokstieren $\geq 2 \mathrm{jr} /$ breeding bulls $\geq 2 \mathrm{yr}$ & 78 & 78 & 78 & 78 & 78 & 78 & 78 & 78 & 78 & 78 & 78 & 78 & 78 & 78 & 78 \\
\hline \multicolumn{16}{|l|}{ Vlees- en weidevee / Beef cattle } \\
\hline vleeskalveren / veal calves & 100 & 100 & 100 & 100 & 100 & 100 & 100 & 100 & 100 & 100 & 100 & 100 & 100 & 100 & 100 \\
\hline vrouwelijk jongvee / female young stock & 66 & 66 & 66 & 66 & 66 & 66 & 66 & 66 & 66 & 66 & 66 & 66 & 66 & 66 & 66 \\
\hline vleesstieren $<2 \mathrm{jr} /$ beef bulls (incl. bullocks) $<2 \mathrm{yr}$ & 67 & 67 & 67 & 67 & 67 & 67 & 67 & 67 & 67 & 67 & 67 & 67 & 67 & 67 & 67 \\
\hline vleesstieren $\geq 2 \mathrm{jr}$ / beef bulls (incl. bullocks) $\geq 2 \mathrm{yr}$ & 65 & 65 & 65 & 65 & 65 & 65 & 65 & 65 & 65 & 65 & 65 & 65 & 65 & 65 & 65 \\
\hline $\begin{array}{l}\text { zoog-, mest- en weidekoeien } \geq 2 \mathrm{jr} \text { / suckling cows } \\
\text { and female fatteners } \geq 2 \mathrm{yr}\end{array}$ & 69 & 69 & 69 & 69 & 69 & 69 & 69 & 69 & 69 & 69 & 69 & 69 & 69 & 69 & 69 \\
\hline $\begin{array}{l}\text { Schapen, geiten, paarden, pony's, ezels / Sheep, } \\
\text { goats, horses, ponies, mules and asses }\end{array}$ & 0 & 0 & 0 & 0 & 0 & 0 & 0 & 0 & 0 & 0 & 0 & 0 & 0 & 0 & 0 \\
\hline $\begin{array}{l}\text { Vlees- en opfokvarkens / Fattening pigs, gilts and } \\
\text { young boars }\end{array}$ & 100 & 100 & 100 & 100 & 100 & 100 & 100 & 100 & 100 & 100 & 100 & 100 & 100 & 100 & 100 \\
\hline Zeugen / Sows & 100 & 100 & 100 & 100 & 100 & 100 & 100 & 100 & 100 & 100 & 100 & 100 & 100 & 100 & 100 \\
\hline Dekberen / Breeding boars & 100 & 100 & 100 & 100 & 100 & 100 & 100 & 100 & 100 & 100 & 100 & 100 & 100 & 100 & 100 \\
\hline Laying hens $<18$ weeks / Laying hens $<18$ weeks & 66 & 66 & 66 & 66 & 60 & 55 & 55 & 55 & 25 & 25 & 25 & 17 & 15 & 9,6 & 9,6 \\
\hline Laying hens $\geq 18$ weeks / Laying hens $\geq 18$ weeks & 60 & 60 & 60 & 60 & 50 & 42 & 42 & 42 & 22 & 22 & 22 & 15 & 13 & 7,2 & 7,2 \\
\hline Overig pluimvee / Other poultry & 0 & 0 & 0 & 0 & 0 & 0 & 0 & 0 & 0 & 0 & 0 & 0 & 0 & 0 & 0 \\
\hline Konijnen / Rabbits & 0 & 0 & 0 & 0 & 0 & 0 & 0 & 0 & 0 & 0 & 0 & 0 & 0 & 0 & 0 \\
\hline Pelsdieren / Fur-bearing animals & 100 & 100 & 100 & 100 & 100 & 100 & 100 & 100 & 100 & 100 & 100 & 100 & 100 & 100 & 100 \\
\hline
\end{tabular}




\begin{tabular}{|c|c|c|c|c|c|c|c|c|c|c|c|c|c|c|c|}
\hline & 2005 & 2006 & 2007 & 2008 & 2009 & 2010 & 2011 & 2012 & 2013 & 2014 & 2015 & 2016 & 2017 & 2018 & 2019 \\
\hline \multicolumn{16}{|l|}{ Melk- en fokvee / Dairy cattle } \\
\hline vrouwelijk jongvee $<1 \mathrm{jr} /$ female young stock $<1 \mathrm{yr}$ & 56 & 56 & 56 & 56 & 56 & 56 & 62 & 62 & 62 & 59 & 59 & 59 & 86 & 86 & 89 \\
\hline mannelijk jongvee $<1 \mathrm{jr} /$ male young stock $<1 \mathrm{yr}$ & 56 & 56 & 56 & 56 & 56 & 56 & 62 & 62 & 62 & 59 & 59 & 59 & 56 & 56 & 58 \\
\hline vrouwelijk jongvee $\geq 1 \mathrm{jr} /$ female young stock $\geq 1 \mathrm{yr}$ & 94 & 95 & 95 & 95 & 95 & 95 & 96 & 96 & 96 & 96 & 96 & 96 & 86 & 86 & 89 \\
\hline mannelijk jongvee $1-2 \mathrm{jr} /$ male young stock $1-2 \mathrm{yr}$ & 94 & 95 & 95 & 95 & 95 & 95 & 96 & 96 & 96 & 96 & 96 & 96 & 56 & 56 & 58 \\
\hline melk- en kalfkoeien / dairy cows & 97 & 98 & 98 & 98 & 98 & 98 & 97 & 97 & 97 & 97 & 97 & 97 & 98 & 98 & 98 \\
\hline fokstieren $\geq 2 \mathrm{jr}$ / breeding bulls $\geq 2 \mathrm{yr}$ & 78 & 78 & 78 & 78 & 78 & 78 & 82 & 82 & 82 & 83 & 83 & 83 & 56 & 56 & 58 \\
\hline \multicolumn{16}{|l|}{ Vlees- en weidevee / Beef cattle } \\
\hline vleeskalveren / veal calves & 100 & 100 & 100 & 100 & 100 & 100 & 100 & 100 & 100 & 100 & 100 & 100 & 100 & 100 & 100 \\
\hline vrouwelijk jongvee / female young stock & 66 & 66 & 66 & 66 & 66 & 66 & 61 & 61 & 61 & 56 & 56 & 56 & 51 & 51 & 50 \\
\hline vleesstieren $<2 \mathrm{jr} /$ beef bulls (incl. bullocks) $<2 \mathrm{yr}$ & 67 & 67 & 67 & 67 & 67 & 67 & 63 & 63 & 63 & 55 & 55 & 55 & 51 & 51 & 50 \\
\hline vleesstieren $\geq 2 \mathrm{jr} /$ beef bulls (incl. bullocks) $\geq 2 \mathrm{yr}$ & 65 & 65 & 65 & 65 & 65 & 65 & 55 & 55 & 55 & 51 & 51 & 51 & 51 & 51 & 50 \\
\hline $\begin{array}{l}\text { zoog-, mest- en weidekoeien } \geq 2 \mathrm{jr} / \text { suckling cows } \\
\text { and female fatteners } \geq 2 \mathrm{yr}\end{array}$ & 69 & 69 & 69 & 69 & 69 & 69 & 66 & 66 & 66 & 66 & 66 & 66 & 51 & 51 & 50 \\
\hline $\begin{array}{l}\text { Schapen, geiten, paarden, pony's, ezels / Sheep, } \\
\text { goats, horses, ponies, mules and asses }\end{array}$ & 0 & 0 & 0 & 0 & 0 & 0 & 0 & 0 & 0 & 0 & 0 & 0 & 0 & 0 & 0 \\
\hline $\begin{array}{l}\text { Vlees- en opfokvarkens / Fattening pigs, gilts and } \\
\text { young boars }\end{array}$ & 100 & 100 & 100 & 100 & 100 & 100 & 100 & 100 & 100 & 100 & 100 & 100 & 100 & 100 & 100 \\
\hline Zeugen / Sows & 100 & 100 & 95 & 95 & 95 & 95 & 97 & 97 & 97 & 97 & 97 & 97 & 96 & 96 & 96 \\
\hline Dekberen / Breeding boars & 100 & 100 & 81 & 81 & 81 & 81 & 88 & 88 & 88 & 81 & 81 & 81 & 71 & 71 & 71 \\
\hline Laying hens $<18$ weeks / Laying hens $<18$ weeks & 9,6 & 9,6 & 5,1 & 5,1 & 5,1 & 5,1 & 0,4 & 0,4 & 0 & 0 & 0 & 0 & 0 & 0 & 0 \\
\hline Laying hens $\geq 18$ weeks / Laying hens $\geq 18$ weeks & 7,2 & 7,2 & 2,4 & 2,4 & 2,4 & 0,7 & 0,6 & 0,6 & 0 & 0 & 0 & 0 & 0 & 0 & 0 \\
\hline Overig pluimvee / Other poultry & 0 & 0 & 0 & 0 & 0 & 0 & 0 & 0 & 0 & 0 & 0 & 0 & 0 & 0 & 0 \\
\hline Konijnen / Rabbits & 0 & 0 & 0 & 0 & 0 & 0 & 0 & 0 & 0 & 0 & 0 & 0 & 0 & 0 & 0 \\
\hline Pelsdieren / Fur-bearing animals & 100 & 100 & 100 & 100 & 100 & 100 & 100 & 100 & 100 & 100 & 100 & 100 & 100 & 100 & 100 \\
\hline
\end{tabular}

Bron: Landbouwtelling / Source: Agricultural census. 


\section{Bijlage 6 Stalsystemen voor rundvee}

\begin{tabular}{|c|c|c|c|c|c|c|c|c|c|c|c|c|c|c|c|}
\hline & 1990 & 1991 & 1992 & 1993 & 1994 & 1995 & 1996 & 1997 & 1998 & 1999 & 2000 & 2001 & 2002 & 2003 & 2004 \\
\hline \multicolumn{16}{|l|}{$\begin{array}{l}\text { Melk- en kalfkoeien (drijfmest)/ Dairy cows } \\
\text { (slurry) }\end{array}$} \\
\hline $\begin{array}{l}\text { emissiearme ligboxenstal of loopstal / low emission } \\
\text { cubicle or loose housing }\end{array}$ & 0 & 0 & 0 & 0 & 0 & 0 & 0 & 0 & 0 & 0 & 1,4 & 1,4 & 1,4 & 1,4 & 2,6 \\
\hline emissiearme grupstal / low emission tie-stalls & 8,8 & 8,8 & 8,8 & 8,8 & 8,8 & 8,8 & 8,8 & 8,8 & 8,8 & 8,8 & 8,8 & 8,8 & 8,8 & 8,8 & 5,8 \\
\hline overige huisvesting / other housing & 91,2 & 91,2 & 91,2 & 91,2 & 91,2 & 91,2 & 91,2 & 91,2 & 91,2 & 91,2 & 89,8 & 89,8 & 89,8 & 89,8 & 91,6 \\
\hline \multicolumn{16}{|l|}{ Vrouwelijk jongvee / Female young stock } \\
\hline $\begin{array}{l}\text { emissiearme grupstal (drijfmest) / low emission tie- } \\
\text { stalls (slurry) }\end{array}$ & 6,4 & 6,4 & 6,4 & 6,4 & 6,4 & 6,4 & 6,4 & 6,4 & 6,4 & 6,4 & 6,4 & 6,4 & 6,4 & 6,4 & 6,4 \\
\hline overige huisvesting / other housing & 93,6 & 93,6 & 93,6 & 93,6 & 93,6 & 93,6 & 93,6 & 93,6 & 93,6 & 93,6 & 93,6 & 93,6 & 93,6 & 93,6 & 93,6 \\
\hline \multicolumn{16}{|l|}{ Vleeskalveren / Veal calves } \\
\hline Luchtwasser $^{1)} /$ air scrubber $^{11}$ & 0 & 0 & 0 & 0 & 0 & 0 & 0 & 0 & 0 & 0 & 0 & 0 & 0 & 0 & 0 \\
\hline overige huisvesting / regular housing & 100 & 100 & 100 & 100 & 100 & 100 & 100 & 100 & 100 & 100 & 100 & 100 & 100 & 100 & 100 \\
\hline
\end{tabular}

\begin{tabular}{|c|c|c|c|c|c|c|c|c|c|c|c|c|c|c|c|}
\hline & 2005 & 2006 & 2007 & 2008 & 2009 & 2010 & 2011 & 2012 & 2013 & 2014 & 2015 & 2016 & 2017 & 2018 & 2019 \\
\hline \multicolumn{16}{|l|}{$\begin{array}{l}\text { Melk- en kalfkoeien (drijfmest) / Dairy cows } \\
\text { (slurry) }\end{array}$} \\
\hline $\begin{array}{l}\text { emissiearme ligboxenstal of loopstal / low emission } \\
\text { cubicle or loose housing }\end{array}$ & 2,6 & 2,6 & 1,4 & 1,4 & 1,4 & 1,4 & 6,7 & 6,7 & 6,7 & 6,7 & 16,6 & 18,7 & 19,5 & 19,5 & 18,4 \\
\hline emissiearme grupstal / low emission tie-stalls & 5,8 & 5,8 & 3,9 & 3,9 & 3,9 & 3,9 & 2,9 & 2,9 & 2,9 & 2,9 & 2,1 & 1,8 & 1,6 & 1,6 & 1,4 \\
\hline overige huisvesting / other housing & 91,6 & 91,6 & 94,7 & 94,7 & 94,7 & 94,7 & 90,4 & 90,4 & 90,4 & 90,4 & 81,3 & 79,5 & 78,9 & 78,9 & 80,2 \\
\hline \multicolumn{16}{|l|}{ Vrouwelijk jongvee / Female young stock } \\
\hline $\begin{array}{l}\text { emissiearme grupstal (drijfmest) / low emission tie- } \\
\text { stalls (slurry) }\end{array}$ & 6,4 & 6,4 & 7,6 & 7,6 & 7,6 & 7,6 & 4,9 & 4,9 & 4,9 & 4,9 & 0 & 0 & 0 & 0 & 0 \\
\hline overige huisvesting / other housing & 93,6 & 93,6 & 92,4 & 92,4 & 92,4 & 92,4 & 95,1 & 95,1 & 95,1 & 95,1 & 100 & 100 & 100 & 100 & 100 \\
\hline \multicolumn{16}{|l|}{ Vleeskalveren / Veal calves } \\
\hline luchtwasser $^{11}$ / air scrubber $\left.{ }^{1}\right)$ & 0 & 0 & 0 & 0 & 0 & 0 & 5,5 & 6,0 & 6,3 & 6,6 & 3,9 & 3,7 & 4,3 & 4,3 & 5,1 \\
\hline overige huisvesting / regular housing & 100 & 100 & 100 & 100 & 100 & 100 & 94,5 & 94,0 & 93,7 & 93,4 & 96,1 & 96,3 & 95,7 & 95,7 & 94,9 \\
\hline
\end{tabular}

1) Gecorrigeerd voor niet-operationele luchtwassers tijdens handhavingsactiviteiten / Adjusted for non-operating air scrubbers during enforcement activities.

Bron: Landbouwtelling / Source: Agricultural census. 



\section{Bijlage 7 Stalsystemen voor varkens}

\begin{tabular}{|c|c|c|c|c|c|c|c|c|c|c|c|c|c|c|c|}
\hline & 1990 & 1991 & 1992 & 1993 & 1994 & 1995 & 1996 & 1997 & 1998 & 1999 & 2000 & 2001 & 2002 & 2003 & 2004 \\
\hline $\begin{array}{l}\text { Fokzeugen incl. biggen tot } 25 \mathrm{~kg} \text {, totaal / Sows } \\
\text { incl. piglets up to } 25 \mathrm{~kg} \text {, total }\end{array}$ & 100 & 100 & 100 & 100 & 100 & 100 & 100 & 100 & 100 & 100 & 100 & 100 & 100 & 100 & 100 \\
\hline \multicolumn{16}{|l|}{ waarvan / of which: } \\
\hline reguliere stal / regular housing & 100 & 100 & 100 & 100 & 100 & 100 & 100 & 92,5 & 92,5 & 92,5 & 83,7 & 83,7 & 83,7 & 83,7 & 83,7 \\
\hline emissiearme stal / reduced emission housing & 0,0 & 0,0 & 0,0 & 0,0 & 0,0 & 0,0 & 0,0 & 7,5 & 7,5 & 7,5 & 16,3 & 16,3 & 16,3 & 16,3 & 16,3 \\
\hline $\begin{array}{l}\text { Emissiearme stal kraamzeugen, totaal / Low } \\
\text { emission housing nursing sows, total }\end{array}$ & 100 & 100 & 100 & 100 & 100 & 100 & 100 & 100 & 100 & 100 & 100 & 100 & 100 & 100 & 100 \\
\hline \multicolumn{16}{|l|}{ waarvan / of which: } \\
\hline luchtwasser ${ }^{1)} /$ air scrubber $\left.{ }^{1}\right)$ & 0,0 & 0,0 & 0,0 & 0,0 & 0,0 & 0,0 & 0,0 & 0,0 & 0,0 & 0,0 & 0,0 & 0,0 & 0,0 & 0,0 & 0,0 \\
\hline $\begin{array}{l}\text { vloer- en/of mestkelderaanpassing / floor and/or } \\
\text { manure pit adaptations }\end{array}$ & 0,0 & 0,0 & 0,0 & 0,0 & 0,0 & 0,0 & 0,0 & 100 & 100 & 100 & 100 & 100 & 100 & 100 & 100 \\
\hline $\begin{array}{l}\text { Emissiearme stal guste en dragende zeugen, } \\
\text { totaal / Low emission housing mating and } \\
\text { gestating sows, total }\end{array}$ & 100 & 100 & 100 & 100 & 100 & 100 & 100 & 100 & 100 & 100 & 100 & 100 & 100 & 100 & 100 \\
\hline \multicolumn{16}{|l|}{ waarvan / of which: } \\
\hline luchtwasser ${ }^{11}$ / air scrubber ${ }^{1)}$ & 0,0 & 0,0 & 0,0 & 0,0 & 0,0 & 0,0 & 0,0 & 0,0 & 0,0 & 0,0 & 0,0 & 0,0 & 0,0 & 0,0 & 0,0 \\
\hline $\begin{array}{l}\text { vloer- en/of mestkelderaanpassing / floor and/or } \\
\text { manure pit adaptations }\end{array}$ & 0,0 & 0,0 & 0,0 & 0,0 & 0,0 & 0,0 & 0,0 & 100 & 100 & 100 & 100 & 100 & 100 & 100 & 100 \\
\hline $\begin{array}{l}\text { Emissiearme stal gespeende biggen, totaal / Low } \\
\text { emission housing weaned piglets, total }\end{array}$ & 100 & 100 & 100 & 100 & 100 & 100 & 100 & 100 & 100 & 100 & 100 & 100 & 100 & 100 & 100 \\
\hline \multicolumn{16}{|l|}{ waarvan / of which: } \\
\hline luchtwasser $^{1)} /$ air scrubber $^{1)}$ & 0,0 & 0,0 & 0,0 & 0,0 & 0,0 & 0,0 & 0,0 & 0,0 & 0,0 & 0,0 & 0,0 & 0,0 & 0,0 & 0,0 & 0,0 \\
\hline $\begin{array}{l}\text { vloer- en/of mestkelderaanpassing / floor and/or } \\
\text { manure pit adaptations }\end{array}$ & 0,0 & 0,0 & 0,0 & 0,0 & 0,0 & 0,0 & 0,0 & 100 & 100 & 100 & 100 & 100 & 100 & 100 & 100 \\
\hline Dekberen, totaal / Breeding boars, totaal & 100 & 100 & 100 & 100 & 100 & 100 & 100 & 100 & 100 & 100 & 100 & 100 & 100 & 100 & 100 \\
\hline \multicolumn{16}{|l|}{ waarvan / of which: } \\
\hline reguliere stal / regular housing & 100 & 100 & 100 & 100 & 100 & 100 & 100 & 95,5 & 95,5 & 95,5 & 90,2 & 90,2 & 90,2 & 90,2 & 90,2 \\
\hline emissiearme stal / low emission housing & 0,0 & 0,0 & 0,0 & 0,0 & 0,0 & 0,0 & 0,0 & 4,5 & 4,5 & 4,5 & 9,8 & 9,8 & 9,8 & 9,8 & 9,8 \\
\hline
\end{tabular}




\begin{tabular}{|c|c|c|c|c|c|c|c|c|c|c|c|c|c|c|c|}
\hline & 1990 & 1991 & 1992 & 1993 & 1994 & 1995 & 1996 & 1997 & 1998 & 1999 & 2000 & 2001 & 2002 & 2003 & 2004 \\
\hline emissiearm, totaal / reduced emission housing, total & 100 & 100 & 100 & 100 & 100 & 100 & 100 & 100 & 100 & 100 & 100 & 100 & 100 & 100 & 100 \\
\hline \multicolumn{16}{|l|}{ waarvan / of which: } \\
\hline luchtwasser $^{1)} /$ air scrubber ${ }^{1)}$ & 0,0 & 0,0 & 0,0 & 0,0 & 0,0 & 0,0 & 0,0 & 100 & 100 & 100 & 100 & 100 & 100 & 100 & 100 \\
\hline $\begin{array}{l}\text { vloer- en/of mestkelderaanpassing / floor and/or } \\
\text { manure pit adaptations }\end{array}$ & 0,0 & 0,0 & 0,0 & 0,0 & 0,0 & 0,0 & 0,0 & 0,0 & 0,0 & 0,0 & 0,0 & 0,0 & 0,0 & 0,0 & 0,0 \\
\hline Vleesvarkens, totaal / Fattening pigs, total & 100 & 100 & 100 & 100 & 100 & 100 & 100 & 100 & 100 & 100 & 100 & 100 & 100 & 100 & 100 \\
\hline \multicolumn{16}{|l|}{ waarvan reguliere stal / of which regular housing: } \\
\hline $\begin{array}{l}\text { volledig onderkelderd } 0,8 \mathrm{~m}^{2} / \text { dierplaats / fully } \\
\text { undercellared } 0.8 \mathrm{~m}^{2} / \text { animal place }\end{array}$ & 50,0 & 50,0 & 50,0 & 50,0 & 50,0 & 50,0 & 50,0 & 48,0 & 48,0 & 48,0 & 43,5 & 43,5 & 43,5 & 43,5 & 43,5 \\
\hline $\begin{array}{l}\text { volledig onderkelderd } 1,0 \mathrm{~m}^{2} / \text { dierplaats / fully } \\
\text { undercellared } 1.0 \mathrm{~m}^{2} / \text { animal place }\end{array}$ & 0,0 & 0,0 & 0,0 & 0,0 & 0,0 & 0,0 & 0,0 & 0,0 & 0,0 & 0,0 & 0,0 & 0,0 & 0,0 & 0,0 & 0,0 \\
\hline overig $0,8 \mathrm{~m}^{2} /$ dierplaats / other $0.8 \mathrm{~m}^{2} /$ animal place & 50,0 & 50,0 & 50,0 & 50,0 & 50,0 & 50,0 & 50,0 & 48,0 & 48,0 & 48,0 & 43,5 & 43,5 & 43,5 & 43,5 & 43,5 \\
\hline overig $1,0 \mathrm{~m}^{2} /$ dierplaats / other $1.0 \mathrm{~m}^{2} /$ animal place & 0,0 & 0,0 & 0,0 & 0,0 & 0,0 & 0,0 & 0,0 & 0,0 & 0,0 & 0,0 & 0,0 & 0,0 & 0,0 & 0,0 & 0,0 \\
\hline \multicolumn{16}{|l|}{$\begin{array}{l}\text { waarvan emissiearme stal / of which reduced emission } \\
\text { housing: }\end{array}$} \\
\hline $\begin{array}{l}\text { luchtwasser }{ }^{1)} 0,8 \mathrm{~m}^{2} / \text { dierplaats / air scrubber }{ }^{1)} 0.8 \\
\mathrm{~m}^{2} / \text { animal place }\end{array}$ & 0,0 & 0,0 & 0,0 & 0,0 & 0,0 & 0,0 & 0,0 & 0,0 & 0,0 & 0,0 & 0,0 & 0,0 & 0,0 & 0,0 & 0,0 \\
\hline 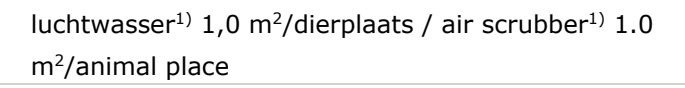 & 0,0 & 0,0 & 0,0 & 0,0 & 0,0 & 0,0 & 0,0 & 0,0 & 0,0 & 0,0 & 0,0 & 0,0 & 0,0 & 0,0 & 0,0 \\
\hline $\begin{array}{l}\text { vloer- en/of mestkelderaanpassing } 0,8 \mathrm{~m}^{2} / \text { dierplaats } \\
\text { / floor and/or manure pit adaptations } 0.8 \mathrm{~m}^{2} / \text { animal } \\
\text { place }\end{array}$ & 0,0 & 0,0 & 0,0 & 0,0 & 0,0 & 0,0 & 0,0 & 4,0 & 4,0 & 4,0 & 13,0 & 13,0 & 13,0 & 13,0 & 13,0 \\
\hline $\begin{array}{l}\text { vloer- en/of mestkelderaanpassing } 1,0 \mathrm{~m}^{2} / \text { dierplaats } \\
\text { / floor and/or manure pit adaptations } 1.0 \mathrm{~m}^{2} / \text { animal } \\
\text { place }\end{array}$ & 0,0 & 0,0 & 0,0 & 0,0 & 0,0 & 0,0 & 0,0 & 0,0 & 0,0 & 0,0 & 0,0 & 0,0 & 0,0 & 0,0 & 0,0 \\
\hline $\begin{array}{l}\text { Opfokzeugen en -beren, totaal / Gilts and young } \\
\text { boars, total }\end{array}$ & 100 & 100 & 100 & 100 & 100 & 100 & 100 & 100 & 100 & 100 & 100 & 100 & 100 & 100 & 100 \\
\hline \multicolumn{16}{|l|}{ waarvan reguliere stal / of which regular housing: } \\
\hline $\begin{array}{l}\text { volledig onderkelderd } 0,8 \mathrm{~m}^{2} / \text { dierplaats / fully } \\
\text { undercellared } 0.8 \mathrm{~m}^{2} / \text { animal place }\end{array}$ & 50,0 & 50,0 & 50,0 & 50,0 & 50,0 & 50,0 & 50,0 & 46,3 & 46,3 & 46,3 & 41,9 & 41,9 & 41,9 & 41,9 & 41,9 \\
\hline $\begin{array}{l}\text { volledig onderkelderd } 1,0 \mathrm{~m}^{2} / \text { dierplaats / fully } \\
\text { undercellared } 1.0 \mathrm{~m}^{2} / \text { animal place }\end{array}$ & 0,0 & 0,0 & 0,0 & 0,0 & 0,0 & 0,0 & 0,0 & 0,0 & 0,0 & 0,0 & 0,0 & 0,0 & 0,0 & 0,0 & 0,0 \\
\hline overig $0,8 \mathrm{~m}^{2} /$ dierplaats / other $0.8 \mathrm{~m}^{2} /$ animal place & 50,0 & 50,0 & 50,0 & 50,0 & 50,0 & 50,0 & 50,0 & 46,3 & 46,3 & 46,3 & 41,9 & 41,9 & 41,9 & 41,9 & 41,9 \\
\hline overig $1,0 \mathrm{~m}^{2} /$ dierplaats / other $1.0 \mathrm{~m}^{2} /$ animal place & 0,0 & 0,0 & 0,0 & 0,0 & 0,0 & 0,0 & 0,0 & 0,0 & 0,0 & 0,0 & 0,0 & 0,0 & 0,0 & 0,0 & 0,0 \\
\hline \multicolumn{16}{|l|}{$\begin{array}{l}\text { waarvan emissiearme stal / of which reduced emission } \\
\text { housing: }\end{array}$} \\
\hline $\begin{array}{l}\text { luchtwasser }{ }^{1)} 0,8 \mathrm{~m}^{2} / \text { dierplaats / air scrubber }{ }^{1)} 0.8 \\
\mathrm{~m}^{2} / \text { animal place }\end{array}$ & 0,0 & 0,0 & 0,0 & 0,0 & 0,0 & 0,0 & 0,0 & 0,0 & 0,0 & 0,0 & 0,0 & 0,0 & 0,0 & 0,0 & 0,0 \\
\hline
\end{tabular}

108 | wot-technical report 203 


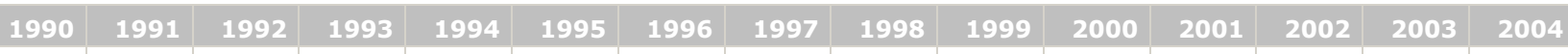

luchtwasser ${ }^{1)} 1,0 \mathrm{~m}^{2} /$ dierplaats / air scrubber ${ }^{1)} 1.0$

$\mathrm{m}^{2} /$ animal place

vloer- en/of mestkelderaanpassing $0,8 \mathrm{~m}^{2} /$ dierplaats

/ floor and/or manure pit adaptations $0.8 \mathrm{~m}^{2} /$ animal

place

vloer- en/of mestkelderaanpassing $1,0 \mathrm{~m}^{2} /$ dierplaats

/ floor and/or manure pit adaptations $1.0 \mathrm{~m}^{2} /$ animal

place

\begin{tabular}{|r|r|r|r|r|r|r|r|r|r|r|r|r|r|r|}
\hline 0,0 & 0,0 & 0,0 & 0,0 & 0,0 & 0,0 & 0,0 & 0,0 & 0,0 & 0,0 & 0,0 & 0,0 & 0,0 & 0,0 & 0,0 \\
\hline & 0,0 & 0,0 & 0,0 & 0,0 & 0,0 & 0,0 & 7,5 & 7,5 & 7,5 & 16,3 & 16,3 & 16,3 & 16,3 & 16,3 \\
\hline
\end{tabular}

B7.1

vervolg / continuation

\begin{tabular}{|c|c|c|c|c|c|c|c|c|c|c|c|c|c|c|c|}
\hline & 2005 & 2006 & 2007 & 2008 & 2009 & 2010 & 2011 & 2012 & 2013 & 2014 & 2015 & 2016 & 2017 & 2018 & 2019 \\
\hline $\begin{array}{l}\text { Fokzeugen incl. biggen tot } 25 \mathrm{~kg} \text {, totaal / Sows } \\
\text { incl. piglets up to } 25 \mathrm{~kg} \text {, total }\end{array}$ & 100 & 100 & 100 & 100 & 100 & 100 & 100 & 100 & 100 & 100 & 100 & 100 & 100 & 100 & 100 \\
\hline \multicolumn{16}{|l|}{ waarvan / of which: } \\
\hline reguliere stal / regular housing & 64,4 & 64,4 & 62,3 & 62,3 & 62,3 & 55,1 & 46,1 & 43,2 & 31,5 & 29,5 & 24,9 & 25,0 & 18,4 & 18,1 & 16,9 \\
\hline emissiearme stal / reduced emission housing & 35,6 & 35,6 & 37,7 & 37,7 & 37,7 & 44,9 & 53,9 & 56,8 & 68,5 & 70,5 & 75,1 & 75,0 & 81,6 & 81,9 & 83,1 \\
\hline $\begin{array}{l}\text { Emissiearme stal kraamzeugen, totaal / Low } \\
\text { emission housing nursing sows, total }\end{array}$ & 100 & 100 & 100 & 100 & 100 & 100 & 100 & 100 & 100 & 100 & 100 & 100 & 100 & 100 & 100 \\
\hline \multicolumn{16}{|l|}{ waarvan / of which: } \\
\hline luchtwasser ${ }^{1)}$ / air scrubber ${ }^{11}$ & 13,9 & 13,9 & 17,2 & 17,2 & 17,2 & 32,1 & 43,0 & 45,5 & 54,7 & 55,8 & 56,7 & 58,5 & 59,4 & 61,4 & 64,6 \\
\hline $\begin{array}{l}\text { vloer- en/of mestkelderaanpassing / floor and/or } \\
\text { manure pit adaptations }\end{array}$ & 86,1 & 86,1 & 82,8 & 82,8 & 82,8 & 67,9 & 57,0 & 54,5 & 45,3 & 44,2 & 43,3 & 41,5 & 40,6 & 38,6 & 35,4 \\
\hline $\begin{array}{l}\text { Emissiearme stal guste en dragende zeugen, } \\
\text { totaal / Low emission housing mating and } \\
\text { gestating sows, total }\end{array}$ & 100 & 100 & 100 & 100 & 100 & 100 & 100 & 100 & 100 & 100 & 100 & 100 & 100 & 100 & 100 \\
\hline \multicolumn{16}{|l|}{ waarvan / of which: } \\
\hline luchtwasser ${ }^{1)}$ / air scrubber ${ }^{1)}$ & 16,6 & 16,6 & 19,6 & 19,6 & 19,6 & 32,1 & 50,5 & 53,0 & 65,3 & 66,3 & 67,8 & 69,8 & 70,0 & 73,6 & 74,5 \\
\hline $\begin{array}{l}\text { vloer- en/of mestkelderaanpassing / floor and/or } \\
\text { manure pit adaptations }\end{array}$ & 83,4 & 83,4 & 80,4 & 80,4 & 80,4 & 67,9 & 49,5 & 47,0 & 34,7 & 33,7 & 32,2 & 30,2 & 30,0 & 26,4 & 25,5 \\
\hline $\begin{array}{l}\text { Emissiearme stal gespeende biggen, totaal / Low } \\
\text { emission housing weaned piglets, total }\end{array}$ & 100 & 100 & 100 & 100 & 100 & 100 & 100 & 100 & 100 & 100 & 100 & 100 & 100 & 100 & 100 \\
\hline \multicolumn{16}{|l|}{ waarvan / of which: } \\
\hline luchtwasser $^{1)} /$ air scrubber ${ }^{1)}$ & 9,7 & 9,7 & 13,3 & 13,3 & 13,3 & 21,5 & 32,8 & 36,3 & 43,7 & 45,7 & 48,8 & 52,7 & 55,5 & 58,0 & 59,4 \\
\hline $\begin{array}{l}\text { vloer- en/of mestkelderaanpassing / floor and/or } \\
\text { manure pit adaptations }\end{array}$ & 90,3 & 90,3 & 86,7 & 86,7 & 86,7 & 78,5 & 67,2 & 63,7 & 56,3 & 54,3 & 51,2 & 47,3 & 44,5 & 42,0 & 40,6 \\
\hline
\end{tabular}




\begin{tabular}{|c|c|c|c|c|c|c|c|c|c|c|c|c|c|c|c|}
\hline & 2005 & 2006 & 2007 & 2008 & 2009 & 2010 & 2011 & 2012 & 2013 & 2014 & 2015 & 2016 & 2017 & 2018 & 2019 \\
\hline Dekberen, totaal / Breeding boars, total & 100 & 100 & 100 & 100 & 100 & 100 & 100 & 100 & 100 & 100 & 100 & 100 & 100 & 100 & 100 \\
\hline \multicolumn{16}{|l|}{ waarvan / of which: } \\
\hline reguliere stal / regular housing & 97,9 & 97,9 & 97,5 & 97,5 & 97,5 & 97,1 & 78,3 & 77,3 & 76,8 & 76,2 & 73,6 & 72,2 & 69,8 & 56,9 & 62,5 \\
\hline emissiearme stal / low emission housing & 2,1 & 2,1 & 2,5 & 2,5 & 2,5 & 2,9 & 21,7 & 22,7 & 23,2 & 23,8 & 26,4 & 27,8 & 30,2 & 43,1 & 37,5 \\
\hline emissiearm, totaal / reduced emission housing, total & 100 & 100 & 100 & 100 & 100 & 100 & 100 & 100 & 100 & 100 & 100 & 100 & 100 & 100 & 100 \\
\hline \multicolumn{16}{|l|}{ waarvan / of which: } \\
\hline luchtwasser ${ }^{11}$ / air scrubber ${ }^{1)}$ & 100 & 100 & 100 & 100 & 100 & 100 & 45,9 & 48,3 & 49,5 & 50,6 & 95,0 & 94,1 & 96,3 & 95,7 & 96,3 \\
\hline $\begin{array}{l}\text { vloer- en/of mestkelderaanpassing / floor and/or } \\
\text { manure pit adaptations }\end{array}$ & 0,0 & 0,0 & 0,0 & 0,0 & 0,0 & 0,0 & 54,1 & 51,7 & 50,5 & 49,4 & 5,0 & 5,9 & 3,7 & 4,3 & 3,7 \\
\hline $\begin{array}{l}\text { Vleesvarkens, opfokzeugen en -beren, totaal / } \\
\text { Fattening pigs, gilts and young boars, total }\end{array}$ & 100 & 100 & 100 & 100 & 100 & 100 & 100 & 100 & 100 & 100 & 100 & 100 & 100 & 100 & 100 \\
\hline \multicolumn{16}{|l|}{ waarvan reguliere stal / of which regular housing: } \\
\hline $\begin{array}{l}\text { volledig onderkelderd } 0,8 \mathrm{~m}^{2} / \text { dierplaats / fully } \\
\text { undercellared } 0,8 \mathrm{~m}^{2} / \text { animal place }\end{array}$ & 33,2 & 33,2 & 36,1 & 36,1 & 36,1 & 28,6 & 9,8 & 9,7 & 5,6 & 5,2 & 7,0 & 5,6 & 5,4 & 3,6 & 2,9 \\
\hline $\begin{array}{l}\text { volledig onderkelderd } 1,0 \mathrm{~m}^{2} / \text { dierplaats / fully } \\
\text { undercellared } 1,0 \mathrm{~m}^{2} / \text { animal place }\end{array}$ & 0,0 & 0,0 & 0,0 & 0,0 & 0,0 & 0,3 & 0,2 & 0,3 & 0,2 & 0,6 & 1,0 & 1,3 & 1,2 & 1,1 & 0,9 \\
\hline overig $0,8 \mathrm{~m}^{2} /$ dierplaats / other $0.8 \mathrm{~m}^{2} /$ animal place & 37,4 & 37,4 & 30,8 & 30,8 & 30,8 & 27,1 & 37,3 & 34,1 & 23,7 & 20,5 & 16,6 & 12,5 & 12,4 & 10,7 & 8,7 \\
\hline overig $1,0 \mathrm{~m}^{2} /$ dierplaats / other $1.0 \mathrm{~m}^{2} /$ animal place & 0,0 & 0,0 & 0,0 & 0,0 & 0,0 & 0,3 & 0,8 & 1,1 & 1,0 & 2,3 & 2,2 & 2,9 & 2,7 & 3,4 & 2,7 \\
\hline \multicolumn{16}{|l|}{$\begin{array}{l}\text { waarvan emissiearme stal / of which reduced emission } \\
\text { housing: }\end{array}$} \\
\hline $\begin{array}{l}\text { luchtwasser }{ }^{1)} 0,8 \mathrm{~m}^{2} / \text { dierplaats / air scrubber }{ }^{1)} 0.8 \\
\mathrm{~m}^{2} / \text { animal place }\end{array}$ & 4,5 & 4,5 & 8,1 & 8,1 & 8,1 & 14,8 & 26,5 & 29,0 & 41,0 & 40,1 & 40,6 & 41,3 & 42,6 & 42,6 & 44,9 \\
\hline $\begin{array}{l}\text { luchtwasser }{ }^{1)} 1,0 \mathrm{~m}^{2} / \text { dierplaats / air scrubber }{ }^{1)} 1.0 \\
\mathrm{~m}^{2} / \text { animal place }\end{array}$ & 0,0 & 0,0 & 0,0 & 0,0 & 0,0 & 0,1 & 0,5 & 0,9 & 1,7 & 4,5 & 5,6 & 9,7 & 9,4 & 13,5 & 14,2 \\
\hline $\begin{array}{l}\text { vloer- en/of mestkelderaanpassing } 0,8 \mathrm{~m}^{2} / \text { dierplaats } \\
\text { / floor and/or manure pit adaptations } 0.8 \mathrm{~m}^{2} / \text { animal } \\
\text { place }\end{array}$ & 24,9 & 24,9 & 25,0 & 25,0 & 25,0 & 28,6 & 24,4 & 24,2 & 25,7 & 24,1 & 23,8 & 21,6 & 21,6 & 19,1 & 19,5 \\
\hline $\begin{array}{l}\text { vloer- en/of mestkelderaanpassing } 1,0 \mathrm{~m}^{2} / \text { dierplaats } \\
\text { / floor and/or manure pit adaptations } 1.0 \mathrm{~m}^{2} / \text { animal } \\
\text { place }\end{array}$ & 0,0 & 0,0 & 0,0 & 0,0 & 0,0 & 0,3 & 0,5 & 0,7 & 1,1 & 2,7 & 3,2 & 5,1 & 4,7 & 6,0 & 6,2 \\
\hline
\end{tabular}

1) Gecorrigeerd voor niet-operationele luchtwassers tijdens handhavingsactiviteiten / Adjusted for non-operating air scrubbers during enforcement activities.

Bron: Landbouwtelling / Source: Agricultural census. 
Vleesvarkens naar aantal aantal sterren 'Beter-Leven' (x 1.000) / Fattening pigs with welfare quality mark (x 1,000).

\begin{tabular}{|c|c|c|c|c|c|c|c|c|c|c|}
\hline & 2010 & 2011 & 2012 & 2013 & 2014 & 2015 & 2016 & 2017 & 2018 & 2019 \\
\hline Vleesvarkens / Fattening pigs & 5.904 & 5.905 & 5.874 & 5.754 & 5.657 & 5.804 & 5.726 & 5.630 & 5.591 & 5.563 \\
\hline Varkens met Beter Leven Keurmerk ${ }^{1)}$ / Pigs with welfare quality mark $^{1)}$ & 59 & 120 & 175 & 220 & 515 & 684 & 1.065 & 979 & 1.307 & 1.290 \\
\hline $\begin{array}{l}\text { Bio-varkens (vergelijkbaar met } 3 \text { sterren) })^{2)} / \text { Organic pigs (comparable with } \\
\text { best welfare quality mark) }{ }^{2)}\end{array}$ & & & 30 & 30 & 34 & 33 & 36 & 46 & 48 & 54 \\
\hline Totaal aandeel dieren met groter leefoppervlak (\%) / Total number with & & & & & & & & & & \\
\hline
\end{tabular}

enlarged floor space (\%)

1) Exclusief biologisch gehouden varkens (Scholtens $(2015 ; 2017)$ en Vaandrager $(2018 ; 2019 ; 2020))$ / Excluding organicly farmed pigs (Scholtens (2015; 2017) and Vaandrager (2018; 2019;

2) Bron: Landbouwtelling / Source: Agricultural census 



\section{Bijlage 8 Stalsystemen voor pluimvee}

\begin{tabular}{|c|c|c|c|c|c|c|c|c|c|c|c|c|c|c|c|}
\hline & 1990 & 1991 & 1992 & 1993 & 1994 & 1995 & 1996 & 1997 & 1998 & 1999 & 2000 & 2001 & 2002 & 2003 & 2004 \\
\hline $\begin{array}{l}\text { Opfokhennen en -hanen legrassen }<18 \text { weken, } \\
\text { totaal / Laying hens and roosters }<18 \text { weeks, } \\
\text { total }\end{array}$ & 100 & 100 & 100 & 100 & 100 & 100 & 100 & 100 & 100 & 100 & 100 & 100 & 100 & 100 & 100 \\
\hline \multicolumn{16}{|l|}{ waarvan / of which: } \\
\hline $\begin{array}{l}\text { batterij met open mestopslag / battery cages with } \\
\text { open manure storage }\end{array}$ & 32,0 & 32,0 & 32,0 & 32,0 & 25,0 & 23,0 & 23,0 & 23,0 & 12,5 & 12,5 & 12,5 & 8,5 & 7,5 & 4,8 & 4,8 \\
\hline $\begin{array}{l}\text { batterij met } 2 x / \text { week ontmesten / battery cages with } \\
2 x / \text { week manure removal }\end{array}$ & 34,0 & 34,0 & 34,0 & 34,0 & 35,0 & 32,0 & 32,0 & 32,0 & 12,5 & 12,5 & 12,5 & 8,5 & 7,5 & 4,8 & 4,8 \\
\hline \multicolumn{16}{|l|}{$\begin{array}{l}\text { batterij met mestbanden en beluchting / battery } \\
\text { cages with manure belts and aeration: }\end{array}$} \\
\hline $\begin{array}{l}\text { droging } 0,2 \mathrm{~m}^{3} / \text { dierplaats } / \mathrm{u} / \text { drying } 0.2 \\
\mathrm{~m}^{3} / \text { place } / \mathrm{h}\end{array}$ & 6,0 & 6,0 & 6,0 & 6,0 & 23,0 & 27,0 & 27,0 & 27,0 & 48,6 & 48,6 & 48,6 & 47,0 & 48,1 & 45,9 & 45,9 \\
\hline $\begin{array}{l}\text { droging } 0,4 \mathrm{~m}^{3} / \text { dierplaats } / \mathrm{u} / \text { drying } 0.4 \\
\mathrm{~m}^{3} / \text { place } / \mathrm{h}\end{array}$ & 0,0 & 0,0 & 0,0 & 0,0 & 0,0 & 0,0 & 0,0 & 0,0 & 0,0 & 0,0 & 0,0 & 0,0 & 0,0 & 0,0 & 0,0 \\
\hline $\begin{array}{l}\text { droging } 0,4 \mathrm{~m}^{3} / \text { dierplaats } / \mathrm{u} \text { met luchtwasser }{ }^{1)} / \\
\text { drying } 0.4 \mathrm{~m}^{3} / \text { place }_{\text {h }} \text { with air scrubber }{ }^{1)}\end{array}$ & 0,0 & 0,0 & 0,0 & 0,0 & 0,0 & 0,0 & 0,0 & 0,0 & 0,0 & 0,0 & 0,0 & 0,0 & 0,0 & 0,0 & 0,0 \\
\hline $\begin{array}{l}\text { overige kooien vaste mest / other cages with solid } \\
\text { manure }\end{array}$ & 0,0 & 0,0 & 0,0 & 0,0 & 4,0 & 4,0 & 4,0 & 4,0 & 2,1 & 2,1 & 2,1 & 0,0 & 0,0 & 0,0 & 0,0 \\
\hline $\begin{array}{l}\text { grondhuisvesting zonder mestbeluchting / floor } \\
\text { housing without manure aeration }\end{array}$ & 28,0 & 28,0 & 28,0 & 28,0 & 13,0 & 14,0 & 14,0 & 14,0 & 24,3 & 24,3 & 24,3 & 23,4 & 24,0 & 34,7 & 34,7 \\
\hline $\begin{array}{l}\text { grondhuisvesting met luchtwasser }{ }^{1)} / \text { floor housing } \\
\text { with air scrubber }{ }^{1)}\end{array}$ & 0,0 & 0,0 & 0,0 & 0,0 & 0,0 & 0,0 & 0,0 & 0,0 & 0,0 & 0,0 & 0,0 & 0,0 & 0,0 & 0,0 & 0,0 \\
\hline $\begin{array}{l}\text { volièrehuisvesting zonder mestbeluchting / aviary } \\
\text { systems without manure aeration }\end{array}$ & 0,0 & 0,0 & 0,0 & 0,0 & 0,0 & 0,0 & 0,0 & 0,0 & 0,0 & 0,0 & 0,0 & 12,6 & 12,9 & 9,2 & 9,2 \\
\hline $\begin{array}{l}\text { volièrehuisvesting met mestbeluchting / aviary } \\
\text { systems with manure aeration }\end{array}$ & 0,0 & 0,0 & 0,0 & 0,0 & 0,0 & 0,0 & 0,0 & 0,0 & 0,0 & 0,0 & 0,0 & 0,0 & 0,0 & 0,0 & 0,0 \\
\hline $\begin{array}{l}\text { volièrehuisvesting met luchtwasser }{ }^{1 /} / \text { aviary } \\
\text { systems with air scrubber }{ }^{1)}\end{array}$ & 0,0 & 0,0 & 0,0 & 0,0 & 0,0 & 0,0 & 0,0 & 0,0 & 0,0 & 0,0 & 0,0 & 0,0 & 0,0 & 0,0 & 0,0 \\
\hline overige huisvesting / other housing systems & 0,0 & 0,0 & 0,0 & 0,0 & 0,0 & 0,0 & 0,0 & 0,0 & 0,0 & 0,0 & 0,0 & 0,0 & 0,0 & 0,6 & 0,6 \\
\hline $\begin{array}{l}\text { Hennen en -hanen legrassen } \geq 18 \text { weken, totaal } \\
\text { / Laying hens and roosters } \geq 18 \text { weeks, total }\end{array}$ & 100 & 100 & 100 & 100 & 100 & 100 & 100 & 100 & 100 & 100 & 100 & 100 & 100 & 100 & 100 \\
\hline
\end{tabular}




\begin{tabular}{|c|c|c|c|c|c|c|c|c|c|c|c|c|c|c|c|}
\hline & 1990 & 1991 & 1992 & 1993 & 1994 & 1995 & 1996 & 1997 & 1998 & 1999 & 2000 & 2001 & 2002 & 2003 & 2004 \\
\hline \multicolumn{16}{|l|}{ waarvan / of which: } \\
\hline $\begin{array}{l}\text { batterij met open mestopslag / battery cages with } \\
\text { open manure storage }\end{array}$ & 20,0 & 20,0 & 20,0 & 20,0 & 15,0 & 8,0 & 8,0 & 8,0 & 9,0 & 9,0 & 9,0 & 3,1 & 2,7 & 1,0 & 1,0 \\
\hline $\begin{array}{l}\text { batterij met } 2 x / \text { week ontmesten / battery cages with } \\
2 x / \text { week manure removal }\end{array}$ & 40,0 & 40,0 & 40,0 & 40,0 & 35,0 & 34,0 & 34,0 & 34,0 & 13,0 & 13,0 & 13,0 & 11,9 & 10,3 & 6,2 & 6,2 \\
\hline deeppitstal / deep pit & 7,0 & 7,0 & 7,0 & 7,0 & 8,0 & 8,0 & 8,0 & 8,0 & 7,0 & 7,0 & 7,0 & 1,4 & 1,4 & 0,6 & 0,6 \\
\hline \multicolumn{16}{|l|}{$\begin{array}{l}\text { batterij met mestbanden en beluchting / battery } \\
\text { cages with manure belts and aeration: }\end{array}$} \\
\hline $\begin{array}{l}\text { droging } 0,5 \mathrm{~m}^{3} / \text { dierplaats } / \mathrm{u} / \text { drying } 0.5 \\
\mathrm{~m}^{3} / \text { place } / \mathrm{h}\end{array}$ & 25,0 & 25,0 & 25,0 & 25,0 & 29,0 & 37,0 & 37,0 & 37,0 & 46,0 & 46,0 & 46,0 & 47,5 & 48,6 & 46,1 & 46,1 \\
\hline $\begin{array}{l}\text { droging } 0,7 \mathrm{~m}^{3} / \text { dierplaats } / \mathrm{u} / \text { drying } 0.7 \\
\mathrm{~m}^{3} / \text { place } / \mathrm{h}\end{array}$ & 0,0 & 0,0 & 0,0 & 0,0 & 0,0 & 0,0 & 0,0 & 0,0 & 0,0 & 0,0 & 0,0 & 0,0 & 0,0 & 0,0 & 0,0 \\
\hline $\begin{array}{l}\text { droging } 0,7 \mathrm{~m}^{3} / \text { dierplaats/u met luchtwasser }{ }^{1)} / \\
\text { drying } 0.7 \mathrm{~m}^{3} / \text { place }^{\prime} \text { h with air scrubber }{ }^{1)}\end{array}$ & 0,0 & 0,0 & 0,0 & 0,0 & 0,0 & 0,0 & 0,0 & 0,0 & 0,0 & 0,0 & 0,0 & 0,0 & 0,0 & 0,0 & 0,0 \\
\hline $\begin{array}{l}\text { overige kooien vaste mest / other cages with solid } \\
\text { manure }\end{array}$ & 0,0 & 0,0 & 0,0 & 0,0 & 2,0 & 2,0 & 2,0 & 2,0 & 2,0 & 2,0 & 2,0 & 4,5 & 4,6 & 2,9 & 2,9 \\
\hline \multicolumn{16}{|l|}{ grondhuisvesting / floor housing: } \\
\hline zonder mestbeluchting / without manure aeration & 8,0 & 8,0 & 8,0 & 8,0 & 11,0 & 11,0 & 11,0 & 11,0 & 23,0 & 23,0 & 23,0 & 25,2 & 25,8 & 33,0 & 33,0 \\
\hline perfosysteem / perfosystem & 0,0 & 0,0 & 0,0 & 0,0 & 0,0 & 0,0 & 0,0 & 0,0 & 0,0 & 0,0 & 0,0 & 0,0 & 0,0 & 0,0 & 0,0 \\
\hline mestbeluchting / manure aeration & 0,0 & 0,0 & 0,0 & 0,0 & 0,0 & 0,0 & 0,0 & 0,0 & 0,0 & 0,0 & 0,0 & 0,0 & 0,0 & 0,0 & 0,0 \\
\hline mestbanden / manure belts & 0,0 & 0,0 & 0,0 & 0,0 & 0,0 & 0,0 & 0,0 & 0,0 & 0,0 & 0,0 & 0,0 & 0,0 & 0,0 & 0,0 & 0,0 \\
\hline $\begin{array}{l}\text { volièrehuisvesting zonder mestbeluchting / aviary } \\
\text { systems without manure aeration }\end{array}$ & 0,0 & 0,0 & 0,0 & 0,0 & 0,0 & 0,0 & 0,0 & 0,0 & 0,0 & 0,0 & 0,0 & 6,4 & 6,6 & 7,6 & 7,6 \\
\hline $\begin{array}{l}\text { volièrehuisvesting met mestbeluchting / aviary } \\
\text { systems with manure aeration }\end{array}$ & 0,0 & 0,0 & 0,0 & 0,0 & 0,0 & 0,0 & 0,0 & 0,0 & 0,0 & 0,0 & 0,0 & 0,0 & 0,0 & 0,0 & 0,0 \\
\hline overige huisvesting / other housing systems & 0,0 & 0,0 & 0,0 & 0,0 & 0,0 & 0,0 & 0,0 & 0,0 & 0,0 & 0,0 & 0,0 & 0,0 & 0,0 & 2,6 & 2,6 \\
\hline $\begin{array}{l}\text { Ouderdieren van vleeskuikens }<18 \text { weken, } \\
\text { totaal / Broiler breeders }<18 \text { weeks, total }\end{array}$ & 100 & 100 & 100 & 100 & 100 & 100 & 100 & 100 & 100 & 100 & 100 & 100 & 100 & 100 & 100 \\
\hline \multicolumn{16}{|l|}{ waarvan / of which: } \\
\hline reguliere huisvesting / regular housing & 100 & 100 & 100 & 100 & 100 & 100 & 100 & 100 & 100 & 100 & 100 & 100 & 100 & 100 & 100 \\
\hline luchtwasser ${ }^{1}$, biofilter / air scrubber ${ }^{1)}$, biofilter & 0,0 & 0,0 & 0,0 & 0,0 & 0,0 & 0,0 & 0,0 & 0,0 & 0,0 & 0,0 & 0,0 & 0,0 & 0,0 & 0,0 & 0,0 \\
\hline $\begin{array}{l}\text { overige emissiearme huisvesting / other low } \\
\text { emission housing }\end{array}$ & 0,0 & 0,0 & 0,0 & 0,0 & 0,0 & 0,0 & 0,0 & 0,0 & 0,0 & 0,0 & 0,0 & 0,0 & 0,0 & 0,0 & 0,0 \\
\hline $\begin{array}{l}\text { Ouderdieren van vleeskuikens } \geq 18 \text { weken, } \\
\text { totaal / Broiler breeders } \geq 18 \text { weeks, total }\end{array}$ & 100 & 100 & 100 & 100 & 100 & 100 & 100 & 100 & 100 & 100 & 100 & 100 & 100 & 100 & 100 \\
\hline \multicolumn{16}{|l|}{ waarvan / of which: } \\
\hline reguliere huisvesting / regular housing & 100 & 100 & 100 & 100 & 100 & 100 & 100 & 100 & 100 & 100 & 100 & 100 & 100 & 100 & 100 \\
\hline emissiearme huisvesting / low emission housing: & & & & & & & & & & & & & & & \\
\hline
\end{tabular}

114 | wot-technical report 203 
groepskooi / colony housing

volièrehuisvesting met mestbeluchting / aviary

system with manure aeration

grondhuisvesting met mestbeluchting van bovenaf

/ floor housing with manure aeration from above

grondhuisvesting met mestbeluchting via verticale

slangen in de mest / floor housing with vertical

aeration tubes in the manure

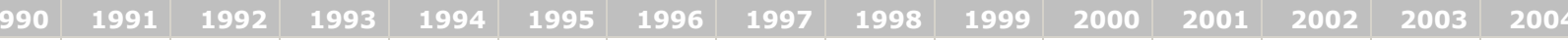

grondhuisvesting - perfosysteem / floor housing -

perfosystem

luchtwasser ${ }^{1)} /$ air scrubber ${ }^{1)}$

grondhuisvesting met mestbanden / floor housing

with manure belts

\begin{tabular}{|c|c|c|c|c|c|c|c|c|c|c|c|c|c|c|}
\hline 0,0 & 0,0 & 0,0 & 0,0 & 0,0 & 0,0 & 0,0 & 0,0 & 0,0 & 0,0 & 0,0 & 0,0 & 0,0 & 0,0 & 0,0 \\
\hline 0,0 & 0,0 & 0,0 & 0,0 & 0,0 & 0,0 & 0,0 & 0,0 & 0,0 & 0,0 & 0,0 & 0,0 & 0,0 & 0,0 & 0,0 \\
\hline 0,0 & 0,0 & 0,0 & 0,0 & 0,0 & 0,0 & 0,0 & 0,0 & 0,0 & 0,0 & 0,0 & 0,0 & 0,0 & 0,0 & 0,0 \\
\hline 0,0 & 0,0 & 0,0 & 0,0 & 0,0 & 0,0 & 0,0 & 0,0 & 0,0 & 0,0 & 0,0 & 0,0 & 0,0 & 0,0 & 0,0 \\
\hline 0,0 & 0,0 & 0,0 & 0,0 & 0,0 & 0,0 & 0,0 & 0,0 & 0,0 & 0,0 & 0,0 & 0,0 & 0,0 & 0,0 & 0,0 \\
\hline 0,0 & 0,0 & 0,0 & 0,0 & 0,0 & 0,0 & 0,0 & 0,0 & 0,0 & 0,0 & 0,0 & 0,0 & 0,0 & 0,0 & 0,0 \\
\hline 0,0 & 0,0 & 0,0 & 0,0 & 0,0 & 0,0 & 0,0 & 0,0 & 0,0 & 0,0 & 0,0 & 0,0 & 0,0 & 0,0 & 0,0 \\
\hline 100 & 100 & 100 & 100 & 100 & 100 & 100 & 100 & 100 & 100 & 100 & 100 & 100 & 100 & 100 \\
\hline 100 & 100 & 100 & 100 & 100 & 100 & 100 & 100 & 100 & 100 & 100 & 100 & 100 & 100 & 100 \\
\hline 0,0 & 0,0 & 0,0 & 0,0 & 0,0 & 0,0 & 0,0 & 0,0 & 0,0 & 0,0 & 0,0 & 0,0 & 0,0 & 0,0 & 0,0 \\
\hline 0,0 & 0,0 & 0,0 & 0,0 & 0,0 & 0,0 & 0,0 & 0,0 & 0,0 & 0,0 & 0,0 & 0,0 & 0,0 & 0,0 & 0,0 \\
\hline 0,0 & 0,0 & 0,0 & 0,0 & 0,0 & 0,0 & 0,0 & 0,0 & 0,0 & 0,0 & 0,0 & 0,0 & 0,0 & 0,0 & 0,0 \\
\hline 0,0 & 0,0 & 0,0 & 0,0 & 0,0 & 0,0 & 0,0 & 0,0 & 0,0 & 0,0 & 0,0 & 0,0 & 0,0 & 0,0 & 0,0 \\
\hline 0,0 & 0,0 & 0,0 & 0,0 & 0,0 & 0,0 & 0,0 & 0,0 & 0,0 & 0,0 & 0,0 & 0,0 & 0,0 & 0,0 & 0,0 \\
\hline 100 & 100 & 100 & 100 & 100 & 100 & 100 & 100 & 100 & 100 & 100 & 100 & 100 & 100 & 100 \\
\hline 100 & 100 & 100 & 100 & 100 & 100 & 100 & 100 & 100 & 100 & 100 & 100 & 100 & 100 & 100 \\
\hline 0,0 & 0,0 & 0,0 & 0,0 & 0,0 & 0,0 & 0,0 & 0,0 & 0,0 & 0,0 & 0,0 & 0,0 & 0,0 & 0,0 & 0,0 \\
\hline 100 & 100 & 100 & 100 & 100 & 100 & 100 & 100 & 100 & 100 & 100 & 100 & 100 & 100 & 100 \\
\hline 100 & 100 & 100 & 100 & 100 & 100 & 100 & 100 & 100 & 100 & 100 & 100 & 100 & 100 & 100 \\
\hline & & 0 & 0 & 0 & 0 & 0 & 0 & 0 & 0 & 0 & 0 & 0 & 0 & \\
\hline
\end{tabular}




\begin{tabular}{|c|c|c|c|c|c|c|c|c|c|c|c|c|c|c|c|}
\hline & 2005 & 2006 & 2007 & 2008 & 2009 & 2010 & 2011 & 2012 & 2013 & 2014 & 2015 & 2016 & 2017 & 2018 & 2019 \\
\hline $\begin{array}{l}\text { Opfokhennen en -hanen legrassen }<18 \text { weken, } \\
\text { totaal / Laying hens and roosters }<18 \text { weeks, } \\
\text { total }\end{array}$ & 100 & 100 & 100 & 100 & 100 & 100 & 100 & 100 & 100 & 100 & 100 & 100 & 100 & 100 & 100 \\
\hline \multicolumn{16}{|l|}{ waarvan / of which: } \\
\hline $\begin{array}{l}\text { batterij met open mestopslag / battery cages with } \\
\text { open manure storage }\end{array}$ & 4,8 & 4,8 & 1,7 & 1,7 & 1,7 & 1,7 & 0,1 & 0,1 & 0,0 & 0,0 & 0,0 & 0,0 & 0,0 & 0,0 & 0,0 \\
\hline $\begin{array}{l}\text { batterij met } 2 x / \text { week ontmesten / battery cages with } \\
2 x / \text { week manure removal }\end{array}$ & 4,8 & 4,8 & 3,4 & 3,4 & 3,4 & 3,4 & 0,3 & 0,3 & 0,0 & 0,0 & 0,0 & 0,0 & 0,0 & 0,0 & 0,0 \\
\hline \multicolumn{16}{|l|}{$\begin{array}{l}\text { batterij met mestbanden en beluchting / battery } \\
\text { cages with manure belts and aeration: }\end{array}$} \\
\hline $\begin{array}{l}\text { droging } 0,2 \mathrm{~m}^{3} / \text { dierplaats } / \mathrm{u} / \text { drying } 0.2 \\
\mathrm{~m}^{3} / \text { place } / \mathrm{h}\end{array}$ & 37,6 & 37,6 & 6,7 & 6,7 & 6,7 & 6,7 & 5,7 & 5,7 & 0,0 & 0,0 & 0,0 & 0,0 & 0,0 & 0,0 & 0,0 \\
\hline $\begin{array}{l}\text { droging } 0,4 \mathrm{~m}^{3} / \text { dierplaats } / \mathrm{u} / \text { drying } 0.4 \\
\mathrm{~m}^{3} / \text { place } / \mathrm{h}\end{array}$ & 8,3 & 8,3 & 18,6 & 18,6 & 18,6 & 18,4 & 4,1 & 4,1 & 0,0 & 0,0 & 0,0 & 0,0 & 0,0 & 0,0 & 0,0 \\
\hline 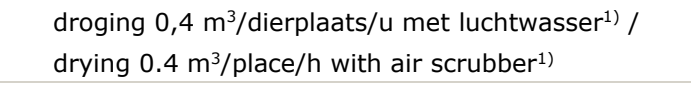 & 0,0 & 0,0 & 0,8 & 0,8 & 0,8 & 1,0 & 0,0 & 0,0 & 0,0 & 0,0 & 0,0 & 0,0 & 0,0 & 0,0 & 0,0 \\
\hline $\begin{array}{l}\text { overige kooien vaste mest / other cages with solid } \\
\text { manure }\end{array}$ & 0,0 & 0,0 & 7,3 & 7,3 & 7,3 & 7,3 & 0,5 & 0,5 & 0,0 & 0,0 & 15,6 & 15,2 & 15,4 & 14,5 & 12,9 \\
\hline $\begin{array}{l}\text { grondhuisvesting zonder mestbeluchting / floor } \\
\text { housing without manure aeration }\end{array}$ & 34,7 & 34,7 & 19,7 & 19,7 & 19,7 & 19,7 & 14,0 & 14,0 & 10,3 & 10,3 & 18,9 & 18,0 & 16,5 & 13,2 & 12,0 \\
\hline $\begin{array}{l}\text { grondhuisvesting met luchtwasser }{ }^{1} \text { / floor housing } \\
\text { with air scrubber }{ }^{1)}\end{array}$ & 0,0 & 0,0 & 0,0 & 0,0 & 0,0 & 0,0 & 0,0 & 0,0 & 0,0 & 0,0 & 3,8 & 3,3 & 2,8 & 0,9 & 2,3 \\
\hline $\begin{array}{l}\text { volièrehuisvesting zonder mestbeluchting / aviary } \\
\text { systems without manure aeration }\end{array}$ & 9,2 & 9,2 & 18,7 & 18,7 & 18,7 & 18,5 & 21,3 & 21,0 & 24,1 & 24,0 & 24,3 & 25,2 & 25,8 & 21,0 & 20,2 \\
\hline $\begin{array}{l}\text { volièrehuisvesting met mestbeluchting / aviary } \\
\text { systems with manure aeration }\end{array}$ & 0,0 & 0,0 & 14,3 & 14,3 & 14,3 & 14,3 & 36,7 & 36,7 & 44,1 & 44,1 & 30,5 & 30,0 & 30,0 & 36,2 & 37,4 \\
\hline $\begin{array}{l}\text { volièrehuisvesting met luchtwasser }{ }^{11} / \text { aviary } \\
\text { systems with air scrubber }{ }^{1)}\end{array}$ & 0,0 & 0,0 & 1,0 & 1,0 & 1,0 & 1,2 & 2,1 & 2,4 & 2,5 & 2,6 & 0,0 & 0,0 & 0,0 & 0,0 & 0,0 \\
\hline overige huisvesting / other housing systems & 0,6 & 0,6 & 7,8 & 7,8 & 7,8 & 7,8 & 15,2 & 15,2 & 19,0 & 19,0 & 6,9 & 8,3 & 9,5 & 14,2 & 15,2 \\
\hline $\begin{array}{l}\text { Hennen en -hanen legrassen } \geq 18 \text { weken, totaal } \\
\text { / Laying hens and roosters } \geq 18 \text { weeks, total }\end{array}$ & 100 & 100 & 100 & 100 & 100 & 100 & 100 & 100 & 100 & 100 & 100 & 100 & 100 & 100 & 100 \\
\hline waarvan / of which: & & & & & & & & & & & & & & & \\
\hline $\begin{array}{l}\text { batterij met open mestopslag / battery cages with } \\
\text { open manure storage }\end{array}$ & 1,0 & 1,0 & 1,5 & 1,5 & 1,5 & 0,4 & 0,2 & 0,2 & 0,0 & 0,0 & 0,0 & 0,0 & 0,0 & 0,0 & 0,0 \\
\hline $\begin{array}{l}\text { batterij met } 2 x / \text { week ontmesten / battery cages with } \\
2 x / \text { week manure removal }\end{array}$ & 6,2 & 6,2 & 0,9 & 0,9 & 0,9 & 0,3 & 0,4 & 0,4 & 0,0 & 0,0 & 0,0 & 0,0 & 0,0 & 0,0 & 0,0 \\
\hline deeppitstal / deep pit & 0,6 & 0,6 & 0,0 & 0,0 & 0,0 & 0,0 & 0,0 & 0,0 & 0,0 & 0,0 & 0,0 & 0,0 & 0,0 & 0,0 & 0,0 \\
\hline
\end{tabular}




\begin{tabular}{|c|c|c|c|c|c|c|c|c|c|c|c|c|c|c|c|}
\hline & 2005 & 2006 & 2007 & 2008 & 2009 & 2010 & 2011 & 2012 & 2013 & 2014 & 2015 & 2016 & 2017 & 2018 & 2019 \\
\hline \multicolumn{16}{|l|}{$\begin{array}{l}\text { batterij met mestbanden en beluchting / battery } \\
\text { cages with manure belts and aeration: }\end{array}$} \\
\hline $\begin{array}{l}\text { droging } 0,5 \mathrm{~m}^{3} / \text { dierplaats } / \mathrm{u} / \text { drying } 0.5 \\
\mathrm{~m}^{3} / \text { place } / \mathrm{h}\end{array}$ & 35,0 & 35,0 & 13,7 & 13,7 & 13,7 & 13,6 & 4,6 & 4,6 & 0,0 & 0,0 & 0,0 & 0,0 & 0,0 & 0,0 & 0,0 \\
\hline $\begin{array}{l}\text { droging } 0,7 \mathrm{~m}^{3} / \text { dierplaats } / \mathrm{u} / \text { drying } 0.7 \\
\mathrm{~m}^{3} / \text { place } / \mathrm{h}\end{array}$ & 11,1 & 11,1 & 23,7 & 23,7 & 23,7 & 23,5 & 3,3 & 3,3 & 0,0 & 0,0 & 0,0 & 0,0 & 0,0 & 0,0 & 0,0 \\
\hline $\begin{array}{l}\text { droging } 0,7 \mathrm{~m}^{3} / \text { dierplaats/u met luchtwasser }{ }^{1)} / \\
\text { drying } 0.7 \mathrm{~m}^{3} / \text { place } / \mathrm{h} \text { with air scrubber }^{1)}\end{array}$ & 0,0 & 0,0 & 0,3 & 0,3 & 0,3 & 0,3 & 0,1 & 0,1 & 0,0 & 0,0 & 0,0 & 0,0 & 0,0 & 0,0 & 0,0 \\
\hline $\begin{array}{l}\text { overige kooien vaste mest / other cages with solid } \\
\text { manure }\end{array}$ & 2,9 & 2,9 & 2,6 & 2,6 & 2,6 & 2,6 & 1,8 & 1,8 & 0,0 & 0,0 & 18,6 & 17,3 & 17,2 & 14,4 & 13,6 \\
\hline \multicolumn{16}{|l|}{ grondhuisvesting / floor housing: } \\
\hline zonder mestbeluchting / without manure aeration & 33,0 & 33,0 & 17,4 & 17,4 & 17,4 & 13,5 & 12,1 & 12,1 & 6,1 & 6,1 & 3,9 & 3,6 & 3,1 & 4,7 & 4,3 \\
\hline perfosysteem / perfosystem & 0,0 & 0,0 & 0,7 & 0,7 & 0,7 & 0,6 & 0,2 & 0,2 & 0,2 & 0,2 & 0,5 & 0,4 & 0,2 & 0,2 & 0,2 \\
\hline mestbeluchting / manure aeration & 0,0 & 0,0 & 3,1 & 3,1 & 3,1 & 2,5 & 3,9 & 3,9 & 3,9 & 3,9 & 5,3 & 5,1 & 4,9 & 3,1 & 2,9 \\
\hline mestbanden / manure belts & 0,0 & 0,0 & 3,3 & 3,3 & 3,3 & 2,6 & 3,5 & 3,5 & 3,6 & 3,6 & 6,2 & 6,0 & 5,7 & 5,4 & 5,2 \\
\hline $\begin{array}{l}\text { volièrehuisvesting zonder mestbeluchting / aviary } \\
\text { systems without manure aeration }\end{array}$ & 6,8 & 6,8 & 8,2 & 8,2 & 8,2 & 14,0 & 14,3 & 14,3 & 16,7 & 16,7 & 27,6 & 29,0 & 27,7 & 23,2 & 22,2 \\
\hline $\begin{array}{l}\text { volièrehuisvesting met mestbeluchting / aviary } \\
\text { systems with manure aeration }\end{array}$ & 0,8 & 0,8 & 19,9 & 19,9 & 19,9 & 21,4 & 46,6 & 46,6 & 53,2 & 53,2 & 37,9 & 38,6 & 41,2 & 49,0 & 51,6 \\
\hline overige huisvesting / other housing systems & 2,6 & 2,6 & 4,7 & 4,7 & 4,7 & 4,7 & 9,0 & 9,0 & 16,3 & 16,3 & 0,0 & 0,0 & 0,0 & 0,0 & 0,0 \\
\hline $\begin{array}{l}\text { Ouderdieren van vleeskuikens }<18 \text { weken, } \\
\text { totaal / Broiler breeders }<18 \text { weeks, total }\end{array}$ & 100 & 100 & 100 & 100 & 100 & 100 & 100 & 100 & 100 & 100 & 100 & 100 & 100 & 100 & 100 \\
\hline \multicolumn{16}{|l|}{ waarvan / of which: } \\
\hline reguliere huisvesting / regular housing & 100 & 100 & 100 & 100 & 100 & 100 & 84,6 & 84,5 & 84,4 & 84,4 & 56,6 & 47,7 & 50,0 & 53,6 & 48,0 \\
\hline luchtwasser ${ }^{1}$, biofilter / air scrubber ${ }^{11}$, biofilter & 0,0 & 0,0 & 0,0 & 0,0 & 0,0 & 0,0 & 0,9 & 1,0 & 1,1 & 1,1 & 3,1 & 4,1 & 3,2 & 5,3 & 6,3 \\
\hline $\begin{array}{l}\text { overige emissiearme huisvesting / other low } \\
\text { emission housing }\end{array}$ & 0,0 & 0,0 & 0,0 & 0,0 & 0,0 & 0,0 & 14,5 & 14,5 & 14,5 & 14,5 & 40,3 & 48,2 & 46,8 & 41,1 & 45,7 \\
\hline $\begin{array}{l}\text { Ouderdieren van vleeskuikens } \geq 18 \text { weken, } \\
\text { totaal / Broiler breeders } \geq 18 \text { weeks, total }\end{array}$ & 100 & 100 & 100 & 100 & 100 & 100 & 100 & 100 & 100 & 100 & 100 & 100 & 100 & 100 & 100 \\
\hline \multicolumn{16}{|l|}{ waarvan / of which: } \\
\hline reguliere huisvesting / regular housing & 73,7 & 73,7 & 76,9 & 76,9 & 76,9 & 68,8 & 48,2 & 48,0 & 47,9 & 47,8 & 15,3 & 13,1 & 13,3 & 16,6 & 13,7 \\
\hline \multicolumn{16}{|l|}{ emissiearme huisvesting / low emission housing: } \\
\hline groepskooi / colony housing & 10,2 & 10,2 & 4,3 & 4,3 & 4,3 & 1,7 & 5,7 & 5,7 & 5,7 & 5,7 & 5,0 & 4,4 & 4,3 & 4,7 & 4,7 \\
\hline $\begin{array}{l}\text { volièrehuisvesting met mestbeluchting / aviary } \\
\text { system with manure aeration }\end{array}$ & 4,1 & 4,1 & 0,8 & 0,8 & 0,8 & 1,3 & 1,3 & 1,3 & 1,3 & 1,3 & 6,5 & 10,0 & 11,4 & 4,3 & 4,3 \\
\hline $\begin{array}{l}\text { grondhuisvesting met mestbeluchting van bovenaf } \\
\text { / floor housing with manure aeration from above }\end{array}$ & 7,8 & 7,8 & 8,1 & 8,1 & 8,1 & 12,7 & 28,4 & 28,4 & 28,4 & 28,4 & 31,6 & 30,6 & 27,6 & 26,6 & 27,2 \\
\hline
\end{tabular}




\begin{tabular}{|c|c|c|c|c|c|c|c|c|c|c|c|c|c|c|c|}
\hline & 2005 & 2006 & 2007 & 2008 & 2009 & 2010 & 2011 & 2012 & 2013 & 2014 & 2015 & 2016 & 2017 & 2018 & 2019 \\
\hline $\begin{array}{l}\text { grondhuisvesting met mestbeluchting via verticale } \\
\text { slangen in de mest / floor housing with vertical } \\
\text { aeration tubes in the manure }\end{array}$ & 0,0 & 0,0 & 0,3 & 0,3 & 0,3 & 0,5 & 8,0 & 8,0 & 8,0 & 8,0 & 35,1 & 35,0 & 37,7 & 40,3 & 42,5 \\
\hline $\begin{array}{l}\text { grondhuisvesting - perfosysteem / floor housing - } \\
\text { perfosystem }\end{array}$ & 3,3 & 3,3 & 1,7 & 1,7 & 1,7 & 2,7 & 3,7 & 3,7 & 3,7 & 3,7 & 1,9 & 0,7 & 0,5 & 2,4 & 2,4 \\
\hline luchtwasser $^{1)}$ / air scrubber ${ }^{1)}$ & 0,9 & 0,9 & 0,3 & 0,3 & 0,3 & 0,5 & 2,1 & 2,3 & 2,4 & 2,5 & 1,9 & 3,0 & 2,2 & 2,2 & 1,5 \\
\hline $\begin{array}{l}\text { grondhuisvesting met mestbanden / floor housing } \\
\text { with manure belts }\end{array}$ & 0,0 & 0,0 & 7,6 & 7,6 & 7,6 & 11,9 & 2,6 & 2,6 & 2,6 & 2,6 & 2,7 & 3,2 & 3,0 & 2,9 & 3,7 \\
\hline Vleeskuikens, totaal / Broilers, total & 100 & 100 & 100 & 100 & 100 & 100 & 100 & 100 & 100 & 100 & 100 & 100 & 100 & 100 & 100 \\
\hline \multicolumn{16}{|l|}{ waarvan / of which: } \\
\hline reguliere huisvesting / regular housing & 91,0 & 91,0 & 82,1 & 82,1 & 82,1 & 64,0 & 33,4 & 33,0 & 18,2 & 18,1 & 12,7 & 12,3 & 11,2 & 10,0 & 8,1 \\
\hline \multicolumn{16}{|l|}{ emissiearme huisvesting / low emission housing: } \\
\hline vloer met strooiseldroging / floor with litter drying & 4,0 & 4,0 & 2,0 & 2,0 & 2,0 & 2,6 & 1,6 & 1,6 & 3,8 & 3,8 & 0,8 & 0,9 & 0,8 & 0,7 & 0,7 \\
\hline $\begin{array}{l}\text { etagesysteem met volledig roostervloer en } \\
\text { mestbandbeluchting / multi-level system with fully } \\
\text { slatted floor and manure belt aeration }\end{array}$ & 1,0 & 1,0 & 0,5 & 0,5 & 0,5 & 0,7 & 0,7 & 0,7 & 1,7 & 1,7 & 2,8 & 3,4 & 3,3 & 1,6 & 1,8 \\
\hline luchtwasser $^{1)}$ / air scrubber ${ }^{1)}$ & 1,4 & 1,4 & 0,7 & 0,7 & 0,7 & 1,1 & 3,3 & 3,7 & 2,2 & 2,3 & 1,8 & 2,0 & 1,5 & 2,5 & 2,4 \\
\hline $\begin{array}{l}\text { grondhuisvesting met vloerverwarming en - } \\
\text { verkoeling / floor housing with floor heating and } \\
\text { cooling }\end{array}$ & 2,6 & 2,6 & 4,6 & 4,6 & 4,6 & 9,9 & 4,5 & 4,5 & 4,2 & 4,2 & 2,8 & 3,1 & 3,1 & 1,5 & 1,9 \\
\hline mixluchtventilatie / mixed air ventilation & 0,0 & 0,0 & 10,1 & 10,1 & 10,1 & 21,7 & 56,5 & 56,5 & 69,9 & 69,9 & 79,1 & 78,3 & 80,1 & 83,7 & 85,1 \\
\hline Eenden, totaal / Ducks, total & 100 & 100 & 100 & 100 & 100 & 100 & 100 & 100 & 100 & 100 & 100 & 100 & 100 & 100 & 100 \\
\hline \multicolumn{16}{|l|}{ waarvan / of which: } \\
\hline reguliere huisvesting / regular housing & 100 & 100 & 100 & 100 & 100 & 100 & 100 & 100 & 100 & 100 & 92,7 & 93,3 & 93,3 & 92,3 & 94,1 \\
\hline emissiearme huisvesting / low emission housing & 0,0 & 0,0 & 0,0 & 0,0 & 0,0 & 0,0 & 0,0 & 0,0 & 0,0 & 0,0 & 7,3 & 6,7 & 6,7 & 7,7 & 5,9 \\
\hline Vleeskalkoenen, totaal / Turkeys, total & 100 & 100 & 100 & 100 & 100 & 100 & 100 & 100 & 100 & 100 & 100 & 100 & 100 & 100 & 100 \\
\hline \multicolumn{16}{|l|}{ waarvan / of which: } \\
\hline reguliere huisvesting / regular housing & 73,9 & 73,9 & 66,6 & 66,6 & 66,6 & 66,6 & 96,0 & 96,0 & 96,0 & 96,0 & 85,0 & 81,5 & 74,2 & 71,4 & 75,9 \\
\hline emissiearme huisvesting / low emission housing & 26,1 & 26,1 & 33,4 & 33,4 & 33,4 & 33,4 & 4,0 & 4,0 & 4,0 & 4,0 & 15,0 & 18,5 & 25,8 & 28,6 & 24,1 \\
\hline
\end{tabular}

1) Gecorrigeerd voor niet-operationele luchtwassers tijdens handhavingsactiviteiten / Adjusted for non-operating air scrubbers during enforcement activities.

Bron: Landbouwtelling / Source: Agricultural census. 


\begin{tabular}{|c|c|c|c|c|c|c|c|c|c|c|c|c|c|}
\hline & $\begin{array}{r}1990- \\
1993\end{array}$ & 1994 & $\begin{array}{r}1995- \\
1997\end{array}$ & $\begin{array}{r}1998- \\
2000\end{array}$ & $\begin{array}{r}2001- \\
2002\end{array}$ & $\begin{array}{r}2003- \\
2006\end{array}$ & $\begin{array}{r}2007- \\
2010\end{array}$ & $\begin{array}{r}2011- \\
2014\end{array}$ & 2015 & 2016 & 2017 & 2018 & 2019 \\
\hline \multicolumn{14}{|l|}{$\begin{array}{l}\text { Opfokhennen en -hanen legrassen }<18 \text { weken / Laying hens } \\
\text { and roosters }<18 \text { weeks }\end{array}$} \\
\hline $\begin{array}{l}\text { kooihuisvesting met mestbanden en beluchting / cages with manure } \\
\text { belts and aeration }\end{array}$ & 0 & 8,7 & 7,4 & 43,4 & 46,0 & 28,4 & 36,0 & 6,0 & 0 & 10,0 & 3,9 & 36,4 & 24,4 \\
\hline volièrehuisvesting / aviary systems & 0 & 0,0 & 0,0 & 0,0 & 0,0 & 0,0 & 15,0 & 24,0 & 21,5 & 25,6 & 24,5 & 30,7 & 41,6 \\
\hline \multicolumn{14}{|l|}{$\begin{array}{l}\text { Hennen en -hanen legrassen } \geq 18 \text { weken / Laying hens and } \\
\text { roosters } \geq 18 \text { weeks }\end{array}$} \\
\hline $\begin{array}{l}\text { kooihuisvesting met mestbanden en beluchting / cages with manure } \\
\text { belts and aeration }\end{array}$ & 60,0 & 37,9 & 29,7 & 43,5 & 46,0 & 28,4 & 36,0 & 32,0 & 0 & 30,6 & 29,7 & 47,6 & 53,9 \\
\hline volièrehuisvesting / aviary systems & 0 & 0 & 0 & 0 & 0 & 0 & 14,0 & 24,0 & 31,1 & 29,6 & 30,2 & 44,4 & 55,4 \\
\hline grondhuisvesting met mestbanden / floor housing with manure belts & 0 & 0 & 0 & 0 & 0 & 0 & 25,0 & 44,0 & 31,5 & 37,4 & 35,0 & 47,9 & 49,9 \\
\hline \multicolumn{14}{|l|}{$\begin{array}{l}\text { Ouderdieren van vleeskuikens } \geq 18 \text { weken / Broiler breeders } \\
\geq 18 \text { weeks }\end{array}$} \\
\hline verrijkte kooi, groepskooi / enriched cages, colony housing & 0 & 0 & 0 & 0 & 0 & 0 & 33,0 & 53,0 & 0 & 0 & 5,3 & 22,2 & 22,5 \\
\hline $\begin{array}{l}\text { volièrehuisvesting met mestbeluchting /aviary system with manure } \\
\text { aeration }\end{array}$ & 0 & 0 & 0 & 0 & 0 & 0 & 33,0 & 53,0 & 0 & 31,7 & 37,5 & 55,9 & 42,0 \\
\hline grondhuisvesting met mestbanden / floor housing with manure belts & 0 & 0 & 0 & 0 & 0 & 0 & 33,0 & 53,0 & 11,2 & 11,3 & 8,5 & 31,0 & 11,7 \\
\hline
\end{tabular}
Bron: Landbouwtelling / Source: Agricultural census.

N.B. Door het geringe aantal bedrijven kan het aandeel additionele techniek flinke schommelingen vertonen / Note: Due to the small number of companies, the share of additional technology can show considerable fluctuations.

Pluimveestallen met uitloop naar buiten (\% dieren) / Free-range poultry housing (\% of animals).

\begin{tabular}{|c|c|c|c|c|c|c|}
\hline & $1990-2000$ & 2001-2002 & 2003-2006 & 2007-2010 & 2011-2014 & 2015-2019 \\
\hline \multicolumn{7}{|c|}{$\begin{array}{l}\text { Hennen en -hanen legrassen } \geq 18 \text { weken / Laying hens and } \\
\text { roosters } \geq 18 \text { weeks }\end{array}$} \\
\hline grondhuisvesting / floor housing & 0 & 43,0 & 42,0 & 23,0 & 20,0 & 20,0 \\
\hline volièrehuisvesting / aviary systems & 0 & 72,0 & 64,0 & 30,0 & 25,0 & 25,0 \\
\hline overige huisvesting / other housing & 0 & 0 & 0 & 0 & 8,0 & 0 \\
\hline
\end{tabular}

Bron: Landbouwtelling / Source: Agricultural census. 



\section{Bijlage 9 Huisvesting van rundvee, varkens en pluimvee in 2019}

\section{Auteur: Cor van Bruggen, CBS}

In de Gecombineerde Opgave (GO) van 2020 is veehouders gevraagd naar de gemiddelde stalbezetting in 2019 per stal. Voor de typering van de stallen is aangesloten bij de indeling van de Regeling ammoniak en veehouderij (Rav:

https://www.infomil.nl/onderwerpen/landbouw/ammoniak/rav-0/).

Voor de inpassing in NEMA zijn op basis van de implementatiegraden gemiddelde emissiefactoren berekend voor emissiearme huisvesting met luchtwassers en voor emissiearme vloeren en/of mestkelders. Bij de huisvesting van pluimvee is rekening gehouden met de aanwezigheid van additionele technieken voor droging van pluimveemest en voor opslag langer dan twee weken buiten de stal.

\section{Melkkoeien}

De implementatiegraden van de stalsystemen zijn weergegeven in Tabel B9.1.

B9.1 Implementatiegraden van stalsystemen voor melkkoeien / Implementation grades of housing systems for dairy cows.

\begin{tabular}{|c|c|c|}
\hline Stalsysteem / Housing system & Aandeel / Share & Groep / Group ${ }^{1)}$ \\
\hline $\mathrm{A} 1.1$ & $1,4 \%$ & {$[1]$} \\
\hline A1.2 & $0,0 \%$ & {$[2]$} \\
\hline A1.3 & $0,1 \%$ & {$[2]$} \\
\hline A1.4 & $0,0 \%$ & {$[2]$} \\
\hline A1.5 & $0,6 \%$ & {$[2]$} \\
\hline A1.6 & $1,3 \%$ & {$[2]$} \\
\hline A1.7 & $0,4 \%$ & {$[2]$} \\
\hline A1.8 & $1,0 \%$ & {$[2]$} \\
\hline A1.9 & $0,8 \%$ & {$[2]$} \\
\hline A1.10 & $1,5 \%$ & {$[2]$} \\
\hline $\mathrm{A} 1.11$ & $0,4 \%$ & {$[2]$} \\
\hline $\mathrm{A} 1.12$ & $0,5 \%$ & {$[2]$} \\
\hline $\mathrm{A} 1.13$ & $3,8 \%$ & {$[2]$} \\
\hline $\mathrm{A} 1.14$ & $2,2 \%$ & {$[2]$} \\
\hline A1.15 & $1,4 \%$ & {$[2]$} \\
\hline A1.16 & $0,2 \%$ & {$[2]$} \\
\hline A1.17 & $0,4 \%$ & {$[2]$} \\
\hline A1.18 & $0,3 \%$ & {$[2]$} \\
\hline A1.19 & $0,5 \%$ & {$[2]$} \\
\hline A1.20 & $0,2 \%$ & {$[2]$} \\
\hline A1.21 & $0,4 \%$ & {$[2]$} \\
\hline $\mathrm{A} 1.22$ & $0,5 \%$ & [2] \\
\hline $\mathrm{A} 1.23$ & $0,2 \%$ & [2] \\
\hline A1.24 & $0,0 \%$ & [2] \\
\hline A1.25 & $0,1 \%$ & [2] \\
\hline A1.26 & $0,2 \%$ & [2] \\
\hline $\mathrm{A} 1.27$ & $0,2 \%$ & [2] \\
\hline $\mathrm{A} 1.28$ & $0,7 \%$ & [2] \\
\hline $\mathrm{A} 1.29$ & $0,1 \%$ & [2] \\
\hline A1.30 & $0,0 \%$ & [2] \\
\hline
\end{tabular}




\begin{tabular}{|c|c|c|}
\hline Stalsysteem / Housing system & Aandeel / Share & Groep / Group ${ }^{1)}$ \\
\hline A1.31 & $0,1 \%$ & {$[2]$} \\
\hline A1.32 & $0,2 \%$ & {$[2]$} \\
\hline A1.33 & $0,0 \%$ & {$[2]$} \\
\hline A1.34 & $0,0 \%$ & {$[2]$} \\
\hline A1.35 & $0,0 \%$ & [2] \\
\hline A1.100 & $80,3 \%$ & [3] \\
\hline A1.Totaal / A1/ Total & $100,0 \%$ & \\
\hline
\end{tabular}

1) [1] Emissiearme grupstal / Low emission tie-stalls.

[2] Emissiearme loop-/ligboxenstal / Low emission cubicle or loose housing.

[3] Overige huisvesting / Other housing.

N.B. Voor stalomschrijvingen en emissiefactoren per dierplaats wordt verwezen naar de Regeling ammoniak en veehouderij / Please note that the description of housing systems and emission factors can be found in the Regulation ammonia and animal husbandry (Dutch: Rav).

Er wordt vanuit gegaan dat emissiearme loop-en ligboxenstallen in de praktijk niet beter presteren dan reguliere melkveestallen (paragraaf 2.6). De emissiefactoren voor emissiearme stallen zijn daarom in Tabel B9.2 gelijkgesteld aan de emissiefactoren voor reguliere stallen. De berekende emissiefactoren voor emissiearme stallen op basis van de implementatiegraden en de Ravemissiefactoren per staltype zijn in de tabel tussen haakjes geplaatst. De reductie van de stalemissie bij beperkt weiden en bij onbeperkt weiden is berekend met de formule in Ogink et al. (2014). Uit gegevens van de Landbouwtelling is gebleken dat de gemiddelde beweidingsduur bij beperkt weiden 7 uur per etmaal is en bij onbeperkt (dag en nacht) weiden 18 uur.

B9.2 Emissiefactoren voor huisvesting van melkkoeien die in NEMA worden toegepast op basis van de implementatiegraden ( $\mathrm{kg} \mathrm{NH} /$ /dierplaats/jaar) / Emission factors for dairy cow housing applied in NEMA based on the implementation rates ( $\mathrm{kg} \mathrm{NH}_{3} /$ animal place/year).

A1.2 - A1.35 emissiearme stallen / reduced emission housing

\begin{tabular}{lr} 
jaarrond bij permanent opstallen / year round with permanent housing & $13,00(8,37)$ \\
\hline jaarrond met overdag weiden / year round with daytime grazing & $11,90(7,66)$ \\
\hline jaarrond met dag en nacht weiden / year round with day and night grazing & $10,17(6,55)$ \\
\hline $\begin{array}{l}\text { stalperiode / housing season } \\
\text { weideperiode met permanent opstallen / grazing season with permanent } \\
\text { housing }\end{array}$ & $6,98(4,49)$ \\
\hline $\begin{array}{l}\text { weideperiode met overdag weiden / grazing season with daytime grazing } \\
\text { weideperiode met dag en nacht weiden / grazing season with day and } \\
\text { night grazing }\end{array}$ & $6,02(3,88)$ \\
\hline
\end{tabular}

A1.100 overige melkveestallen / other dairy housing

jaarrond bij permanent opstallen / year round with permanent housing $\quad 13,00$

$\begin{array}{ll}\text { jaarrond met overdag weiden / year round with daytime grazing } & 11,90\end{array}$

$\begin{array}{lr}\text { jaarrond met dag en nacht weiden / year round with day and night grazing } & 10,17\end{array}$

$\begin{array}{lc}\text { stalperiode / housing season } & 6,98\end{array}$

weideperiode met permanent opstallen / grazing season with permanent housing

1) Er wordt vanuit gegaan dat emissiearme melkveestallen in de praktijk niet beter presteren dan reguliere stallen. De emissiefactoren voor reguliere stallen gelden daarom ook voor emissiearme melkveestallen. De berekende emissiefactoren op basis van de Rav zijn tussen haakjes geplaatst. / It is assumed that low-emission dairy housing do not perform better in practice than regular housing. The emission factors therefore apply to both regular and low-emission dairy housing. The calculated emission factors based on the Rav are placed in brackets.

\section{Vleeskalveren}


De implementatiegraden van de stalsystemen zijn weergegeven in Tabel B9.3.

Ten opzichte van de reguliere stal met een $\mathrm{NH}_{3}$-emissie van 3,5 $\mathrm{kg}$ per dierplaats is de gemiddelde emissiereductie door luchtwassers 86\%. Met het geringe aandeel A4.7 en A4.8 (bouwkundige aanpassingen) wordt vooralsnog geen rekening gehouden.

B9.3 Implementatiegraden van stalsystemen voor vleeskalveren / Implementation grades of housing systems for veal calves.

\begin{tabular}{|c|c|c|}
\hline systeem / Housing system & Aandeel / Share & Groep / Group ${ }^{1)}$ \\
\hline A4.1 & $1,3 \%$ & [1] \\
\hline A 4.2 & $0,6 \%$ & [1] \\
\hline A4. 3 & $0,4 \%$ & [1] \\
\hline A4.4 & $1,5 \%$ & [1] \\
\hline A4.5.6 & $0,0 \%$ & [1] \\
\hline A4. 6 & $0,9 \%$ & [1] \\
\hline A4.7 & $1,4 \%$ & {$[2]$} \\
\hline A4.8 & $0,9 \%$ & {$[2]$} \\
\hline
\end{tabular}

1) [1] Luchtwasser / Air scrubber.

[2] Overige emissiearme stal / Other low emission housing.

[3] Overige huisvesting / Other housing.

N.B. Voor stalomschrijvingen en emissiefactoren per dierplaats wordt verwezen naar de Regeling ammoniak en veehouderij / Please note that the description of housing systems and emission factors can be found in the Regulation ammonia and animal husbandry (Dutch: Rav).

\section{Gespeende biggen}

De implementatiegraden van de stalsystemen zijn weergegeven in Tabel B9.4. In Tabel B9.5 zijn op basis van de implementatiegraden en de emissiefactoren per staltype gewogen gemiddelde emissiefactoren berekend voor stallen met luchtwassers en voor emissiearme stallen met aanpassingen aan vloer en/of mestkelder. Voor stallen met aanpassingen aan vloer en/of mestkelder wordt ervan uitgegaan dat het verschil in ammoniakemissie met een reguliere stal in de praktijk kleiner is dan het verschil op basis van de Rav-factoren (Paragraaf 2.6).

B9.4 Implementatiegraden van stalsystemen voor gespeende biggen / Implementation grades of housing systems for weaned piglets.

\begin{tabular}{|c|c|c|}
\hline Stalsysteem / Housing system & Aandeel / Share & Groep / Group ${ }^{1}$ \\
\hline D1.1.1 & $0,1 \%$ & {$[2]$} \\
\hline $\mathrm{D} 1.1 .2$ & $1,0 \%$ & {$[2]$} \\
\hline D1.1.3 & $16,1 \%$ & {$[2]$} \\
\hline $\mathrm{D} 1.1 .4 .1$ & $2,8 \%$ & {$[2]$} \\
\hline D1.1.4.2 & $1,5 \%$ & {$[2]$} \\
\hline D1.1.5 & $1,3 \%$ & {$[2]$} \\
\hline D1.1.6 & $0,1 \%$ & {$[2]$} \\
\hline D1.1.7 & $0,1 \%$ & {$[2]$} \\
\hline D1.1.8 & $0,0 \%$ & {$[2]$} \\
\hline D1.1.9 & $4,0 \%$ & [1] \\
\hline D1.1.10 & $5,2 \%$ & {$[1]$} \\
\hline D1.1.11 & $3,0 \%$ & {$[2]$} \\
\hline D1.1.12.1 & $1,5 \%$ & {$[2]$} \\
\hline D1.1.12.2 & $2,0 \%$ & {$[2]$} \\
\hline D1.1.12.3 & $1,5 \%$ & {$[2]$} \\
\hline D1.1.13 & $3,7 \%$ & {$[2]$} \\
\hline D1.1.14 & $10,1 \%$ & {$[1]$} \\
\hline D1.1.15.1 & $1,4 \%$ & [1] \\
\hline
\end{tabular}




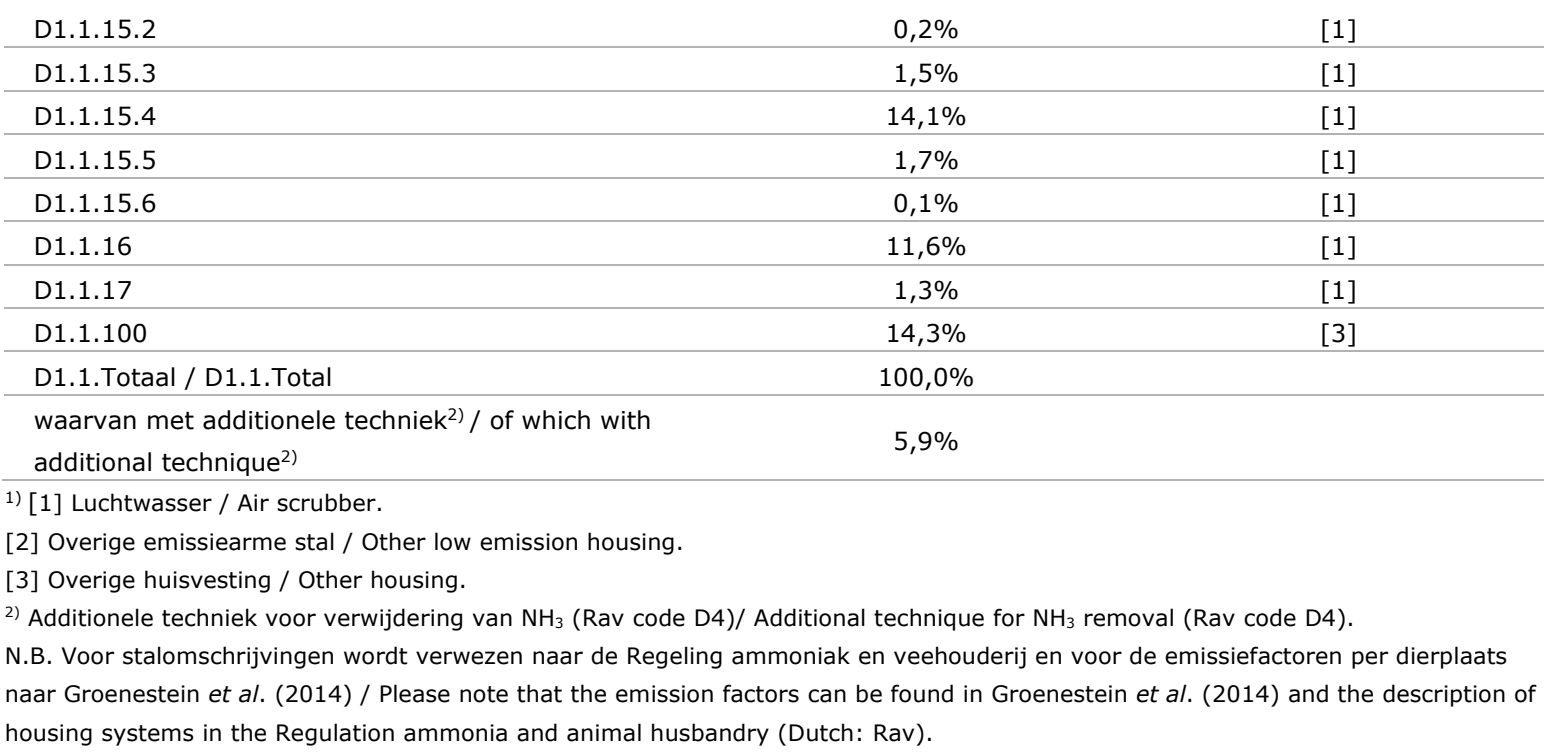

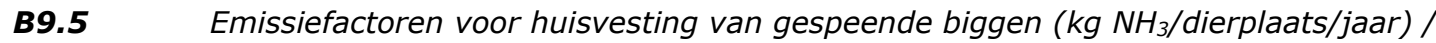

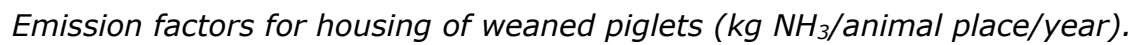

\begin{tabular}{l} 
Stalsysteem / Housing system \\
$\begin{array}{l}\text { Luchtwassers / Air scrubbers } \\
\text { Vloer-/kelderaanpassingen / Floor and/or manure cellar adaptations }\end{array}$ \\
\hline Reguliere stal $\left(0,35 \mathrm{~m}^{2}\right.$ per dierplaats) / Regular housing $\left(0.35 \mathrm{~m}^{2}\right.$ per \\
animal place)
\end{tabular}

\section{Kraamzeugen}

De implementatiegraden van de stalsystemen zijn weergegeven in Tabel B9.6. In Tabel B9.7 zijn op basis van de implementatiegraden en de emissiefactoren per staltype gewogen gemiddelde emissiefactoren berekend voor stallen met luchtwassers en voor emissiearme stallen met aanpassingen aan vloer en/of mestkelder. Voor stallen met aanpassingen aan vloer en/of mestkelder wordt ervan uitgegaan dat het het verschil in ammoniakemissie met een reguliere stal in de praktijk kleiner is dan het verschil op basis van de Rav-factoren (paragraaf 2.6).

B9.6 Implementatiegraden van stalsystemen voor kraamzeugen / Implementation grades of housing systems for nursing sows.

\begin{tabular}{|c|c|c|}
\hline Stalsysteem / Housing system & Aandeel / Share & Groep / Group ${ }^{1)}$ \\
\hline $\mathrm{D} 1.2 .1$ & $1,5 \%$ & {$[2]$} \\
\hline $\mathrm{D} 1.2 .3$ & $0,0 \%$ & {$[2]$} \\
\hline $\mathrm{D} 1.2 .5$ & $0,4 \%$ & {$[2]$} \\
\hline D1.2.6 & $8,8 \%$ & {$[2]$} \\
\hline $\mathrm{D} 1.2 .7$ & $0,1 \%$ & {$[2]$} \\
\hline $\mathrm{D} 1.2 .8$ & $0,1 \%$ & {$[2]$} \\
\hline D1.2.9 & $0,4 \%$ & {$[2]$} \\
\hline D1.2.10 & $4,6 \%$ & [1] \\
\hline $\mathrm{D} 1.2 .11$ & $6,4 \%$ & [1] \\
\hline D1.2.12 & $2,3 \%$ & {$[2]$} \\
\hline D1.2.13 & $2,8 \%$ & {$[2]$} \\
\hline $\mathrm{D} 1.2 .14$ & $3,4 \%$ & {$[2]$} \\
\hline D1.2.15 & $12,1 \%$ & [1] \\
\hline D1.2.16 & $7,7 \%$ & {$[2]$} \\
\hline D1.2.17.1 & $1,5 \%$ & [1] \\
\hline D1.2.17.2 & $0,1 \%$ & [1] \\
\hline
\end{tabular}




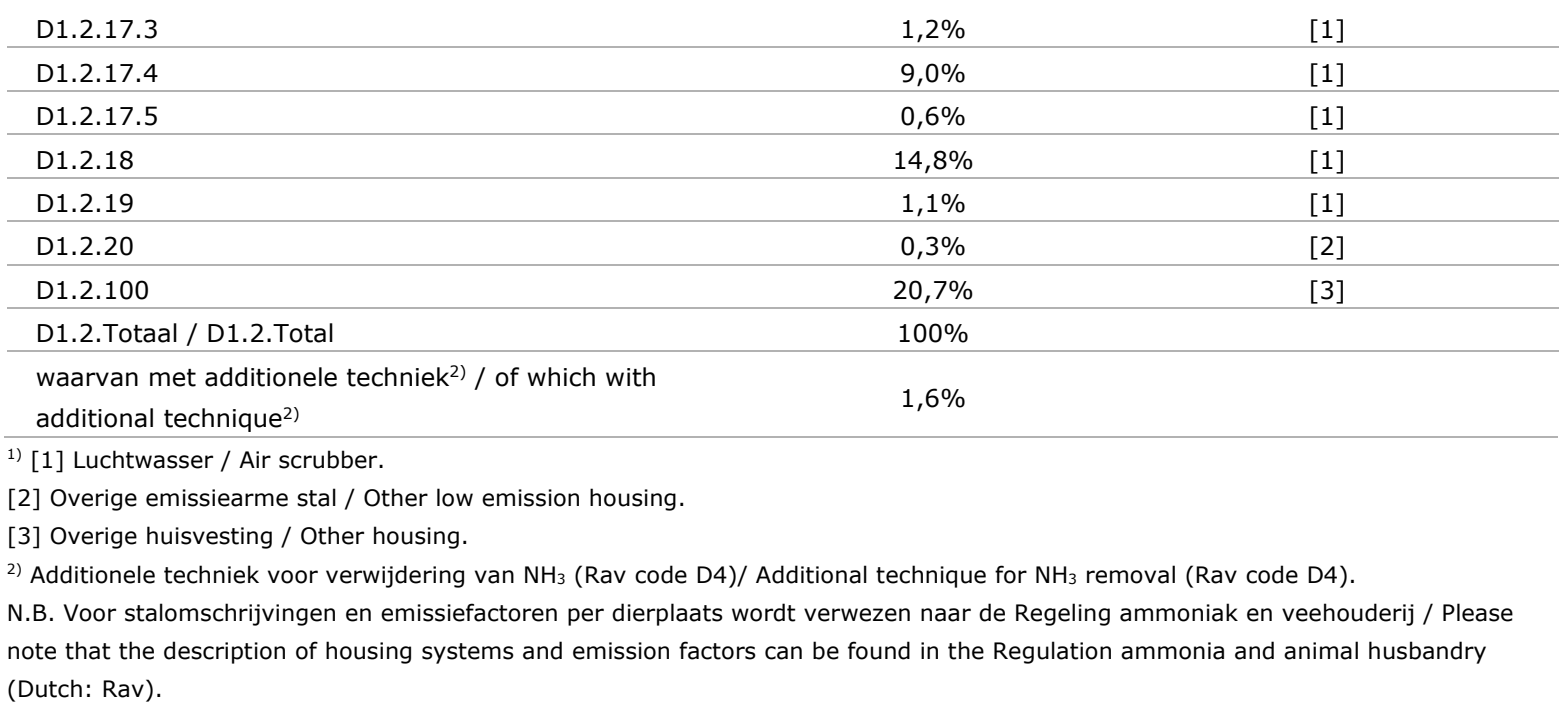

B9.7 Emissiefactoren voor huisvesting van kraamzeugen ( $k g \mathrm{NH}_{3} /$ dierplaats/jaar) / Emission factors for housing of nursing sows ( $\mathrm{kg} \mathrm{NH}$ /animal place/year).

\begin{tabular}{l} 
Stalsysteem / Housing system \\
Luchtwassers / Air scrubbers \\
\hline Vloer-/kelderaanpassingen / Floor and/or manure cellar adaptations \\
Reguliere stal / Regular housing \\
1) Tussen haakjes staat de gemiddelde factor die berekend is uit de implementatiegraden en de factoren per dierplaats van de \\
onderliggende systemen in de Rav / The average factor calculated from the implementation grades and the emission factors per \\
animal place for the underlying systems in the Rav is placed in brackets. \\
N.B. De emissiefactoren per dierplaats voor de onderliggende systemen zijn overgenomen van de Regeling ammoniak en veehouderij \\
/ The emission factors per animal place for the underlying systems are taken from the Regulation ammonia and animal husbandry \\
(Dutch: Rav).
\end{tabular}

\section{Guste en dragende zeugen}

De implementatiegraden van de stalsystemen zijn weergegeven in Tabel B9.8. In Tabel B9.9 zijn op basis van de implementatiegraden en de emissiefactoren per staltype gewogen gemiddelde emissiefactoren berekend voor stallen met luchtwassers en voor emissiearme stallen met aanpassingen aan vloer en/of mestkelder. Voor stallen met aanpassingen aan vloer en/of mestkelder wordt ervan uitgegaan dat het het verschil in ammoniakemissie met een reguliere stal in de praktijk kleiner is dan het verschil op basis van de Rav-factoren (paragraaf 2.6).

B9.8 Implementatiegraden van stalsystemen voor guste en dragende zeugen / Implementation grades of housing systems for mating and gestating sows.

\begin{tabular}{|c|c|c|}
\hline Stalsysteem / Housing system & Aandeel / Share & Groep / Group ${ }^{1)}$ \\
\hline D1.3.1 & $2,0 \%$ & [2] \\
\hline D1.3.3 & $1,8 \%$ & [2] \\
\hline D1.3.4 & $0,1 \%$ & {$[2]$} \\
\hline D1.3.7 & $9,2 \%$ & {$[1]$} \\
\hline D1.3.8.1 & $0,9 \%$ & {$[2]$} \\
\hline D1.3.8.2 & $3,8 \%$ & {$[2]$} \\
\hline D1.3.9.1 & $3,2 \%$ & {$[2]$} \\
\hline D1.3.12.1 & $3,5 \%$ & {$[1]$} \\
\hline D1.3.12.2 & $0,2 \%$ & {$[1]$} \\
\hline D1.3.12.3 & $1,8 \%$ & {$[1]$} \\
\hline
\end{tabular}




\begin{tabular}{|c|c|c|}
\hline D1.3.12.4 & $13,1 \%$ & [1] \\
\hline D1.3.12.5 & $0,8 \%$ & {$[1]$} \\
\hline D1.3.12.6 & $0,6 \%$ & {$[1]$} \\
\hline D1.3.14 & $1,4 \%$ & {$[1]$} \\
\hline D1.3.15 & $0,0 \%$ & {$[2]$} \\
\hline D1.3.101 & $1,7 \%$ & [3] \\
\hline D1.3.Totaal / D1.3.Total & $100 \%$ & \\
\hline $\begin{array}{l}\text { waarvan met additionele techniek }{ }^{2} \text { / of which with } \\
\text { additional technique }\end{array}$ & $1,97 \%$ & \\
\hline
\end{tabular}

1) [1] Luchtwasser / Air scrubber.

[2] Overige emissiearme stal / Other low emission housing.

[3] Overige huisvesting / Other housing.

2) Additionele techniek voor verwijdering van $\mathrm{NH}_{3}$ (Rav code D4)/ Additional technique for $\mathrm{NH}_{3}$ removal (Rav code D4).

N.B. Voor stalomschrijvingen en emissiefactoren per dierplaats wordt verwezen naar de Regeling ammoniak en veehouderij / Please note that the description of housing systems and emission factors can be found in the Regulation ammonia and animal husbandry (Dutch: Rav).

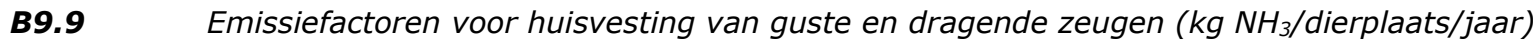
/ Emission factors for housing of mating and gestating sows ( $\mathrm{kg} \mathrm{NH} /$ animal place/year).

\begin{tabular}{l} 
Stalsysteem / Housing system \\
Luchtwassers / Air scrubbers \\
\hline Vloer-/kelderaanpassingen / Floor and/or manure cellar adaptations \\
\hline Reguliere stal / Regular housing \\
1) Tussen haakjes staat de gemiddelde factor die berekend is uit de implementatiegraden en de factoren per dierplaats van de \\
onderliggende systemen in de Rav / The average factor calculated from the implementation grades and the emission factors per \\
animal place for the underlying systems in the Rav is placed in brackets. \\
N.B. De emissiefactoren per dierplaats voor de onderliggende systemen zijn overgenomen van de Regeling ammoniak en veehouderij \\
/ The emission factors per animal place for the underlying systems are taken from the Regulation ammonia and animal husbandry \\
(Dutch: Rav).
\end{tabular}

\section{Dekberen}

De implementatiegraden van de stalsystemen zijn weergegeven in Tabel B9.10. In Tabel B9.11 zijn op basis van de implementatiegraden en de emissiefactoren per staltype gewogen gemiddelde emissiefactoren berekend voor stallen met luchtwassers en voor emissiearme stallen met aanpassingen aan vloer en/of mestkelder. Voor stallen met aanpassingen aan vloer en/of mestkelder wordt ervan uitgegaan dat het het verschil in ammoniakemissie met een reguliere stal in de praktijk kleiner is dan het verschil op basis van de Rav-factoren (Paragraaf 2.6). 
B9.12 Implementatiegraden van stalsystemen voor vlees- en opfokvarkens / Implementation grades of housing systems for fattening pigs, gilts and young boars.

\begin{tabular}{|c|c|c|}
\hline Stalsysteem / Housing system & Aandeel / Share & Groep / Group 1 ) \\
\hline D3.2.1 & $3,9 \%$ & [3] \\
\hline D3.2.2 & $0,1 \%$ & [2] \\
\hline D3.2.3 & $0,7 \%$ & [2] \\
\hline D3.2.4 & $0,1 \%$ & [2] \\
\hline D3.2.5 & $0,2 \%$ & [2] \\
\hline D3.2.6.1.1 & $1,1 \%$ & [2] \\
\hline D3.2.6.1.2 & $0,4 \%$ & [2] \\
\hline D3.2.6.2.1 & $0,6 \%$ & [2] \\
\hline D3.2.6.2.2 & $0,1 \%$ & [2] \\
\hline D3.2.7.1.1 & $3,8 \%$ & [2] \\
\hline D3.2.7.1.2 & $1,3 \%$ & [2] \\
\hline D3.2.7.2.1 & $7,5 \%$ & [2] \\
\hline D3.2.7.2.2 & $1,9 \%$ & [2] \\
\hline D3.2.8 & $5,3 \%$ & {$[1]$} \\
\hline D3.2.9 & $6,4 \%$ & [1] \\
\hline D3.2.10.1 & $3,5 \%$ & [2] \\
\hline D3.2.10.2 & $1,3 \%$ & {$[2]$} \\
\hline D3.2.11 & $0,6 \%$ & [2] \\
\hline D3.2.12 & $0,6 \%$ & [2] \\
\hline D3.2.13 & $1,5 \%$ & [2] \\
\hline D3.2.14 & $13,9 \%$ & [1] \\
\hline D3.2.15.1 & $1,5 \%$ & [1] \\
\hline D3.2.15.2 & $0,2 \%$ & [1] \\
\hline D3.2.15.3 & $1,4 \%$ & [1] \\
\hline D3.2.15.4 & $10,6 \%$ & [1] \\
\hline D3.2.15.5 & $1,1 \%$ & [1] \\
\hline D3.2.15.6 & $0,3 \%$ & [1] \\
\hline D3.2.16 & $0,0 \%$ & [2] \\
\hline D3.2.17 & $16,2 \%$ & [1] \\
\hline D3.2.18 & $2,1 \%$ & [1] \\
\hline D3.3.1 & $0,0 \%$ & [2] \\
\hline D3.3.2 & $0,8 \%$ & [3] \\
\hline D3.100 & $11,1 \%$ & [3] \\
\hline D3.Totaal / D3.Total & $100 \%$ & \\
\hline $\begin{array}{l}\text { waarvan met additionele techniek }{ }^{2)} / \text { of which with } \\
\text { additional technique }^{2)}\end{array}$ & $5,0 \%$ & \\
\hline
\end{tabular}

1) [1] Luchtwasser / Air scrubber.

[2] Overige emissiearme stal / Other low emission housing.

[3] Overige huisvesting / Other housing.

2) Additionele techniek voor verwijdering van $\mathrm{NH}_{3}$ (Rav code D4)/ Additional technique for $\mathrm{NH}_{3}$ removal (Rav code D4).

N.B. Voor stalomschrijvingen wordt verwezen naar de Regeling ammoniak en veehouderij en voor de emissiefactoren per dierplaats naar Groenestein et al. (2014) / Please note that the emission factors can be found in Groenestein et al. (2014) and the description of housing systems in the Regulation ammonia and animal husbandry (Dutch: Rav).

B9.13 Emissiefactoren voor huisvesting van vlees- en opfokvarkens ( $\mathrm{kg} \mathrm{NH}_{3} /$ dierplaats/jaar) / Emission factors for housing of fattening pigs, gilts and young boars ( $\mathrm{kg} \mathrm{NH}_{3} /$ animal place/year).

\begin{tabular}{lcc} 
Stalsysteem / Housing system & $\begin{array}{c}\text { Oppervlakte dierplaatsi) / Surface area } \\
\text { animal place }\end{array}$ \\
& $\mathbf{0 , 8} \mathbf{~ m}^{\mathbf{2}}$ & $\mathbf{1 , 0} \mathbf{~ m}^{\mathbf{2}}$ \\
\hline Luchtwassers / Air scrubbers & 0,76 & 0,90 \\
\hline $\begin{array}{l}\text { Vloer-/kelderaanpassingen / Floor and/or manure cellar adaptations } \\
\text { Reguliere stal - volledig onderkelderd / Regular housing - fully }\end{array}$ & $3,1(1,7)$ & $3,5(1,9)$ \\
\hline $\begin{array}{l}\text { undercellared } \\
\text { Reguliere stal - overig / Regular housing - other }\end{array}$ & 5,0 & 6,1 \\
\hline
\end{tabular}


1) Tussen haakjes staat de gemiddelde factor die berekend is uit de implementatiegraden en de factoren per dierplaats van de onderliggende systemen in Groenestein et al. (2014) / The average factor calculated from the implementation grades and the emission factors per animal place for the underlying systems in Groenestein et al. (2014) is placed in brackets.

N.B. De emissiefactoren per dierplaats voor de onderliggende systemen zijn overgenomen van Groenestein et al. (2014) / The emission factors per animal place for the underlying systems are taken from Groenestein et al. (2014).

\section{Opfokhennen en hanen van legrassen jonger dan ca. 18 weken}

De implementatiegraden van de stalsystemen zijn weergegeven in Tabel B9.14 inclusief de implementatiegraden van systemen waaraan een additionele techniek is gekoppeld voor mestdroging of mestopslag langer dan twee weken buiten de stal.

Batterijhuisvesting met natte mest is inmiddels verboden. De incidentele opgaven van dit systeem zijn opgeteld bij koloniehuisvesting met vaste mest.

Bij batterij/koloniehuisvesting wordt ervan uitgegaan dat het bij alle Rav-codes E1.5.x gaat om de toegestane huisvesting E1.5.5.

Een aantal bedrijven heeft een additionele techniek opgeven in combinatie met E1.7 grondhuisvesting terwijl dit volgens de toelichting in de Rav niet mogelijk is. Besloten is om bij additionele technieken de toelichting van de Rav aan te houden en alleen rekening te houden met additionele techniek voor mestdroging en mestopslag bij E1.5 (batterij) en E1.8 (volière).

B9.14 Implementatiegraden van stalsystemen voor opfokhennen en -hanen van legrassen jonger dan ca. 18 weken / Implementation grades of housing systems for hens and roosters of laying breeds under approx. 18 weeks.

\begin{tabular}{|c|c|c|}
\hline Stalsysteem / Housing system & Aandeel / Share & Groep / Group \\
\hline $\mathrm{E} 1.1$ & $0,1 \%$ & {$[1]$} \\
\hline $\mathrm{E} 1.2$ & $1,2 \%$ & [1] \\
\hline E1.3 & $0,4 \%$ & [1] \\
\hline $\mathrm{E} 1.5 .1$ & $0,8 \%$ & {$[1]$} \\
\hline E1.5.2 & $9,8 \%$ & [1] \\
\hline E1.5.4 & $0,7 \%$ & [1] \\
\hline $\mathrm{E} 1.7$ & $7,6 \%$ & {$[2]$} \\
\hline $\mathrm{E} 1.8 .1$ & $20,2 \%$ & {$[3]$} \\
\hline E1.8.2 & $19,9 \%$ & {$[4]$} \\
\hline E1.8.3.1 & $7,8 \%$ & {$[4]$} \\
\hline $\mathrm{E} 1.8 .3 .2$ & $4,2 \%$ & {$[4]$} \\
\hline $\mathrm{E} 1.8 .4$ & $2,7 \%$ & {$[4]$} \\
\hline E1.8.5 & $2,7 \%$ & {$[4]$} \\
\hline E1.9 & $1,0 \%$ & {$[5]$} \\
\hline $\mathrm{E} 1.10$ & $1,3 \%$ & {$[5]$} \\
\hline $\mathrm{E} 1.11$ & $0,8 \%$ & {$[6]$} \\
\hline $\mathrm{E} 1.12$ & $0,0 \%$ & [5] \\
\hline $\mathrm{E} 1.14$ & $14,4 \%$ & {$[6]$} \\
\hline E1.100 & $4,5 \%$ & [2] \\
\hline E1.Totaal / E1.Total & $100 \%$ & \\
\hline waarvan met additionele techniek / of which with additional technique & $27,1 \%$ & \\
\hline
\end{tabular}

N.B. Voor stalomschrijvingen en emissiefactoren per dierplaats wordt verwezen naar de Regeling ammoniak en veehouderij / Please note that the description of housing systems and emission factors can be found in the Regulation ammonia and animal husbandry (Dutch: Rav).

De indeling is groepen is weergegeven in Tabel B9.15 / The classification into groups is shown in Table B9.15.

In Tabel B9.15 zijn de emissiefactoren weergegeven voor de typen huisvesting die in het rekenmodel worden onderscheiden. Voor verschillende systemen wordt ervan uitgegaan dat de ammoniakemissie per dierplaats in de praktijk hoger is dan de Rav-waarde (Paragraaf 2.6). 
B9.15 Emissiefactoren van stalsystemen voor opfokhennen en -hanen van legrassen jonger dan ca. 18 weken ( $\mathrm{kg} \mathrm{NH}$ /dierplaats/jaar) / Emission factors for housing of hens and roosters of laying breeds younger than approx. 18 weeks ( $\mathrm{kg} \mathrm{NH} /$ animal place/year).

\begin{tabular}{|c|c|c|}
\hline Stalsysteem / Housing system & Emissiefactor ${ }^{1)} /$ Emission factor ${ }^{1)}$ & Groep / Group \\
\hline $\begin{array}{l}\text { Verrijkte kooi-/koloniehuisvesting met vaste mest / } \\
\text { Enriched cages and colony housing with solid manure }\end{array}$ & 0,020 & [1] \\
\hline $\begin{array}{l}\text { Grondhuisvesting zonder mestbeluchting / Floor housing } \\
\text { without manure aeration }\end{array}$ & 0,170 & [2] \\
\hline $\begin{array}{l}\text { Grondhuisvesting met luchtwasser / Floor housing with air } \\
\text { scrubber }\end{array}$ & 0,037 & [5] \\
\hline $\begin{array}{l}\text { Volièrehuisvesting zonder mestbeluchting / Aviary system } \\
\text { without manure aeration }\end{array}$ & 0,050 & [3] \\
\hline $\begin{array}{l}\text { Volièrehuisvesting met mestbeluchting / Aviary system } \\
\text { with manure aeration }\end{array}$ & $0,050(0,027)$ & [4] \\
\hline Overig, heaters e.d. / Others, heaters etc. & $0,121(0,109)$ & [6] \\
\hline \multicolumn{3}{|c|}{$\begin{array}{l}\text { 1) Tussen haakjes staat de gemiddelde factor die berekend is uit de implementatiegraden en de factoren per dierplaats van de } \\
\text { onderliggende systemen in de Rav / The average factor calculated from the implementation grades and the emission factors per } \\
\text { animal place for the underlying systems in the Rav is placed in brackets. }\end{array}$} \\
\hline \multicolumn{3}{|c|}{$\begin{array}{l}\text { N.B. De emissiefactoren per dierplaats voor de onderliggende systemen zijn overgenomen van de Regeling ammoniak en veehouderij } \\
\text { / The emission factors per animal place for the underlying systems are taken from the Regulation ammonia and animal husbandry } \\
\text { (Dutch: Rav). }\end{array}$} \\
\hline \multicolumn{3}{|c|}{$\begin{array}{l}\text { De bijtelling voor additionele technieken is voor volièresystemen zonder mestbeluchting } 0,013 \text { en voor volièresystemen met } \\
\text { mestbeluchting } 0,016 \mathrm{~kg} \mathrm{NH}_{3} / \text { dierplaats/jaar / The addition for additional techniques for aviary housing without manure aeration is }\end{array}$} \\
\hline
\end{tabular}

\section{Hennen en hanen van legrassen van ca. 18 weken en ouder}

De implementatiegraden van de stalsystemen zijn weergegeven in Tabel B9.16 inclusief de implementatiegraden van systemen waaraan een additionele techniek is gekoppeld voor mestdroging of mestopslag langer dan twee weken buiten de stal.

Additionele techniek E7.10 verwijdert zowel fijnstof als ammoniak en komt voor bij volièresystemen. Hierdoor valt de emissiefactor per dierplaats bij deze systemen lager uit.

Batterijhuisvesting met natte mest is inmiddels verboden. De incidentele opgaven van dit systeem zijn opgeteld bij batterij-/koloniehuisvesting met vaste mest.

Het aandeel luchtwasser $(<1 \%)$ is aan volière met beluchting toegevoegd.

De vraag naar huisvesting in de Gecombineerde Opgave levert geen informatie over uitloop.

B9.16 Implementatiegraden van stalsystemen voor hennen en -hanen van legrassen van ca. 18 weken en ouder / Implementation grades of housing systems for hens and roosters of laying breeds of approx. 18 weeks and older.

\begin{tabular}{|c|c|c|}
\hline Stalsysteem / Housing system & Aandeel / Share & Groep / Group \\
\hline E2.2 & $0,2 \%$ & [1] \\
\hline E2.5.1 & $0,6 \%$ & [1] \\
\hline E2.5.5 & $1,9 \%$ & {$[1]$} \\
\hline E2.6 & $0,6 \%$ & [1] \\
\hline E2.7 & $1,6 \%$ & [2] \\
\hline E2.8 & $0,2 \%$ & [3] \\
\hline E2.9.1 & $2,1 \%$ & {$[4]$} \\
\hline E2.11.1 & $22,2 \%$ & [5] \\
\hline
\end{tabular}




\begin{tabular}{|c|c|c|}
\hline E2.11.2.1 & $21,0 \%$ & [6] \\
\hline E2.11.2.2 & $18,2 \%$ & {$[6]$} \\
\hline E2.11.3 & $4,8 \%$ & [6] \\
\hline E2.12.1 & $3,7 \%$ & [7] \\
\hline E2.12.2 & $1,5 \%$ & [7] \\
\hline E2.100 & $2,0 \%$ & [2] \\
\hline E2.101 & $0,2 \%$ & [1] \\
\hline E2.Totaal / E2.Total & $100 \%$ & \\
\hline waarvan met additionele techniek / of which with additional technique & $50,8 \%$ & \\
\hline
\end{tabular}

N.B. Voor stalomschrijvingen en emissiefactoren per dierplaats wordt verwezen naar de Regeling ammoniak en veehouderij / Please note that the description of housing systems and emission factors can be found in the Regulation ammonia and animal husbandry (Dutch: Rav).

De indeling is groepen is weergegeven in Tabel B9.17 / The classification into groups is shown in Table B9.17.

In Tabel B9.17 zijn de emissiefactoren weergegeven voor de typen huisvesting die in het rekenmodel worden onderscheiden. Voor verschillende systemen wordt ervan uitgegaan dat de ammoniakemissie per dierplaats in de praktijk hoger is dan de Rav-waarde (Paragraaf 2.6).

B9.17 Emissiefactoren van stalsystemen voor hennen en -hanen van legrassen van ca. 18 weken en ouder ( $\mathrm{kg} \mathrm{NH} /$ dierplaats/jaar) / Emission factors for housing of hens and roosters of laying breeds of approx. 18 weeks and older ( $k g \mathrm{NH}_{3}$ /animal place/year).

\begin{tabular}{|c|c|c|}
\hline Stalsysteem / Housing system & Emissiefactor $\left.{ }^{1}\right)$ / Emission factor ${ }^{1}$ ) & Groep / Group ${ }^{1)}$ \\
\hline $\begin{array}{l}\text { Verrijkte kooi-/koloniehuisvesting met vaste mest / Enriched } \\
\text { cages and colony housing with solid manure }\end{array}$ & 0,037 & {$[1]$} \\
\hline $\begin{array}{l}\text { Grondhuisvesting zonder mestbeluchting of mestbanden / } \\
\text { Floor housing without manure aeration or manure belts }\end{array}$ & 0,402 & {$[2]$} \\
\hline \multicolumn{3}{|l|}{ Grondhuisvesting / Floor housing: } \\
\hline perfosysteem / perfo system & 0,140 & [3] \\
\hline mestbeluchting / manure aeration & $0,301(0,169)$ & [4] \\
\hline mestbanden / manure belts & $0,212(0,101)$ & [7] \\
\hline $\begin{array}{l}\text { Volièrehuisvesting zonder mestbeluchting / Aviary system } \\
\text { without manure aeration }\end{array}$ & 0,087 & {$[5]$} \\
\hline $\begin{array}{l}\text { Volièrehuisvesting met mestbeluchting incl. luchtwasser / } \\
\text { Aviary system with manure aeration incl. air scrubber }\end{array}$ & $0,087(0,043)$ & [6] \\
\hline \multicolumn{3}{|c|}{$\begin{array}{l}\text { 1) Tussen haakjes staat de gemiddelde factor die berekend is uit de implementatiegraden en de factoren per dierplaats van de } \\
\text { onderliggende systemen in de Rav / The average factor calculated from the implementation grades and the emission factors per } \\
\text { animal place for the underlying systems in the Rav is placed in brackets. }\end{array}$} \\
\hline \multicolumn{3}{|c|}{$\begin{array}{l}\text { De bijtelling voor additionele technieken voor mestdroging of mestopslag langer dan twee weken buiten de stal is voor } \\
\text { reguliere volièresystemen } 0,025 \text {, bij emissiearme volièresystemen } 0,023 \text { en bij grondhuisvesting met mestbeluchting }\end{array}$} \\
\hline
\end{tabular}

\section{Ouderdieren van vleeskuikens jonger dan ca. 18 weken}

De implementatiegraden van de stalsystemen zijn weergegeven in Tabel B9.18. Volgens de toelichting in de Rav is er geen additionele techniek van toepassing op stalsystemen van deze diercategorie.

B9.18 Implementatiegraden van stalsystemen voor ouderdieren van vleeskuikens jonger dan ca. 18 weken / Implementation of housing systems for broiler breeders younger than approx. 18 weeks.

\begin{tabular}{|c|c|c|}
\hline Stalsysteem / Housing system & Aandeel / Share & Groep / Group ${ }^{11}$ \\
\hline E3.1 & $5,4 \%$ & {$[1]$} \\
\hline E3.4 & $14,7 \%$ & [2] \\
\hline
\end{tabular}




\begin{tabular}{|c|c|c|}
\hline E3.5 & $0,0 \%$ & [1] \\
\hline E3.6 & $0,9 \%$ & [1] \\
\hline E3.7 & $4,5 \%$ & [2] \\
\hline E3.8 & $19,0 \%$ & [2] \\
\hline E3.100 & $48,0 \%$ & [3] \\
\hline
\end{tabular}

N.B. Voor stalomschrijvingen en emissiefactoren per dierplaats wordt verwezen naar de Regeling ammoniak en veehouderij / Please note that the description of housing systems and emission factors can be found in the Regulation ammonia and animal husbandry (Dutch: Rav).

De indeling is groepen is weergegeven in Tabel B9.19 / The classification into groups is shown in Table B9.19.

In Tabel B9.19 zijn de emissiefactoren weergegeven voor de typen huisvesting die in het rekenmodel worden onderscheiden. Voor verschillende systemen wordt ervan uitgegaan dat de ammoniakemissie per dierplaats in de praktijk hoger is dan de Rav-waarde (Paragraaf 2.6).

B9.19 Emissiefactoren voor huisvesting van ouderdieren van vleeskuikens jonger dan ca. 18 weken ( $\mathrm{kg} \mathrm{NH} /$ /dierplaats/jaar) / Emission factors for housing of broiler breeders younger than of approx. 18 weeks ( $\mathrm{kg} \mathrm{NH}$ /animal place/year).

\begin{tabular}{|c|c|c|}
\hline Stalsysteem / Housing system & Emissiefactor ${ }^{1}$ ) / Emission factor ${ }^{1}$ ) & Groep / Group ${ }^{1}$ \\
\hline Luchtwasser / Air scrubber & 0,016 & {$[1]$} \\
\hline $\begin{array}{l}\text { Overige emissiearme huisvesting / Other low emission } \\
\text { housing }\end{array}$ & $0,122(0,045)$ & {$[2]$} \\
\hline Overige huisvesting / Other housing & 0,122 & {$[3]$} \\
\hline \multicolumn{3}{|c|}{$\begin{array}{l}\text { 1) Tussen haakjes staat de gemiddelde factor die berekend is uit de implementatiegraden en de factoren per dierplaats van de } \\
\text { onderliggende systemen in de Rav / The average factor calculated from the implementation grades and the emission factors per } \\
\text { animal place for the underlying systems in the Rav is placed in brackets. } \\
\text { N.B. De emissiefactoren per dierplaats voor de onderliggende systemen zijn overgenomen van de Regeling ammoniak en veehouderij } \\
\text { / The emission factors per animal place for the underlying systems are taken from the Regulation ammonia and animal husbandry } \\
\text { (Dutch: Rav). }\end{array}$} \\
\hline
\end{tabular}

\section{Ouderdieren van vleeskuikens van ca. 18 weken en ouder}

De implementatiegraden van de stalsystemen zijn weergegeven in Tabel B9.20 inclusief de implementatiegraden van systemen waaraan een additionele techniek is gekoppeld voor mestdroging of mestopslag langer dan twee weken buiten de stal.

B9.20 Implementatiegraden van stalsystemen voor ouderdieren van vleeskuikens van ca. 18 weken en ouder / Implementation grades of housing systems for broiler breeders of approx. 18 weeks and older.

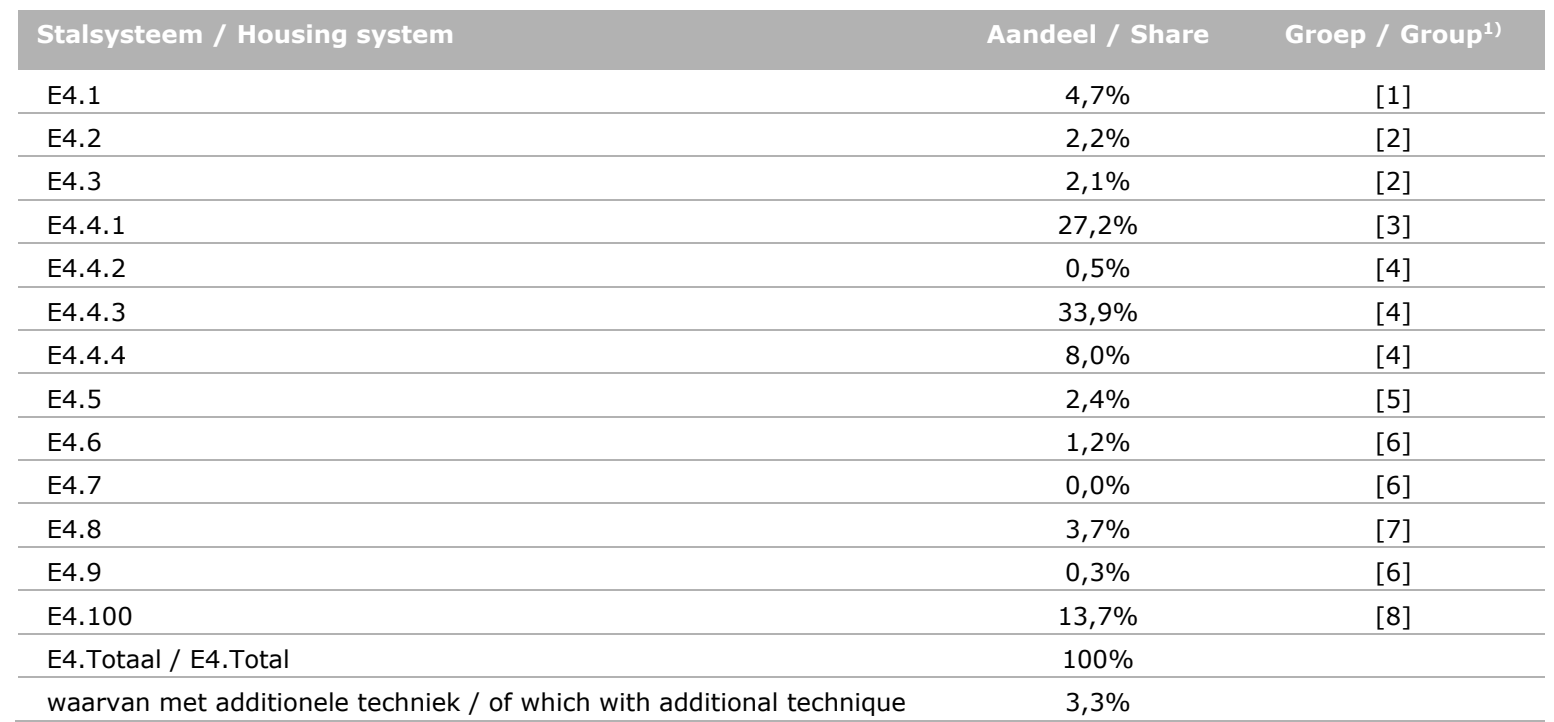

N.B. Voor stalomschrijvingen en emissiefactoren per dierplaats wordt verwezen naar de Regeling ammoniak en veehouderij / Please note that the description of housing systems and emission factors can be found in the Regulation ammonia and animal husbandry (Dutch: Rav).

De indeling is groepen is weergegeven in Tabel B9.21/ The classification into groups is shown in Table B9.21. 
In Tabel B9.21 zijn de emissiefactoren weergegeven voor de typen huisvesting die in het rekenmodel worden onderscheiden.

B9.21 Emissiefactoren voor huisvesting van ouderdieren van vleeskuikens van ca. 18 weken en ouder ( $\mathrm{kg} \mathrm{NH}$ /dierplaats/jaar) / Emission factors for housing of broiler breeders of approx. 18 weeks and older ( $\mathrm{kg} \mathrm{NH}$ /animal place/year).

\begin{tabular}{|c|c|c|}
\hline Stalsysteem / Housing system & imissiefactor ${ }^{1}$ / Emission factor ${ }^{1}$ ) & Groep / Group ${ }^{1)}$ \\
\hline $\begin{array}{l}\text { Groepskooi met mestbanden en geforceerde mestbeluchting / } \\
\text { Colony housing with manure belts and forced manure drying }\end{array}$ & 0,063 & [1] \\
\hline $\begin{array}{l}\text { Volièrehuisvesting met mestbeluchting / Aviary system with } \\
\text { manure aeration }\end{array}$ & 0,118 & {$[2]$} \\
\hline $\begin{array}{l}\text { Grondhuisvesting met mestbeluchting van bovenaf / Floor } \\
\text { housing with manure aeration from above }\end{array}$ & $0,310(0,196)$ & [3] \\
\hline $\begin{array}{l}\text { Grondhuisvesting met verticale slangen in de mest of via } \\
\text { buizen onder de beun / Floor housing with vertical aeration } \\
\text { tubes in the manure or through tubes under the bin }\end{array}$ & $0,456(0,342)$ & [4] \\
\hline Perfosysteem / Perfo system & $0,286(0,181)$ & [5] \\
\hline Luchtwassers / Air scrubbers & 0,046 & {$[6]$} \\
\hline $\begin{array}{l}\text { Grondhuisvesting met mestbanden / Floor housing with } \\
\text { manure belts }\end{array}$ & $0,303(0,192)$ & [7] \\
\hline Overige huisvesting / Other housing & 0,456 & {$[8]$} \\
\hline \multicolumn{3}{|c|}{$\begin{array}{l}\text { 1) Tussen haakjes staat de gemiddelde factor die berekend is uit de implementatiegraden en de factoren per dierplaats van de } \\
\text { onderliggende systemen in de Rav / The average factor calculated from the implementation grades and the emission factors per } \\
\text { animal place for the underlying systems in the Rav is placed in brackets. } \\
\text { N.B. De emissiefactoren per dierplaats voor de onderliggende systemen zijn overgenomen van de Regeling ammoniak en veehouderij } \\
\text { / The emission factors per animal place for the underlying systems are taken from the Regulation ammonia and animal husbandry } \\
\text { (Dutch: Rav). } \\
\text { De bijtelling voor additionele technieken is bij groepskooi } 0,002 \text {, bij volièresystemen met mestbeluchting } 0,029 \text { en bij } \\
\text { grondhuisvesting met mestbanden } 0,002 \mathrm{~kg} \mathrm{NH} / \text { dierplaats/jaar / The addition for additional techniques for group cages is } 0.002 \text {, for } \\
\text { aviary housing with manure aeration } 0.029 \text { and for floor housing with manure belts } 0.002 \mathrm{~kg} \mathrm{NH}_{3} / \text { animal place/year. }\end{array}$} \\
\hline
\end{tabular}

\section{Vleeskuikens}

De implementatiegraden van de stalsystemen zijn weergegeven in Tabel B9.22.

\section{B9.22 Implementatiegraden van stalsystemen voor vleeskuikens / Implementation grades of} housing systems for broilers.

\begin{tabular}{|c|c|c|}
\hline Stalsysteem / Housing system & Aandeel / Share & Groep / Group ${ }^{1)}$ \\
\hline E5.1 & $0,5 \%$ & [1] \\
\hline E5.4 & $2,2 \%$ & [3] \\
\hline E5.5 & $1,9 \%$ & {$[4]$} \\
\hline E5.7 & $0,3 \%$ & [3] \\
\hline E5.8 & $1,5 \%$ & {$[2]$} \\
\hline E5.9.1.1.5 & $0,1 \%$ & {$[5]$} \\
\hline E5.9.1.2.3 & $0,2 \%$ & [2] \\
\hline E5.9.1.2.5 & $0,1 \%$ & {$[5]$} \\
\hline E5.14 & $17,0 \%$ & {$[5]$} \\
\hline E5.15 & $4,1 \%$ & {$[5]$} \\
\hline E5.100 & $8,1 \%$ & {$[6]$} \\
\hline E5.Totaal / E5.Total & $100 \%$ & \\
\hline
\end{tabular}

N.B. Voor stalomschrijvingen en emissiefactoren per dierplaats wordt verwezen naar de Regeling ammoniak en veehouderij / Please note that the description of housing systems and emission factors can be found in the Regulation ammonia and animal husbandry (Dutch: Rav).

De indeling is groepen is weergegeven in Tabel B9.23 / The classification into groups is shown in Table B9.23. 
In Tabel B9.23 zijn de emissiefactoren weergegeven voor de typen huisvesting die in het rekenmodel worden onderscheiden.

B9.23 Emissiefactoren van stalsystemen voor vleeskuikens ( $k g \mathrm{NH}_{3} /$ dierplaats/jaar) / Emission factors for housing of broilers ( $\mathrm{kg} \mathrm{NH}$ /animal place/year).

\begin{tabular}{|c|c|c|}
\hline Stalsysteem / Housing system & Emissiefactor $\left.{ }^{1}\right) /$ Emission factor $\left.^{1}\right)$ & Groep / Group ${ }^{1)}$ \\
\hline Vloer met strooiseldroging / Floor with litter drying & 0,007 & [1] \\
\hline Etagesystemen / Multi-level system & 0,016 & {$[2]$} \\
\hline Luchtwassers / Air scrubbers & 0,008 & [3] \\
\hline $\begin{array}{l}\text { Grondhuisvesting met vloerverwarming en -verkoeling / } \\
\text { Floor housing with floor heating and cooling }\end{array}$ & $0,068(0,038)$ & [4] \\
\hline $\begin{array}{l}\text { Mixluchtventilatie, warmteheaters en ventilatoren, } \\
\text { luchtmenging / Mixed air ventilation, heaters and fans, } \\
\text { air mixing }\end{array}$ & $0,068(0,018)$ & {$[5]$} \\
\hline Overige huisvesting / Other housing & 0,068 & {$[6]$} \\
\hline \multicolumn{3}{|c|}{$\begin{array}{l}\text { 1) Tussen haakjes staat de gemiddelde factor die berekend is uit de implementatiegraden en de factoren per dierplaats van de } \\
\text { onderliggende systemen in de Rav / The average factor calculated from the implementation grades and the emission factors per } \\
\text { animal place for the underlying systems in the Rav is placed in brackets. } \\
\text { N.B. De emissiefactoren per dierplaats voor de onderliggende systemen zijn overgenomen van de Regeling ammoniak en veehouderi } \\
\text { / The emission factors per animal place for the underlying systems are taken from the Regulation ammonia and animal husbandry } \\
\text { (Dutch: Rav). }\end{array}$} \\
\hline
\end{tabular}

\section{Kalkoenen}

De implementatiegraden van de stalsystemen voor vleeskalkoenen zijn weergegeven in Tabel B9.24. De analyse beperkt zich tot de staltypen voor vleeskalkoenen (F4) aangezien kalkoenen voor de broedeierproductie nauwelijks voorkomen.

B9.24 Implementatiegraden van stalsystemen voor vleeskalkoenen / Implementation grades of housing systems for meat turkeys.

\begin{tabular}{lcc} 
Stalsysteem / Housing system & Aandeel / Share & Groep / Group ${ }^{1)}$ \\
F4.3 & $0,0 \%$ & {$[1]$} \\
\hline F4.5 & $9,0 \%$ & $10,5 \%$ \\
\hline F4.8 & {$[1]$} & $4,6 \%$ \\
\hline F4.9 & {$[1]$} & $75,9 \%$ \\
\hline F4.100 & $10 \%$ & $100 \%$ \\
\hline F4.Totaal / F4.Total & {$[2]$} & {$[1]$} \\
\hline
\end{tabular}

N.B. Voor stalomschrijvingen en emissiefactoren per dierplaats wordt verwezen naar de Regeling ammoniak en veehouderij / Please note that the description of housing systems and emission factors can be found in the Regulation ammonia and animal husbandry (Dutch: Rav).

De indeling is groepen is weergegeven in Tabel B9.25 / The classification into groups is shown in Table B9.25.

In Tabel B9.25 zijn de emissiefactoren weergegeven voor de typen huisvesting die in het rekenmodel worden onderscheiden.

B9.25 Emissiefactoren van stalsystemen voor vleeskalkoenen ( $\mathrm{kg} \mathrm{NH}_{3} /$ dierplaats/jaar) /

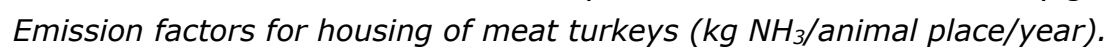

\begin{tabular}{|c|c|c|}
\hline Stalsysteem / Housing system & Emissiefactor / Emission factor & Groep / Group ${ }^{1)}$ \\
\hline Emissiearme huisvesting / Low emission housing & 0,378 & [1] \\
\hline Overige huisvesting / Other housing & 0,932 & [2] \\
\hline
\end{tabular}




\section{Eenden}

De implementatiegraden van de stalsystemen voor eenden zijn weergegeven in Tabel B9.26.

Staltypen van zowel vleeseenden als ouderdieren zijn geselecteerd. Staltype G1.100 is niet-

emissiearme huisvesting van ouderdieren tot 24 maanden. G2.1 is huisvesting van vleeseenden die binnen worden gemest.

B9.26 Implementatiegraden van stalsystemen voor eenden / Implementation grades of housing systems for ducks.

\begin{tabular}{lcc} 
Stalsysteem / Housing system & Aandeel / Share & Groep / Group ${ }^{1)}$ \\
\hline G1.100 & $8,6 \%$ & {$[2]$} \\
\hline G2.1.1 & $5,9 \%$ & {$[1]$} \\
\hline G2.1.100 & $85,5 \%$ & {$[2]$} \\
\hline G.Totaal / G.Total & $100 \%$
\end{tabular}

N.B. Voor stalomschrijvingen en emissiefactoren per dierplaats wordt verwezen naar de Regeling ammoniak en veehouderij

/ Please note that the description of housing systems and emission factors can be found in the Regulation ammonia and animal husbandry (Dutch: Rav).

In Tabel B9.27 zijn de emissiefactoren weergegeven voor de typen huisvesting die in het rekenmodel worden onderscheiden.

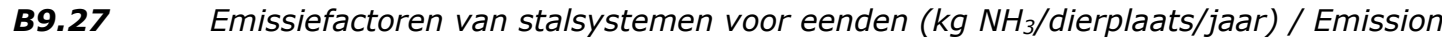

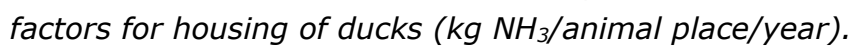

\begin{tabular}{|c|c|c|}
\hline Stalsysteem / Housing system & Emissiefactor / Emission factor & Groep / Group ${ }^{1)}$ \\
\hline Luchtwassers / Air scrubbers & 0,021 & [1] \\
\hline Overige huisvesting (G2.1.100) / Other housing (G2.1.100) & 0,210 & {$[2]$} \\
\hline
\end{tabular}





\section{Bijlage $10 \quad \mathrm{NH}_{3}$-emissiefactoren rundveestallen}

B10.1

$\mathrm{NH}_{3}$-emissiefactoren voor rundveestallen (\% van TAN-excretie) / $\mathrm{NH}_{3}$ emission factors for cattle housing (\% of TAN excretion).

\begin{tabular}{|c|c|c|c|c|c|c|c|c|c|c|c|c|c|c|c|}
\hline & 1990 & 1991 & 1992 & 1993 & 1994 & 1995 & 1996 & 1997 & 1998 & 1999 & 2000 & 2001 & 2002 & 2003 & 2004 \\
\hline \multicolumn{16}{|l|}{ Melkkoeien / Dairy cows } \\
\hline drijfmest: gemiddeld / slurry: average & 13,1 & 13,0 & 13,3 & 13,0 & 12,8 & 12,8 & 13,1 & 12,9 & 12,3 & 12,6 & 12,2 & 12,4 & 13,5 & 13,8 & 14,4 \\
\hline vaste mest / solid manure & 15,6 & 15,4 & 16,1 & 15,4 & 15,0 & 15,1 & 15,7 & 15,4 & 14,2 & 14,6 & 14,0 & 14,3 & 16,2 & 16,2 & 16,9 \\
\hline \multicolumn{16}{|l|}{ Vrouwelijk jongvee / Female young stock } \\
\hline drijfmest: gemiddeld / slurry: average & 10,6 & 10,6 & 10,6 & 10,6 & 10,6 & 10,6 & 10,6 & 10,6 & 10,6 & 10,6 & 10,6 & 10,6 & 11,2 & 11,7 & 12,2 \\
\hline vaste mest / solid manure & 11,0 & 11,0 & 11,0 & 11,0 & 11,0 & 11,0 & 11,0 & 11,0 & 11,0 & 11,0 & 11,0 & 11,0 & 11,6 & 12,1 & 12,7 \\
\hline Witvleeskalveren / Calves for white veal production & 27,1 & 27,1 & 27,1 & 27,1 & 27,1 & 27,1 & 27,1 & 27,1 & 27,1 & 27,2 & 27,2 & 27,2 & 27,2 & 27,3 & 27,3 \\
\hline Rosévleeskalveren / Calves for rosé veal production & 13,0 & 13,0 & 13,0 & 13,0 & 13,0 & 13,0 & 13,0 & 13,0 & 13,0 & 13,7 & 14,4 & 15,0 & 15,7 & 16,4 & 17,1 \\
\hline 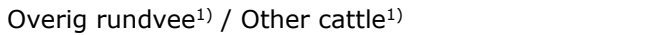 & 11,0 & 11,0 & 11,0 & 11,0 & 11,0 & 11,0 & 11,0 & 11,0 & 11,0 & 11,0 & 11,0 & 11,0 & 11,6 & 12,1 & 12,7 \\
\hline
\end{tabular}

\begin{tabular}{|c|c|c|c|c|c|c|c|c|c|c|c|c|c|c|c|}
\hline & 2005 & 2006 & 2007 & 2008 & 2009 & 2010 & 2011 & 2012 & 2013 & 2014 & 2015 & 2016 & 2017 & 2018 & 2019 \\
\hline \multicolumn{16}{|l|}{ Melkkoeien / Dairy cows } \\
\hline drijfmest: gemiddeld / slurry: average & 14,9 & 15,2 & 15,3 & 15,8 & 15,3 & 15,2 & 15,2 & 15,2 & 15,2 & 15,1 & 15,1 & 15,0 & 15,0 & 15,0 & 15,0 \\
\hline vaste mest / solid manure & 17,6 & 17,9 & 18,3 & 18,4 & 18,2 & 18,2 & 18,0 & 17,9 & 18,0 & 18,1 & 17,9 & 17,5 & 17,5 & 17,5 & 17,2 \\
\hline \multicolumn{16}{|l|}{ Vrouwelijk jongvee / Female young stock } \\
\hline drijfmest: gemiddeld / slurry: average & 12,7 & 13,2 & 13,7 & 13,7 & 13,7 & 13,7 & 13,9 & 13,9 & 13,9 & 13,9 & 14,3 & 14,3 & 14,3 & 14,3 & 14,3 \\
\hline vaste mest / solid manure & 13,2 & 13,7 & 14,3 & 14,3 & 14,3 & 14,3 & 14,3 & 14,3 & 14,3 & 14,3 & 14,3 & 14,3 & 14,3 & 14,3 & 14,3 \\
\hline Witvleeskalveren / Calves for white veal production & 27,3 & 27,3 & 27,4 & 27,4 & 27,4 & 27,4 & 26,3 & 26,2 & 26,1 & 26,1 & 26,5 & 26,6 & 26,4 & 26,4 & 26,3 \\
\hline Rosévleeskalveren / Calves for rosé veal production & 17,8 & 18,4 & 19,1 & 19,8 & 20,5 & 21,2 & 20,9 & 21,5 & 21,4 & 21,4 & 21,8 & 21,8 & 21,7 & 21,7 & 21,5 \\
\hline 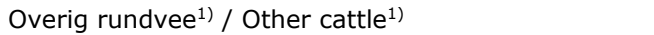 & 13,2 & 13,7 & 14,3 & 14,3 & 14,3 & 14,3 & 14,3 & 14,3 & 14,3 & 14,3 & 14,3 & 14,3 & 14,3 & 14,3 & 14,3 \\
\hline
\end{tabular}

1) Mannelijk jongvee, fokstieren, vleesstieren, zoog-, mest- en weidekoeien / Male young stock, breeding bulls, beef bulls, suckling cows and female fatteners.

N.B. De emissiefactoren zijn het gewogen gemiddelde van de factoren per staltype / Note: The emission factors are the weighted average of the factors per housing type. 



\section{Bijlage $11 \mathrm{NH}_{3}$-emissiefactoren voor varkensstallen}

B11.1

$\mathrm{NH}_{3}$-emissiefactoren voor varkensstallen (\% van TAN-excretie) / $\mathrm{NH}_{3}$ emission factors for pig housing (\% of TAN excretion).

\begin{tabular}{|c|c|c|c|c|c|c|c|c|c|c|c|c|c|c|c|}
\hline & 1990 & 1991 & 1992 & 1993 & 1994 & 1995 & 1996 & 1997 & 1998 & 1999 & 2000 & 2001 & 2002 & 2003 & 2004 \\
\hline $\begin{array}{l}\text { Fokzeugen incl. biggen tot } 25 \mathrm{~kg} \text { / Sows incl. piglets } \\
\text { up to } 25 \mathrm{~kg}\end{array}$ & 26,5 & 26,5 & 26,5 & 26,5 & 26,5 & 26,5 & 26,5 & 26,3 & 26,3 & 26,3 & 26,1 & 26,1 & 26,1 & 26,1 & 26,1 \\
\hline Dekberen / Breeding boars & 26,2 & 26,2 & 26,2 & 26,2 & 26,2 & 26,2 & 26,2 & 25,4 & 25,4 & 25,4 & 24,4 & 24,4 & 24,4 & 24,4 & 24,4 \\
\hline Vleesvarkens / Fattening pigs & 39,6 & 39,6 & 39,6 & 39,6 & 39,6 & 39,6 & 39,6 & 39,3 & 39,3 & 39,3 & 38,6 & 38,6 & 38,6 & 38,6 & 38,6 \\
\hline Opfokvarkens / Gilts and young boars & 39,6 & 39,6 & 39,6 & 39,6 & 39,6 & 39,6 & 39,6 & 39,0 & 39,0 & 39,0 & 38,3 & 38,3 & 38,3 & 38,3 & 38,3 \\
\hline
\end{tabular}

Fokzeugen incl. biggen tot $25 \mathrm{~kg} /$ Sows incl. piglets up to $25 \mathrm{~kg}$

Dekberen / Breeding boars

Vleesvarkens / Fattening pigs

Opfokvarkens / Gilts and young boars

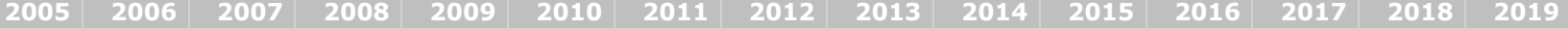

\begin{tabular}{|c|c|c|c|c|c|c|c|c|c|c|c|c|c|c|}
\hline 23,8 & 23,8 & 23,5 & 23,5 & 23,5 & 22,1 & 20,0 & 19,5 & 17,1 & 16,7 & 16,2 & 16,0 & 15,1 & 14,0 & 13,5 \\
\hline 25,8 & 25,8 & 25,7 & 25,7 & 25,7 & 25,6 & 24,4 & 24,2 & 24,1 & 24,0 & 21,5 & 21,3 & 20,8 & 16,7 & 19,0 \\
\hline 5,2 & 35,2 & 34,7 & 34,7 & 34,7 & 31,8 & 26,4 & 25,8 & 22,4 & 22,1 & 22,2 & 21,1 & 20,8 & 18,7 & 17,7 \\
\hline 2 & 35,2 & 34,8 & 34,8 & 34,8 & 31,9 & 26,0 & 25,3 & 22,4 & 22,1 & 22,2 & 21,1 & 20,8 & 18,7 & 17 \\
\hline
\end{tabular}





\section{Bijlage $12 \mathrm{NH}_{3}$-emissiefactoren voor pluimveestallen}

B12.1

$\mathrm{NH}_{3}$-emissiefactoren voor pluimveestallen (\% van TAN-excretie) / $\mathrm{NH}_{3}$ emission factors for poultry housing (\% of TAN excretion).

\begin{tabular}{|c|c|c|c|c|c|c|c|c|c|c|c|c|c|c|c|}
\hline & 1990 & 1991 & 1992 & 1993 & 1994 & 1995 & 1996 & 1997 & 1998 & 1999 & 2000 & 2001 & 2002 & 2003 & 2004 \\
\hline \multicolumn{16}{|l|}{ Leghennen $<18$ weken / Laying hens $<18$ weeks: } \\
\hline $\begin{array}{l}\text { batterijhuisvesting met drijfmest / battery cages } \\
\text { with slurry }\end{array}$ & 10,2 & 10,2 & 10,2 & 10,2 & 9,6 & 9,7 & 9,7 & 9,7 & 10,3 & 10,3 & 10,3 & 10,3 & 10,3 & 10,3 & 10,3 \\
\hline $\begin{array}{l}\text { huisvesting met vaste mest / housing with solid } \\
\text { manure }\end{array}$ & 50,5 & 50,5 & 50,5 & 50,5 & 23,9 & 23,1 & 23,1 & 23,1 & 24,2 & 24,2 & 24,2 & 23,4 & 23,4 & 28,4 & 28,4 \\
\hline \multicolumn{16}{|l|}{ Leghennen $\geq 18$ weken / Laying hens $\geq 18$ weeks: } \\
\hline $\begin{array}{l}\text { batterijhuisvesting met drijfmest / battery cages } \\
\text { with slurry }\end{array}$ & 7,1 & 7,1 & 7,1 & 7,1 & 6,9 & 6,1 & 6,1 & 6,1 & 7,7 & 7,7 & 7,7 & 7,5 & 7,5 & 6,9 & 6,9 \\
\hline $\begin{array}{l}\text { huisvesting met vaste mest / housing with solid } \\
\text { manure }\end{array}$ & 22,1 & 22,1 & 22,1 & 22,1 & 22,0 & 19,6 & 19,6 & 19,8 & 22,1 & 22,4 & 22,6 & 20,7 & 21,0 & 24,5 & 24,8 \\
\hline $\begin{array}{l}\text { Ouderdieren van vleeskuikens }<18 \text { weken / Broiler } \\
\text { breeders }<18 \text { weeks }\end{array}$ & 51,7 & 51,7 & 51,7 & 51,7 & 51,7 & 51,7 & 51,7 & 51,7 & 51,7 & 51,7 & 51,7 & 51,7 & 51,7 & 51,7 & 51,7 \\
\hline $\begin{array}{l}\text { Ouderdieren van vleeskuikens } \geq 18 \text { weken / Broiler } \\
\text { breeders } \geq 18 \text { weeks }\end{array}$ & 53,9 & 53,9 & 53,9 & 53,9 & 53,9 & 53,9 & 53,9 & 53,5 & 53,1 & 52,8 & 52,4 & 52,0 & 51,6 & 51,3 & 50,9 \\
\hline Vleeskuikens / Broilers & 18,6 & 18,6 & 18,6 & 18,6 & 18,6 & 18,6 & 18,6 & 18,6 & 18,6 & 18,6 & 18,6 & 18,6 & 18,6 & 18,6 & 18,6 \\
\hline Eenden / Ducks & 29,7 & 29,7 & 29,7 & 29,7 & 29,7 & 29,7 & 29,7 & 29,7 & 29,7 & 29,7 & 29,7 & 29,7 & 29,7 & 29,7 & 29,7 \\
\hline Kalkoenen / Turkeys & 42,2 & 42,2 & 42,2 & 42,2 & 42,2 & 42,2 & 42,2 & 42,2 & 42,2 & 44,7 & 47,1 & 49,5 & 52,0 & 54,4 & 56,8 \\
\hline
\end{tabular}




\begin{tabular}{|c|c|c|c|c|c|c|c|c|c|c|c|c|c|c|c|}
\hline & 2005 & 2006 & 2007 & 2008 & 2009 & 2010 & 2011 & 2012 & 2013 & 2014 & 2015 & 2016 & 2017 & 2018 & 2019 \\
\hline \multicolumn{16}{|l|}{ Leghennen $<18$ weken / Laying hens $<18$ weeks: } \\
\hline $\begin{array}{l}\text { batterijhuisvesting met drijfmest / battery cages } \\
\text { with slurry }\end{array}$ & 10,3 & 10,3 & 9,0 & 9,0 & 9,0 & 9,0 & 8,3 & 8,3 & $\begin{array}{r}\text { n.v.t. / } \\
\text { n.a. }\end{array}$ & $\begin{array}{r}\text { n.v.t. / } \\
\text { n.a. }\end{array}$ & $\begin{array}{r}\text { n.v.t. / } \\
\text { n.a. }\end{array}$ & $\begin{array}{r}\text { n.v.t. / } \\
\text { n.a. }\end{array}$ & $\begin{array}{r}\text { n.v.t. / } \\
\text { n.a. }\end{array}$ & $\begin{array}{r}\text { n.v.t. / } \\
\text { n.a. }\end{array}$ & $\begin{array}{r}\text { n.v.t. / } \\
\text { n.a. }\end{array}$ \\
\hline $\begin{array}{l}\text { huisvesting met vaste mest / housing with solid } \\
\text { manure }\end{array}$ & 28,0 & 28,0 & 23,6 & 23,6 & 23,6 & 23,6 & 26,9 & 26,9 & 24,0 & 24,0 & 24,9 & 25,3 & 24,7 & 25,0 & 25,3 \\
\hline \multicolumn{16}{|l|}{ Leghennen $\geq 18$ weken / Laying hens $\geq 18$ weeks: } \\
\hline $\begin{array}{l}\text { batterijhuisvesting met drijfmest / battery cages } \\
\text { with slurry }\end{array}$ & 6,9 & 6,9 & 11,1 & 11,1 & 11,1 & 11,1 & 8,6 & 8,6 & $\begin{array}{r}\text { n.v.t. / } \\
\text { n.a. }\end{array}$ & $\begin{array}{r}\text { n.v.t. / } \\
\text { n.a. }\end{array}$ & $\begin{array}{r}\text { n.v.t. / } \\
\text { n.a. }\end{array}$ & $\begin{array}{r}\text { n.v.t. / } \\
\text { n.a. }\end{array}$ & $\begin{array}{r}\text { n.v.t. / } \\
\text { n.a. }\end{array}$ & $\begin{array}{r}\text { n.v.t. / } \\
\text { n.a. }\end{array}$ & $\begin{array}{r}\text { n.v.t. / } \\
\text { n.a. }\end{array}$ \\
\hline $\begin{array}{l}\text { huisvesting met vaste mest / housing with solid } \\
\text { manure }\end{array}$ & 24,7 & 25,1 & 20,3 & 20,6 & 20,6 & 18,5 & 22,5 & 22,5 & 18,4 & 18,4 & 16,7 & 16,8 & 16,6 & 17,4 & 17,5 \\
\hline $\begin{array}{l}\text { Ouderdieren van vleeskuikens }<18 \text { weken / Broiler } \\
\text { breeders }<18 \text { weeks }\end{array}$ & 51,7 & 51,7 & 51,7 & 51,7 & 51,7 & 51,7 & 51,2 & 51,2 & 51,2 & 51,1 & 50,3 & 49,8 & 50,2 & 49,3 & 48,8 \\
\hline $\begin{array}{l}\text { Ouderdieren van vleeskuikens } \geq 18 \text { weken / Broiler } \\
\text { breeders } \geq 18 \text { weeks }\end{array}$ & 42,3 & 42,0 & 44,7 & 44,4 & 44,4 & 43,6 & 40,2 & 40,1 & 40,1 & 40,0 & 38,3 & 37,2 & 37,7 & 39,8 & 39,9 \\
\hline Vleeskuikens / Broilers & 17,6 & 17,6 & 18,0 & 18,0 & 18,0 & 17,7 & 17,3 & 17,3 & 16,9 & 16,9 & 17,3 & 17,2 & 17,3 & 17,3 & 17,3 \\
\hline Eenden / Ducks & 29,7 & 29,7 & 29,7 & 29,7 & 29,7 & 29,7 & 29,7 & 29,7 & 29,7 & 29,7 & 27,8 & 27,9 & 27,9 & 27,7 & 28,1 \\
\hline Kalkoenen / Turkeys & 53,0 & 54,8 & 54,5 & 56,1 & 56,1 & 56,1 & 65,1 & 65,1 & 65,0 & 65,0 & 60,7 & 59,2 & 56,2 & 54,9 & 57,0 \\
\hline
\end{tabular}




\section{Bijlage 13 Mestopslag buiten de stal}

B13.1

Mestopslag buiten de stal (\% van geproduceerde mest) / Manure storage outside the animal housing (\% of produced manure).

\begin{tabular}{|c|c|c|c|c|c|c|c|c|c|c|c|c|c|c|c|}
\hline Mestsoort / Manure type & $\begin{array}{r}1990- \\
2004\end{array}$ & 2005 & 2006 & 2007 & 2008 & 2009 & $\begin{array}{r}2010- \\
2011\end{array}$ & 2012 & 2013 & 2014 & 2015 & 2016 & 2017 & 2018 & 2019 \\
\hline Rundveedrijfmest / Cattle slurry & 25 & 27 & 27 & 27 & 27 & 27 & 24 & 24 & 23 & 23 & 23 & 23 & 20 & 20 & 20 \\
\hline Varkensdrijfmest / Pig slurry & 10 & 15 & 15 & 15 & 15 & 15 & 21 & 21 & 19 & 19 & 19 & 19 & 19 & 19 & 19 \\
\hline Pluimveedrijfmest / Poultry slurry & 15 & 88 & 88 & 88 & 88 & 88 & 100 & 100 & $\begin{array}{r}\text { n.v.t. / } \\
\text { n.a. }\end{array}$ & $\begin{array}{r}\text { n.v.t. / } \\
\text { n.a. }\end{array}$ & $\begin{array}{r}\text { n.v.t. / } \\
\text { n.a. }\end{array}$ & $\begin{array}{r}\text { n.v.t. / } \\
\text { n.a. }\end{array}$ & $\begin{array}{r}\text { n.v.t. / } \\
\text { n.a. }\end{array}$ & $\begin{array}{r}\text { n.v.t. / } \\
\text { n.a. }\end{array}$ & $\begin{array}{r}\text { n.v.t. / } \\
\text { n.a. }\end{array}$ \\
\hline $\begin{array}{l}\text { Drijfmest van pelsdieren / Slurry from fur-bearing } \\
\text { animals }\end{array}$ & 50 & 50 & 50 & 50 & 50 & 50 & 50 & 50 & 50 & 50 & 50 & 50 & 50 & 50 & 50 \\
\hline $\begin{array}{l}\text { Vaste mest van graasdieren, varkens en konijnen / } \\
\text { Solid manure from grazing livestock, pigs and } \\
\text { rabbits }\end{array}$ & 100 & 100 & 100 & 100 & 100 & 100 & 100 & 100 & 100 & 100 & 100 & 100 & 100 & 100 & 100 \\
\hline \multicolumn{16}{|l|}{ Vaste pluimveemest / Solid poultry manure: } \\
\hline $\begin{array}{l}\text { gedroogde bandmest (kooien en volière) / forced } \\
\text { dried manure from cages and aviary systems }\end{array}$ & 100 & 100 & 100 & 100 & 100 & 100 & 100 & 100 & 100 & 100 & 100 & 100 & 100 & 100 & 100 \\
\hline nagedroogde mest / additionally dried manure & 100 & 100 & 100 & 100 & 100 & 100 & 100 & 100 & 100 & 100 & 100 & 100 & 100 & 100 & 100 \\
\hline legpluimvee - strooiselmest / laying hen litter & 100 & 90 & 60 & 40 & 0 & 0 & 0 & 40 & 40 & 45 & 35 & 35 & 40 & 45 & 35 \\
\hline vleeskuikenmest / broiler litter & 100 & 85 & 65 & 70 & 40 & 35 & 25 & 25 & 30 & 35 & 20 & 25 & 25 & 15 & 0 \\
\hline eendenmest / duck litter & 100 & 100 & 100 & 100 & 85 & 90 & 95 & 95 & 100 & 85 & 70 & 65 & 75 & 70 & 75 \\
\hline kalkoenenmest / turkey litter & 100 & 75 & 5 & 95 & 0 & 0 & 0 & 0 & 0 & 0 & 25 & 30 & 15 & 10 & 0 \\
\hline
\end{tabular}

Bronnen: Landbouwtelling (opslagcapaciteit), WUM (mestproductie) en Vervoersbewijzen Dierlijke Mest / Source: Agricultural census (storage capacity), WUM (manure production) and Registered transports of livestock manure.

B13.2 Afgedekte mestopslagen (\% van buiten de stal opgeslagen mest) / Covered manure storage (\% of stored manure outside the animal housing).

\begin{tabular}{|c|c|c|c|c|c|}
\hline Mestsoort / Manure type & $1990^{1)}$ & 19911) & $\begin{array}{c}1992- \\
1996^{2)}\end{array}$ & $\begin{array}{l}1997- \\
2004^{3)}\end{array}$ & $\begin{array}{l}2005- \\
2019^{4}\end{array}$ \\
\hline Runderdrijfmest / Cattle slurry & 25 & 25 & 67 & 97 & 100 \\
\hline Varkensdrijfmest / Pig slurry & 70 & 75 & 82 & 100 & 100 \\
\hline \multicolumn{6}{|l|}{ Pluimveedrijfmest / Poultry slurry } \\
\hline drijfmest uit open stalopslag / slurry from open storage in animal houses & 60 & 70 & 78 & 100 & 100 \\
\hline drijfmest van mestbandafvoer / slurry from manure belt removal & 0 & 17 & 78 & 100 & 100 \\
\hline
\end{tabular}

(drijfmest van mestbandafvoer / slurry from manure belt removal

2) Landbouwtelling 1993 .

3) Van der Hoek (2002).

4) Hoogeveen et al. (2010). 
B13.3

Emissiefactoren voor $\mathrm{NH}_{3}-\mathrm{N}$ uit mestopslag buiten de stal (\% van opgeslagen $\mathrm{N}$ ) / $\mathrm{NH}_{3}-\mathrm{N}$ emission factors from manure storages outside the animal housing (\% of stored $N$ ).

\begin{tabular}{|c|c|c|c|}
\hline \multirow[t]{2}{*}{ Mestsoort / Manure type } & \multicolumn{2}{|c|}{$1990-2004^{11}$} & 2005-20192) \\
\hline & $\begin{array}{r}\text { niet afgedekt / not } \\
\text { covered }\end{array}$ & afgedekt / covered & afgedekt / covered \\
\hline Runderdrijfmest / Cattle slurry & 4,80 & 0,96 & 1,00 \\
\hline Vleesvarkensdrijfmest / Fattening pig slurry & 8,30 & 1,66 & 2,00 \\
\hline Fokvarkensdrijfmest / Breeding pig slurry & 11,80 & 2,36 & 2,00 \\
\hline Mest van pelsdieren en konijnen / Manure from fur-bearing animals and rabbits & 2,00 & 2,00 & 2,00 \\
\hline \multicolumn{4}{|l|}{ Pluimveedrijfmest / Poultry slurry } \\
\hline drijfmest uit open stalopslag / slurry from open storage in animal houses & 14,00 & 2,80 & 1,00 \\
\hline drijfmest van mestbandafvoer / slurry from manure belt removal & 4,50 & 0,90 & 1,00 \\
\hline Vaste graasdiermest / Solid manure from grazing livestock & 2,45 & 0,49 & 2,00 \\
\hline Vaste varkensmest / Solid pig manure & & & 2,00 \\
\hline \multicolumn{4}{|l|}{ Vaste pluimveemest / Solid poultry manure } \\
\hline deeppit / deep pit & 4,20 & n.v.t. / n.a. & 4,20 \\
\hline voorgedroogde bandmest batterijhuisvesting / pre-dried manure from battery cages with manure belts & 5,30 & n.v.t. / n.a. & * \\
\hline volièrehuisvesting / aviary housing & 9,50 & n.v.t. / n.a. & $*$ \\
\hline nagedroogde mest / additional dried manure & 0,00 & n.v.t. / n.a. & 0,00 \\
\hline legpluimvee-strooiselmest / laying hen litter & 3,00 & n.v.t. / n.a. & 2,50 \\
\hline vleespluimvee-strooiselmest / meat poultry litter & 2,70 & n.v.t. / n.a. & 2,50 \\
\hline *Voorgedroogde bandmest en volièremest ${ }^{3)} /$ pre-dried belt manure and manure from aviary housing ${ }^{3)}$ & & & $\begin{array}{l}\mathrm{kg} \mathrm{NH}_{3} \text { per dierplaats / } \mathrm{kg} \\
\mathrm{NH}_{3} \text { per animal place }\end{array}$ \\
\hline laying hens $<18$ weeks / laying hens $<18$ weeks & & & 0,025 \\
\hline laying hens $\geq 18$ weeks / laying hens $\geq 18$ weeks & & & 0,050 \\
\hline ouderdieren van vleeskuikens / broiler parents & & & 0,075 \\
\hline
\end{tabular}

1) Van der Hoek (2002).

2) Hoogeveen et al. (2010).

3) Oenema et al. (2000). 


\section{Bijlage 14 Mestbewerking}

B14.1

$\mathrm{N}$-aanvoer per mestbewerkingstechniek (miljoen $\mathrm{kg}$ ) / N-supply per manure treatment technique (million $\mathrm{kg}$ ).

\begin{tabular}{|c|c|c|c|c|c|c|c|c|c|c|c|c|c|c|c|}
\hline Mestsoort / Manure type & 1990 & 1991 & 1992 & 1993 & 1994 & 1995 & 1996 & 1997 & 1998 & 1999 & 2000 & 2001 & 2002 & 2003 & 2004 \\
\hline \multicolumn{16}{|c|}{$\begin{array}{l}\text { Mestscheiding en kalvergierzuivering / } \\
\text { Separation of slurry and treatment of veal calves } \\
\text { slurry }\end{array}$} \\
\hline \multicolumn{16}{|l|}{ Drijfmest melkkoeien / Dairy cows slurry } \\
\hline \multicolumn{16}{|l|}{ Drijfmest jongvee / Young stock slurry } \\
\hline Vleeskalvermest / Veal calves slurry & 0,750 & 0,750 & 0,750 & 0,750 & 0,750 & 1,625 & 1,750 & 1,750 & 1,800 & 1,700 & 1,820 & 1,701 & 1,547 & 1,463 & 1,461 \\
\hline \multicolumn{16}{|l|}{ Vleesvarkens / Fattening pig slurry } \\
\hline \multicolumn{16}{|l|}{ Drijfmest fokvarkens / Breeding pig slurry } \\
\hline \multicolumn{16}{|l|}{ Mineralenconcentraat / Mineral concentrates } \\
\hline \multicolumn{16}{|l|}{ Drijfmest vleesvarkens / Fattening pig slurry } \\
\hline \multicolumn{16}{|l|}{ Drijfmest fokvarkens / Breeding pig slurry } \\
\hline \multicolumn{16}{|l|}{ Mestvergisting / Manure digestion } \\
\hline \multicolumn{16}{|l|}{ Drijfmest melkkoeien / Dairy cows slurry } \\
\hline \multicolumn{16}{|l|}{ Drijfmest jongvee / Young stock slurry } \\
\hline \multicolumn{16}{|l|}{ Drijfmest vleesvarkens / Fattening pig slurry } \\
\hline \multicolumn{16}{|l|}{ Drijfmest fokvarkens / Breeding pig slurry } \\
\hline \multicolumn{16}{|c|}{$\begin{array}{l}\text { Mest drogen en korrelen / Drying and pelletizing } \\
\text { manure }\end{array}$} \\
\hline Legpluimveemest / Laying poultry solid manure & & & & & & & & & 2,623 & 3,813 & 3,240 & 2,700 & 2,673 & 2,275 & 2,967 \\
\hline \multicolumn{16}{|l|}{ Vleeskuikenmest / Broiler litter } \\
\hline \multicolumn{16}{|l|}{$\begin{array}{l}\text { Mestverbranding (vooropslag) / Manure } \\
\text { incineration (storage before incineration) }\end{array}$} \\
\hline Legpluimveemest / Laying poultry solid manure & & & & & & & & & & & & 0,572 & 1,073 & 0,431 & 0,773 \\
\hline Vleeskuikenmest / Broiler litter & & & & & & & & & & & & & & & \\
\hline Kalkoenenmest / Turkey manure & & & & & & & & & & & & & & & \\
\hline
\end{tabular}




\begin{tabular}{|c|c|c|c|c|c|c|c|c|c|c|c|c|c|c|c|}
\hline Mestsoort / Manure type & 2005 & 2006 & 2007 & 2008 & 2009 & 2010 & 2011 & 2012 & 2013 & 2014 & 2015 & 2016 & 2017 & 2018 & 2019 \\
\hline \multicolumn{16}{|c|}{$\begin{array}{l}\text { Mestscheiding en kalvergierzuivering / } \\
\text { Separation of slurry and treatment of veal calves } \\
\text { slurry }\end{array}$} \\
\hline Drijfmest melkkoeien / Dairy cows slurry & & & & & 0,149 & 0,435 & 0,697 & 1,274 & 1,867 & 3,068 & 5,940 & 7,765 & 5,558 & 2,375 & 1,740 \\
\hline Drijfmest jongvee / Young stock slurry & & & & & 0,037 & 0,105 & 0,183 & 0,331 & 0,484 & 0,818 & 1,495 & 1,728 & 1,121 & 0,443 & 0,304 \\
\hline Vleeskalvermest / Veal calves slurry & 1,455 & 1,691 & 1,778 & 1,855 & 1,885 & 1,969 & 1,955 & 1,990 & 2,000 & 2,117 & 2,534 & 2,683 & 2,738 & 2,975 & 2,830 \\
\hline Vleesvarkens / Fattening pig slurry & & & & & 0,864 & 1,455 & 2,636 & 3,678 & 3,791 & 4,810 & 7,780 & 10,390 & 10,721 & 11,771 & 13,087 \\
\hline Drijfmest fokvarkens / Breeding pig slurry & & & & & 0,413 & 0,713 & 1,261 & 1,669 & 1,921 & 2,361 & 3,912 & 5,159 & 5,321 & 5,847 & 6,305 \\
\hline \multicolumn{16}{|l|}{ Mineralenconcentraat / Mineral concentrates } \\
\hline Drijfmest vleesvarkens / Fattening pig slurry & & & & & & & 1,295 & 1,908 & 1,887 & 1,116 & 2,511 & 2,506 & 2,876 & 3,239 & 2,939 \\
\hline Drijfmest fokvarkens / Breeding pig slurry & & & & & & & 0,336 & 0,466 & 0,377 & 0,265 & 0,431 & 0,457 & 0,552 & 0,699 & 0,699 \\
\hline \multicolumn{16}{|l|}{ Mestvergisting / Manure digestion } \\
\hline Drijfmest melkkoeien / Dairy cows slurry & & 0,552 & 0,727 & 1,162 & 1,439 & 2,590 & 3,035 & 3,061 & 3,082 & 2,634 & 2,631 & 3,042 & 2,707 & 2,298 & 2,267 \\
\hline Drijfmest jongvee / Young stock slurry & & 0,108 & 0,138 & 0,255 & 0,359 & 0,651 & 0,798 & 0,796 & 0,799 & 0,702 & 0,662 & 0,677 & 0,546 & 0,429 & 0,397 \\
\hline Drijfmest vleesvarkens / Fattening pig slurry & & 0,445 & 0,999 & 2,603 & 2,265 & 2,958 & 2,808 & 3,588 & 4,168 & 5,183 & 4,682 & 5,367 & 5,663 & 4,728 & 4,863 \\
\hline Drijfmest fokvarkens / Breeding pig slurry & & 0,206 & 0,467 & 1,153 & 1,009 & 1,421 & 1,344 & 1,628 & 2,112 & 2,544 & 2,354 & 2,665 & 2,811 & 2,349 & 2,343 \\
\hline \multicolumn{16}{|c|}{$\begin{array}{l}\text { Mest drogen en korrelen / Drying and pelletizing } \\
\text { manure }\end{array}$} \\
\hline Legpluimveemest / Laying poultry solid manure & 3,122 & 3,149 & 2,616 & 3,162 & 3,734 & 3,481 & 3,312 & 3,896 & 3,587 & 4,121 & 4,598 & 5,274 & 5,757 & 5,374 & 5,057 \\
\hline Vleeskuikenmest / Broiler litter & & & 0,396 & 0,186 & 0,134 & 0,207 & 0,188 & 0,012 & 0,010 & 0,414 & 0,743 & 0,534 & 0,440 & 0,461 & 0,484 \\
\hline \multicolumn{16}{|l|}{$\begin{array}{l}\text { Mestverbranding (vooropslag) / Manure } \\
\text { incineration (storage before incineration) }\end{array}$} \\
\hline Legpluimveemest / Laying poultry solid manure & 0,745 & 0,312 & & 3,465 & 5,194 & 5,779 & 5,924 & 5,727 & 6,048 & 5,731 & 6,284 & 5,824 & 5,223 & 3,932 & 3,963 \\
\hline Vleeskuikenmest / Broiler litter & & & & 1,918 & 4,738 & 7,016 & 6,543 & 7,544 & 7,112 & 6,574 & 7,001 & 6,742 & 7,225 & 6,405 & 8,062 \\
\hline Kalkoenenmest / Turkey manure & & & & 0,459 & 0,715 & 0,932 & 0,883 & 0,874 & 0,811 & 0,690 & 0,802 & 0,695 & 0,679 & 0,596 & 0,609 \\
\hline
\end{tabular}




\section{Bijlage 15 Mestafzet buiten de landbouw}

B15.1 Afzet van dierlijke mest van landbouwbedrijven bij hobbybedrijven en particulieren (miljoen $\left.\mathrm{kg} \mathrm{P}_{2} \mathrm{O}_{5}\right)$ / Disposal of manure from agricultural holdings to hobby farms and private parties (million $\mathrm{kg}_{2} \mathrm{P}_{2} \mathrm{O}_{5}$ )

\begin{tabular}{|c|c|c|c|c|c|c|c|c|c|c|c|c|c|c|c|}
\hline Mestsoort / Manure type & 1990 & 1991 & 1992 & 1993 & 1994 & 1995 & 1996 & 1997 & 1998 & 1999 & 2000 & 2001 & 2002 & 2003 & 2004 \\
\hline Melk- en kalfkoeien - drijfmest / Dairy cows - slurry & 0,157 & 0,281 & 0,281 & 0,281 & 0,281 & 0,281 & 0,281 & 0,332 & 0,482 & 0,298 & 0,193 & 0,178 & 0,210 & 0,235 & 0,247 \\
\hline \multicolumn{16}{|l|}{$\begin{array}{l}\text { Melk- en kalfkoeien - vaste mest / Dairy cows - solid } \\
\text { manure }\end{array}$} \\
\hline $\begin{array}{l}\text { Jongvee incl. fokstieren - drijfmest / Young stock incl. } \\
\text { breeding bulls - slurry }\end{array}$ & 0,050 & 0,799 & 0,799 & 0,799 & 0,799 & 0,799 & 0,799 & 0,942 & 1,021 & 0,888 & 0,528 & 0,421 & 1,019 & 0,853 & 0,450 \\
\hline \multicolumn{16}{|l|}{$\begin{array}{l}\text { Jongvee incl. fokstieren - vaste mest / Young stock } \\
\text { incl. breeding bulls - solid manure }\end{array}$} \\
\hline $\begin{array}{l}\text { Vleesvee excl. vleeskalveren - drijfmest / Beef cattle } \\
\text { excl. veal calves - slurry }\end{array}$ & 0,250 & 0,069 & 0,069 & 0,069 & 0,069 & 0,069 & 0,069 & 0,081 & 0,073 & 0,028 & 0,044 & 0,068 & 0,093 & 0,087 & 0,064 \\
\hline $\begin{array}{l}\text { Vleesvee excl. vleeskalveren - vaste mest / Beef cattle } \\
\text { excl. veal calves - solid manure }\end{array}$ & 0,017 & 0,226 & 0,226 & 0,226 & 0,226 & 0,226 & 0,226 & 0,266 & 0,288 & 0,194 & 0,208 & 0,165 & 0,245 & 0,221 & 0,106 \\
\hline Vleeskalveren / Veal calves & 0,259 & 0,073 & 0,073 & 0,073 & 0,073 & 0,073 & 0,073 & 0,085 & 0,056 & 0,049 & 0,057 & 0,105 & 0,072 & 0,112 & 0,021 \\
\hline Schapen / Sheep & 0,053 & & & & & & & & & & & & & & \\
\hline \multicolumn{16}{|l|}{ Geiten / Goats } \\
\hline \multicolumn{16}{|l|}{ Paarden / Horses } \\
\hline Vleesvarkens drijfmest / Fattening pig slurry & 1,546 & 3,976 & 3,976 & 3,976 & 3,976 & 3,976 & 3,976 & 4,686 & 4,559 & 3,021 & 1,650 & 5,796 & 4,031 & 3,828 & 4,458 \\
\hline Fokvarkens drijfmest / Breeding pig slurry & 0,683 & 0,179 & 0,179 & 0,179 & 0,179 & 0,179 & 0,179 & 0,210 & 0,255 & 0,237 & 0,203 & 0,111 & 0,086 & 0,087 & 0,102 \\
\hline \multicolumn{16}{|l|}{ Fokvarkens vaste mest / Breeding pig solid manure } \\
\hline Legpluimvee drijfmest / Laying poultry slurry & 2,755 & 0,167 & 0,167 & 0,167 & 0,167 & 0,167 & 0,167 & 0,197 & 0,166 & 0,192 & 0,159 & 0,010 & 0,008 & 0,261 & 0,221 \\
\hline \multicolumn{16}{|l|}{ Legpluimvee vaste mest / Laying poultry solid manure } \\
\hline \multicolumn{16}{|l|}{ Vleeskuikenmest / Broiler litter } \\
\hline \multicolumn{16}{|l|}{ Eenden- en kalkoenenmest / Duck and turkey manure } \\
\hline \multicolumn{16}{|l|}{ Konijnenmest / Rabbit manure } \\
\hline \multicolumn{16}{|l|}{ Nertsenmest / Mink manure } \\
\hline $\begin{array}{l}\text { Totaal in miljoen } \mathbf{k g ~} \mathrm{P}_{2} \mathrm{O}_{5} / \text { Total in million } \mathrm{kg} \\
\mathrm{P}_{2} \mathrm{O}_{5}\end{array}$ & 5,770 & 5,770 & 5,770 & 5,770 & 5,770 & 5,770 & 5,770 & 6,799 & 6,900 & 4,907 & 3,042 & 6,854 & 5,764 & 5,684 & 5,669 \\
\hline Totaal in miljoen $\mathbf{k g ~} \mathbf{N}^{1)} /$ Total in million $\mathbf{k g ~} \mathbf{N}^{1)}$ & 9,707 & 11,161 & 11,827 & 11,769 & 12,203 & 12,480 & 12,808 & 15,760 & 15,662 & 11,092 & 6,886 & 14,528 & 12,711 & 12,124 & 11,918 \\
\hline
\end{tabular}




\begin{tabular}{|c|c|c|c|c|c|c|c|c|c|c|c|c|c|c|c|}
\hline Mestsoort / Manure type & 2005 & 2006 & 2007 & 2008 & 2009 & 2010 & 2011 & 2012 & 2013 & 2014 & 2015 & 2016 & 2017 & 2018 & 2019 \\
\hline Melk- en kalfkoeien - drijfmest / Dairy cows - slurry & 0,810 & 1,050 & 0,645 & 1,127 & 1,300 & 0,318 & 0,321 & 0,352 & 1,096 & 1,156 & 1,273 & 1,275 & 0,930 & 0,836 & 0,800 \\
\hline $\begin{array}{l}\text { Melk- en kalfkoeien - vaste mest / Dairy cows - solid } \\
\text { manure }\end{array}$ & & & & & 0,070 & 0,219 & 0,233 & 0,244 & 0,259 & 0,253 & 0,318 & 0,376 & 0,080 & 0,065 & 0,066 \\
\hline $\begin{array}{l}\text { Jongvee incl. fokstieren - drijfmest / Young stock incl. } \\
\text { breeding bulls - slurry }\end{array}$ & 0,987 & 0,007 & 0,066 & 0,302 & 0,321 & 0,920 & 0,920 & 0,920 & 0,440 & 0,440 & 0,935 & 0,935 & 0,176 & 0,143 & 0,128 \\
\hline $\begin{array}{l}\text { Jongvee incl. fokstieren - vaste mest / Young stock } \\
\text { incl. breeding bulls - solid manure }\end{array}$ & & & & 0,083 & 0,087 & 0,228 & 0,228 & 0,228 & 0,372 & 0,372 & & & 0,193 & 0,144 & 0,103 \\
\hline $\begin{array}{l}\text { Vleesvee excl. vleeskalveren - drijfmest / Beef cattle } \\
\text { excl. veal calves - slurry }\end{array}$ & 0,038 & & 0,028 & 0,063 & 0,202 & 0,012 & 0,012 & 0,012 & 0,039 & 0,039 & 0,007 & 0,007 & 0,022 & 0,022 & 0,021 \\
\hline $\begin{array}{l}\text { Vleesvee excl. vleeskalveren - vaste mest / Beef cattle } \\
\text { excl. veal calves - solid manure }\end{array}$ & 0,045 & 0,081 & & 0,005 & 0,005 & 0,026 & 0,026 & 0,026 & 0,014 & 0,014 & 0,005 & 0,005 & 0,125 & 0,113 & 0,106 \\
\hline Vleeskalveren / Veal calves & 0,184 & 0,346 & 0,493 & 0,384 & 0,240 & 0,329 & 0,345 & 0,340 & 0,291 & 0,291 & 0,164 & 0,142 & 0,172 & 0,233 & 0,243 \\
\hline Schapen / Sheep & 0,265 & 0,068 & 0,006 & 0,005 & 0,032 & 0,005 & 0,006 & 0,007 & 0,006 & 0,006 & 0,007 & 0,008 & 0,009 & 0,007 & 0,006 \\
\hline Geiten / Goats & & 0,013 & 0,014 & 0,015 & 0,012 & 0,085 & 0,086 & 0,093 & 0,165 & 0,160 & 0,361 & 0,359 & 0,042 & 0,045 & 0,048 \\
\hline Paarden / Horses & & 0,030 & 0,034 & 0,025 & 0,036 & 0,035 & 0,039 & 0,032 & 0,037 & 0,036 & 0,038 & 0,042 & 0,058 & 0,062 & 0,067 \\
\hline Vleesvarkens drijfmest / Fattening pig slurry & 2,727 & 1,682 & 1,766 & 0,981 & 1,085 & 1,478 & 1,617 & 1,649 & 1,594 & 1,433 & 0,572 & 0,454 & 0,730 & 0,582 & 0,607 \\
\hline Fokvarkens drijfmest / Breeding pig slurry & 1,382 & 2,463 & 2,123 & 1,997 & 1,918 & 1,043 & 1,148 & 1,175 & 0,883 & 0,831 & 1,122 & 1,062 & 0,531 & 0,441 & 0,457 \\
\hline Fokvarkens vaste mest / Breeding pig solid manure & & & & & & 0,085 & 0,132 & 0,164 & 0,079 & 0,053 & 0,060 & 0,055 & 0,050 & 0,062 & 0,033 \\
\hline Legpluimvee drijfmest / Laying poultry slurry & 0,199 & 0,017 & 0,003 & & & & & & & & & & & & \\
\hline Legpluimvee vaste mest / Laying poultry solid manure & & 0,085 & 0,062 & 0,067 & 0,064 & 0,061 & 0,106 & 0,145 & 0,700 & 0,184 & 0,366 & 0,386 & 0,448 & 0,400 & 0,410 \\
\hline Vleeskuikenmest / Broiler litter & & 0,043 & 0,037 & 0,036 & 0,021 & 0,019 & 0,012 & 0,021 & 0,028 & 0,052 & 0,054 & 0,049 & 0,059 & 0,051 & 0,050 \\
\hline Eenden- en kalkoenenmest / Duck and turkey manure & & & & 0,002 & 0,001 & 0,002 & 0,001 & 0,017 & 0,035 & 0,001 & 0,001 & 0,002 & 0,010 & 0,007 & 0,003 \\
\hline Konijnenmest / Rabbit manure & & 0,039 & 0,067 & 0,056 & 0,047 & 0,002 & 0,002 & 0,002 & 0,001 & 0,003 & 0,004 & 0,003 & 0,003 & 0,001 & 0,004 \\
\hline Nertsenmest / Mink manure & & 0,014 & 0,010 & 0,008 & 0,005 & 0,005 & 0,018 & 0,033 & 0,022 & 0,018 & 0,040 & 0,035 & 0,009 & 0,013 & 0,008 \\
\hline $\begin{array}{l}\text { Totaal in miljoen } \mathrm{kg} \mathrm{P}_{2} \mathrm{O}_{5} / \text { Total in million } \\
\mathrm{P}_{2} \mathrm{O}_{5}\end{array}$ & 6,637 & 5,938 & 5,354 & 5,156 & 446 & 872 & 5,252 & 460 & 6,061 & 342 & 327 & 195 & 647 & 227 & 160 \\
\hline
\end{tabular}

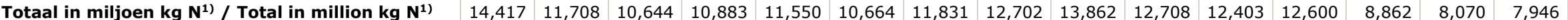
1) De mestafzet uitgedrukt in $\mathrm{N}$ is berekend door de afzet in $\mathrm{P}_{2} \mathrm{O}_{5}$ te vermenigvuldigen met de $\mathrm{N} / \mathrm{P}_{2} \mathrm{O}_{5}$-verhouding van opgeslagen mest / The manure removal expressed as $\mathrm{N}$ is calculated by multiplication of $\mathrm{P}_{2} \mathrm{O}_{5}$ removal with the $\mathrm{N} / \mathrm{P}_{2} \mathrm{O}_{5}$ ratio of stored manure.

Bron: Vervoersbewijzen dierlijke mest (bewerkt) / Source: Registered transports of livestock manure (adapted). 
B15.2 Afzet van dierlijke mest van landbouwbedrijven naar natuurterreinen (miljoen $\mathrm{kg}_{2} \mathrm{O}_{5}$ ) / Disposal of manure from agricultural holdings to nature areas (million $\mathrm{kg} \mathrm{P}_{2} \mathrm{O}_{5}$ ).

\begin{tabular}{|c|c|c|c|c|c|c|c|c|c|c|c|c|c|c|c|}
\hline Mestsoort / Manure type & $\begin{array}{r}1990- \\
2005\end{array}$ & 2006 & 2007 & 2008 & 2009 & 2010 & 2011 & 2012 & 2013 & 2014 & 2015 & 2016 & 2017 & 2018 & 2019 \\
\hline $\begin{array}{l}\text { Vrouwelijk jongvee en fokstieren / Female } \\
\text { young stock and breeding bulls }\end{array}$ & & 0,217 & 0,221 & 0,167 & 0,192 & 0,204 & 0,184 & 0,189 & 0,183 & 0,200 & 0,205 & 0,197 & 0,386 & 0,290 & 0,254 \\
\hline Melk- en kalfkoeien / Dairy cows & & 0,308 & 0,289 & 0,372 & 0,327 & 0,570 & 0,608 & 0,693 & 0,755 & 0,763 & 0,802 & 0,854 & 0,532 & 0,501 & 0,530 \\
\hline Vleeskalveren / Veal calves & & & & & & 0,001 & & 0,002 & 0,003 & 0,005 & 0,003 & 0,001 & 0,002 & 0,001 & 0,002 \\
\hline $\begin{array}{l}\text { Zoog-, mest- en weidekoeien } \geq 2 \mathrm{jr} / \\
\text { Suckling cows and female fatteners } \geq 2 \mathrm{yr}\end{array}$ & & 0,056 & 0,062 & 0,050 & 0,054 & 0,051 & 0,053 & 0,056 & 0,044 & 0,045 & 0,044 & 0,042 & 0,041 & 0,044 & 0,039 \\
\hline Overig vleesvee / Other beef cattle & & 0,021 & 0,022 & 0,017 & 0,020 & 0,019 & 0,017 & 0,018 & 0,016 & 0,016 & 0,016 & 0,013 & 0,146 & 0,125 & 0,139 \\
\hline Schapen / Sheep & & 0,068 & 0,070 & 0,059 & 0,066 & 0,077 & 0,085 & 0,097 & 0,093 & 0,094 & 0,092 & 0,088 & 0,091 & 0,105 & 0,111 \\
\hline Geiten / Goats & & & & & & 0,005 & 0,007 & 0,011 & 0,012 & 0,013 & 0,014 & 0,011 & 0,009 & 0,008 & 0,008 \\
\hline Paarden en pony's / Horses and ponies & & 0,030 & 0,037 & 0,035 & 0,042 & 0,042 & 0,048 & 0,050 & 0,049 & 0,045 & 0,042 & 0,038 & 0,040 & 0,053 & 0,056 \\
\hline Vleesvarkens / Fattening pigs & & & & & & 0,006 & 0,007 & 0,002 & 0,003 & 0,009 & 0,001 & 0,006 & 0,002 & 0,001 & 0,002 \\
\hline Fokvarkens / Breeding pigs & & & & & & 0,004 & 0,006 & 0,007 & 0,003 & 0,003 & 0,006 & 0,002 & 0,004 & 0,003 & 0,003 \\
\hline Pluimvee / Poultry & & & & & & 0,001 & 0,002 & 0,003 & 0,007 & 0,005 & 0,002 & & 0,003 & 0,003 & 0,002 \\
\hline $\begin{array}{l}\text { Konijnen en pelsdieren / Rabbits and fur- } \\
\text { bearing animals }\end{array}$ & & & & & & & & 0,015 & 0,003 & 0,003 & & & & & \\
\hline $\begin{array}{l}\text { Totaal in miljoen } \mathrm{kg}_{2} \mathrm{O}_{5} / \text { Total in } \\
\text { million } \mathrm{kg} \mathrm{P}_{2} \mathrm{O}_{5}\end{array}$ & & 0,700 & 0,700 & 0,700 & 0,700 & 0,981 & 1,017 & 1,142 & 1,171 & 1,202 & 1,226 & 1,253 & 1,257 & 1,134 & 1,146 \\
\hline $\begin{array}{l}\text { Totaal in miljoen } \mathbf{~} \mathbf{g} \mathbf{N}^{1)} / \text { Total in } \\
\text { million } \mathbf{~} \mathbf{g} \mathbf{N}^{1)}\end{array}$ & & 2,215 & 2,151 & 2,236 & 2,298 & 2,939 & 3,046 & 3,340 & 3,520 & 3,465 & 3,322 & 3,775 & 4,084 & 3,867 & 4,060 \\
\hline
\end{tabular}

1) De mestafzet uitgedrukt in $\mathrm{N}$ is berekend door de afzet in fosfaat te vermenigvuldigen met de $\mathrm{N} / \mathrm{P}_{2} \mathrm{O}_{5}$-verhouding van opgeslagen mest / The manure removal expressed as nitrogen is calculated by multiplication of phosphate removal with the $\mathrm{N} / \mathrm{P}_{2} \mathrm{O}_{5}$ ratio of stored manure.

N.B. Inclusief de excretie van landbouwdieren die grazen in natuurterreinen. De totale excretie in natuurterreinen is verdeeld over de diersoorten naar rato van de fosfaatexcretie tijdens beweiding / Including excretion of livestock grazing in nature areas. The total excretion in nature areas is divided among the livestock categories in proportion to the phosphate excretion during grazing.

Bron: Vervoersbewijzen dierlijke mest (bewerkt) en Luesink et al. (2011) / Source: Registered transports of livestock manure (adapted) and Luesink et al. (2011). 
B15.3 Afzet van dierlijke mest buiten de Nederlandse landbouw door mestverwerking (miljoen $\mathrm{kg}_{2} \mathrm{O}_{5}$ ) / Disposal of manure from agriculture by manure processing (million $\mathrm{kg}_{2} \mathrm{O}_{5}$ ).

\begin{tabular}{|c|c|c|c|c|c|c|c|c|c|c|c|c|c|c|c|}
\hline Mestsoort / Manure type & 1990 & 1991 & 1992 & 1993 & 1994 & 1995 & 1996 & 1997 & 1998 & 1999 & 2000 & 2001 & 2002 & 2003 & 2004 \\
\hline Mest van melk- en kalfkoeien / Dairy cow manure & & & & & 0,200 & 0,200 & 0,100 & 0,100 & 0,300 & 0,300 & 0,100 & 0,200 & 0,100 & & \\
\hline \multicolumn{16}{|l|}{$\begin{array}{l}\text { Mest van jongvee en fokstieren / Young stock and } \\
\text { breeding bull manure }\end{array}$} \\
\hline \multicolumn{16}{|l|}{$\begin{array}{l}\text { Mest van vleesrundvee excl. vleeskalveren / Beef } \\
\text { cattle manure excl. veal calves }\end{array}$} \\
\hline \multicolumn{16}{|l|}{ Geitenmest / Goat manure } \\
\hline \multicolumn{16}{|l|}{ Paardenmest / Horse manure } \\
\hline Vleeskalvermest / Veal calf manure & & & & & & & & & & 0,100 & 0,300 & 0,200 & 0,200 & & \\
\hline Vleesvarkensmest / Fattening pig manure & 0,178 & & & & 0,600 & 0,400 & 0,100 & 0,200 & 0,100 & 0,300 & 0,100 & 1,100 & 0,900 & 0,600 & 0,500 \\
\hline Fokvarkensmest / Breeding pig manure & & & & & 0,200 & 0,200 & 0,100 & 0,100 & 0,100 & & & 0,100 & & 0,100 & 0,100 \\
\hline Legpluimveemest / Laying poultry manure & & & & & 3,200 & 2,500 & 1,400 & 0,830 & 2,000 & 3,700 & 5,200 & 6,300 & 7,300 & 4,250 & 8,800 \\
\hline Vleeskuikenmest / Broiler manure & 4,881 & 3,400 & 5,600 & 7,700 & 9,200 & 8,700 & 4,900 & 4,000 & 3,300 & 5,000 & 6,200 & 6,400 & 7,100 & 2,750 & 1,500 \\
\hline \multicolumn{16}{|l|}{ Eendenmest / Duck manure } \\
\hline \multicolumn{16}{|l|}{ Kalkoenenmest / Turkey manure } \\
\hline Pluimveemestkorrels / Poultry manure pellets & 0,266 & & & & & 0,100 & 0,300 & 0,800 & 2,600 & 3,000 & 2,600 & 2,700 & 2,300 & 2,100 & 2,200 \\
\hline Konijnenmest / Rabbit manure & & & & & & & & & & & & & & 0,161 & 0,183 \\
\hline $\begin{array}{l}\text { Mest van pelsdieren / Manure from fur-bearing } \\
\text { animals }\end{array}$ & & & & & 0,400 & 0,400 & 0,300 & & 0,100 & 0,200 & 0,300 & 0,800 & 1,258 & 1,121 & 1,217 \\
\hline $\begin{array}{l}\text { Totaal in miljoen } \mathbf{k g ~} \mathrm{P}_{2} \mathrm{O}_{5} / \text { Total in million } \mathrm{kg} \\
\mathrm{P}_{2} \mathrm{O}_{5}\end{array}$ & 5,325 & 3,400 & 5,600 & 7,700 & 13,800 & 12,500 & 7,200 & 6,030 & 8,500 & 12,600 & 14,800 & 17,800 & 19,158 & 11,082 & 14,500 \\
\hline Totaal in miljoen $\mathrm{kg} \mathrm{N}^{1)} /$ Total in million $\mathrm{kg}^{1}{ }^{1)}$ & 12,562 & 8,901 & 13,678 & 18,020 & 27,362 & 29,184 & 16,950 & 13,482 & 16,557 & 22,393 & 25,078 & 32,442 & 35,450 & 18,917 & 23,116 \\
\hline
\end{tabular}

$B 15.3$

vervolg / continuation

\begin{tabular}{|c|c|c|c|c|c|c|c|c|c|c|c|c|c|c|c|}
\hline Mestsoort / Manure type & 2005 & 2006 & 2007 & 2008 & 2009 & 2010 & 2011 & 2012 & 2013 & 2014 & 2015 & 2016 & 2017 & 2018 & 2019 \\
\hline Mest van melk- en kalfkoeien / Dairy cow manure & 0,040 & 0,050 & 0,095 & 0,455 & 0,397 & 0,267 & 0,281 & 0,350 & 0,445 & 0,756 & 1,279 & 1,792 & 1,238 & 0,582 & 0,367 \\
\hline $\begin{array}{l}\text { Mest van jongvee en fokstieren / Young stock and } \\
\text { breeding bull manure }\end{array}$ & & & & & & & & & & & & & 0,217 & 0,094 & 0,056 \\
\hline $\begin{array}{l}\text { Mest van vleesrundvee excl. vleeskalveren / Beef } \\
\text { cattle manure excl. veal calves }\end{array}$ & 0,045 & & & & & & & & & & & & 0,027 & 0,014 & 0,009 \\
\hline Geitenmest / Goat manure & & 0,001 & 0,010 & 0,003 & 0,005 & 0,043 & 0,047 & 0,096 & 0,015 & 0,018 & 0,037 & 0,043 & 0,018 & 0,022 & 0,055 \\
\hline Paardenmest / Horse manure & 0,167 & 0,452 & 0,491 & 0,487 & 0,436 & 0,326 & 0,243 & 0,302 & 0,381 & 0,412 & 0,299 & 0,189 & 0,160 & 0,123 & 0,071 \\
\hline Vleeskalvermest / Veal calf manure & 0,141 & 0,008 & 0,025 & 0,035 & 0,031 & 0,059 & 0,040 & 0,049 & 0,098 & 0,217 & 0,183 & 0,227 & 0,153 & 0,123 & 0,129 \\
\hline Vleesvarkensmest / Fattening pig manure & 1,399 & 0,493 & 0,445 & 1,977 & 3,279 & 1,973 & 2,306 & 3,358 & 3,327 & 4,471 & 6,165 & 7,193 & 8,175 & 8,008 & 8,546 \\
\hline
\end{tabular}

150 | wot-technical report 203 


\begin{tabular}{|c|c|c|c|c|c|c|c|c|c|c|c|c|c|c|c|}
\hline Mestsoort / Manure type & 2005 & 2006 & 2007 & 2008 & 2009 & 2010 & 2011 & 2012 & 2013 & 2014 & 2015 & 2016 & 2017 & 2018 & 2019 \\
\hline Fokvarkensmest / Breeding pig manure & 0,480 & 0,204 & 0,881 & 2,300 & 1,011 & 0,886 & 1,309 & 1,726 & 1,601 & 2,311 & 3,327 & 4,700 & 3,725 & 4,098 & 4,486 \\
\hline Legpluimveemest / Laying poultry manure & 11,372 & 6,890 & 10,902 & 12,955 & 14,852 & 16,329 & 15,013 & 14,919 & 15,027 & 15,345 & 16,037 & 16,309 & 15,069 & 14,139 & 14,685 \\
\hline Vleeskuikenmest / Broiler manure & 3,829 & 3,365 & 4,649 & 5,740 & 6,139 & 6,591 & 6,388 & 5,990 & 6,224 & 5,919 & 6,210 & 5,987 & 5,551 & 4,767 & 4,875 \\
\hline Eendenmest / Duck manure & & 0,001 & 0,021 & 0,049 & 0,037 & 0,029 & 0,026 & 0,014 & 0,003 & 0,063 & 0,108 & 0,122 & 0,093 & 0,102 & 0,093 \\
\hline Kalkoenenmest / Turkey manure & & 0,965 & 0,698 & 0,909 & 1,035 & 0,968 & 0,921 & 0,752 & 0,824 & 0,714 & 0,635 & 0,511 & 0,524 & 0,401 & 0,372 \\
\hline Pluimveemestkorrels / Poultry manure pellets & 2,400 & 2,414 & 2,188 & 2,572 & 2,882 & 2,730 & 2,349 & 2,846 & 2,827 & 3,245 & 3,877 & 4,063 & 4,521 & 3,972 & 3,873 \\
\hline Konijnenmest / Rabbit manure & & & & 0,043 & 0,053 & 0,027 & 0,009 & 0,006 & 0,007 & 0,032 & 0,080 & 0,103 & 0,089 & 0,041 & 0,079 \\
\hline $\begin{array}{l}\text { Mest van pelsdieren / Manure from fur-bearing } \\
\text { animals }\end{array}$ & & 0,039 & 0,118 & 0,277 & 0,289 & 0,598 & 0,422 & 0,295 & 0,324 & 0,218 & 0,196 & 0,266 & 0,196 & 0,183 & 0,148 \\
\hline $\begin{array}{l}\text { Totaal in miljoen } \mathrm{kg} \mathrm{P}_{2} \mathrm{O}_{5} / \text { Total in million } \mathrm{kg} \\
\mathrm{P}_{2} \mathrm{O}_{5}\end{array}$ & 19,874 & 14,882 & 20,523 & 27,802 & 30,446 & 30,826 & 29,354 & 30,704 & 31,103 & 33,721 & 38,433 & 41,505 & 39,756 & 36,668 & 37,844 \\
\hline Totaal in miljoen $\mathbf{k g} \mathbf{N}^{1)} /$ Total in million $\mathbf{k g} \mathbf{~}^{1)}$ & 34,053 & 25,950 & 36,669 & 50,024 & 53,502 & 56,130 & 52,300 & 55,396 & 56,588 & 59,442 & 66,241 & 68,472 & 65,402 & 60,832 & 62,467 \\
\hline
\end{tabular}

1) De mestafzet uitgedrukt in $\mathrm{N}$ is berekend door de afzet in fosfaat te vermenigvuldigen met de $\mathrm{N} / \mathrm{P}_{2} \mathrm{O}_{5}$-verhouding van opgeslagen mest. Het stikstofverlies door kalvergierzuivering wordt hier bij opgeteld / The manure removal expressed as nitrogen is calculated by multiplication of phosphate removal with the $\mathrm{N} / \mathrm{P}_{2} \mathrm{O}_{5}$ ratio of stored manure. The nitrogen losses due to the treatment of veal calve manure is added.

Bron: Vervoersbewijzen dierlijke mest (bewerkt) / Source: Registered transports of livestock manure (adapted). 


\title{
Bijlage 16 Berekening mestverdeling met INITIATOR ten behoeve van NEMA voor ammoniakemissie en lachgasemissie
}

\author{
Auteur: Hans Kros \\ Versie: Maart 2021
}

\section{Berekeningsmethodiek mestverdeling voor ammoniakemissie}

De berekeningen zijn uitgevoerd met INITIATOR versie 5 (Kros et al., 2019). Dit model berekent echter de mestverdeling voor mest- en landgebruikscategorieën die niet een-op-een aansluiten op de NEMAcategorieën. Om die aansluiting te realiseren vindt een nabewerking plaats op de resultaten van de oorspronkelijke mestverdelingsprocedure. De berekeningen zijn alleen voor P zijn uitgevoerd.

Hiertoe zijn achtereenvolgens zijn de volgende stappen uitgevoerd:

1. Groepering van INITIATOR-dier/mestcategorieën naar de NEMA-dier/mestcategorieën.

2. Bereken de standaard mestverdeling INITIATOR rekening houdend met bovenstaande groepering.

3. Bereken toegediende hoeveelheden en fracties per NEMA-dier/mestcategorie.

Deze procedure is uitgevoerd voor de tijdreeks 2000-2019, waarbij rekening is gehouden met overbenutting (niet binnen de gebruiksnorm te plaatsen mest wordt toegediend in de regio waar deze is geproduceerd). Om een relatie te kunnen leggen tussen de in NEMA gehanteerde mestcategorieën en landgebruik en die INITIATOR zijn diverse clusteringen en aannames gemaakt. Het gaat hierbij om (i) het maken van onderscheid in beteeld- en onbeteeld bouwland en (ii) en het vertalen van de in INITIATOR gehanteerde Rav-indeling naar de NEMA-indeling. Dit wordt hieronder toegelicht. Verder is er ook een globale vergelijking gemaakt tussen de met INITIATOR berekende mestverdeling en de tot nu toe door NEMA gebruikte verdeling gebaseerd op berekeningen met de modellen MAM (Groenwold et al., 2002) en MAMBO (Kruseman et al., 2013).

\section{Beteeld- en onbeteeld bouwland}

Het onderscheid in beteeld en onbeteeld bouwland is van belang omdat de ammoniakemissiefactor voor beteeld bouwland hoger is. Omdat het beteeld/onbeteeld zijn van een perceel niet bevraagd is in de Gecombineerde Opgave (GO), is de indeling gebaseerd op het gewastype uit de Basisregistratie Gewaspercelen (BRP). Hierbij zijn de bouwlandpercelen voorzien van de wintergewassen: wintertarwe, wintergerst en triticale als beteeld beschouwd en de overige als onbeteeld.

\section{Clustering dieren}

In INITIATOR wordt voor dieren gebruik gemaakt van de Rav-indeling en in NEMA-indeling (zie tabel B16.1).

Tabel B16.1 In NEMA gehanteerde mestcategorieën.

\begin{tabular}{ll} 
Nr & NEMA categorie \\
1 & melk- en kalfkoeien, dun \\
\hline 2 & jongvee incl. fokstieren, dun \\
\hline 3 & zoog-, mest- en weidekoeien, dun \\
\hline 4 & overig vleesvee excl. vleeskalveren, dun \\
\hline 5 & melk- en kalfkoeien, vast \\
\hline 7 & jongvee incl. fokstieren, vast \\
\hline 8 & zoog-, mest- en weidekoeien, vast \\
\hline
\end{tabular}




\begin{tabular}{ll}
9 & Schapen \\
\hline 10 & Geiten \\
\hline 11 & paarden en pony's \\
\hline 12 & ezels (onbewerkte mest) \\
\hline 13 & Vleeskalveren \\
\hline 14 & vleesvarkensmest - dunne mest \\
\hline 15 & fokvarkensmest - dunne mest \\
\hline 16 & fokvarkensmest vaste mest \\
\hline 18 & legpluimvee dunne mest onbewerkt \\
\hline 20 & eenden \\
\hline 21 & kalkoenen \\
\hline 22 & legpluimvee vaste mest (incl mestkorrels en via \\
\hline & vleeskuikens (incl. mestkorrels en champost) \\
\hline
\end{tabular}

De clustering van Rav naar NEMA-indeling is weergegeven in Tabel B16.2.

Tabel B16.2 De clustering van Rav naar NEMA-indeling

\begin{tabular}{|c|c|c|c|c|c|}
\hline Rav & Type & Omschrijving categorie & Sub & NEMA Hoofgroep & NEMA Subgroep \\
\hline a1 & drijf & melk/kalfkoeien > 2 jr & ZO & Rundvee & Melkkoeien \\
\hline a1 & vast & melk/kalfkoeien > 2 jr & ZO & Rundvee & Melkkoeien \\
\hline a1 & drijf & melk/kalfkoeien > 2 jr & NW & Rundvee & Melkkoeien \\
\hline a1 & vast & melk/kalfkoeien $>2 \mathrm{jr}$ & NW & Rundvee & Melkkoeien \\
\hline a2 & drijf & zoogkoeien en overig rundvee $>2 \mathrm{jr}$ & & Rundvee & Overig rundvee \\
\hline a2 & vast & zoogkoeien en overig rundvee $>2 \mathrm{jr}$ & & Rundvee & Overig rundvee \\
\hline a3 & drijf & vrouwelijk jongvee $<2 \mathrm{jr}$ & & Rundvee & Jongvee \\
\hline a3 & vast & vrouwelijk jongvee $<2 \mathrm{jr}$ & & Rundvee & Jongvee \\
\hline a4 & wit & vleeskalveren & witvleesprod & Rundvee & Vleeskalveren \\
\hline a4 & rose & vleeskalveren & rosevleespro & Rundvee & Vleeskalveren \\
\hline a6 & drijf & $\begin{array}{l}\text { vleesstieren en overig vleesvee van circa } 8 \\
\text { tot } 24 \text { maanden (roodvleesproductie) }\end{array}$ & & Rundvee & Overig rundvee \\
\hline a6 & vast & $\begin{array}{l}\text { vleesstieren en overig vleesvee van circa } 8 \\
\text { tot } 24 \text { maanden (roodvleesproductie) }\end{array}$ & & Rundvee & Overig rundvee \\
\hline a7 & drijf & fokstieren en overig rundvee ouder dan 2 & & Rundvee & Jongvee \\
\hline a7 & vast & fokstieren en overig rundvee ouder dan 2 & & Rundvee & Jongvee \\
\hline $\mathrm{d} 2$ & drijf & Dekberen, >=7 mnd & & Varkens & Fokvarkens \\
\hline $\mathrm{d} 2$ & vast & Dekberen, $>=7 \mathrm{mnd}$ & & Varkens & Fokvarkens \\
\hline $\mathrm{d} 12$ & n.v.t & kraamzeugen (incl. biggen tot spenen) & & Varkens & Fokvarkens \\
\hline d13 & n.v.t & Overige fokvarkens & & Varkens & Fokvarkens \\
\hline d3 & n.v.t & Vleesvarkens, opfokberen en -zeugen & & Varkens & Vleesvarkens \\
\hline e1 & n.v.t & Opfokhennen en hanen van legras < 18 wk & & Pluimvee & Legpluimvee \\
\hline e2 & n.v.t & Legkippen & & Pluimvee & Legpluimvee \\
\hline e3 & n.v.t & Ouderdieren van vleeskuikens in opfok < & & Pluimvee & Vleespluimvee \\
\hline e4 & n.v.t & Ouderdieren van vleeskuikens & & Pluimvee & Vleespluimvee \\
\hline e5 & n.v.t & Vleeskuikens & & Pluimvee & Vleespluimvee \\
\hline f4 & n.v.t & Vleeskalkoenen & & Pluimvee & Vleespluimvee \\
\hline $\mathrm{g} 12$ & n.v.t & Vleeseenden en ouderdieren van & & Pluimvee & Vleespluimvee \\
\hline b1 & n.v.t & schapen > $1 \mathrm{jr}$ & & Rundvee & Overige \\
\hline $\mathrm{c} 1$ & n.v.t & geiten $>1 \mathrm{jr}$ & & Rundvee & Overige \\
\hline h1 & n.v.t & Nertsen & & Pelsdieren & \\
\hline ¡1 & n.v.t & Konijnen, voedsters & & Overige hokdieren & \\
\hline $\mathrm{k} 12$ & n.v.t & volwassen paarden & & Rundvee & Overige \\
\hline $\mathrm{k} 12$ & n.v.t & paarden in opfok & & Rundvee & Overige \\
\hline k34 & n.v.t & Pony's (volwassen en in opfok) & & Rundvee & Overige \\
\hline
\end{tabular}

Hierbij zijn de volgende aannamen gedaan:

- d13 dieraantallen worden bij d12 opgeteld.

- Ezels worden als paarden/pony's behandeld. 
- Parelhoenders, komen na 2007 niet meer voor.

- Import ongescheiden rundermest wordt uniform verdeeld over 11 categorieën (rundvee, schapen, geiten) $(1-10,13)$.

- Gescheiden rundermest wordt verdeeld over de 5 categorieën dunne rundveemest $(1-4,13)$.

- Varkensmest wordt verdeeld over de 2 varkens categorieën met dunne varkensmest (14-15).

- Pluimveemest wordt verdeeld over de categorieën 18-23.

- Indeling vaste en vloeibare mest: hiervoor is voor 2015 per bedrijf de fractie dunne mest voor a1, a2, a3, a4, a6, a7, d12, d2 en d3 bepaald. Deze fracties zijn gebruikt voor 2015-2019. Voor bedrijven zonder data is het gemiddelde van de andere bedrijven gebruikt.

\section{Vergelijking INITIATOR-MAM/MAMBO zoals gebruikt in NEMA}

De tot nu toe in NEMA gebruikte mestverdeling is gebaseerd op de resultaten van het model MAM voor de jaren 2000-2005 en van het model MAMBO voor de jaren 2006-2012 en 2015. In het model MAM werd een andere berekeningsmethodiek toegepast dan in het MAMBO model. Voor de jaren 2013 en 2014 is gebruik gemaakt van schattingen gebaseerd op de MAMBO-resultaten van 2012. Voor de jaren 2016-2018 zijn in NEMA de MAMBO-resultaten voor het jaar 2015 aangehouden.

In Figuur B16.1 wordt de mestverdeling zoals gebruikt in NEMA voor de jaren 2000-2018 vergeleken met de INITIATOR-resultaten.

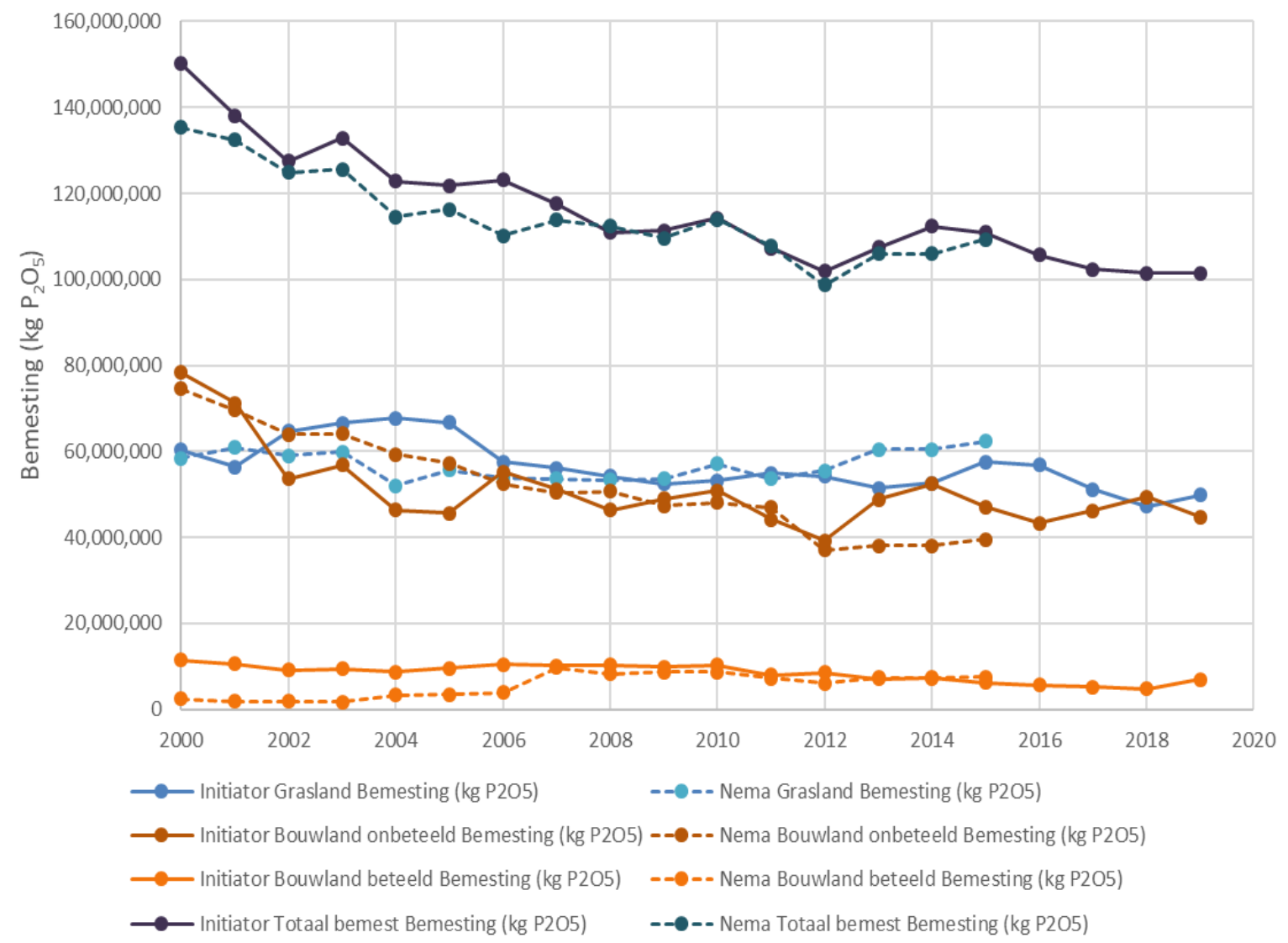

Figuur B16.1 Vergelijking van de mestverdeling zoals gebruikt in NEMA (Nema) voor de periode 2000-2015 en de met INITIATOR (Initiator) berekende mestverdeling voor de periode 2000-2019.

Een aantal zaken die opvallen:

- In grote lijnen lijken de resultaten redelijk goed met elkaar overeen te komen, maar voor bepaalde jaren is er sprake van soms relatief grote verschillen.

- INITIATOR berekent in de periode 2000-2007 een hogere P-bemesting. 
- Voor grasland berekent INITIATOR in de periode 2002-2006 een lagere bemesting en voor onbeteeld bouwland een hogere. Voor de periode 2012-2015 is het omgekeerde het geval.

- Voor beteeld bouwland berekent INITIATOR voor de periode 2000-2006 een lagere P-bemesting.

- Voor de periode 2007-2012 zijn er nauwelijks verschillen tussen beide modellen voor landgebruikstypen.

- Voor de periode 2013-2014 treden grasland en onbeteeld bouwland verschillen op. Zo neemt INITIATOR de bemesting van onbeteeld bouwland toe, terwijl NEMA juist een toename van de bemesting van grasland plaats vindt. Dit is waarschijnlijk het gevolg van het ontbreken van MAMBO-berekeningen voor deze twee jaren. Voor MAMBO is er alleen voor 2012 en 2015 een goede schatting, als je die twee jaren vergelijkt met INTIATOR dan zijn de verschillen gering.

Naar de oorzaak van de verschillen is (nog) niet nader gekeken.

\section{Berekeningsmethodiek mestverdeling voor lachgasemissie}

Voor de lachgasemissie maakt NEMA gebruik gemaakt van de dezelfde INITIATOR-berekening als voor de ammoniakemissie. Maar de lachgasberekeningen vereist een wat andere benadering omdat de lachgasemissie door andere factoren wordt bepaald dan ammoniak. Het gaat hierbij om:

1. Omdat de lachgasemissie door de $\mathrm{N}$-toevoer wordt bepaald dient de toevoer van dierlijke mest aangeleverd te worden als totale $\mathrm{N}$-toevoer i.p.v. P-toevoer.

2. Naast de dierlijke mest verdeling in termen van $\mathrm{N}$ dient ook de verdeling van $\mathrm{N}$-kunstmest aangeleverd te worden.

3. Omdat lachgasemissie ook afhankelijk is van toedieningstechniek en grondsoort, dient deze informatie ook aangeleverd te worden.

Omdat in INITIATOR standaard al de uitsplitsing naar type mest, toedieningstechniek en landgebruik wordt gemaakt, kunnen de INITIATOR-resultaten vrijwel een-op-een vertaald en/of geclusterd worden naar de NEMA-categorieën. Alleen voor het aandeel bovengronds toedienen en het toekennen van grondsoort zijn enkele kleine aanpassingen doorgevoerd. In Tabel B16.3 wordt een overzicht geven van combinaties mesttype/toedieningstechniek (lachgasbron), grondsoort en landgebruik (grasland, bouwland).

Tabel B16.3 Voorbeeld tabel met verdeling van stikstof over de verschillende bronnen, in miljoen $\mathrm{kg} N$ op te leveren door INITIATOR aan NEMA.

\begin{tabular}{|c|c|c|c|c|}
\hline Lachgasbron & Grondsoort & Grasland & Bouwland & Totaal \\
\hline \multirow[t]{2}{*}{ Dierlijke mest, ammoniak-emissiearm } & Minerale gronden & $\mathrm{a}$ & $f$ & $a+f$ \\
\hline & Veengronden & $\mathrm{b}$ & $\mathrm{g}$ & $b+g$ \\
\hline \multirow[t]{2}{*}{ Dierlijke mest bovengronds } & Minerale gronden & $\mathrm{C}$ & $\mathrm{h}$ & $\mathrm{c}+\mathrm{h}$ \\
\hline & Veengronden & $\mathrm{d}$ & $\mathrm{i}$ & $d+i$ \\
\hline Totaal dierlijke mest & & $a+b+c+d$ & $f+g+h+i$ & Totaal \\
\hline \multirow[t]{2}{*}{ Kunstmest } & Minerale gronden & j & 1 & $j+1$ \\
\hline & Veengronden & $\mathrm{k}$ & $\mathrm{m}$ & $\mathrm{k}+\mathrm{m}$ \\
\hline Totaal kunstmest & & $j+k$ & $\mathrm{I}+\mathrm{m}$ & Totaal \\
\hline \multirow[t]{2}{*}{ Beweiding } & Minerale gronden & $\mathrm{n}$ & n.v.t & $\mathrm{n}$ \\
\hline & Veengronden & 0 & n.v.t. & 0 \\
\hline Totaal beweiding & & $n+o$ & n.v.t. & Totaal \\
\hline
\end{tabular}


Aandeel bovengronds toedienen:

Hiervoor is de hoeveelheid $\mathrm{N}$ die via dierlijke mest bovengronds wordt toegediend berekend. Waarbij per bedrijf expliciet het aandeel dunne mest is bepaald dat bovengronds wordt toegediend. Standaard wordt in INITIATOR een emissiefactor gewogen gemiddelde per bedrijf bepaald. Verder gaat het hierbij, zowel voor dunne- als vaste mest, om de $\mathrm{N}$-totaal omdat de $\mathrm{N}_{2} \mathrm{O}$-emissie in NEMA een functie van $\mathrm{N}$ totaal is, dit in tegenstelling tot $\mathrm{NH}_{3}$-emissie. Met deze aanpassing is in INITIATOR de totale hoeveelheid bovengronds aangewende mest, in termen van $\mathrm{N}$-totaal nu expliciet te berekenen.

Toekennen grondsoort:

Voor het toekenning van de grondsoort is gebruik gemaakt van de grondsoortenkaart 2016 uit de mestwet. Deze wordt in INITIATOR tevens gebruikt voor het vaststellen van de gebruiksnorm en daarvoor aan de BRP-plots is gekoppeld.

\section{Referenties}

Groenwold, J.G., D. Oudendag, H. Luesink, G. Cotteleer \& H. Vrolijk, 2002. Het Mest- en Ammoniakmodel. Den Haag, LEI. Rapport 8.02.03. http://www.lei.dlo.nl/publicaties/PDF/2002/8_xxx/8_02_03.pdf

Kros, H., J. van Os, J.C. Voogd, P. Groenendijk, C. van Bruggen, R. te Molder \& G. Ros, 2019. Ruimtelijke allocatie van mesttoediening en ammoniakemissie : beschrijving mestverdelingsmodule INITIATOR versie 5. Wageningen, Wageningen Environmental Research. http://edepot.wur.nl/474513

Kruseman, G., H.H. Luesink, P.W. Blokland, M.W. Hoogeveen \& T.J. de Koeijer, 2013. MAMBO 2.x : design principles, model structure and data use. Wageningen, Wettelijke Onderzoekstaken Natuur \& Milieu. http://edepot.wur.nl/251877 


\section{Bijlage 17 Mesttoediening aan grasland en bouwland}

B17.1 Toediening van dierlijke mest aan grasland en bouwland (\% van toegediende $\mathrm{P}_{2} \mathrm{O}_{5}$ ) / Application of manure to grassland and arable land (\% of applied $\mathrm{P}_{2} \mathrm{O}_{5}$ ).

\begin{tabular}{|c|c|c|c|c|c|c|c|c|c|c|c|c|c|c|c|}
\hline Mestsoort / Manure type & 1990 & 1991 & 1992 & 1993 & 1994 & 1995 & 1996 & 1997 & 1998 & 1999 & 2000 & 2001 & 2002 & 2003 & 2004 \\
\hline Grasland / Grassland & 39,6 & 52,0 & 47,8 & 54,3 & 52,9 & 56,8 & 46,1 & 43,5 & 49,0 & 42,8 & 43,1 & 46,0 & 47,3 & 47,6 & 45,3 \\
\hline \multicolumn{16}{|l|}{ waarvan $($ totaal $=100 \%)$} \\
\hline rundvee / cattle & 59,5 & 71,3 & 53,9 & 57,4 & 56,4 & 66,2 & 73,1 & 72,2 & 67,1 & 71,6 & 71,7 & 74,6 & 77,5 & 80,3 & 83,2 \\
\hline \multicolumn{16}{|l|}{ drijfmest melkkoeien / dairy cow slurry } \\
\hline \multicolumn{16}{|l|}{ drijfmest jongvee / young stock slurry } \\
\hline \multicolumn{16}{|l|}{ drijfmest overige koeien / other cow slurry } \\
\hline \multicolumn{16}{|l|}{$\begin{array}{l}\text { drijfmest vleesvee exclusief vleeskalveren / beef } \\
\text { cattle slurry excluding fattening calves }\end{array}$} \\
\hline \multicolumn{16}{|l|}{ vaste mest melkkoeien / dairy cow solid manure } \\
\hline \multicolumn{16}{|l|}{ vaste mest jongvee / young stock solid manure } \\
\hline \multicolumn{16}{|l|}{ vaste mest overige koeien / other cow solid manure } \\
\hline \multicolumn{16}{|l|}{$\begin{array}{l}\text { vaste mest vleesvee exclusief vleeskalveren / beef } \\
\text { cattle solid manure excluding fattening calves }\end{array}$} \\
\hline drijfmest vleeskaveren / fattening calves slurry & 2,9 & 2,6 & 2,9 & 2,7 & 3,4 & 3,9 & 4,7 & 4,5 & 6,1 & 4,8 & 4,6 & 4,1 & 3,5 & 3,0 & 2,4 \\
\hline \multicolumn{16}{|l|}{ schapen / sheep } \\
\hline \multicolumn{16}{|l|}{ geiten / goats } \\
\hline \multicolumn{16}{|l|}{ paarden en pony's / horses and ponies } \\
\hline \multicolumn{16}{|l|}{ ezels / mules and asses } \\
\hline drijfmest vleesvarkens / fattening pig slurry & 21,0 & 12,7 & 23,7 & 25,5 & 27,6 & 18,5 & 14,6 & 14,2 & 13,6 & 13,5 & 13,7 & 12,4 & 11,1 & 9,7 & 8,4 \\
\hline drijfmest fokvarkens / breeding pig slurry & 0,4 & 0,2 & 1,9 & 4,6 & 5,6 & 8,3 & 7,0 & 5,0 & 8,1 & 7,7 & 8,0 & 7,3 & 6,7 & 6,0 & 5,4 \\
\hline \multicolumn{16}{|l|}{ vaste mest fokvarkens / breeding pig solid manure } \\
\hline pluimvee / poultry & 16,1 & 13,2 & 17,5 & 9,8 & 7,0 & 3,1 & 0,6 & 4,2 & 5,1 & 2,4 & 2,0 & 1,6 & 1,3 & 0,9 & 0,6 \\
\hline \multicolumn{16}{|l|}{ dunne legpluimveemest / laying hen slurry } \\
\hline \multicolumn{16}{|l|}{ eenden / ducks } \\
\hline \multicolumn{16}{|l|}{ kalkoenen / turkeys } \\
\hline \multicolumn{16}{|l|}{ vaste legpluimveemest / laying hen solid manure } \\
\hline \multicolumn{16}{|l|}{ vleespluimvee / broilers } \\
\hline \multicolumn{16}{|l|}{ konijnen / rabbits } \\
\hline \multicolumn{16}{|l|}{ pelsdieren / fur bearing annimals } \\
\hline Onbeteeld bouwland / Uncultivated arable lan & 60,1 & 47,7 & 52,0 & 45,4 & 46,4 & 41,8 & 52,9 & 55,3 & 49,7 & 56,4 & 55,0 & 52,6 & 51,2 & 51,0 & 51,8 \\
\hline
\end{tabular}




\begin{tabular}{|c|c|c|c|c|c|c|c|c|c|c|c|c|c|c|c|}
\hline Mestsoort / Manure type & 1990 & 1991 & 1992 & 1993 & 1994 & 1995 & 1996 & 1997 & 1998 & 1999 & 2000 & 2001 & 2002 & 2003 & 2004 \\
\hline \multicolumn{16}{|l|}{ waarvan $($ totaal $=100 \%)$} \\
\hline rundvee / cattle & 27,0 & 10,1 & 27,6 & 26,8 & 27,4 & 30,7 & 25,7 & 17,5 & 28,9 & 27,5 & 26,3 & 27,8 & 29,3 & 30,8 & 32,3 \\
\hline \multicolumn{16}{|l|}{ drijfmest melkkoeien / dairy cow slurry } \\
\hline \multicolumn{16}{|l|}{ drijfmest jongvee / young stock slurry } \\
\hline \multicolumn{16}{|l|}{ drijfmest overige koeien / other cow slurry } \\
\hline \multicolumn{16}{|l|}{$\begin{array}{l}\text { drijfmest vleesvee exclusief vleeskalveren / beef } \\
\text { cattle slurry excluding fattening calves }\end{array}$} \\
\hline \multicolumn{16}{|l|}{ vaste mest melkkoeien / dairy cow solid manure } \\
\hline \multicolumn{16}{|l|}{ vaste mest jongvee / young stock solid manure } \\
\hline \multicolumn{16}{|l|}{ vaste mest overige koeien / other cow solid manure } \\
\hline \multicolumn{16}{|l|}{$\begin{array}{l}\text { vaste mest vleesvee exclusief vleeskalveren / beef } \\
\text { cattle solid manure excluding fattening calves }\end{array}$} \\
\hline drijfmest vleeskaveren / fattening calves slurry & & & & & & & & & 0,8 & 2,6 & 2,9 & 3,3 & 3,6 & 3,9 & 4,2 \\
\hline \multicolumn{16}{|l|}{ schapen / sheep } \\
\hline \multicolumn{16}{|l|}{ geiten / goats } \\
\hline \multicolumn{16}{|l|}{ paarden en pony's / horses and ponies } \\
\hline \multicolumn{16}{|l|}{ ezels / mules and asses } \\
\hline drijfmest vleesvarkens / fattening pig slurry & 25,1 & 35,3 & 22,5 & 20,7 & 24,6 & 31,0 & 36,3 & 32,8 & 30,0 & 29,5 & 28,4 & 28,0 & 27,6 & 27,2 & 26,8 \\
\hline drijfmest fokvarkens / breeding pig slurry & 31,6 & 33,3 & 30,8 & 28,3 & 29,9 & 22,7 & 21,9 & 24,0 & 20,8 & 17,4 & 17,9 & 18,1 & 18,3 & 18,5 & 18,7 \\
\hline \multicolumn{16}{|l|}{ vaste mest fokvarkens / breeding pig solid manure } \\
\hline pluimvee / poultry & 16,2 & 21,3 & 19,2 & 24,2 & 18,1 & 15,5 & 16,1 & 25,7 & 19,5 & 23,0 & 24,4 & 22,8 & 21,2 & 19,6 & 18,0 \\
\hline \multicolumn{16}{|l|}{ dunne legpluimveemest / laying hen slurry } \\
\hline \multicolumn{16}{|l|}{ eenden / ducks } \\
\hline \multicolumn{16}{|l|}{ kalkoenen / turkeys } \\
\hline \multicolumn{16}{|l|}{ vaste legpluimveemest / laying hen solid manure } \\
\hline \multicolumn{16}{|l|}{ vleespluimvee / broilers } \\
\hline \multicolumn{16}{|l|}{ konijnen / rabbits } \\
\hline \multicolumn{16}{|l|}{ pelsdieren / fur bearing annimals } \\
\hline Beteeld bouwland / Cultivated arable land & 0,2 & 0,2 & 0,2 & 0,3 & 0,7 & 1,4 & 1,0 & 1,1 & 1,3 & 0,9 & 1,8 & 1,4 & 1,5 & 1,4 & 2,9 \\
\hline \multicolumn{16}{|l|}{ waarvan (totaal = 100\%) } \\
\hline rundvee / cattle & 0,7 & & 4,2 & 3,8 & 1,5 & 3,3 & 3,4 & 0,2 & 12,5 & 10,5 & 12,6 & 11,3 & 10,0 & 8,6 & 7,3 \\
\hline \multicolumn{16}{|l|}{ drijfmest melkkoeien / dairy cow slurry } \\
\hline drijfmest jongvee / young stock slurry & & & & & & & & & & & & & & & \\
\hline drijfmest overige koeien / other cow slurry & & & & & & & & & & & & & & & \\
\hline $\begin{array}{l}\text { drijfmest vleesvee exclusief vleeskalveren / beef } \\
\text { cattle slurry excluding fattening calves }\end{array}$ & & & & & & & & & & & & & & & \\
\hline vaste mest melkkoeien / dairy cow solid manure & & & & & & & & & & & & & & & \\
\hline vaste mest jongvee / young stock solid manure & & & & & & & & & & & & & & & \\
\hline
\end{tabular}

158 | wot-technical report 203 


\begin{tabular}{|c|c|c|c|c|c|c|c|c|c|c|c|c|c|c|c|}
\hline Mestsoort / Manure type & 1990 & 1991 & 1992 & 1993 & 1994 & 1995 & 1996 & 1997 & 1998 & 1999 & 2000 & 2001 & 2002 & 2003 & 2004 \\
\hline \multicolumn{16}{|c|}{ vaste mest overige koeien / other cow solid manure } \\
\hline \multicolumn{16}{|c|}{$\begin{array}{l}\text { vaste mest vleesvee exclusief vleeskalveren / beef } \\
\text { cattle solid manure excluding fattening calves }\end{array}$} \\
\hline \multicolumn{16}{|l|}{ drijfmest vleeskaveren / fattening calves slurry } \\
\hline \multicolumn{16}{|l|}{ schapen / sheep } \\
\hline \multicolumn{16}{|l|}{ geiten / goats } \\
\hline \multicolumn{16}{|l|}{ paarden en pony's / horses and ponies } \\
\hline \multicolumn{16}{|l|}{ ezels / mules and asses } \\
\hline drijfmest vleesvarkens / fattening pig slurry & 42,4 & 41,0 & 38,8 & 26,8 & 53,5 & 62,9 & 45,1 & 22,1 & 28,8 & 61,6 & 44,6 & 46,0 & 47,4 & 48,8 & 50,3 \\
\hline drijfmest fokvarkens / breeding pig slurry & 54,5 & & 54,6 & 63,8 & 30,6 & 29,7 & 36,4 & 19,6 & 27,0 & 17,5 & 28,8 & 26,5 & 24,1 & 21,7 & 19,2 \\
\hline \multicolumn{16}{|c|}{ vaste mest fokvarkens / breeding pig solid manure } \\
\hline pluimvee / poultry & 2,4 & 59,0 & 2,4 & 5,5 & 14,3 & 4,2 & 15,1 & 58,1 & 31,7 & 10,4 & 14,0 & 16,2 & 18,5 & 20,9 & 23,2 \\
\hline \multicolumn{16}{|l|}{ dunne legpluimveemest / laying hen slurry } \\
\hline \multicolumn{16}{|l|}{ eenden / ducks } \\
\hline \multicolumn{16}{|l|}{ kalkoenen / turkeys } \\
\hline \multicolumn{16}{|l|}{ vaste legpluimveemest / laying hen solid manure } \\
\hline \multicolumn{16}{|l|}{ vleespluimvee / broilers } \\
\hline \multicolumn{16}{|l|}{ konijnen / rabbits } \\
\hline pelsdieren / fur bearing annimals & & & & & & & & & & & & & & & \\
\hline
\end{tabular}




\begin{tabular}{|c|c|c|c|c|c|c|c|c|c|c|c|c|c|c|c|}
\hline Mestsoort / Manure type & 2005 & 2006 & 2007 & 2008 & 2009 & 2010 & 2011 & 2012 & 2013 & 2014 & 2015 & 2016 & 2017 & 2018 & 2019 \\
\hline Grasland / Grassland & 47,8 & 48,9 & 47,1 & 47,5 & 48,9 & 50,1 & 49,7 & 56,3 & 57,1 & 57,1 & 56,9 & 53,7 & 49,9 & 46,6 & 49,1 \\
\hline \multicolumn{16}{|l|}{ waarvan (totaal $=100 \%)$} \\
\hline \multicolumn{16}{|l|}{ rundvee / cattle } \\
\hline drijfmest melkkoeien / dairy cow slurry & 62,7 & 65,7 & 63,7 & 68,8 & 69,9 & 69,0 & 74,7 & 70,5 & 67,1 & 67,1 & 68,3 & 66,9 & 67,6 & 70,5 & 67,3 \\
\hline drijfmest jongvee / young stock slurry & 14,5 & 9,0 & 10,9 & 11,2 & 10,8 & 13,2 & 10,5 & 10,5 & 7,5 & 7,5 & 11,3 & 12,0 & 11,2 & 7,1 & 8,9 \\
\hline drijfmest overige koeien / other cow slurry & & & & & & & & & & & & 0,7 & 0,7 & 1,0 & 1,0 \\
\hline $\begin{array}{l}\text { drijfmest vleesvee exclusief vleeskalveren / beef } \\
\text { cattle slurry excluding fattening calves }\end{array}$ & 5,1 & 4,7 & 4,3 & 4,6 & 4,3 & 4,3 & 4,2 & 3,8 & 3,1 & 3,1 & 3,5 & 0,3 & 0,4 & 0,5 & 0,9 \\
\hline vaste mest melkkoeien / dairy cow solid manure & & & & & & & & & & & & 3,8 & 3,8 & 4,0 & 3,7 \\
\hline vaste mest jongvee / young stock solid manure & & & & & & & & & & & & 4,6 & 4,3 & 2,8 & 3,5 \\
\hline vaste mest overige koeien / other cow solid manure & & & & & & & & & & & & 0,6 & 0,7 & 0,8 & 0,8 \\
\hline $\begin{array}{l}\text { vaste mest vleesvee exclusief vleeskalveren / beef } \\
\text { cattle solid manure excluding fattening calves }\end{array}$ & & & & & & & & & & & & 0,3 & 0,4 & 0,5 & 0,9 \\
\hline drijfmest vleeskaveren / fattening calves slurry & 1,9 & 2,5 & 3,0 & 3,1 & 3,8 & 1,2 & 1,2 & 2,5 & 2,5 & 2,5 & 2,4 & 2,9 & 2,9 & 3,3 & 2,8 \\
\hline schapen / sheep & 3,0 & 2,9 & 3,3 & 2,9 & 2,1 & 2,1 & 2,9 & 2,6 & 2,6 & 2,6 & 2,7 & 0,5 & 0,5 & 0,5 & 0,5 \\
\hline geiten / goats & & & & & & & & & & & & 1,0 & 1,2 & 1,4 & 1,6 \\
\hline paarden en pony's / horses and ponies & & & & & & & & & & & & 0,1 & 0,1 & 0,1 & 0,1 \\
\hline ezels / mules and asses & & & & & & & & & & & & 0,0 & 0,0 & 0,0 & 0,0 \\
\hline drijfmest vleesvarkens / fattening pig slurry & 7,2 & 8,8 & 8,0 & 2,7 & 2,3 & 1,7 & 3,3 & 5,2 & 8,3 & 8,3 & 2,7 & 4,0 & 3,9 & 5,1 & 5,5 \\
\hline drijfmest fokvarkens / breeding pig slurry & 4,8 & 6,1 & 6,2 & 6,2 & 6,6 & 8,3 & 3,0 & 4,7 & 8,0 & 8,0 & 8,4 & 2,3 & 2,4 & 2,4 & 2,4 \\
\hline vaste mest fokvarkens / breeding pig solid manure & & & & & & & & & & & & 0,0 & 0,0 & 0,0 & 0,0 \\
\hline \multicolumn{16}{|l|}{ pluimvee / poultry } \\
\hline \multicolumn{16}{|l|}{ dunne legpluimveemest / laying hen slurry } \\
\hline eenden / ducks & & & & & & & & & & & & 0,0 & 0,0 & 0,0 & 0,0 \\
\hline kalkoenen / turkeys & & & & & & & & & & & & 0,0 & 0,0 & 0,0 & 0,0 \\
\hline vaste legpluimveemest / laying hen solid manure & 0,3 & 0,2 & 0,3 & 0,1 & 0,1 & 0,1 & 0,1 & 0,1 & 0,1 & 0,1 & 0,0 & 0,0 & 0,0 & 0,0 & 0,0 \\
\hline vleespluimvee / broilers & & & & & & & & & & & & 0,0 & 0,0 & 0,0 & 0,0 \\
\hline konijnen / rabbits & 0,4 & 0,1 & 0,3 & 0,4 & 0,2 & 0,1 & 0,1 & 0,1 & 0,7 & 0,7 & 0,2 & 0,0 & 0,0 & 0,0 & 0,0 \\
\hline pelsdieren / fur bearing annimals & & & & & & & & & & & 0,5 & 0,0 & 0,0 & 0,0 & 0,0 \\
\hline Onbeteeld bouwland / Uncultivated arable land & 49,2 & 47,6 & 44,3 & 45,2 & 43,2 & 42,2 & 43,6 & 37,6 & 36,0 & 36,0 & 36,2 & 41,0 & 45,1 & 48,7 & 44,1 \\
\hline \multicolumn{16}{|l|}{ waarvan $($ totaal $=100 \%)$} \\
\hline \multicolumn{16}{|l|}{ rundvee / cattle } \\
\hline drijfmest melkkoeien / dairy cow slurry & 19,9 & 16,2 & 22,8 & 18,0 & 18,6 & 17,9 & 22,3 & 21,4 & 21,8 & 21,8 & 27,5 & 34,4 & 36,6 & 32,9 & 32,9 \\
\hline drijfmest jongvee / young stock slurry & 4,7 & 6,5 & 4,5 & 8,9 & 11,7 & 9,5 & 10,3 & 14,6 & 19,1 & 19,1 & 15,9 & 6,5 & 6,0 & 3,4 & 4,2 \\
\hline drijfmest overige koeien / other cow slurry & & & & & & & & & & & & 0,5 & 0,5 & 0,7 & 0,6 \\
\hline $\begin{array}{l}\text { drijfmest vleesvee exclusief vleeskalveren / beef } \\
\text { cattle slurry excluding fattening calves }\end{array}$ & 3,2 & 3,3 & 3,9 & 3,5 & 3,2 & 2,9 & 2,8 & 3,2 & 3,8 & 3,8 & 2,8 & 0,7 & 0,8 & 0,5 & 1,2 \\
\hline
\end{tabular}

160 | wot-technical report 203 


\begin{tabular}{|c|c|c|c|c|c|c|c|c|c|c|c|c|c|c|c|}
\hline Mestsoort / Manure type & 2005 & 2006 & 2007 & 2008 & 2009 & 2010 & 2011 & 2012 & 2013 & 2014 & 2015 & 2016 & 2017 & 2018 & 2019 \\
\hline vaste mest melkkoeien / dairy cow solid manure & & & & & & & & & & & & 2,0 & 2,1 & 2,0 & 1,9 \\
\hline vaste mest jongvee / young stock solid manure & & & & & & & & & & & & 2,3 & 2,2 & 1,2 & 1,6 \\
\hline vaste mest overige koeien / other cow solid manure & & & & & & & & & & & & 0,4 & 0,4 & 0,5 & 0,5 \\
\hline $\begin{array}{l}\text { vaste mest vleesvee exclusief vleeskalveren / beef } \\
\text { cattle solid manure excluding fattening calves }\end{array}$ & & & & & & & & & & & & 0,6 & 0,7 & 0,5 & 1,1 \\
\hline drijfmest vleeskaveren / fattening calves slurry & 4,7 & 6,3 & 5,1 & 6,0 & 6,0 & 8,5 & 9,4 & 9,4 & 8,9 & 8,9 & 9,4 & 8,5 & 8,8 & 10,4 & 8,6 \\
\hline schapen / sheep & 2,1 & 2,0 & 2,3 & 3,0 & 3,5 & 3,1 & 2,2 & 2,8 & 3,3 & 3,3 & 3,0 & 0,6 & 0,7 & 0,7 & 0,8 \\
\hline geiten / goats & & & & & & & & & & & & 2,2 & 2,4 & 2,9 & 3,4 \\
\hline paarden en pony's / horses and ponies & & & & & & & & & & & & 0,3 & 0,3 & 0,3 & 0,3 \\
\hline ezels / mules and asses & & & & & & & & & & & & 0,0 & 0,0 & 0,0 & 0,0 \\
\hline drijfmest vleesvarkens / fattening pig slurry & 26,9 & 33,6 & 32,0 & 32,9 & 34,7 & 37,1 & 27,8 & 27,8 & 29,1 & 29,1 & 19,8 & 26,0 & 24,7 & 30,8 & 30,3 \\
\hline drijfmest fokvarkens / breeding pig slurry & 19,3 & 19,1 & 21,9 & 17,0 & 17,1 & 18,4 & 22,7 & 18,0 & 10,4 & 10,4 & 17,7 & 14,6 & 13,8 & 13,1 & 12,6 \\
\hline vaste mest fokvarkens / breeding pig solid manure & & & & & & & & & & & & 0,0 & 0,0 & 0,0 & 0,0 \\
\hline \multicolumn{16}{|l|}{ pluimvee / poultry } \\
\hline dunne legpluimveemest / laying hen slurry & 6,4 & 4,2 & 1,5 & 3,6 & 1,1 & 1,1 & 0,9 & 1,1 & 1,2 & 1,2 & 0,8 & & & & \\
\hline eenden / ducks & & & & & & & & & & & & 0,0 & 0,0 & 0,0 & 0,0 \\
\hline kalkoenen / turkeys & & & & & & & & & & & & 0,0 & 0,0 & 0,0 & 0,0 \\
\hline vaste legpluimveemest / laying hen solid manure & & & & & & & & & & & & 0,0 & 0,0 & 0,0 & 0,0 \\
\hline vleespluimvee / broilers & 10,4 & 6,0 & 3,4 & 5,7 & 2,3 & 1,4 & 1,4 & 1,4 & 1,3 & 1,3 & 1,1 & 0,0 & 0,0 & 0,0 & 0,0 \\
\hline konijnen / rabbits & 2,4 & 2,8 & 2,5 & 1,6 & 1,8 & 0,2 & 0,2 & 0,3 & 1,4 & 1,4 & 0,7 & 0,0 & 0,0 & 0,0 & 0,0 \\
\hline pelsdieren / fur bearing annimals & & & & & & & & & & & 1,1 & 0,0 & 0,0 & 0,0 & 0,0 \\
\hline Beteeld bouwland / Cultivated arable land & 3,0 & 3,5 & 8,6 & 7,4 & 7,9 & 7,7 & 6,7 & 6,2 & 7,0 & 7,0 & 6,9 & 5,3 & 5,0 & 4,7 & 6,9 \\
\hline \multicolumn{16}{|l|}{ waarvan $($ totaal $=100 \%)$} \\
\hline \multicolumn{16}{|l|}{ rundvee / cattle } \\
\hline drijfmest melkkoeien / dairy cow slurry & 0,3 & 4,9 & 2,9 & 3,8 & 8,2 & 6,2 & 8,7 & 6,8 & 6,3 & 6,3 & 11,3 & 30,4 & 32,8 & 28,2 & 27,2 \\
\hline drijfmest jongvee / young stock slurry & 0,6 & 2,5 & 0,9 & 2,8 & 3,5 & 5,8 & 3,7 & 6,9 & 13,1 & 13,1 & 3,6 & 5,8 & 5,4 & 3,0 & 3,5 \\
\hline drijfmest overige koeien / other cow slurry & & & & & & & & & & & & 0,7 & 0,7 & 1,0 & 0,7 \\
\hline $\begin{array}{l}\text { drijfmest vleesvee exclusief vleeskalveren / beef } \\
\text { cattle slurry excluding fattening calves }\end{array}$ & 1,0 & 1,3 & 1,2 & 0,9 & 0,9 & 1,3 & 1,7 & 2,0 & 1,2 & 1,2 & 1,1 & 0,8 & 0,9 & 0,7 & 1,1 \\
\hline vaste mest melkkoeien / dairy cow solid manure & & & & & & & & & & & & 2,3 & 2,3 & 2,1 & 1,8 \\
\hline vaste mest jongvee / young stock solid manure & & & & & & & & & & & & 2,2 & 2,2 & 1,2 & 1,4 \\
\hline vaste mest overige koeien / other cow solid manure & & & & & & & & & & & & 0,7 & 0,6 & 0,9 & 0,7 \\
\hline $\begin{array}{l}\text { vaste mest vleesvee exclusief vleeskalveren / beef } \\
\text { cattle solid manure excluding fattening calves }\end{array}$ & & & & & & & & & & & & 0,8 & 0,9 & 0,6 & 1,1 \\
\hline drijfmest vleeskaveren / fattening calves slurry & 2,2 & 6,3 & 6,4 & 0,5 & 13,7 & 5,5 & 2,1 & 7,2 & 5,8 & 5,8 & 9,3 & 7,1 & 7,2 & 8,6 & 7,6 \\
\hline schapen / sheep & 1,6 & 0,5 & 0,2 & 0,3 & 0,4 & 1,2 & 0,7 & 1,1 & 0,4 & 0,4 & 0,3 & 1,0 & 1,0 & 1,1 & 1,0 \\
\hline geiten / goats & & & & & & & & & & & & 2,2 & 2,4 & 3,0 & 3,6 \\
\hline paarden en pony's / horses and ponies & & & & & & & & & & & & 0,4 & 0,4 & 0,3 & 0,3 \\
\hline
\end{tabular}




\begin{tabular}{|c|c|c|c|c|c|c|c|c|c|c|c|c|c|c|c|}
\hline Mestsoort / Manure type & 2005 & 2006 & 2007 & 2008 & 2009 & 2010 & 2011 & 2012 & 2013 & 2014 & 2015 & 2016 & 2017 & 2018 & 2019 \\
\hline ezels / mules and asses & & & & & & & & & & & & 0,0 & 0,0 & 0,0 & 0,0 \\
\hline drijfmest vleesvarkens / fattening pig slurry & 49,8 & 62,1 & 55,1 & 81,8 & 56,1 & 66,8 & 69,0 & 54,0 & 49,2 & 49,2 & 35,7 & 29,1 & 27,9 & 34,5 & 35,4 \\
\hline drijfmest fokvarkens / breeding pig slurry & 16,1 & 7,5 & 29,3 & 5,0 & 12,3 & 8,3 & 9,3 & 16,4 & 19,0 & 19,0 & 32,1 & 16,2 & 15,1 & 14,7 & 14,3 \\
\hline vaste mest fokvarkens / breeding pig solid manure & & & & & & & & & & & & 0,0 & 0,0 & 0,0 & 0,0 \\
\hline \multicolumn{16}{|l|}{ pluimvee / poultry } \\
\hline dunne legpluimveemest / laying hen slurry & 14,1 & 2,4 & 1,2 & 1,7 & 1,4 & 1,6 & 1,6 & 1,7 & 1,1 & 1,1 & 1,2 & & & & \\
\hline eenden / ducks & & & & & & & & & & & & 0,0 & 0,0 & 0,0 & 0,0 \\
\hline kalkoenen / turkeys & & & & & & & & & & & & 0,0 & 0,0 & 0,0 & 0,0 \\
\hline vaste legpluimveemest / laying hen solid manure & & & & & & & & & & & & 0,0 & 0,0 & 0,0 & 0,0 \\
\hline vleespluimvee / broilers & 10,6 & 11,9 & 2,5 & 3,0 & 2,9 & 3,1 & 2,9 & 3,4 & 2,4 & 2,4 & 2,8 & 0,0 & 0,0 & 0,0 & 0,0 \\
\hline konijnen / rabbits & 3,7 & 0,5 & 0,3 & 0,3 & 0,6 & 0,3 & 0,3 & 0,4 & 1,4 & 1,4 & 0,2 & 0,0 & 0,0 & 0,0 & 0,0 \\
\hline pelsdieren / fur bearing annimals & & & & & & & & & & & 2,4 & 0,0 & 0,0 & 0,0 & 0,0 \\
\hline
\end{tabular}

1) Vleeskuikens, eenden en kalkoenen / Broilers, ducks and turkeys.

Bron / Source: Wageningen Economic Research (bewerkt / edited). 


\begin{tabular}{|c|c|c|c|c|c|c|c|c|c|c|c|}
\hline Toedieningstechniek / Application technique & 1990 & 1991 & $\begin{array}{r}1992- \\
1993\end{array}$ & 1994 & $\begin{array}{r}1995- \\
1999\end{array}$ & $\begin{array}{r}2000- \\
2003\end{array}$ & 2004 & $\begin{array}{r}2005- \\
2007\end{array}$ & $\begin{array}{r}2008- \\
2014\end{array}$ & $\begin{array}{r}2015- \\
2018\end{array}$ & 2019 \\
\hline \multicolumn{12}{|l|}{ 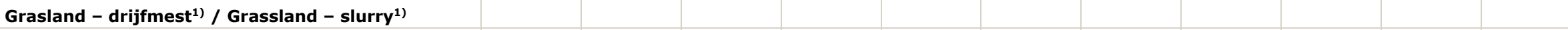 } \\
\hline in sleufjes in de grond / shallow injection & 0 & 10 & 30 & 20 & 57 & 56 & 56 & 60 & 62 & 64 & 84 \\
\hline $\begin{array}{l}\text { deels in sleufjes in de grond en deels op de grond / sod } \\
\text { injection }\end{array}$ & 0 & 0 & 0 & 0 & 22 & 23 & 23 & 15 & 24 & 22 & 0 \\
\hline in strookjes op de grond / narrow band application & 0 & 0 & 0 & 50 & 19 & 20 & 20 & 24 & 14 & 13 & 15 \\
\hline bovengronds bemesten / surface spreading & 100 & 90 & 70 & 30 & 2 & 1 & 1 & 1 & 1 & 1 & 2 \\
\hline \multicolumn{12}{|l|}{$\begin{array}{l}\text { Onbeteeld bouwland - drijfmest }{ }^{1)} \text { / Uncultivated } \\
\text { arable land - slurry }{ }^{1)}\end{array}$} \\
\hline mestinjectie / injection & 0 & 0 & 0 & 0 & 39 & 51 & 51 & 38 & 80 & 86 & 81 \\
\hline in sleufjes in de grond / shallow injection & 0 & 0 & 0 & 0 & 0 & 0 & 0 & 0 & 14 & 9 & 16 \\
\hline $\begin{array}{l}\text { deels in sleufjes in de grond en deels op de grond / sod } \\
\text { injection }\end{array}$ & 0 & 0 & 0 & 0 & 0 & 0 & 0 & 0 & 0 & 0 & 0 \\
\hline in strookjes op de grond / narrow band application & 0 & 0 & 0 & 0 & 0 & 0 & 0 & 7 & 0 & 0 & 0 \\
\hline onderwerken in 1 werkgang / incorporation in 1 track & 0 & 2,5 & 50 & 50 & 18 & 12 & 12 & 30 & 6 & 5 & 3 \\
\hline $\begin{array}{l}\text { onderwerken in } 2 \text { werkgangen / incorporation in } 2 \\
\text { tracks }\end{array}$ & 0 & 2,5 & 50 & 50 & 41 & 36 & 36 & 24 & 0 & 0 & 0 \\
\hline bovengronds bemesten / surface spreading & 100 & 95 & 0 & 0 & 2 & 1 & 1 & 1 & 0 & 0 & 0 \\
\hline \multicolumn{12}{|l|}{$\begin{array}{l}\text { Onbeteeld bouwland - vaste mest }{ }^{2} \text { / Uncultivated } \\
\text { arable land - solid manure }\end{array}$} \\
\hline $\begin{array}{l}\text { onderwerken in } 2 \text { werkgangen / incorporation in } 2 \\
\text { tracks }\end{array}$ & 0 & 3 & 100 & 100 & 100 & 100 & 100 & 100 & 95 & 97 & 97 \\
\hline $\begin{array}{l}\text { bovengronds bemesten met mest en zuiveringsslib / } \\
\text { surface spreading of manure and sewage sludge }\end{array}$ & 100 & 97 & 0 & 0 & 0 & 0 & 0 & 0 & 5 & 3 & 3 \\
\hline \multicolumn{12}{|l|}{$\begin{array}{l}\text { Beteeld bouwland - drijfmest }{ }^{2} \text { / Cultivated arable } \\
\text { land - slurry }{ }^{2} \text { ) }\end{array}$} \\
\hline in sleufjes in de grond / shallow injection & 0 & 0 & 0 & 0 & 0 & 0 & 70 & 70 & 70 & 70 & 70 \\
\hline in strookjes op de grond / narrow band application & 0 & 0 & 0 & 0 & 0 & 0 & 30 & 30 & 30 & 30 & 30 \\
\hline
\end{tabular}

kjes op de grond / narrow band application

1) Landbouwtelling / Agricultural census.

2) Onbeteeld bouwland: Landbouwtelling (tot 2015); beteeld bouwland: Landbouwtelling (tot 2004), overige jaren: Huijsmans en Verwijs (2008) / Uncultivated arable land: Agricultural census (till 2015); cultivated arable land: Agricultural census (till 2004); other years: Huijsmans and Verwijs (2008). 


\begin{tabular}{|c|c|c|c|c|c|}
\hline Toedieningstechniek / Application technique & 1990-1991 & 1992-1993 & 1994-1998 & 1999-2018 & 2019 \\
\hline \multicolumn{6}{|l|}{ Grasland - drijfmest / Grassland - slurry } \\
\hline in sleufjes in de grond / shallow injection & 10,0 & 10,0 & 13,5 & 17,0 & 17,0 \\
\hline deels in sleufjes in de grond en deels op de grond / sod injection & 18,2 & 18,2 & 20,0 & 21,7 & 17,0 \\
\hline in strookjes op de grond / narrow band application & 26,4 & 26,4 & 26,4 & 26,4 & 17,0 \\
\hline bovengronds bemesten / surface spreading & 64,0 & 68,0 & 68,0 & 68,0 & 68,0 \\
\hline \multicolumn{6}{|l|}{ Bouwland - drijfmest / Arable land - slurry } \\
\hline mestinjectie / injection & 2,0 & 2,0 & 2,0 & 2,0 & 2,0 \\
\hline in sleufjes in de grond / shallow injection & 13,0 & 13,0 & 19,0 & 24,0 & 24,0 \\
\hline deels in sleufjes in de grond en deels op de grond / sod injection & 24,5 & 24,5 & 27,5 & 30,0 & 30,0 \\
\hline in strookjes op de grond / narrow band application & 36,0 & 36,0 & 36,0 & 36,0 & 36,0 \\
\hline onderwerken in 1 werkgang / incorporation in 1 track & 22,0 & 22,0 & 22,0 & 22,0 & 22,0 \\
\hline onderwerken in 2 werkgangen / incorporation in 2 tracks & 46,0 & 46,0 & 46,0 & 46,0 & 46,0 \\
\hline bovengronds mest en zuiveringsslib / surface spreading of manure and sewage sludge & 64,0 & 69,0 & 69,0 & 69,0 & 69,0 \\
\hline bovengronds compost / surface spreading of compost & 69,0 & 69,0 & 69,0 & 69,0 & 69,0 \\
\hline
\end{tabular}

Bronnen / Sources: Huijsmans en/and Schils (2009); Huijsmans en/and Hol (2012); Huijsmans et al. (2018; ook/also Van Bruggen et al., 2018 bijlage/annex 4 en/and 5).

Zie ook / See also: Van Bruggen et al. (2015). 


\section{Bijlage 18 Ammonia emission factors for manure applied to grassland in The Netherlands; new estimates 2020}

\section{Auteurs: Paul W. Goedhart, Jan F.M. Huijsmans \& Julio Mosquera}

In onderstaand artikel zijn 160 emissie-experimenten op grasland van ná 1995 opnieuw geanalyseerd.

Goedhart, PW, Mosquera, J, Huijsmans, JFM (2020). Estimating ammonia emission after field application of manure by the integrated horizontal flux method: a comparison of concentration and wind speed profiles. Soil Use and Management, 36, 338-350. https://doi.org/10.1111/sum.12564

Belangrijkste conclusie uit deze publicatie is dat, bij de berekening van de emissie in een experiment, een exponentieel concentratieprofiel over het algemeen beter fit dan het eerder toegepaste profiel. Alternatieve windprofielen hebben daarentegen nauwelijks effect op de hoogte van de emissie. Toepassing van het exponentieel concentratieprofiel geeft gemiddeld ongeveer $10 \%$ (relatief) lagere emissies bij alle drie methoden van mesttoediening (bovengronds verspreiden, sleepvoet en zodenbemesting).

Verschillende benaderingen zijn gebruikt om deze bevindingen te vertalen naar nieuwe emissiefactoren. Het gaat daarbij om de vertaling naar additionele emissie experimenten uitgevoerd vóór 1995, rekening houdend met de duur en het verloop van de emissie experimenten, en het meenemen van recente nieuwe experimenten. Er wordt voorgesteld om:

- Het emissiepercentage van experimenten uitgevoerd vóór 1995 te corrigeren met een vaste correctiefactor per methode van mest uitrijden.

- De emissiefactoren te baseren op experimenten, zowel vóór als ná 1995, die langer dan 90 uur duren en waarbij de relatieve bijdrage van het laatste meetinterval aan de emissie kleiner is dan $5 \%$ van de cumulatieve emissie tot en met het voorgaande meetinterval. Voor deze experimenten mag ervan uitgegaan worden dat de emissie na het einde van het experiment verwaarloosbaar is.

- Voor de zodenbemester de emissiefactor te baseren op experimenten uitgevoerd ná 1995, omdat er aanwijzingen zijn dat er vóór 1995 dieper geïnjecteerd werd.

Dit voorstel geeft de volgende emissiefactoren met daarachter het aantal experimenten $\mathrm{N}$ waarop deze is gebaseerd, een $95 \%$ betrouwbaarheidsinterval, de huidige emissiefactor en de ratio van de nieuwe en de huidige emissiefactor:

- $68,0 \%$ voor bovengronds verspreiden $\mathrm{N}=62, \mathrm{BI}=(63,8,72,3)$, huidig $74,0 \%$, ratio 0,92 ;

- $\quad 26,4 \%$ voor de sleepvoet $\mathrm{N}=18, \mathrm{BI}=(21,2,31,7)$, huidig $30,5 \%$, ratio 0,87 ;

- $17,0 \%$ voor zodenbemesting $\mathrm{N}=38, \mathrm{BI}=(13,4,20,6)$, huidig $19,0 \%$, ratio 0,89 .

\section{Opmerkingen:}

- Bovengenoemde ratio's zijn vrijwel identiek aan de ratio's van de emissies conform het nieuwe exponentiële concentratieprofiel en het traditionele profiel voor de experimenten uitgevoerd ná 1995;

- $\quad$ Toepassing van een saturatiecurve (eindemissie) geeft vergelijkbare emissiefactoren met name in het licht van de grote variatie in emissie tussen experimenten;

- Een her-analyse bevestigt dat het uitrijden van verdunde mest met een sleepvoet (minimale verdunning $50 \%$ ) een vergelijkbaar emissieniveau geeft als bij zodenbemesting. 
Aanbeveling:

De emissies in de verschillende experimenten vertonen een grote spreiding die deels verklaard kan worden door wisselende weersomstandigheden, mestsamenstelling en mestdosering, bodemsoort en grashoogte. Een modelmatige aanpak geeft een meer realistische inschatting van de ammoniakemissie voor de praktijksituaties waarbij mest wordt uitgereden. Met een dergelijk model kan een gewogen emissiefactor afgeleid worden waarbij gewogen wordt conform bovengenoemde condities en omstandigheden in Nederland. Deze modelaanpak heeft daarnaast het voordeel dat de data van alle emissie experimenten gebruikt kunnen worden, dus niet alleen de langer durende experimenten. 


\section{Bijlage 19 Kunstmestverbruik 2015 tot en met 2019}

\section{Auteur: Harry Luesink (Wageningen Economic Research)}

Versie: 6 Januari 2021

\section{Aanleiding}

Met het project Statistiek kunstmest uitgevoerd door Wageningen Economic Research (WECR) wordt inzicht gegeven in het verbruik van kunstmest in de Nederlandse land- en tuinbouw. De kunstmeststatistiek wordt geleverd aan PBL, FAO, NEMA, RIVM (Emissieregistratie) en CBS ten behoeve van het Nationale kunstmestgebruik en de emissiejaarrapportages. Door Meststoffen Nederland (MSN) wordt eveneens een inventarisatie uitgevoerd naar het kunstmestgebruik in Nederland door middel van een inventarisatie bij de groothandel welke lid zijn van MSN. Doordat de afgelopen jaren de bereidheid van de fabrikanten van kunstmest en de groothandel in kunstmeststoffen om aan de enquête van WECR mee te werken gering was en het niet gelukt is om met Meststoffen Nederland een gezamenlijke enquête op te stellen, heeft de adviescommissie WOT in overleg met RIVM en de NEMA-werkgroep halverwege 2018 besloten om het verbruik van kunstmest te baseren op gegevens in het Bedrijveninformatienet van Wageningen Economic Research (in het vervolg aangeduid als het Informatienet) en aan WECR de opdracht gegeven om dat te gaan uitvoeren. In 2018 is dat voor het eerst gedaan voor de definitieve gegevens van 2016 en de voorlopige van 2017.

De adviescommissie WOT heeft begin 2020 opdracht gegeven om op basis van het Informatienet de definitieve kunstmestgegevens van 2018 en de voorlopige van 2019 te berekenen. In het aanhangsel bij deze bijlage is een tabel opgenomen waarin op totaalniveau voor 2018 zowel de voorlopige als definitieve cijfers staan vermeld.

\section{Doel}

Het berekenen van het verbruik van kunstmest in de Nederlandse land- en tuinbouw op basis van de kunstmestgegevens uit het Informatienet voor de jaren 2018 (definitief) en 2019 (voorlopig).

\section{Procedure}

\subsection{Kunstmest in het Informatienet}

Het Informatienet is een gestratificeerde steekproef van land- en tuinbouwbedrijven met een minimale omvang van 25.000 SO (Standaard Opbrengst). Elk bedrijf in een stratum van de steekproef krijgt een weging. Die weging is het aantal bedrijven geregistreerd in de Landbouwtelling van het CBS in dat stratum gedeeld door het aantal bedrijven in dat stratum in het Informatienet. Het Informatienet vertegenwoordigd daarmee 43.000 à 44.000 land- en tuinbouwbedrijven. Het aantal land- en tuinbouwbedrijven in de Landbouwtelling is in 2018 en 2019 ongeveer 53.000 à 54.000. Het verschil van 10.000 bedrijven betreft kleine bedrijven met een omvang van minder dan $25.000 \mathrm{SO}$, deze 10.000 bedrijven hadden in 2018 en 2019 ongeveer 3\% van het areaal cultuurgrond welke in de Landbouwtelling werd geteld (CBS, Statline). 
Hoeveel kunstmest een bedrijf aangekocht heeft in het betreffende jaar wordt door de medewerkers van WECR die de gegevens verzamelen van de facturen gehaald, die ze van de deelnemende boeren aan het Informatienet krijgen. Per factuur wordt dat als transactie in het Informatienet ingevoerd. Een deel van de boeren laat het bemesten aan de loonwerker over. Als dat zo is dan wordt de hoeveelheid bemeste kunstmest naar soort in kg product van de factuur gehaald die de loonwerker heeft ingediend. Soms komt het voor dat uit de factuur van de loonwerker niet gehaald kan worden hoeveel kunstmest er is toegediend. In die situatie wordt de hoeveelheid toegediende kunstmest nagevraagd naar soort in kg product bij de deelnemer aan het Informatienet. Naast transacties van kunstmest worden in het Informatienet de begin- en eindvoorraden van kunstmest vastgelegd. De begin- en eindvoorraden naar soort en in kg product worden opgevraagd bij de deelnemende boeren aan het Informatienet.

\subsection{Berekening kunstmestgegevens naar kunstmestsoort uit het Informatienet}

In het Informatienet is per product bekend hoeveel stikstof, fosfaat en kali in het product zit. Deze gegevens (normen) worden van de factuur gehaald, en wanneer ze daar niet opstaan komen ze van internet of worden ze opgevraagd bij de fabrikant van het product.

Alle ongeveer 800 kunstmestproducten in het Informatienet van 2015 tot en met 2019 zijn voor zowel stikstof, fosfaat, kalium als kalk van codes en gehalten voorzien zodat ze opgeteld kunnen worden tot de groepen van kunstmestsoorten waarover gerapporteerd wordt. Wat gerapporteerd wordt is het verbruik wat inhoudt dat alle kunstmesttransacties van het betreffende jaar worden opgeteld en gecorrigeerd met voorraadverschillen. Vervolgens wordt het kunstmestverbruik van het betreffende bedrijf vermenigvuldigd met de weging en worden ze geaggregeerd tot het nationale verbruik.

De resultaten zijn gecontroleerd op uitbijters van kunstmestgiften per ha en of bepaalde bedrijven vanwege hun weging erg zwaar meetellen. Alle land- en tuinbouwbedrijven met giften per ha van meer dan $500 \mathrm{~kg}$ stikstof per ha, $100 \mathrm{~kg}$ fosfaat per ha en $300 \mathrm{~kg}$ kali per ha zijn individueel nagelopen of die hoge giften zouden kunnen. Dat is eveneens gedaan voor de glastuinbouw maar dan voor giften van hoger dan $2.000 \mathrm{~kg}$ stikstof, $1.500 \mathrm{~kg}$ fosfaat en $1.500 \mathrm{~kg}$ kali per ha. Bij de definitieve gegevens van 2018 en de voorlopige van 2019 kwamen daar geen extreme giften uit. De voorlopige gegevens van 2019 betreft de stand van zaken van het aantal uitgewerkte bedrijven per 17 November 2020. De definitie gegevens van het jaar 2019 die in November 2021 beschikbaar komen kunnen hier enkele procenten van afwijken.

In het Informatienet zitten geen normen voor kalk (zowel calcium- als magnesiumhoudende kalk) om daarmee de neutraliserende waarde te kunnen berekenen. Alleen kunstmeststoffen met kalk en magnesium in de vorm van carbonaat hebben een neutraliserende waarde en zijn gelabeld als kalkmeststof en voorzien van normen ten aanzien van de kalk en magnesium inhoud.

In 2020 zijn alle stikstofmeststoffen in de groepen (1) gemengde stikstofmeststof en (2) overige stikstofmeststoffen gecontroleerd of er geen meststoffen tussen zitten die feitelijk tot een andere groep behoren. Daarbij is er vooral op gelet of er geen amide stikstofmeststoffen bij zaten, omdat dat een ureumvorm is en thuishoort bij ureummeststoffen. In overleg met Gerard Velthof (Wageningen Environmental Research) is afgesproken dat alle NPK, NP en NK stikstofmeststoffen, waarvan de stikstofvorm voor $50 \%$ of meer uit ureum bestaat ingedeeld worden als ureummeststof. Alle meststoffen waarvan een deel anorganische stikstof is en een deel organische stikstof is, is ingedeeld in een aparte groep van kunstmest. Deze veranderingen hebben er toe geleid dat 22 kunstmestsoorten in een andere kunstmestgroep zijn ingedeeld. Daardoor is de omvang van de groep gemengde stikstofmeststof verdubbeld en de omvang van de groep overige stikstofmeststoffen is met een derde gedaald. Zie tabel B19.1 voor de veranderingen die tussen die groepen van mestsoorten die tussen 2017 en 2018 hebben plaatsgevonden. 
De koppeling van de kunstmestsoorten uit het Informatienet aan de 31 groepen van kunstmest en de gehalten aan kalk en magnesium zijn voorgelegd aan Gerard Velthof (Wageningen Environmental Research) en door hem gecontroleerd en van op- en aanmerkingen voorzien. Vervolgens zijn die open aanmerkingen verwerkt en de berekeningen uitgevoerd ten aanzien van het kunstmestverbruik.

\section{Resultaat}

Het verbruik van stikstofkunstmeststoffen daalt van $236 \mathrm{mln}$. kg in 2015 naar $198 \mathrm{mln}$. kg in 2019 (tabel B19.1). Die daling vindt vooral plaats bij kalkammonsalpeter en in mindere mate bij NPK-, NPen NK-meststoffen. Het lagere kunstmeststikstofgebruik in 2018 en 2019 zou een gevolg kunnen zijn van de droogte in voorjaar en zomer in beide jaren. De grasgroei kwam toen in de zomer stil te liggen, waardoor er in de zomer van 2018 en 2019 geen of minder stikstofkunstmest op grasland werd aangewend dan in de voorgaande jaren.

Tabel B19.1 Verbruik in de land- en tuinbouw van stikstofkunstmeststoffen (in mln. $\mathrm{kg} \mathrm{N}$ ) in 20152019 / Use in agri- and horticulture of inorganic nitrogen fertilisers (in m/n. kg N) in 2015-2019.

\begin{tabular}{|c|c|c|c|c|c|}
\hline Kunstmestsoort / Fertiliser type & 2015 & 2016 & 2017 & 2018 & $2019 v * *)$ \\
\hline 1. Ammoniumsulfaat / Ammonium sulphate & 1 & 1 & 1 & 2 & 1 \\
\hline $\begin{array}{l}\text { 2. Kalkammonsalpeter / Calcium ammonium } \\
\text { nitrate }\end{array}$ & 139 & 132 & 129 & 115 & 112 \\
\hline 3. Stikstofmagnesia / Nitrogen magnesia & 1 & 1 & 1 & 1 & 1 \\
\hline 4. Ureum, waarvan / Urea, of which: & 26 & 28 & 30 & 31 & 28 \\
\hline $\begin{array}{l}\text { Vloeibaar met ureaseremmers / Liquid with } \\
\text { urease inhibitor }\end{array}$ & - & - & - & - & - \\
\hline Overige vloeibare / Other liquid & 21 & 21 & 21 & 22 & 18 \\
\hline $\begin{array}{l}\text { Originele in korrelvorm / Original in } \\
\text { granular form }\end{array}$ & 3 & 5 & 6 & 4 & 5 \\
\hline $\begin{array}{l}\text { Korrelvorm met nitrificatie remmer / } \\
\text { Granular form with nitrification inhibitor }\end{array}$ & - & - & - & - & - \\
\hline $\begin{array}{l}\text { Korrelvorm met urease remmers / } \\
\text { Granular form with urease inhibitor }\end{array}$ & 2 & 2 & 3 & 5 & 4 \\
\hline $\begin{array}{l}\text { 5. Gemengde stikstofmeststof / Mixed } \\
\text { nitrogen fertiliser }\end{array}$ & 8 & 6 & 6 & 12 & 13 \\
\hline $\begin{array}{l}\text { 6. NPK-, NP- en NK-meststoffen / NPK, NP and } \\
\text { NK fertilisers }\end{array}$ & 41 & 37 & 35 & 32 & 30 \\
\hline $\begin{array}{l}\text { 7. Overige stikstofmeststoffen / Other } \\
\text { nitrogen fertilisers }\end{array}$ & 21 & 17 & 22 & 13 & 13 \\
\hline $\begin{array}{l}\text { 8. Organische meststoffen } * \text { ) / Organic } \\
\text { fertilisers } * \text { ) }\end{array}$ & 1 & 1 & 1 & 1 & - \\
\hline Totaal / Total & 236 & 224 & 224 & 209 & 198 \\
\hline
\end{tabular}

*) Schuimaarde en een deel van de organische mest die tot mestproducten is verwerkt / Earth foam and a part of the organic manure that is processed to manure products.

$* *$ ) voorlopig / preliminary.

Bron: Bedrijveninformatienet van Wageningen Economic Research / Source: Farm Accountancy Data Network of Wageningen Economic Research.

Het verbruik van fosfaatkunstmeststoffen uit het Informatienet daalt van $15 \mathrm{mln}$. $\mathrm{kg}$ fosfaat in 2015 naar $11 \mathrm{mln}$. kg in 2019 (Tabel B19.2). Het gebruik van de traditionele kunstmeststoffen superfosfaat en tripelsuperfosfaat komt bijna niet meer voor. Ongeveer $70 \%$ van de fosfaatkunstmest wordt in de periode 2015-2018 toegediend in de vorm van NPK- NP- en PK-meststoffen. De daling van fosfaat gebruik uit de groep organische meststoffen komt doordat het gebruik van schuimaarde is gehalveerd (zie ook tabel B19.4). De daling van het gebruik van schuimaarde wordt zeer waarschijnlijk veroorzaakt doordat de akkerbouwer voor het gebruik van fosfaat in schuimaarde dient te betalen en wanneer hij fosfaat in de vorm van dierlijke mest afneemt geld toe krijgt. Om economische redenen 
zal een akkerbouwer daarom binnen de fosfaatgebruiksnormen het gebruik van fosfaat uit dierlijke mest willen maximaliseren en dat van schuimaarde minimaliseren.

Tabel B19.2 Verbruik in de land- en tuinbouw van fosfaatkunstmest (in m/n. $\mathrm{kg} \mathrm{P}_{2} \mathrm{O}_{5}$ ) in 20152019 / Use in agri- and horticulture of inorganic phosphate fertiliser (in m/n. $k g P_{2} \mathrm{O}_{5}$ ) in 2015-2019.

\begin{tabular}{|c|c|c|c|c|c|}
\hline Kunstmestsoort / Fertiliser type & 2015 & 2016 & 2017 & 2018 & $\begin{array}{r}2019 v \\
* *)\end{array}$ \\
\hline 1. Superfosfaat / Super phosphate & 0 & 0 & 0 & 0 & 0 \\
\hline 2. Tripelsuperfosfaat / Triple phosphate & 1 & 1 & 1 & 1 & 1 \\
\hline $\begin{array}{l}\text { 3. NPK-, NP-, en PK-meststoffen / NPK, NP and PK } \\
\text { fertilisers }\end{array}$ & 10 & 10 & 9 & 8 & 8 \\
\hline $\begin{array}{l}\text { 4. Overige fosfaatmeststoffen / Other phosphate } \\
\text { fertilisers }\end{array}$ & 2 & 2 & 2 & 2 & 1 \\
\hline 5. Organische meststoffen $*$ ) / Organic fertilisers $*$ ) & 2 & 2 & 2 & 3 & 1 \\
\hline Totaal / Total & 15 & 14 & 13 & 13 & 11 \\
\hline
\end{tabular}

*) Schuimaarde en een deel van de organische mest die tot mestproducten is verwerkt / Earth foam and a part of the organic manure that is processed to manure products.

**) voorlopig / preliminary.

Bron: Bedrijveninformatienet van Wageningen Economic Research / Source: Farm Accountancy Data Network of Wageningen Economic Research.

Gebruik van kaliummeststoffen wordt in de NEMA-berekeningen niet meegenomen, maar voor de volledigheid van rapportage van het kunstmestgebruik worden deze gegevens hier wel vermeld. Het verbruik van kalikunstmest daalt van circa $70 \mathrm{mln}$. kg in 2015 naar $54 \mathrm{mln}$. kg in 2019 (Tabel B19.3). De kali wordt met name toegediend als kaliumchloride 60 en als NPK- NK- en PK-meststoffen. De waarschijnlijke oorzaak van deze daling is dat er in de akkerbouw de laatste jaren steeds meer dierlijke mest van rundvee wordt gebruikt en minder varkensmest. Omdat er met rundveemest meer kali wordt toegediend dan met varkensmest is er minder kalikunstmest nodig om aan de gewasbehoefte te voldoen.

Tabel B19.3 Verbruik in de land- en tuinbouw van kalikunstmeststoffen (in $\mathrm{mln} . \mathrm{kg} \mathrm{K}_{2} \mathrm{O}$ ) in 20152019 / Use in agri- and horticulture of inorganic potassium fertiliser (in m/n. kg $\mathrm{K}_{2} \mathrm{O}$ ) in 2015-2019.

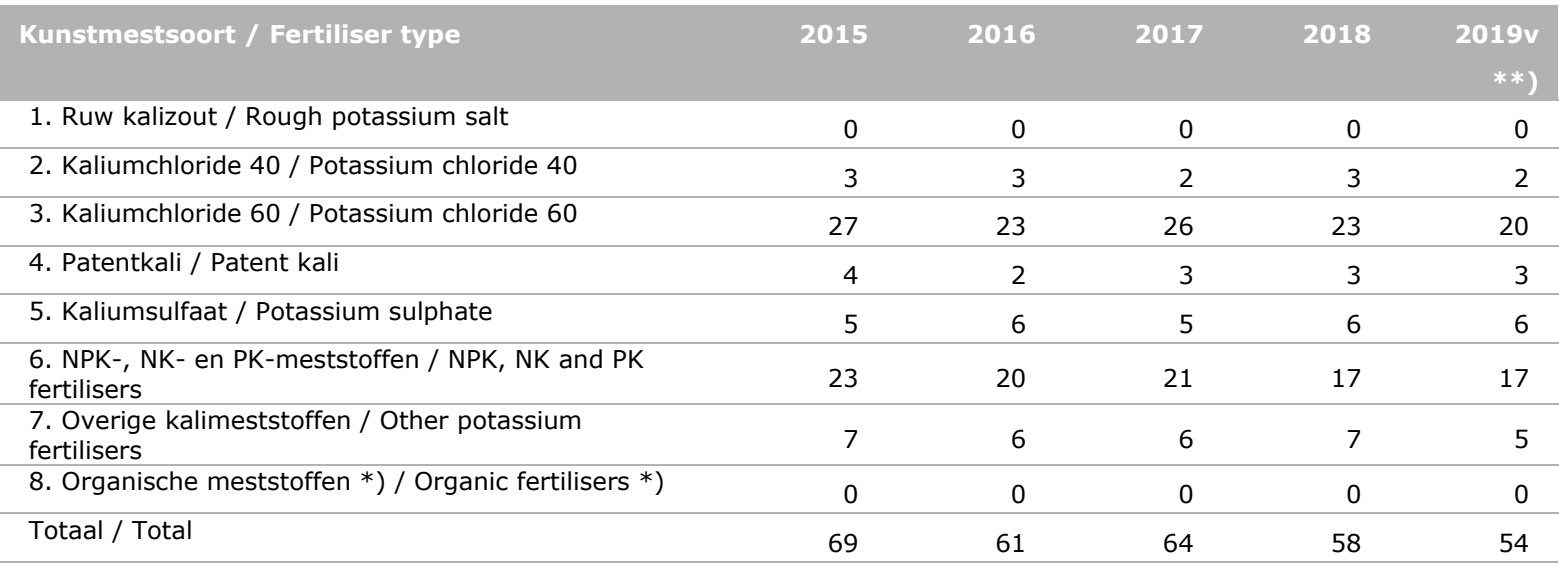

*) Schuimaarde en een deel van de organische mest die tot mestproducten is verwerkt / Earth foam and a part of the organic manure that is processed to manure products.

$* *$ ) voorlopig / preliminary

Bron: Bedrijveninformatienet van Wageningen Economic Research / Source: Farm Accountancy Data Network of Wageningen Economic Research.

Het niveau van verbruik van kalkmeststoffen omgerekend naar neutraliserende waarde daalde in de periode 2015-2019 van zo'n $180 \mathrm{mln}$. kg naar $120 \mathrm{mln}$. kg. De meststoffen die het meest gebruikt worden zijn schuimaarde en overige kalkmeststoffen. In 2019 is er extra aandacht besteed aan de groepen NPK-, NP-, PK- en NK-meststoffen en overige kalkmeststoffen van in welke vorm de kalk en magnesium in de betreffende meststof zit. Dat heeft er toe geleid dat een aantal kalkmeststoffen in 
een andere groep zijn ingedeeld. Daarnaast waren er een aantal meststoffen ten onrechte als kalkmeststof geclassificeerd, dit is hersteld.

Waarom in 2019 het verbruik van schuimaarde is gehalveerd komt zeer waarschijnlijk, doordat de suikerbietindustrie minder streng is dat bij levering van suikerbieten er schuimaarde afgenomen dient te worden. Omdat een akkerbouwer voor schuimaarde dient te betalen en voor dierlijke mest geld toe krijgt zal hij om economische redenen kiezen om binnen de fosfaatgebruiksruimte zo veel mogelijk fosfaat uit dierlijke mest af te nemen.

Tabel B19.4 Verbruik in de land- en tuinbouw van kalkkunstmeststoffen (in m/n. $\mathrm{kg}$ neutraliserende waarde (NW)) in 2015-2019 / Use in agri- and horticulture of inorganic lime fertiliser (in $\mathrm{mln}$. kg neutralizing value (NV)) in 2015-2019.

\begin{tabular}{|c|c|c|c|c|c|}
\hline Kunstmestsoort / Fertiliser type & 2015 & 2016 & 2017 & 2018 & $\begin{array}{r}2019 v \\
* *)\end{array}$ \\
\hline 1. Koolzure landbouwkalk / Cabonated agricultural lime & 19 & 13 & 14 & 20 & 18 \\
\hline 2. Kalkmergel / Lime marl & 6 & 8 & 4 & 10 & 6 \\
\hline 3. Koolzure magnesiakalk / Carbonic magnesium lime & 22 & 18 & 15 & 5 & 10 \\
\hline 4. Schuimaarde / Earth foam & 46 & 54 & 40 & 66 & 29 \\
\hline 5. Magnesiakalkmergel / Magnesium lime marl & 0 & 0 & 0 & 0 & 0 \\
\hline $\begin{array}{l}\text { 6. Gekorrelde koolzure magnesiakalk / Granulated } \\
\text { carbonic magnesium lime }\end{array}$ & 0 & 0 & 0 & 0 & 0 \\
\hline $\begin{array}{l}\text { 7. NPK-, NP-, PK- en NK-meststoffen / NPK, NP and NK } \\
\text { fertilisers }\end{array}$ & 0 & 0 & 0 & 0 & 0 \\
\hline 8. Overige kalkmeststoffen / Other lime fertilisers & 81 & 91 & 64 & 58 & 54 \\
\hline Totaal & 175 & 185 & 148 & 159 & 116 \\
\hline
\end{tabular}

*) Schuimaarde en een deel van de organische mest die tot mestproducten is verwerkt / Earth foam and a part of the organic manure that is processed to manure products.

$* *$ ) voorlopig / preliminary.

Bron: Bedrijveninformatienet van Wageningen Economic Research / Source: Farm Accountancy Data Network of Wageningen Economic Research.

\section{Vertaalslag naar volledig areaal cultuurgrond}

Het Informatienet is een steekproef van land- en tuinbouwbedrijven met een minimale omvang van 25.000 SO. Het Informatienet vertegenwoordigd 43.000 à 44.000 land- en tuinbouwbedrijven. Het aantal land- en tuinbouwbedrijven in de Landbouwtelling is in 2018 en 2019 ongeveer 53.000 à 54.000. Het verschil van 10.000 bedrijven betreft kleine bedrijven met een omvang van minder dan 25.000 SO, deze 10.000 bedrijven hadden in 2018 en 2019 ongeveer 3\% van het areaal cultuurgrond welke in de Landbouwtelling werd geteld. Om het kunstmestgebruik voor het volledige areaal cultuurgrond in de Landbouwtelling te schatten dienen de gegevens van de tabellen B19.1, B19.2, B19.3 en B19.4 nog verhoogd te worden met het verwachte kunstmestgebruik op de bedrijven welke niet door het Informatienet worden vertegenwoordigd. Als uitgegaan wordt dat op de 3\% cultuurgrond gemiddeld net zo veel wordt bemest als op de cultuurgrond van de bedrijven in het Informatienet dan is die verhoging $3 \%$.

\section{Literatuur}

Luesink, H.H. (10 December 2018). Kunstmestgebruik 2016 en 2017. Den Haag, Wageningen Economic research, Interne notitie

Luesink, H.H. (17 mei 2018). Databronnen van kunstmestgebruik. Den Haag, Wageningen Economic Research, Interne notitie

\section{Aanhangsel: Voorlopige en definitieve resultaten kunstmestverbruik 2018.}

Het stikstofverbruik bij de voorlopige gegevens van 2018 was $201 \mathrm{mln}$. kg (Luesink, 15 januari 2020) en bij de definitieve gegevens is het $209 \mathrm{mln}$. $\mathrm{kg}$. Dat het verbruik van stikstofkunstmeststoffen bij de definitieve gegevens van 2018 hoger is dan bij de voorlopige had als oorzaak dat er bij de ruim 100 bedrijven waarvan het kunstmestgebruik bij de voorlopige gegevens nog niet bekend was er relatief 
veel kunstmeststikstof werd verbruikt. Bij fosfaat, kali en kalk zijn de verschillen tussen de voorlopige en definitieve resultaten gering.

Tabel B19.5 Voorlopige en definitieve kunstmestgegevens in $2018 \mathrm{in} \mathrm{m/n.} \mathrm{kg} /$ Preliminary and definitive inorganic fertiliser figures in $2018 \mathrm{in} \mathrm{mln} . \mathrm{kg}$.

\begin{tabular}{lrr} 
Mineraal / Mineral & Voorlopig / Preliminary & Definitief / Definitive \\
Stikstof $(\mathrm{N})$ / Nitrogen $(\mathrm{N})$ & 201 & 209 \\
\hline Fosfaat $\left(\mathrm{P}_{2} \mathrm{O}_{5}\right)$ / Phosphate $\left(\mathrm{P}_{2} \mathrm{O}_{5}\right)$ & 13 & 13 \\
\hline Kali $\left(\mathrm{K}_{2} \mathrm{O}\right)$ / Potassium $\left(\mathrm{K}_{2} \mathrm{O}\right)$ & 57 & 58 \\
\hline Kalk / Lime & 158 & 159
\end{tabular}




\section{Bijlage 20 Verbruik van kunstmest en spuiwater}

B20.1

Verbruik van kunstmest en spuiwater (miljoen $\mathrm{kg} \mathrm{N}$ ) / Application of fertiliser and effluent from air scrubbers (million $\mathrm{kg} N$ ).

\begin{tabular}{|c|c|c|c|c|c|c|c|c|c|c|c|c|c|c|c|}
\hline Kunstmestsoort / Fertiliser type & 1990 & 1991 & 1992 & 1993 & 1994 & 1995 & 1996 & 1997 & 1998 & 1999 & 2000 & 2001 & 2002 & 2003 & 2004 \\
\hline Ammoniumnitraat / Ammonium nitrate & 0,0 & 0,0 & 0,1 & 0,0 & 0,4 & 0,5 & 0,0 & 1,8 & 0,0 & 0,0 & 1,2 & 0,8 & 0,5 & 1,4 & 2,6 \\
\hline Ammoniumsulfaat / Ammonium sulphate & 2,8 & 6,4 & 2,5 & 1,8 & 1,7 & 4,7 & 4,8 & 3,1 & 3,1 & 4,4 & 6,6 & 13,3 & 27,8 & 40,1 & 38,7 \\
\hline $\begin{array}{l}\text { Ammoniumsulfaatsalpeter / Mix ammonium } \\
\text { nitrate/ammonium sulphate }\end{array}$ & 0,0 & 0,0 & 0,0 & 0,0 & 0,0 & 0,0 & 0,0 & 0,0 & 0,0 & 2,7 & 2,5 & 1,7 & 0,2 & 1,9 & 2,6 \\
\hline Chilisalpeter / Sodium nitrate & 1,6 & 1,7 & 2,8 & 1,4 & 1,2 & 1,2 & 1,1 & 1,2 & 1,5 & 0,5 & 0,6 & 1,1 & 0,8 & 1,3 & 0,1 \\
\hline Diammoniumfosfaat / Diammonium phosphate & 0,5 & 0,6 & 2,6 & 4,5 & 6,0 & 6,4 & 6,4 & 6,7 & 6,6 & 6,4 & 0,0 & 0,0 & 0,0 & 0,0 & 0,0 \\
\hline Gemengde stikstofmeststof / Mixed nitrogen fertiliser & 7,1 & 1,0 & 1,1 & 1,1 & 0,9 & 0,8 & 1,3 & 1,4 & 1,3 & 1,5 & 2,5 & 2,5 & 7,0 & 3,0 & 4,0 \\
\hline Kalisalpeter / Potassium nitrate & 2,4 & 2,6 & 2,2 & 1,5 & 0,7 & 0,8 & 0,8 & 0,7 & 1,1 & 0,7 & 0,5 & 0,8 & 0,4 & 0,7 & 0,8 \\
\hline Kalkammonsalpeter / Calcium ammonium nitrate & 258,7 & 250,2 & 248,7 & 267,3 & 256,7 & 288,0 & 278,2 & 288,9 & 299,6 & 282,7 & 251,2 & 221,5 & 188,7 & 171,2 & 196,7 \\
\hline Kalksalpeter / Calcium nitrate & 7,0 & 4,3 & 4,0 & 3,6 & 3,7 & 2,5 & 1,1 & 1,0 & 0,1 & 0,0 & 0,2 & 0,4 & 0,9 & 0,1 & 0,0 \\
\hline Monoammoniumfosfaat / Mono ammonium phosphate & 0,2 & 0,0 & 0,3 & 0,0 & 0,2 & 0,1 & 0,1 & 0,1 & 0,1 & 0,1 & 0,0 & 0,0 & 0,0 & 0,0 & 0,0 \\
\hline $\begin{array}{l}\text { Overige NPK-, NP- en NK-meststoffen volle grond / } \\
\text { Other NPK, NP and NK fertilisers open field }\end{array}$ & 63,4 & 67,7 & 56,6 & 42,1 & 39,8 & 39,3 & 43,6 & 44,5 & 43,3 & 44,7 & 41,5 & 35,8 & 46,3 & 46,7 & 30,7 \\
\hline $\begin{array}{l}\text { Overige NPK-, NP- en NK-meststoffen in de } \\
\text { glastuinbouw / Other NPK, NP and NK fertilisers in } \\
\text { greenhouse cultivation }\end{array}$ & 13,0 & 13,0 & 13,0 & 13,0 & 13,0 & 13,0 & 12,8 & 12,8 & 12,8 & 12,8 & 12,8 & 7,7 & 8,7 & 10,5 & 9,9 \\
\hline $\begin{array}{l}\text { Stikstoffosfaatkalimagnesiummeststoffen / N, P, K, Mg } \\
\text { fertilisers }\end{array}$ & 1,6 & 0,0 & 0,0 & 0,0 & 0,0 & 0,0 & 0,0 & 0,0 & 0,0 & 0,0 & 0,0 & 0,0 & 0,0 & 0,0 & 1,5 \\
\hline Stikstofmagnesia / Nitrogen magnesia & 51,1 & 48,7 & 51,1 & 49,3 & 44,5 & 45,3 & 35,2 & 34,9 & 30,8 & 24,5 & 17,2 & 9,4 & 8,5 & 6,1 & 6,6 \\
\hline Ureum / Urea: & & & & & & & & & & & & & & & \\
\hline $\begin{array}{l}\text { korrelvormig incl. ureum met nitrificatieremmer / } \\
\text { granular incl. urea with nitrification inhibitor }\end{array}$ & 0,5 & 1,2 & 1,0 & 1,0 & 1,0 & 0,6 & 0,6 & 0,4 & 0,3 & 0,2 & 0,2 & 0,4 & 0,5 & 0,9 & 1,0 \\
\hline $\begin{array}{l}\text { korrelvormig met ureaseremmer / granular with } \\
\text { urease inhibitor }\end{array}$ & 0,0 & 0,0 & 0,0 & 0,0 & 0,0 & 0,0 & 0,0 & 0,0 & 0,0 & 0,0 & 0,0 & 0,0 & 0,0 & 0,0 & 0,0 \\
\hline $\begin{array}{l}\text { vloeibaar, oppervlakkig toegediend / liquid, surface } \\
\text { spreading }\end{array}$ & 0,5 & 1,3 & 1,3 & 1,3 & 1,6 & 1,0 & 1,2 & 1,0 & 0,8 & 0,7 & 1,0 & 1,9 & 1,3 & 5,1 & 3,8 \\
\hline vloeibaar, geïnjecteerd / liquid, injected & 0,0 & 0,0 & 0,0 & 0,0 & 0,1 & 0,1 & 0,1 & 0,1 & 0,1 & 0,1 & 0,1 & 0,2 & 0,2 & 0,8 & 0,7 \\
\hline $\begin{array}{l}\text { vloeibaar, met ureaseremmer / liquid, with uease } \\
\text { inhibitor }\end{array}$ & 0,0 & 0,0 & 0,0 & 0,0 & 0,0 & 0,0 & 0,0 & 0,1 & 0,0 & 0,0 & 0,1 & 0,2 & 0,1 & 0,5 & 0,4 \\
\hline $\begin{array}{l}\text { ureum in glastuinbouw / urea in greenhouse } \\
\text { cultivation }\end{array}$ & 0,0 & 0,0 & 0,0 & 0,0 & 0,0 & 0,0 & 0,0 & 0,0 & 0,0 & 0,0 & 0,1 & 0,1 & 0,2 & 0,4 & 0,5 \\
\hline Vloeibare ammoniak / Liquid ammonia & 2,0 & 1,3 & 4,3 & 1,6 & 0,0 & 1,4 & 1,7 & 1,8 & 1,6 & 1,3 & 1,1 & 0,4 & 0,0 & 0,0 & 0,0 \\
\hline
\end{tabular}




\begin{tabular}{|c|c|c|c|c|c|c|c|c|c|c|c|c|c|c|c|}
\hline Kunstmestsoort / Fertiliser type & 1990 & 1991 & 1992 & 1993 & 1994 & 1995 & 1996 & 1997 & 1998 & 1999 & 2000 & 2001 & 2002 & 2003 & 2004 \\
\hline Zwavel gecoate ureum / Sulpher coated urea & 0,0 & 0,0 & 0,0 & 0,0 & 0,0 & 0,0 & 0,0 & 0,0 & 0,0 & 0,0 & 0,0 & 0,0 & 0,0 & 0,0 & 0,0 \\
\hline Overige stikstofmeststoffen / Other nitrogen fertilisers & 0,0 & 0,0 & 0,0 & 0,0 & 0,0 & 0,0 & 0,0 & 0,0 & 0,0 & 0,0 & 0,0 & 0,0 & 0,0 & 0,0 & 0,0 \\
\hline Totale afzet / Total use & 412,4 & 400,1 & 391,8 & 389,9 & 371,6 & 405,8 & 388,9 & 400,6 & 402,9 & 383,3 & 339,5 & 298,3 & 292,2 & 290,6 & 300,5 \\
\hline \multicolumn{16}{|l|}{ waarvan / of which: } \\
\hline landbouw / agriculture & 395,0 & 382,7 & 374,4 & 372,5 & 354,2 & 388,4 & 371,5 & 383,2 & 385,5 & 365,9 & 322,1 & 280,9 & 274,8 & 273,2 & 283,1 \\
\hline hobbybedrijven / hobby farms & 12,4 & 12,4 & 12,4 & 12,4 & 12,4 & 12,4 & 12,4 & 12,4 & 12,4 & 12,4 & 12,4 & 12,4 & 12,4 & 12,4 & 12,4 \\
\hline particulieren e.d. / private parties etc. & 5,0 & 5,0 & 5,0 & 5,0 & 5,0 & 5,0 & 5,0 & 5,0 & 5,0 & 5,0 & 5,0 & 5,0 & 5,0 & 5,0 & 5,0 \\
\hline Spuiwater luchtwassers / Effluent from air scrubbers & 0,0 & 0,0 & 0,0 & 0,0 & 0,0 & 0,0 & 0,0 & 0,0 & 0,0 & 0,0 & 0,0 & 0,0 & 0,0 & 0,0 & 0,0 \\
\hline
\end{tabular}

\section{B20.1 vervolg / continuation}

\begin{tabular}{|c|c|c|c|c|c|c|c|c|c|c|c|c|c|c|c|}
\hline Kunstmestsoort / Fertiliser type & 2005 & 2006 & 2007 & 2008 & 2009 & 2010 & 2011 & 2012 & 2013 & 2014 & 2015 & 2016 & 2017 & 2018 & 2019 \\
\hline Ammoniumnitraat / Ammonium nitrate & 3,3 & 1,9 & 1,7 & 0,0 & 0,0 & 0,0 & 0,0 & 0,0 & 0,0 & 0,0 & 0,0 & 0,0 & 0,0 & 0,0 & 0,0 \\
\hline Ammoniumsulfaat / Ammonium sulphate & 29,3 & 42,1 & 17,2 & 12,8 & 5,7 & 3,4 & 4,8 & 4,4 & 9,5 & 9,6 & 16,3 & 1,5 & 1,5 & 2,0 & 1,3 \\
\hline $\begin{array}{l}\text { Ammoniumsulfaatsalpeter / Mix ammonium } \\
\text { nitrate/ammonium sulphate }\end{array}$ & 4,8 & 9,3 & 4,5 & 4,7 & 3,9 & 3,9 & 1,8 & 3,5 & 2,3 & 6,0 & 4,6 & 0,0 & 0,0 & 0,0 & 0,0 \\
\hline Chilisalpeter / Sodium nitrate & 0,4 & 0,0 & 0,0 & 0,0 & 0,0 & 0,0 & 0,0 & 0,0 & 0,0 & 0,0 & 0,0 & 0,0 & 0,0 & 0,0 & 0,0 \\
\hline Diammoniumfosfaat / Diammonium phosphate & 1,3 & 0,8 & 0,0 & 0,0 & 0,0 & 0,0 & 0,0 & 0,0 & 0,0 & 0,0 & 0,0 & 0,0 & 0,0 & 0,0 & 0,0 \\
\hline Gemengde stikstofmeststof / Mixed nitrogen fertiliser & 8,1 & 3,4 & 4,8 & 5,9 & 7,7 & 6,9 & 4,7 & 9,6 & 8,3 & 11,6 & 13,3 & 6,5 & 5,7 & 12,6 & 13,0 \\
\hline Kalisalpeter / Potassium nitrate & 0,8 & 0,8 & 0,0 & 0,0 & 0,0 & 0,0 & 0,0 & 0,0 & 0,0 & 0,0 & 0,0 & 0,0 & 0,0 & 0,0 & 0,0 \\
\hline Kalkammonsalpeter / Calcium ammonium nitrate & 174,5 & 179,3 & 160,1 & 156,8 & 169,1 & 161,9 & 151,0 & 127,8 & 145,1 & 125,2 & 156,0 & 136,4 & 133,1 & 118,6 & 114,9 \\
\hline Kalksalpeter / Calcium nitrate & 0,2 & 0,0 & 0,0 & 0,0 & 0,0 & 0,0 & 0,0 & 0,0 & 0,0 & 0,0 & 0,0 & 0,0 & 0,0 & 0,0 & 0,0 \\
\hline Monoammoniumfosfaat / Mono ammonium phosphate & 0,0 & 0,0 & 0,0 & 0,0 & 0,0 & 0,0 & 0,0 & 0,0 & 0,0 & 0,0 & 0,0 & 0,0 & 0,0 & 0,0 & 0,0 \\
\hline $\begin{array}{l}\text { Overige NPK-, NP- en NK-meststoffen volle grond / } \\
\text { Other NPK, NP and NK fertilisers open field }\end{array}$ & 31,0 & 24,8 & 27,1 & 35,3 & 11,5 & 9,2 & 17,9 & 11,6 & 16,3 & 27,3 & 18,9 & 30,4 & 28,6 & 25,2 & 23,0 \\
\hline $\begin{array}{l}\text { Overige NPK-, NP- en NK-meststoffen in de } \\
\text { glastuinbouw / Other NPK, NP and NK fertilisers in } \\
\text { greenhouse cultivation }\end{array}$ & 10,9 & 8,8 & 9,2 & 7,5 & 7,5 & 10,8 & 9,4 & 9,3 & 9,3 & 8,8 & 8,4 & 7,5 & 7,7 & 7,6 & 7,6 \\
\hline $\begin{array}{l}\text { Stikstoffosfaatkalimagnesiummeststoffen / N, P, K, Mg } \\
\text { fertilisers }\end{array}$ & 3,8 & 6,4 & 14,6 & 7,1 & 1,5 & 1,6 & 2,0 & 1,3 & 0,8 & 1,0 & 1,0 & 0,0 & 0,0 & 0,0 & 0,0 \\
\hline Stikstofmagnesia / Nitrogen magnesia & 5,6 & 2,4 & 3,7 & 1,4 & 2,8 & 1,2 & 0,0 & 0,0 & 0,4 & 0,4 & 0,4 & 0,7 & 0,8 & 1,0 & 1,1 \\
\hline \multicolumn{16}{|l|}{ Ureum / Urea: } \\
\hline $\begin{array}{l}\text { korrelvormig incl. ureum met nitrificatieremmer / } \\
\text { granular incl. urea with nitrification inhibitor }\end{array}$ & 0,8 & 0,9 & 2,0 & 1,5 & 2,6 & 1,9 & 2,7 & 4,0 & 1,9 & 1,1 & 1,6 & 5,3 & 5,8 & 4,3 & 5,3 \\
\hline $\begin{array}{l}\text { korrelvormig met ureaseremmer / granular with } \\
\text { urease inhibitor }\end{array}$ & 0,0 & 0,0 & 0,0 & 0,0 & 0,0 & 0,0 & 0,0 & 0,8 & 2,5 & 5,5 & 10,3 & 1,6 & 3,0 & 5,4 & 4,5 \\
\hline
\end{tabular}

174 | wot-technical report 203 


\begin{tabular}{|c|c|c|c|c|c|c|c|c|c|c|c|c|c|c|c|}
\hline Kunstmestsoort / Fertiliser type & 2005 & 2006 & 2007 & 2008 & 2009 & 2010 & 2011 & 2012 & 2013 & 2014 & 2015 & 2016 & 2017 & 2018 & 2019 \\
\hline $\begin{array}{l}\text { vloeibaar, oppervlakkig toegediend / liquid, surface } \\
\text { spreading }\end{array}$ & 3,1 & 4,5 & 8,0 & 3,1 & 8,6 & 11,3 & 12,3 & 25,1 & 20,4 & 18,7 & 17,7 & 15,5 & 15,4 & 16,0 & 13,1 \\
\hline vloeibaar, geïnjecteerd / liquid, injected & 0,6 & 0,9 & 1,8 & 0,7 & 2,2 & 3,2 & 3,7 & 8,1 & 7,0 & 6,9 & 7,0 & 6,1 & 6,1 & 6,3 & 5,3 \\
\hline $\begin{array}{l}\text { vloeibaar, met ureaseremmer / liquid, with uease } \\
\text { inhibitor }\end{array}$ & 0,4 & 0,6 & 1,2 & 0,5 & 1,5 & 2,1 & 2,5 & 5,5 & 4,8 & 4,7 & 4,8 & 0,0 & 0,0 & 0,0 & 0,0 \\
\hline $\begin{array}{l}\text { ureum in glastuinbouw / urea in greenhouse } \\
\text { cultivation }\end{array}$ & 0,3 & 0,8 & 1,6 & 1,0 & 0,9 & 2,1 & 1,3 & 2,1 & 1,9 & 0,8 & 0,6 & 0,3 & 0,2 & 0,3 & 0,5 \\
\hline Vloeibare ammoniak / Liquid ammonia & 0,0 & 0,0 & 0,0 & 0,0 & 0,0 & 0,0 & 0,0 & 0,0 & 0,0 & 0,0 & 0,0 & 0,0 & 0,0 & 0,0 & 0,0 \\
\hline Zwavel gecoate ureum / Sulpher coated urea & 0,0 & 0,0 & 0,0 & 0,0 & 0,0 & 0,0 & 0,0 & 0,0 & 0,0 & 0,0 & 0,0 & 0,0 & 0,0 & 0,0 & 0,0 \\
\hline Overige stikstofmeststoffen / Other nitrogen fertilisers & 0,0 & 0,0 & 0,0 & 0,0 & 0,0 & 0,0 & 0,0 & 0,0 & 0,0 & 0,0 & 0,0 & 18,0 & 22,2 & 13,0 & 13,6 \\
\hline Totale afzet / Total use & 279,2 & 287,8 & 257,5 & 238,1 & 225,7 & 219,5 & 214,1 & 213,2 & 230,3 & 227,5 & 261,1 & 244,7 & 245,2 & 226,6 & 216,9 \\
\hline \multicolumn{16}{|l|}{ waarvan / of which: } \\
\hline landbouw / agriculture & 261,8 & 270,4 & 240,1 & 220,7 & 211,4 & 205,2 & 200,4 & 199,5 & 216,0 & 213,2 & 244,9 & 229,8 & 230,2 & 212,3 & 203,2 \\
\hline hobbybedrijven / hobby farms & 12,4 & 12,4 & 12,4 & 12,4 & 9,3 & 9,3 & 8,7 & 8,7 & 9,3 & 9,3 & 11,2 & 9,9 & 9,9 & 9,3 & 8,7 \\
\hline particulieren e.d. / private parties etc. & 5,0 & 5,0 & 5,0 & 5,0 & 5,0 & 5,0 & 5,0 & 5,0 & 5,0 & 5,0 & 5,0 & 5,0 & 5,0 & 5,0 & 5,0 \\
\hline Spuiwater luchtwassers / Effluent from air scrubbers & 0,8 & 0,8 & 1,3 & 1,4 & 1,4 & 2,5 & 4,6 & 5,0 & 6,5 & 6,7 & 7,1 & 7,6 & 7,8 & 9,1 & 9,2 \\
\hline
\end{tabular}

Bron / Source: Wageningen Enonomic Research. 



\section{Bijlage 21 Gebruik van overige organische meststoffen}

B21.1

Gebruik van overige organische meststoffen / Use of other organic fertilisers.

\begin{tabular}{|c|c|c|c|c|c|c|c|c|c|c|c|c|c|c|c|}
\hline $\begin{array}{l}\text { Overige organische meststoffen / Other organic } \\
\text { fertilisers }\end{array}$ & 1990 & 1991 & 1992 & 1993 & 1994 & 1995 & 1996 & 1997 & 1998 & 1999 & 2000 & 2001 & 2002 & 2003 & 2004 \\
\hline \multicolumn{16}{|l|}{ Zuiveringsslib / Sewage sludge } \\
\hline $\begin{array}{l}\text { gebruik in de landbouw (mln. } \mathrm{kg} \mathrm{N}) / \text { agricultural use } \\
(\mathrm{mln} . \mathrm{kg} \mathrm{N})\end{array}$ & 5,0 & 5,0 & 5,7 & 3,8 & 2,5 & 1,5 & 1,6 & 1,2 & 1,0 & 0,9 & 1,5 & 1,4 & 1,6 & 1,6 & 1,1 \\
\hline fractie dun slib / fraction liquid sludge & 0,90 & 0,82 & 0,73 & 0,34 & 0,28 & 0,48 & 0,55 & 0,44 & 0,25 & 0,28 & 0,32 & 0,46 & 0,35 & 0,42 & 0,52 \\
\hline fractie vast slib / fraction solid sludge & 0,10 & 0,18 & 0,27 & 0,66 & 0,72 & 0,52 & 0,45 & 0,56 & 0,75 & 0,72 & 0,68 & 0,54 & 0,65 & 0,58 & 0,48 \\
\hline TAN-fractie dun slib / TAN-fraction in liquid sludge & 0,41 & 0,41 & 0,41 & 0,41 & 0,41 & 0,41 & 0,41 & 0,41 & 0,41 & 0,41 & 0,41 & 0,41 & 0,41 & 0,41 & 0,41 \\
\hline TAN-fractie vast slib / TAN-fraction in solid sludge & 0,13 & 0,13 & 0,13 & 0,13 & 0,13 & 0,13 & 0,13 & 0,13 & 0,13 & 0,13 & 0,13 & 0,13 & 0,13 & 0,13 & 0,13 \\
\hline $\begin{array}{l}\text { fractie emissiearm toegediend / fraction of low } \\
\text { emission application }\end{array}$ & 0 & 0 & 1 & 1 & 1 & 1 & 1 & 1 & 1 & 1 & 1 & 1 & 1 & 1 & 1 \\
\hline $\begin{array}{l}\text { emissiefactor dun slib (\% van TAN) / emission factor } \\
\text { liquid sludge ( } \% \text { of TAN) }\end{array}$ & 64 & 64 & 13 & 13 & 19 & 19 & 19 & 19 & 19 & 24 & 24 & 24 & 24 & 24 & 24 \\
\hline $\begin{array}{l}\text { emissiefactor vast slib (\% van TAN) / emission factor } \\
\text { solid sludge ( } \% \text { of TAN) }\end{array}$ & 64 & 64 & 46 & 46 & 46 & 46 & 46 & 46 & 46 & 46 & 46 & 46 & 46 & 46 & 46 \\
\hline \multicolumn{16}{|l|}{ Compost / Compost } \\
\hline $\begin{array}{l}\text { GFT-compost in de landbouw }(\mathrm{mln} . \mathrm{kg} \mathrm{N}) / \mathrm{VGF}^{1)} \text { - } \\
\text { compost in agriculture }(\mathrm{mln} . \mathrm{kg} \mathrm{N})\end{array}$ & 0 & 0 & 0,20 & 0,80 & 1,3 & 2,0 & 2,8 & 3,6 & 2,8 & 3,1 & 3,2 & 3,2 & 2,1 & 2,6 & 2,9 \\
\hline $\begin{array}{l}\text { overige compost landbouw }(\mathrm{mln} . \mathrm{kg} \mathrm{N}) / \text { other } \\
\text { compost in agriculture }(\mathrm{mln} . \mathrm{kg} \mathrm{N})\end{array}$ & 2,0 & 2,0 & 2,0 & 2,0 & 2,0 & 2,0 & 2,0 & 2,0 & 2,0 & 2,0 & 2,0 & 2,0 & 2,0 & 2,0 & 2,0 \\
\hline $\begin{array}{l}\text { GFT-compost andere sectoren }(\mathrm{mln} . \mathrm{kg} \mathrm{N}) / \text { VGF- } \\
\text { compost in other sectors }(\mathrm{mln} . \mathrm{kg} \mathrm{N})\end{array}$ & 0 & 0 & 0,60 & 0,70 & 3,2 & 3,4 & 3,0 & 2,1 & 2,2 & 3,3 & 2,8 & 3,6 & 3,9 & 2,6 & 2,6 \\
\hline TAN-fractie compost / TAN-fraction compost & 0,09 & 0,09 & 0,09 & 0,09 & 0,09 & 0,09 & 0,09 & 0,09 & 0,09 & 0,09 & 0,09 & 0,09 & 0,09 & 0,09 & 0,09 \\
\hline emissiefactor compost / TAN fraction compost & 69 & 69 & 69 & 69 & 69 & 69 & 69 & 69 & 69 & 69 & 69 & 69 & 69 & 69 & 69 \\
\hline $\begin{array}{l}\text { Overige organische meststoffen }{ }^{2}(\mathrm{mln} . \mathrm{kg} \mathrm{N}) / \\
\text { Other organic fertilisers }{ }^{2}(\mathrm{~m} / \mathrm{ln} . \mathrm{kg} \mathrm{N})\end{array}$ & 0 & 0 & 0 & 0 & 0 & 0 & 0 & 0 & 0 & 0 & 0 & 0 & 0 & 0 & 0 \\
\hline
\end{tabular}




\begin{tabular}{|c|c|c|c|c|c|c|c|c|c|c|c|c|c|c|c|}
\hline $\begin{array}{l}\text { Overige organische meststoffen / Other organic } \\
\text { fertilisers }\end{array}$ & 2005 & 2006 & 2007 & 2008 & 2009 & 2010 & 2011 & 2012 & 2013 & 2014 & 2015 & 2016 & 2017 & 2018 & 2019 \\
\hline \multicolumn{16}{|l|}{ Zuiveringsslib / Sewage sludge } \\
\hline $\begin{array}{l}\text { gebruik in de landbouw (mln. } \mathrm{kg} \mathrm{N}) / \text { agricultural use } \\
(\mathrm{m} \ln . \mathrm{kg} \mathrm{N})\end{array}$ & 1,2 & 1,1 & 1,0 & 1,0 & 0,90 & 0,90 & 0,80 & 0,80 & 1,19 & 0,80 & 0,63 & 0,63 & 0,25 & 0,28 & 0,24 \\
\hline fractie dun slib / fraction liquid sludge & 0,52 & 0,37 & 0,52 & 0,53 & 0,46 & 0,53 & 0,46 & 0,51 & 0,42 & 0,57 & 0,57 & 0,57 & 0,57 & 0,57 & 0,67 \\
\hline fractie vast slib / fraction solid sludge & 0,48 & 0,63 & 0,48 & 0,47 & 0,54 & 0,47 & 0,54 & 0,49 & 0,58 & 0,43 & 0,43 & 0,43 & 0,43 & 0,43 & 0,33 \\
\hline TAN-fractie dun slib / TAN-fraction in liquid sludge & 0,41 & 0,41 & 0,41 & 0,41 & 0,41 & 0,41 & 0,41 & 0,41 & 0,41 & 0,41 & 0,41 & 0,41 & 0,41 & 0,41 & 0,41 \\
\hline TAN-fractie vast slib / TAN-fraction in solid sludge & 0,13 & 0,13 & 0,13 & 0,13 & 0,13 & 0,13 & 0,13 & 0,13 & 0,13 & 0,13 & 0,13 & 0,13 & 0,13 & 0,13 & 0,13 \\
\hline $\begin{array}{l}\text { fractie emissiearm toegediend / fraction of low } \\
\text { emission application }\end{array}$ & 1 & 1 & 1 & 1 & 1 & 1 & 1 & 1 & 1 & 1 & 1 & 1 & 1 & 1 & 1 \\
\hline $\begin{array}{l}\text { emissiefactor dun slib ( } \% \text { van TAN) / emission factor } \\
\text { liquid sludge ( } \% \text { of TAN) }\end{array}$ & 24 & 24 & 24 & 24 & 24 & 24 & 24 & 24 & 24 & 24 & 24 & 24 & 24 & 24 & 24 \\
\hline $\begin{array}{l}\text { emissiefactor vast slib ( } \% \text { van TAN) / emission factor } \\
\text { solid sludge ( } \% \text { of TAN) }\end{array}$ & 46 & 46 & 46 & 46 & 46 & 46 & 46 & 46 & 46 & 46 & 46 & 46 & 46 & 46 & 46 \\
\hline \multicolumn{16}{|l|}{ Compost / Compost } \\
\hline $\begin{array}{l}\text { GFT-compost in de landbouw (mln. } \mathrm{kg} \mathrm{N}) / \mathrm{VGF}^{1)_{-}} \\
\text {compost in agriculture }(\mathrm{mln} . \mathrm{kg} \mathrm{N})\end{array}$ & 2,9 & 2,3 & 3,6 & 3,3 & 3,7 & 3,4 & 3,2 & 3,8 & 4,0 & 4,0 & 3,7 & 4,5 & 4,1 & 6,0 & 5,5 \\
\hline $\begin{array}{l}\text { overige compost landbouw }(\mathrm{mln} . \mathrm{kg} \mathrm{N}) / \text { other } \\
\text { compost in agriculture }(\mathrm{m} \ln . \mathrm{kg} \mathrm{N})\end{array}$ & 2,0 & 2,0 & 2,0 & 2,0 & 2,0 & 2,0 & 2,0 & 2,0 & 2,0 & 2,0 & 2,0 & 2,0 & 2,0 & 0,0 & 0,0 \\
\hline $\begin{array}{l}\text { GFT-compost andere sectoren ( } \mathrm{mln} . \mathrm{kg} \mathrm{N}) / \text { VGF- } \\
\text { compost in other sectors }(\mathrm{mln} . \mathrm{kg} \mathrm{N})\end{array}$ & 2,8 & 2,6 & 2,3 & 1,7 & 1,8 & 2,0 & 2,1 & 1,5 & 1,3 & 1,6 & 1,6 & 1,2 & 1,4 & 2,0 & 1,7 \\
\hline TAN-fractie compost / TAN-fraction compost & 0,09 & 0,09 & 0,09 & 0,09 & 0,09 & 0,09 & 0,09 & 0,09 & 0,09 & 0,09 & 0,09 & 0,09 & 0,09 & 0,09 & 0,09 \\
\hline emissiefactor compost / TAN fraction compost & 69 & 69 & 69 & 69 & 69 & 69 & 69 & 69 & 69 & 69 & 69 & 69 & 69 & 69 & 69 \\
\hline $\begin{array}{l}\text { Overige organische meststoffen }{ }^{2}(\mathrm{~m} / \mathrm{n} . \mathrm{kg} \mathrm{N}) / \\
\text { Other organic fertilisers }{ }^{2}(\mathrm{~m} / \mathrm{l} . \mathbf{k g ~ N})\end{array}$ & 0 & 0 & 0 & 0 & 0 & 0 & 0 & 0 & 0 & 0 & 0 & 0,97 & 0,86 & 0,94 & 0,43 \\
\hline
\end{tabular}

\section{1) Vegetable, garden and fruit waste.}

2) Gebruik van organische meststoffen in het overzicht van kunstmestgebruik van Wageningen Economic Research / Use of organic fertilisers from the survey on fertiliser use from Wageningen Economic Research. Bronnen: Rijkswaterstaat en Centraal Bureau voor de Statistiek / Sources: Rijkswaterstaat and Statistics Netherlands. 


\section{Bijlage 22 Gewasarealen, $\mathrm{N}$ in gewasresten en emissiefactor voor $\mathrm{NH}_{3}$}

Gewasarealen (ha) / Crop area (ha).

\begin{tabular}{|c|c|c|c|c|c|c|c|c|c|c|}
\hline Gewas / Crop & 1990 & 1991 & 1992 & 1993 & 1994 & 1995 & 1996 & 1997 & 1998 & 1999 \\
\hline Wintertarwe / Winter wheat & 135.104 & 115.201 & 116.697 & 99.819 & 98.559 & 125.599 & 134.122 & 124.985 & 128.276 & 61.638 \\
\hline Zomertarwe / Spring wheat & 5.499 & 8.033 & 10.195 & 18.214 & 23.028 & 9.813 & 7.485 & 12.526 & 11.038 & 41.142 \\
\hline Wintergerst / Winter barley & 9.941 & 7.126 & 6.040 & 4.398 & 2.502 & 3.100 & 2.673 & 2.626 & 3.075 & 1.980 \\
\hline Zomergerst / Spring barley & 30.447 & 34.791 & 28.052 & 35.657 & 41.169 & 32.480 & 32.811 & 39.329 & 36.658 & 56.313 \\
\hline Rogge / Rye & 8.604 & 6.997 & 6.207 & 7.432 & 5.603 & 8.175 & 6.893 & 4.980 & 6.330 & 2.652 \\
\hline Haver / Oats & 3.401 & 3.324 & 3.646 & 5.153 & 5.518 & 2.914 & 1.909 & 1.955 & 2.066 & 2.518 \\
\hline Triticale / Triticale & 0 & 2.978 & 2.367 & 1.904 & 1.622 & 2.579 & 3.270 & 2.933 & 4.429 & 1.835 \\
\hline Groene erwten en schokkers / Dried and green peas & 10.908 & 6.887 & 4.420 & 2.221 & 1.394 & 691 & 827 & 674 & 730 & 862 \\
\hline Erwten / Peas & 7.667 & 7.635 & 7.579 & 6.628 & 6.931 & 7.131 & 6.170 & 4.395 & 4.589 & 6.085 \\
\hline Kapucijners / Marrowfats & 794 & 638 & 917 & 953 & 891 & 367 & 764 & 486 & 424 & 638 \\
\hline Bruine bonen / Kidney beans & 3.730 & 4.099 & 2.673 & 2.348 & 2.039 & 2.221 & 2.856 & 2.033 & 1.956 & 1.935 \\
\hline Veld- en tuinbonen / Broad and field beans & 3.169 & 2.032 & 1.670 & 1.274 & 802 & 532 & 664 & 1.008 & 755 & 648 \\
\hline Graszaad / Grass seed & 26.314 & 27.957 & 26.863 & 27.098 & 19.755 & 21.893 & 21.302 & 23.882 & 28.418 & 21.299 \\
\hline Koolzaad incl. raapzaad / Oilseed rape incl. rape seed & 8.415 & 7.070 & 4.234 & 2.350 & 1.424 & 1.493 & 878 & 579 & 873 & 1.319 \\
\hline Karwijzaad / Caraway seed & 342 & 142 & 141 & 125 & 328 & 1.211 & 613 & 236 & 190 & 113 \\
\hline Blauwmaanzaad / Pop seed & 264 & 374 & 108 & 1.030 & 3.393 & 1.411 & 332 & 592 & 1.199 & 1.452 \\
\hline Vlas / Flax & 5.535 & 4.408 & 4.727 & 3.758 & 4.651 & 4.407 & 3.874 & 4.253 & 3.498 & 3.753 \\
\hline Pootaardappelen / Seed potatoes & 35.587 & 39.156 & 41.241 & 38.423 & 37.023 & 37.799 & 38.737 & 39.992 & 39.948 & 41.014 \\
\hline Aardappelen / Potatoes & 76.894 & 77.773 & 81.374 & 74.641 & 73.849 & 80.157 & 83.606 & 77.497 & 84.391 & 86.265 \\
\hline Zetmeelaardappelen / Industrial potatoes & 62.838 & 62.650 & 64.710 & 62.854 & 60.154 & 61.345 & 62.881 & 62.414 & 56.962 & 52.526 \\
\hline Suikerbieten / Sugar beets & 124.995 & 123.316 & 120.736 & 116.685 & 114.509 & 116.081 & 116.574 & 114.066 & 113.032 & 119.748 \\
\hline Voederbieten / Fodder beets & 3.023 & 2.817 & 2.573 & 2.157 & 2.066 & 1.576 & 1.357 & 1.166 & 1.158 & 991 \\
\hline Luzerne / Lucerne & 5.960 & 5.686 & 6.075 & 6.566 & 6.425 & 5.836 & 5.675 & 6.055 & 6.257 & 6.408 \\
\hline Snijmaïs incl. energiemaïs / Green maize incl. energy maize & 201.811 & 202.014 & 217.525 & 228.683 & 228.508 & 219.217 & 222.872 & 231.985 & 219.940 & 230.746 \\
\hline Groenbemestingsgewassen / Green manure crops & 7.282 & 12.125 & 13.368 & 15.746 & 16.397 & 12.248 & 5.621 & 2.284 & 2.347 & 2.932 \\
\hline Korrelmaïs / Grain maize & 0 & 11.165 & 7.790 & 10.819 & 11.624 & 9.005 & 10.872 & 12.682 & 13.698 & 16.036 \\
\hline Corn Cob Mix / Corn Cob Mix & 0 & 3.237 & 2.583 & 3.767 & 5.236 & 5.005 & 5.644 & 5.416 & 5.761 & 5.970 \\
\hline Cichorei / Chicory & 0 & 0 & 0 & 0 & 0 & 0 & 0 & 4.222 & 4.196 & 4.471 \\
\hline Hennep / Hemp & 0 & 0 & 0 & 0 & 0 & 0 & 0 & 1.249 & 1.083 & 1.150 \\
\hline Uien / Onions & 12.828 & 13.773 & 14.183 & 13.578 & 15.504 & 16.082 & 16.674 & 15.566 & 18.349 & 19.682 \\
\hline Overige akkerbouwgewassen / Other horticultural crops & 8.084 & 3.120 & 5.966 & 7.233 & 5.399 & 5.982 & 9.262 & 6.691 & 8.451 & 8.101 \\
\hline
\end{tabular}




\begin{tabular}{|c|c|c|c|c|c|c|c|c|c|c|}
\hline Gewas / Crop & 1990 & 1991 & 1992 & 1993 & 1994 & 1995 & 1996 & 1997 & 1998 & 1999 \\
\hline Aardbeien / Strawberry & 1.867 & 1.720 & 1.761 & 1.768 & 1.949 & 1.763 & 1.595 & 1.817 & 1.968 & 1.863 \\
\hline Andijvie / Endive & 234 & 250 & 248 & 292 & 272 & 276 & 239 & 228 & 260 & 268 \\
\hline Asperges / Asparagus & 2.663 & 2.641 & 2.749 & 2.584 & 2.389 & 2.324 & 2.281 & 2.243 & 2.304 & 2.219 \\
\hline Augurken / Gherkin & 257 & 278 & 146 & 67 & 89 & 0 & 0 & 0 & 0 & 0 \\
\hline Bloemkool / Cauliflower & 2.368 & 2.581 & 2.722 & 2.820 & 2.622 & 2.430 & 2.351 & 2.174 & 2.250 & 2.287 \\
\hline Broccoli / Broccoli & 0 & 0 & 0 & 0 & 0 & 534 & 589 & 618 & 769 & 865 \\
\hline Sluitkool / Cabbage & 2.578 & 2.892 & 3.053 & 3.199 & 2.759 & 2.922 & 3.046 & 2.985 & 2.941 & 2.946 \\
\hline Knolselderij / Celeriac & 1.363 & 1.344 & 1.423 & 1.237 & 1.208 & 1.414 & 1.566 & 1.448 & 1.534 & 1.601 \\
\hline Kroten / Beetroot & 0 & 0 & 0 & 0 & 0 & 353 & 282 & 334 & 408 & 462 \\
\hline Sla / Lettuce & 955 & 992 & 999 & 1.247 & 1.004 & 1.042 & 1.081 & 963 & 935 & 1.060 \\
\hline Prei / Leeks & 2.873 & 3.552 & 4.119 & 3.934 & 4.250 & 3.854 & 3.642 & 3.746 & 3.641 & 3.724 \\
\hline Schorseneren / Scorzonera & 1.395 & 1.352 & 1.658 & 1.687 & 1.585 & 1.480 & 1.608 & 1.646 & 1.839 & 1.601 \\
\hline Spinazie / Spinach & 1.153 & 945 & 922 & 907 & 881 & 965 & 954 & 1.062 & 1.195 & 1.331 \\
\hline Spruitkool / Brussels sprouts & 4.803 & 5.058 & 5.820 & 5.728 & 5.041 & 4.388 & 4.235 & 4.197 & 4.622 & 5.207 \\
\hline Stam(sperzie-)bonen / Industrial French beans & 3.695 & 4.588 & 4.926 & 4.198 & 4.654 & 4.678 & 4.478 & 4.576 & 4.852 & 4.840 \\
\hline Stokbonen / Runner beans & 225 & 177 & 164 & 192 & 166 & 0 & 0 & 0 & 0 & 0 \\
\hline Tuinbonen (groen te oogsten) / Broad beans green & 1.178 & 1.249 & 1.101 & 879 & 922 & 877 & 959 & 1.269 & 935 & 781 \\
\hline Was- en bospeen / Carrot & 3.030 & 3.127 & 3.236 & 3.015 & 3.225 & 3.274 & 3.197 & 2.981 & 2.934 & 3.160 \\
\hline Winterpeen / Winter Carrot (Danvers) & 2.951 & 3.932 & 3.585 & 3.929 & 4.296 & 4.675 & 4.404 & 4.197 & 4.822 & 5.753 \\
\hline Witlofwortel / Chicory & 5.919 & 5.991 & 4.842 & 5.161 & 4.519 & 3.889 & 4.020 & 4.615 & 4.242 & 4.759 \\
\hline Overige groenten / Other vegetables & 2.774 & 3.072 & 3.286 & 3.487 & 3.412 & 2.867 & 2.549 & 3.552 & 3.858 & 3.468 \\
\hline $\begin{array}{l}\text { Groenbemester na akkerbouwgewas / Green manure following } \\
\text { arable crop }\end{array}$ & 85.350 & 85.350 & 85.350 & 85.350 & 85.350 & 85.350 & 85.350 & 85.350 & 85.350 & 85.350 \\
\hline Groenbemester na maïs / Green manure following maize & 0 & 0 & 0 & 0 & 0 & 0 & 0 & 0 & 0 & 0 \\
\hline
\end{tabular}




\begin{tabular}{|c|c|c|c|c|c|c|c|c|c|c|}
\hline Gewas / Crop & 2000 & 2001 & 2002 & 2003 & 2004 & 2005 & 2006 & 2007 & 2008 & 2009 \\
\hline Wintertarwe / Winter wheat & 120.510 & 95.791 & 113.190 & 105.879 & 117.224 & 116.040 & 121.502 & 124.429 & 140.617 & 128.894 \\
\hline Zomertarwe / Spring wheat & 16.176 & 28.931 & 22.659 & 24.066 & 20.864 & 20.670 & 19.622 & 16.892 & 15.893 & 22.088 \\
\hline Wintergerst / Winter barley & 3.635 & 3.236 & 2.660 & 3.101 & 3.206 & 2.970 & 3.488 & 4.263 & 4.669 & 4.873 \\
\hline Zomergerst / Spring barley & 43.537 & 63.525 & 54.280 & 51.924 & 44.781 & 47.620 & 41.091 & 41.729 & 45.565 & 39.591 \\
\hline Rogge / Rye & 5.961 & 3.568 & 3.567 & 3.535 & 3.430 & 2.535 & 2.386 & 2.845 & 2.117 & 2.320 \\
\hline Haver / Oats & 2.404 & 2.556 & 2.462 & 2.527 & 2.046 & 1.697 & 1.614 & 1.703 & 1.491 & 1.585 \\
\hline Triticale / Triticale & 6.646 & 4.808 & 5.006 & 4.246 & 4.292 & 4.083 & 3.694 & 3.889 & 3.199 & 2.735 \\
\hline Groene erwten en schokkers / Dried and green peas & 752 & 801 & 1.138 & 2.075 & 2.284 & 1.925 & 574 & 606 & 394 & 521 \\
\hline Erwten / Peas & 5.867 & 5.534 & 6.278 & 6.033 & 4.861 & 5.091 & 5.302 & 6.027 & 5.969 & 4.855 \\
\hline Kapucijners / Marrowfats & 388 & 700 & 632 & 766 & 434 & 396 & 482 & 278 & 523 & 692 \\
\hline Bruine bonen / Kidney beans & 1.126 & 1.514 & 1.556 & 2.304 & 2.223 & 1.099 & 1.139 & 1.094 & 911 & 1.383 \\
\hline Veld- en tuinbonen / Broad and field beans & 679 & 703 & 522 & 592 & 517 & 441 & 509 & 524 & 607 & 592 \\
\hline Graszaad / Grass seed & 21.960 & 19.743 & 17.918 & 21.599 & 25.325 & 27.639 & 26.147 & 20.107 & 15.661 & 17.729 \\
\hline Koolzaad incl. raapzaad / Oilseed rape incl. rape seed & 854 & 707 & 481 & 963 & 1.615 & 2.096 & 3.411 & 3.358 & 2.467 & 2.667 \\
\hline Karwijzaad / Caraway seed & 138 & 163 & 176 & 183 & 158 & 90 & 29 & 39 & 36 & 93 \\
\hline Blauwmaanzaad / Pop seed & 588 & 798 & 368 & 436 & 281 & 283 & 612 & 503 & 842 & 679 \\
\hline Vlas / Flax & 4.379 & 4.755 & 4.096 & 4.553 & 4.485 & 4.733 & 4.426 & 3.456 & 2.618 & 2.161 \\
\hline Pootaardappelen / Seed potatoes & 41.802 & 39.410 & 38.959 & 39.293 & 39.739 & 39.262 & 37.428 & 36.729 & 36.534 & 38.142 \\
\hline Aardappelen / Potatoes & 87.441 & 75.910 & 77.213 & 70.558 & 72.669 & 65.830 & 69.478 & 72.464 & 69.302 & 70.520 \\
\hline Zetmeelaardappelen / Industrial potatoes & 50.958 & 48.614 & 48.986 & 48.794 & 51.496 & 50.692 & 49.592 & 47.980 & 46.034 & 46.570 \\
\hline Suikerbieten / Sugar beets & 110.998 & 109.126 & 108.894 & 102.787 & 97.736 & 91.313 & 82.782 & 82.026 & 72.231 & 72.701 \\
\hline Voederbieten / Fodder beets & 891 & 800 & 731 & 637 & 640 & 532 & 358 & 331 & 353 & 329 \\
\hline Luzerne / Lucerne & 6.616 & 7.114 & 5.981 & 6.259 & 5.984 & 5.878 & 6.441 & 5.898 & 4.918 & 5.712 \\
\hline Snijmaïs incl. energiemaïs / Green maize incl. energy maize & 205.321 & 203.874 & 214.403 & 216.897 & 224.468 & 235.088 & 218.036 & 221.554 & 243.445 & 241.972 \\
\hline Groenbemestingsgewassen / Green manure crops & 2.615 & 3.453 & 24.253 & 24.090 & 20.420 & 31.020 & 18.143 & 14.904 & 5.011 & 3.679 \\
\hline Korrelmaïs / Grain maize & 20.298 & 27.173 & 23.694 & 24.547 & 22.420 & 20.748 & 19.772 & 19.340 & 22.132 & 18.904 \\
\hline Corn Cob Mix / Corn Cob Mix & 7.219 & 7.672 & 6.690 & 7.067 & 6.788 & 6.678 & 7.508 & 7.200 & 7.598 & 7.645 \\
\hline Cichorei / Chicory & 4.756 & 4.845 & 4.313 & 4.792 & 4.917 & 4.338 & 2.362 & 2.586 & 3.409 & 4.416 \\
\hline Hennep / Hemp & 792 & 981 & 2.079 & 1.461 & 31 & 100 & 27 & 135 & 278 & 892 \\
\hline Uien / Onions & 19.979 & 20.465 & 21.101 & 23.243 & 26.212 & 22.520 & 24.634 & 26.178 & 26.140 & 26.026 \\
\hline Overige akkerbouwgewassen / Other horticultural crops & 10.883 & 10.272 & 9.795 & 8.768 & 9.397 & 11.869 & 9.551 & 9.734 & 9.292 & 8.704 \\
\hline Aardbeien / Strawberry & 1.746 & 1.721 & 1.734 & 1.915 & 2.128 & 2.301 & 2.959 & 2.964 & 2.926 & 3.055 \\
\hline Andijvie / Endive & 252 & 262 & 330 & 355 & 300 & 280 & 278 & 332 & 288 & 210 \\
\hline Asperges / Asparagus & 2.084 & 2.117 & 2.173 & 2.423 & 2.361 & 2.334 & 2.461 & 2.383 & 2.477 & 2.620 \\
\hline Augurken / Gherkin & 0 & 0 & 0 & 0 & 0 & 0 & 182 & 253 & 419 & 486 \\
\hline Bloemkool / Cauliflower & 2.160 & 2.175 & 2.269 & 2.326 & 2.321 & 2.394 & 2.667 & 2.633 & 2.539 & 2.400 \\
\hline Broccoli / Broccoli & 846 & 1.064 & 1.099 & 1.165 & 1.210 & 1.311 & 1.485 & 1.587 & 1.732 & 1.979 \\
\hline Sluitkool / Cabbage & 2.544 & 2.400 & 2.619 & 2.690 & 2.572 & 2.473 & 2.736 & 2.864 & 3.064 & 2.789 \\
\hline
\end{tabular}




\begin{tabular}{|c|c|c|c|c|c|c|c|c|c|c|}
\hline Gewas / Crop & 2000 & 2001 & 2002 & 2003 & 2004 & 2005 & 2006 & 2007 & 2008 & 2009 \\
\hline Knolselderij / Celeriac & 1.285 & 1.396 & 1.363 & 1.327 & 1.326 & 1.128 & 1.227 & 1.385 & 1.330 & 1.223 \\
\hline Kroten / Beetroot & 290 & 360 & 379 & 334 & 318 & 276 & 359 & 370 & 405 & 415 \\
\hline Sla / Lettuce & 1.090 & 1.082 & 1.151 & 1.361 & 1.373 & 1.304 & 1.596 & 1.919 & 2.076 & 1.956 \\
\hline Prei / Leeks & 3.184 & 3.226 & 3.319 & 3.241 & 3.038 & 2.725 & 3.047 & 3.063 & 3.012 & 2.926 \\
\hline Schorseneren / Scorzonera & 1.138 & 1.104 & 1.169 & 1.339 & 1.020 & 867 & 917 & 996 & 959 & 1.118 \\
\hline Spinazie / Spinach & 1.208 & 1.164 & 1.190 & 1.036 & 848 & 914 & 1.172 & 1.302 & 1.175 & 1.384 \\
\hline Spruitkool / Brussels sprouts & 4.834 & 4.394 & 3.890 & 4.232 & 3.465 & 3.095 & 3.354 & 3.352 & 3.243 & 2.997 \\
\hline Stam(sperzie-)bonen / Industrial French beans & 3.627 & 3.668 & 3.810 & 4.145 & 4.404 & 4.254 & 3.894 & 3.751 & 3.429 & 2.920 \\
\hline Stokbonen / Runner beans & 0 & 0 & 0 & 0 & 0 & 0 & 109 & 68 & 71 & 59 \\
\hline Tuinbonen (groen te oogsten) / Broad beans green & 694 & 779 & 969 & 1.113 & 1.069 & 790 & 1.517 & 1.548 & 1.838 & 1.597 \\
\hline Was- en bospeen / Carrot & 2.985 & 3.012 & 2.910 & 2.830 & 2.435 & 2.551 & 2.731 & 2.648 & 2.658 & 2.688 \\
\hline Winterpeen / Winter Carrot (Danvers) & 4.729 & 4.837 & 4.981 & 5.439 & 5.451 & 4.700 & 5.936 & 5.478 & 5.286 & 5.742 \\
\hline Witlofwortel / Chicory & 4.199 & 3.767 & 3.692 & 3.566 & 2.937 & 3.423 & 3.592 & 3.478 & 3.162 & 3.012 \\
\hline Overige groenten / Other vegetables & 3.171 & 3.072 & 5.634 & 4.887 & 4.429 & 4.312 & 4.106 & 3.669 & 3.620 & 3.150 \\
\hline $\begin{array}{l}\text { Groenbemester na akkerbouwgewas / Green manure following } \\
\text { arable crop }\end{array}$ & 85.350 & 85.350 & 85.350 & 85.350 & 85.350 & 85.350 & 85.350 & 85.350 & 85.350 & 85.350 \\
\hline Groenbemester na maïs / Green manure following maize & 0 & 0 & 0 & 0 & 0 & 0 & 183.298 & 185.506 & 204.716 & 200.383 \\
\hline
\end{tabular}




\begin{tabular}{|c|c|c|c|c|c|c|c|c|c|c|}
\hline Gewas / Crop & 2010 & 2011 & 2012 & 2013 & 2014 & 2015 & 2016 & 2017 & 2018 & 2019 \\
\hline Wintertarwe / Winter wheat & 134.999 & 113.153 & 136.388 & 124.771 & 122.290 & 127.467 & 117.014 & 108.015 & 96.273 & 112.203 \\
\hline Zomertarwe / Spring wheat & 19.024 & 38.371 & 15.237 & 27.983 & 19.922 & 15.001 & 11.051 & 8.414 & 15.771 & 8.861 \\
\hline Wintergerst / Winter barley & 4.711 & 4.071 & 4.213 & 4.450 & 5.558 & 7.648 & 9.818 & 9.299 & 8.244 & 11.134 \\
\hline Zomergerst / Spring barley & 28.727 & 30.036 & 25.631 & 25.167 & 22.055 & 25.173 & 24.980 & 20.905 & 27.911 & 22.570 \\
\hline Rogge / Rye & 2.343 & 1.650 & 1.934 & 1.820 & 1.720 & 1.628 & 1.612 & 1.496 & 1.599 & 1.875 \\
\hline Haver / Oats & 1.692 & 1.493 & 1.739 & 1.893 & 1.751 & 1.528 & 1.484 & 1.495 & 1.447 & 1.535 \\
\hline Triticale / Triticale & 2.679 & 1.828 & 1.925 & 1.953 & 1.520 & 1.361 & 1.047 & 1.227 & 1.154 & 1.334 \\
\hline Groene erwten en schokkers / Dried and green peas & 493 & 157 & 141 & 231 & 189 & 273 & 201 & 263 & 257 & 313 \\
\hline Erwten / Peas & 3.434 & 3.949 & 3.456 & 3.901 & 3.709 & 3.492 & 3.312 & 3.042 & 3.104 & 3.823 \\
\hline Kapucijners / Marrowfats & 457 & 280 & 391 & 382 & 266 & 343 & 468 & 596 & 511 & 338 \\
\hline Bruine bonen / Kidney beans & 2.006 & 1.335 & 1.595 & 1.796 & 1.829 & 1.574 & 822 & 1.347 & 1.036 & 1.413 \\
\hline Veld- en tuinbonen / Broad and field beans & 564 & 491 & 516 & 355 & 468 & 557 & 620 & 805 & 1.049 & 1.390 \\
\hline Graszaad / Grass seed & 12.680 & 10.548 & 13.668 & 12.309 & 12.014 & 10.789 & 9.974 & 10.084 & 9.483 & 11.310 \\
\hline Koolzaad incl. raapzaad / Oilseed rape incl. rape seed & 2.628 & 2.026 & 2.129 & 3.477 & 3.086 & 2.269 & 1.696 & 1.947 & 2.048 & 1.794 \\
\hline Karwijzaad / Caraway seed & 111 & 129 & 96 & 51 & 22 & 25 & 30 & 14 & 35 & 11 \\
\hline Blauwmaanzaad / Pop seed & 708 & 508 & 370 & 380 & 501 & 774 & 584 & 330 & 545 & 638 \\
\hline Vlas / Flax & 1.896 & 2.156 & 2.077 & 1.881 & 1.983 & 2.405 & 2.415 & 2.564 & 2.232 & 2.291 \\
\hline Pootaardappelen / Seed potatoes & 38.537 & 37.911 & 39.159 & 40.223 & 39.874 & 44.604 & 44.531 & 45.403 & 46.611 & 46.638 \\
\hline Aardappelen/ Potatoes & 73.035 & 72.607 & 67.452 & 71.568 & 74.068 & 71.736 & 73.321 & 76.304 & 76.348 & 78.887 \\
\hline Zetmeelaardappelen / Industrial potatoes & 46.698 & 49.168 & 43.321 & 44.031 & 42.310 & 40.171 & 40.048 & 40.964 & 42.015 & 41.999 \\
\hline Suikerbieten / Sugar beets & 70.584 & 73.329 & 72.724 & 73.194 & 75.094 & 58.436 & 70.722 & 85.352 & 85.196 & 79.176 \\
\hline Voederbieten / Fodder beets & 343 & 262 & 270 & 263 & 279 & 424 & 708 & 1.535 & 1.837 & 2.110 \\
\hline Luzerne / Lucerne & 6.422 & 6.388 & 5.908 & 5.485 & 5.257 & 7.172 & 7.593 & 7.495 & 7.559 & 7.620 \\
\hline Snijmaïs incl. energiemaïs / Green maize incl. energy maize & 230.765 & 229.637 & 231.811 & 230.287 & 226.151 & 224.214 & 206.868 & 205.249 & 205.574 & 187.400 \\
\hline Groenbemestingsgewassen / Green manure crops & 3.594 & 3.246 & 3.614 & 3.869 & 3.703 & 7.321 & 8.411 & 9.513 & 11.417 & 11.073 \\
\hline Korrelmaïs / Grain maize & 17.091 & 16.570 & 15.505 & 15.512 & 12.594 & 11.188 & 9.123 & 8.690 & 9.735 & 12.668 \\
\hline Corn Cob Mix / Corn Cob Mix & 7.265 & 6.128 & 5.813 & 5.927 & 4.930 & 4.615 & 3.930 & 3.589 & 4.511 & 6.632 \\
\hline Cichorei / Chicory & 4.686 & 3.196 & 2.913 & 3.888 & 3.555 & 3.903 & 3.884 & 3.235 & 3.151 & 4.041 \\
\hline Hennep / Hemp & 1.142 & 890 & 1.274 & 1.284 & 1.633 & 2.041 & 2.262 & 2.272 & 2.122 & 1.877 \\
\hline Uien / Onions & 28.866 & 29.842 & 27.235 & 28.616 & 30.199 & 32.157 & 33.431 & 34.917 & 34.849 & 36.889 \\
\hline Overige akkerbouwgewassen / Other horticultural crops & 10.634 & 7.925 & 8.270 & 8.778 & 8.338 & 8.316 & 7.540 & 7.933 & 9.071 & 9.968 \\
\hline Aardbeien / Strawberry & 3.111 & 3.211 & 3.553 & 3.200 & 3.167 & 2.391 & 2.377 & 2.273 & 2.128 & 1.883 \\
\hline Andijvie / Endive & 211 & 239 & 230 & 212 & 207 & 216 & 220 & 217 & 165 & 157 \\
\hline Asperges / Asparagus & 2.695 & 2.922 & 2.893 & 3.123 & 3.316 & 3.566 & 3.795 & 3.807 & 3.855 & 3.684 \\
\hline Augurken / Gherkin & 492 & 478 & 467 & 521 & 605 & 1.018 & 1.053 & 1.176 & 1.095 & 1.235 \\
\hline Bloemkool / Cauliflower & 2.369 & 2.267 & 2.249 & 2.108 & 2.103 & 2.198 & 2.114 & 2.097 & 2.322 & 2.215 \\
\hline Broccoli / Broccoli & 1.966 & 2.080 & 1.803 & 1.701 & 1.554 & 1.678 & 1.790 & 1.884 & 1.962 & 1.741 \\
\hline Sluitkool / Cabbage & 2.753 & 2.775 & 2.617 & 2.755 & 2.727 & 2.593 & 2.798 & 2.891 & 2.499 & 2.611 \\
\hline
\end{tabular}




\begin{tabular}{|c|c|c|c|c|c|c|c|c|c|c|}
\hline Gewas / Crop & 2010 & 2011 & 2012 & 2013 & 2014 & 2015 & 2016 & 2017 & 2018 & 2019 \\
\hline Knolselderij / Celeriac & 1.311 & 1.650 & 1.559 & 1.529 & 1.579 & 1.561 & 1.723 & 1.923 & 1.876 & 1.887 \\
\hline Kroten / Beetroot & 405 & 496 & 468 & 552 & 620 & 650 & 737 & 945 & 863 & 869 \\
\hline Sla /Lettuce & 1.914 & 1.939 & 1.955 & 1.940 & 2.027 & 2.110 & 2.210 & 2.055 & 2.063 & 1.959 \\
\hline Prei / Leeks & 2.843 & 2.748 & 2.426 & 2.682 & 2.593 & 2.200 & 2.167 & 2.279 & 2.000 & 2.126 \\
\hline Schorseneren / Scorzonera & 852 & 844 & 881 & 1.005 & 1.038 & 775 & 460 & 667 & 748 & 695 \\
\hline Spinazie / Spinach & 1.363 & 1.529 & 1.790 & 1.787 & 1.720 & 1.693 & 1.661 & 2.057 & 2.162 & 2.273 \\
\hline Spruitkool / Brussels sprouts & 2.950 & 2.917 & 2.707 & 2.708 & 2.730 & 2.757 & 2.606 & 2.635 & 2.691 & 2.772 \\
\hline Stam(sperzie-)bonen / Industrial French beans & 2.753 & 2.280 & 2.390 & 2.161 & 2.133 & 2.241 & 2.386 & 2.419 & 2.578 & 2.756 \\
\hline Stokbonen / Runner beans & 44 & 52 & 42 & 72 & 55 & 22 & 20 & 34 & 39 & 24 \\
\hline Tuinbonen (groen te oogsten) / Broad beans green & 1.144 & 1.393 & 1.323 & 1.541 & 1.417 & 1.043 & 1.081 & 1.107 & 932 & 995 \\
\hline Was- en bospeen /Carrot & 2.402 & 2.845 & 2.458 & 2.781 & 2.671 & 2.708 & 3.063 & 2.774 & 2.954 & 3.100 \\
\hline Winterpeen / Winter Carrot (Danvers) & 5.568 & 6.101 & 6.176 & 6.142 & 6.126 & 5.959 & 6.644 & 6.479 & 6.184 & 6.879 \\
\hline Witlofwortel / Chicory & 3.016 & 3.272 & 3.357 & 3.345 & 2.961 & 2.950 & 2.898 & 3.211 & 3.093 & 3.095 \\
\hline Overige groenten / Other vegetables & 3.007 & 3.323 & 3.075 & 3.079 & 3.261 & 3.385 & 3.525 & 3.843 & 4.249 & 4.251 \\
\hline $\begin{array}{l}\text { Groenbemester na akkerbouwgewas / Green manure following } \\
\text { arable crop }\end{array}$ & 85.350 & 85.350 & 85.350 & 85.350 & 85.350 & 85.350 & 85.350 & 85.350 & 85.350 & 85.350 \\
\hline Groenbemester na maïs / Green manure following maize & 190.165 & 188.797 & 189.364 & 188.227 & 182.207 & 179.349 & 164.274 & 162.627 & 163.916 & 153.218 \\
\hline
\end{tabular}

Bron: Landbouwtelling / Source: Agricultural census. 


\begin{tabular}{|c|c|c|c|c|}
\hline Gewas / Crop & $\begin{array}{l}\text { Restfractie op het veld / } \\
\text { Field residu fraction }{ }^{1)}\end{array}$ & $\begin{array}{l}\mathrm{N} \text { in bovengrondse } \\
\text { gewasrest / } \mathrm{N} \text { in } \\
\text { crop residu above } \\
\text { ground }(\mathrm{kg} \mathrm{N} / \mathrm{ha})^{2)}\end{array}$ & $\begin{array}{l}\mathrm{N} \text { in ondergrondse } \\
\text { gewasrest / } \mathrm{N} \text { in crop } \\
\text { residu below ground } \\
(\mathrm{kg} \mathrm{N} / \mathrm{ha})^{2)}\end{array}$ & $\begin{array}{c}\mathrm{NH}_{3}-\mathrm{N}(\% \mathrm{~N} \text { in } \\
\text { bovengrondse } \\
\text { gewasrest) / } \mathrm{NH}_{3}-\mathrm{N} \\
\text { (\% } \mathrm{N} \text { in crop residu } \\
\text { above ground) }{ }^{2)}\end{array}$ \\
\hline Wintertarwe / Winter wheat & 0,1 & 35,3 & 23,0 & 0 \\
\hline Zomertarwe / Spring wheat & 0,1 & 28,9 & 23,0 & 0 \\
\hline Wintergerst / Winter barley & 0,1 & 20,7 & 20,0 & 0 \\
\hline Zomergerst / Spring barley & 0,1 & 16,3 & 20,0 & 0 \\
\hline Rogge / Rye & 0,1 & 17,0 & 17,0 & 0 \\
\hline Haver / Oats & 0,1 & 19,0 & 20,0 & 0 \\
\hline Triticale / Triticale & 0,1 & 24,0 & 17,0 & 0 \\
\hline $\begin{array}{l}\text { Groene erwten en schokkers / Drie } \\
\text { and green peas }\end{array}$ & 1 & 25,0 & 13,0 & 4,83 \\
\hline Erwten / Peas & 1 & 127,7 & 13,0 & 1,09 \\
\hline Kapucijners / Marrowfats & 1 & 22,0 & 13,0 & 3,60 \\
\hline Bruine bonen / Kidney beans & 1 & 16,0 & 13,0 & 0 \\
\hline $\begin{array}{l}\text { Veld- en tuinbonen / Broad and fie } \\
\text { beans }\end{array}$ & 1 & 33,0 & 13,0 & 0 \\
\hline Graszaad / Grass seed & 1 & 43,0 & 14,0 & 0 \\
\hline $\begin{array}{l}\text { Koolzaad incl. raapzaad / Oilseed } \\
\text { rape incl. rape seed }\end{array}$ & 1 & 40,0 & 21,0 & 0 \\
\hline Karwijzaad / Caraway seed & 1 & 27,0 & 21,0 & 0 \\
\hline Blauwmaanzaad / Pop seed & 1 & 15,0 & 21,0 & 0,73 \\
\hline Vlas / Flax & 1 & 8,0 & 3,0 & 0 \\
\hline Pootaardappelen / Seed potatoes & 1 & 84,5 & 19,0 & 5,62 \\
\hline Aardappelen / Potatoes & 1 & 28,4 & 19,0 & 0,30 \\
\hline $\begin{array}{l}\text { Zetmeelaardappelen / Industrial } \\
\text { potatoes }\end{array}$ & 1 & 28,4 & 19,0 & 0,30 \\
\hline Suikerbieten / Sugar beets & 1 & 110,0 & 11,0 & 0,72 \\
\hline Voederbieten / Fodder beets & 1 & 123,0 & 11,0 & 2,19 \\
\hline Luzerne / Lucerne & 1 & 23,0 & 67,0 & 7,29 \\
\hline $\begin{array}{l}\text { Snijmaïs incl. energiemaïs / Green } \\
\text { maize incl. energy maize }\end{array}$ & 0,1 & 4,6 & 21,0 & 0 \\
\hline $\begin{array}{l}\text { Groenbemestingsgewassen / Greer } \\
\text { manure crops }\end{array}$ & 1 & 51,5 & 14,0 & 1,52 \\
\hline Korrelmaïs / Grain maize & 1 & 56,5 & 21,0 & 0 \\
\hline Corn Cob Mix / Corn Cob Mix & 1 & 56,5 & 21,0 & 0 \\
\hline Cichorei / Chicory & 1 & 42,7 & 0,0 & 0,31 \\
\hline Hennep / Hemp & 1 & 23,0 & 3,0 & 0,73 \\
\hline Uien / Onions & 1 & 18,5 & 4,0 & 0 \\
\hline $\begin{array}{l}\text { Overige akkerbouwgewassen / Oth } \\
\text { horticultural crops }\end{array}$ & 1 & 40,0 & 13,0 & 0 \\
\hline Aardbeien / Strawberry & 1 & 30,0 & 6,0 & 0 \\
\hline Andijvie / Endive & 1 & 36,9 & 6,0 & 1,60 \\
\hline Asperges / Asparagus & 1 & 23,5 & 6,0 & 0 \\
\hline Augurken / Gherkin & 1 & 78,0 & 6,0 & 2,00 \\
\hline $\begin{array}{l}\text { Bewaarkool / Cabbage for } \\
\text { preservation }\end{array}$ & 1 & 111,0 & 14,0 & 2,71 \\
\hline Bloemkool / Cauliflower & 1 & 132,2 & 14,0 & 5,55 \\
\hline Broccoli / Broccoli & 1 & 155,8 & 14,0 & 5,76 \\
\hline Sluitkool / Cabbage & 1 & 113,1 & 14,0 & 3,49 \\
\hline Knolselderij / Celeriac & 1 & 75,0 & 14,0 & 1,09 \\
\hline Kroten / Beetroot & 1 & 95,0 & 14,0 & 1,24 \\
\hline Sla / Lettuce & 1 & 49,6 & 6,0 & 2,49 \\
\hline
\end{tabular}




\begin{tabular}{|c|c|c|c|c|}
\hline Gewas / Crop & $\begin{array}{l}\text { Restfractie op het veld / } \\
\text { Field residu fraction }{ }^{1} \text { ) }\end{array}$ & $\begin{array}{l}\mathbf{N} \text { in bovengrondse } \\
\text { gewasrest / } \mathbf{N} \text { in } \\
\text { crop residu above } \\
\text { ground (kg } \mathbf{N} / \mathrm{ha})^{2)}\end{array}$ & $\begin{array}{l}\mathbf{N} \text { in ondergrondse } \\
\text { gewasrest / } \mathbf{N} \text { in crop } \\
\text { residu below ground } \\
(\mathrm{kg} \mathrm{N} / \mathrm{ha})^{2)}\end{array}$ & $\begin{array}{c}\mathrm{NH}_{3}-\mathrm{N}(\% \mathrm{~N} \text { in } \\
\text { bovengrondse } \\
\text { gewasrest) } / \mathrm{NH}_{3}-\mathrm{N} \\
(\% \mathrm{~N} \text { in crop residu } \\
\text { above ground) })^{2)}\end{array}$ \\
\hline Prei / Leeks & 1 & 81,8 & 4,0 & 3,55 \\
\hline Schorseneren / Scorzonera & 1 & 46,0 & 14,0 & 0,29 \\
\hline Spinazie / Spinach & 1 & 42,0 & 6,0 & 1,20 \\
\hline Spruitkool / Brussels sprouts & 1 & 167,8 & 14,0 & 3,28 \\
\hline \multicolumn{5}{|l|}{ Stam(sperzie-)bonen / Industrial } \\
\hline French beans & 1 & 77,3 & 13,0 & 1,73 \\
\hline Stokbonen / Runner beans & 1 & 61,0 & 13,0 & 1,76 \\
\hline \multicolumn{5}{|l|}{ Tuinbonen (groen te oogsten) / Broad } \\
\hline Was- en bospeen / Carrot & 1 & 69,7 & 0,0 & 0,44 \\
\hline Winterpeen / Winter Carrot (Danvers) & 1 & 79,0 & 0,0 & 0,45 \\
\hline Witlofwortel / Chicory & 1 & 59,5 & 0,0 & 0,98 \\
\hline Overige groenten / Other vegetables & 1 & 92,9 & 6,0 & 1,18 \\
\hline \multicolumn{5}{|l|}{ Groenbemester na akkerbouwgewas / } \\
\hline Green manure following arable crop & 1 & 51,5 & 14,0 & 1,52 \\
\hline \multicolumn{5}{|l|}{ Groenbemester na maïs / Green } \\
\hline manure following maize & 1 & 19,5 & 5,0 & 2,01 \\
\hline
\end{tabular}

1) Van der Hoek et al. (2007).

2) De Ruijter en/and Huijsmans (2019). Suppl. Info, Table S6. Application of ammonia volatilization regression model for crop residues in the Netherlands. 


\section{Bijlage 23 Uitgangspunten voor N-verliezen van grasland}

B23.1

Uitgangspunten voor $\mathrm{N}$-verliezen van grasland / Starting points for $\mathrm{N}$ losses from grassland.

\begin{tabular}{|c|c|c|c|c|c|c|c|c|c|c|}
\hline & 1990 & 1991 & 1992 & 1993 & 1994 & 1995 & 1996 & 1997 & 1998 & 1999 \\
\hline \multicolumn{11}{|l|}{ Herinzaai / Renovation: } \\
\hline Blijvend grasland (ha) / Permanent grassland (ha) & 1.061 .615 & 1.044 .214 & 1.029 .596 & 1.029 .619 & 1.012 .060 & 1.010 .671 & 989.465 & 958.146 & 951.889 & 926.213 \\
\hline $\begin{array}{l}\text { Omploegfactor ( } \% \text { van blijvend grasland) / Ploughing factor } \\
\text { (\% of permanent grassland) }\end{array}$ & 5,7 & 5,3 & 4,8 & 4,4 & 4,9 & 5,4 & 6,0 & 6,4 & 6,8 & 7,2 \\
\hline Doorzaai (ha) / Sod seeding (ha) & 14.000 & 13.667 & 13.333 & 13.000 & 25.333 & 37.667 & 50.000 & 36.333 & 22.667 & 9.000 \\
\hline Omzetting in bouwland (ha) / Change into arable land (ha) & 52.000 & 45.000 & 38.000 & 31.000 & 35.333 & 39.667 & 44.000 & 47.667 & 51.333 & 55.000 \\
\hline $\begin{array}{l}\text { Doodspuiten bij herinzaai en doorzaai (\%) / Spray at renovation } \\
\text { and sod seeding (\%) }\end{array}$ & 90 & 90 & 90 & 90 & 90 & 90 & 90 & 90 & 90 & 90 \\
\hline $\begin{array}{l}\text { Doodspuiten bij omzetting in bouwland (\%) / Spray at change } \\
\text { into arable land (\%) }\end{array}$ & 50 & 50 & 50 & 50 & 50 & 50 & 50 & 50 & 50 & 50 \\
\hline Maaien $(\text { ha })^{1)} /$ Mowing $(\text { ha })^{1)}$ & 1.857 .000 & 1.760 .000 & 1.865 .000 & 1.960 .000 & 1.860 .000 & 1.891 .000 & 1.789 .000 & 1.960 .000 & 1.926 .000 & 1.928 .000 \\
\hline $\begin{array}{l}\mathrm{N} \text {-gehalte vers gras ( } \mathrm{g} \mathrm{N} / \mathrm{kg} \mathrm{DS}) / \mathrm{N} \text {-content fresh grass ( } \mathrm{g} \mathrm{N} / \mathrm{kg} \\
\mathrm{DM} \text { ) }\end{array}$ & 42,9 & 42,1 & 40,3 & 41,1 & 41,4 & 41,3 & 44,5 & 42,8 & 41,6 & 36,0 \\
\hline $\begin{array}{l}\mathrm{N} \text {-gehalte gras bij omzetten in bouwland (g N/kg DS) / N- } \\
\text { content grass at changing into arable land (g N/kg DM) }\end{array}$ & 34,3 & 33,7 & 32,2 & 32,9 & 33,1 & 33,0 & 35,6 & 34,2 & 33,3 & 28,8 \\
\hline $\begin{array}{l}\mathrm{N} \text {-inhoud maaiverliezen }(\mathrm{kg} \mathrm{N} / \mathrm{ha}) / \mathrm{N} \text { content mowing losses } \\
(\mathrm{kg} \mathrm{N} / \mathrm{ha})\end{array}$ & 8,6 & 8,4 & 8,1 & 8,2 & 8,3 & 8,3 & 8,9 & 8,6 & 8,3 & 7,2 \\
\hline $\mathrm{N}$-inhoud doodspuiten ( $\mathrm{kg} \mathrm{N} / \mathrm{ha}$ ) / N content spray ( $\mathrm{kg} \mathrm{N} / \mathrm{ha}$ ) & 103 & 101 & 97 & 99 & 99 & 99 & 107 & 103 & 100 & 86 \\
\hline $\begin{array}{l}\mathrm{NH}_{3}-\mathrm{N} \text { emissiefactor maaiverliezen (\%) / } \mathrm{NH}_{3}-\mathrm{N} \text { emission factor } \\
\text { mowing losses (\%) }\end{array}$ & 12,2 & 11,8 & 11,1 & 11,4 & 11,6 & 11,5 & 12,8 & 12,1 & 11,6 & 9,3 \\
\hline $\begin{array}{l}\mathrm{NH}_{3}-\mathrm{N} \text { emissiefactor doodspuiten (\%) / } \mathrm{NH}_{3}-\mathrm{N} \text { emission factor } \\
\text { spray (\%) }\end{array}$ & 8,7 & 8,4 & 7,8 & 8,1 & 8,2 & 8,1 & 9,2 & 8,6 & 8,2 & 6,4 \\
\hline $\begin{array}{l}\mathrm{N}_{2} \mathrm{O}-\mathrm{N} \text { emissiefactor voor herinzaai }\left(\mathrm{kg} \mathrm{N} \mathrm{N}_{2} \mathrm{O}-\mathrm{N} / \mathrm{ha}\right) / \mathrm{N}_{2} \mathrm{O}-\mathrm{N} \\
\text { emission factor for renovation }\left(\mathrm{kg} \mathrm{N}_{2} \mathrm{O}-\mathrm{N} / \mathrm{ha}\right)\end{array}$ & 5,5 & 5,5 & 5,5 & 5,5 & 5,5 & 5,5 & 5,5 & 5,5 & 5,5 & 5,5 \\
\hline
\end{tabular}




\begin{tabular}{|c|c|c|c|c|c|c|c|c|c|c|}
\hline & 2000 & 2001 & 2002 & 2003 & 2004 & 2005 & 2006 & 2007 & 2008 & 2009 \\
\hline \multicolumn{11}{|l|}{ Herinzaai / Renovation: } \\
\hline Blijvend grasland (ha) / Permanent grassland (ha) & 900.017 & 875.147 & 888.150 & 785.800 & 756.687 & 770.584 & 794.654 & 794.297 & 791.558 & 784.823 \\
\hline $\begin{array}{l}\text { Omploegfactor (\% van blijvend grasland) / Ploughing factor } \\
\text { ( } \% \text { of permanent grassland) }\end{array}$ & 6,6 & 6,0 & 5,4 & 5,1 & 4,7 & 4,4 & 2,9 & 1,5 & 1,8 & 1,9 \\
\hline Doorzaai (ha) / Sod seeding (ha) & 7.667 & 6.333 & 5.000 & 5.333 & 5.667 & 6.000 & 6.000 & 6.000 & 6.000 & 6.000 \\
\hline Omzetting in bouwland (ha) / Change into arable land (ha) & 52.000 & 49.000 & 46.000 & 46.000 & 46.000 & 46.000 & 46.000 & 46.000 & 46.000 & 46.000 \\
\hline $\begin{array}{l}\text { Doodspuiten bij herinzaai en doorzaai (\%) / Spray at renovation } \\
\text { and sod seeding (\%) }\end{array}$ & 90 & 90 & 90 & 90 & 90 & 90 & 90 & 90 & 90 & 90 \\
\hline $\begin{array}{l}\text { Doodspuiten bij omzetting in bouwland (\%) / Spray at change } \\
\text { into arable land (\%) }\end{array}$ & 50 & 50 & 50 & 50 & 50 & 50 & 50 & 50 & 50 & 50 \\
\hline Maaien $\left.(\text { ha })^{1}\right) /$ Mowing $(h a)^{1)}$ & 1.943 .000 & 1.866 .000 & 1.979 .000 & 1.778 .000 & 1.958 .000 & 1.965 .000 & 2.613 .000 & 2.485 .932 & 2.358 .000 & 2.359 .000 \\
\hline $\begin{array}{l}\mathrm{N} \text {-gehalte vers gras ( } \mathrm{g} \mathrm{N} / \mathrm{kg} \mathrm{DS}) / \mathrm{N} \text {-content fresh grass }(\mathrm{g} \mathrm{N} / \mathrm{kg} \\
\mathrm{DM})\end{array}$ & 37,1 & 36,6 & 36,2 & 36,0 & 33,0 & 33,3 & 32,0 & 30,6 & 32,3 & 31,4 \\
\hline $\begin{array}{l}\mathrm{N} \text {-gehalte gras bij omzetten in bouwland (g N/kg DS) / N- } \\
\text { content grass at changing into arable land (g N/kg DM) }\end{array}$ & 29,7 & 29,3 & 29,0 & 28,8 & 26,4 & 26,6 & 25,6 & 24,5 & 25,8 & 25,1 \\
\hline $\begin{array}{l}\mathrm{N} \text {-inhoud maaiverliezen }(\mathrm{kg} \mathrm{N} / \mathrm{ha}) / \mathrm{N} \text { content mowing losses } \\
(\mathrm{kg} \mathrm{N} / \mathrm{ha})\end{array}$ & 7,4 & 7,3 & 7,2 & 7,2 & 6,6 & 6,7 & 6,4 & 6,1 & 6,5 & 6,3 \\
\hline N-inhoud doodspuiten (kg N/ha) / N content spray (kg N/ha) & 89 & 88 & 87 & 86 & 79 & 80 & 77 & 73 & 78 & 75 \\
\hline $\begin{array}{l}\mathrm{NH}_{3}-\mathrm{N} \text { emissiefactor maaiverliezen }(\%)^{2)} / \mathrm{NH}_{3}-\mathrm{N} \text { emission factor } \\
\text { mowing losses }(\%)^{2)}\end{array}$ & 9,8 & 9,6 & 9,4 & 9,3 & 8,1 & 8,2 & 7,7 & 7,1 & 7,8 & 7,5 \\
\hline $\begin{array}{l}\mathrm{NH}_{3}-\mathrm{N} \text { emissiefactor doodspuiten (\%) / } \mathrm{NH}_{3}-\mathrm{N} \text { emission factor } \\
\text { spray (\%) }\end{array}$ & 6,7 & 6,6 & 6,5 & 6,4 & 5,4 & 5,5 & 5,1 & 4,6 & 5,2 & 4,9 \\
\hline $\begin{array}{l}\mathrm{N}_{2} \mathrm{O}-\mathrm{N} \text { emissiefactor voor herinzaai }\left(\mathrm{kg} \mathrm{N} \mathrm{N}_{2} \mathrm{O}-\mathrm{N} / \mathrm{ha}\right) / \mathrm{N}_{2} \mathrm{O}-\mathrm{N} \\
\text { emission factor for renovation }\left(\mathrm{kg} \mathrm{N} \mathrm{N}_{2} \mathrm{O}-\mathrm{N} / \mathrm{ha}\right)\end{array}$ & 5,5 & 5,5 & 5,5 & 5,5 & 5,5 & 5,5 & 5,5 & 5,5 & 5,5 & 5,5 \\
\hline
\end{tabular}




\begin{tabular}{|c|c|c|c|c|c|c|c|c|c|c|}
\hline & 2010 & 2011 & 2012 & 2013 & 2014 & 2015 & 2016 & 2017 & 2018 & 2019 \\
\hline \multicolumn{11}{|l|}{ Herinzaai / Renovation: } \\
\hline Blijvend grasland (ha) / Permanent grassland (ha) & 768.746 & 766.389 & 746.170 & 722.089 & 705.817 & 714.337 & 691.216 & 680.252 & 683.741 & 690.917 \\
\hline $\begin{array}{l}\text { Omploegfactor ( } \% \text { van blijvend grasland) / Ploughing factor } \\
\text { (\% of permanent grassland) }\end{array}$ & 2,4 & 2,9 & 3,1 & 1,3 & 2,1 & 1,6 & 1,0 & 2,2 & 2,1 & 1,6 \\
\hline Doorzaai (ha) / Sod seeding (ha) & 6.000 & 6.000 & 6.000 & 6.000 & 6.000 & 6.000 & 6.000 & 6.000 & 6.000 & 6.000 \\
\hline Omzetting in bouwland (ha) / Change into arable land (ha) & 46.000 & 46.000 & 46.000 & 46.000 & 46.000 & 46.000 & 46.000 & 46.000 & 46.000 & 46.000 \\
\hline $\begin{array}{l}\text { Doodspuiten bij herinzaai en doorzaai (\%) / Spray at renovation } \\
\text { and sod seeding (\%) }\end{array}$ & 90 & 90 & 90 & 90 & 90 & 90 & 90 & 90 & 90 & 90 \\
\hline $\begin{array}{l}\text { Doodspuiten bij omzetting in bouwland (\%) / Spray at change } \\
\text { into arable land (\%) }\end{array}$ & 50 & 50 & 50 & 50 & 50 & 50 & 50 & 50 & 50 & 50 \\
\hline Maaien $(\mathrm{ha})^{1)} /$ Mowing $(\mathrm{ha})^{1)}$ & 2.423 .000 & 2.617 .000 & 2.436 .000 & 2.482 .000 & 2.760 .000 & 2.714 .000 & 2.671 .000 & 2.645 .000 & 2.499 .000 & 2.557 .000 \\
\hline $\begin{array}{l}\mathrm{N} \text {-gehalte vers gras ( } \mathrm{g} \mathrm{N} / \mathrm{kg} \mathrm{DS}) / \mathrm{N} \text {-content fresh grass ( } \mathrm{g} \mathrm{N} / \mathrm{kg} \\
\mathrm{DM} \text { ) }\end{array}$ & 32,2 & 29,8 & 29,1 & 30,7 & 29,7 & 27,5 & 29,0 & 31,2 & 31,2 & 32,2 \\
\hline $\begin{array}{l}\mathrm{N} \text {-gehalte gras bij omzetten in bouwland (g N/kg DS) / N- } \\
\text { content grass at changing into arable land ( } \mathrm{g} \mathrm{N} / \mathrm{kg} \mathrm{DM})\end{array}$ & 25,8 & 23,8 & 23,3 & 24,6 & 23,8 & 22,0 & 23,2 & 25,0 & 24,9 & 25,7 \\
\hline $\begin{array}{l}\mathrm{N} \text {-inhoud maaiverliezen ( } \mathrm{kg} \mathrm{N} / \mathrm{ha} \text { ) / } \mathrm{N} \text { content mowing losses }(\mathrm{kg} \\
\mathrm{N} / \mathrm{ha} \text { ) }\end{array}$ & 6,4 & 6,0 & 5,8 & 6,1 & 5,9 & 5,5 & 5,8 & 6,2 & 6,2 & 6,4 \\
\hline $\mathrm{N}$-inhoud doodspuiten ( $\mathrm{kg} \mathrm{N} / \mathrm{ha}$ ) / N content spray ( $\mathrm{kg} \mathrm{N} / \mathrm{ha}$ ) & 77 & 71 & 70 & 74 & 71 & 66 & 70 & 75 & 75 & 77 \\
\hline $\begin{array}{l}\mathrm{NH}_{3}-\mathrm{N} \text { emissiefactor maaiverliezen }(\%)^{2)} / \mathrm{NH}_{3}-\mathrm{N} \text { emission factor } \\
\text { mowing losses }(\%)^{2)}\end{array}$ & 7,8 & 6,8 & 6,5 & 7,2 & 6,8 & 5,9 & 6,5 & 7,4 & 7,4 & 7,8 \\
\hline $\begin{array}{l}\mathrm{NH}_{3}-\mathrm{N} \text { emissiefactor doodspuiten }(\%)^{2)} / \mathrm{NH}_{3}-\mathrm{N} \text { emission factor } \\
\text { spray }(\%)^{2)}\end{array}$ & 5,1 & 4,3 & 4,1 & 4,7 & 4,3 & 3,6 & 4,1 & 4,8 & 4,8 & 5,1 \\
\hline $\begin{array}{l}\mathrm{N}_{2} \mathrm{O}-\mathrm{N} \text { emissiefactor voor herinzaai }\left(\mathrm{kg} \mathrm{N} \mathrm{N}_{2} \mathrm{O}-\mathrm{N} / \mathrm{ha}\right) / \mathrm{N}_{2} \mathrm{O}-\mathrm{N} \\
\text { emission factor for renovation }\left(\mathrm{kg} \mathrm{N} \mathrm{N}_{2} \mathrm{O}-\mathrm{N} / \mathrm{ha}\right)\end{array}$ & 5,5 & 5,5 & 5,5 & 5,5 & 5,5 & 5,5 & 5,5 & 5,5 & 5,5 & 5,5 \\
\hline
\end{tabular}

1) Areaal vermenigvuldigd met maaifrequentie / Area multiplied by mowing frequency.

2) De Ruijter en/and Huijsmans (2019). Suppl Info, Table S6. Application of ammonia volatilization regression model for crop residues in the Netherlands.

Bronnen / Sources: Wageningen Economic Research, Wageningen Plant Research en/and Landbouwtelling (Agricultural census). 



\section{Bijlage 24 Organische bodems}

B24.1

Arealen organische bodems (ha) / Area organic soils (ha).

\begin{tabular}{|c|c|c|c|c|c|c|c|c|c|c|c|c|c|}
\hline & 1990 & 1991 & 1992 & 1993 & 1994 & 1995 & 1996 & 1997 & 1998 & 1999 & 2000 & 2001 & 2002 \\
\hline \multicolumn{14}{|l|}{ Veengrond / Peat soil } \\
\hline grasland / grassland & 218.058 & 216.507 & 214.964 & 213.429 & 211.901 & 210.382 & 208.870 & 207.367 & 205.871 & 204.383 & 202.903 & 201.431 & 199.966 \\
\hline bouwland / arable land & 44.196 & 43.209 & 42.227 & 41.250 & 40.278 & 39.311 & 38.350 & 37.393 & 36.441 & 35.495 & 34.553 & 33.617 & 32.685 \\
\hline totaal / total & 262.254 & 259.716 & 257.191 & 254.679 & 252.180 & 249.693 & 247.220 & 244.760 & 242.312 & 239.878 & 237.456 & 235.048 & 232.652 \\
\hline \multicolumn{14}{|c|}{ Moerige grond / Peat-like soil } \\
\hline grasland / grassland & 93.677 & 93.118 & 92.562 & 92.008 & 91.456 & 90.907 & 90.360 & 89.816 & 89.274 & 88.734 & 88.196 & 87.661 & 87.129 \\
\hline bouwland / arable land & 63.022 & 62.247 & 61.478 & 60.713 & 59.954 & 59.201 & 58.452 & 57.709 & 56.970 & 56.237 & 55.510 & 54.787 & 54.070 \\
\hline totaal / total & 156.699 & 155.365 & 154.040 & 152.721 & 151.411 & 150.108 & 148.812 & 147.524 & 146.244 & 144.971 & 143.706 & 142.449 & 141.199 \\
\hline Totaal / Total & 418.953 & 415.081 & 411.230 & 407.400 & 403.590 & 399.801 & 396.032 & 392.284 & 388.556 & 384.849 & 381.162 & 377.496 & 373.850 \\
\hline
\end{tabular}

\begin{tabular}{|c|c|c|c|c|c|c|c|c|c|c|c|c|c|}
\hline & 2003 & 2004 & 2005 & 2006 & 2007 & 2008 & 2009 & 2010 & 2011 & 2012 & 2013 & 2014 & 2015 \\
\hline \multicolumn{14}{|l|}{ Veengrond / Peat soil } \\
\hline grasland / grassland & 198.510 & 196.969 & 195.436 & 193.909 & 192.390 & 190.878 & 189.914 & 188.958 & 188.010 & 187.071 & 186.602 & 186.110 & 185.201 \\
\hline bouwland / arable land & 31.759 & 31.326 & 30.896 & 30.469 & 30.046 & 29.627 & 28.783 & 27.938 & 27.090 & 26.241 & 24.754 & 23.291 & 22.313 \\
\hline totaal / total & 230.269 & 228.295 & 226.331 & 224.378 & 222.436 & 220.505 & 218.697 & 216.895 & 215.100 & 213.312 & 211.356 & 209.401 & 207.514 \\
\hline \multicolumn{14}{|c|}{ Moerige grond / Peat-like soil } \\
\hline grasland / grassland & 86.599 & 86.043 & 85.488 & 84.932 & 84.377 & 83.822 & 83.208 & 82.592 & 81.975 & 81.356 & 82.029 & 82.690 & 83.385 \\
\hline bouwland / arable land & 53.358 & 52.912 & 52.473 & 52.039 & 51.611 & 51.189 & 50.814 & 50.445 & 50.082 & 49.725 & 48.377 & 47.039 & 45.606 \\
\hline totaal / total & 139.956 & 138.955 & 137.960 & 136.971 & 135.988 & 135.012 & 134.022 & 133.037 & 132.057 & 131.081 & 130.406 & 129.729 & 128.991 \\
\hline Totaal / Total & 370.225 & 367.250 & 364.292 & 361.350 & 358.425 & 355.517 & 352.719 & 349.933 & 347.158 & 344.393 & 341.761 & 339.130 & 336.504 \\
\hline
\end{tabular}




\section{B24.1}

vervolg / continuation

\begin{tabular}{|l|r|r|r|r|}
\hline Veengrond / Peat soil & 2016 & 2017 & 2018 & 2019 \\
\hline grasland / grassland & 184.290 & 183.365 & 182.438 & 181.509 \\
\hline bouwland / arable land & 21.344 & 20.379 & 19.424 & 18.479 \\
\hline totaal / total & 205.634 & 203.744 & 201.862 & 199.988 \\
\hline Moerige grond / Peat-like soil & & & & \\
\hline grasland / grassland & 84.058 & 84.700 & 85.320 & 85.919 \\
\hline bouwland / arable land & 44.189 & 42.776 & 41.380 & 40.001 \\
\hline totaal / total & 128.247 & 127.476 & 126.700 & 125.920 \\
\hline Totaal / Total & 333.881 & 331.220 & 328.562 & 325.908 \\
\hline
\end{tabular}

Bron / Source: Wageningen Environmental Research. 


\title{
Bijlage 25 Verteerbaarheid van ruw eiwit en organische stof (OS) voor berekening van de TAN-excretie en OS-excretie in 2019
}

\author{
Auteurs: Paul Bikker, Gerrit Remmelink, Marinus van Krimpen (Wageningen Livestock \\ Research)
}

Ruw eiwit

De ammoniakemissie vanuit de veehouderij wordt berekend op basis van de excretie van totaal ammoniakaal stikstof (TAN) in de mest. Met behulp van de TAN-excretie kan een betere inschatting gemaakt worden van de emissie dan op basis van totaal stikstof in de mest omdat hierbij rekening gehouden wordt met de verdeling van uitgescheiden stikstof $(\mathrm{N})$ over de urine en feces. De TAN-excretie wordt berekend uit de opname aan verteerbaar ruw eiwit (VRE) en de retentie van eiwit in dierlijk product. De VRE wordt bepaald uit het ruw eiwit (RE, N×6.25) gehalte van het voer en de fecale verteerbaarheid van het RE (VCRE). Op dit moment zijn geen representatieve gegevens van de samenstelling en fecale eiwitverteerbaarheid van in de praktijk gebruikte voeders beschikbaar. Daarom zijn met behulp van lineaire programmering met gepubliceerde en in de praktijk gebruikte randvoorwaarden van voeders en prijzen van grondstoffen voeders geoptimaliseerd voor de door het Centraal Bureau voor de Statistiek (CBS) gehanteerde diercategorieën. Aansluitend is de VCRE van de voeders berekend. De resultaten zijn samengevat in onderstaande tabel B25.1 en B25.2. De vleesveevoeders in tabel B25.2 kunnen gebruikt worden om door interpolatie zowel voor de voeders voor rosékalveren als voor vleesstieren de VCRE bij de in tabel B25.1 vermelde N-gehalten te schatten.

Tabel B25.1 Door CBS gespecificeerde diercategorieën, verbruik van mengvoer (kton) en stikstofgehalte $(\mathrm{g} / \mathrm{kg}$ ) en daarbij berekende fecale verteerbaarheid (VCRE, \%) van het ruw eiwit / Animal categories specified by Statistics Netherlands, use of compound feed (kton) and nitrogen content $(\mathrm{g} / \mathrm{kg}$ ) and thereby calculated fecal digestibility (DCRP, \%) of the raw protein.

\begin{tabular}{|c|c|c|c|}
\hline \multirow[t]{4}{*}{ Diercategorieën / Animal categories } & 2019 & 2019 & Berekende \\
\hline & & & $\operatorname{VCRE}(\%) /$ \\
\hline & & & Calculated \\
\hline & (kton) & $N(\mathrm{~g} / \mathrm{kg})$ & DCRP $(\%)$ \\
\hline Standaardvoer melkvee (90-115 DVE ${ }^{1}$ ) / Standard feed dairy cattle (90-115 IDP ${ }^{1}$ ) & 2108 & 24,9 & Tab. B25.2 \\
\hline Eiwitrijk voer melkvee (120 DVE en meer) / High protein feed dairy cattle (120 IDP & & & Tab. B25.2 \\
\hline and over) & 1365 & 34,6 & \\
\hline Rosévleeskalvervoer - opfokvoer / Rosé veal calves feed - start feed & 43 & 32,5 & Tab. B25.2 \\
\hline Rosévleeskalvervoer - afmestvoer / Rosé veal calves feed - fattening feed & 334 & 25,6 & Tab. B25.2 \\
\hline Vleesstierenvoer - opfokvoer (130 DVE en meer) / Beef bull feed - start feed (130 & & & Tab. B25.2 \\
\hline IDP and over) & 58 & 37,6 & \\
\hline Vleesstierenvoer - afmestvoer (90-110 DVE) / Beef bull feed - fattening feed (90- & & & Tab. B25.2 \\
\hline 110 IDP) & 20 & 25,6 & \\
\hline Vleesvarkens / Fattening pigs & 3871 & 24,6 & 79,1 \\
\hline Opfokzeugen en opfokberen / Gilts and young boars & 174 & 24,4 & 78,3 \\
\hline Fokzeugen, incl. biggen tot $25 \mathrm{~kg}$ / Sows, incl. piglets to $25 \mathrm{~kg}$ & 1800 & 24,1 & 77,8 \\
\hline Dekberen / Breeding boars & 6 & 23,4 & 75,0 \\
\hline Leghennen tot ca. 18 weken / Laying hens to ca. 18 weeks & 177 & 27,3 & 83,0 \\
\hline Leghennen van ca. 18 weken en ouder / Laying hens of ca. 18 weeks and older & 1520 & 26,1 & 83,3 \\
\hline Ouderdieren van vleeskuikens tot ca. 18 weken / Broiler parents to ca. 18 weeks & 56 & 25,2 & 81,8 \\
\hline
\end{tabular}




\begin{tabular}{|c|c|c|c|}
\hline \multirow[t]{4}{*}{ Diercategorieën / Animal categories } & 2019 & 2019 & Berekende \\
\hline & & & $\operatorname{VCRE}(\%) /$ \\
\hline & & & Calculated \\
\hline & (kton) & $N(g / k g)$ & DCRP $(\%)$ \\
\hline Ouderdieren van vleeskuikens van ca. 18 weken en ouder / Broiler parents of ca. & & & 83,2 \\
\hline 18 weeks and older & 272 & 22,8 & \\
\hline Vleeskuikens / Broilers & 1439 & 29,0 & 84,2 \\
\hline Vleeseenden / Ducks for slaughter & 51 & 25,8 & 84,6 \\
\hline Vleeskalkoenen / Turkeys for slaughter & 57 & 28,7 & 86,8 \\
\hline
\end{tabular}

${ }^{1} \mathrm{DVE}=$ darmverteerbaar eiwit $/{ }^{1} \mathrm{IDP}=$ intestinal digestible protein

Tabel B25.2 N-gehalte $(\mathrm{g} / \mathrm{kg})$ en VCRE (\%) in melkvee- en vleesveevoeders met oplopend DVE-gehalte, gemiddeld in $2019^{1)} / \mathrm{N}$ contents $(\mathrm{g} / \mathrm{kg}$ ) and DCRP (\%) in dairy and beef cattle feeds with ascending IDP content, average in 20191).

\begin{tabular}{|c|c|c|c|c|c|}
\hline & $\begin{array}{c}90 \text { DVE / } 90 \\
\text { IDP }\end{array}$ & $\begin{array}{c}105 \text { DVE / } 105 \\
\text { IDP }\end{array}$ & $\begin{array}{c}120 \text { DVE / } 120 \\
\text { IDP }\end{array}$ & $\begin{array}{c}150 \text { DVE / } 150 \\
\text { IDP }\end{array}$ & $\begin{array}{c}180 \text { DVE / } 180 \\
\text { IDP }\end{array}$ \\
\hline $\mathrm{N}, \mathrm{g} / \mathrm{kg}$ & 21,8 & 26,4 & 30,3 & 37,9 & 45,7 \\
\hline \multirow[t]{2}{*}{ VCRE / DCRP } & 74,0 & 78,1 & 80,5 & 83,8 & 86,4 \\
\hline & $\begin{array}{l}\text { Stier } 90 \text { DVE } \\
\text { / Bull } 90 \text { IDP }\end{array}$ & $\begin{array}{l}\text { Stier } 100 \text { DVE } \\
\text { / Bull } 100 \text { IDP }\end{array}$ & $\begin{array}{l}\text { Rosé } 110 \text { DVE } \\
\text { / Rosé } 110 \\
\text { IDP }\end{array}$ & $\begin{array}{c}\text { Rosé } 120 \text { DVE } \\
\text { / Rosé } 120 \\
\text { IDP }\end{array}$ & $\begin{array}{c}\text { Rosé } 130 \text { DVE } \\
\text { / Rosé } 130 \\
\text { IDP }\end{array}$ \\
\hline $\mathrm{N}, \mathrm{g} / \mathrm{kg}$ & 25,5 & 27,9 & 30,2 & 32,6 & 34,9 \\
\hline VCRE / DCRP & 77,7 & 79,1 & 80,5 & 81,7 & 82,6 \\
\hline
\end{tabular}

1) Daarnaast is er opfok- en afmestvoeder met 1.050 VEVI i.p.v. 1.000 VEVI wat is bestemd voor zowel stieren als rosé kalveren. Opfok 110 DVE had in 2019 een VCRE van gemiddeld 78,9\% en een N-gehalte van 27,4 g/kg. Afmest 100 DVE had in 2019 een VCRE van gemiddeld $79,4 \%$ en een $\mathrm{N}$-gehalte van $27,5 \mathrm{~g} / \mathrm{kg} /{ }^{1}$ ) Besides there is start and fattening feed with 1.050 VEVI (feed unit beef cattle intensive) instead of 1.000 VEVI which is meant for both bulls and rosé veal calves. Rearing 110 IDP in 2019 had a DCRP of $78.9 \%$ on average and a $\mathrm{N}$ content of $27.4 \mathrm{~g} / \mathrm{kg}$. Fattening $100 \mathrm{IDP}$ in 2019 had a DCRP of $79.4 \%$ on average and a $\mathrm{N}$ content of $27.5 \mathrm{~g} / \mathrm{kg}$.

Organische stof

Vanaf 2018 wordt van de geoptimaliseerde voeders tevens het gehalte en de verteerbaarheid van de organische stof (OS) berekend om de OS-excretie in mest en urine te kunnen berekenen. Hiervoor wordt gebruik gemaakt van het OS-gehalte in voedermiddelen en de verteerbaarheid hiervan bij rundvee en varkens zoals weergegeven in de CVB Veevoedertabel. Bij pluimvee wordt de verteerbare OS (VOS) berekend als som van de verteerbare ruw eiwit, ruw vet en overige koolhydraten. Met behulp van het OS-gehalte van het rantsoen en de VCOS kan de excretie van onverteerbare OS in de feces berekend worden als: voeropname $\times$ oS-gehalte $\times(100-\mathrm{VCOS})$.

De OS-excretie in de urine wordt gebaseerd op de $\mathrm{N}$-excretie (TAN) in de urine. Bij rundvee en varkens betreft dit hoofdzakelijk ureum $\left(\mathrm{CH}_{4} \mathrm{~N}_{2} \mathrm{O}\right)$ en wordt de OS berekend als 60/28 maal de $\mathrm{N}$-excretie (in g). Bij pluimvee betreft dit hoofdzakelijk urinezuur $\left(\mathrm{C}_{5} \mathrm{H}_{4} \mathrm{~N}_{4} \mathrm{O}_{3}\right)$ en wordt de OS berekend als 168/56 maal de $\mathrm{N}$-excretie (in g), gebaseerd op het $\mathrm{N}$-gewicht per mol ureum dan wel urinezuur.

De resultaten voor OS-gehalte en VCOS zijn samengevat in onderstaande tabellen B25.3 en B25.4. De vleesveevoeders in tabel B25.4 kunnen gebruikt worden om door interpolatie zowel voor de voeders voor rosékalveren als voor vleesstieren de VCOS bij de in tabel B25.1 en B25.2 vermelde N-gehalten te schatten. 
Tabel B25.3 Door CBS gespecificeerde diercategorieën en verbruik mengvoer (kton) en daarbij berekend gehalte en verteerbaarheid (VCOS, \%) van de organische stof (OS) in 2019 / Animal categories specified by Statistics Netherlands and use of compound feed (kton) and thereby calculated content and digestibility (DCOM, \%) of the organic matter (OM) in 2019.

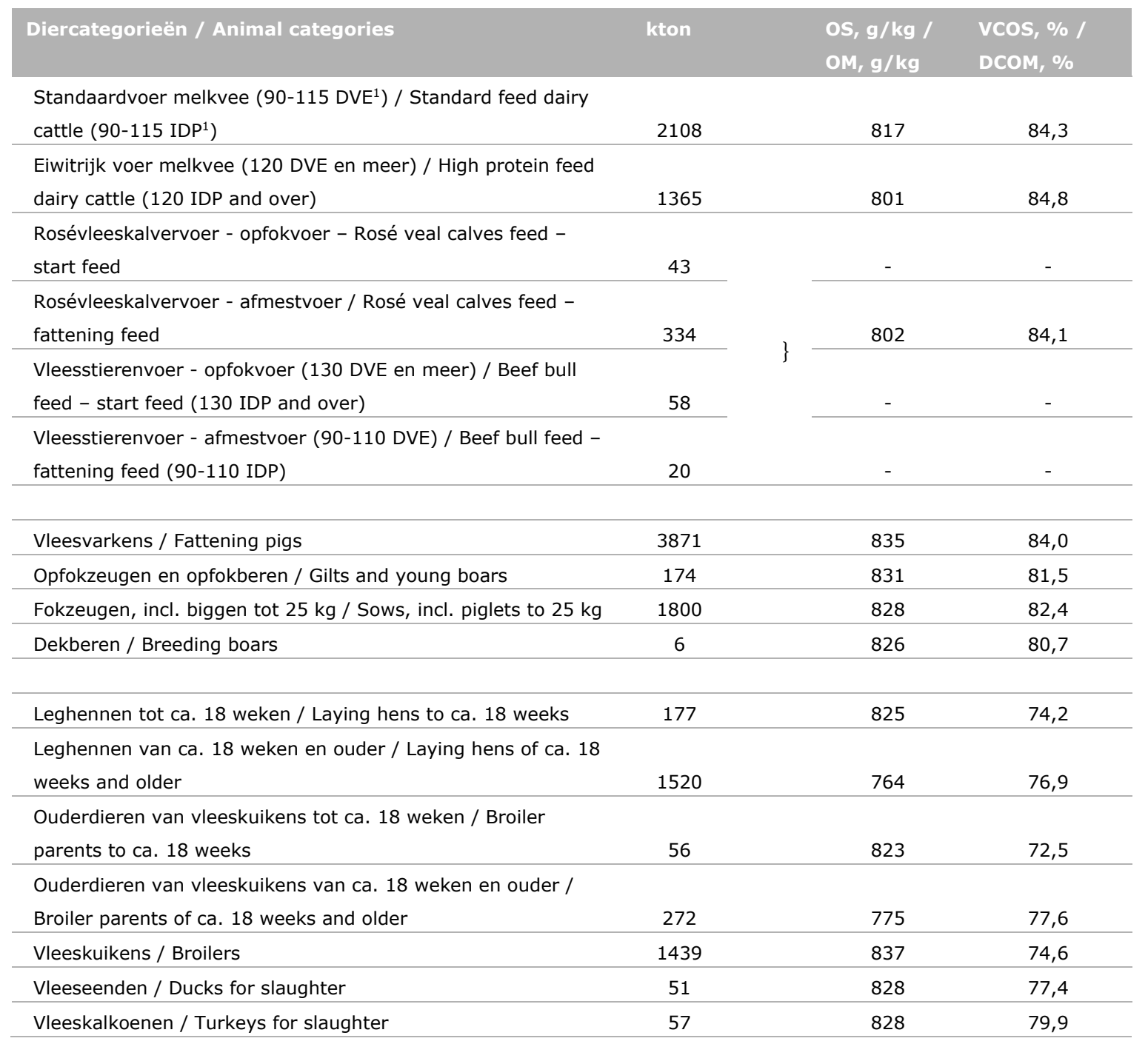

1) DVE = darmverteerbaar eiwit $/{ }^{1)}$ IDP = intestinal digestible protein

Tabel B25.4 Organische stof (OS) gehalte $(\mathrm{g} / \mathrm{kg})$ en berekende verteringscoëfficiënt (VCOS, \%) in melkvee- en vleesveevoeders met oplopend DVE-gehalte, gemiddeld in 20191) / Organic matter (OM) content $(\mathrm{g} / \mathrm{kg}$ ) and calculated digestion coefficient (DCOM, \%) in dairy and beef cattle feeds with ascending IDP content, average in 20191).

\begin{tabular}{|c|c|c|c|c|c|}
\hline & 90 DVE / 90 & 105 DVE / 105 & 120 DVE / 120 & 150 DVE / 150 & 180 DVE / 180 \\
\hline & IDP & IDP & IDP & IDP & IDP \\
\hline OS / OM & 819 & 815 & 811 & 803 & 790 \\
\hline \multirow[t]{2}{*}{ VCOS / DCOM } & 84,3 & 84,3 & 83,9 & 84,9 & 85,5 \\
\hline & $\begin{array}{l}\text { Stier } 90 \text { DVE } \\
\text { / Bull } 90 \text { IDP }\end{array}$ & $\begin{array}{l}\text { Stier } 100 \text { DVE } \\
\text { / Bull } 100 \text { IDP }\end{array}$ & $\begin{array}{c}\text { Rosé } 110 \text { DVE } \\
\text { / Rosé } 110 \\
\text { IDP }\end{array}$ & $\begin{array}{c}\text { Rosé } 120 \text { DVE } \\
\text { / Rosé } 120 \\
\text { IDP }\end{array}$ & $\begin{array}{c}\text { Rosé } 130 \text { DVE } \\
\text { / Rosé } 130 \\
\text { IDP }\end{array}$ \\
\hline OS / OM & 801 & 799 & 799 & 797 & 795 \\
\hline VCOS /DCOM & 82,2 & 82,1 & 82,3 & 82,7 & 82,9 \\
\hline
\end{tabular}


1) Daarnaast is er opfok- en afmestvoeder met 1.050 VEVI i.p.v. 1.000 VEVI wat is bestemd voor zowel stieren als rosé kalveren. Opfok 110 DVE had in 2018 een VCOS van gemiddeld 84,6\% en een OS-gehalte van $806 \mathrm{~g} / \mathrm{kg}$. Afmest 100 DVE had in 2018 een VCOS van gemiddeld $84,3 \%$ en een OS-gehalte van $803 \mathrm{~g} / \mathrm{kg} /{ }^{1}$ ) Besides there is start and fattening feed with 1.050 VEVI (feed unit beef cattle intensive) instead of 1.000 VEVI which is meant for both bulls and rosé veal calves. Rearing 110 IDP in 2018 had a DCOM of $84.6 \%$ on average and a OM content of $806 \mathrm{~g} / \mathrm{kg}$. Fattening 100 IDP in 2018 had a DCOM of $84.3 \%$ on average and a OM content of $803 \mathrm{~g} / \mathrm{kg}$.

De berekende VCRE en VCOS kunnen afwijken van in de praktijk gebruikte mengvoeders door gebruik van bedrijfseigen informatie over normen voor nutriënten, grondstoffen, prijzen en beschikbaarheid van grondstoffen en dergelijke. Op basis van expertise en aanvullende berekeningen komen we tot de inschatting dat de berekende verteringscoëfficiënten met een marge van 2 tot $3 \%$ de verteerbaarheid van in de praktijk gebruikte voeders weergeven. 


\title{
Bijlage 26 Methaanemissie door melkvee en verteerbaarheid ruw eiwit in 2019
}

\author{
Auteur: A. Bannink (Wageningen Livestock Research) \\ Versie: 20 oktober 2020, Wageningen
}

\section{Inleiding}

Op dezelfde wijze als de berekeningen van de methaanemissie door melkvee in de jaren 1990 tot en met 2018 is in deze studie de methaanemissie berekend voor het registratiejaar 2019.

Naast een berekening voor het gemiddelde rantsoen is eveneens een onderscheid gemaakt tussen de rantsoenen in de regio ZuidOost en NoordWest. Hiervoor is gebruik gemaakt van de Tier 3 methode zoals gepubliceerd door Bannink et al. (2011) en beschreven in een achtergronddocument voor deze Tier 3 methode door Bannink (2011).

Naast de methaanberekeningen is deze notitie met uitkomsten van de Tier 3 methode uitgebreid met berekeningen voor de (schijnbare) fecale vertering van stikstof (VC_RE) en organische stof (VC_OS).

\section{Methode}

\subsection{Gebruikte gegevens}

Hieronder worden de gegevens genoemd die als specifieke waarde voor het jaar 2019 (Van Bruggen, 2020) zijn meegenomen in de huidige studie:

- Werkgroep Uniformering berekening Mest- en mineralencijfers (WUM)-voeropnamegegevens (zowel met als zonder correctie voor voerverliezen die, conform WUM, $0 \%, 5 \%, 3 \%$ en $2 \%$ bedragen voor resp. vers gras, gras- en maïskuil, vochtrijke bijproducten en krachtvoeders).

- WUM-melkproductiegegevens (melkproductie, FPCM (vet en eiwit gecorrigeerde melk) \& FCM (vet gecorrigeerde melk)).

- Samenstelling ruwvoer conform WUM methodologie (vers gras, graskuil/grashooi en maïskuil).

- Op WUM gebaseerde gegevens van vochtrijke bijproducten.

- $\quad$ Op WUM gebaseerd ruw eiwit (RE)-gehalte krachtvoeders.

\subsection{Uitgangspunten / gehanteerde Tier 3 model / overige aannames}

\section{Vorming vluchtige vetzuren (VVZ)}

Het gebruikte model komt overeen met dat beschreven door Mills et al. (2001), afgezien van de weergave van de VVZ-vorming. In de studie van Mills et al. (2001) werd de weergave volgens Bannink et al. (2000; 2006) gebruikt. Daarentegen werd zowel in de studie van Smink et al. (2005) als in de huidige studie een update van deze weergave van VVZ-vorming gebruikt zoals omschreven door Bannink \& Dijkstra (2005). Deze update (Bannink et al., 2011; Bannink, 2011) verschilt in twee opzichten van die van Bannink et al. (2000; 2006) en Mills et al. (2001):

1. Een andere afleidingsmethodiek maakt dat de coëfficiënten voor VVZ-vorming uit gefermenteerd substraat verschillen van die van Bannink et al. (2000; 2006).

2. De VVZ-vorming uit suikers en zetmeel (snel-fermenteerbare koolhydraten) is afhankelijk gemaakt van de $\mathrm{pH}$ in de pens.

$\mathrm{pH}$, deeltjespassage, vloeistofpassage en vloeistofvolume

Conform Mills et al. (2001) werden de $\mathrm{pH}$, de passagesnelheid van deeltjes en vloeistof en het vloeistofvolume voorspeld door middel van in het model opgenomen empirische vergelijkingen. De $\mathrm{pH}$ is lineair afhankelijk van de concentratie VVZ in de vloeistof, terwijl de passagesnelheden en het vloeistofvolume lineair afhankelijk zijn 
van de voeropname. Deze vergelijkingen werden tevens toegepast in de eerdere studies van Smink et al. (2005), Bannink \& Dijkstra (2006) en in studies in de daarop volgende jaren (Bannink et al., 2011).

\section{Voersamenstelling}

De aannames zijn gemaakt conform de methode in voorgaande jaren en zoals gerapporteerd door Bannink (2009). Jaarspecifieke gegevens werden gebruikt voor weidegras, graskuil en maïskuil.

\subsection{Toebedeling OS-restfractie}

Niet-gekarakteriseerde organische stof als restfractie (restfractie OS = OS - ruw vet - ruw eiwit (excl. ammoniakfractie in silages) - NDF - zetmeel - suikers - ruw as - zuren) werd voor $50 \%$ aan suikers en voor $50 \%$ aan NDF (neutral detergent fibre; (hemi-)cellulose, lignine) toebedeeld in producten waarin dit de grootste koohydraatfracties zijn (bijv. alle grasproducten). In geval zetmeel de grootste fractie is naast NDF (bijv. maïskuil) werd de restfractie voor 50\% aan zetmeel en $50 \%$ aan NDF toebedeeld. Deze uitgangspunten zijn gehanteerd voor alle jaren in de reeks 1990 - 2019.

Voor vochtrijke bijproducten werd op basis van door het CBS aangereikte gegevens (Van Bruggen, 2020) voor 2019 aangenomen dat deze voor 42, 16 en 42\% uit resp. bierbostel (inclusief de droge stof van overige eiwitrijke producten), aardappelproducten (inclusief de droge stof van overige zetmeelrijke producten) en bietenpulp (inclusief de droge stof van overige pectinerijke producten) bestond. Deze verdeling is gebaseerd op de WUM-opgave voor vochtrijke bijproducten verwerkt in de rundveehouderij.

\subsection{Correctie RE-gehalte voor de ammoniakfractie}

Het methaanmodel vraagt om een invoer van de totale $\mathrm{N}$-fractie in het rantsoen, inclusief ammoniak- $\mathrm{N}$, en apart daarvan de ammoniakfractie als N-fractie. De WUM-gegevens (Van Bruggen, 2020) maken op basis van Eurofins / BLGG AgroXpertus - gegevens ook dit onderscheid tussen een ruw eiwit fractie inclusief ammoniak, en een eiwitfractie exclusief ammoniak. Bij de modelberekeningen is de eiwitfractie exclusief ammoniak als invoer voor ruw eiwit aangehouden, de eiwitfractie gekoppeld aan ammoniak is als invoer voor ammoniak aangehouden. Beide zijn opgeteld om tot de totale $\mathrm{N}$-fractie in het rantsoen als modelinvoer te komen.

\subsection{Correctie voeropname voor zogeheten "voerverliezen"}

In de studie van Smink et al. (2005) werden geen correcties doorgevoerd voor voerverliezen. Echter, volgens de WUM-methodiek (Van Bruggen, 2020) zijn voerverliezen van 0, 5, 3 en 2\% voor respectievelijk vers gras, graskuil en maïskuil, vochtige bijproducten en krachtvoeders van toepassing. Deze voerverliezen treden op voorafgaand aan de opname van voeders door het melkvee, en dragen dus niet bij aan methaanproductie in het maagdarmkanaal. Deze correctie voor voeropname kan dus ook voor enterisch methaan aangehouden worden. Voor de methaanberekeningen zijn geen extra correcties toegepast en de voeropname is volledig conform WUM-systematiek overgenomen.

\subsection{Aanpassing in de Tier $\mathbf{3}$ methode ten behoeve van verbeterde schatting van de fecale verteerbaarheid van ruw eiwit in melkvee}

De Tier 3 methode is recent aangepast om berekeningen van de (schijnbare) fecale N verteerbaarheid (VC_RE) mogelijk te maken (Bannink et al., 2018). Met deze VC_RE berekening wordt de sterke overschatting die met de oude VC_RE berekeningsmethode werd verkregen voorkomen. De oude methode was gebaseerd op tabelwaarden voor VC_RE die echter niet direct toepasbaar bleken op melkvee, en die ook niet het doel hadden om de VC_RE van melkvee te schatten, maar om de energetische voedingswaarde van voeders te schatten (Bannink et al., 2015). Met de nieuwe Tier 3 methode wordt beter weergegeven wat de bijdrage is van endogeen en microbieel materiaal aan de fecale excretie, en wordt eveneens de bijdrage van microbiële groei in de dikke darm aan de uitscheiding met feces meegerekend. Met hetzelfde model wordt tevens de (schijnbare) fecale vertering van organische stof berekend (VC_OS). 
Tabel B26.1 Voeropname en voersamenstelling in 2019 / Feed uptake en feed composition in 2019

\begin{tabular}{|c|c|}
\hline & $\begin{array}{l}\text { Na correctie voor voerverliezen / } \\
\text { After correction for feeding losses }\end{array}$ \\
\hline \multicolumn{2}{|l|}{2019 NL gemiddeld / 2019 NL average } \\
\hline \multicolumn{2}{|l|}{ Opname (kg DS/koe/jr) / Uptake (kg DM/cow/yr) } \\
\hline Vers gras / Fresh grass & 741 \\
\hline Graskuil / Grass silage & 2837 \\
\hline Maïskuil / Maize silage & 1482 \\
\hline Vochtrijke bijproducten / Moist by-products & 291 \\
\hline Standaard krachtvoer / Standard concentrate & 1036 \\
\hline Eiwitrijk krachtvoer / Protein-rich concentrate & 738 \\
\hline Totaal / Total & 7126 \\
\hline \multicolumn{2}{|l|}{ FCM $(\mathrm{kg} /$ cow/year $)$} \\
\hline \multicolumn{2}{|l|}{ FPCM (kg/cow/year) } \\
\hline \multicolumn{2}{|l|}{2019 ZuidOost / 2019 SouthEast } \\
\hline \multicolumn{2}{|l|}{ Opname (kg DS/koe/jr) / Uptake (kg DM/cow/yr) } \\
\hline Vers gras / Fresh grass & 533 \\
\hline Graskuil / Grass silage & 2528 \\
\hline Maïskuil / Maize silage & 2061 \\
\hline Vochtrijke bijproducten / Moist by-products & 291 \\
\hline Standaard krachtvoer / Standard concentrate & 749 \\
\hline Eiwitrijk krachtvoer / Protein-rich concentrate & 1025 \\
\hline Totaal / Total & 7187 \\
\hline $\begin{array}{l}\text { Melkproductie FCM (kg/koe/jaar) / Milk production } \\
\text { FCM (kg/cow/year) }\end{array}$ & 9608 \\
\hline $\begin{array}{l}\text { Melkproductie FPCM (kg/koe/jaar) / Milk production } \\
\text { FPCM (kg/cow/year) }\end{array}$ & 9624 \\
\hline \multicolumn{2}{|l|}{2019 NoordWest / 2019 NorthWest } \\
\hline \multicolumn{2}{|l|}{ Opname (kg DS/koe/jr) / Uptake (kg DM/cow/yr) } \\
\hline Vers gras / Fresh grass & 1020 \\
\hline Graskuil / Grass silage & 3252 \\
\hline Maïskuil / Maize silage & 707 \\
\hline Vochtrijke bijproducten / Moist by-products & 291 \\
\hline Standaard krachtvoer / Standard concentrate & 1422 \\
\hline Eiwitrijk krachtvoer / Protein-rich concentrate & 352 \\
\hline Totaal / Total & 7043 \\
\hline $\begin{array}{l}\text { Melkproductie FCM (kg/koe/jaar) / Milk production } \\
\text { FCM (kg/cow/year) }\end{array}$ & 9155 \\
\hline $\begin{array}{l}\text { Melkproductie FPCM (kg/koe/jaar) / Milk production } \\
\text { FPCM (kg/cow/year) }\end{array}$ & 9171 \\
\hline
\end{tabular}

\section{Berekeningen enterisch methaan}

Op basis van bovengenoemde voeropnamegegevens zijn modelberekeningen uitgevoerd, en in onderstaande tabel worden de voeropnames (van droge stof, DS, en van bruto energie, GE) naast de methaanproductie (in kilogrammen en megajoule per koe per jaar) weergegeven. 
Tabel B26.2 Voeropname, GE-opname en methaanemissie in 2019 / Feed uptake, GE uptake and methane emission in 2019.

\begin{tabular}{|c|c|c|c|c|}
\hline Rantsoentype/regio / & Voeropname & & & \\
\hline Ration type/region & $\begin{array}{c}\text { (kg DS/jr) / Feed } \\
\text { uptake (kg } \\
\text { DM/yr) }\end{array}$ & $\begin{array}{c}\text { Opname GE } \\
\text { (MJ/koe/jr) / } \\
\text { Uptake GE } \\
\text { (MJ/cow/yr) }\end{array}$ & $\begin{array}{l}\text { Methaan / } \\
\text { (kg/koe/jr) } \\
\text { (kg/cow/yr) }\end{array}$ & $\begin{array}{l}\text { Methane } \\
\text { (MJ/koe/jr) } \\
\text { (MJ/cow/yr) }\end{array}$ \\
\hline ZuidOost / SouthEast & 7187 & 133336 & 134,792 & 7501 \\
\hline NoordWest / NorthWest & 7043 & 128858 & 136,016 & 7569 \\
\hline $\begin{array}{l}\text { NL gemiddeld / NL } \\
\text { average }\end{array}$ & 7125 & 131432 & 135,406 & 7536 \\
\hline
\end{tabular}

Tabel B26.3 geeft enkele kengetallen voor de berekende methaanvorming, zoals het \% van de opgenomen bruto energie die als methaan wordt uitgeademd door het melkvee (MCF) en de methaanproductie per $\mathrm{kg}$ gecorrigeerde melk.

Tabel B26.3 Voeropname, methaanconversiefactor (MCF) en methaanemissie per kg melk in 2019 / Feed uptake, methane conversion factor (MCF) and methane emission per kg milk in 2019.

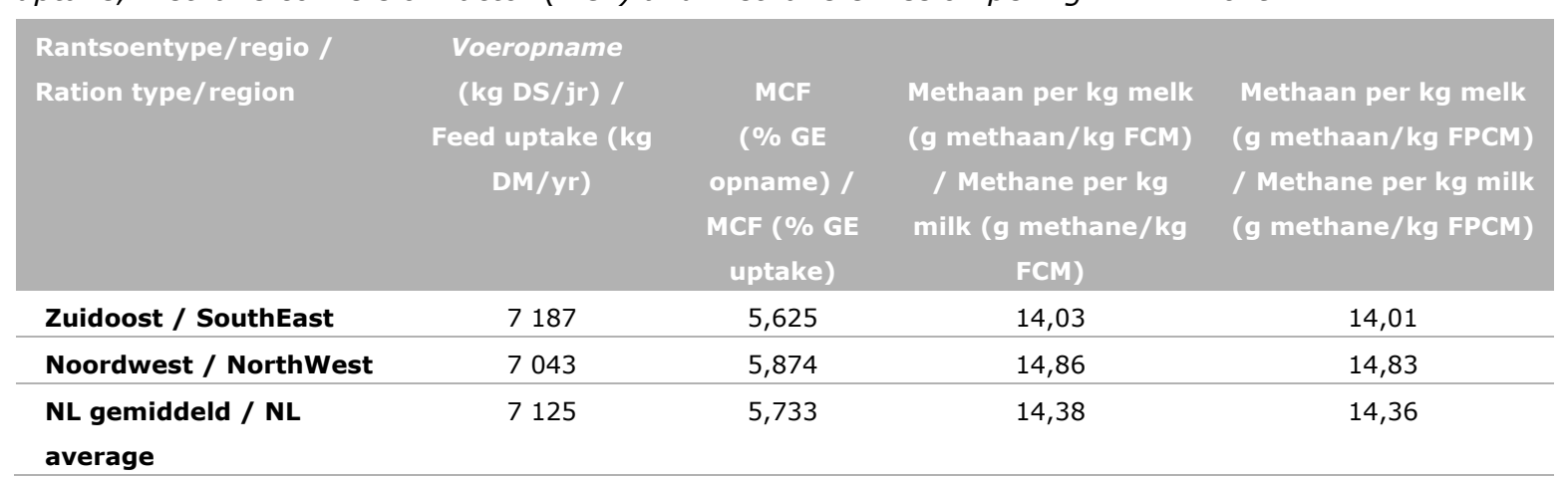

\section{Conclusies methaanberekeningen 2019}

De berekeningen geven een 5,6\% lagere methaanemissie per $\mathrm{kg}$ vet en eiwit gecorrigeerde melk in de regio ZuidOost Nederland vergeleken met de regio NoordWest Nederland. Dit verschil tussen beide regio's wordt veroorzaakt door het hogere aandeel snijmaïs en het lagere aandeel graskuil en vers gras in het rantsoen in de regio ZuidOost en de hogere jaarlijks gerealiseerde melkproductie per melkkoe.

In het gemiddelde rantsoen van de Nederlandse melkkoe in 2019 was het aandeel grasproducten in de rantsoen droge stof met 50,2\% één \% eenheid hoger dan in 2018, terwijl het aandeel maïskuil daalde met $0,6 \%$ eenheden tot $20,8 \%$. Het aandeel vers gras in de rantsoen droge stof nam af met $0,6 \%$ eenheden tot $10,4 \%$ terwijl graskuil met $1,7 \%$ eenheden toenam tot 39,8\%. De energetische voederwaarde van deze ruwvoeders waren nagenoeg onveranderd ten opzichte van 2018 (gemiddeld 2,5\% en 0,7\% hoger voor vers gras en maïskuil, en $0,6 \%$ lager voor graskuil). Het aandeel krachtvoer bleef nagenoeg gelijk en nam met slechts $0,1 \%$ toe tot $24,9 \%$, terwijl het aandeel eiwitrijk krachtvoer met $2,4 \%$ afnam in de rantsoen DS. Het aandeel vochtige bijproducten nam met $0,7 \%$ af tot $4,1 \%$. De energetische voederwaarde van de rantsoen DS bleef gelijk aan die in 2018 met 981 VEM/kg DS.

De veranderingen in de rantsoensamenstelling gaven geringe veranderingen in de chemische samenstelling van het aandeel suiker $(+0,2 \%)$, zetmeel $(-0,6 \%)$, NDF $(+0,4 \%)$ en ruw eiwit $(-0,1 \%)$ in de rantsoen DS.

De totale jaarlijkse methaanemissie van de gemiddelde Nederlandse melkkoe steeg met 0,5\% in 2019 ten opzichte van 2018. Deze uitkomst ging samen met een $0,5 \%$ stijging van de DS opname en een $0,8 \%$ stijging van FPCM productie. Ondanks de stijging van de voeropname en methaanemissie was de methaanemissie per $\mathrm{kg}$ FPCM of per kg FCM 0,3\% lager vanwege het compenserende effect door procentueel grotere stijging van de melkproductie uitgedrukt in FPCM. 


\section{Berekeningen VC_RE \& VC_OS}

Voor registratiejaar 2019 werd een VC_RE (de N die met feces wordt uitgescheiden uitgedrukt als \% van de opgenomen $\mathrm{N}$ ) berekend van $68,4 \%, 67,3 \%$ en $69,7 \%$ voor respectievelijk Nederland gemiddeld, de regio ZuidOost en de regio NoordWest. Dit is $0,44 \%$ verteringseenheden lager dan in 2018. Deze daling gaat samen met een hogere voeropname, en een geringe stijging in het aandeel graskuil en een geringe daling in het aandeel vers gras en maïskuil. De $\mathrm{N}$ opname en het RE gehalte van het rantsoen nam licht af ten opzichte van 2018 (toename slechts $0,1 \%$ van de rantsoen DS).

Voor registratiejaar 2019 werd een VC_OS (de OS die met feces wordt uitgescheiden uitgedrukt als \% van de opgenomen OS) berekend van $77,3 \%, 75,8 \%$ en $79,2 \%$ voor respectievelijk Nederland gemiddeld, de regio ZuidOost en de regio NoordWest. Dit is gemiddeld 0,11 \% verteringseenheden lager dan in 2018. Deze daling gaat samen met een hogere voeropname, en een geringe toename van het aandeel graskuil ten koste van vers gras en maïskuil.

\section{Conclusies}

De aangepaste Tier 3 methode berekent een gemiddelde VC_RE voor 2019 van 68,4\% welke waarde 0,4\% eenheden lager is dan die berekend voor 2018.

De aangepaste Tier 3 methode berekent met 77,3\% een 8,9\% eenheden hogere VC_OS dan VC_RE voor 2019, welke $8,6 \%$ eenheid hoger was in 2018.

\section{Literatuur}

Bannink, A., W. Spek, J. Dijkstra \& L.B.J. Šebek. 2018. A Tier 3 Method for enteric methane in dairy cows applied for fecal $\mathrm{N}$ digestibility in the ammonia inventory. Frontiers in Sustainable Food Systems (Waste Management in Agroecosystems) 2:66. doi: 10.3389/fsufs.2018.00066

Bannink, A., L.B.J. Šebek \& J. Dijkstra. 2015. Evaluatie berekening VC_RE in NEMA 2015. Vertrouwelijk Wageningen Livestock Research Rapport 465, Wageningen.

Bannink, A., M.W. van Schijndel \& J. Dijkstra. 2011. A model of enteric fermentation in dairy cows to estimate methane emission for the Dutch National Inventory Report using the IPCC Tier 3 approach. Animal Feed Science and Technology 166-167: 603-618.

Bannink, A. 2011. Methane emissions from enteric fermentation in dairy cows, 1990-2008. Background document on the calculation method and uncertainty analysis for the Dutch National Inventory Report on Greenhouse Gas Emissions. Werkdocument 265, Wettelijke Onderzoekstaken Natuur \& Milieu, Wageningen.

Bannink, A., J. Kogut, J. Dijkstra, J. France, S. Tamminga \& A.M. van Vuuren. 2000. Modelling production and portal appearance of volatile fatty acids in cows. Pages 87-102. In: Modelling Nutrient Utilization in Farm Animals. Eds. J.P. McNamara, J. France and D.E. Beever. CAB International, Wallingford, United Kingdom.

Bannink, A. \& J. Dijkstra. 2005. Schatting van de vorming van vluchtige vetzuren uit gefermenteerd substraat in de pens van melkvee. Animal Sciences Group, Vertrouwelijk ASG-rapport 05/I002371, Lelystad.

Bannink, A., J. Kogut, J. Dijkstra, E. Kebreab, J. France, S. Tamminga \& A.M. Van Vuuren. 2006. Estimation of the stoichiometry of volatile fatty acid production in the rumen of lactating cows. Journal of Theoretical Biology 238: 36-51.

Bannink, A. \& J. Dijkstra. 2006. Berekening van de methaanemissie door melkvee in NL in 2004. ASG-notitie t.b.v. MNP.

Mills, J.A.N., J. Dijkstra, A. Bannink, S.B. Cammell, E. Kebreab \& J. France. 2001. A mechanistic model of whole tract digestion and methanogenesis in the lactating dairy cow: model development, evaluation and application. Journal of Animal Science 81: 3141-3150.

Smink, W., K.W. van der Hoek, A. Bannink \& J. Dijkstra. 2005. Calculation of methane production from enteric fermentation in dairy cows. FIS-report, Wageningen.

Van Bruggen, C. 2020. Rapportage Dierlijke mest en mineralen 2019. CBS, Den Haag/Heerlen. In druk. 



\section{Bijlage 27 Bruto energie-opname door rundvee}

Bruto energie-opname door rundvee $\left(M J /\right.$ dier/dag) ${ }^{1)}$ / Gross energy intake by cattle (MJ/animal/day) ${ }^{1)}$.

\begin{tabular}{|c|c|c|c|c|c|c|c|c|c|c|c|c|c|c|c|}
\hline Diercategorie / Livestock c & 1990 & 1991 & 1992 & 1993 & 1994 & 1995 & 1996 & 1997 & 1998 & 1999 & 2000 & 2001 & 2002 & 2003 & 2004 \\
\hline \multicolumn{16}{|l|}{ Melk- en fokvee / Dairy cattle } \\
\hline vrouwelijk jongvee $<1 \mathrm{jr}$ / female young stock $<1 \mathrm{yr}$ & 73,6 & 74,7 & 76,3 & 74,9 & 75,0 & 75,6 & 73,7 & 74,5 & 74,9 & 76,4 & 75,0 & 75,3 & 74,8 & 76,6 & 76,7 \\
\hline mannelijk jongvee $<1 \mathrm{jr} /$ male young stock $<1 \mathrm{yr}$ & 86,1 & 86,5 & 87,6 & 86,5 & 87,6 & 86,7 & 85,4 & 85,9 & 85,7 & 86,7 & 85,1 & 85,6 & 85,6 & 86,6 & 89,7 \\
\hline vrouwelijk jongvee $1-2 \mathrm{jr} /$ female young stock $1-2 \mathrm{yr}$ & 139,5 & 141,2 & 144,8 & 141,7 & 141,2 & 142,5 & 138,4 & 140,7 & 141,0 & 141,6 & 139,5 & 140,2 & 139,2 & 147,9 & 147,0 \\
\hline mannelijk jongvee $1-2 \mathrm{jr} /$ male young stock $1-2 \mathrm{yr}$ & 151,1 & 157,7 & 162,3 & 158,3 & 158,2 & 162,2 & 156,5 & 157,1 & 160,7 & 160,9 & 155,9 & 155,7 & 152,9 & 158,3 & 157,7 \\
\hline vrouwelijk jongvee $\geq 2 \mathrm{jr}$ / female young stock $\geq 2 \mathrm{yr}$ & 139,4 & 141,2 & 144,7 & 141,7 & 141,1 & 142,5 & 138,3 & 140,6 & 141,0 & 141,5 & 139,5 & 140,1 & 139,2 & 147,9 & 147,0 \\
\hline $\begin{array}{l}\text { melk- en kalfkoeien - NoordWest Nederland }{ }^{2} \text { / dairy } \\
\text { cows - NorthWest Netherlands }{ }^{2} \text { ) }\end{array}$ & 279,0 & 282,1 & 286,0 & 290,0 & 293,1 & 292,8 & 293,2 & 297,0 & 301,0 & 304,2 & 308,8 & 311,3 & 307,6 & 319,8 & 322,2 \\
\hline $\begin{array}{l}\text { melk- en kalfkoeien - ZuidOost Nederland }{ }^{2} \text { / dairy } \\
\text { cows - SouthEast Netherlands }{ }^{2} \text { ) }\end{array}$ & 280,2 & 281,2 & 284,1 & 286,8 & 295,4 & 291,5 & 289,9 & 297,0 & 300,9 & 300,2 & 304,9 & 309,5 & 307,5 & 318,1 & 320,3 \\
\hline fokstieren $\geq 2 \mathrm{jr} /$ breeding bulls $\geq 2 \mathrm{yr}$ & 151,1 & 157,7 & 162,3 & 158,3 & 158,2 & 162,2 & 156,5 & 157,1 & 160,7 & 160,9 & 155,9 & 155,7 & 152,9 & 158,3 & 157,7 \\
\hline \multicolumn{16}{|l|}{ Vlees- en weidevee / Beef cattle } \\
\hline witvleeskalveren / calves for white veal production & 35,2 & 35,2 & 35,2 & 35,2 & 35,2 & 36,9 & 36,9 & 36,9 & 39,7 & 40,1 & 40,1 & 40,1 & 41,0 & 41,0 & 38,9 \\
\hline rosévleeskalveren / calves for rosé veal production & 77,9 & 77,9 & 77,9 & 77,9 & 77,9 & 77,9 & 77,9 & 77,9 & 71,6 & 95,5 & 95,5 & 95,5 & 80,9 & 80,9 & 82,8 \\
\hline vrouwelijk jongvee $<1 \mathrm{jr} /$ female young stock $<1 \mathrm{yr}$ & 73,6 & 74,6 & 76,2 & 74,8 & 74,9 & 75,5 & 73,6 & 74,4 & 74,7 & 76,2 & 74,9 & 75,1 & 74,6 & 76,5 & 76,6 \\
\hline $\begin{array}{l}\text { mannelijk jongvee (incl. ossen) }<1 \mathrm{jr} / \text { male young } \\
\text { stock (incl. bullocks) }<1 \mathrm{yr}\end{array}$ & 82,3 & 83,8 & 80,9 & 79,2 & 89,2 & 87,6 & 85,6 & 88,7 & 91,4 & 90,4 & 88,8 & 86,9 & 87,8 & 87,5 & 86,6 \\
\hline vrouwelijk jongvee $1-2 \mathrm{jr} /$ female young stock $1-2 \mathrm{yr}$ & 139,5 & 141,2 & 144,7 & 141,7 & 141,1 & 142,4 & 138,3 & 140,6 & 140,8 & 141,4 & 139,3 & 139,9 & 139,1 & 147,8 & 146,8 \\
\hline $\begin{array}{l}\text { mannelijk jongvee (incl. ossen) } 1-2 \mathrm{jr} / \text { male young } \\
\text { stock (incl. bullocks) } 1-2 \mathrm{yr}\end{array}$ & 167,3 & 179,7 & 182,3 & 196,2 & 161,5 & 164,1 & 154,7 & 158,7 & 157,1 & 156,5 & 154,1 & 154,9 & 156,2 & 155,9 & 157,4 \\
\hline vrouwelijk jongvee $\geq 2 \mathrm{jr} /$ female young stock $\geq 2 \mathrm{yr}$ & 139,5 & 141,2 & 144,8 & 141,7 & 141,1 & 142,5 & 138,4 & 140,6 & 140,8 & 141,4 & 139,4 & 140,0 & 139,0 & 147,8 & 146,8 \\
\hline $\begin{array}{l}\text { mannelijk jongvee (incl. ossen) } \geq 2 \mathrm{jr} / \text { male young } \\
\text { stock (incl. bullocks) } \geq 2 \mathrm{yr}\end{array}$ & 167,3 & 179,7 & 182,3 & 196,2 & 161,5 & 164,1 & 154,7 & 158,7 & 157,1 & 156,5 & 154,1 & 154,9 & 156,2 & 155,9 & 157,4 \\
\hline $\begin{array}{l}\text { zoog-, mest- en weidekoeien } \geq 2 \mathrm{jr} / \text { suckling cows } \\
\text { and female fatteners } \geq 2 \mathrm{yr}\end{array}$ & 165,0 & 166,2 & 170,2 & 166,8 & 165,7 & 167,1 & 162,5 & 165,6 & 164,4 & 170,0 & 169,1 & 170,0 & 169,7 & 182,5 & 183,2 \\
\hline
\end{tabular}




\section{Melk- en fokvee / Dairy cattle}

vrouwelijk jongvee $<1 \mathrm{jr} /$ female young stock $<1 \mathrm{yr}$ mannelijk jongvee $<1 \mathrm{jr} /$ male young stock $<1 \mathrm{yr}$

vrouwelijk jongvee 1-2 jr / female young stock 1-2 yr mannelijk jongvee $1-2 \mathrm{jr} /$ male young stock $1-2 \mathrm{yr}$

vrouwelijk jongvee $\geq 2 \mathrm{jr} /$ female young stock $\geq 2 \mathrm{yr}$ melk- en kalfkoeien - NoordWest Nederland ${ }^{2}$ / dairy

cows - NorthWest Netherlands ${ }^{2}$

melk- en kalfkoeien - ZuidOost Nederland ${ }^{2}$ / dairy

cows - SouthEast Netherlands ${ }^{2}$

fokstieren $\geq 2 \mathrm{jr} /$ breeding bulls $\geq 2 \mathrm{yr}$

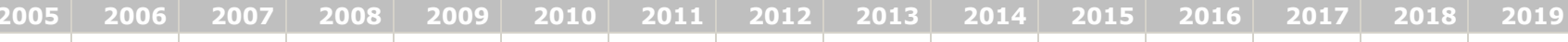

\section{Vlees- en weidevee / Beef cattle}

\begin{tabular}{|l|r|r|r|r|r|r|r|r|r|r|r|r|r|r|r|r|r|r|r|r|r|}
\hline witvleeskalveren / calves for white veal production & 38,9 & 41,4 & 41,4 & 41,4 & 41,4 & 46,1 & 46,2 & 45,6 & 45,6 & 47,8 & 47,8 & 50,6 & 52,9 & 53,9 & 55,0 \\
\hline
\end{tabular}

\begin{tabular}{|l|r|r|r|r|r|r|r|r|r|r|r|r|r|r|r|r|r|r|r|r|r|r|}
\hline rosévleeskalveren / calves for rosé veal production & 82,8 & 82,8 & 82,8 & 82,8 & 82,8 & 77,1 & 77,1 & 77,1 & 77,1 & 71,8 & 74,9 & 74,9 & 74,9 & 81,4 & 81,4 \\
\hline
\end{tabular}

\begin{tabular}{|l|l|l|l|l|l|l|l|l|r|r|r|r|r|r|r|r|r|r|}
\hline vrouwelijk jongvee $<1 \mathrm{jr} /$ female young stock $<1 \mathrm{yr}$ & 75,8 & 76,2 & 76,7 & 75,3 & 74,1 & 73,8 & 73,8 & 74,5 & 74,7 & 74,3 & 73,6 & 73,0 & 73,5 & 70,4 & 70,4 \\
\hline
\end{tabular}

mannelijk jongvee (incl. ossen) $<1 \mathrm{jr} /$ male young

\begin{tabular}{|l|r|r|r|r|r|r|r|r|r|r|r|r|r|r|}
\hline 86,7 & 86,7 & 85,7 & 86,2 & 85,6 & 84,7 & 85,1 & 84,7 & 84,6 & 84,4 & 84,6 & 84,3 & 83,8 & 84,4 & 84,1 \\
\hline
\end{tabular}

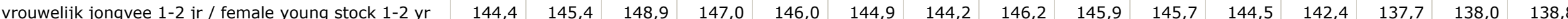

mannelijk jongvee (incl. ossen) $1-2 \mathrm{jr} /$ male young

stock (incl. bullocks) $1-2 \mathrm{yr}$

mannelijk jongvee (incl. ossen) $\geq 2 \mathrm{jr} /$ male young

stock (incl. bullocks) $\geq 2 \mathrm{yr}$

zoog-, mest- en weidekoeien $\geq 2 \mathrm{jr} /$ suckling cows

and female fatteners $\geq 2 \mathrm{yr}$

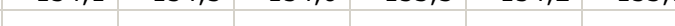

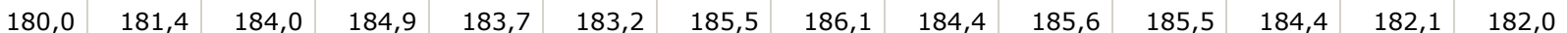

1) Berekend door vermenigvuldiging van de voeropname in droge stof (bron: WUM) met het bruto energiegehalte $(18,45 \mathrm{MJ} / \mathrm{kg}$ DS) / Calculated by multiplying the feed uptake (source: WUM) with the gross energy content (18.45 MJ/kg DM).

2) Waarde gegeven ter referentie, methaanemissie door pens- en darmfermentatie van melkkoeien wordt bepaald op basis van Bannink (2011) / Value given for reference, methane emission through enteric fermentation of dairy cows is determined based on Bannink (2011). 


\section{Bijlage 28 Emissiefactoren voor $\mathrm{CH}_{4}$ uit pens- en darmfermentatie}

Emissiefactoren voor $\mathrm{CH}_{4}$ uit pens- en darmfermentatie $(\mathrm{kg} \mathrm{CH} / \text { dier/jaar })^{1)} / \mathrm{CH}_{4}$ emission factors from enteric fermentation ( $\mathrm{kg} \mathrm{CH}_{4} /$ animal/day) ${ }^{1}$.

\begin{tabular}{|c|c|c|c|c|c|c|c|c|c|c|c|c|c|c|c|}
\hline Diercategorie / Livestock category & 1990 & 1991 & 1992 & 1993 & 1994 & 1995 & 1996 & 1997 & 1998 & 1999 & 2000 & 2001 & 2002 & 2003 & 2004 \\
\hline \multicolumn{16}{|l|}{ Melk- en fokvee / Dairy cattle } \\
\hline vrouwelijk jongvee $<1 \mathrm{jr} /$ female young stock $<1 \mathrm{yr}$ & 31,4 & 31,9 & 32,5 & 31,9 & 32,0 & 32,2 & 31,4 & 31,8 & 31,9 & 32,6 & 32,0 & 32,1 & 31,9 & 32,7 & 32,7 \\
\hline mannelijk jongvee $<1 \mathrm{jr} /$ male young stock $<1 \mathrm{yr}$ & 36,7 & 36,9 & 37,3 & 36,9 & 37,3 & 37,0 & 36,4 & 36,6 & 36,5 & 37,0 & 36,3 & 36,5 & 36,5 & 36,9 & 38,3 \\
\hline vrouwelijk jongvee $1-2 \mathrm{jr} /$ female young stock $1-2 \mathrm{yr}$ & 59,5 & 60,2 & 61,7 & 60,4 & 60,2 & 60,7 & 59,0 & 60,0 & 60,1 & 60,4 & 59,5 & 59,8 & 59,4 & 63,1 & 62,7 \\
\hline mannelijk jongvee $1-2 \mathrm{jr} /$ male young stock $1-2 \mathrm{yr}$ & 64,4 & 67,2 & 69,2 & 67,5 & 67,4 & 69,1 & 66,7 & 67,0 & 68,5 & 68,6 & 66,4 & 66,4 & 65,2 & 67,5 & 67,2 \\
\hline vrouwelijk jongvee $\geq 2 \mathrm{jr}$ / female young stock $\geq 2 \mathrm{yr}$ & 59,4 & 60,2 & 61,7 & 60,4 & 60,2 & 60,7 & 59,0 & 60,0 & 60,1 & 60,3 & 59,5 & 59,7 & 59,3 & 63,1 & 62,7 \\
\hline $\begin{array}{l}\text { melk- en kalfkoeien - NoordWest Nederland / dairy } \\
\text { cows - NorthWest Netherlands }\end{array}$ & 111,0 & 110,8 & 112,9 & 113,8 & 114,4 & 115,4 & 115,9 & 115,7 & 117,1 & 118,2 & 121,7 & 121,7 & 121,3 & 124,3 & 125,9 \\
\hline $\begin{array}{l}\text { melk- en kalfkoeien - ZuidOost Nederland / dairy cows } \\
\text { - SouthEast Netherlands }\end{array}$ & 109,9 & 109,7 & 111,5 & 112,1 & 113,9 & 113,5 & 112,8 & 114,5 & 114,8 & 115,7 & 118,4 & 119,5 & 119,1 & 121,1 & 122,7 \\
\hline fokstieren $\geq 2 \mathrm{jr} /$ breeding bulls $\geq 2 \mathrm{yr}$ & 64,4 & 67,2 & 69,2 & 67,5 & 67,4 & 69,1 & 66,7 & 67,0 & 68,5 & 68,6 & 66,4 & 66,4 & 65,2 & 67,5 & 67,2 \\
\hline \multicolumn{16}{|l|}{ Vlees- en weidevee / Beef cattle } \\
\hline witvleeskalveren / calves for white veal production & 0,7 & 0,7 & 0,7 & 0,7 & 0,7 & 1,3 & 1,3 & 1,3 & 1,7 & 1,7 & 1,7 & 1,7 & 2,0 & 2,0 & 2,5 \\
\hline rosévleeskalveren / calves for rosé veal production & 30,6 & 30,6 & 30,6 & 30,6 & 30,6 & 33,2 & 33,2 & 33,2 & 30,5 & 40,7 & 40,7 & 40,7 & 34,5 & 34,5 & 35,3 \\
\hline vrouwelijk jongvee $<1 \mathrm{jr} /$ female young stock $<1 \mathrm{yr}$ & 31,4 & 31,8 & 32,5 & 31,9 & 31,9 & 32,2 & 31,4 & 31,7 & 31,9 & 32,5 & 31,9 & 32,0 & 31,8 & 32,6 & 32,6 \\
\hline $\begin{array}{l}\text { mannelijk jongvee (incl. ossen) }<1 \mathrm{jr} / \text { male young } \\
\text { stock (incl. bullocks) }<1 \mathrm{yr}\end{array}$ & 35,1 & 35,7 & 34,5 & 33,8 & 38,0 & 37,4 & 36,5 & 37,8 & 38,9 & 38,5 & 37,8 & 37,0 & 37,4 & 37,3 & 36,9 \\
\hline vrouwelijk jongvee $1-2 \mathrm{jr} /$ female young stock $1-2 \mathrm{yr}$ & 59,5 & 60,2 & 61,7 & 60,4 & 60,1 & 60,7 & 59,0 & 59,9 & 60,0 & 60,3 & 59,4 & 59,7 & 59,3 & 63,0 & 62,6 \\
\hline $\begin{array}{l}\text { mannelijk jongvee (incl. ossen) } 1-2 \mathrm{jr} / \text { male young } \\
\text { stock (incl. bullocks) } 1-2 \mathrm{yr}\end{array}$ & 71,3 & 76,6 & 77,7 & 83,6 & 68,9 & 69,9 & 65,9 & 67,6 & 67,0 & 66,7 & 65,7 & 66,0 & 66,6 & 66,5 & 67,1 \\
\hline vrouwelijk jongvee $\geq 2 \mathrm{jr}$ / female young stock $\geq 2 \mathrm{yr}$ & 59,5 & 60,2 & 61,7 & 60,4 & 60,2 & 60,7 & 59,0 & 59,9 & 60,0 & 60,3 & 59,4 & 59,7 & 59,3 & 63,0 & 62,6 \\
\hline $\begin{array}{l}\text { mannelijk jongvee (incl. ossen) } \geq 2 \mathrm{jr} / \text { male young } \\
\text { stock (incl. bullocks) } \geq 2 \mathrm{yr}\end{array}$ & 71,3 & 76,6 & 77,7 & 83,6 & 68,9 & 69,9 & 65,9 & 67,6 & 67,0 & 66,7 & 65,7 & 66,0 & 66,6 & 66,5 & 67,1 \\
\hline $\begin{array}{l}\text { zoog-, mest- en weidekoeien } \geq 2 \mathrm{jr} / \text { suckling cows } \\
\text { and female fatteners } \geq 2 \mathrm{yr}\end{array}$ & 70,3 & 70,8 & 72,6 & 71,1 & 70,6 & 71,3 & 69,3 & 70,6 & 70,1 & 72,5 & 72,1 & 72,5 & 72,3 & 77,8 & 78,1 \\
\hline \multicolumn{16}{|l|}{$\begin{array}{l}\text { Overige dieren (Tier 1-defaults) / Other } \\
\text { livestock (Tier } 1 \text { defaults) }\end{array}$} \\
\hline schapen / sheep & 8 & 8 & 8 & 8 & 8 & 8 & 8 & 8 & 8 & 8 & 8 & 8 & 8 & 8 & 8 \\
\hline geiten / goats & 5 & 5 & 5 & 5 & 5 & 5 & 5 & 5 & 5 & 5 & 5 & 5 & 5 & 5 & 5 \\
\hline paarden en ponies / horses and ponies & 18 & 18 & 18 & 18 & 18 & 18 & 18 & 18 & 18 & 18 & 18 & 18 & 18 & 18 & 18 \\
\hline varkens / pigs & 1,5 & 1,5 & 1,5 & 1,5 & 1,5 & 1,5 & 1,5 & 1,5 & 1,5 & 1,5 & 1,5 & 1,5 & 1,5 & 1,5 & 1,5 \\
\hline ezels / mules and asses & 10 & 10 & 10 & 10 & 10 & 10 & 10 & 10 & 10 & 10 & 10 & 10 & 10 & 10 & 10 \\
\hline
\end{tabular}




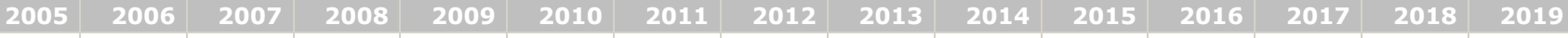

\section{Melk- en fokvee / Dairy cattle}

mannelijk jongvee $<1$ jr / male young stock $<1$ yr

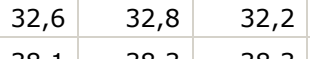

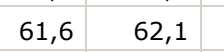

mannelijk jongvee $1-2 \mathrm{jr} /$ male young stock $1-2 \mathrm{yr}$

\begin{tabular}{|l|l|l|l|}
65,7 & 65,7 & 66,4 & 66,0 \\
\hline 61,6 & 62,1 & 63,6 & 62,7
\end{tabular}

vrouwelijk jongvee $\geq 2 \mathrm{jr} /$ female young stock $\geq 2 \mathrm{yr}$

\begin{tabular}{|l|l|l|l|}
\hline 61,6 & 62,1 & 63,6 & 62,7 \\
\hline
\end{tabular}

melk- en kalfkoeien - NoordWest Nederland / dairy

cows - NorthWest Netherlands

melk- en kalfkoeien - ZuidOost Nederland / dairy cows

- SouthEast Netherlands

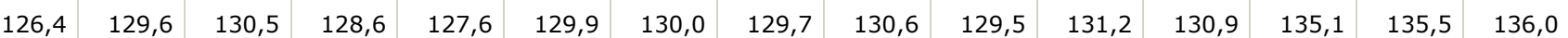

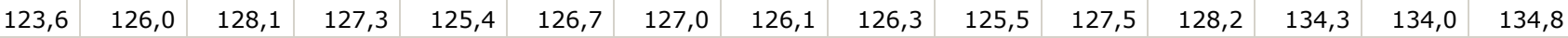

fokstieren $\geq 2 \mathrm{jr} /$ breeding bulls $\geq 2 \mathrm{yr}$

\section{Vlees- en weidevee / Beef cattle}

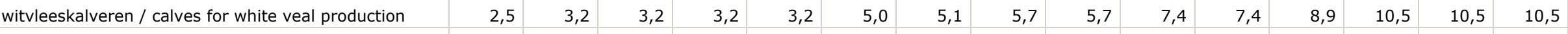

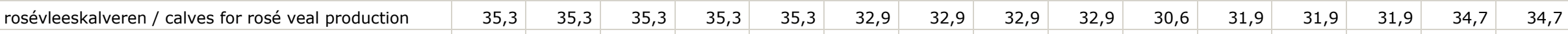

\begin{tabular}{|l|l|l|l|l|l|r|r|r|r|r|r|r|r|r|r|r|}
\hline vrouwelijk jongvee $<1 \mathrm{jr} /$ female young stock $<1 \mathrm{yr}$ & 32,3 & 32,5 & 32,7 & 32,1 & 31,6 & 31,5 & 31,5 & 31,8 & 31,8 & 31,7 & 31,4 & 31,1 & 31,3 & 30,0 & 30,0 \\
\hline
\end{tabular}

mannelijk jongvee (incl. ossen) $<1 \mathrm{jr} /$ male young

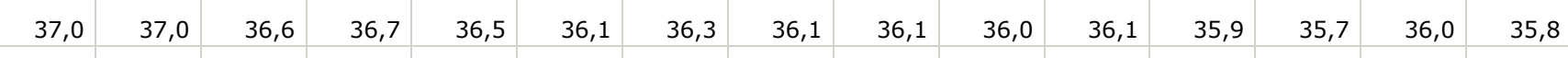

\begin{tabular}{|l|r|r|r|r|r|r|r|r|r|r|r|r|r|r|r|}
\hline vrouwelijk jongvee $1-2 \mathrm{jr} /$ female young stock 1-2 yr & 61,6 & 62,0 & 63,5 & 62,7 & 62,2 & 61,8 & 61,5 & 62,3 & 62,2 & 62,1 & 61,6 & 60,7 & 58,7 & 58,9 & 59,2 \\
\hline
\end{tabular}

mannelijk jongvee (incl. ossen) $1-2 \mathrm{jr} /$ male young

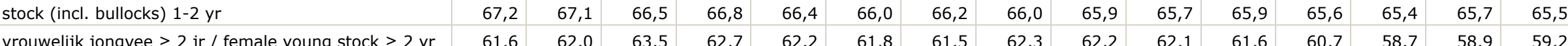

mannelijk jongvee (incl. ossen) $\geq 2 \mathrm{jr} /$ male young

stock (incl. bullocks) $\geq 2 \mathrm{yr}$

zoog-, mest- en weidekoeien $\geq 2 \mathrm{jr} /$ suckling cows

and female fatteners $\geq 2 \mathrm{yr}$

s

Overige dieren (Tier 1-defaults) / Other

\section{livestock (Tier 1 defaults)}

schapen / sheep

geiten / goats

paarden en ponies / horses and ponies

\begin{tabular}{|l|l|l|l|l|l|l|l|l|}
\hline 61,6 & 62,0 & 63,5 & 62,7 & 62,2 & 61,8 & 61,5 & 62,3 & 62,2 \\
\hline
\end{tabular}

\begin{tabular}{|l|r|}
62,1 & 61,6
\end{tabular}

60,7

\begin{tabular}{|l|r|r|}
\hline 58,7 & 58,9 & 59,2 \\
\hline
\end{tabular}

varkens / pigs

ezels / mules and asses

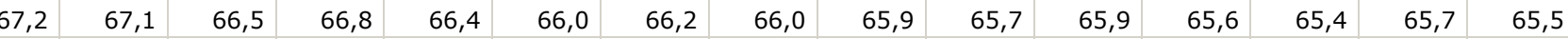

1) Berekend door vermenigvuldiging van de bruto energieopname per jaar met de methaanconversiefactor / Calculated by multiplying the gross energy uptake per year with the methane conversion factor. 


\section{Bijlage 29 Excretie van organische stof}

B29.1 Excretie van organische stof (OS) voor diercategorieën waarvoor een Tier 2-berekening is toegepast (kg OS/dier/jaar) / Excretion of volatile solids (VS) for livestock categories with a Tier 2 calculation ( $k g$ VS/animal/year).

\begin{tabular}{|c|c|c|c|c|c|c|c|c|c|c|c|c|c|c|c|}
\hline Diercategorie / Livestock category & 1990 & 1991 & 1992 & 1993 & 1994 & 1995 & 1996 & 1997 & 1998 & 1999 & 2000 & 2001 & 2002 & 2003 & 2004 \\
\hline \multicolumn{16}{|l|}{ Melk- en fokvee / Dairy cattle } \\
\hline vrouwelijk jongvee $<1 \mathrm{jr}$ / female young stock $<1 \mathrm{yr}$ & 381 & 383 & 386 & 388 & 391 & 393 & 393 & 393 & 392 & 392 & 392 & 389 & 387 & 384 & 382 \\
\hline mannelijk jongvee $<1 \mathrm{jr} /$ male young stock $<1 \mathrm{yr}$ & 466 & 466 & 465 & 465 & 464 & 464 & 461 & 458 & 455 & 452 & 449 & 452 & 454 & 457 & 459 \\
\hline vrouwelijk jongvee $1-2 \mathrm{jr} /$ female young stock $1-2 \mathrm{yr}$ & 730 & 733 & 736 & 740 & 743 & 746 & 743 & 739 & 736 & 732 & 729 & 728 & 727 & 727 & 726 \\
\hline mannelijk jongvee $1-2 \mathrm{jr} /$ male young stock $1-2 \mathrm{yr}$ & 910 & 923 & 937 & 950 & 964 & 977 & 969 & 961 & 954 & 946 & 938 & 927 & 916 & 906 & 895 \\
\hline vrouwelijk jongvee $\geq 2 \mathrm{jr}$ / female young stock $\geq 2 \mathrm{yr}$ & 730 & 733 & 736 & 740 & 743 & 746 & 743 & 739 & 736 & 732 & 729 & 728 & 727 & 727 & 726 \\
\hline melk- en kalfkoeien / dairy cows & 1402 & 1409 & 1416 & 1422 & 1429 & 1436 & 1457 & 1478 & 1499 & 1520 & 1541 & 1554 & 1567 & 1580 & 1593 \\
\hline fokstieren $\geq 2 \mathrm{jr} /$ breeding bulls $\geq 2 \mathrm{yr}$ & 910 & 923 & 937 & 950 & 964 & 977 & 969 & 961 & 953 & 945 & 937 & 926 & 916 & 905 & 895 \\
\hline \multicolumn{16}{|l|}{ Vlees- en weidevee / Beef cattle } \\
\hline witvleeskalveren / calves for white veal production & 46 & 48 & 51 & 53 & 56 & 58 & 59 & 60 & 61 & 62 & 63 & 65 & 67 & 68 & 70 \\
\hline rosévleeskalveren / calves for rosé veal production & 473 & 473 & 473 & 473 & 473 & 473 & 473 & 473 & 473 & 473 & 473 & 460 & 446 & 433 & 419 \\
\hline vrouwelijk jongvee $<1 \mathrm{jr} /$ female young stock $<1 \mathrm{yr}$ & 381 & 383 & 385 & 387 & 389 & 391 & 391 & 391 & 391 & 391 & 391 & 388 & 386 & 383 & 381 \\
\hline $\begin{array}{l}\text { mannelijk jongvee (incl. ossen) }<1 \mathrm{jr} / \text { male young } \\
\text { stock (incl. bullocks) }<1 \mathrm{yr}\end{array}$ & 449 & 452 & 455 & 459 & 462 & 465 & 462 & 459 & 456 & 453 & 450 & 450 & 451 & 451 & 452 \\
\hline vrouwelijk jongvee $1-2 \mathrm{jr} /$ female young stock $1-2 \mathrm{yr}$ & 730 & 733 & 736 & 739 & 742 & 745 & 741 & 738 & 734 & 731 & 727 & 726 & 725 & 725 & 724 \\
\hline $\begin{array}{l}\text { mannelijk jongvee (incl. ossen) } 1-2 \mathrm{jr} / \text { male young } \\
\text { stock (incl. bullocks) } 1-2 \mathrm{yr}\end{array}$ & 955 & 938 & 920 & 903 & 885 & 868 & 852 & 836 & 820 & 804 & 788 & 797 & 807 & 816 & 826 \\
\hline vrouwelijk jongvee $\geq 2 \mathrm{jr} /$ female young stock $\geq 2 \mathrm{yr}$ & 730 & 733 & 736 & 740 & 743 & 746 & 742 & 739 & 735 & 732 & 728 & 727 & 726 & 726 & 725 \\
\hline $\begin{array}{l}\text { mannelijk jongvee (incl. ossen) } \geq 2 \mathrm{jr} / \text { male young } \\
\text { stock (incl. bullocks) } \geq 2 \mathrm{yr}\end{array}$ & 955 & 938 & 920 & 903 & 885 & 868 & 852 & 836 & 820 & 804 & 788 & 797 & 807 & 816 & 826 \\
\hline $\begin{array}{l}\text { zoog-, mest- en weidekoeien } \geq 2 \mathrm{jr} / \text { suckling cows } \\
\text { and female fatteners } \geq 2 \mathrm{yr}\end{array}$ & 821 & 823 & 826 & 828 & 831 & 833 & 832 & 832 & 831 & 831 & 830 & 838 & 845 & 853 & 860 \\
\hline vleesvarkens / fattening pigs & 172 & 169 & 166 & 164 & 161 & 158 & 155 & 126 & 150 & 147 & 144 & 141 & 138 & 135 & 133 \\
\hline opfokzeugen / gilts & 201 & 198 & 195 & 193 & 190 & 187 & 184 & 181 & 179 & 176 & 173 & 170 & 168 & 165 & 162 \\
\hline zeugen / sows & 397 & 393 & 390 & 386 & 383 & 379 & 375 & 346 & 368 & 365 & 361 & 358 & 354 & 351 & 347 \\
\hline opfokberen / young boars & 201 & 198 & 195 & 193 & 190 & 187 & 184 & 181 & 179 & 176 & 173 & 170 & 168 & 165 & 162 \\
\hline dekberen / breeding boars & 293 & 289 & 285 & 280 & 276 & 272 & 268 & 264 & 259 & 255 & 251 & 247 & 242 & 238 & 234 \\
\hline vleeskuikens / broilers & 7,5 & 7,5 & 7,5 & 7,6 & 7,6 & 7,6 & 7,6 & 7,6 & 7,7 & 7,7 & 7,7 & 7,7 & 7,7 & 7,8 & 7,8 \\
\hline
\end{tabular}




\begin{tabular}{|c|c|c|c|c|c|c|c|c|c|c|c|c|c|c|c|}
\hline Diercategorie / Livestock category & 1990 & 1991 & 1992 & 1993 & 1994 & 1995 & 1996 & 1997 & 1998 & 1999 & 2000 & 2001 & 2002 & 2003 & 2004 \\
\hline $\begin{array}{l}\text { ouderdieren van vleeskuikens }<18 \text { weken / broiler } \\
\text { breeders }<18 \text { weeks }\end{array}$ & 5,2 & 5,2 & 5,2 & 5,2 & 5,2 & 5,2 & 5,2 & 5,2 & 5,2 & 5,2 & 5,2 & 5,2 & 5,2 & 5,2 & 5,2 \\
\hline $\begin{array}{l}\text { ouderdieren van vleeskuikens } \geq 18 \text { weken / broiler } \\
\text { breeders } \geq 18 \text { weeks }\end{array}$ & 13,1 & 13,1 & 13,0 & 13,0 & 13,0 & 12,9 & 12,9 & 12,9 & 12,8 & 12,8 & 12,7 & 12,7 & 12,7 & 12,6 & 12,6 \\
\hline leghennen $<18$ weken / laying hens $<18$ weeks & 3,9 & 3,9 & 3,9 & 3,9 & 3,9 & 3,9 & 3,9 & 3,9 & 4,0 & 4,0 & 4,0 & 4,0 & 4,0 & 4,0 & 4,0 \\
\hline leghennen $\geq 18$ weeks / laying hens $\geq 18$ weeks & 8,0 & 8,1 & 8,1 & 8,1 & 8,1 & 8,2 & 8,2 & 8,2 & 8,2 & 8,2 & 8,3 & 8,3 & 8,3 & 8,3 & 8,3 \\
\hline eenden / ducks & 7,5 & 7,5 & 7,5 & 7,6 & 7,6 & 7,6 & 7,6 & 7,6 & 7,7 & 7,7 & 7,7 & 7,7 & 7,7 & 7,8 & 7,8 \\
\hline kalkoenen / turkeys & 13,1 & 13,1 & 13,0 & 13,0 & 13,0 & 12,9 & 12,9 & 12,9 & 12,8 & 12,8 & 12,7 & 12,7 & 12,7 & 12,6 & 12,6 \\
\hline
\end{tabular}

B29.1

vervolg / continuation

Diercategorie / Livestock centiegrory

\section{Melk- en fokvee / Dairy cattle}

vrouwelijk jongvee $<1 \mathrm{jr} /$ female young stock $<1 \mathrm{yr}$

mannelijk jongvee $<1 \mathrm{jr} /$ male young stock $<1 \mathrm{yr} \quad 462 \quad 457$

vrouwelijk jongvee 1-2 jr / female young stock 1-2 yr

mannelijk jongvee 1-2 jr / male young stock 1-2 yr 884

vrouwelijk jongvee $\geq 2 \mathrm{jr} /$ female young stock $\geq 2 \mathrm{yr}$

melk- en kalfkoeien / dairy cows

\begin{tabular}{|l|r|r|r|r|r|}
825 & 729 & 733 & 737 & 741
\end{tabular}

fokstieren $\geq 2 \mathrm{jr} /$ breeding bulls $\geq 2 \mathrm{yr}$

$1606 \quad 1622$

\section{Vlees- en weidevee / Beef cattle}

\begin{tabular}{|c|c|c|c|c|c|c|c|c|c|c|c|c|c|c|c|}
\hline witvleeskalveren / calves for white veal production & 72 & 80 & 88 & 95 & 103 & 111 & 110 & 110 & 109 & 109 & 109 & 109 & 158 & 160 & 169 \\
\hline rosévleeskalveren / calves for rosé veal production & 406 & 397 & 388 & 380 & 371 & 362 & 359 & 355 & 352 & 352 & 352 & 352 & 341 & 361 & 362 \\
\hline vrouwelijk jongvee $<1 \mathrm{jr} /$ female young stock $<1 \mathrm{yr}$ & 378 & 379 & 379 & 380 & 380 & 381 & 385 & 390 & 394 & 394 & 394 & 394 & 376 & 359 & 359 \\
\hline $\begin{array}{l}\text { mannelijk jongvee (incl. ossen) }<1 \mathrm{jr} / \text { male young } \\
\text { stock (incl. bullocks) }<1 \mathrm{yr}\end{array}$ & 452 & 446 & 440 & 435 & 429 & 423 & 419 & 414 & 410 & 410 & 410 & 410 & 425 & 426 & 421 \\
\hline vrouwelijk jongvee $1-2 \mathrm{jr} /$ female young stock $1-2 \mathrm{yr}$ & 723 & 727 & 731 & 735 & 739 & 743 & 756 & 769 & 782 & 782 & 782 & 782 & 725 & 723 & 728 \\
\hline $\begin{array}{l}\text { mannelijk jongvee (incl. ossen) } 1-2 \mathrm{jr} / \text { male young } \\
\text { stock (incl. bullocks) } 1-2 \mathrm{yr}\end{array}$ & 835 & 825 & 815 & 806 & 796 & 786 & 780 & 775 & 769 & 769 & 769 & 769 & 779 & 777 & 772 \\
\hline vrouwelijk jongvee $\geq 2 \mathrm{jr}$ / female young stock $\geq 2 \mathrm{yr}$ & 724 & 728 & 732 & 735 & 739 & 743 & 756 & 769 & 782 & 782 & 782 & 782 & 723 & 722 & 729 \\
\hline $\begin{array}{l}\text { mannelijk jongvee (incl. ossen) } \geq 2 \mathrm{jr} / \text { male young } \\
\text { stock (incl. bullocks) } \geq 2 \mathrm{yr}\end{array}$ & 835 & 825 & 815 & 806 & 796 & 786 & 780 & 775 & 769 & 769 & 769 & 769 & 779 & 777 & 772 \\
\hline $\begin{array}{l}\text { zoog-, mest- en weidekoeien } \geq 2 \mathrm{jr} \text { / suckling cows } \\
\text { and female fatteners } \geq 2 \mathrm{yr}\end{array}$ & 868 & 872 & 877 & 881 & 886 & 890 & 899 & 908 & 917 & 917 & 917 & 917 & 946 & 950 & 949 \\
\hline vleesvarkens / fattening pigs & 130 & 127 & 124 & 121 & 118 & 116 & 113 & 110 & 107 & 107 & 107 & 107 & 114 & 114 & 121 \\
\hline opfokzeugen / gilts & 159 & 157 & 154 & 151 & 148 & 146 & 143 & 140 & 137 & 137 & 137 & 137 & 149 & 146 & 150 \\
\hline zeugen / sows & 344 & 340 & 337 & 333 & 330 & 326 & 323 & 319 & 315 & 315 & 315 & 315 & 349 & 340 & 344 \\
\hline opfokberen / young boars & 159 & 157 & 154 & 151 & 148 & 146 & 143 & 140 & 137 & 137 & 137 & 137 & 149 & 146 & 150 \\
\hline
\end{tabular}

208 | wot-technical report 203 


\begin{tabular}{|c|c|c|c|c|c|c|c|c|c|c|c|c|c|c|c|}
\hline Diercategorie / Livestock category & 2005 & 2006 & 2007 & 2008 & 2009 & 2010 & 2011 & 2012 & 2013 & 2014 & 2015 & 2016 & 2017 & 2018 & 2019 \\
\hline dekberen / breeding boars & 230 & 225 & 221 & 217 & 213 & 208 & 204 & 200 & 196 & 196 & 196 & 196 & 212 & 207 & 209 \\
\hline vleeskuikens / broilers & 7,8 & 7,8 & 7,9 & 7,9 & 7,9 & 7,9 & 7,9 & 8,0 & 8,0 & 8,0 & 8,0 & 8,0 & 7,9 & 8,0 & 8,0 \\
\hline $\begin{array}{l}\text { ouderdieren van vleeskuikens }<18 \text { weken / broiler } \\
\text { breeders }<18 \text { weeks }\end{array}$ & 5,2 & 5,2 & 5,2 & 5,2 & 5,2 & 5,2 & 5,2 & 5,2 & 5,2 & 5,2 & 5,2 & 5,2 & 5,3 & 5,1 & 5,7 \\
\hline $\begin{array}{l}\text { ouderdieren van vleeskuikens } \geq 18 \text { weken / broiler } \\
\text { breeders } \geq 18 \text { weeks }\end{array}$ & 12,5 & 12,5 & 12,5 & 12,4 & 12,4 & 12,3 & 12,3 & 12,3 & 12,2 & 12,2 & 12,2 & 12,2 & 12,5 & 11,8 & 12,3 \\
\hline leghennen $<18$ weken / laying hens $<18$ weeks & 4,0 & 4,0 & 4,0 & 4,0 & 4,0 & 4,0 & 4,0 & 4,0 & 4,0 & 4,0 & 4,0 & 4,0 & 4,5 & 4,5 & 4,5 \\
\hline leghennen $\geq 18$ weeks / laying hens $\geq 18$ weeks & 8,4 & 8,4 & 8,4 & 8,4 & 8,5 & 8,5 & 8,5 & 8,5 & 8,5 & 8,5 & 8,5 & 8,5 & 8,6 & 8,8 & 9,8 \\
\hline eenden / ducks & 7,8 & 7,8 & 7,9 & 7,9 & 7,9 & 7,9 & 7,9 & 8,0 & 8,0 & 8,0 & 8,0 & 8,0 & 12,3 & 11,9 & 11,9 \\
\hline kalkoenen / turkeys & 12,5 & 12,5 & 12,5 & 12,4 & 12,4 & 12,3 & 12,3 & 12,3 & 12,2 & 12,2 & 12,2 & 12,2 & 22,9 & 22,0 & 21,5 \\
\hline
\end{tabular}

N.B. 1990-2016: Zom en Groenestein (2015). Vanaf 2017: Actualisering OS-excretie per dier. Tot en met 2016 was de OS-excretie van eenden gelijkgesteld aan die van vleeskuikens en de OS-excretie van kalkoenen aan die van ouderdieren van vleeskuikens ouder dan ca. 18 weken / Note 1990-2016: Zom and Groenestein (2015). From 2017: Actualisation VS excretion per animal. Up to 2016 the VS excretion of ducks was set equal to broilers

and the VS excretion of turkeys equal to broiler breeders 18 weeks and over. 



\section{Bijlage 30 Emissiefactoren voor $\mathrm{CH}_{4}$ uit dierlijke mest}

Emissiefactoren voor $\mathrm{CH}_{4}$ uit drijfmest ( $\mathrm{kg} \mathrm{CH}$ /dier/jaar) / $\mathrm{CH}_{4}$ emission factors for slurry ( $\mathrm{kg} \mathrm{CH} /$ animal/year).

\begin{tabular}{|c|c|c|c|c|c|c|c|c|c|c|c|c|c|c|c|}
\hline Diercategorie / Livestock category & 1990 & 1991 & 1992 & 1993 & 1994 & 1995 & 1996 & 1997 & 1998 & 1999 & 2000 & 2001 & 2002 & 2003 & 2004 \\
\hline \multicolumn{16}{|l|}{ Melk- en fokvee / Dairy cattle } \\
\hline vrouwelijk jongvee $<1 \mathrm{jr} /$ female young stock $<1 \mathrm{yr}$ & 7,1 & 7,1 & 7,2 & 7,2 & 7,3 & 7,3 & 7,3 & 7,3 & 7,3 & 7,3 & 7,3 & 7,2 & 7,2 & 6,1 & 6,0 \\
\hline mannelijk jongvee $<1 \mathrm{jr} /$ male young stock $<1 \mathrm{yr}$ & 11,7 & 11,7 & 11,7 & 11,6 & 11,6 & 11,6 & 11,6 & 11,5 & 11,4 & 11,3 & 11,3 & 11,3 & 11,4 & 11,4 & 11,5 \\
\hline vrouwelijk jongvee $1-2 \mathrm{jr} /$ female young stock $1-2 \mathrm{yr}$ & 10,3 & 10,3 & 10,4 & 10,4 & 10,5 & 10,5 & 10,5 & 10,4 & 10,4 & 10,3 & 10,3 & 10,3 & 10,2 & 10,2 & 10,2 \\
\hline mannelijk jongvee $1-2 \mathrm{jr} /$ male young stock $1-2 \mathrm{yr}$ & 22,8 & 23,1 & 23,5 & 23,8 & 24,1 & 24,5 & 24,3 & 24,1 & 23,9 & 23,7 & 23,5 & 23,2 & 23,0 & 22,7 & 22,4 \\
\hline vrouwelijk jongvee $\geq 2 \mathrm{jr} /$ female young stock $\geq 2 \mathrm{yr}$ & 10,3 & 10,3 & 10,4 & 10,4 & 10,5 & 10,5 & 10,5 & 10,4 & 10,4 & 10,3 & 10,3 & 10,3 & 10,2 & 10,2 & 10,2 \\
\hline melk- en kalfkoeien / dairy cows & 24,2 & 24,4 & 24,1 & 24,6 & 24,7 & 24,8 & 25,2 & 25,6 & 26,2 & 27,2 & 28,2 & 28,4 & 31,4 & 31,3 & 30,9 \\
\hline fokstieren $\geq 2 \mathrm{jr} /$ breeding bulls $\geq 2 \mathrm{yr}$ & 22,8 & 23,1 & 23,5 & 23,8 & 24,1 & 24,5 & 24,3 & 24,1 & 23,9 & 23,7 & 23,5 & 23,2 & 22,9 & 22,7 & 22,4 \\
\hline \multirow{2}{*}{\multicolumn{16}{|c|}{ Vlees- en weidevee / Beef cattle }} \\
\hline & & & & & & & & & & & & & & & \\
\hline witvleeskalveren / calves for white veal production & 1,1 & 1,1 & 1,2 & 1,2 & 1,3 & 1,2 & 1,2 & 1,2 & 1,3 & 1,4 & 1,3 & 1,4 & 1,4 & 1,5 & 1,5 \\
\hline rosévleeskalveren / calves for rosé veal production & 11,9 & 11,9 & 11,9 & 11,9 & 11,9 & 11,9 & 11,9 & 11,9 & 11,9 & 11,9 & 11,9 & 11,5 & 11,2 & 10,8 & 10,5 \\
\hline vrouwelijk jongvee $<1 \mathrm{jr} /$ female young stock $<1 \mathrm{yr}$ & 7,1 & 7,1 & 7,2 & 7,2 & 7,3 & 7,3 & 7,3 & 7,3 & 7,3 & 7,3 & 7,3 & 7,2 & 7,2 & 6,1 & 6,0 \\
\hline $\begin{array}{l}\text { mannelijk jongvee (incl. ossen) }<1 \mathrm{jr} / \text { male young } \\
\text { stock (incl. bullocks) }<1 \mathrm{yr}\end{array}$ & 11,3 & 11,3 & 11,4 & 11,5 & 11,6 & 11,7 & 11,6 & 11,5 & 11,4 & 11,4 & 11,3 & 11,3 & 11,3 & 11,3 & 11,3 \\
\hline vrouwelijk jongvee $1-2 \mathrm{jr} /$ female young stock $1-2 \mathrm{yr}$ & 10,3 & 10,3 & 10,4 & 10,4 & 10,4 & 10,5 & 10,4 & 10,4 & 10,3 & 10,3 & 10,2 & 10,2 & 10,2 & 10,2 & 10,2 \\
\hline $\begin{array}{l}\text { mannelijk jongvee (incl. ossen) } 1-2 \mathrm{jr} / \text { male young } \\
\text { stock (incl. bullocks) } 1-2 \mathrm{yr}\end{array}$ & 23,9 & 23,5 & 23,1 & 22,6 & 22,2 & 21,8 & 21,3 & 20,9 & 20,5 & 20,1 & 19,7 & 20,0 & 20,2 & 20,5 & 20,7 \\
\hline vrouwelijk jongvee $\geq 2 \mathrm{jr} /$ female young stock $\geq 2 \mathrm{yr}$ & 10,3 & 10,3 & 10,4 & 10,4 & 10,5 & 10,5 & 10,5 & 10,4 & 10,4 & 10,3 & 10,3 & 10,2 & 10,2 & 10,2 & 10,2 \\
\hline $\begin{array}{l}\text { mannelijk jongvee (incl. ossen) } \geq 2 \mathrm{jr} / \text { male young } \\
\text { stock (incl. bullocks) } \geq 2 \mathrm{yr}\end{array}$ & 23,9 & 23,5 & 23,1 & 22,6 & 22,2 & 21,8 & 21,3 & 20,9 & 20,5 & 20,1 & 19,7 & 20,0 & 20,2 & 20,5 & 20,7 \\
\hline $\begin{array}{l}\text { zoog-, mest- en weidekoeien } \geq 2 \mathrm{jr} / \text { suckling cows } \\
\text { and female fatteners } \geq 2 \mathrm{yr}\end{array}$ & 9,3 & 9,3 & 9,4 & 9,4 & 9,4 & 9,4 & 9,4 & 9,4 & 9,4 & 9,4 & 9,4 & 9,5 & 9,6 & 9,7 & 9,7 \\
\hline \multicolumn{16}{|l|}{ Varkens / Pigs } \\
\hline vleesvarkens / fattening pigs & 12,9 & 12,7 & 12,4 & 12,2 & 12,0 & 11,8 & 11,6 & 9,4 & 11,2 & 11,0 & 10,8 & 10,5 & 10,3 & 10,1 & 9,9 \\
\hline opfokzeugen / gilts & 15,0 & 14,8 & 14,6 & 14,4 & 14,2 & 14,0 & 13,8 & 13,6 & 13,4 & 13,2 & 12,9 & 12,7 & 12,5 & 12,3 & 12,1 \\
\hline zeugen / sows & 29,7 & 29,4 & 29,1 & 28,9 & 28,6 & 28,3 & 28,1 & 25,9 & 27,5 & 27,3 & 27,0 & 26,8 & 26,5 & 26,2 & 26,0 \\
\hline opfokberen / young boars & 15,0 & 14,8 & 14,6 & 14,4 & 14,2 & 14,0 & 13,8 & 13,6 & 13,4 & 13,2 & 12,9 & 12,7 & 12,5 & 12,3 & 12,1 \\
\hline dekberen / breeding boars & 21,9 & 21,6 & 21,3 & 21,0 & 20,7 & 20,3 & 20,0 & 19,7 & 19,4 & 19,1 & 18,8 & 18,4 & 18,1 & 17,8 & 17,5 \\
\hline
\end{tabular}


\begin{tabular}{|l|l|l|l|l|l|l|l|l|l|l|l|l|l|l|l|l|l|l|l|l|}
\hline Diercategorie/ Livestock category & 1990 & 1991 & 1992 & 1993 & 1994 & 1995 & 1996 & 1997 & 1998 & 1999 & 2000 & 2001 & 2002 & 2003 & 2004 \\
\hline
\end{tabular}

Pluimvee en pelsdieren / Poultry and fur-bearing

animals

leghennen $\geq 18$ weeks / laying hens $\geq 18$ weeks

0,32

pelsdieren (teven) / fur-bearing animals (dams)

$0,66 \quad 0,66$

0,66

0,32

0,32

B30.1

vervolg / continuation

\section{Diercategorie / Livestock category}

\section{Melk- en fokvee / Dairy cattle}

\section{vrouwelijk jongvee $<1 \mathrm{jr}$ / female young stock $<1 \mathrm{yr}$}

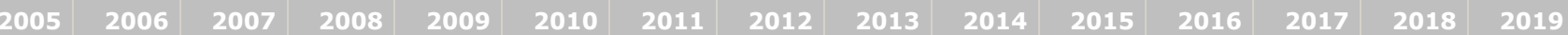

\begin{tabular}{|r|r|r|r|r|r|r|r|r|r|r|r|r|r|r|r|r|r|}
\hline 6,0 & 6,0 & 6,4 & 7,9 & 7,9 & 7,9 & 8,2 & 8,4 & 8,4 & 8,4 & 8,4 & 8,5 & 8,3 & 8,0 & 8,0 \\
\hline
\end{tabular}

vrouwelijk jongvee $1-2 \mathrm{jr} /$ female young stock $1-2 \mathrm{yr}$

\begin{tabular}{r|r|r|r|r|}
11,6 & 11,4 & 1 \\
\hline
\end{tabular}

\begin{tabular}{|l|l|l|l|l|l|l|l|}
\hline 11,6 & 11,7 & 11,4 & 11,4 & 12,8 & 13,1 \\
\hline
\end{tabular}

\begin{tabular}{|l|r|r|r|r|r|r|r|}
22,2 & 21,9 & 21,8 & 21,6 & 21,4 & 21,1 & 21,4 & 21,6 \\
\hline
\end{tabular}

vrouwelijk jongvee $\geq 2 \mathrm{jr} /$ female young stock $\geq 2 \mathrm{yr}$

melk- en kalfkoeien / dairy cows

\begin{tabular}{r|r|r|}
10,2 & 9,7
\end{tabular}

\begin{tabular}{|r|r|r|r|r|}
\hline 10,2 & 9,7 & 10,1 & 11,4 & 11,4 \\
\hline
\end{tabular}

fokstieren $\geq 2 \mathrm{jr}$ / breeding bulls $\geq 2 \mathrm{yr}$

\begin{tabular}{|l|l|l|l|}
\hline 10,1 & 11,4 & 11,4 \\
\hline 33,4 & 32,1 & 34,3 & 34, \\
\hline
\end{tabular}

\begin{tabular}{r|r}
12,4 \\
12,8 \\
\hline
\end{tabular}

12,8

13,1

10,8

\begin{tabular}{|l|r|r|}
\hline 3,3 & 13,3 & 13,3 \\
\hline
\end{tabular}

10,8

10,7
13,9

\begin{tabular}{|l|l|}
\hline, 7 & 10,3 \\
\hline & 13 \\
\hline
\end{tabular}

8

\begin{tabular}{|l|r|}
\hline 10,5 & 10,4 \\
\hline 14,0 & 14,3
\end{tabular}

\begin{tabular}{|l|l|l|l|l|}
\hline 22,2 & 21,9 & 21,8 & 21,6 & 21,4 \\
\hline
\end{tabular}

21,1

\section{Vlees- en weidevee / Beef cattle}

\begin{tabular}{|c|c|c|c|c|c|c|c|c|c|c|c|c|c|c|c|}
\hline witvleeskalveren / calves for white veal production & 1,5 & 1,7 & 1,8 & 2,0 & 2,1 & 2,4 & 2,4 & 2,4 & 2,4 & 2,4 & 2,3 & 2,4 & 3,4 & 3,6 & 3,6 \\
\hline rosévleeskalveren / calves for rosé veal production & 10,2 & 10,0 & 9,7 & 9,5 & 9,3 & 9,1 & 9,0 & 8,9 & 8,8 & 8,8 & 8,8 & 8,8 & 8,5 & 9,0 & 9,0 \\
\hline vrouwelijk jongvee $<1 \mathrm{jr}$ / female young stock $<1 \mathrm{yr}$ & 6,0 & 6,0 & 6,5 & 8,0 & 8,0 & 8,0 & 8,4 & 8,6 & 8,7 & 8,7 & 8,7 & 8,9 & 8,6 & 8,2 & 8,2 \\
\hline $\begin{array}{l}\text { mannelijk jongvee (incl. ossen) }<1 \mathrm{jr} / \text { male young } \\
\text { stock (incl. bullocks) }<1 \mathrm{yr}\end{array}$ & 11,3 & 11,2 & 11,0 & 10,9 & 10,7 & 10,6 & 10,5 & 10,4 & 10,3 & 10,3 & 10,3 & 10,3 & 10,6 & 10,7 & 10,5 \\
\hline vrouwelijk jongvee $1-2 \mathrm{jr} /$ female young stock $1-2 \mathrm{yr}$ & 10,2 & 9,7 & 10,2 & 11,3 & 11,4 & 11,4 & 13,0 & 13,5 & 13,7 & 13,7 & 13,7 & 14,4 & 13,8 & 13,8 & 14,0 \\
\hline $\begin{array}{l}\text { mannelijk jongvee (incl. ossen) } 1-2 \mathrm{jr} / \text { male young } \\
\text { stock (incl. bullocks) } 1-2 \mathrm{yr}\end{array}$ & 20,9 & 20,7 & 20,4 & 20,2 & 19,9 & 19,7 & 19,6 & 19,4 & 19,3 & 19,3 & 19,3 & 19,3 & 19,5 & 19,5 & 19,3 \\
\hline vrouwelijk jongvee $\geq 2 \mathrm{jr}$ / female young stock $\geq 2 \mathrm{yr}$ & 10,2 & 9,7 & 10,2 & 11,3 & 11,4 & 11,4 & 13,0 & 13,5 & 13,7 & 13,7 & 13,7 & 14,4 & 13,8 & 13,7 & 14,1 \\
\hline $\begin{array}{l}\text { mannelijk jongvee (incl. ossen) } \geq 2 \mathrm{jr} / \text { male young } \\
\text { stock (incl. bullocks) } \geq 2 \mathrm{yr}\end{array}$ & 20,9 & 20,7 & 20,4 & 20,2 & 19,9 & 19,7 & 19,6 & 19,4 & 19,3 & 19,3 & 19,3 & 19,3 & 19,5 & 19,5 & 19,3 \\
\hline $\begin{array}{l}\text { zoog-, mest- en weidekoeien } \geq 2 \mathrm{jr} / \text { suckling cows } \\
\text { and female fatteners } \geq 2 \mathrm{yr}\end{array}$ & 9,8 & 9,9 & 9,9 & 10,0 & 10,0 & 10,1 & 10,2 & 10,3 & 10,4 & 10,4 & 10,4 & 10,4 & 10,7 & 10,8 & 10,7 \\
\hline \multicolumn{16}{|l|}{ Varkens / Pigs } \\
\hline vleesvarkens / fattening pigs & 9,7 & 9,4 & 9,2 & 8,8 & 8,6 & 8,3 & 7,9 & 7,4 & 7,0 & 6,9 & 6,6 & 6,3 & 6,5 & 6,5 & 6,7 \\
\hline opfokzeugen / gilts & 11,9 & 11,7 & 11,4 & 11,0 & 10,8 & 10,4 & 10,0 & 9,5 & 9,2 & 9,0 & 8,7 & 8,3 & 8,7 & 8,6 & 8,6 \\
\hline zeugen / sows & 25,7 & 25,3 & 24,9 & 24,3 & 23,9 & 23,3 & 22,6 & 21,6 & 21,1 & 20,6 & 19,9 & 19,0 & 20,4 & 19,9 & 19,6 \\
\hline opfokberen / young boars & 11,9 & 11,7 & 11,4 & 11,0 & 10,8 & 10,4 & 10,0 & 9,5 & 9,2 & 9,0 & 8,7 & 8,3 & 8,7 & 8,6 & 8,6 \\
\hline dekberen / breeding boars & 17,2 & 16,8 & 16,4 & 15,8 & 15,4 & 14,9 & 14,3 & 13,5 & 13,1 & 12,8 & 12,4 & 11,8 & 12,4 & 12,1 & 11,9 \\
\hline
\end{tabular}

212 | wot-technical report 203 


\begin{tabular}{|c|c|c|c|c|c|c|c|c|c|c|c|c|c|c|c|}
\hline Diercategorie / Livestock category & 2005 & 2006 & 2007 & 2008 & 2009 & 2010 & 2011 & 2012 & 2013 & 2014 & 2015 & 2016 & 2017 & 2018 & 2019 \\
\hline \multicolumn{16}{|l|}{$\begin{array}{l}\text { Pluimvee en pelsdieren / Poultry and fur-bearing } \\
\text { animals }\end{array}$} \\
\hline leghennen $<18$ weken / laying hens $<18$ weeks & 0,33 & 0,33 & 0,33 & 0,33 & 0,33 & 0,33 & 0,33 & $\begin{array}{r}\text { n.v.t./ } \\
\text { n.a. }\end{array}$ & $\begin{array}{r}\text { n.v.t./ } \\
\text { n.a. }\end{array}$ & $\begin{array}{r}\text { n.v.t./ } \\
\text { n.a. }\end{array}$ & $\begin{array}{r}\text { n.v.t./ } \\
\text { n.a. }\end{array}$ & $\begin{array}{r}\text { n.v.t./ } \\
\text { n.a. }\end{array}$ & $\begin{array}{r}\text { n.v.t./ } \\
\text { n.a. }\end{array}$ & $\begin{array}{r}\text { n.v.t./ } \\
\text { n.a. }\end{array}$ & $\begin{array}{r}\text { n.v.t./ } \\
\text { n.a. }\end{array}$ \\
\hline leghennen $\geq 18$ weeks / laying hens $\geq 18$ weeks & 0,69 & 0,69 & 0,69 & 0,69 & 0,69 & 0,70 & 0,70 & $\begin{array}{r}\text { n.v.t./ } \\
\text { n.a. }\end{array}$ & $\begin{array}{r}\text { n.v.t./ } \\
\text { n.a. }\end{array}$ & $\begin{array}{r}\text { n.v.t./ } \\
\text { n.a. }\end{array}$ & $\begin{array}{r}\text { n.v.t./ } \\
\text { n.a. }\end{array}$ & $\begin{array}{r}\text { n.v.t./ } \\
\text { n.a. }\end{array}$ & $\begin{array}{r}\text { n.v.t./ } \\
\text { n.a. }\end{array}$ & $\begin{array}{r}\text { n.v.t./ } \\
\text { n.a. }\end{array}$ & $\begin{array}{r}\text { n.v.t./ } \\
\text { n.a. }\end{array}$ \\
\hline pelsdieren (teven) / fur-bearing animals (dams) & 0,68 & 0,68 & 0,68 & 0,68 & 0,68 & 0,68 & 0,68 & 0,68 & 0,68 & 0,68 & 0,68 & 0,68 & 0,68 & 0,68 & 0,68 \\
\hline
\end{tabular}

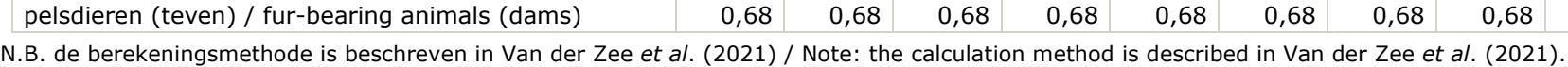




\begin{tabular}{|c|c|c|c|c|c|c|c|c|c|c|c|c|c|c|c|}
\hline Diercategorie / Livestock category & 1990 & 1991 & 1992 & 1993 & 1994 & 1995 & 1996 & 1997 & 1998 & 1999 & 2000 & 2001 & 2002 & 2003 & 2004 \\
\hline \multicolumn{16}{|l|}{ Melk- en fokvee / Dairy cattle } \\
\hline vrouwelijk jongvee $<1 \mathrm{jr} /$ female young stock $<1 \mathrm{yr}$ & 0,8 & 0,8 & 0,8 & 0,8 & 0,9 & 0,9 & 0,9 & 0,9 & 0,9 & 0,9 & 0,9 & 0,9 & 0,8 & 0,7 & 0,7 \\
\hline mannelijk jongvee $<1 \mathrm{jr} /$ male young stock $<1 \mathrm{yr}$ & 1,4 & 1,4 & 1,4 & 1,4 & 1,4 & 1,4 & 1,4 & 1,4 & 1,3 & 1,3 & 1,3 & 1,3 & 1,3 & 1,3 & 1,4 \\
\hline vrouwelijk jongvee $1-2 \mathrm{jr} /$ female young stock $1-2 \mathrm{yr}$ & 1,2 & 1,2 & 1,2 & 1,2 & 1,2 & 1,2 & 1,2 & 1,2 & 1,2 & 1,2 & 1,2 & 1,2 & 1,2 & 1,2 & 1,2 \\
\hline mannelijk jongvee $1-2 \mathrm{jr} /$ male young stock $1-2 \mathrm{yr}$ & 2,7 & 2,7 & 2,8 & 2,8 & 2,8 & 2,9 & 2,9 & 2,8 & 2,8 & 2,8 & 2,8 & 2,7 & 2,7 & 2,7 & 2,6 \\
\hline vrouwelijk jongvee $\geq 2 \mathrm{jr} /$ female young stock $\geq 2 \mathrm{yr}$ & 1,2 & 1,2 & 1,2 & 1,2 & 1,2 & 1,2 & 1,2 & 1,2 & 1,2 & 1,2 & 1,2 & 1,2 & 1,2 & 1,2 & 1,2 \\
\hline melk- en kalfkoeien / dairy cows & 2,9 & 2,9 & 2,8 & 2,9 & 2,9 & 2,9 & 3,0 & 3,0 & 3,1 & 3,2 & 3,3 & 3,3 & 3,7 & 3,7 & 3,6 \\
\hline fokstieren $\geq 2 \mathrm{jr} /$ breeding bulls $\geq 2 \mathrm{yr}$ & 2,7 & 2,7 & 2,8 & 2,8 & 2,8 & 2,9 & 2,9 & 2,8 & 2,8 & 2,8 & 2,8 & 2,7 & 2,7 & 2,7 & 2,6 \\
\hline & & & & & & & & & & & & & & & \\
\hline \multicolumn{16}{|l|}{ Vlees- en weidevee / Beef cattle } \\
\hline vrouwelijk jongvee $<1 \mathrm{jr} /$ female young stock $<1 \mathrm{yr}$ & 0,8 & 0,8 & 0,8 & 0,8 & 0,9 & 0,9 & 0,9 & 0,9 & 0,9 & 0,9 & 0,9 & 0,9 & 0,8 & 0,7 & 0,7 \\
\hline $\begin{array}{l}\text { mannelijk jongvee (incl. ossen) }<1 \mathrm{jr} / \text { male young } \\
\text { stock (incl. bullocks) }<1 \mathrm{yr}\end{array}$ & 1,3 & 1,3 & 1,3 & 1,4 & 1,4 & 1,4 & 1,4 & 1,4 & 1,3 & 1,3 & 1,3 & 1,3 & 1,3 & 1,3 & 1,3 \\
\hline vrouwelijk jongvee $1-2 \mathrm{jr} /$ female young stock $1-2 \mathrm{yr}$ & 1,2 & 1,2 & 1,2 & 1,2 & 1,2 & 1,2 & 1,2 & 1,2 & 1,2 & 1,2 & 1,2 & 1,2 & 1,2 & 1,2 & 1,2 \\
\hline $\begin{array}{l}\text { mannelijk jongvee (incl. ossen) } 1-2 \mathrm{jr} / \text { male young } \\
\text { stock (incl. bullocks) } 1-2 \mathrm{yr}\end{array}$ & 2,8 & 2,8 & 2,7 & 2,7 & 2,6 & 2,6 & 2,5 & 2,5 & 2,4 & 2,4 & 2,3 & 2,4 & 2,4 & 2,4 & 2,4 \\
\hline vrouwelijk jongvee $\geq 2 \mathrm{jr}$ / female young stock $\geq 2 \mathrm{yr}$ & 1,2 & 1,2 & 1,2 & 1,2 & 1,2 & 1,2 & 1,2 & 1,2 & 1,2 & 1,2 & 1,2 & 1,2 & 1,2 & 1,2 & 1,2 \\
\hline $\begin{array}{l}\text { mannelijk jongvee (incl. ossen) } \geq 2 \mathrm{jr} / \text { male young } \\
\text { stock (incl. bullocks) } \geq 2 \mathrm{yr}\end{array}$ & 2,8 & 2,8 & 2,7 & 2,7 & 2,6 & 2,6 & 2,5 & 2,5 & 2,4 & 2,4 & 2,3 & 2,4 & 2,4 & 2,4 & 2,4 \\
\hline $\begin{array}{l}\text { zoog-, mest- en weidekoeien } \geq 2 \mathrm{jr} / \text { suckling cows } \\
\text { and female fatteners } \geq 2 \mathrm{yr}\end{array}$ & 1,1 & 1,1 & 1,1 & 1,1 & 1,1 & 1,1 & 1,1 & 1,1 & 1,1 & 1,1 & 1,1 & 1,1 & 1,1 & 1,1 & 1,1 \\
\hline \multicolumn{16}{|l|}{ Varkens / Pigs } \\
\hline zeugen / sows & 1,6 & 1,6 & 1,6 & 1,6 & 1,6 & 1,6 & 1,6 & 1,4 & 1,5 & 1,5 & 1,5 & 1,5 & 1,5 & 1,5 & 1,4 \\
\hline dekberen / breeding boars & 1,2 & 1,2 & 1,2 & 1,2 & 1,1 & 1,1 & 1,1 & 1,1 & 1,1 & 1,1 & 1,0 & 1,0 & 1,0 & 1,0 & 1,0 \\
\hline \multirow{2}{*}{\multicolumn{16}{|c|}{ Pluimvee / Poultry }} \\
\hline & & & & & & & & & & & & & & & \\
\hline vleeskuikens / broilers & 0,03 & 0,03 & 0,03 & 0,03 & 0,03 & 0,03 & 0,03 & 0,03 & 0,03 & 0,03 & 0,03 & 0,03 & 0,03 & 0,03 & 0,03 \\
\hline $\begin{array}{l}\text { ouderdieren van vleeskuikens }<18 \text { weken / broiler } \\
\text { breeders }<18 \text { weeks }\end{array}$ & 0,02 & 0,02 & 0,02 & 0,02 & 0,02 & 0,02 & 0,02 & 0,02 & 0,02 & 0,02 & 0,02 & 0,02 & 0,02 & 0,02 & 0,02 \\
\hline $\begin{array}{l}\text { ouderdieren van vleeskuikens } \geq 18 \text { weken / broiler } \\
\text { breeders } \geq 18 \text { weeks }\end{array}$ & 0,04 & 0,04 & 0,04 & 0,04 & 0,04 & 0,04 & 0,04 & 0,04 & 0,04 & 0,04 & 0,04 & 0,04 & 0,04 & 0,04 & 0,04 \\
\hline leghennen $<18$ weken / laying hens $<18$ weeks & 0,01 & 0,01 & 0,01 & 0,01 & 0,01 & 0,01 & 0,01 & 0,01 & 0,01 & 0,01 & 0,01 & 0,01 & 0,01 & 0,01 & 0,01 \\
\hline leghennen $\geq 18$ weeks / laying hens $\geq 18$ weeks & 0,03 & 0,03 & 0,03 & 0,03 & 0,03 & 0,03 & 0,03 & 0,03 & 0,03 & 0,03 & 0,03 & 0,03 & 0,03 & 0,03 & 0,03 \\
\hline eenden / ducks & 0,03 & 0,03 & 0,03 & 0,03 & 0,03 & 0,03 & 0,03 & 0,03 & 0,03 & 0,03 & 0,03 & 0,03 & 0,03 & 0,03 & 0,03 \\
\hline kalkoenen / turkeys & 0,04 & 0,04 & 0,04 & 0,04 & 0,04 & 0,04 & 0,04 & 0,04 & 0,04 & 0,04 & 0,04 & 0,04 & 0,04 & 0,04 & 0,04 \\
\hline
\end{tabular}

\section{Overige dieren / Other livestock}

214 | wot-technical report 203 


\begin{tabular}{|c|c|c|c|c|c|c|c|c|c|c|c|c|c|c|c|}
\hline Diercategorie / Livestock category & 1990 & 1991 & 1992 & 1993 & 1994 & 1995 & 1996 & 1997 & 1998 & 1999 & 2000 & 2001 & 2002 & 2003 & 2004 \\
\hline schapen (alle) / sheep (all) & 0,19 & 0,19 & 0,19 & 0,19 & 0,19 & 0,19 & 0,19 & 0,19 & 0,19 & 0,19 & 0,19 & 0,19 & 0,19 & 0,19 & 0,19 \\
\hline geiten (alle) / goats (all) & 0,13 & 0,13 & 0,13 & 0,13 & 0,13 & 0,13 & 0,13 & 0,13 & 0,13 & 0,13 & 0,13 & 0,13 & 0,13 & 0,13 & 0,13 \\
\hline paarden / horses & 1,56 & 1,56 & 1,56 & 1,56 & 1,56 & 1,56 & 1,56 & 1,56 & 1,56 & 1,56 & 1,56 & 1,56 & 1,56 & 1,56 & 1,56 \\
\hline pony's / ponies & 1,56 & 1,56 & 1,56 & 1,56 & 1,56 & 1,56 & 1,56 & 1,56 & 1,56 & 1,56 & 1,56 & 1,56 & 1,56 & 1,56 & 1,56 \\
\hline ezels / mules & 0,76 & 0,76 & 0,76 & 0,76 & 0,76 & 0,76 & 0,76 & 0,76 & 0,76 & 0,76 & 0,76 & 0,76 & 0,76 & 0,76 & 0,76 \\
\hline konijnen (alle) / rabbits (all) & 0,08 & 0,08 & 0,08 & 0,08 & 0,08 & 0,08 & 0,08 & 0,08 & 0,08 & 0,08 & 0,08 & 0,08 & 0,08 & 0,08 & 0,08 \\
\hline
\end{tabular}

\section{$B 30.2$}

vervolg / continuation

Diercategorie / Livestock category

\section{Melk- en fokvee / Dairy cattle}

vrouwelijk jongvee $<1$ jr / female young stock $<1 \mathrm{yr}$

mannelijk jongvee $<1 \mathrm{jr} /$ male young stock $<1 \mathrm{yr}$

vrouwelijk jongvee 1-2 jr / female young stock $1-2 \mathrm{yr}$

mannelijk jongvee $1-2 \mathrm{jr} /$ male young stock $1-2 \mathrm{yr} \quad 2,6$

vrouwelijk jongvee $\geq 2 \mathrm{jr} /$ female young stock $\geq 2 \mathrm{yr}$

melk- en kalfkoeien / dairy cows

fokstieren $\geq 2 \mathrm{jr} /$ breeding bulls $\geq 2 \mathrm{yr}$

\section{Vlees- en weidevee / Beef cattle}

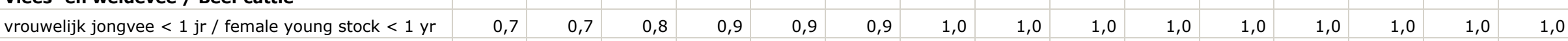

mannelijk jongvee (incl. ossen) $<1 \mathrm{jr} /$ male young

stock (incl. bullocks) $<1 \mathrm{yr}$

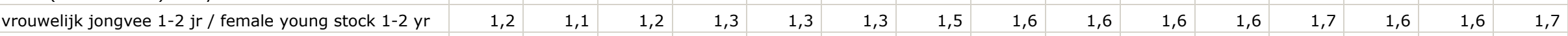

mannelijk jongvee (incl. ossen) $1-2 \mathrm{jr} /$ male youn

stock (incl. bullocks) $1-2 \mathrm{yr}$

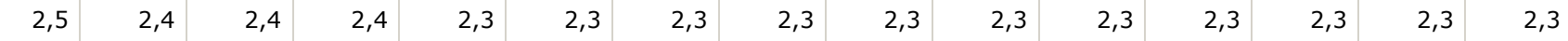

vrouwelijk jongvee $\geq 2 \mathrm{jr} /$ female young stock $\geq 2 \mathrm{yr}$

mannelijk jongvee (incl. ossen) $\geq 2 \mathrm{jr} /$ male young

stock (incl. bullocks) $\geq 2 \mathrm{yr}$

zoog-, mest- en weidekoeien $\geq 2 \mathrm{jr} /$ suckling cows

and female fatteners $\geq 2 \mathrm{yr}$

\section{Varkens / Pigs}

zeugen / sows

dekberen / breeding boars

\begin{tabular}{|l|l|l|l|l|l|l|l|l|l|l|l|l|l|l|}
1,2 & 1,1 & 1,2 & 1,3 & 1,3 & 1,3 & 1,5 & 1,6 & 1,6 & 1,6 & 1,6 & 1,7 & 1,6 & 1,6 & 1,7 \\
\hline
\end{tabular}

\begin{tabular}{|l|l|l|l|l|l|l|l|l|l|l|l|l|l|l|}
\hline 2,5 & 2,4 & 2,4 & 2,4 & 2,3 & 2,3 & 2,3 & 2,3 & 2,3 & 2,3 & 2,3 & 2,3 & 2,3 & 2,3 & 2,3 \\
\hline
\end{tabular}

\begin{tabular}{|l|r|r|r|r|r|r|r|r|r|r|r|r|r|r|r|}
\hline 1,2 & 1,2 & 1,2 & 1,2 & 1,2 & 1,2 & 1,2 & 1,2 & 1,2 & 1,2 & 1,2 & 1,2 & 1,3 & 1,3 & 1,3 \\
\hline
\end{tabular}

\section{Pluimvee / Poultry}

vleeskuikens / broilers

ouderdieren van vleeskuikens $<18$ weken / broiler

breeders $<18$ weeks

\begin{tabular}{|c|c|c|c|c|c|c|c|c|c|c|c|c|c|}
\hline 1,4 & 1,4 & 1,4 & 1,4 & 1,4 & 1,3 & 1,3 & 1,3 & 1,3 & 1,3 & 1,3 & 1,4 & 1,4 & 1,4 \\
\hline 0,9 & 0,9 & 0,9 & 0,9 & 0,9 & 0,8 & 0,8 & 0,8 & 0,8 & 0,8 & 0,8 & 0,9 & 0,9 & 0,9 \\
\hline & & & & & & & & & & & & & \\
\hline 0,03 & 0,03 & 0,03 & 0,03 & 0,03 & 0,03 & 0,03 & 0,03 & 0,03 & 0,03 & 0,03 & 0,03 & 0,03 & 0,03 \\
\hline 0,02 & 0,02 & 0,02 & 0,02 & 0,02 & 0,02 & 0,02 & 0,02 & 0,02 & 0,02 & 0,02 & 0,02 & 0,02 & 0,02 \\
\hline
\end{tabular}




\begin{tabular}{|c|c|c|c|c|c|c|c|c|c|c|c|c|c|c|c|}
\hline Diercategorie / Livestock category & 2005 & 2006 & 2007 & 2008 & 2009 & 2010 & 2011 & 2012 & 2013 & 2014 & 2015 & 2016 & 2017 & 2018 & 2019 \\
\hline $\begin{array}{l}\text { ouderdieren van vleeskuikens } \geq 18 \text { weken / broiler } \\
\text { breeders } \geq 18 \text { weeks }\end{array}$ & 0,04 & 0,04 & 0,04 & 0,04 & 0,04 & 0,04 & 0,04 & 0,04 & 0,04 & 0,04 & 0,04 & 0,04 & 0,04 & 0,04 & 0,04 \\
\hline leghennen $<18$ weken / laying hens $<18$ weeks & 0,01 & 0,01 & 0,01 & 0,01 & 0,01 & 0,01 & 0,01 & 0,01 & 0,01 & 0,01 & 0,01 & 0,01 & 0,02 & 0,02 & 0,02 \\
\hline leghennen $\geq 18$ weeks / laying hens $\geq 18$ weeks & 0,03 & 0,03 & 0,03 & 0,03 & 0,03 & 0,03 & 0,03 & 0,03 & 0,03 & 0,03 & 0,03 & 0,03 & 0,03 & 0,03 & 0,03 \\
\hline eenden / ducks & 0,03 & 0,03 & 0,03 & 0,03 & 0,03 & 0,03 & 0,03 & 0,03 & 0,03 & 0,03 & 0,03 & 0,03 & 0,04 & 0,04 & 0,04 \\
\hline kalkoenen / turkeys & 0,04 & 0,04 & 0,04 & 0,04 & 0,04 & 0,04 & 0,04 & 0,04 & 0,04 & 0,04 & 0,04 & 0,04 & 0,08 & 0,08 & 0,07 \\
\hline \multicolumn{16}{|l|}{ Overige dieren / Other livestock } \\
\hline schapen (alle) / sheep (all) & 0,19 & 0,19 & 0,19 & 0,19 & 0,19 & 0,19 & 0,19 & 0,19 & 0,19 & 0,19 & 0,19 & 0,19 & 0,19 & 0,19 & 0,19 \\
\hline geiten (alle) / goats (all) & 0,13 & 0,13 & 0,13 & 0,13 & 0,13 & 0,13 & 0,13 & 0,13 & 0,13 & 0,13 & 0,13 & 0,13 & 0,13 & 0,13 & 0,13 \\
\hline paarden / horses & 1,56 & 1,56 & 1,56 & 1,56 & 1,56 & 1,56 & 1,56 & 1,56 & 1,56 & 1,56 & 1,56 & 1,56 & 1,56 & 1,56 & 1,56 \\
\hline pony's / ponies & 1,56 & 1,56 & 1,56 & 1,56 & 1,56 & 1,56 & 1,56 & 1,56 & 1,56 & 1,56 & 1,56 & 1,56 & 1,56 & 1,56 & 1,56 \\
\hline ezels / mules & 0,76 & 0,76 & 0,76 & 0,76 & 0,76 & 0,76 & 0,76 & 0,76 & 0,76 & 0,76 & 0,76 & 0,76 & 0,76 & 0,76 & 0,76 \\
\hline konijnen (alle) / rabbits (all) & 0,08 & 0,08 & 0,08 & 0,08 & 0,08 & 0,08 & 0,08 & 0,08 & 0,08 & 0,08 & 0,08 & 0,08 & 0,08 & 0,08 & 0,08 \\
\hline
\end{tabular}

N.B. de berekeningsmethode is beschreven in Van der Zee et al. (2021) / Note: the calculation method is described in Van der Zee et al. (2021). 


\begin{tabular}{|c|c|c|c|c|c|c|c|c|c|c|c|c|c|c|c|}
\hline Diercategorie / Livestock category & 1990 & 1991 & 1992 & 1993 & 1994 & 1995 & 1996 & 1997 & 1998 & 1999 & 2000 & 2001 & 2002 & 2003 & 2004 \\
\hline \multicolumn{16}{|l|}{ Melk- en fokvee / Dairy cattle } \\
\hline vrouwelijk jongvee $<1 \mathrm{jr} /$ female young stock $<1 \mathrm{yr}$ & 0,14 & 0,15 & 0,15 & 0,15 & 0,15 & 0,15 & 0,15 & 0,15 & 0,15 & 0,15 & 0,15 & 0,15 & 0,15 & 0,21 & 0,21 \\
\hline vrouwelijk jongvee $1-2 \mathrm{jr} /$ female young stock $1-2 \mathrm{yr}$ & 0,47 & 0,47 & 0,48 & 0,48 & 0,48 & 0,48 & 0,48 & 0,48 & 0,48 & 0,47 & 0,47 & 0,47 & 0,47 & 0,47 & 0,47 \\
\hline vrouwelijk jongvee $\geq 2 \mathrm{jr} /$ female young stock $\geq 2 \mathrm{yr}$ & 0,47 & 0,47 & 0,48 & 0,48 & 0,48 & 0,48 & 0,48 & 0,48 & 0,48 & 0,47 & 0,47 & 0,47 & 0,47 & 0,47 & 0,47 \\
\hline melk- en kalfkoeien / dairy cows & 0,64 & 0,64 & 0,67 & 0,65 & 0,65 & 0,66 & 0,67 & 0,68 & 0,67 & 0,64 & 0,61 & 0,62 & 0,46 & 0,49 & 0,53 \\
\hline \multicolumn{16}{|l|}{ Vlees- en weidevee / Beef cattle } \\
\hline vrouwelijk jongvee $<1 \mathrm{jr} /$ female young stock $<1 \mathrm{yr}$ & 0,14 & 0,14 & 0,15 & 0,15 & 0,15 & 0,15 & 0,15 & 0,15 & 0,15 & 0,15 & 0,15 & 0,15 & 0,15 & 0,21 & 0,21 \\
\hline vrouwelijk jongvee $1-2 \mathrm{jr} /$ female young stock $1-2 \mathrm{yr}$ & 0,47 & 0,47 & 0,48 & 0,48 & 0,48 & 0,48 & 0,48 & 0,48 & 0,47 & 0,47 & 0,47 & 0,47 & 0,47 & 0,47 & 0,47 \\
\hline vrouwelijk jongvee $\geq 2 \mathrm{jr} /$ female young stock $\geq 2 \mathrm{yr}$ & 0,47 & 0,47 & 0,48 & 0,48 & 0,48 & 0,48 & 0,48 & 0,48 & 0,47 & 0,47 & 0,47 & 0,47 & 0,47 & 0,47 & 0,47 \\
\hline $\begin{array}{l}\text { zoog-, mest- en weidekoeien } \geq 2 \mathrm{jr} \text { / suckling cows } \\
\text { and female fatteners } \geq 2 \mathrm{yr}\end{array}$ & 0,66 & 0,67 & 0,67 & 0,67 & 0,67 & 0,67 & 0,67 & 0,67 & 0,67 & 0,67 & 0,67 & 0,68 & 0,68 & 0,69 & 0,69 \\
\hline
\end{tabular}

\section{B30.3 vervolg / continuation}

\begin{tabular}{|c|c|c|c|c|c|c|c|c|c|c|c|c|c|c|c|}
\hline Diercategorie / Livestock category & 2005 & 2006 & 2007 & 2008 & 2009 & 2010 & 2011 & 2012 & 2013 & 2014 & 2015 & 2016 & 2017 & 2018 & 2019 \\
\hline \multicolumn{16}{|l|}{ Melk- en fokvee / Dairy cattle } \\
\hline vrouwelijk jongvee $<1 \mathrm{jr} /$ female young stock $<1 \mathrm{yr}$ & 0,21 & 0,21 & 0,18 & 0,09 & 0,09 & 0,09 & 0,08 & 0,07 & 0,07 & 0,07 & 0,07 & 0,06 & 0,05 & 0,05 & 0,05 \\
\hline vrouwelijk jongvee $1-2 \mathrm{jr} /$ female young stock $1-2 \mathrm{yr}$ & 0,47 & 0,50 & 0,49 & 0,41 & 0,42 & 0,42 & 0,35 & 0,34 & 0,35 & 0,35 & 0,35 & 0,31 & 0,27 & 0,27 & 0,26 \\
\hline vrouwelijk jongvee $\geq 2 \mathrm{jr} /$ female young stock $\geq 2 \mathrm{yr}$ & 0,47 & 0,50 & 0,49 & 0,41 & 0,42 & 0,42 & 0,35 & 0,34 & 0,35 & 0,35 & 0,35 & 0,31 & 0,27 & 0,27 & 0,26 \\
\hline melk- en kalfkoeien / dairy cows & 0,53 & 0,49 & 0,44 & 0,54 & 0,43 & 0,40 & 0,37 & 0,35 & 0,36 & 0,35 & 0,32 & 0,28 & 0,29 & 0,29 & 0,30 \\
\hline \multicolumn{16}{|l|}{ Vlees- en weidevee / Beef cattle } \\
\hline vrouwelijk jongvee $<1 \mathrm{jr} /$ female young stock $<1 \mathrm{yr}$ & 0,20 & 0,20 & 0,18 & 0,09 & 0,09 & 0,09 & 0,08 & 0,07 & 0,07 & 0,07 & 0,07 & 0,06 & 0,05 & 0,05 & 0,05 \\
\hline vrouwelijk jongvee $1-2 \mathrm{jr} /$ female young stock $1-2 \mathrm{yr}$ & 0,47 & 0,50 & 0,48 & 0,42 & 0,42 & 0,42 & 0,35 & 0,34 & 0,35 & 0,35 & 0,35 & 0,30 & 0,26 & 0,26 & 0,25 \\
\hline vrouwelijk jongvee $\geq 2 \mathrm{jr} /$ female young stock $\geq 2 \mathrm{yr}$ & 0,47 & 0,50 & 0,48 & 0,42 & 0,42 & 0,42 & 0,35 & 0,34 & 0,35 & 0,35 & 0,35 & 0,30 & 0,26 & 0,26 & 0,25 \\
\hline $\begin{array}{l}\text { zoog-, mest- en weidekoeien } \geq 2 \mathrm{jr} / \text { suckling cows } \\
\text { and female fatteners } \geq 2 \mathrm{yr}\end{array}$ & 0,70 & 0,70 & 0,71 & 0,71 & 0,72 & 0,72 & 0,73 & 0,73 & 0,74 & 0,74 & 0,74 & 0,74 & 0,76 & 0,77 & 0,77 \\
\hline
\end{tabular}

N.B. de berekeningsmethode is beschreven in Van der Zee et al. (2021) / Note: the calculation method is described in Van der Zee et al. (2021). 



\section{Bijlage 31 Organische stof in aanvoer naar mestbewerking}

B31.1

OS-aanvoer per mestbewerkingstechniek (miljoen kg OS) / OS-supply per manure treatment technique (million kg OS).

\begin{tabular}{|c|c|c|c|c|c|c|c|c|c|c|c|c|c|c|c|}
\hline $\begin{array}{l}\text { Mestbewerkingsproces / Manure treatment } \\
\text { process }\end{array}$ & 1990 & 1991 & 1992 & 1993 & 1994 & 1995 & 1996 & 1997 & 1998 & 1999 & 2000 & 2001 & 2002 & 2003 & 2004 \\
\hline \multicolumn{16}{|c|}{$\begin{array}{l}\text { Mestscheiding en kalvergierzuivering / } \\
\text { Separation of slurry and treatment of veal calves } \\
\text { slurry }\end{array}$} \\
\hline \multicolumn{16}{|l|}{ Drijfmest melkkoeien / Dairy cows slurry } \\
\hline \multicolumn{16}{|l|}{ Drijfmest jongvee / Young stock slurry } \\
\hline Vleeskalvermest / Veal calves slurry & 4,5 & 4,7 & 4,9 & 5,2 & 5,4 & 11,4 & 14,3 & 14,2 & 10,0 & 9,8 & 11,7 & 11,4 & 10,5 & 10,0 & 11,6 \\
\hline \multicolumn{16}{|l|}{ Vleesvarkens / Fattening pig slurry } \\
\hline \multicolumn{16}{|l|}{ Drijfmest fokvarkens / Breeding pig slurry } \\
\hline \multicolumn{16}{|l|}{ Mineralenconcentraat / Mineral concentrates } \\
\hline \multicolumn{16}{|l|}{ Drijfmest vleesvarkens / Fattening pig slurry } \\
\hline \multicolumn{16}{|l|}{ Drijfmest fokvarkens / Breeding pig slurry } \\
\hline \multicolumn{16}{|l|}{ Mestvergisting / Maure digestion } \\
\hline \multicolumn{16}{|l|}{ Drijfmest melkkoeien / Dairy cows slurry } \\
\hline \multicolumn{16}{|l|}{ Drijfmest jongvee / Young stock slurry } \\
\hline \multicolumn{16}{|l|}{ Drijfmest vleesvarkens / Fattening pig slurry } \\
\hline \multicolumn{16}{|l|}{ Drijfmest fokvarkens / Breeding pig slurry } \\
\hline \multicolumn{16}{|c|}{$\begin{array}{l}\text { Mest drogen en korrelen / Drying and pelletizing } \\
\text { manure }\end{array}$} \\
\hline Legpluimveemest / Laying poultry solid manure & & & & & & & & & 31,9 & 45,9 & 30,6 & 27,9 & 27,7 & 29,3 & 38,0 \\
\hline \multicolumn{16}{|l|}{ Vleeskuikenmest / Broiler litter } \\
\hline \multicolumn{16}{|l|}{$\begin{array}{l}\text { Mestverbranding (vooropslag) / Manure } \\
\text { incineration (pre-storage) }\end{array}$} \\
\hline Legpluimveemest / Laying poultry solid manure & & & & & & & & & & & & 8,4 & 14,9 & 7,5 & 13,8 \\
\hline \multicolumn{16}{|l|}{ Vleeskuikenmest / Broiler litter } \\
\hline Kalkoenenmest / Turkey manure & & & & & & & & & & & & & & & \\
\hline
\end{tabular}




\begin{tabular}{|c|c|c|c|c|c|c|c|c|c|c|c|c|c|c|c|}
\hline $\begin{array}{l}\text { Mestbewerkingsproces / Manure treatment } \\
\text { process }\end{array}$ & 2005 & 2006 & 2007 & 2008 & 2009 & 2010 & 2011 & 2012 & 2013 & 2014 & 2015 & 2016 & 2017 & 2018 & 2019 \\
\hline \multicolumn{16}{|c|}{$\begin{array}{l}\text { Mestscheiding en kalvergierzuivering / } \\
\text { Separation of slurry and treatment of veal calves } \\
\text { slurry }\end{array}$} \\
\hline Drijfmest melkkoeien / Dairy cows slurry & & & & & 2,5 & 6,9 & 11,7 & 22,5 & 32,5 & 51,6 & 94,7 & 131,9 & 92,1 & 41,7 & 31,0 \\
\hline Drijfmest jongvee / Young stock slurry & & & & & 0,5 & 1,4 & 2,5 & 4,8 & 7,0 & 11,3 & 20,4 & 26,1 & 17,0 & 6,7 & 4,8 \\
\hline Vleeskalvermest / Veal calves slurry & 13,0 & 13,0 & 17,0 & 20,7 & 22,3 & 20,2 & 17,0 & 17,1 & 17,5 & 15,1 & 20,3 & 15,8 & 24,8 & 23,5 & 30,9 \\
\hline Vleesvarkens / Fattening pig slurry & & & & & 11,2 & 19,2 & 34,8 & 51,6 & 52,2 & 65,6 & 106,2 & 142,5 & 161,2 & 175,6 & 208,5 \\
\hline Drijfmest fokvarkens / Breeding pig slurry & & & & & 5,6 & 9,6 & 17,9 & 25,9 & 27,3 & 35,3 & 56,1 & 73,4 & 87,0 & 92,0 & 100,9 \\
\hline \multicolumn{16}{|l|}{ Mineralenconcentraat / Mineral concentrates } \\
\hline Drijfmest vleesvarkens / Fattening pig slurry & & & & & & & 18,8 & 29,5 & 31,1 & 19,1 & 40,1 & 38,7 & 48,4 & 50,9 & 50,9 \\
\hline Drijfmest fokvarkens / Breeding pig slurry & & & & & & & 4,7 & 7,6 & 5,6 & 4,3 & 6,8 & 7,2 & 10,5 & 12,1 & 13,0 \\
\hline \multicolumn{16}{|l|}{ Mestvergisting / Maure digestion } \\
\hline Drijfmest melkkoeien / Dairy cows slurry & & 12,9 & 17,1 & 27,0 & 35,8 & 61,3 & 76,1 & 85,4 & 89,5 & 73,4 & 54,4 & 62,9 & 49,7 & 44,1 & 41,6 \\
\hline Drijfmest jongvee / Young stock slurry & & 2,0 & 2,7 & 4,8 & 6,9 & 12,9 & 16,5 & 18,2 & 19,2 & 16,0 & 11,7 & 12,4 & 9,2 & 7,1 & 6,4 \\
\hline Drijfmest vleesvarkens / Fattening pig slurry & & 6,5 & 14,5 & 35,4 & 29,5 & 39,2 & 37,8 & 54,9 & 65,3 & 80,0 & 74,4 & 82,3 & 98,0 & 75,9 & 84,4 \\
\hline Drijfmest fokvarkens / Breeding pig slurry & & 3,1 & 7,1 & 17,3 & 14,5 & 20,1 & 19,4 & 27,6 & 34,1 & 43,0 & 39,3 & 42,4 & 52,9 & 39,8 & 40,9 \\
\hline \multicolumn{16}{|c|}{$\begin{array}{l}\text { Mest drogen en korrelen / Drying and pelletizing } \\
\text { manure }\end{array}$} \\
\hline Legpluimveemest / Laying poultry solid manure & 37,9 & 35,4 & 31,1 & 39,1 & 47,9 & 44,3 & 43,6 & 53,2 & 49,5 & 57,3 & 72,9 & 80,1 & 89,6 & 83,6 & 87,8 \\
\hline Vleeskuikenmest / Broiler litter & & & 8,8 & 3,8 & 2,7 & 4,3 & 5,1 & 0,3 & 0,2 & 7,9 & 19,8 & 14,4 & 11,5 & 11,9 & 13,1 \\
\hline \multicolumn{16}{|l|}{$\begin{array}{l}\text { Mestverbranding (vooropslag) / Manure } \\
\text { incineration (pre-storage) }\end{array}$} \\
\hline Legpluimveemest / Laying poultry solid manure & 14,9 & 6,1 & & 67,7 & 97,7 & 106,3 & 113,4 & 114,8 & 123,3 & 120,1 & 123,3 & 110,1 & 101,1 & 74,7 & 83,2 \\
\hline Vleeskuikenmest / Broiler litter & & & & 40,5 & 108,4 & 172,4 & 151,1 & 204,8 & 185,2 & 192,8 & 200,8 & 188,4 & 210,1 & 191,0 & 244,0 \\
\hline Kalkoenenmest / Turkey manure & & & & 4,7 & 6,8 & 8,4 & 7,8 & 8,5 & 7,7 & 7,4 & 8,1 & 6,6 & 12,9 & 12,4 & 12,8 \\
\hline
\end{tabular}

Bronnen: Vervoersbewijzen Dierlijke Mest (bewerkt) en praktijkgegevens mestscheiding / Sources: Registered transports of livestock manure (adapted) and practice data on manure separation 


\section{Bijlage 32 Verhouding tussen $\mathrm{NH}_{3}$ bij mesttoediening en bij huisvesting}

B32.1 Verhouding tussen $\mathrm{NH}_{3}$-emissie bij mesttoedening en bij huisvesting / Ratio between $\mathrm{NH}_{3}$ emission from manure application and from housing.

\begin{tabular}{|c|c|c|c|c|c|c|c|c|c|c|c|c|c|c|c|}
\hline Diercategorie / Livestock category & 1990 & 1991 & 1992 & 1993 & 1994 & 1995 & 1996 & 1997 & 1998 & 1999 & 2000 & 2001 & 2002 & 2003 & 2004 \\
\hline Jongvee voor de melkveehouderij / Young dairy cattle & 5,0 & 4,9 & 3,6 & 3,7 & 3,1 & 2,1 & 2,1 & 2,1 & 2,1 & 2,2 & 2,1 & 2,0 & 1,9 & 1,8 & 1,7 \\
\hline Melkkoeien / Dairy cows & 3,9 & 3,9 & 2,7 & 2,9 & 2,3 & 1,4 & 1,4 & 1,4 & 1,4 & 1,5 & 1,5 & 1,4 & 1,3 & 1,3 & 1,2 \\
\hline Vleeskalveren / Fattening calves & 1,6 & 1,6 & 1,3 & 1,3 & 1,0 & 0,5 & 0,5 & 0,5 & 0,5 & 0,6 & 0,5 & 0,6 & 0,5 & 0,6 & 0,6 \\
\hline Overig vleesvee / Other beef cattle & 4,7 & 4,7 & 3,5 & 3,7 & 3,1 & 2,3 & 2,2 & 2,2 & 2,2 & 2,3 & 2,2 & 2,2 & 2,1 & 2,0 & 1,9 \\
\hline Zoog-, mest- en weidekoeien & 4,8 & 4,8 & 3,6 & 3,7 & 3,1 & 2,2 & 2,2 & 2,3 & 2,3 & 2,3 & 2,2 & 2,2 & 2,1 & 2,0 & 1,9 \\
\hline Vleesvarkens / Fattening pigs & 0,9 & 0,9 & 0,6 & 0,6 & 0,5 & 0,3 & 0,3 & 0,3 & 0,3 & 0,3 & 0,3 & 0,3 & 0,3 & 0,3 & 0,3 \\
\hline Fokvarkens / Breeding pigs & 1,6 & 1,5 & 0,9 & 0,9 & 0,8 & 0,6 & 0,6 & 0,6 & 0,6 & 0,6 & 0,5 & 0,5 & 0,5 & 0,5 & 0,5 \\
\hline Legpluimvee / Laying poultry & 2,1 & 2,1 & 1,6 & 1,5 & 1,2 & 1,1 & 1,1 & 1,1 & 0,8 & 0,7 & 0,6 & 0,5 & 0,4 & 0,4 & 0,2 \\
\hline Vleeskuikens / Broilers & 1,2 & 1,7 & 1,1 & 0,6 & 0,1 & 0,1 & 0,9 & 1,2 & 1,3 & 1,1 & 0,9 & 0,6 & 0,5 & 1,3 & 1,6 \\
\hline Eenden / Ducks & 1,4 & 1,5 & 1,3 & 1,2 & 1,2 & 1,1 & 1,0 & 1,1 & 1,1 & 1,1 & 1,1 & 1,1 & 1,1 & 1,1 & 1,0 \\
\hline Kalkoenen / Turkeys & 0,8 & 0,8 & 0,7 & 0,7 & 0,7 & 0,6 & 0,6 & 0,6 & 0,6 & 0,6 & 0,5 & 0,5 & 0,4 & 0,4 & 0,3 \\
\hline Schapen / Sheep & 1,4 & 1,5 & 1,3 & 1,4 & 1,3 & 1,4 & 1,4 & 1,3 & 1,4 & 1,3 & 1,3 & 1,3 & 1,3 & 1,3 & 1,3 \\
\hline Geiten / Goats & 2,5 & 2,6 & 2,3 & 2,4 & 2,3 & 2,4 & 2,4 & 2,4 & 2,4 & 2,3 & 2,3 & 2,3 & 2,3 & 2,3 & 2,3 \\
\hline Paarden / Horses & 2,1 & 2,2 & 1,9 & 2,0 & 1,9 & 2,0 & 2,0 & 2,0 & 2,0 & 1,9 & 1,9 & 1,9 & 1,9 & 1,9 & 1,9 \\
\hline Pony's / Ponies & 2,1 & 2,2 & 1,9 & 2,0 & 1,9 & 2,0 & 2,0 & 2,0 & 2,0 & 1,9 & 1,9 & 1,9 & 1,9 & 1,9 & 1,9 \\
\hline Ezels / Mules and asses & $\begin{array}{r}\text { n.v.t./ } \\
\text { n.a. }\end{array}$ & $\begin{array}{r}\text { n.v.t./ } \\
\text { n.a. }\end{array}$ & $\begin{array}{r}\text { n.v.t./ } \\
\text { n.a. }\end{array}$ & $\begin{array}{r}\text { n.v.t./ } \\
\text { n.a. }\end{array}$ & $\begin{array}{r}\text { n.v.t./ } \\
\text { n.a. }\end{array}$ & $\begin{array}{r}\text { n.v.t./ } \\
\text { n.a. }\end{array}$ & $\begin{array}{r}\text { n.v.t./ } \\
\text { n.a. }\end{array}$ & $\begin{array}{r}\text { n.v.t./ } \\
\text { n.a. }\end{array}$ & $\begin{array}{r}\text { n.v.t./ } \\
\text { n.a. }\end{array}$ & $\begin{array}{r}\text { n.v.t./ } \\
\text { n.a. }\end{array}$ & $\begin{array}{r}\text { n.v.t./ } \\
\text { n.a. }\end{array}$ & $\begin{array}{r}\text { n.v.t./ } \\
\text { n.a. }\end{array}$ & $\begin{array}{r}\text { n.v.t./ } \\
\text { n.a. }\end{array}$ & $\begin{array}{r}\text { n.v.t./ } \\
\text { n.a. }\end{array}$ & $\begin{aligned} \text { n.v.t./ } \\
\text { n.a. }\end{aligned}$ \\
\hline Pelsdieren / Fur-bearing animals & 6,2 & 6,0 & 4,1 & 3,9 & 2,5 & 1,7 & 1,9 & 2,5 & 2,2 & 2,2 & 1,6 & 0,8 & 0,0 & 0,0 & 0,0 \\
\hline Konijnen / Rabbits & 0,4 & 0,4 & 0,4 & 0,4 & 0,4 & 0,3 & 0,3 & 0,3 & 0,3 & 0,3 & 0,3 & 0,3 & 0,3 & 0,0 & 0,0 \\
\hline Paarden - particulieren / Horses - private parties & 1,4 & 1,4 & 1,4 & 1,4 & 1,4 & 1,4 & 1,4 & 1,4 & 1,4 & 1,4 & 1,4 & 1,4 & 1,4 & 1,4 & 1,4 \\
\hline Pony's - particulieren / Ponies - private parties & 1,4 & 1,4 & 1,4 & 1,4 & 1,4 & 1,4 & 1,4 & 1,4 & 1,4 & 1,4 & 1,4 & 1,4 & 1,4 & 1,4 & 1,4 \\
\hline $\begin{array}{l}\text { Ezels - particulieren / Mules and asses - private } \\
\text { parties }\end{array}$ & $\begin{array}{r}\text { n.v.t./ } \\
\text { n.a. }\end{array}$ & $\begin{array}{r}\text { n.v.t./ } \\
\text { n.a. }\end{array}$ & $\begin{array}{r}\text { n.v.t./ } \\
\text { n.a. }\end{array}$ & $\begin{array}{r}\text { n.v.t./ } \\
\text { n.a. }\end{array}$ & $\begin{array}{r}\text { n.v.t./ } \\
\text { n.a. }\end{array}$ & $\begin{array}{r}\text { n.v.t./ } \\
\text { n.a. }\end{array}$ & $\begin{array}{r}\text { n.v.t./ } \\
\text { n.a. }\end{array}$ & $\begin{array}{r}\text { n.v.t./ } \\
\text { n.a. }\end{array}$ & $\begin{array}{r}\text { n.v.t./ } \\
\text { n.a. }\end{array}$ & $\begin{array}{r}\text { n.v.t./ } \\
\text { n.a. }\end{array}$ & $\begin{array}{r}\text { n.v.t./ } \\
\text { n.a. }\end{array}$ & $\begin{array}{r}\text { n.v.t./ } \\
\text { n.a. }\end{array}$ & $\begin{array}{r}\text { n.v.t./ } \\
\text { n.a. }\end{array}$ & $\begin{array}{r}\text { n.v.t./ } \\
\text { n.a. }\end{array}$ & $\begin{array}{r}\text { n.v.t./ } \\
\text { n.a. }\end{array}$ \\
\hline Schap & $\begin{array}{r}\text { n.v.t./ } \\
\text { n.a. }\end{array}$ & $\begin{array}{r}\text { n.v.t./ } \\
\text { n.a. }\end{array}$ & $\begin{array}{r}\text { n.v.t./ } \\
\text { n.a. }\end{array}$ & $\begin{array}{r}\text { n.v.t./ } \\
\text { n.a. }\end{array}$ & $\begin{array}{r}\text { n.v.t./ } \\
\text { n.a. }\end{array}$ & $\begin{array}{r}\text { n.v.t./ } \\
\text { n.a. }\end{array}$ & $\begin{array}{r}\text { n.v.t./ } \\
\text { n.a. }\end{array}$ & $\begin{array}{r}\text { n.v.t./ } \\
\text { n.a. }\end{array}$ & $\begin{array}{r}\text { n.v.t./ } \\
\text { n.a. }\end{array}$ & $\begin{array}{r}\text { n.v.t./ } \\
\text { n.a. }\end{array}$ & $\begin{array}{r}\text { n.v.t./ } \\
\text { n.a. }\end{array}$ & $\begin{array}{r}\text { n.v.t./ } \\
\text { n.a. }\end{array}$ & $\begin{array}{r}\text { n.v.t./ } \\
\text { n.a. }\end{array}$ & $\begin{array}{r}\text { n.v.t./ } \\
\text { n.a. }\end{array}$ & $\begin{array}{r}\text { n.v.t./ } \\
\text { n.a. }\end{array}$ \\
\hline
\end{tabular}


Diercategorie / Livestock category

\begin{tabular}{|c|c|c|c|c|c|c|c|c|c|c|c|c|c|c|c|}
\hline & & & & & & & & & & & & & & & \\
\hline Jongvee voor de melkveehouderij / Young dairy cattle & 1,7 & 1,6 & 1,5 & 1,1 & 1,1 & 1,2 & 1,0 & 1,1 & 1,0 & 1,0 & 1,0 & 1,2 & 1,1 & 1,1 & 1,1 \\
\hline Melkkoeien / Dairy cows & 1,1 & 1,1 & 1,1 & 0,9 & 0,9 & 0,9 & 1,0 & 1,0 & 1,0 & 1,0 & 0,9 & 0,9 & 0,8 & 0,8 & 0,8 \\
\hline Vleeskalveren / Fattening calves & 0,6 & 0,6 & 0,6 & 0,3 & 0,4 & 0,3 & 0,2 & 0,3 & 0,3 & 0,3 & 0,3 & 0,3 & 0,3 & 0,3 & 0,3 \\
\hline Overig vleesvee / Other beef cattle & 1,8 & 1,8 & 1,7 & 1,4 & 1,4 & 1,5 & 1,6 & 1,6 & 1,5 & 1,7 & 1,7 & 1,5 & 1,6 & 1,7 & 1,7 \\
\hline Zoog-, mest- en weidekoeien & 1,8 & 1,7 & 1,6 & 1,4 & 1,4 & 1,4 & 1,5 & 1,5 & 1,5 & 1,5 & 1,5 & 1,5 & 1,8 & 1,8 & 1,8 \\
\hline Vleesvarkens / Fattening pigs & 0,4 & 0,4 & 0,4 & 0,2 & 0,2 & 0,2 & 0,3 & 0,3 & 0,4 & 0,3 & 0,3 & 0,2 & 0,2 & 0,2 & 0,3 \\
\hline Fokvarkens / Breeding pigs & 0,6 & 0,6 & 0,6 & 0,3 & 0,4 & 0,4 & 0,3 & 0,4 & 0,6 & 0,6 & 0,6 & 0,4 & 0,4 & 0,4 & 0,5 \\
\hline Legpluimvee / Laying poultry & 0,1 & 0,5 & 0,3 & 0,2 & 0,1 & 0,1 & 0,1 & 0,0 & 0,1 & 0,1 & 0,0 & 0,0 & 0,0 & 0,1 & 0,0 \\
\hline Vleeskuikens / Broilers & 1,2 & 1,2 & 0,8 & 0,6 & 0,5 & 0,3 & 0,4 & 0,2 & 0,3 & 0,3 & 0,1 & 0,2 & 0,2 & 0,1 & 0,0 \\
\hline Eenden / Ducks & 1,0 & 1,0 & 1,0 & 0,9 & 1,0 & 1,0 & 1,0 & 1,0 & 1,1 & 0,9 & 0,8 & 0,9 & 1,0 & 0,9 & 1,0 \\
\hline Kalkoenen / Turkeys & 0,4 & 0,0 & 0,1 & 0,0 & 0,0 & 0,0 & 0,0 & 0,0 & 0,0 & 0,0 & 0,0 & 0,1 & 0,0 & 0,0 & 0,0 \\
\hline Schapen / Sheep & 1,3 & 1,4 & 1,4 & 1,3 & 1,3 & 1,3 & 1,3 & 1,3 & 1,4 & 1,3 & 1,4 & 1,3 & 1,3 & 1,3 & 1,3 \\
\hline Geiten / Goats & 2,3 & 2,4 & 2,3 & 2,2 & 2,1 & 2,1 & 2,2 & 2,1 & 2,3 & 2,3 & 2,3 & 2,1 & 2,1 & 2,1 & 2,1 \\
\hline Paarden / Horses & 1,7 & 1,3 & 1,3 & 1,2 & 1,3 & 1,4 & 1,6 & 1,5 & 1,4 & 1,3 & 1,5 & 1,4 & 1,5 & 1,6 & 1,7 \\
\hline Pony's / Ponies & 1,7 & 1,3 & 1,3 & 1,2 & 1,3 & 1,4 & 1,6 & 1,5 & 1,4 & 1,3 & 1,5 & 1,4 & 1,5 & 1,6 & 1,7 \\
\hline Ezels / Mules and asses & $\begin{array}{r}\text { n.v.t./ } \\
\text { n.a. }\end{array}$ & $\begin{array}{r}\text { n.v.t./ } \\
\text { n.a. }\end{array}$ & $\begin{array}{r}\text { n.v.t./ } \\
\text { n.a. }\end{array}$ & $\begin{array}{r}\text { n.v.t./ } \\
\text { n.a. }\end{array}$ & $\begin{array}{r}\text { n.v.t./ } \\
\text { n.a. }\end{array}$ & 1,2 & 1,3 & 1,3 & 1,3 & 1,3 & 1,3 & 1,2 & 1,2 & 1,1 & 1,1 \\
\hline Pelsdieren / Fur-bearing animals & 2,2 & 2,2 & 2,0 & 0,8 & 0,6 & 0,4 & 0,5 & 0,7 & 1,0 & 1,1 & 0,9 & 0,9 & 1,0 & 0,9 & 1,1 \\
\hline Konijnen / Rabbits & 0,3 & 0,3 & 0,4 & 0,3 & 0,2 & 0,3 & 0,3 & 0,3 & 0,4 & 0,3 & 0,3 & 0,2 & 0,2 & 0,3 & 0,2 \\
\hline Paarden - particulieren / Horses - private parties & 1,5 & 1,5 & 1,5 & 1,5 & 1,5 & 1,5 & 1,5 & 1,5 & 1,5 & 1,5 & 1,5 & 1,5 & 1,5 & 1,5 & 1,5 \\
\hline Pony's - particulieren / Ponies - private parties & 1,5 & 1,5 & 1,5 & 1,5 & 1,5 & 1,5 & 1,5 & 1,5 & 1,5 & 1,5 & 1,5 & 1,5 & 1,5 & 1,5 & 1,5 \\
\hline $\begin{array}{l}\text { Ezels - particulieren / Mules and asses - private } \\
\text { parties }\end{array}$ & $\begin{array}{r}\text { n.v.t./ } \\
\text { n.a. }\end{array}$ & $\begin{array}{r}\text { n.v.t./ } \\
\text { n.a. }\end{array}$ & $\begin{array}{r}\text { n.v.t./ } \\
\text { n.a. }\end{array}$ & $\begin{array}{r}\text { n.v.t./ } \\
\text { n.a. }\end{array}$ & $\begin{array}{r}\text { n.v.t./ } \\
\text { n.a. }\end{array}$ & $\begin{array}{r}\text { n.v.t./ } \\
\text { n.a. }\end{array}$ & $\begin{array}{r}\text { n.v.t./ } \\
\text { n.a. }\end{array}$ & $\begin{array}{r}\text { n.v.t./ } \\
\text { n.a. }\end{array}$ & $\begin{array}{r}\text { n.v.t./ } \\
\text { n.a. }\end{array}$ & $\begin{array}{r}\text { n.v.t./ } \\
\text { n.a. }\end{array}$ & $\begin{array}{r}\text { n.v.t./ } \\
\text { n.a. }\end{array}$ & 1,0 & 1,0 & 0,9 & 0,9 \\
\hline Schapen - particulieren / Sheep - private parties & $\begin{array}{r}\text { n.v.t./ } \\
\text { n.a. }\end{array}$ & $\begin{array}{r}\text { n.v.t./ } \\
\text { n.a. }\end{array}$ & $\begin{array}{r}\text { n.v.t./ } \\
\text { n.a. }\end{array}$ & $\begin{array}{r}\text { n.v.t./ } \\
\text { n.a. }\end{array}$ & $\begin{array}{r}\text { n.v.t./ } \\
\text { n.a. }\end{array}$ & $\begin{array}{r}\text { n.v.t./ } \\
\text { n.a. }\end{array}$ & $\begin{array}{r}\text { n.v.t./ } \\
\text { n.a. }\end{array}$ & $\begin{array}{r}\text { n.v.t./ } \\
\text { n.a. }\end{array}$ & $\begin{array}{r}\text { n.v.t./ } \\
\text { n.a. }\end{array}$ & $\begin{array}{r}\text { n.v.t./ } \\
\text { n.a. }\end{array}$ & $\begin{array}{r}\text { n.v.t./ } \\
\text { n.a. }\end{array}$ & 1,5 & 1,5 & 1,5 & 1,5 \\
\hline
\end{tabular}




\section{Bijlage 33 Aandeel kuilvoer in het rantsoen}

B33.1 Aandeel kuilvoer ${ }^{1)}$ in het rantsoen van graasdieren / Fraction of silage ${ }^{1)}$ in the diet of grazing livestock.

\begin{tabular}{|c|c|c|c|c|c|c|c|c|c|c|c|c|c|c|c|}
\hline Diercategorie / Livestock category & 1990 & 1991 & 1992 & 1993 & 1994 & 1995 & 1996 & 1997 & 1998 & 1999 & 2000 & 2001 & 2002 & 2003 & 2004 \\
\hline \multicolumn{16}{|l|}{ Melk- en fokvee / Dairy cattle } \\
\hline vrouwelijk jongvee $<1 \mathrm{jr} /$ female young stock $<1 \mathrm{yr}$ & 1,00 & 1,00 & 1,00 & 1,00 & 1,00 & 1,00 & 1,00 & 1,00 & 1,00 & 1,00 & 1,00 & 1,00 & 1,00 & 0,47 & 0,47 \\
\hline mannelijk jongvee $<1 \mathrm{jr} /$ male young stock $<1 \mathrm{yr}$ & 1,00 & 1,00 & 1,00 & 1,00 & 1,00 & 1,00 & 1,00 & 1,00 & 1,00 & 1,00 & 1,00 & 1,00 & 1,00 & 1,00 & 1,00 \\
\hline vrouwelijk jongvee $1-2 \mathrm{jr} /$ female young stock $1-2 \mathrm{yr}$ & 0,48 & 1,00 & 1,00 & 1,00 & 1,00 & 1,00 & 1,00 & 0,50 & 1,00 & 1,00 & 0,50 & 0,50 & 0,49 & 0,48 & 0,48 \\
\hline mannelijk jongvee $1-2 \mathrm{jr} /$ male young stock $1-2 \mathrm{yr}$ & 1,00 & 1,00 & 1,00 & 1,00 & 1,00 & 1,00 & 1,00 & 1,00 & 1,00 & 1,00 & 1,00 & 1,00 & 1,00 & 1,00 & 1,00 \\
\hline vrouwelijk jongvee $\geq 2 \mathrm{jr} /$ female young stock $\geq 2 \mathrm{yr}$ & 0,48 & 0,50 & 1,00 & 0,50 & 1,00 & 1,00 & 1,00 & 0,50 & 1,00 & 1,00 & 0,50 & 0,50 & 0,49 & 0,48 & 0,48 \\
\hline \multicolumn{16}{|l|}{ melk- en kalfkoeien / dairy cows: } \\
\hline NoordWest NL / NorthWest NL & 0,35 & 0,35 & 0,27 & 0,38 & 0,37 & 0,32 & 0,37 & 0,31 & 0,44 & 0,42 & 0,45 & 0,41 & 0,40 & 1,00 & 0,49 \\
\hline ZuidOost NL / SouthEast NL & 0,40 & 0,39 & 0,33 & 0,38 & 0,44 & 0,38 & 0,35 & 0,39 & 1,00 & 0,45 & 1,00 & 1,00 & 1,00 & 1,00 & 1,00 \\
\hline fokstieren $\geq 2 \mathrm{jr} /$ breeding bulls $\geq 2 \mathrm{yr}$ & 1,00 & 1,00 & 1,00 & 1,00 & 1,00 & 1,00 & 1,00 & 1,00 & 1,00 & 1,00 & 1,00 & 1,00 & 1,00 & 1,00 & 1,00 \\
\hline \multicolumn{16}{|l|}{ Vlees- en weidevee / Beef cattle } \\
\hline witvleeskalveren / calves for white veal production & 0,00 & 0,00 & 0,00 & 0,00 & 0,00 & 0,05 & 0,05 & 0,05 & 0,04 & 0,04 & 0,04 & 0,04 & 0,05 & 0,05 & 0,14 \\
\hline rosévleeskalveren / calves for rosé veal production & 0,00 & 0,00 & 0,00 & 0,00 & 0,00 & 0,28 & 0,28 & 0,28 & 0,26 & 0,44 & 0,44 & 0,44 & 0,34 & 0,34 & 0,39 \\
\hline vrouwelijk jongvee $<1 \mathrm{jr} /$ female young stock $<1 \mathrm{yr}$ & 1,00 & 1,00 & 1,00 & 1,00 & 1,00 & 1,00 & 1,00 & 1,00 & 1,00 & 1,00 & 1,00 & 1,00 & 1,00 & 0,47 & 0,47 \\
\hline $\begin{array}{l}\text { mannelijk jongvee (incl. ossen) }<1 \mathrm{jr} / \text { male young } \\
\text { stock (incl. bullocks) }<1 \mathrm{yr}\end{array}$ & 1,00 & 1,00 & 0,50 & 1,00 & 1,00 & 1,00 & 1,00 & 1,00 & 1,00 & 1,00 & 1,00 & 1,00 & 1,00 & 1,00 & 1,00 \\
\hline vrouwelijk jongvee $1-2 \mathrm{jr} /$ female young stock $1-2 \mathrm{yr}$ & 0,48 & 0,50 & 1,00 & 0,50 & 1,00 & 1,00 & 1,00 & 0,50 & 1,00 & 1,00 & 0,50 & 0,49 & 0,49 & 0,48 & 0,48 \\
\hline $\begin{array}{l}\text { mannelijk jongvee (incl. ossen) } 1-2 \mathrm{jr} / \text { male young } \\
\text { stock (incl. bullocks) } 1-2 \mathrm{yr}\end{array}$ & 1,00 & 0,46 & 0,41 & 0,41 & 0,35 & 0,47 & 0,44 & 0,48 & 0,46 & 0,46 & 0,45 & 0,45 & 0,46 & 0,45 & 1,00 \\
\hline vrouwelijk jongvee $\geq 2 \mathrm{jr}$ / female young stock $\geq 2 \mathrm{yr}$ & 0,48 & 1,00 & 1,00 & 1,00 & 1,00 & 1,00 & 1,00 & 0,50 & 1,00 & 1,00 & 0,50 & 0,49 & 0,49 & 0,48 & 0,48 \\
\hline $\begin{array}{l}\text { mannelijk jongvee (incl. ossen) } \geq 2 \mathrm{jr} / \text { male young } \\
\text { stock (incl. bullocks) } \geq 2 \mathrm{yr}\end{array}$ & 1,00 & 0,46 & 0,41 & 0,41 & 0,35 & 0,47 & 0,44 & 0,48 & 0,46 & 0,46 & 0,45 & 0,45 & 0,46 & 0,45 & 1,00 \\
\hline $\begin{array}{l}\text { zoog-, mest- en weidekoeien } \geq 2 \mathrm{jr} / \text { suckling cows and } \\
\text { female fatteners } \geq 2 \mathrm{yr}\end{array}$ & 0,38 & 0,39 & 0,40 & 0,39 & 0,40 & 0,40 & 0,40 & 0,39 & 0,38 & 0,43 & 0,42 & 0,42 & 0,42 & 0,43 & 0,44 \\
\hline Schapen / Sheep & 0,16 & 0,16 & 0,16 & 0,16 & 0,16 & 0,16 & 0,16 & 0,16 & 0,15 & 0,13 & 0,13 & 0,13 & 0,13 & 0,13 & 0,13 \\
\hline Geiten / Goats & 1,00 & 1,00 & 1,00 & 1,00 & 1,00 & 1,00 & 1,00 & 1,00 & 0,46 & 0,47 & 0,47 & 0,47 & 0,47 & 0,47 & 1,00 \\
\hline
\end{tabular}




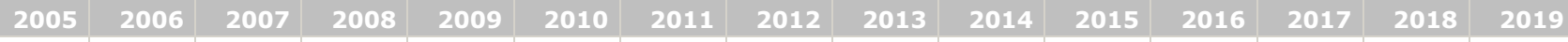

\title{
Melk- en fokvee / Dairy cattle
}

vrouwelijk jongvee $<1 \mathrm{jr} /$ female young stock $<1 \mathrm{yr}$ 0,47 \begin{tabular}{|l|r|r|r|r|}
\hline 0,46 & 0,50 & 1,00 & 1,00 \\
\hline 1,00 & 1,00 & 1,00 & 1,00 & 1,00 \\
\hline
\end{tabular} vrouwelijk jongvee $1-2 \mathrm{jr} /$ female young stock $1-2 \mathrm{yr}$ mannelijk jongvee 1-2 jr/ male young stock 1-2 y 0,48 vrouwelijk jongvee $\geq 2 \mathrm{jr}$ / female young stock $\geq 2 \mathrm{yr}$ \begin{tabular}{|l|r|r|r|r|}
\hline 1,00 & 1,00 & 1,00 \\
\hline
\end{tabular} melk- en kalfkoeien / dairy cows:

NoordWest NL/ NorthWest

ZuidOost NL / SouthEast NL

fokstieren $\geq 2 \mathrm{jr} /$ breeding bulls $\geq 2 \mathrm{yr}$

\begin{tabular}{|l|l|l|l|l|l|l|l|l|l|l|l|l|l|}
\hline 1,00 & 1,00 & 1,00 & 1,00 & 1,00 & 1,00 & 1,00 & 1,00 & 1,00 & 1,00 & 1,00 & 1,00 \\
\hline
\end{tabular}

\section{Vlees- en weidevee / Beef cattle} róves

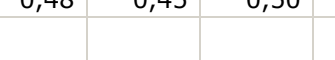

\author{
0,49
}

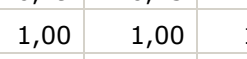

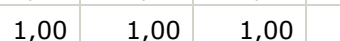

\begin{tabular}{|r|r|r|r|r|r|r|}
\hline $\mathbf{4}$ & 0,46 & 1,00 & 1,00 & 1,00 & 1,00 \\
\hline 00 & 1,00 & 1,00 & 1,00 & 1,00 & 1,00 \\
\hline & 1,00 & 1,00 & 1,00 & 1,00 & 1,00 \\
\hline
\end{tabular}

vrouwelijk jongvee $<1 \mathrm{jr} /$ female young stock $<1 \mathrm{yr}$

mannelijk jongvee (incl. ossen) $<1 \mathrm{jr} /$ male young

stock (incl. bullocks) $<1 \mathrm{yr}$

vrouwelijk jongvee 1-2 jr / female young stock 1-2 yr

mannelijk jongvee (incl. ossen) $1-2 \mathrm{jr} /$ male young

stock (incl. bullocks) $1-2$ y

vrouwelijk jongvee $\geq 2 \mathrm{jr} /$ female young stock $\geq 2 \mathrm{yr}$

mannelijk jongvee (incl. ossen) $\geq 2 \mathrm{jr} /$ male young

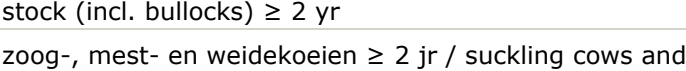

female fatteners $\geq 2 \mathrm{yr}$

\begin{tabular}{|c|c|c|c|c|c|c|c|c|c|c|c|c|c|}
\hline 0,19 & 0,19 & 0,19 & 0,19 & 0,29 & 0,19 & 0,13 & 0,13 & 0,03 & 0,03 & 0,03 & 0,03 & 0,03 & 0,05 \\
\hline 0,39 & 0,39 & 0,39 & 0,39 & 0,34 & 0,34 & 0,34 & 0,34 & 0,30 & 0,33 & 0,33 & 0,33 & 0,35 & 0,35 \\
\hline 0,46 & 0,50 & 1,00 & 1,00 & 1,00 & 1,00 & 1,00 & 1,00 & 1,00 & 1,00 & 1,00 & 1,00 & 1,00 & 1,00 \\
\hline 1,00 & 1,00 & 1,00 & 1,00 & 1,00 & 1,00 & 1,00 & 1,00 & 1,00 & 1,00 & 1,00 & 1,00 & 1,00 & 1,00 \\
\hline 0,45 & 1,00 & 1,00 & 1,00 & 1,00 & 1,00 & 1,00 & 1,00 & 1,00 & 1,00 & 1,00 & 1,00 & 1,00 & 1,00 \\
\hline 1,00 & 1,00 & 1,00 & 1,00 & 1,00 & 1,00 & 1,00 & 1,00 & 1,00 & 1,00 & 1,00 & 1,00 & 1,00 & 1,00 \\
\hline 0,45 & 1,00 & 1,00 & 1,00 & 1,00 & 1,00 & 1,00 & 1,00 & 1,00 & 1,00 & 1,00 & 1,00 & 1,00 & 1,00 \\
\hline 1,00 & 1,00 & 1,00 & 1,00 & 1,00 & 1,00 & 1,00 & 1,00 & 1,00 & 1,00 & 1,00 & 1,00 & 1,00 & 1,00 \\
\hline 0,44 & 0,43 & 0,44 & 0,43 & 0,43 & 0,43 & 0,42 & 0,43 & 0,43 & 0,43 & 0,43 & 0,43 & 0,43 & 0,43 \\
\hline 0,13 & 0,13 & 0,13 & 0,07 & 0,07 & 0,02 & 0,02 & 0,02 & 0,02 & 0,08 & 0,08 & 0,08 & 0,08 & 0,08 \\
\hline 1,00 & 1,00 & 1,00 & 1,00 & 1,00 & 1,00 & 1,00 & 1,00 & 1,00 & 1,00 & 1,00 & 1,00 & 1,00 & 1,00 \\
\hline
\end{tabular}

Schapen / Sheep

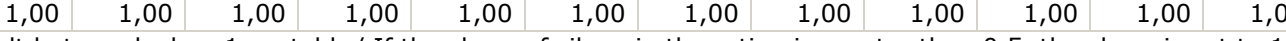

1) Als het aandeel kuilvoer in het rantsoen groter is dan 0,5 wordt het aandeel op 1 gesteld. / If the share of silage in the ration is greater than 0.5 , the share is set to 1 . 


\section{Bijlage 34 Stalsystemen in de berekening van fijnstofemissies}

B34.1 Aandelen van stalsystemen in de berekening van fijnstofemissies (\%) / Shares of housing systems in the calculation of particulate matter emissions (\%)

\begin{tabular}{|c|c|c|c|c|c|c|c|c|c|c|c|c|c|c|c|}
\hline Diercategorie / Livestock category & 1990 & 1991 & 1992 & 1993 & 1994 & 1995 & 1996 & 1997 & 1998 & 1999 & 2000 & 2001 & 2002 & 2003 & 2004 \\
\hline \multicolumn{16}{|l|}{ Melkvee / Dairy cattle } \\
\hline $\begin{array}{l}\text { Vrouwelijk en mannelijk jongvee en fokstieren / } \\
\text { Female and male young stock and breeding bulls }\end{array}$ & 100,0 & 100,0 & 100,0 & 100,0 & 100,0 & 100,0 & 100,0 & 100,0 & 100,0 & 100,0 & 100,0 & 100,0 & 100,0 & 100,0 & 100,0 \\
\hline \multicolumn{16}{|l|}{ Melk- en kalfkoeien / Dairy cows } \\
\hline Grupstal en potstal / tie-stall and deep bedding & 12,0 & 12,0 & 12,0 & 12,0 & 12,0 & 12,0 & 12,0 & 12,0 & 12,0 & 12,0 & 12,0 & 12,0 & 12,0 & 12,0 & 8,0 \\
\hline ligbox beweiden / cubicle grazing & 83,0 & 83,0 & 83,0 & 83,0 & 83,0 & 83,0 & 83,0 & 83,0 & 83,0 & 83,0 & 83,0 & 83,0 & 71,0 & 74,0 & 75,0 \\
\hline ligbox opstallen / cubicle without grazing & 5,0 & 5,0 & 5,0 & 5,0 & 5,0 & 5,0 & 5,0 & 5,0 & 5,0 & 5,0 & 5,0 & 5,0 & 17,0 & 14,0 & 17,0 \\
\hline \multicolumn{16}{|l|}{ Vleesvee / Beef cattle } \\
\hline $\begin{array}{l}\text { Wit- en rosévleeskalveren / Calves for white and rosé } \\
\text { veal production }\end{array}$ & 100,0 & 100,0 & 100,0 & 100,0 & 100,0 & 100,0 & 100,0 & 100,0 & 100,0 & 100,0 & 100,0 & 100,0 & 100,0 & 100,0 & 100,0 \\
\hline \multicolumn{16}{|l|}{ regulier / regular } \\
\hline \multicolumn{16}{|l|}{ chemische wasser / chemical air scrubber } \\
\hline \multicolumn{16}{|l|}{$\begin{array}{l}\text { biologische wasser-kort / biological air scrubber- } \\
\text { short }\end{array}$} \\
\hline \multicolumn{16}{|l|}{ biologische wasser-lang / biological air scubber-long } \\
\hline \multicolumn{16}{|l|}{ combi-wasser / combined air scrubber } \\
\hline Overig vleesvee / Other beef cattle & 100,0 & 100,0 & 100,0 & 100,0 & 100,0 & 100,0 & 100,0 & 100,0 & 100,0 & 100,0 & 100,0 & 100,0 & 100,0 & 100,0 & 100,0 \\
\hline \multicolumn{16}{|l|}{ Varkens / Pigs } \\
\hline \multicolumn{16}{|l|}{ Biggen / Piglets } \\
\hline \multicolumn{16}{|l|}{ regulier gedeeltelijk rooster / regular partially raster } \\
\hline \multicolumn{16}{|l|}{ chemische wasser / chemical air scrubber } \\
\hline \multicolumn{16}{|l|}{$\begin{array}{l}\text { biologische wasser-kort / biological air scrubber- } \\
\text { short }\end{array}$} \\
\hline \multicolumn{16}{|l|}{ biologische wasser-lang / biological air scrubber-long } \\
\hline \multicolumn{16}{|l|}{ combi-wasser / combined air scrubber } \\
\hline regulier volledig rooster / regular fully raster & 100,0 & 100,0 & 100,0 & 100,0 & 100,0 & 100,0 & 100,0 & 100,0 & 100,0 & 100,0 & 100,0 & 100,0 & 100,0 & 100,0 & 100,0 \\
\hline \multicolumn{16}{|l|}{ chemische wasser / chemical air scrubber } \\
\hline \multicolumn{16}{|l|}{$\begin{array}{l}\text { biologische wasser-kort / biological air scrubber- } \\
\text { short }\end{array}$} \\
\hline \multicolumn{16}{|l|}{ biologische wasser-lang / biological air scrubber-long } \\
\hline \multicolumn{16}{|l|}{ combi-wasser / combined air scrubber } \\
\hline Vleesvarkens / Fattening pigs & & & & & & & & & & & & & & & \\
\hline
\end{tabular}




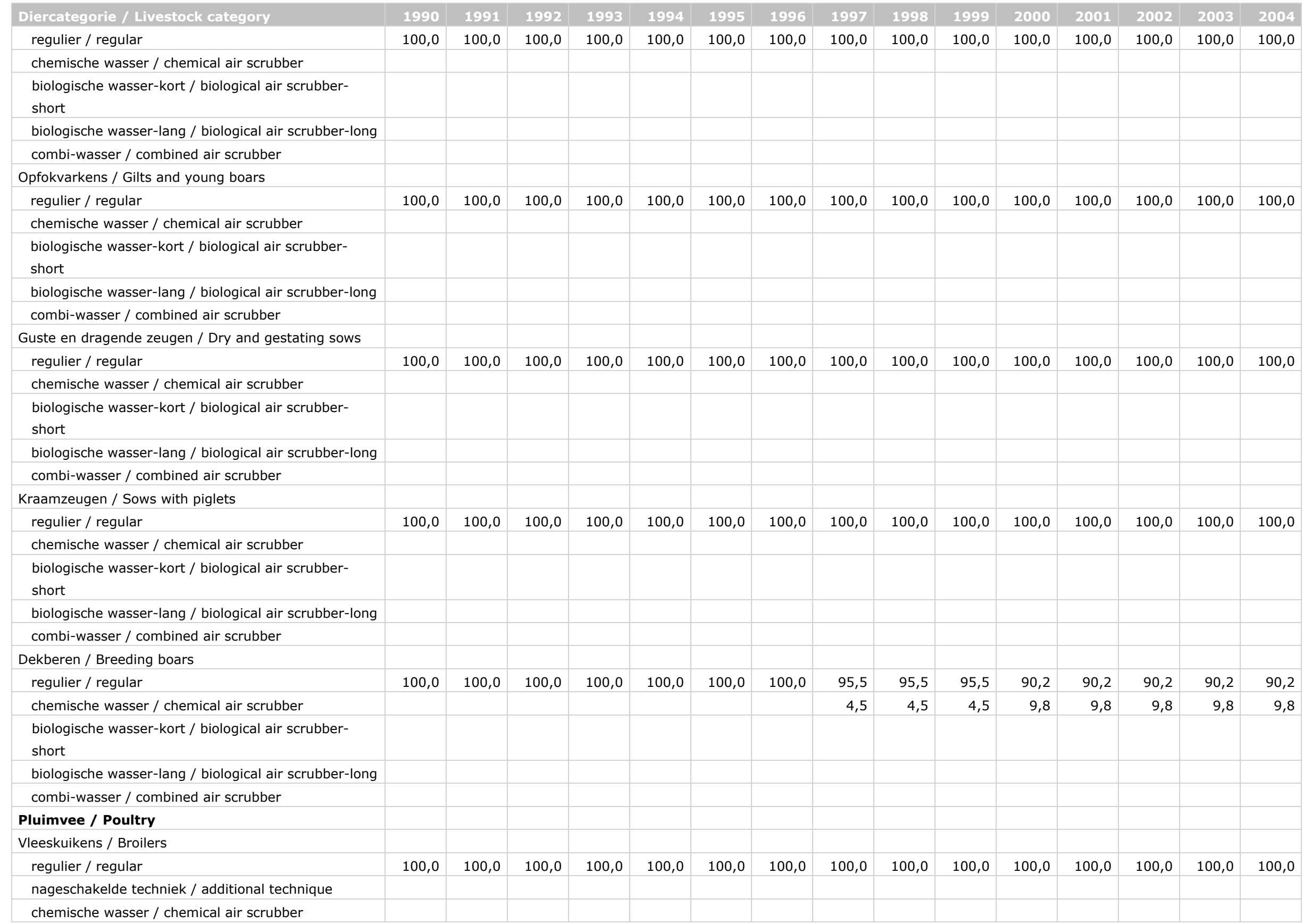

226 | wot-technical report 203 


\begin{tabular}{|c|c|c|c|c|c|c|c|c|c|c|c|c|c|c|c|}
\hline Diercategorie / Livestock category & 1990 & 1991 & 1992 & 1993 & 1994 & 1995 & 1996 & 1997 & 1998 & 1999 & 2000 & 2001 & 2002 & 2003 & 2004 \\
\hline \multicolumn{16}{|l|}{$\begin{array}{l}\text { biologische wasser-kort / biological air scrubber- } \\
\text { short }\end{array}$} \\
\hline \multicolumn{16}{|l|}{ biologische wasser-lang / biological air scrubber-long } \\
\hline \multicolumn{16}{|l|}{ combi-wasser / combined air scrubber } \\
\hline \multicolumn{16}{|l|}{$\begin{array}{l}\text { Ouderdieren van slachtrassen, jonger dan } 18 \text { weken / } \\
\text { Broiler breeders, younger than } 18 \text { weeks }\end{array}$} \\
\hline grondhuisvesting / floor housing & 100,0 & 100,0 & 100,0 & 100,0 & 100,0 & 100,0 & 100,0 & 100,0 & 100,0 & 100,0 & 100,0 & 100,0 & 100,0 & 100,0 & 100,0 \\
\hline \multicolumn{16}{|l|}{ nageschakelde techniek / additional technique } \\
\hline \multicolumn{16}{|l|}{ chemische wasser / chemical air scrubber } \\
\hline \multicolumn{16}{|l|}{$\begin{array}{l}\text { Ouderdieren van slachtrassen, } 18 \text { weken en ouder / } \\
\text { Broiler breeders, } 18 \text { weeks and older }\end{array}$} \\
\hline kooihuisvesting / cage housing & 10,0 & 10,0 & 10,0 & 10,0 & 10,0 & 10,0 & 10,0 & 10,0 & 10,0 & 10,0 & 10,0 & 10,0 & 10,0 & 10,0 & 10,0 \\
\hline grondhuisvesting + volière / floor housing + aviary & 90,0 & 90,0 & 90,0 & 90,0 & 90,0 & 90,0 & 90,0 & 90,0 & 90,0 & 90,0 & 90,0 & 90,0 & 90,0 & 90,0 & 90,0 \\
\hline \multicolumn{16}{|l|}{ nageschakelde techniek / additional technique } \\
\hline \multicolumn{16}{|l|}{ chemische wasser / chemical air scrubber } \\
\hline \multicolumn{16}{|l|}{$\begin{array}{l}\text { biologische wasser-kort / biological air scrubber- } \\
\text { short }\end{array}$} \\
\hline \multicolumn{16}{|l|}{ biologische wasser-lang / biological air scrubber-long } \\
\hline \multicolumn{16}{|l|}{ combi-wasser / combined air scrubber } \\
\hline \multicolumn{16}{|l|}{$\begin{array}{l}\text { Leghennen, jonger dan } 18 \text { weken / Laying hens, } \\
\text { younger than } 18 \text { weeks }\end{array}$} \\
\hline batterijhuisvesting / battery cages & 72,0 & 72,0 & 72,0 & 72,0 & 87,0 & 86,0 & 86,0 & 86,0 & 75,7 & 75,7 & 75,7 & 64,0 & 63,1 & 55,5 & 55,5 \\
\hline \multicolumn{16}{|l|}{ koloniehuisvesting / colony housing } \\
\hline grondhuisvesting / floor housing & 28,0 & 28,0 & 28,0 & 28,0 & 13,0 & 14,0 & 14,0 & 14,0 & 24,3 & 24,3 & 24,3 & 23,4 & 24,0 & 35,3 & 35,3 \\
\hline \multicolumn{16}{|l|}{ nageschakelde techniek / additional technique } \\
\hline volièrehuisvesting / aviary housing & & & & & & & & & & & & 12,6 & 12,9 & 9,2 & 9,2 \\
\hline \multicolumn{16}{|l|}{ chemische wasser / chemical air scrubber } \\
\hline \multicolumn{16}{|l|}{$\begin{array}{l}\text { biologische wasser-kort / biological air scrubber- } \\
\text { short }\end{array}$} \\
\hline \multicolumn{16}{|l|}{ biologische wasser-lang / biological air scrubber-long } \\
\hline \multicolumn{16}{|l|}{ combi-wasser / combined air scrubber } \\
\hline \multicolumn{16}{|l|}{$\begin{array}{l}\text { Leghennen, } 18 \text { weken en ouder / Laying hens, } 18 \\
\text { weeks and older }\end{array}$} \\
\hline batterijhuisvesting / battery cages & 92,0 & 92,0 & 92,0 & 92,0 & 89,0 & 89,0 & 89,0 & 89,0 & 77,0 & 77,0 & 77,0 & 68,4 & 67,6 & 55,5 & 55,5 \\
\hline $\begin{array}{l}\text { verrijkte kooi/koloniehuisvesting / enriched } \\
\text { cage/colony housing }\end{array}$ & & & & & & & & & & & & & & 1,3 & 1,3 \\
\hline grondhuisvesting / floor housing & 8,0 & 8,0 & 8,0 & 8,0 & 11,0 & 11,0 & 11,0 & 11,0 & 23,0 & 23,0 & 23,0 & 25,2 & 25,8 & 35,6 & 35,6 \\
\hline \multicolumn{16}{|l|}{ nageschakelde techniek / additional technique } \\
\hline volièrehuisvesting / aviary housing & & & & & & & & & & & & 6,4 & 6,6 & 7,6 & 7,6 \\
\hline chemische wasser / chemical air scrubber & & & & & & & & & & & & & & & \\
\hline
\end{tabular}




\begin{tabular}{|c|c|c|c|c|c|c|c|c|c|c|c|c|c|c|c|}
\hline Diercategorie / Livestock category & 1990 & 1991 & 1992 & 1993 & 1994 & 1995 & 1996 & 1997 & 1998 & 1999 & 2000 & 2001 & 2002 & 2003 & 2004 \\
\hline \multicolumn{16}{|l|}{$\begin{array}{l}\text { biologische wasser-kort / biological air scrubber- } \\
\text { short }\end{array}$} \\
\hline \multicolumn{16}{|l|}{ biologische wasser-lang / biological air scrubber-long } \\
\hline \multicolumn{16}{|l|}{ combi-wasser / combined air scrubber } \\
\hline \multicolumn{16}{|l|}{ Eenden / Ducks } \\
\hline regulier / regular & 100,0 & 100,0 & 100,0 & 100,0 & 100,0 & 100,0 & 100,0 & 100,0 & 100,0 & 100,0 & 100,0 & 100,0 & 100,0 & 100,0 & 100,0 \\
\hline \multicolumn{16}{|l|}{ nageschakelde techniek / additional technique } \\
\hline \multicolumn{16}{|l|}{ chemische wasser / chemical air scrubber } \\
\hline \multicolumn{16}{|l|}{ Kalkoenen / Turkeys } \\
\hline regulier / regular & 100,0 & 100,0 & 100,0 & 100,0 & 100,0 & 100,0 & 100,0 & 100,0 & 100,0 & 100,0 & 100,0 & 100,0 & 100,0 & 100,0 & 100,0 \\
\hline \multicolumn{16}{|l|}{ nageschakelde techniek / additional technique } \\
\hline $\begin{array}{l}\text { Konijnen en pelsdieren / Rabbits and fur-bearing } \\
\text { animals }\end{array}$ & 100,0 & 100,0 & 100,0 & 100,0 & 100,0 & 100,0 & 100,0 & 100,0 & 100,0 & 100,0 & 100,0 & 100,0 & 100,0 & 100,0 & 100,0 \\
\hline Schapen en geiten / Sheep and goats & 100,0 & 100,0 & 100,0 & 100,0 & 100,0 & 100,0 & 100,0 & 100,0 & 100,0 & 100,0 & 100,0 & 100,0 & 100,0 & 100,0 & 100,0 \\
\hline $\begin{array}{l}\text { Paarden, pony's en ezels / Horses, ponies, mules and } \\
\text { asses }\end{array}$ & 100,0 & 100,0 & 100,0 & 100,0 & 100,0 & 100,0 & 100,0 & 100,0 & 100,0 & 100,0 & 100,0 & 100,0 & 100,0 & 100,0 & 100,0 \\
\hline
\end{tabular}

\section{B34.1 vervolg / continuation}

\begin{tabular}{|c|c|c|c|c|c|c|c|c|c|c|c|c|c|c|c|}
\hline Diercategorie / Livestock category & 2005 & 2006 & 2007 & 2008 & 2009 & 2010 & 2011 & 2012 & 2013 & 2014 & 2015 & 2016 & 2017 & 2018 & 2019 \\
\hline \multicolumn{16}{|l|}{ Melkvee / Dairy cattle } \\
\hline $\begin{array}{l}\text { Vrouwelijk en mannelijk jongvee en fokstieren / } \\
\text { Female and male young stock and breeding bulls }\end{array}$ & 100,0 & 100,0 & 100,0 & 100,0 & 100,0 & 100,0 & 100,0 & 100,0 & 100,0 & 100,0 & 100,0 & 100,0 & 100,0 & 100,0 & 100,0 \\
\hline \multicolumn{16}{|l|}{ Melk- en kalfkoeien / Dairy cows } \\
\hline grupstal en potstal / tie-stall and deep bedding & 8,0 & 8,0 & 8,0 & 5,0 & 5,0 & 5,0 & 4,0 & 4,0 & 4,0 & 4,0 & 2,1 & 1,8 & 1,6 & 1,6 & 1,4 \\
\hline ligbox beweiden / cubicle grazing & 75,0 & 71,0 & 72,0 & 74,0 & 71,0 & 69,0 & 67,0 & 66,0 & 66,0 & 64,0 & 62,9 & 63,2 & 66,4 & 69,4 & 71,6 \\
\hline ligbox opstallen / cubicle without grazing & 17,0 & 21,0 & 20,0 & 21,0 & 24,0 & 26,0 & 29,0 & 30,0 & 30,0 & 32,0 & 35,0 & 35,0 & 32,0 & 29,0 & 27,0 \\
\hline \multicolumn{16}{|l|}{ Vleesvee / Beef cattle } \\
\hline $\begin{array}{l}\text { Wit- en rosévleeskalveren / Calves for white and rosé } \\
\text { veal production }\end{array}$ & 100,0 & 100,0 & 100,0 & 100,0 & 100,0 & 100,0 & 94,5 & 94,0 & 93,7 & 93,4 & 96,1 & 96,3 & 95,7 & 95,7 & 94,9 \\
\hline \multicolumn{16}{|l|}{ regulier / regular } \\
\hline chemische wasser / chemical air scrubber & & & & & & & 1,6 & 1,8 & 2,3 & 2,4 & 2,9 & 3,0 & 3,4 & 3,0 & 3,3 \\
\hline $\begin{array}{l}\text { biologische wasser-kort / biological air scrubber- } \\
\text { short }\end{array}$ & & & & & & & 3,8 & 4,2 & 0,2 & 0,3 & 0,6 & 0,3 & 0,3 & 0,8 & 1,1 \\
\hline biologische wasser-lang / biological air scubber-long & & & & & & & & & 3,8 & 3,9 & 0,2 & 0,1 & 0,3 & 0,3 & 0,3 \\
\hline combi-wasser / combined air scrubber & & & & & & & & & & & 0,3 & 0,3 & 0,3 & 0,2 & 0,3 \\
\hline Overig vleesvee / Other beef cattle & 100,0 & 100,0 & 100,0 & 100,0 & 100,0 & 100,0 & 100,0 & 100,0 & 100,0 & 100,0 & 100,0 & 100,0 & 100,0 & 100,0 & 100,0 \\
\hline \multicolumn{16}{|l|}{ Varkens / Pigs } \\
\hline \multicolumn{16}{|l|}{ Biggen / Piglets } \\
\hline regulier gedeeltelijk rooster / regular partially raster & 29,3 & 29,3 & 29,1 & 29,1 & 29,1 & 27,2 & 23,6 & 22,9 & 19,8 & 19,3 & 18,3 & 16,9 & 16,0 & 15,5 & 21,6 \\
\hline
\end{tabular}

228 | wot-technical report 203 


\begin{tabular}{|c|c|c|c|c|c|c|c|c|c|c|c|c|c|c|c|}
\hline Diercategorie / Livestock category & 2005 & 2006 & 2007 & 2008 & 2009 & 2010 & 2011 & 2012 & 2013 & 2014 & 2015 & 2016 & 2017 & 2018 & 2019 \\
\hline chemische wasser / chemical air scrubber & 1,1 & 1,1 & 1,6 & 1,6 & 1,6 & 3,1 & 3,5 & 3,9 & 4,1 & 4,3 & 4,2 & 4,4 & 4,5 & 4,8 & 7,3 \\
\hline $\begin{array}{l}\text { biologische wasser-kort / biological air scrubber- } \\
\text { short }\end{array}$ & 0,3 & 0,3 & 0,3 & 0,3 & 0,3 & 0,6 & 0,7 & 0,7 & 0,7 & 0,7 & 1,1 & 1,2 & 1,4 & 3,9 & 6,0 \\
\hline biologische wasser-lang / biological air scrubber-long & & & & & & & & & 0,2 & 0,2 & 0,2 & 0,5 & 0,6 & 0,6 & 0,9 \\
\hline combi-wasser / combined air scrubber & & & 0,2 & 0,2 & 0,2 & 0,4 & 2,7 & 3,0 & 5,4 & 5,7 & 6,4 & 7,2 & 7,7 & 5,4 & 8,4 \\
\hline regulier volledig rooster / regular fully raster & 66,1 & 66,1 & 64,2 & 64,2 & 64,2 & 60,0 & 53,8 & 52,2 & 45,7 & 44,6 & 42,3 & 39,1 & 37,0 & 35,7 & 27,3 \\
\hline chemische wasser / chemical air scrubber & 2,5 & 2,5 & 3,5 & 3,5 & 3,5 & 6,8 & 8,0 & 8,8 & 9,5 & 9,9 & 9,7 & 10,2 & 10,3 & 11,2 & 9,2 \\
\hline $\begin{array}{l}\text { biologische wasser-kort / biological air scrubber- } \\
\text { short }\end{array}$ & 0,7 & 0,7 & 0,6 & 0,6 & 0,6 & 1,2 & 1,5 & 1,7 & 1,6 & 1,7 & 2,6 & 2,8 & 3,3 & 9,0 & 7,6 \\
\hline biologische wasser-lang / biological air scrubber-long & & & & & & & & & 0,4 & 0,4 & 0,4 & 1,1 & 1,4 & 1,3 & 1,1 \\
\hline combi-wasser / combined air scrubber & & & 0,4 & 0,4 & 0,4 & 0,8 & 6,2 & 6,8 & 12,6 & 13,1 & 14,8 & 16,6 & 17,9 & 12,6 & 10,6 \\
\hline \multicolumn{16}{|l|}{ Vleesvarkens / Fattening pigs } \\
\hline regulier / regular & 95,5 & 95,5 & 91,9 & 91,9 & 91,9 & 85,1 & 72,9 & 70,1 & 57,3 & 55,4 & 53,8 & 49,0 & 48,0 & 43,9 & 41,0 \\
\hline chemische wasser / chemical air scrubber & 3,5 & 3,5 & 6,5 & 6,5 & 6,5 & 12,0 & 15,1 & 16,7 & 20,2 & 21,1 & 18,4 & 19,7 & 19,4 & 21,4 & 22,4 \\
\hline $\begin{array}{l}\text { biologische wasser-kort / biological air scrubber- } \\
\text { short }\end{array}$ & 1,0 & 1,0 & 1,0 & 1,0 & 1,0 & 1,8 & 2,4 & 2,7 & 3,4 & 3,5 & 4,1 & 3,1 & 3,4 & 16,5 & 18,1 \\
\hline biologische wasser-lang / biological air scrubber-long & & & & & & & 0,4 & 0,4 & 0,9 & 1,0 & 0,9 & 2,2 & 2,4 & 3,3 & 3,4 \\
\hline combi-wasser / combined air scrubber & & & 0,6 & 0,6 & 0,6 & 1,1 & 9,2 & 10,1 & 18,2 & 19,0 & 22,8 & 26,0 & 26,9 & 14,9 & 15,1 \\
\hline \multicolumn{16}{|l|}{ Opfokvarkens / Gilts and young boars } \\
\hline regulier / regular & 95,5 & 95,5 & 91,4 & 91,4 & 91,4 & 85,1 & 71,3 & 68,2 & 57,3 & 55,4 & 53,8 & 49,0 & 48,0 & 43,9 & 41,0 \\
\hline chemische wasser / chemical air scrubber & 3,5 & 3,5 & 6,9 & 6,9 & 6,9 & 12,0 & 16,0 & 17,7 & 20,2 & 21,1 & 18,4 & 19,7 & 19,4 & 21,4 & 22,4 \\
\hline $\begin{array}{l}\text { biologische wasser-kort / biological air scrubber- } \\
\text { short }\end{array}$ & 1,0 & 1,0 & 1,0 & 1,0 & 1,0 & 1,8 & 2,6 & 2,8 & 3,4 & 3,5 & 4,1 & 3,1 & 3,4 & 16,5 & 18,1 \\
\hline biologische wasser-lang / biological air scrubber-long & & & & & & & 0,4 & 0,4 & 0,9 & 1,0 & 0,9 & 2,2 & 2,4 & 3,3 & 3,4 \\
\hline combi-wasser / combined air scrubber & & & 0,6 & 0,6 & 0,6 & 1,1 & 9,7 & 10,8 & 18,2 & 19,0 & 22,8 & 26,0 & 26,9 & 14,9 & 15,1 \\
\hline \multicolumn{16}{|l|}{ Guste en dragende zeugen / Dry and gestating sows } \\
\hline regulier / regular & 93,5 & 93,5 & 92,6 & 92,6 & 92,6 & 85,6 & 72,4 & 69,5 & 54,9 & 52,8 & 48,3 & 47,5 & 41,9 & 38,7 & 37,1 \\
\hline chemische wasser / chemical air scrubber & 5,1 & 5,1 & 5,8 & 5,8 & 5,8 & 11,2 & 16,7 & 18,5 & 23,2 & 24,3 & 21,0 & 20,8 & 20,4 & 25,3 & 37,8 \\
\hline $\begin{array}{l}\text { biologische wasser-kort / biological air scrubber- } \\
\text { short }\end{array}$ & 1,4 & 1,4 & 1,1 & 1,1 & 1,1 & 2,2 & 2,8 & 3,1 & 2,7 & 2,8 & 3,7 & 2,4 & 2,3 & 13,4 & 1,9 \\
\hline biologische wasser-lang / biological air scrubber-long & & & & & & & 0,2 & 0,2 & 1,3 & 1,4 & 1,4 & 1,9 & 2,1 & 3,2 & 3,2 \\
\hline combi-wasser / combined air scrubber & & & 0,5 & 0,5 & 0,5 & 1,0 & 7,8 & 8,7 & 17,9 & 18,7 & 25,7 & 27,4 & 33,3 & 19,3 & 20,0 \\
\hline \multicolumn{16}{|l|}{ Kraamzeugen / Sows with piglets } \\
\hline regulier / regular & 95,1 & 95,1 & 93,8 & 93,8 & 93,8 & 85,6 & 77,6 & 75,2 & 63,8 & 62,2 & 60,4 & 56,7 & 55,6 & 53,0 & 48,6 \\
\hline chemische wasser / chemical air scrubber & 3,6 & 3,6 & 4,7 & 4,7 & 4,7 & 10,8 & 12,9 & 14,2 & 16,4 & 17,2 & 16,7 & 18,0 & 18,7 & 20,3 & 19,7 \\
\hline $\begin{array}{l}\text { biologische wasser-kort / biological air scrubber- } \\
\text { short }\end{array}$ & 1,2 & 1,2 & 1,0 & 1,0 & 1,0 & 2,3 & 2,0 & 2,3 & 1,9 & 2,0 & 2,5 & 2,0 & 2,2 & 10,4 & 15,9 \\
\hline biologische wasser-lang / biological air scrubber-long & & & & & & & 0,4 & 0,4 & 1,4 & 1,4 & 1,4 & 1,8 & 2,1 & 2,2 & 3,5 \\
\hline combi-wasser / combined air scrubber & & & 0,5 & 0,5 & 0,5 & 1,2 & 7,1 & 7,9 & 16,5 & 17,2 & 19,0 & 21,6 & 21,4 & 14,1 & 12,4 \\
\hline Dekberen / Breeding boars & & & & & & & & & & & & & & & \\
\hline
\end{tabular}




\begin{tabular}{|c|c|c|c|c|c|c|c|c|c|c|c|c|c|c|c|}
\hline Diercategorie / Livestock category & 2005 & 2006 & 2007 & 2008 & 2009 & 2010 & 2011 & 2012 & 2013 & 2014 & 2015 & 2016 & 2017 & 2018 & 2019 \\
\hline regulier / regular & 97,9 & 97,9 & 97,5 & 97,5 & 97,5 & 97,1 & 90,0 & 89,0 & 88,5 & 87,9 & 74,9 & 73,8 & 70,9 & 58,8 & 63,9 \\
\hline chemische wasser / chemical air scrubber & 1,6 & 1,6 & 1,9 & 1,9 & 1,9 & 2,2 & 6,6 & 7,3 & 5,7 & 6,0 & 13,1 & 13,5 & 19,0 & 34,4 & 21,2 \\
\hline $\begin{array}{l}\text { biologische wasser-kort / biological air scrubber- } \\
\text { short }\end{array}$ & 0,5 & 0,5 & 0,4 & 0,4 & 0,4 & 0,5 & 0,7 & 0,8 & 0,7 & 0,7 & 2,1 & 1,7 & 1,4 & 2,9 & 4,9 \\
\hline biologische wasser-lang / biological air scrubber-long & & & & & & & 0,0 & 0,0 & 0,1 & 0,1 & 0,2 & 0,7 & 0,8 & 0,5 & 1,9 \\
\hline combi-wasser / combined air scrubber & & & 0,2 & 0,2 & 0,2 & 0,2 & 2,5 & 2,8 & 5,0 & 5,3 & 9,6 & 10,3 & 7,9 & 3,4 & 8,1 \\
\hline \multicolumn{16}{|l|}{ Pluimvee / Poultry } \\
\hline \multicolumn{16}{|l|}{ Vleeskuikens / Broilers } \\
\hline regulier / regular & 98,6 & 98,6 & 98,9 & 98,9 & 98,9 & 98,1 & 95,5 & 95,1 & 89,2 & 89,1 & 90,6 & 95,8 & 89,8 & 74,9 & 71,1 \\
\hline nageschakelde techniek / additional technique & & & & & & & 1,2 & 1,2 & 8,6 & 8,6 & 7,6 & 2,2 & 8,7 & 22,6 & 26,5 \\
\hline chemische wasser / chemical air scrubber & 1,4 & 1,4 & 0,7 & 0,7 & 0,7 & 1,0 & 2,5 & 2,7 & 1,6 & 1,7 & 1,4 & 1,6 & 1,1 & 2,1 & 2,1 \\
\hline $\begin{array}{l}\text { biologische wasser-kort / biological air scrubber- } \\
\text { short }\end{array}$ & & & 0,4 & 0,4 & 0,4 & 1,0 & 0,2 & 0,2 & 0,2 & 0,2 & 0,1 & 0,3 & 0,1 & 0,1 & 0,1 \\
\hline biologische wasser-lang / biological air scrubber-long & & & & & & & 0,7 & 0,8 & 0,4 & 0,4 & 0,3 & 0,1 & 0,2 & 0,3 & 0,2 \\
\hline combi-wasser / combined air scrubber & & & & & & & & & & & & & & & \\
\hline \multicolumn{16}{|l|}{$\begin{array}{l}\text { Ouderdieren van slachtrassen, jonger dan } 18 \text { weken / } \\
\text { Broiler breeders, younger than } 18 \text { weeks }\end{array}$} \\
\hline grondhuisvesting / floor housing & 100,0 & 100,0 & 100,0 & 100,0 & 100,0 & 100,0 & 99,1 & 99,0 & 98,9 & 98,9 & 95,7 & 93,8 & 92,4 & 81,6 & 76,2 \\
\hline nageschakelde techniek / additional technique & & & & & & & & & & & 1,2 & 2,1 & 4,4 & 13,1 & 17,5 \\
\hline chemische wasser / chemical air scrubber & & & & & & & 0,9 & 1,0 & 1,1 & 1,1 & 3,1 & 4,1 & 3,2 & 5,3 & 6,3 \\
\hline \multicolumn{16}{|l|}{$\begin{array}{l}\text { Ouderdieren van slachtrassen, } 18 \text { weken en ouder / } \\
\text { Broiler breeders, } 18 \text { weeks and older }\end{array}$} \\
\hline kooihuisvesting / cage housing & 10,0 & 10,0 & 4,3 & 4,3 & 4,3 & 1,7 & 5,7 & 5,7 & 5,7 & 5,7 & 5,0 & 4,4 & 4,3 & 4,7 & 4,7 \\
\hline grondhuisvesting + volière / floor housing + aviary & 89,1 & 89,1 & 95,4 & 95,4 & 95,4 & 97,8 & 92,2 & 92,0 & 91,9 & 91,8 & 91,2 & 89,4 & 90,9 & 87,2 & 76,7 \\
\hline nageschakelde techniek / additional technique & & & & & & & & & & & 1,9 & 3,2 & 2,6 & 5,9 & 17,1 \\
\hline chemische wasser / chemical air scrubber & 0,9 & 0,9 & 0,2 & 0,2 & 0,2 & 0,4 & 0,5 & 0,6 & 0,7 & 0,7 & 1,7 & 3,0 & 2,2 & 2,2 & 1,5 \\
\hline $\begin{array}{l}\text { biologische wasser-kort / biological air scrubber- } \\
\text { short }\end{array}$ & & & & & & & & & 0,2 & 0,2 & 0,0 & & & & \\
\hline biologische wasser-lang / biological air scrubber-long & & & 0,1 & 0,1 & 0,1 & 0,1 & 1,5 & 1,7 & 1,5 & 1,6 & 0,2 & & & & \\
\hline combi-wasser / combined air scrubber & & & & & & & & & & & & & & & \\
\hline \multicolumn{16}{|l|}{$\begin{array}{l}\text { Leghennen, jonger dan } 18 \text { weken / Laying hens, } \\
\text { younger than } 18 \text { weeks }\end{array}$} \\
\hline batterijhuisvesting / battery cages & 55,5 & 55,5 & 38,5 & 38,5 & 38,5 & 38,5 & 10,7 & 10,7 & & & & & & & \\
\hline koloniehuisvesting / colony housing & & & & & & & & & 10,4 & 10,4 & 15,6 & 15,2 & 15,4 & 14,5 & 12,9 \\
\hline grondhuisvesting / floor housing & 35,3 & 35,3 & 27,5 & 27,5 & 27,5 & 27,5 & 29,2 & 29,2 & 18,9 & 18,9 & 25,8 & 26,3 & 26,0 & 27,4 & 27,2 \\
\hline nageschakelde techniek / additional technique & & & & & & & & & & & 3,4 & 2,8 & 2,2 & 10,6 & 23,8 \\
\hline volièrehuisvesting / aviary housing & 9,2 & 9,2 & 33,0 & 33,0 & 33,0 & 32,8 & 58,0 & 57,7 & 68,2 & 68,1 & 51,4 & 52,4 & 53,6 & 46,6 & 33,8 \\
\hline chemische wasser / chemical air scrubber & & & 1,0 & 1,0 & 1,0 & 1,2 & 1,2 & 1,3 & 1,1 & 1,1 & 1,8 & 0,9 & 0,8 & 0,9 & 1,0 \\
\hline $\begin{array}{l}\text { biologische wasser-kort / biological air scrubber- } \\
\text { short }\end{array}$ & & & & & & & 0,3 & 0,4 & & & & 0,8 & & & 1,3 \\
\hline
\end{tabular}

230 | wot-technical report 203 


\begin{tabular}{|c|c|c|c|c|c|c|c|c|c|c|c|c|c|c|c|}
\hline Diercategorie / Livestock category & 2005 & 2006 & 2007 & 2008 & 2009 & 2010 & 2011 & 2012 & 2013 & 2014 & 2015 & 2016 & 2017 & 2018 & 2019 \\
\hline biologische wasser-lang / biological air scrubber-long & & & & & & & 0,6 & 0,7 & 1,4 & 1,5 & 1,8 & 0,3 & & & \\
\hline combi-wasser / combined air scrubber & & & & & & & & & & & 0,2 & 1,3 & 2,0 & 0,0 & 0,0 \\
\hline \multicolumn{16}{|l|}{$\begin{array}{l}\text { Leghennen, } 18 \text { weken en ouder / Laying hens, } 18 \\
\text { weeks and older }\end{array}$} \\
\hline batterijhuisvesting / battery cages & 55,5 & 55,5 & 41,4 & 41,4 & 41,4 & 39,4 & 5,3 & 5,3 & & & & & & & \\
\hline $\begin{array}{l}\text { verrijkte kooi/koloniehuisvesting / enriched } \\
\text { cage/colony housing }\end{array}$ & 1,3 & 1,3 & 1,3 & 1,3 & 1,3 & 1,3 & 5,1 & 5,1 & 13,3 & 13,3 & 18,6 & 17,3 & 17,2 & 14,4 & 13,6 \\
\hline grondhuisvesting / floor housing & 35,6 & 35,6 & 29,2 & 29,2 & 29,2 & 23,9 & 26,7 & 26,7 & 14,8 & 14,8 & 15,9 & 15,1 & 13,9 & 13,4 & 12,6 \\
\hline nageschakelde techniek / additional technique & & & & & & & & & & & 1,9 & 5,7 & 3,4 & 21,0 & 44,3 \\
\hline volièrehuisvesting / aviary housing & 7,6 & 7,6 & 28,1 & 28,1 & 28,1 & 35,4 & 61,3 & 61,2 & 70,1 & 70,0 & 63,6 & 61,9 & 65,5 & 51,2 & 29,5 \\
\hline chemische wasser / chemical air scrubber & & & & & & & 1,0 & 1,1 & 1,7 & 1,8 & & & & & \\
\hline \multicolumn{16}{|l|}{$\begin{array}{l}\text { biologische wasser-kort / biological air scrubber- } \\
\text { short }\end{array}$} \\
\hline biologische wasser-lang / biological air scrubber-long & & & & & & & 0,5 & 0,6 & 0,0 & 0,0 & & & & & \\
\hline combi-wasser / combined air scrubber & & & & & & & & & & & & & & & \\
\hline \multicolumn{16}{|l|}{ Eenden / Ducks } \\
\hline regulier / regular & 100,0 & 100,0 & 100,0 & 100,0 & 100,0 & 100,0 & 100,0 & 100,0 & 100,0 & 100,0 & 92,7 & 90,6 & 89,8 & 92,3 & 91,5 \\
\hline nageschakelde techniek / additional technique & & & & & & & & & & & & 2,7 & 3,5 & & 2,6 \\
\hline chemische wasser / chemical air scrubber & & & & & & & & & & & 7,3 & 6,7 & 6,7 & 7,7 & 5,9 \\
\hline \multicolumn{16}{|l|}{ Kalkoenen / Turkeys } \\
\hline regulier / regular & 100,0 & 100,0 & 100,0 & 100,0 & 100,0 & 100,0 & 100,0 & 100,0 & 100,0 & 100,0 & 100,0 & 100,0 & 96,4 & 95,3 & 93,3 \\
\hline nageschakelde techniek / additional technique & & & & & & & & & & & & & 3,6 & 4,7 & 6,7 \\
\hline $\begin{array}{l}\text { Konijnen en pelsdieren / Rabbits and fur-bearing } \\
\text { animals }\end{array}$ & 100,0 & 100,0 & 100,0 & 100,0 & 100,0 & 100,0 & 100,0 & 100,0 & 100,0 & 100,0 & 100,0 & 100,0 & 100,0 & 100,0 & 100,0 \\
\hline Schapen en geiten / Sheep and goats & 100,0 & 100,0 & 100,0 & 100,0 & 100,0 & 100,0 & 100,0 & 100,0 & 100,0 & 100,0 & 100,0 & 100,0 & 100,0 & 100,0 & 100,0 \\
\hline $\begin{array}{l}\text { Paarden, pony's en ezels / Horses, ponies, mules and } \\
\text { asses }\end{array}$ & 100,0 & 100,0 & 100,0 & 100,0 & 100,0 & 100,0 & 100,0 & 100,0 & 100,0 & 100,0 & 100,0 & 100,0 & 100,0 & 100,0 & 100,0 \\
\hline
\end{tabular}


B34.2 Emissiefactoren voor $P M_{10}$ en $P M_{2,5}$ (g/dier/jaar) / Emission factors for $P M_{10}$ and $P M_{2.5}$ (g/animal/year).

\section{Diercategorie / Livestock category}

Stalsysteem ${ }^{1)} /$ Housing system ${ }^{1}$

\section{Melkvee / Dairy cattle}

Vrouwelijk jongvee $<1 \mathrm{jr} /$ Female young stock $<1 \mathrm{yr}$

Mannelijk jongvee $<1 \mathrm{jr} /$ Male young stock $<1 \mathrm{yr}$

Vrouwelijk jongvee, 1-2 jr / Female young stock, 1-2 yr

Mannelijk jongvee, 1-2 jr / Male young stock, 1-2 yr

Vrouwelijk jongvee, $\geq 2 \mathrm{jr} /$ Female young stock $\geq 2 \mathrm{yr}$

Melk- en kalfkoeien / Dairy cows

Fokstieren / Breeding bulls

\section{Vleesvee / Beef cattle}

Wit- en rosévleeskalveren / White and rosé veal calves

\begin{tabular}{|c|c|c|}
\hline regulier / regular & 37,7 & 10,4 \\
\hline regulier / regular & 170,1 & 46,8 \\
\hline regulier / regular & 37,7 & 10,4 \\
\hline regulier / regular & 170,1 & 46,8 \\
\hline regulier / regular & 117,8 & 32,5 \\
\hline grupstal / tie-stall & 80,8 & 22,3 \\
\hline ligbox met beweiden / cubicle with grazing & 117,8 & 32,5 \\
\hline ligbox met opstallen / cubicle without grazing & 147,5 & 40,6 \\
\hline regulier / regular & 170,1 & 46,8 \\
\hline regulier / regular & 35,7 & 9,8 \\
\hline luchtwasser2) / air scrubber ${ }^{2)}$ & 23,2 & 6,4 \\
\hline luchtwasser ${ }^{3)}$ / air scrubber ${ }^{3)}$ & 14,3 & 3,9 \\
\hline luchtwasser(4) / air scrubber ${ }^{4}$ & 8,9 & 2,5 \\
\hline luchtwasser ${ }^{5)}$ / air scrubber ${ }^{5}$ & 7,1 & 2,0 \\
\hline regulier / regular & 37,7 & 10,4 \\
\hline regulier / regular & 170,1 & 46,8 \\
\hline regulier / regular & 37,7 & 10,4 \\
\hline regulier / regular & 170,1 & 46,8 \\
\hline regulier / regular & 86,2 & 23,8 \\
\hline regulier / regular & 170,1 & 46,8 \\
\hline regulier / regular & 86,2 & 23,8 \\
\hline
\end{tabular}

Vrouwelijk jongvee $<1 \mathrm{jr} /$ Female young stock $<1 \mathrm{yr}$

Mannelijk jongvee (incl. ossen) $<1 \mathrm{jr} /$ Male young stock (incl. bullocks) $<1 \mathrm{yr}$

Vrouwelijk jongvee, 1-2 jr / Female young stock, 1-2 yr

Mannelijk jongvee (incl. ossen), 1-2 jr / Male young stock (incl. bullocks), 1-2 yr

Vrouwelijk jongvee, $2 \mathrm{jr}$ en ouder / Female young stock $\geq 2 \mathrm{yr}$

Mannelijk jongvee (incl. ossen), $\geq 2 \mathrm{jr} /$ Male young stock (incl. bullocks) $\geq 2 \mathrm{yr}$

Zoog-, mest- en weidekoeien $\geq 2 \mathrm{jr} /$ Suckling cows and female fatteners $\geq 2 \mathrm{yr}$

regulier / regular

\section{Varkens / Pigs}

\section{Biggen / Piglets}

(n)

(20)

$+2$

Vlees- en opfokvarkens / Fattening pigs, gilts and young boars regulier gedeeltelijk rooster / regular partially raster

luchtwasser ${ }^{2}$ / $/$ air scrubber ${ }^{2}$ )

luchtwasser ${ }^{3}$ / $/$ air scrubber ${ }^{3}$ )

luchtwasser $r^{4)} /$ air scrubber ${ }^{4}$

luchtwasser ${ }^{5}$ / $/$ air scrubber ${ }^{5}$

regulier volledig rooster / regular fully raster

luchtwasser ${ }^{2)} /$ air scrubber ${ }^{2}$

luchtwasser $^{3)} /$ air scrubber ${ }^{3)}$

luchtwasser ${ }^{4)}$ / air scrubber ${ }^{4}$ )

luchtwasser $^{5)}$ / air scrubber ${ }^{5)}$

regulier / regular

luchtwasser ${ }^{2}$ / air scrubber ${ }^{2)}$

luchtwasser $^{3)}$ / air scrubber ${ }^{3}$

\begin{tabular}{rr}
\hline 81,2 & 2,0 \\
\hline 52,8 & 1,3 \\
\hline 32,5 & 0,8 \\
\hline 20,3 & 0,5 \\
16,2 & 0,4 \\
\hline 62,0 & 2,1 \\
\hline 40,3 & 1,4 \\
\hline 24,8 & 0,8 \\
\hline 15,5 & 0,5 \\
\hline 12,4 & 0,4 \\
\hline 157,3 & 7,4 \\
102,2 & 4,8 \\
\hline 62,9 & 3,0 \\
\hline
\end{tabular}

232 | wot-technical report 203 


\section{Diercategorie / Livestock category}

\section{Guste en dragende zeugen / Mating and gestating sows}

Kraamzeugen / Nursing sows

\section{Dekberen / Breeding boars}

Ouderdieren van slachtrassen $<18$ weken / Broiler breeders $<18$ weeks

Ouderdieren van slachtrassen $\geq 18$ weken / Broiler breeders $\geq 18$ weeks

Leghennen $<18$ weken / Laying hens $<18$ weeks
Stalsysteem ${ }^{1)}$ / Housing system ${ }^{1)}$

luchtwasser ${ }^{4)} /$ air scrubber ${ }^{4}$

luchtwasser ${ }^{5}$ / air scrubber ${ }^{5)}$

regulier / regular

luchtwasser ${ }^{2)}$ / air scrubber ${ }^{2)}$

luchtwasser $^{3)} /$ air scrubber ${ }^{3)}$

luchtwasser ${ }^{4)} /$ air scrubber ${ }^{4}$

luchtwasser $^{5)}$ / air scrubber ${ }^{5)}$

regulier / regular

luchtwasser $^{2)} /$ air scrubber ${ }^{2)}$

luchtwasser ${ }^{3}$ / air scrubber ${ }^{3}$

luchtwasser ${ }^{4)} /$ air scrubber

luchtwasser ${ }^{5}$ / $/$ air scrubber ${ }^{5}$

regulier / regular

luchtwasser ${ }^{2}$ / air scrubber ${ }^{2}$

luchtwasser $^{3)} /$ air scrubber ${ }^{3}$

luchtwasser $^{4)} /$ air scrubber ${ }^{4)}$

luchtwasser ${ }^{5}$ / $/$ air scrubber ${ }^{5}$

regulier / regular

nageschakelde techniek / additional technique

luchtwasser ${ }^{2)}$ / air scrubber ${ }^{2}$ )

luchtwasser ${ }^{3)}$ / air scrubber ${ }^{3)}$

luchtwasser $r^{4}$ / air scrubber ${ }^{4}$

luchtwasser ${ }^{5)} /$ air scrubber ${ }^{5}$

grondhuisvesting / floor housing

nageschakelde techniek / additional technique

luchtwasser ${ }^{2)}$ / air scrubber ${ }^{2}$

kooihuisvesting / cage housing

grondhuisvesting + volière / floor housing + aviary

nageschakelde techniek / additional technique

luchtwasser ${ }^{2}$ / air scrubber ${ }^{2}$ )

luchtwasser ${ }^{3)}$ / air scrubber ${ }^{3}$

luchtwasser ${ }^{4}$ / $/$ air scrubber ${ }^{4}$

luchtwasser ${ }^{5}$ ) / air scrubber ${ }^{5}$

koloniehuisvesting / colony housing

grondhuisvesting / floor housing

nageschakelde techniek / additional technique

volière / aviary housing

luchtwasser ${ }^{2}$ / air scrubber ${ }^{2}$

\begin{tabular}{|c|c|}
\hline$P M_{10}$ & $\mathrm{PM}_{2,5}$ \\
\hline 39,3 & 1,9 \\
\hline 31,5 & 1,5 \\
\hline $174,3^{6)}$ & $12,3^{6)}$ \\
\hline 113,3 & 8,0 \\
\hline 69,7 & 4,9 \\
\hline 43,6 & 3,1 \\
\hline 34,9 & 2,5 \\
\hline 164,9 & 14,2 \\
\hline 107,2 & 9,2 \\
\hline 66,0 & 5,7 \\
\hline 41,2 & 3,6 \\
\hline 33,0 & 2,8 \\
\hline 185,6 & 15,9 \\
\hline 120,6 & 10,3 \\
\hline 74,2 & 6,4 \\
\hline 46,4 & 4,0 \\
\hline 37,1 & 3,2 \\
\hline 26,8 & 2,0 \\
\hline $18,2^{6)}$ & $1,4^{6)}$ \\
\hline 17,4 & 1,3 \\
\hline 10,7 & 0,8 \\
\hline 6,7 & 0,5 \\
\hline 5,4 & 0,4 \\
\hline 17,0 & 1,3 \\
\hline $11,2^{6)}$ & $0,9^{6)}$ \\
\hline 11,1 & 0,8 \\
\hline 8,7 & 1,8 \\
\hline 49,1 & 3,8 \\
\hline $31,4^{6)}$ & $2,5^{6)}$ \\
\hline 31,9 & 2,5 \\
\hline 19,6 & 1,5 \\
\hline 12,3 & 1,0 \\
\hline 9,8 & 0,8 \\
\hline 9,6 & 0,9 \\
\hline 34,8 & 1,7 \\
\hline $16,0^{6)}$ & $1,0^{6)}$ \\
\hline 26,9 & 1,6 \\
\hline 22,6 & 1,1 \\
\hline
\end{tabular}




\begin{tabular}{|c|c|c|c|}
\hline Diercategorie / Livestock category & Stalsysteem ${ }^{1}$ / Housing system ${ }^{1}$ ) & $\mathrm{PM}_{10}$ & $\mathrm{PM}_{2,5}$ \\
\hline & luchtwasser $^{3)}$ / air scrubber ${ }^{3)}$ & 13,9 & 0,7 \\
\hline & luchtwasser ${ }^{4)}$ / air scrubber $\left.{ }^{4}\right)$ & 8,7 & 0,4 \\
\hline & luchtwasser ${ }^{5)}$ / air scrubber $\left.{ }^{5}\right)$ & 7,0 & 0,3 \\
\hline \multirow[t]{8}{*}{ Leghennen $\geq 18$ weken / Laying hens $\geq 18$ weeks } & $\begin{array}{l}\text { verrijkte kooi/koloniehuisvesting / enriched } \\
\text { cage/colony housing }\end{array}$ & 24,0 & 2,3 \\
\hline & grondhuisvesting / floor housing & 87,1 & 4,2 \\
\hline & nageschakelde techniek / additional technique & $37,6^{6)}$ & $2,3^{6)}$ \\
\hline & volière / aviary housing & 67,3 & 4,0 \\
\hline & luchtwasser2) / air scrubber²) & 56,6 & 2,7 \\
\hline & luchtwasser $^{3)} /$ air scrubber $^{3)}$ & 34,8 & 1,7 \\
\hline & luchtwasser ${ }^{4)}$ / air scrubber ${ }^{4)}$ & 21,8 & 1,1 \\
\hline & luchtwasser $\left.{ }^{5}\right)$ / air scrubber ${ }^{5)}$ & 17,4 & 0,8 \\
\hline \multirow[t]{3}{*}{ Vleeseenden / Ducks for slaughter } & regulier / regular & 104,5 & 5,0 \\
\hline & nageschakelde techniek / additional technique & $65,8^{6}$ & $3,2^{6)}$ \\
\hline & luchtwasser²) / air scrubber²) & 67,9 & 3,3 \\
\hline \multirow[t]{2}{*}{ Vleeskalkoenen / Turkeys for slaughter } & regulier / regular & 95,1 & 44,6 \\
\hline & nageschakelde techniek / additional technique & $73,9^{6)}$ & $34,6^{6)}$ \\
\hline Konijnen (voedsters) / Rabbits (does) & regulier / regular & 10,7 & 2,1 \\
\hline Nertsen (teven) / Minks (dams) & regulier / regular & 8,1 & 4,2 \\
\hline Schapen $^{7)} /$ Sheep $^{7)}$ & regulier / regular & 1,8 & 0,5 \\
\hline Geiten / Goats & regulier / regular & 19,0 & 5,7 \\
\hline Paarden $^{8)} /$ Horses $^{8)}$ & regulier / regular & 220,0 & 140,0 \\
\hline Pony's s) $^{\text {Ponies }}{ }^{8)}$ & regulier / regular & 220,0 & 140,0 \\
\hline Ezels $^{8)} /$ Mules and $^{2}$ ssses $^{8)}$ & regulier / regular & 160,0 & 100,0 \\
\hline
\end{tabular}

1) Het onderscheid tussen stalsystemen heeft betrekking op verschillen in emissie van fijnstof / The distinction between housing systems refers to differences in emissions of particulate matter.

2) Chemische wasser / Chemical air scrubber.

3) Biologische wasser - kort / Biological air scrubber - short.

4) Biologische wasser - lang / Biological air scrubber - long.

5) Combi-wasser / Combined air scrubber.

6) Jaarspecifieke factoren, afhankelijk van verdeling onderliggende systemen, geldend voor 2019 / Year specific factors, depending on shares underlying systems, applicable for 2019 .

7) De emissiefactoren voor schapen zijn afgeleid van de emissiefactoren van geiten door deze te vermenigvuldigen met het aandeel van de excretie van schapen die plaatsvindt in de stal.

8) Deze emissiefactoren zijn de default emissiefactoren uit het EMEP 2019 Guidebook / These emission factors are the defaults from the EMEP 2019 Guidebook.

Bron / Source: Wageningen UR Livestock Research. 


\section{Bijlage 35 Verbruik van kalkmeststoffen}

B35.1 Gebruik van kalkmeststoffen (miljoen $\mathrm{kg}$ neutraliserende waarde (CaO)) en ureum(miljoen $\mathrm{kg} \mathrm{CH} \mathrm{CN}_{2} \mathrm{O}$ ) / Use of lime fertilisers (million $\mathrm{kg}$

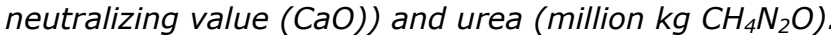

\begin{tabular}{|c|c|c|c|c|c|c|c|c|c|c|c|c|c|c|c|}
\hline $\begin{array}{l}\text { Gebruik van kalkmeststoffen / Use of lime } \\
\text { fertilisers }\end{array}$ & 1990 & 1991 & 1992 & 1993 & 1994 & 1995 & 1996 & 1997 & 1998 & 1999 & 2000 & 2001 & 2002 & 2003 & 2004 \\
\hline kalksteen / calcic limestone & 58,4 & 43,6 & 44,7 & 36,7 & 34,0 & 35,5 & 57,4 & 59,7 & 59,0 & 31,8 & 53,7 & 42,3 & 53,0 & 60,8 & 52,0 \\
\hline dolomiet / dolomite & 330,1 & 267,4 & 254,0 & 247,8 & 169,4 & 173,1 & 178,8 & 175,5 & 163,6 & 147,6 & 155,1 & 128,7 & 128,5 & 125,0 & 117,6 \\
\hline ureum / urea & 2,1 & 5,5 & 5,1 & 5,2 & 6,1 & 3,8 & 4,0 & 3,5 & 2,5 & 2,4 & 3,1 & 6,1 & 4,7 & 16,5 & 13,9 \\
\hline
\end{tabular}

B35.1 vervolg / continuation.

\begin{tabular}{|c|c|c|c|c|c|c|c|c|c|c|c|c|c|c|c|}
\hline $\begin{array}{l}\text { Gebruik van kalkmeststoffen / Use of lime } \\
\text { fertilisers }\end{array}$ & 2005 & 2006 & 2007 & 2008 & 2009 & 2010 & 2011 & 2012 & 2013 & 2014 & 2015 & 2016 & 2017 & 2018 & 2019 \\
\hline kalksteen / calcic limestone & 58,1 & 59,7 & 53,0 & 50,0 & 43,1 & 43,1 & 57,5 & 60,0 & 60,0 & 60,0 & 71,7 & 34,1 & 33,5 & 54,7 & 43,1 \\
\hline dolomiet / dolomite & 103,1 & 115,0 & 100,2 & 102,0 & 85,5 & 85,5 & 100,7 & 92,3 & 92,3 & 92,3 & 77,9 & 53,5 & 75,3 & 17,2 & 33,5 \\
\hline ureum / urea & 11,3 & 16,6 & 31,3 & 14,4 & 34,2 & 44,1 & 48,3 & 97,7 & 82,4 & 80,7 & 89,9 & 61,8 & 65,5 & 69,4 & 61,6 \\
\hline
\end{tabular}

Bron / Source: Wageningen Economic Research. 

168 Arets, E.J.M.M., J.W.H van der Kolk, G.M. Hengeveld, J.P. Lesschen, H. Kramer, P.J. Kuikman \& M.J. Schelhaas (2020). Greenhouse gas reporting of the LULUCF sector in the Netherlands. Methodological background, update 2020.

169 Van Kraalingen, D., E.L. Wipfler, F. van den Berg, W.H.J. Beltman, M.M.S. ter Horst \& J.A. te Roller (2020). User manual for FOCUSSPIN version 3.3.

170 Bos-Groenendijk, G.I., C.A.M van Swaay (2020). Habitatrichtlijnrapportage 2019: Annex B Habitatrichtlijnsoorten; Achtergronddocument.

171 Janssen, J.A.M. (red.), R.J. Bijlsma (red.), G.H.P. Arts, M.J. Baptist, S.M. Hennekens, B. de Knegt, T. van der Meij, J.H.J. Schaminée, A.J. van Strien, S. Wijnhoven, T.J.W. Ysebaert (2020). Habitatrichtlijnrapportage 2019: Annex $D$ Habitattypen. Achtergronddocument.

172 Van Kleunen, A., M. van Roomen, E. van Winden, M. Hornman, A. Boele, C. Kampichler, D. Zoetebier, H. Sierdsema \& C. van Turnhout (2020). Vogelrichtlijnrapportage 2013-2018 van Nederland - status en trends van soorten.

173 Glorius, S.T., A. Meijboom (2020). Ontwikkeling van de bodemdiergemeenschap in de geulen van referentiegebied Rottum;

Tussenrapportage 13 jaar na sluiting (najaar 2018).

174 Kuindersma, W., D. van Doren, R. Arnouts, D.A. Kamphorst, J.G. Nuesink, E. de Wit-de Vries (2020). Realisatie Natuurnetwerk door provincies. Achtergrondstudie bij de Tweede Lerende Evaluatie Natuurpact.

175 Bouwma, I.M., D.A. Kamphorst, D. van Doren, T.A. de Boer, A.E. Buijs, C.M. Goossen, J.L.M. Donders, J.Y. Frissel, S. van Broekhoven (2020). Provinciaal beleid voor maatschappelijke betrokkenheid bij natuur het beleid nader bekeken in 8 casussen. Achtergrondstudie bij de Tweede Lerende Evaluatie Natuurpact.

176 Gerritsen, A.L., H. Agricola, C. Aalbers, J. van Os (2020). Natuur en landbouw verbinden. Achtergrondstudie bij de Tweede Lerende Evaluatie Natuurpact.

177 Brouwer, F., D.J.J. Walvoort (2020). Basisregistratie Ondergrond (BRO) Actualisatie bodemkaart. Herkartering van de veengebieden aan de flanken van de Utrechtse Heuvelrug.

178 Bruggen, C. van, A. Bannink, C.M. Groenestein, J.F.M. Huijsmans, L.A. Lagerwerf, H.H. Luesink, G.L. Velthof \& J. Vonk (2020). Emissies naar lucht uit de landbouw, 1990-2018; Emissies van ammoniak, stikstofoxide, lachgas, methaan, niet-methaan vluchtige organische stoffen, fijnstof en koolstofdioxide uit kalkmeststoffen - Berekeningen met het model NEMA.

179 Knegt, de B., M. Pleijte, E. de Wit-de Vries, I. Bouwma, F. Kistenkas, W. Nieuwenhuizen (2020). Samenhang Klimaatakkoord en natuurbeleid. Proces en implementatie van het Klimaatakkoord door provincies en maatschappelijke partijen en de potentiële effecten op biodiversiteitsdoelen van de Vogelen Habitatrichtlijn.

180 Mattijssen T.J.M., M. Pleijte, J. Dengerink, T. Koster, M. Visscher (2020). Indicatoren voor burgerbetrokkenheid bij natuur: een zoektocht naar nieuwe aanknopingspunten voor monitoring.

181 Kamphorst, D.A., M. Pleijte, F. Kistenkas (2020). Uitvoering van de Vogel- en Habitatrichtlijn in de praktijk: spanningen en mogelijke oplossingsrichtingen.

182 Elschot K., M.E.B. Van Puijenbroek, D.D.G. Lagendijk, J-T. Van der Wal, C. Sonneveld (2020). Lange-termijnontwikkeling van kwelders in de Waddenzee (1960-2018).

183 Koffijberg K., P. de Boer, S.C.V. Geelhoed, J. Nienhuis, K. Oosterbeek, J. Postma (2020). Broedsucces van kustbroedvogels in de Waddenzee in 2018.

184 IJsseldijk, L.L., M.J.L. Kik, L. van Schalkwijk \& A. Gröne (2020). Postmortaal onderzoek van bruinvissen (Phocoena phocoena) uit Nederlandse wateren, 2019. Biologische gegevens, gezondheidsstatus en doodsoorzaken.

185 Os, J. van, L.J.J. Jeurissen, J.C. Verkaik (2020). Rekenregels schapen en geiten voor de landbouwtelling; Verantwoording van het gebruik van het Identificatie \& Registratiesysteem.

186 Bakker, G., M. Heinen, H.P.A. Gooren, W.J.M. de Groot, P.D. Peters (2020). Hydrofysische gegevens van de bodem in de Basisregistratie Ondergrond (BRO) en het Bodemkundig Informatie Systeem (BIS); Update 2019.

187 Kuindersma, W., E. de Wit - de Vries, F.G. Boonstra, M. Pleijte, D.A. Kamphorst (2020). Het Nederlandse natuurbeleid in zijn institutionele context. Beschrijving en analyse van de interne en externe congruentie van het Nederlandse natuurbeleidsarrangement in relatie tot landbouwbeleid, waterbeleid (voor de grote rivieren) en recreatiebeleid (19752018). 
188 Kuiters, A.T., G.A. de Groot, D.R. Lammertsma, H.A.H. Jansman, J. Bovenschen (2020). Genetische monitoring van de Nederlandse otterpopulatie; Ontwikkeling van populatieomvang en genetische status 2019/2020.

189 Gerritsen, A.L., H.J. Agricola \& J. van Os (2020). Ruimtelijk-economische dynamiek van de landbouw. Rapport 1: analyses van ontwikkelingen in gewasarealen, dieraantallen, grondgebruik, grondprijzen, verdiencapaciteiten en verbredingsactiviteiten.

190 Pouwels, R., A. van Hinsberg, V. Mensing, S. van Tol \& J.Y. Frissel (2020). Achtergrondrapport referentiescenario's natuurverkenning 2050

191 Hennekens, S., J. Holtland, N. van Rooijen, W. Wamelink \& W. Ozinga (2020).

Indicatiewaarden voor voedselrijkdom van de bodem; een vergelijking tussen drie indicatiesystemen.

192 Glorius, S.T. \& A. Meijboom (2020). Ontwikkeling van enkele droogvallende mosselbanken in de Nederlandse Waddenzee; situatie 2019.

193 Glorius, S.T. \& A. Meijboom (2020). Ontwikkeling van de bodemdiergemeenschap in de geulen van referentiegebied Rottum; Tussenrapportage 14 jaar na sluiting (najaar 2019).

194 Adams, A.S. \& W.J. Remmelts (2020). Achtergronddocumentatie Vogel- en Habitatrichtlijnrapportage Annex A.

195 Van der Meij, W.M. \& G.J. Maas (2020). Kwaliteitsdocument van de Geomorfologische kaart van Nederland.
196 Buijs, A.E., D.A. Kamphorst, C.B.E.M. Aalbers (2020). Draagt maatschappelijke betrokkenheid bij aan de legitimiteit van het natuurbeleid? Inventarisatie van beleidsverwachtingen en review van literatuur.

197 Knegt, B. de, M. van der Aa, L. van Gerven, K. Hendriks, S. Koopmans, M. Lof, M. Riksen, H. Roelofsen, S. de Vries, I. Woltjer (2020). Graadmeter Diensten van Natuur, update 2020; Vraag, aanbod, gebruik en trend van goederen en diensten uit ecosystemen in Nederland.

198 Bouwma, I.M., M.C. van Riel, J.G. Nuesink, J.A. Veraart, R. Pouwels (2020). Verkenning naar de samenhang van de Vogel- en Habitatrichtlijn en de Kaderrichtlijn Water. Een analyse voor het vergroten van de synergie tussen de richtlijnen.

199 Müskens, G., M. La Haye, R. van Kats, S. Moonen \& E.A. van der Grift (2020). Ontwikkeling van de hamsterpopulatie in Limburg; Stand van zaken 2019-2020.

201 Arets, E.J.M.M., J.W.H van der Kolk, G.M. Hengeveld, J.P. Lesschen, H. Kramer, P.J. Kuikman \& M.J. Schelhaas (2021). Greenhouse gas reporting of the LULUCF sector in the Netherlands. Methodological background, update 2021.

203 Bruggen, C. van, A. Bannink, C.M. Groenestein, J.F.M. Huijsmans, L.A. Lagerwerf, H.H. Luesink, M.B.H. Ros, G.L. Velthof, J. Vonk en T. van der Zee (2021). Emissies naar lucht uit de landbouw berekend met NEMA voor 19902019. 



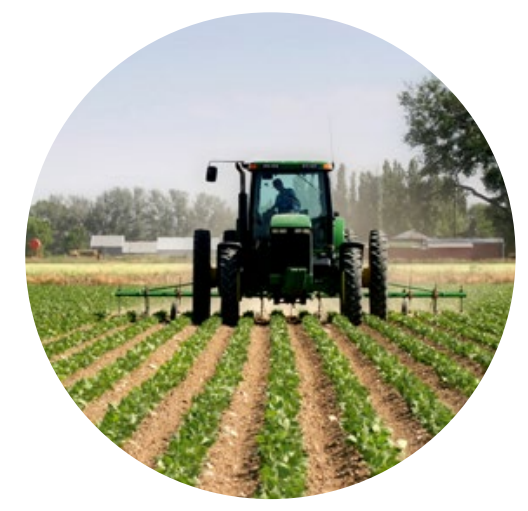

Thema Agromilieu

Wettelijke Onderzoekstaken Natuur \& Milieu

Postbus 47

6700 AA Wageningen

T (0317) 485471

E info.wnm@wur.nl

ISSN 2352-2739

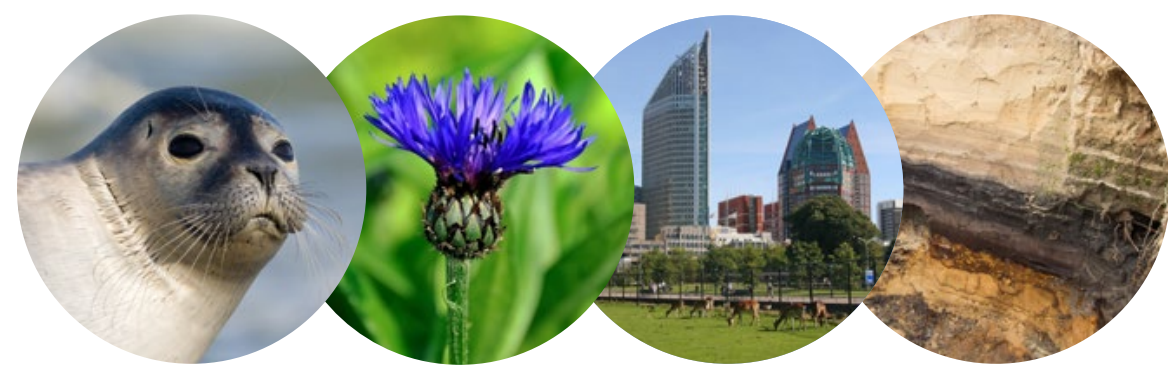

De missie van Wageningen University \& Research is 'To explore the potential of nature to improve the quality of life'. Binnen Wageningen University \& Research bundelen Wageningen University en gespecialiseerde onderzoeksinstituten van Stichting Wageningen Research hun krachten om bij te dragen aan de oplossing van belangrijke vragen in het domein van gezonde voeding en leefomgeving. Met ongeveer 30 vestigingen, 6.500 medewerkers ( $5.500 \mathrm{fte}$ ) en 12.500 studenten behoort Wageningen University \& Research wereldwijd tot de aansprekende kennisinstellingen binnen haar domein. De integrale benadering van de vraagstukken en de samenwerking tussen verschillende disciplines vormen het hart van de unieke Wageningen aanpak. 